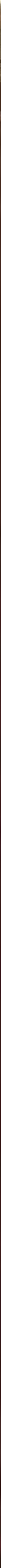




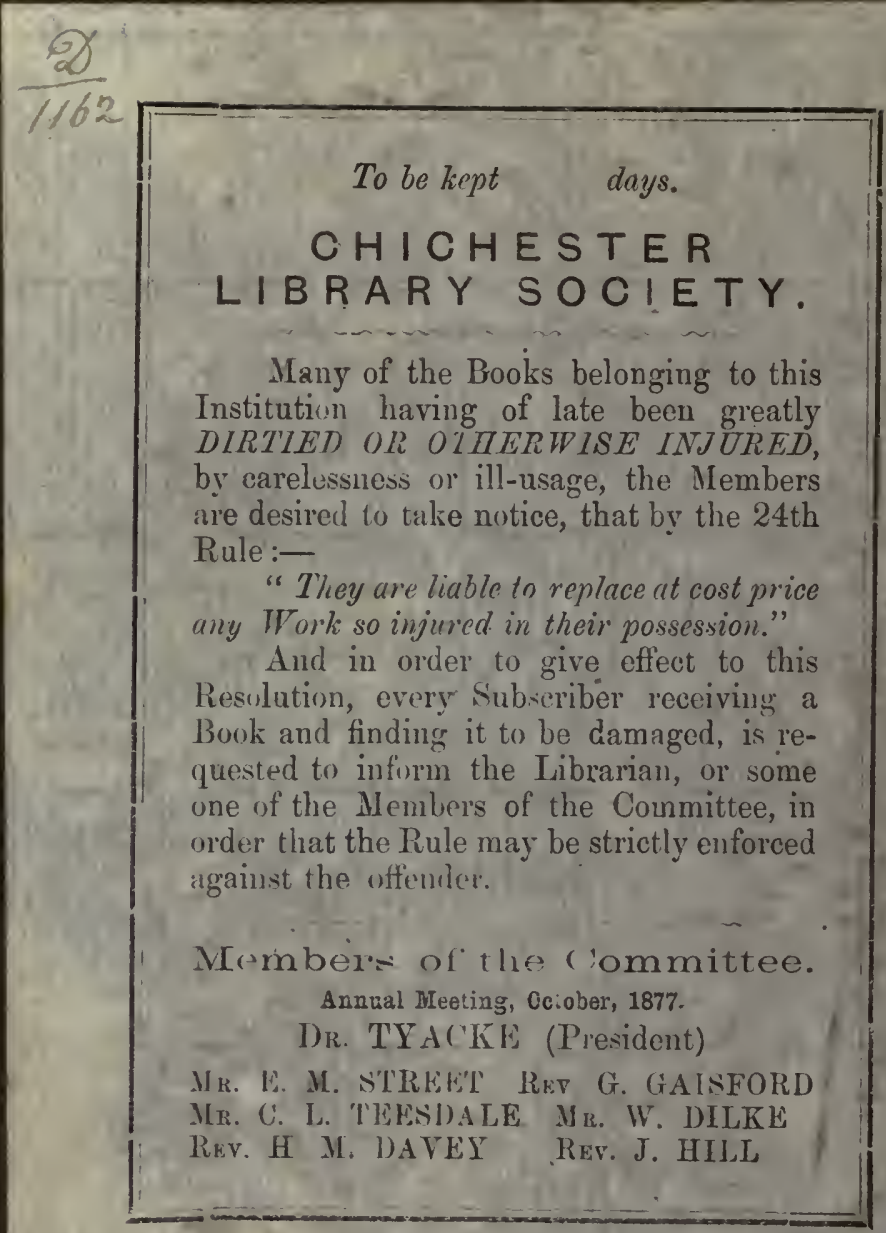



UCSB LIBRARY

$$
X-21816
$$




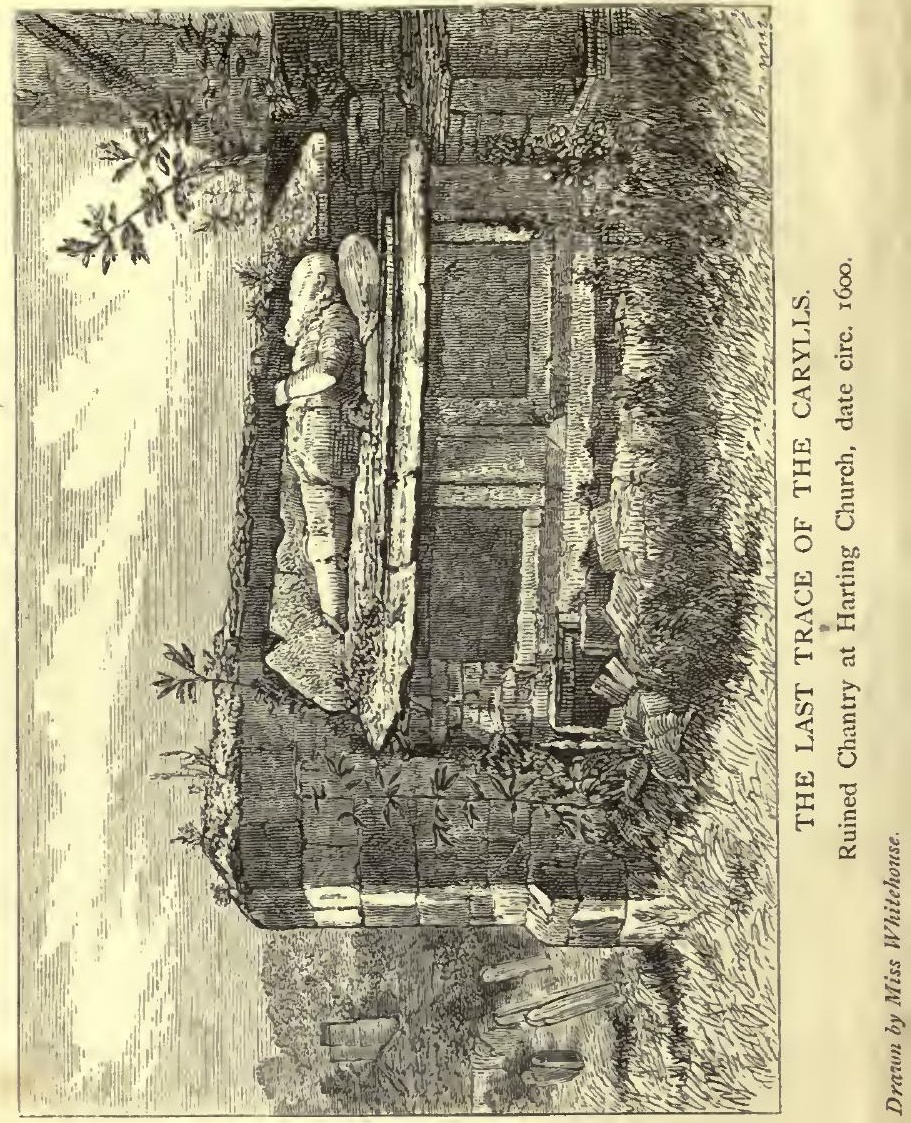




\section{THE HISTORY OF HARTING,} ви тив

REV. H. D. GORDON, M.A., Rector and Vicar of the Parish;

With a Chapter on the Geology of the Distriet, BY THE LATE

SIR RODERICK IMPEY MURCHISON, BART., F.G.S., ETC., ETC., ETC.,

\section{AND SOME NOTICE OF ITS FAUNA AND FLORA,}

$$
\text { BY J. WEAVER. }
$$

\section{LONDON:}

PRINTED FOR THE AUTHORS BY

W. DAVY \& SON, 8, GILBERT STREET, W.

$$
1877 \text {. }
$$


Digitized by the Internet Archive in 2007 with funding from Microsoft Corporation 


\section{P R E F A C E.}

IT is generally allowed that the story of each parish ought to be written separately. County histories, however imposing, are generally wholesale collections of fragmentary gossip, full of inaccuracies which, once printed, have been copied with all care from one book into another. The fault does not arise from lack of material, for there is scarcely an acre of Old England, especially if it nestles under an ancient church, that has not a history of its own, which, if told, might help local education and even inspire patriotism; and so great is the wealth of public historical documents in England as compared with France (which in this respect lost irretricvably by the wanton destruction of her records in the Revolution), that search of the most ordinary diligence will be sure to recover some historical title-deeds for the dullest hillside.

A humble attempt has been made in the following pages to describe a corner parish in West Sussex of 7,832 acres (nearly thirteen square miles), interest- 
ing in its flora and fauna, which, from their sheltered position and the variety of soil and climate, are unusually fertile, and also to unfold its remoter history, and incidentally that of its immediate neighbourhood, in the hope that an interest may be created, which may lead better explorers to take up the clue.

The soil was at all events rich: the authors must throw themselves upon the reader's indulgence for the verdict that shall say whether it was worth while to put in the spade. 


\section{N D E X.}

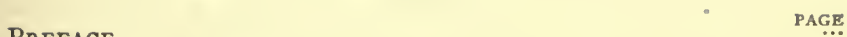

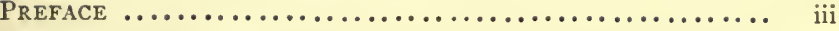

CHAP. I. -Geological Sketch ................... I

\section{HISTORY OF HARTING.}

Chap. I.-Position of Harting described $\ldots \ldots \ldots \ldots \ldots \ldots \ldots$ I4

CHap. II. - Harting before the Conquest ........... I7-26

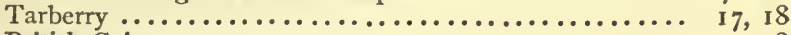

British Coin ............................ I 8

Derivation of "Harting" ..................... 20

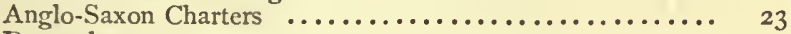

Domesday $\ldots \ldots \ldots \ldots \ldots \ldots \ldots \ldots \ldots \ldots \ldots \ldots \ldots . \ldots \ldots$

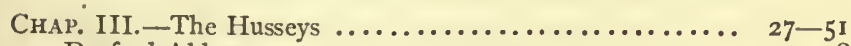

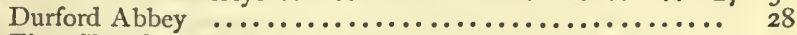

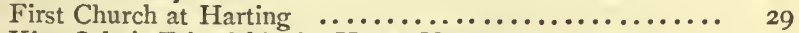

King John's Friendship for Henry Hussey ............ 30

Harting Church Restored and Extended temp. Hen. III..... 32

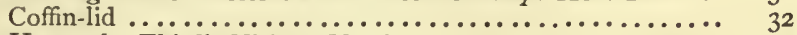

Henry the Third's Visit to Harting ................ 33

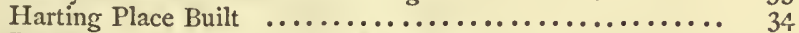

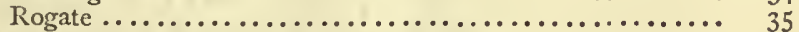

Richard de Wych and St. Richard's Hill ............. 36

Edynton, Rector of Harting .................. $3^{8}$

Richard de Herton, Wykeham's Schoolmaster ......... 39

Surveys of Harting temp. Ed. III.............. 40-48

Sir Henry Hussee at Rouen after Agincourt .......... 49

Cardinal Pole ............................. 50

The Windsor Family ........................... $5^{\text {I }}$

Chap. IV.-The Fords .................... 52-I05

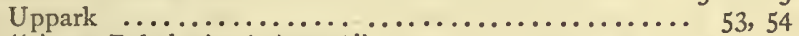

"Away Babylonian! Away!".................. 55

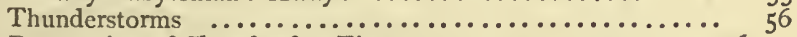

Restoration of Church after Fire $\ldots \ldots \ldots \ldots \ldots \ldots \ldots \ldots, 56,57$

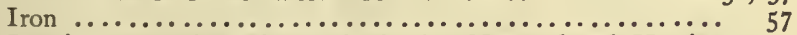

Inquiry concerning Waste of Wood at Nywood and Harting

Combe ........................... $57,5^{8}$

Woolmer's Bridge and Sheet Bridge $($ note $) \ldots \ldots \ldots \ldots \ldots \ldots . . . .59$

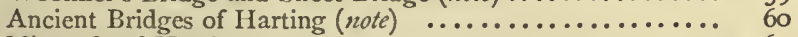

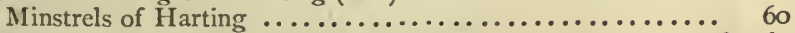

Farmers in Sixteenth Century at Harting .......... 6 r, 63 
Ford and Fortescue $\ldots \ldots \ldots \ldots \ldots \ldots \ldots \ldots \ldots \ldots, 66_{3,64}{ }^{{ }_{\text {AGE }}}$

Posy Rings .............................. 64

Sir Edward Caryll ........................ 64, 65

Mercy Pope.............................. 65

Derivation of the name "Caryll" ................. 67

Kitchen Book of Harting Place $\ldots \ldots \ldots \ldots \ldots \ldots \ldots \ldots .69$

Murder at Hale Wood, near Lady Holt, I601 .......... 7I

Sir Edward Ford $\ldots \ldots \ldots \ldots \ldots \ldots \ldots \ldots \ldots \ldots \ldots, \quad 7 \mathrm{I}-88$

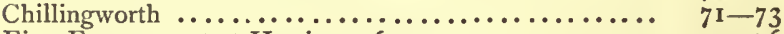

First Engagement at Harting, $1643 \ldots \ldots \ldots \ldots \ldots \ldots$ 74-76

John Caryll, loyalist (John Caryll I.) ............. 77

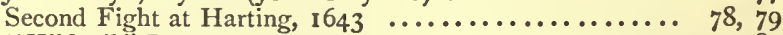

"Kildevil" Lane .............................. 8I

"Amens Plenty" .......................... 81

Misery of Harting in the Civil War $\ldots \ldots \ldots \ldots \ldots \ldots .628$

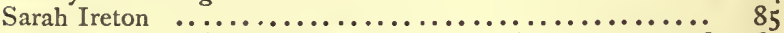

Sir Edward Ford's Inventions, Death, and Character... 85-89

Ford Lord Grey, afterwards Lord Tankerville ....... 89-103

Earl of Berkeley ......................... 91

Uppark and Ryehouse Plot $\ldots \ldots \ldots \ldots \ldots \ldots \ldots \ldots \ldots . . \ldots 9 . \ldots$

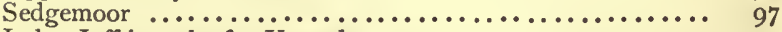

Judge Jeffries asks for Uppark .................. I I00

New Uppark (the present Mansion) built $\ldots \ldots \ldots \ldots \ldots \ldots$ IoI

Blacksmith's Forge (note) ..................... 102

Death of Ford Lord Grey, Lord Tankerville ........... I0 3

CHAP. V.-The Carylls....................... ${ }_{0} 3$

The Caryll Manuscripts (British Museum) ............ I04

Secretary Caryll (John Caryll II.) ............. 103-120

"Rape of the Lock" not suggested by the Secretary ..... I06

Lord Cutts takes possession of West Harting Estate........ I09

Steele's acquaintance with the younger Caryll (the "Squire") I I

Lord Cutts bought off by the young "Squire" ....... I I 2, I I 3

Letters of James II. and his Queen to the Secretary .. II4-II9

The Secretary's Death and Pope's Epitaph............. I I 9

A Jacobite Edition of Esop's Fable (note) ............. I 20

Chap. VI. -John Caryll III., the "Squire" and Friend of Pope I2I-I6I

Date of Building of Lady Holt $\ldots \ldots \ldots \ldots \ldots \ldots \ldots$ I 2 I $-\mathbf{I} 23$

Terwick Register..$\ldots \ldots \ldots \ldots \ldots \ldots \ldots \ldots \ldots \ldots \ldots \ldots \ldots$

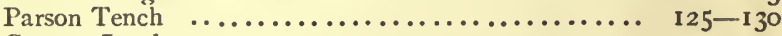

Cannon Lands....................... 125

Oliver Whitby, sen., Patron of Harting Vicarage ........ 127

A Fancy Valuation of the Vicarage (I7II) ............ I29

Mrs. Cope .......................... I I0-13I

The Squire's Apology to his Uncle for being in Debt .. I I32-I34

The Secretary's Will ....................... I35

Pope's relations with John Caryll "the Squire" 
Wedding of the Squire's Son (John Caryll IV....... .9 PAgk

Peter Mee and the Hattons

Pope's Iliad ............................... I39

Pope and Gay at Lady Holt .................... I40

Pope and the Smuggled Wine from Lady Holt .......... I42

Death of the Squire's son (John Caryll IV.) by Small-pox .. I44

Mr. Roper, Lessee of Lady Holt ................... I44

The Squire's letter in French and Latin to his little grandson

(John Caryll V.) ......................... I 45

Parson Newlin and his child Mary............. 146-1 52

Dr. James Bramston ...................... I 53

Deer ................................... I 54

Fish at West Harting Pond .................. I 55

"Collin's Lane" ...................... I56-166

Richard Cobden Malster ................... I57

The Squire's verses on his own life $\ldots \ldots \ldots \ldots \ldots \ldots \ldots \ldots$ I 58

Last letter of Pope ........................ I60

Squire's Golden Wedding, Death and Character ...... I60, I6I

CHAP. VII.-End of the Fords and Carylls of Harting ... I 162-206

Mr. Tench's fee at Lord Ossulton's Wedding ......... I62

Oliver Whitby, jun., and his Bluecoat School ....... I62-I64

Collins the poet...................... I66-I69

Uppark sold to Sir Matt. Fetherstonhaugh .......... I I I

Lady Mary Caryll and her Son's (John Caryll V.)

wedding .......................... I $72-$ I 77

Coal dug for in Harting Combe ................. I 78

A virago amongst the boys at Cricket .............. I80

A battle for the living of Harting................ I 82

Death of Lady Mary; her Character ............ I85, I86

Caryll deserts his sisters ..................... I87

Arms at Lady Holt seized ...................... I 89

Dr. Hunt ...................... 190-195; 202

Fishing of West Harting Pond................. I93

Petersfield Pond ............................. I95

The Smuggler's Murder, Lady Holt ............. I95-I 98

Mr. John Rickman, late Clerk of House of Commons ...... I97

Caryll's Aunt Benedicta claims her Debt .......... I99-200

Sale of Lady Holt ........................ 202

Exile and death of the last Caryll (John Caryll V.).... 202-204

Lady Holt demolished ....................... 202

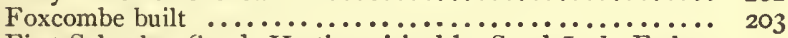

First School at South Harting visited by Sarah Lady Fether-

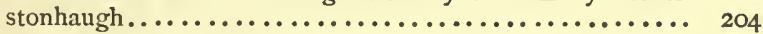

Chap. VIII. - Odds and Ends ................ 206-230

Gilbert White and Oliver Whitby ............. 206-208

"Severals" ................................ 207

The Miller's daughter at Harting (I 780) ......... 209-2 I I

The Hero of Five Godfathers acquired in a Stag-hunt ..... 2 I I

Sketch of Harvester's life at the end of last Century.... 212, 213 


\section{viii}

Timothy Luff, a Wizard ; Superstitions ........ 215-2I8

Population ............................. 2 I9

Conjectured Meaning of some local names ........ 22I-224

Great Well at Lady Holt, and others in Upper Chalk 224-226

Ancient Family of Cowper and Coles, Ditcham ..... 226, 227

Fears of French Invasion .................. 228, 229

Wellington Correspondence, Uppark ........... 229, 230

\section{NATURAL HISTORY OF HARTING.}

Chap. I.-Quadrupeds ........................ 233

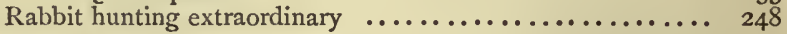

Chap. II. - Birds .......................... 252

Hen's Egg $\ldots \ldots \ldots \ldots \ldots \ldots \ldots \ldots \ldots \ldots \ldots \ldots \ldots \ldots \ldots \ldots \ldots \ldots{ }_{27}$

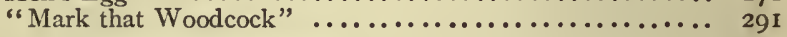

CHAP. III.-Reptiles and Fishes................... 296

Monster Carp ............................ 304

CHap. IV.-Slugs and Snails ................... 307

Musical Snail ........................... 3 I 5

CHaP. V.-Insects. - Beetles .................... 324

CHAP. VI. - Earwigs. - Cockroaches, Crickets, Grasshoppers and

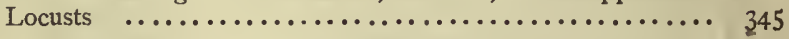

Chap. VII.-Thrips, Lace-winged Flies, May Flies ....... $35^{2}$

Chap. VIII._Bees, Wasps, Ants, and Ichneumons ....... 366

CHaP. IX.-Butterflies and Moths .................. 389

Ghost Story ............................. 404

"Sembling" ............................ 409

CHAP. X.-Frog-hoppers, Plant Lice, Scale Insects, Bugs and

Fleas ................................ 420

Chap. XI.-Two-winged Flies ................... 429

Chap. XII.-Wingless Insects-Mites, Spiders and Cudworms.. 445

Chap. XIII._Flora ............................ 459

Timber Trees ............................. 459

Flowering Plants $\ldots \ldots \ldots \ldots \ldots \ldots \ldots \ldots \ldots \ldots \ldots \ldots \ldots \ldots \ldots \ldots$

Orchids $\ldots \ldots \ldots \ldots \ldots \ldots \ldots \ldots \ldots \ldots \ldots \ldots \ldots \ldots \ldots \ldots . \ldots \ldots 48$

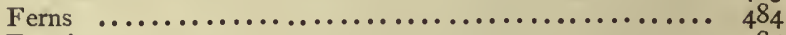

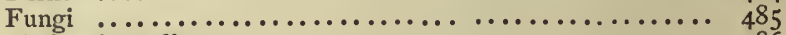

Phallus impudicus $\ldots \ldots \ldots \ldots \ldots \ldots \ldots \ldots \ldots \ldots \ldots \ldots . \ldots \ldots \ldots$ 


\section{SUBSCRIBERS.}

Albery, Edwin, Esq., Midhurst.

Ashwell, Rev. Canon, Chichester.

Anon., Io Copies.

Banham, Mr., South Harting.

Barrow, Rev. J. S., Rogate.

Bompas, G. C., Esq., ro Copies.

Bonham Carter, The Hon. Mrs., Adhurst St. Mary, Petersfield.

Cammell, Charles, Esq., Ditcham Lodge.

Cardew, The Hon. Mrs., East Hill, Lyss.

Carnegie, The Hon. J. J., Fair Oak.

Chase, Charles, Esq., Jewry Street, Winchester.

Chase, Miss Fanny, Petersfield.

Chichester, The Lord Bishop of.

Chichester and West Sussex Natural History Society.

Clarke, Frederick, Esq., St. Mary Cray.

Coles, Mrs., I, Royal Crescent, Weymouth.

Cooper, Mrs. White, I9, Berkeley Square.

Cross, R. S., Esq., Petersfield.

Crossley, H., Esq.

Cruickshanks, Miss, Alverstoke.

Curtis, Mrs., South Harting, 3 Copies.

Curtis, Rev. Edward, Netheringham Vicarage, Lincoln.

Curtis, Robert, Esq., Rood Lane, City.

Deane, Rev. A. M., East Marden Rectory.

De Brisay, Rev. Henry Delacour, Oxford.

Denman, The Hon. R.

Dyne, Rev. J. B., D.D., Rogate.

Earle, Rt. Hon. Sir William, Bramshott Grange, Liphook, Hants, 4 Copies.

Edgell, Mrs., Northend House, South Harting. 
Egerton, Rev. P. R., Warden of All Saints', Bloxham. Ellison, Mrs., Nyewoods.

Fiennes, The Hon. and Rev. Wingfield, Silchester Rectory.

Gordon, Rev. Canon, Elsfield, Oxford, 2 Copies.

Goddard, Major H. N., Cliffe Pypard, Wilts.

Green, Rev. Vernon T., Littlemore Vicarage, Oxford.

Harting, J. V., Esq., Ladymead, Harting.

Harting, J. E., Esq., 27, Carlton Hill, St. John's Wood.

Harting, R. A., Esq., 2, Upper Montague Street, Russell Square.

Harting, J. T., Esq., 49, Priory Road, Kilburn.

Hawker, Mrs., Ashford Lodge, Petersfield.

Hawkshaw, Sir John, Hollycombe, Liphook.

Haydon, Rev. W., Midhurst, Rural Dean.

Heath, Rev. J. M., Milland House.

Hervey, Rev. Frederick, Upton Pyne Rectory, Exeter.

Hill, Mrs. Birnie, Southsea.

Jeffery, Mr. W., Ratham Mill, Bosham.

Jervoise, Sir Jervoise Clarke, Bart., Idsworth.

King, Captain, R.N., Chithurst.

Knight, Miss, Littleacreage, Marston, Oxford.

Langdale, Mrs., Compton Rectory.

Leachman, A. W., Esq., M.D., Petersfield.

Lickfold, Mr., Ryefields.

Longcroft, C., Esq.

Lucas, Mrs., Oaklands, West Lavington, Midhurst.

Luff, Mrs., East Harting.

Medlicott, Rev. W. E., Swanmore Rectory, Bishop's Waltham.

Moore, Miss, The Hermitage, Southsea.

Neville, The Lady Dorothy, Dangstein.

Ogle, Miss, West Denton, Newcastle-on-Tyne.

Parkinson, Miss, Brighton.

Phillips, M. J., Esq., South Harting, 2 Copies.

Porter, Mrs., Huxholt.

Richards, Miss Mary, Terwick Rectory.

Richards, Mrs., Terwick Rectory.

Robinson, Dr., Midhurst.

Shuttleworth, Colonel, Dunannie, Petersfield.

Stephens, Rev. W. R. W., Woolbeding Rectory. 


\section{$\mathrm{xi}$}

Stephens, Mrs., Westcotes, The Parks, Oxford.

Stowe, H. J. D., Esq., Castle House, Petersfield.

Taswell, Rev. G., Stonerhouse.

Taylor, Mr. James, Northchapel, 2 Copies.

Tidey, Robert, Esq., 29, Southgate Road, N.

Tourle, Miss, Midhurst.

Traherne, Mrs., Coedriglan, Glamorgan, 2 Copies.

Ubsdell, H. R. C., Esq., I, Green Row, Portsmouth.

Vincent, Rev. F. A., Elsted Rectory, Petersfield.

Ward, Mr., Ottley.

Weaver, Per J., Esq., 6 Copies.

Wheeler, Cornelius, Esq., Manor House, Wymering.

Wild, Mr. John, South Harting.

Wollaston, G. B., Esq., Bishop's Well, Chislehurst.

Yeo, Mrs. Gerald. 



\section{THE GEOLOGICAL STRUCTURE \\ OF THE PARISH OF HARTING.}

UPWARDS of half a century having elapsed since I became acquainted with the country around Harting, and forty-two years having passed since I described the geological re lations of the western extremity of the great Wealden valley between the South and North Downs,* I gladly comply with the request of the Vicar of Harting, the Reverend Henry D. Gordon, and will endeavour briefly to delineate the main geological features of a parish, in which, through the kindness of my valued friends the late Sir Harry Fetherstonhaugh and his excellent Widow, I have enjoyed so many pleasant days.

I must first beg the reader to cast his eye over a geological map of England, in order to understand that the several formations which I am about to describe, as exhibited in and near the parish of Harting, are simply segments of the several zones of rock which constitute the sides and centre of the great Wealden valley of Sussex,

NoTE.-In I8r5 I married Charlotte, the only daughter of General Hugonin, of Nursted House, in the adjacent parish of Buriton. In 1825 I published the geological memoir, entitled "Geological Sketch of the North-western Extremity of Sussex, and the adjacent Parts of Hants and Surrey."(Trans. Geol. Soc. Lond., 2 ser., v. 2., p. 97.) 
Surrey, and Kent, as subtended on the north and south by the chalk of the North and South Downs, and on the west by the range of the Hampshire hills of Selbourne, \&c. He will then understand that the following is simply the description of one slice across the successive ledges of strata which rise to the surface as you advance from the South Downs to the centre of the great valley.

In taking a bird's-eye view from the lofty ground near the ruined tower in Up Park, the spectator commands within his vision a large portion of the parish of Harting, and sees, in looking northwards, in the distance of little more than five miles only, all the formations, from the Upper Chalk on which he stands, to the Wealden deposit which forms the base of the whole Cretaceous series. These different formations and their subdivisions are exhibited in the accompanying general diagram, and the observer who proceeds from the high road by Up Park, through Harting and Rogate, and thence over the sandstone hills to the valley of Harting Combe, will pass over successively the following strata :-Chalk with Flints; white Chalk passing down into grey Chalk and Chalk marl; Upper Greensand or Malm Rock; Gault clay; Lower Greensand, the upper part iron shot and yellow; the inferior greenish grey; and, lastly, the Weald Clay in Harting Combe. This succession, from the highest to the lowest strata in the district, is given in the accompanying geological section.

As every one of these formations, and even their subdivisions, has a separate stony structure, so the decomposition of each gives to the soil above it a distinctive agricultural character. In consequence, the parish of Harting, for the most part the property of Lady Fetherstonhaugh, embraces a variety of soils very rarely to be found within the same compass.

In the following description the reader is conducted from the highest to the lowest formation in the parish 
and adjacent grounds. He must further understand, that if he extended his research, and proceeded from the valley of Harting Combe, either to the north-west or to the north, he would pass across the same formations, in ascending order, as those over which he has descended; and whether he reached the hills of Hampshire above Selbourne, or the North Downs of Surrey above Godalming, he would again meet with the same Chalk with Flints from which he began his journey at Up Park.

In geological language the intervening depression between these two chalk ranges is called a "Valley of Elevation," because the lowest strata of the region, as at Harting Combe, have been raised to the surface, and have thrown off the formations which once covered them. In other words, the time was, when the Chalk, the Upper and Lower Greensand, and the Gault, were all continuous over this now bare country. The great natural convulsions by which this state of things was brought about were necessarily accompanied by vast deluges of water; and as all the overlying deposits were formed under the sea, so it is supposed (by me at least), that powerful waves of translation necessarily resulting passed over the surface, and removed all the immense heaps of broken materials, which must have been produced by such great earthquakes and upheavings from a common centre of elevation. That such a denudation took place is indeed proved by the fact, that, with the exception of a few very limited patches of broken flints for the most part that lie near the bottom of the escarpments of the South Downs, the great valley of the Wealden has been clean swept, and its flanks nearly so, of all such débris. The exceptions are in this western extremity of the Wealden denudation only, as in the Lower Greensand of Trotton Common, and near the west end of Harting Combe, where patches of broken chalk flints strew the surface. It is from this great denudation that the parent rock is 
so constantly near the surface, and that its decomposition has had, and has, so great an influence on the soil.

The youngest rock in the parish is the Upper Chalk, or Chalk with Flints, which, inclining gently to the south of Up Park and Lady Holt Park, is eventually covered by the Tertiary clays and sands, which occupy all the low maritime tract extending from Bognor to Portsmouth.

The Upper Chalk is named by many geologists the "Chalk with Flints," as distinguished from the mass of chalk beneath it in which a flint is very rarely discernible. The great and central mass, consisting of white chalk becomes less purely calcareous and more argillaceous, assuming a greyish colour in its lower part, as is well seen in the sides of the steep road descending from Up Park to South Harting. At the base of the hill this grey chalk is underlaid by a thin band of chalk marl, much used as a manure for certain soils and crops. The Chalk formation, so constituted from top to bottom, exhibits the same structure in its range, whether we proceed to Butsor Hill* on the west, or to the Brighton Downs on the east.

As a whole, the Chalk formation is a great absorbent of the rain-fall on the hills, the water of which penetrates downwards through chinks and fissures, until it is held up by the tenacious chalk marl ; and hence, at Harting, as at Buriton on the west and at numerous places to the east, a series of ponds of crystal clear water is formed.

At the mansion of Up Park, long the residence of Sir Harry Fetherstonhaugh, Bart., and now the property of his relict, standing upon the Chalk with

- Note.-Butsor Hill is 990 feet above the sea, and is the highest point of the adjacent South Downs. The tower at Up Park is about 690 feet. Boundary of the Park at Two Beech Gate, 646.6 feet. Spithead Bench, 672.5. Near north end of Kill-devil Lane, 626.8. Beacon Hill, the eastern boundary of Harting parish, over 790 . The Leith nearly 1000. 
Flints, and at an elevation of 650 feet above the sea, water was only reached by sinking a well to the depth of 250 feet. To have rendered this supply useful would have been most costly and irksome, and hence the water which gushes out from the base of the hill near Harting was turned to account for working an ingenious but simple mechanical contrivance, by which water is thrown up, by the action of an overshot wheel, from the valley to the summit of the hill.

In its range to the east, as to the west, the Chalk formation of the South Downs is charged with numerous marine remains of various groups of animals, whether zoophytes, mollusca, or fishes, though few have been found in the escarpment south of Harting and the hills of Up Park. On the whole, the following species of fossils characterize the Upper Chalk:Inoceramus Brongniarti, Lima spinosa, Ammonites Lewisiensis, Nautilus radiatus, Belemnitella mucronata, and the fishes Beryx Lewisiensis, and palates of Ptychodi.

As might be expected from the scanty covering of soil, the hills consisting of chalk with flints are most favourable to pasture, and it is on the short, sweet bite of the grass that the far-famed and fine-shaped South Down sheep are reared; whilst the lower parts of the undulations of the same rock, as at the Castle Farm and Huck's Holt, where the soil is mixed with flints, yield fair crops of barley, turnips, \&c.

The Lower Chalk and Chalk Marl are distinguished from the Upper Chalk by containing the following well-marked species:-Inoceramus Cuvieri, I. mytiloides, Pecten Beaveri, Pholadomya decussata, Pleurotomaria perspectiva, Ammonites Mantellii, A. variolaris, A. Rhotomagensis, Nautilus, pseudo-elegans, Turrilites tuberculatus.

It is, however, when we reach the next formation beneath the Chalk marl, as spread out in a broad plateau of about a mile and a half in width, that we 
find ourselves upon lands which constitute the real wealth of the parish, i.e., upon some of the finest wheat soils of the kingdom. This soil is literally made up of the decomposition of the rock on which it lies, i.e., the Malm Rock or Upper Greensand of geologists. The name of "Upper Greensand," though well applied in Wiltshire, is wholly inapplicable to it in the parish of Harting, or, indeed, in any part of its range from Weston and Nursted on the west to the sea near Eastbourne, i.e., all along the escarpment of the South Downs. Far from being a sandstone, this rock is highly argillaceous, and yields a very stiff soil. Examples of it are seen in the sides of numerous deep lanes and natural ravines, and of the latter the low cliffs on either side of the narrow dell called the Mill Hanger, so renowned for its preserves of pheasants. A clear section of the strata, showing how the Malm Rock is surmounted by chalk marl and the lower chalk, is exhibited at the north end of Tarberry Hill. This is a singular narrow promontory of chalk, which protrudes and stands out from the escarpment of Harting Warren and the Side Hills. Lying upon the plateau of Malm Rock, it is what geologists call an "outlier," since between it and the main range of the hills, the chalk has been worn away or denuded to its base.

The upper beds of Malm Rock are the most chalky in appearance, but in some central parts of the deposit the grey colour gives way to a bluish tint, and in these cases the stone is more compact, and hence preferred as a building stone; the ordinary grey Malm Rock being of a very decomposing nature. Composed of clay, sand, and lime (the first predominating), the best soils are those where there is a due admixture of each, and particularly where the calcareous matter reaches 25 to 30 per cent. of the mass; this soil, though very tenacious, is highly fertile in the production of wheat, clover, beans, \&c. On the whole, there is a striking 
unity of composition in this soil, whether we examine it in the farms of South, East, and West Harting, or in the adjacent lands of Nursted.

The formation beneath the soil has a thickness varying from 80 to I 20 feet, as known by the wells sunk in it, for, just as the water which percolates through the chalk is held up by the Chalk Marl, so is that which sinks by fissures through the Malm Rock, sustained by the argillaceous shale or clay beneath it, which, in geological language, is termed the "Gault."

The fossils of the Malm Rock which are most common were formerly enumerated by me as Ammonites rostratus, A. varians, Pecten orbicularis, Gryphæa vesiculosa, Avicula, with forms of the Sea Urchins, Echino spatangus, and portions of fishes. In other tracts, and where the formation is sandy, it affords a vast quantity of organic remains. Among which the following may be cited as most characteristic:-Pecten asper, Exogyra conica, Cardium gentianum, Panopœea plicata, Solarium ornatum, Nautilus elegans, N. Fittoni, with numerous Sponges, Ventriculites, \&c.

In some parts of England, particularly in Cambridgeshire, remains of fishes, including their excrement, called Coprolites, so abound in this Upper Greensand or Malm Rock, that these, mixed with other animal matter, constitute a phosphatic manure of high value to the proprietor; but the paucity of such fossil remains in the district under review forbids the anticipation of any discovery of this source of wealth in or near the parish of Harting.

In proceeding northwards down Bohemy or Bohemia Hill, the student will observe that the Malm rock becomes gradually darker-coloured and more argillaceous, and that at the bottom of the hill it passes into a pure, stiff, blue, shale clay, which is the Gault Occupying a zone of about a mile or more in width, this clay, usually free of all superficial foreign cover, or flints and gravel, is as continuous all around the 
great Wealden denudation as the Malm Rock or the Chalk above it. Everywhere, in short, whether in the parish of Harting, or in that of Buriton on the west, and of Elstead on the east, it yields grass and trees only, and is scarcely ever turned into arable land. In short, the outline of the Gault is everywhere marked as enclosed between the grey Malm Rock above it and the yellow and white sands on which it lies. Fine specimens of the meadows on this formation are those of Down Park; and it is by this same clay that the adjacent large ponds, the property of Lady Fetherstonhaugh, are held up. The woodlands called the Severalls are also on it. Houses are rarely built on the Gault; and if people value good health, and eschew rheumatism, they would never live on this retentive clay, which is only suitable for fattening bullocks and raising oaks.

Though rare in this parish, fossils occur in great abundance elsewhere in the Gault, and notably at Folkestone, where the Ammonites dentatus, which I have found in West Sussex, is associated with Plicatula pectenoides, Inoceramus concentricus, I. sulcatus, $\mathrm{Cu}$ cullæa fibrosa, Nucula pectinata, Dentalium decussatum, Rostellaria carinata, Natica Gaultina, Ammonites splendens, $\mathrm{A}$. tuberculatus, $\mathrm{A}$. interruptus, and Hamites intermedius.

The junction of the Gault with the upper beds of the Lower Greensand is admirably exposed at the Kilns to the right of the road that runs between Down Park and the Ryefield Farm, where the contact of clay and sand has led to the manufacture of bricks. There the sands, both ferruginous and pure white, rise up from beneath the Gault to form the beautiful low hills called West Heath, the most northern portion of the Up Park estate, and distant from the mansion upwards of three miles. A very instructive section of these sands is exhibited on the side of the road as you advance to the valley of the Rother; 
and they are in parts so fine and incoherent, and of so purely white a colour, as to be used by ladies in washing. In a recent cutting of the railroad from Petersfield to Midhurst, which passes by the north side of West Heath, a rich argillaceous ironstone, found by Mr. Buxton, exhibited on its surface small circular cavities in pairs, evidently the work of a marine worm or annelid, together with casts of, probably, the remains of seaweeds. In many other places the ferruginous structure of this band is very conspicuous. This is well seen on the side of the road from Petersfield to Midhurst, particularly to the east of the latter town, where the ironsand assumes singular concretionary forms. Where the black oxyde of iron prevails, the stone found in this layer rings under the hammer, and is the clinkstone used in road making.

It is on the western termination of this ferruginous portion of the Lower Greensand that the town of Petersfield stands. There the geologist has only to explore southwards to Butser Hill, or northwards to the Froxfield Hangers, and he passes successively upwards over all the formations I have enumerated to the Chalk with Flints inclusive; the pointed mass of sandstone at Petersfield being wrapped round to the north-west and north by the confluence of the younger. formations of the Gault, Upper Greensand, and Chalk.

The fossils of this upper band of the Lower Greensand are not numerous hereabouts. In other tracts, as at Parham Park, the following are characteristic - two or three of them, however, were found by me many years ago on the commons north of Petersfield :-Gervillia acuta, Trigonia alæformis, Cytherea (Venus) parva, Panopæa plicata, Cucullæa decussata, Thetis Sowerbii, Modiola æqualis, Tellina æqualis, Cyprina angulata, Rostellaria Parkinsonii, Ammonites dentatus.

Though not exhibited in this neighbourhood, the calcareous conglomerate called Bargate Stone, occasionally burnt for lime, and abundant near Godalming, 
in Surrey, lies at the base of the upper zone of the Lower Greensand.

To render the geological description complete, we must quit the parish of Harting, and, entering that of Rogate, continue our little trip to the north. By so doing we pass over other and inferior members of the Lower Greensand until we reach the Weald Clay of Harting Combe.

The river Rother, on which is placed Fair Oak, the seat of the Honorable J. Carnegie, runs from west to east, between the higher or Petersfield and Shanklin sand; and the next lower portion of the formation, or the Sandgate beds of Kent, is the Rogate Sandstone of this tract. To the north other and inferior strata rise into hills of some altitude, on the southern slopes of which are situated the country houses of Rogate Lodge and Dangstein. It is in this portion of the formation that the greater number of fossils occur, particularly near Hythe in the so-called Kentish Rag at Maidstone and Seven Oaks. The following are typical forms :-Perna alæformis, Pinna crassa, Trigonia spectabilis, Trigonia alæformis, Corbis corrugata, Astarte obovata, Cyprina angulata, Pholas giganteus, Ammonites Nutfieldiensis.

There are thin layers of clay in both the sandstones above described, which serve to hold up lines of ponds, as at Petersfield, Sping, Woolmer Forest, \&c.

The hills which constitute the escarpments of the valley of Harting Combe are composed of a sandstone, a variety of the Kentish Rag, which is no longer so ferruginous as the upper portion of the deposit, green grains being abundant in the body of the rock, which constitutes an imperfect building stone, and becomes more and more argillaceous as you descend into the valley.

Farther to the east, i.e., at Petworth and beyond it, this standstone is a more compact building stone, though affording few fossils here.

The bottom bed of the Lower Greensand is a zone 
of dark clay, which was formerly, from its mineral character, not distinguished from the subjacent Weald Clay, but is now clearly recognized to be very distinct, and to represent the Atherfield rocks of the Isle of Wight, and the lower Neocomian of foreign geologists, i.e., the lowest of all the marine deposits of the Cretaceous age.

Though I do not believe that as yet any fossils of this zone have been detected in Harting Combe, I have observed them in great quantities near Haslemere, where the railroad has been cut through this same zone. of clay.

The fossils are all marine, viz. :-Gervillia anceps, Ostræa frons, Perna Mulleti, Trigonia dædalea, T. caudata, Venus parva, Panopœa Neocomiensis, Rostellaria Robinalbina, Pteroceras Fittoni, Ammonites Deshayesii, A. Martini, A. Hambrovii, Crioceras Bowerbankii, and Ancyloceras gigas.

The agricultural characters of the Lower Greensand necessarily vary considerably in its several parts. Thus, in the uppermost portion we find West Heath yielding little more than heather and ferns, while the adjacent farm of Ryfield produces excellent barley, root crops, and fine grass. Indeed, the character of a good loamy soil characterises this zone all along the course of the Rother to Habing Bridge and Trotton.

On the other hand, the lower portion of the formation, which rises into the commons of Rogate and Vining, and constitutes Holder Hill, is usually sterile and heathy.

In descending from the hills of Rogate and Vining Commons to Harting Combe, we reach the Weald Clay, the lowest formation to be seen in our downward exploration from the summit of the South Downs. Let me here remind the reader that he will pass over the very same strata downwards if he proceeds from the Chalk of the North Downs across the Lower Greensandstone of Hind Head, or from the Hampshire 
plateau above Selbourne, across Woolmer Forest, to this same valley of Harting Combe.

Unlike all the formations which cover it, the Wealden is a fresh-water deposit, or one which was formed at the mouth of some great marshy river, inasmuch as it only contains shells of fresh-water origin, and fragments of bones which belonged to great aquatic and terrestrial lizards. It is the upper portion only, however, of the vast deposit, which, having this character, and occupying the larger portion of the Wealden of Sussex, Surrey, and Kent, has its nether termination in Harting Combe. All the lower part, consisting of alternations of sands and clays, constitutes what was formerly called the Hastings Sands; and in their range to Crowborough Beacon and Pevensey Bay they are marked at intervals by strong bands of sandstone, as at Horsham, Tunbridge Wells, Hastings, \&c.

This whole series, from the base to the summit, is eminently ferruginous; and even in the little nook of Harting Combe, as at Lynch and Redford, when I first examined the tract in 1824, the old slag of the iron furnaces was used as a road material-having been found where the ore was smelted with the charcoal resulting from the burning of the wild forests of this "Anderida" of the Romans.

The uppermost or purely argillaceous member of the Wealden, particularly where the valley widens between the promontories of Green sandstone of Black Down on the north and Holder and Bexley Hills on the south (points all visible from the hills of Up Park), is characterized by containing at intervals the shelly limestone called Petworth Marble, and in which the shells of the Paludina fluviorum are often covered with layers of compact clay or shale, replete with the minute white bivalve crustacean called cypres faba.

It would lead me too far from the interest attached to the parish of Harting and its immediate neighbourhood to discourse at greater length on the structure of 
the Wealden deposits, or those which surround and overlap them, whether on the north, west, or south. It suffices if I have by this brief sketch so placed the subject before the general reader that he may see at all events how intimately the agriculture, drainage, and well being of the district are based upon its geological structure.

Those persons who wish to pursue their geological enquiries as respects this region must consult the important Memoir of my lamented friend, the late Dr. Fitton, in which they will find a full account of all the rocks mentioned, not only as respects this tract, but all the region in and around the Weald, and extending over the south-east of England, with accurate lists of their fossils, and descriptive maps and sections.*

Lastly, I specially recommend the reader to provide himself, at small cost, $\uparrow$ with a copy of the geological map of the tract in which he may reside-for, as I have been the Director-General of the Geological Survey during the last eleven years, so I have had the truest satisfaction in seeing that the maps finished by my associates have so well illustrated that very part of England in which my geological researches began.

\section{RODERICK I. MURCHISON.}

Jan. 3,1867 .

- See "Trans. Geol. Soc.," Lond., 2nd ser., Vol. IV., p. Iо3. + Stanford, Charing Cross. 


\section{THE HISTORY OF HARTING.}

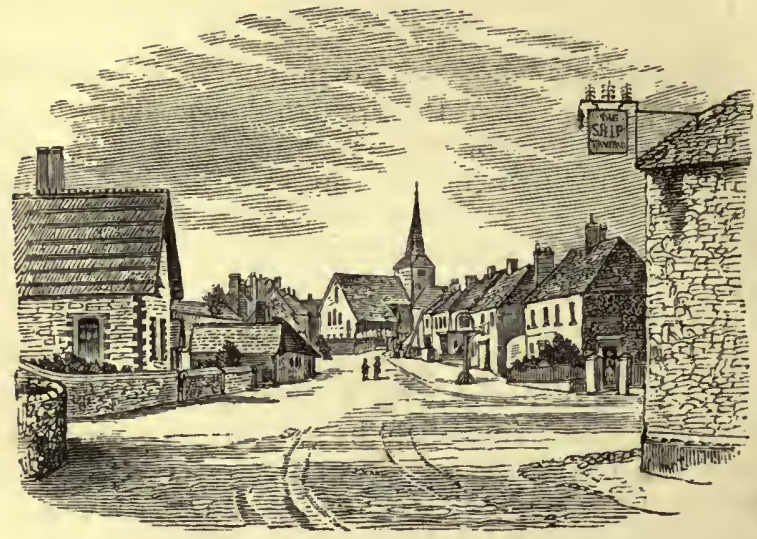

CHAPTER I.

THE habitable part of the village of Harting, co. Sussex, may be roughly described as a wedge driven from the north side upon the head of that great coiling serpent, the South Downs. Of this wedge South Harting Church is the point, and East and West Harting the two sides: the base is made by the Midhurst branch of the London and South-Western Railway.

The Church stands on a knoll which is the highest point of the lowlands under the downs, a spot of singular beauty. To the west is a large natural amphitheatre of hanging woods, continued by the curve of Hemner and Tarberry, two outlying Downs trending to the north, which are separated by a raised causeway, and form a western gate of the hills. This 
circuit embraces ancient park lands of inexhaustible fertility. At the centre, as you look south from the Church, is the steep ascent to the far-famed Up Park; to the left is another winding road to Chilgrove and Chichester, which converges at the foot of a hill a mile long with the road to Up Park. Two separate streams of beeches are thus brought together; and, near the spot of their confluence, two sweet and abundant springs of the purest water arise to feed the Rother. To the east the downs are open, a wide expanse "on which the sea breezes of the Channel seem to come forth to sun and dry themselves;" on the table land below is another amphitheatre to the east, while in the far distance the range of the South downs is seen winding its never-ending curve against the horizon, and throwing its graceful folds upon a rich plain.

Secure on all points to those who could command the Southern hills, there could be no more beautiful bower in England in which to found a home. Doubtless what determined the first choice of the spot for habitation was the constant supply of water, so necessary for man and beast, so important in time of war, and so useful for obtaining motive-power for early machines, which was here provided at what was called, at least as early as Edward the Third's reign, "Typut's Well," when it supplied the Lord's mansion at South Harting. It still has its local memory in an adjacent lane called Typper lane. For miles to the south there is no natural supply of water; and the well of Lady Holt, not sunk till the end of the I6th Century, is 240 feet deep. The villages and hamlets in this country were formed in two military lines for defence against the lawless inhabitants of the Weald on the north. A first line, made at the foot of the downs, would strike Buriton, Harting, Elsted, Treyford, Didling, Bepton, Heyshot, Cocking, and Graffham : a second parallel, about three miles to the north, flanking the Rother, gives the position of Sheet, 
Rogate, Terwick, Trotton, Chithurst, Iping, Stedham, Woolbeding, and Midhurst.

Of all the surrounding northward country as far as Harting Combe, the old mansion formerly adjoining Harting Church was the Lord's citadel and stronghold. In modern times this was called "Harting Place," * but in Edward the Third's time "Tullecombe" Park. $\dagger$ It was in the centre of that beautiful scenery south of the Churchyard that the great Norman barons, the Husseys, settled their homestead, and encased and rebuilt the older church which they found on the spot. The only direct work for God, the Church, still survives, and gives us the history of our village in Henry the Third's reign written in stone.

- It was suffered by the Carylls to decay, and entirely removed before 1777 .

† Close, 6 Ed. III.: "Hen. Husee and Isabella had a park in Herting called Tullecombe, belonging to the manor of Herting, with a watermill in the said park" (probably between West Harting pond and Down Park). 


\section{CHAPTER II.}

HARTING BEFORE THE CONQUEST.

What traces of former inhabitants did the Husseys find here on their arrival?

The Britons and Romans clung to the heights, and apparently cleared very little of the lower ground, which was part of the great forest which the Britons called Coit Andred, and which afterwards assumed a Latinised form of Sylva Anderida.

The conical hill of Tarberry, the barrow of the tor or point, still carries its Celtic name.* It has a clear trace of a foss on its south side, as though it had been taken and occupied by the Romans. Seen from the plain about South Harting, Tarberry assumes the form of a ship turned keel upwards. On the western or Petersfield side it has the shape of an inverted spoon; one local legend being that the Devil, rejecting the scalding spoon from his "Punch bowl" at Hinde Head in Surrey, threw it over to Sussex, when it alighted here bowl upwards. Seen from the direction of East Meon, Tarberry has the remarkable appearance of a large altar stretching across the sunrise. On its height there is supposed to have been a British settlement, and perhaps a town. The misletoe still grows upon some of its oldest trees, and at its foot, on the north side, is a field called Cannicombe, which the Normans seem to have christened Chené-combe, "the Coombe of the Oak grove." There are also many yews here. A very old oracular saying of double meaning is still repeated by the peasants :-

- Other British names are Caergasson (so registered in Caryll accounts, now "Gastons"), Dyddyths, \&c. : thus Treyford-the village on the road. 
"Who knows what Tarberry would bear, Would plough it with a golden share."

Sir Roderick Murchison, with characteristic Scotch caution, interpreted the couplet as meaning that it would cost a man a golden share to plough Tarberry because the soil on the brow was so hungry, and that the tiller would be a fool for his pains. But the mysterious saying will bear another solution, and one day a Dousterswivel and Sir Arthur Wardour, most likely from America, may yet dig for treasure on Tarberry. The lines have, at all events, from their ambiguity a curious smack of antiquity about them, and may be compared with the saying about Cuckamsley, near the Vale of the White Horse, current at the beginning of the I I th Century, to the effect that

"If the Danes got up to Cuckamsley,

They never again would go to sea;"

or the Roll right șaying (Camden's "Britannia," 295) :-

\section{"If Long Compton thou canst see,}

King of England thou shalt be."

Such couplets were probably rhymed long after the sentiment that they record was expressed, in order to aid the memory.

Through the kindness of Mr. Weaver, of Up Park, I am able to mention that he has a small British silver coin which was ploughed up more than 40 years ago in one of the fields of Church Farm, part of the ancient demesne and probably first-cleared land, in the immediate neighbourhood of Tarberry.
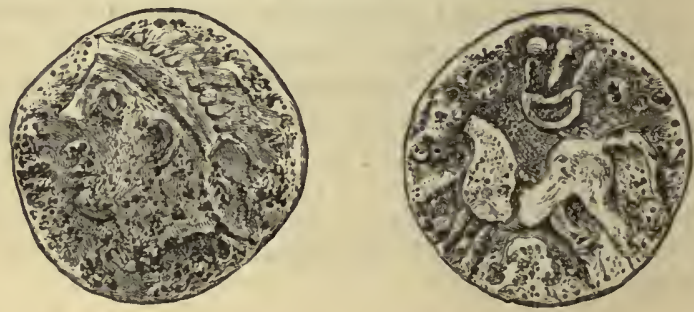
Mr. Evans pronounced it to be " a coin of Verica, a son of the Commius mentioned by Cæsar, whose dominions appear to have comprised Sussex." Mr. Evans adds that he was unacquainted with the type when he published his "Ancient British Coins" twelve years since.

At Denshire meadow, near Hill Ash, on the northwest of Tarberry, a very beautiful flint axe was discovered in 1873 , and shown to me by Mr. Knight, of Hill Ash. There are visible traces of Barrows under Beacon Hill, in Up Park, at Foxcombe, and on West Harting Down.

Tarberry corner, where four roads meet, and where for many generations those who laid violent hands upon themselves were buried, is a famous haunt for ghosts. Some years ago a man returning from Petersfield in the dusk, saw an apparition here which made him quake. He groaned, fell on his knees, "said his prayers sharp," and when he came to the end of the Lord's Prayer, to his horror the spectre advanced to meet him. It was a jackass! On the summit of Tarberry are "Pharisees" (fairies') rings, the simple folk say; and the "Pharisees" dance there on Midsummer's night. These blundering superstitions are veritable specimens of old Sussex folk-lore.

The Romans seem to have kept to the southern line of our hills. On a level platform of about half an acre, just under the east wind on the western escarpment of Beacon Hill, the moles have turned up several. pieces of pottery. At another point, about a mile due westward on the downs, in a field called "Hemner field," a small brass Roman coin was found a few years ago, and given to me by Mr. Tickner. It is the coin of a son of Constantine the Great (Crispus, or Constantine junior), struck at London A.D. 323-330. R Providentia CAESS P. LON.

There is evidence that on or alongside of the Downs between these two points ran what is called in the 
first detailed Survey of Harting, to which we shall hereafter refer (I 7 th Oct., I349), the Akermaincoure, which has a Roman ring in its sound; and four Roman coins of Victorinus have been found at Eckenfields. I have not as yet been able to trace the existence of any other Roman remains connected with Harting.

Of Anglo-Saxon predecessors we have more evidence. Sir P. Burrell (MSS. 5,689, p. 284) quotes from 3 Dugd. Mon., p. I I6, to the effect that "Numa, King of Sussex, was seized of the lordship of Herting." The title of "King of Sussex" would seem to have been a barren honour, for Speed, Book vii., 300, says :- "The Kingdom of the South Saxons, though it began with the first, in the second yeere after the entrance of Hengist, and Ella was their first king . . . . y yet after Ella his death, it was the most obscure of all the rest, had the fewest kings, and the shortest time of their kingdom's continuance. . . . The two last that governed are rather called 'Captains' than kings." It is probable that Numa was king of East and Wêst Harting and of the Combe, and ruler over a few hamlets in the clearings of the great forest of Anderida.

The Saxons, however, undoubtedly gave Harting its name. The nomenclature is unusually varied. "Herotinum," alias "Hertinges," alias "Herting," alias "Harting," (Burrell, 5,689, p. 24,) alias "Hertone," (a pronunciation still kept among the peasants,) as it is written in the Carta de Dureford, I200 A.D. ; and from this last "Hirtum" the medieval and present ecclesiastical and punning name, signifying the "hirsute" or "razorless," on account of its woods.

"With regard to the derivation of 'Harting," "writes Mr. Thomas Arnold, "Lye gives it as 'cervi pascua" (the run of the hart or stag). But this is, I think, nonsensical. I have no doubt, the original forms of the word being Hertinges, Hertingas, Heortingas, that it is a patronymic place-name, like Reading, Barking, Bocking, Bobbing, Brading, and many more. 'Hæort' 
(Saxon for Hart) I have not actually met with as the name of a person, but it seems a very probable one. Ulf, Wulf (Wolf) and Wulfingas I have met with; the first two of which are of course the same as a man's name; the second occurs in. the sense of the 'descendants or kindred of Wulf.' If Heort were the name of some original Saxon invader, some comrade of Elle and Cissa, then the Heortingas would mean the kindred of Heort (the Saxons fought in Mægðe or clans, like the Highlanders), and the lands assigned to them after the conquest of Sussex, where Harting now stands, would naturally come to bear their name. Or, possibly, there may already have been a Mægðe or clan of Heortingas in Germany before the invasion took place, and the whole, or a portion of them, took part in the conquest, and gave their name to the lands assigned to them."

In the time of Edward the Confessor Harting is said to have been returned as 80 hides of land, each hide being sufficient for the maintenance of a family. (Gibbon, quoted by Horsfield, I., 64.)

In A.D. 970, during the long and peaceful reign of King Edgar, under Dunstan's primacy, Harting appears to have been Church land.

Both for security and order the old missionary Bishops seem to have had a regular chain of posts from their Sees, much after the plan of Roman military stations, at certain intervals of their road. These were used as inns and mansions for rest and refreshment, as well as for the refuge of the distressed, and security from the Danes, the still pagan Saxons, or the lawless freebooters of the Weald. Thus there was a regular chain from Canterbury to Mayfield in Sussex, where St. Dunstan built a wooden church; and, indeed, all the way to Land's End the peculiars of Canterbury, about 20 miles apart, extended. By degrees at these Church centres were built churches and palaces, and the work of civilization and husbandry began. It is 
said of the Sussex Saxons that they took their religion hardly: and Bede's words are :- “The whole province of the South Saxons was ignorant of the Divine Name and faith."

Being strong conservatives after their fashion, they clung to their idols with a peculiar fondness and pertinacity, and were only won by Wilfrid, Bishop at Selsey, some 90 years after the rest of England. $\dagger$ When Wilfrid went northward to be restored to York, Le Neve says that from 680-7 I I A.D. the Chichester diocese was administered by the Bishop of Winchester. Thus the chain of the Bishop of Winchester manors, between his sees of Winchester and Chichester, were Droxford, West and East Meon, Langrish, Steep, Petersfield, Buriton, all still connected with the See of Winchester. The line thus formed entered the Sussex woods at Harting and extended to several places round Chichester, and even to Pagham and Slindon, which actually at one time belonged to the See of Winton.

Accordingly, in King Edgar's time, Harting was church land, and belonged to Ethelwold Bishop of Winchester, the chief builder of Winchester Cathedral, and next to Dunstan the foremost man of his day. But as the Sussex see had now bishops of its own to take care of it after the interregnum of 31 years, Winchester appears to have exchanged Harting with the king, probably as outlying and in another diocese, for the minster lands of Ely.

(Kemble Codex Diplom., Vol. V, No. 563, 564.) There are two Saxon charters, the second dated A.D. 970 , relating to this event. No. 563 is a charter operating an exchange of lands between King Edgar and Ethelwold, by which the bishop hands over Harting to the king. Harting is here described as consisting of 60 hides, reduced, owing to Danish troubles,

- Bede iv.-xii. p. 310. † Le Neve's Dignitaries, p. 55. 
from the 80 hides of Edward the Confessor's survey (see Domesday), and measuring half-way to its still lower point of decline, when in the Domesday survey it numbered only 47 hides. The charter specifies "pone hám Heartingas on sixtigum hidum ("the estate of Harting containing sixty hides')" as exchanged "wið $\gamma a m$ mynsterlande $\gamma e$ lið into Elig ("against the minsterland that lieth at Ely')." The King grants to Ethelwold the lands of Ely for the purpose of the re-establishment of the monastery there, together with "jryhamas (three estates), Mildeburna, Earmingford, and Norðwold," and ten thousand eels ("eel-fixa =eel fixings,") from "æt-wyllan" (some wells somewhere), besides various rights of jurisdiction and the fourth penny on the taxes due from Granta-briege (Cambridge). The old abbey lands at Ely having been long desolate after the Danish raids, had naturally come into the possession of the Crown; so that Ethelwold, the great church-builder of his time, exchanged Harting with the Crown in order to rebuild the monastery at Ely. In charter No. 564, dated 970 A.D., the same transaction is referred to, and the place is spelt in its usual medieval form "Hertingas."

The name of "Canon Lands" near Bohemia Hollow, the only 23 acres out of nearly 8,000 that are tithefree by ancient prescription, possibly recalls the time when the See of Winchester had possession here.

The manor of Harting thus taken in exchange by the Crown in 970 was, we are told in the Domesday record, assigned to Gytha or Gida, mother of King Harold; and thus formed part of the possessions of royalty at the time of the Conquest.*

- Gida or Gytha, sister to Suane (Sweyn) King of Denmark (Burrell 5689, p. 284), 2nd wife and widow of Earl Godwin, mother of Harold, possessed some 39,000 acres of land, the greater part of Kent and Sussex. She lost three sons at Hastings, Harold, Gurth, and Leofwine. Sir H. Ellis (general introduction to Domesday, Vol. II, I17) says that "she died by stroke of lightning in Flanders." 
Immediately after the Conquest Harting formed part of the ample territory in Sussex given by the Conqueror to Roger Earl of Montgomery, who fought in the van at Hastings, and was made Lord of Arundel, Chichester, and some 70 manors in Sussex. It was William the Conqueror's policy in the first critical state of his invasion to secure his retreat to Normandy in case of misadventure, by giving the approaches to the South Eastern coast, by which he had entered England, to his most trusty soldiers.

The origin of the Domesday tax was the Hidegeld, a tax on land against the Danes and foreign invasion. The word "Domesday" is a corruption of "Domus Dei " the house of God, the book being laid up in the King's Treasury, the Church of Winchester. The date of the Domesday survey is 1080 .

Harting is thus mentioned in Domesday Book.

"Hundred of Hamesford, Hertinges. Held by Roger Earl of Montgomery. Countess Gida held it of King Edward (Confessor). Anciently assessed at 80 hides; now cleared for 47 . Arable land 63 carucates* In the desmesne 90 carucates and 128 villani, and 35 bordarii with $5 \mathrm{I}$ carucates. There are 20 servi, and 9 mills of the value of 4 pounds and 18 pence. Grass land ('herbagium,' including downs) 18 shillings, and 30 acres of meadow. Forest of 100 hogs. In Chichester 9 holdings (' hagœ,' building enclosures), value 15 shillings. Of the land of this manor the clerks of St. Nicholas (of Arundel) hold 6 hides, and they have therein 6 villani and 7 bordarii with 3 carucates, and so it was in the time of King Edward (the Confessor's survey). The sum total of this manor in

" "Hide," said to mean "Iooth part," Ed. the Confessor's rating; "a piece of land sufficient for the maintenance of a family ;" about thirty acres of arable land with a due proportion of woodland and meadow attached. "Carucate," Will. the Conqueror's rating, variously estimated at 60 , or 80 , or 100 acres; "as much ploughland as could be farmed by one plough in a year." 
the time of King Edward was valued at 80 pounds, and afterwards at 60 pounds; now its value is 100 pounds."

It is plain from the large assessment of 100 pounds, which one estimate would make equivalent to $£$ I 0,000 of our money,* that the manor of Harting was, in the days of the Conqueror, one of the largest in the county. "Rogate" (says Horsfield ii. 92) "is not particularised in the Conqueror's survey; it was probably, with Terwick, parcel of the paramount manor of Hertinges, and included in the terrier of that Lordship." The extent of the ancient northern bounds of the manor is still preserved in the name of Harting Combe, which belonged to the Lords of Harting till quite a recent date. The lands at Harting were doubtless cleared at a very early time, partly because the place was a stronghold under the hills and very capable of defence, partly because the soil was found to be unusually fertile. The backwoodsmen following their hogs, tapped the soil at various places, and then chose the best for tillage. In the Domesday survey of Harting, there are in all 204 carucates of the lord's land (perhaps 8,000 acres of arable), exclusive of the 60 hides of Church land; for it is probable that the clerks of St. Nicholas served the church. There is a trace of this holding now : Harting Rectory is under the manor of Rogate Bohunte (Sir John Hawkshaw), which has, in this respect, absorbed the manor of Arundel. There are in all I 34 villani (men who farmed small holdings under the lord of the manor, with certain service in sowing and harvest); 42 bordarii (men who performed lower and more service at the lord's board, e.g. the gathering of his fuel, storing his grain, grinding his corn, still, however, having their own holdings); and 20 servi or serfs, who belonged, as slaves, to the soil.

"Windham ("Wiltshire Domesday," 1788) thinks the Norman pound was equivalent to twenty-two and a half times our own. Thus $£ 100$ of Domesday money $=£ 2,250$ in 1788 , but much more now. 
In all, the total of male agricultural population is 216 . The mention of nine hagæ or holdings in Chichester is interesting as connecting our village with that city from the earliest date. Dalloway (xxx. Preliminary) quotes Sir Henry Spelman to the effect that hagæ were houses with shops in them, if they stood in a city or borough. "The neighbouring manors held tenements, houses and shops in Chichester and Lewes. The successive state of warfare frequently made it necessary to seek security in a fortified borough." This would explain the statement of Dalton ("English Travel") that "when William the Conqueror landed in England there were only 100 houses in Chichester," and, accordingly, "that Roger de Montgomery made several additions." He would seem to have reserved nine enclosures in Chichester for his vassals in Harting in case of hard times.

Such was the fair manor of Harting, held by the Montgomeries, as part of the four knight's fees given for suit and service of defending Arundel Castle in time of war. It is remarkable that six hundred years after, Sir Edward Ford, lord of Harting, did defend Arundel Castle, but in vain, against Waller and the Parliamentarians. In West Harting to the present day some pasture land, now occupied by Mr. Stubington, is called "The Knight's Ham."

Harting was possessed by Earl Roger during the reigns of William the Conqueror and William Rufus, for a period of 35 years after Domesday. But when Earl Roger's son, Robert Earl of Belesme, in the year I II5 (the 6th year of Henry I) headed the English Barons in favour of Count Robert the king's elder brother, who had just returned from the Holy Land to claim the crown, the Montgomeries' lands, and Harting amongst them, were confiscated by Henry. The manor of Harting was thenceforth granted by the crown to a more peaceful and popular family, the Husseys, who held it for 434 years. A.D. I I $5-$ I 549. (3rd Ed. vi.) 


\section{CHAPTER III.}

HaRting in the TIME OF the Husseys.

THE variations of Hoese, or De Hoese, Hosatus, Husee, Huse, Huss, Hussey, are all derivable from the name of a place in Normandy, a mile to the north of Rouen, called " La Houssaie," the "Holly-wood."

Thus Froissart mentions Sir Alayne of Houssaye as being, with other Englishmen, at the siege of the Castle of Mount Paon in France. The West Hartinge Leager, or Ledger Book, I632 (Add. MSS., 28, 529, p. 16), says "that a certain Allane Hussey was son to Ravletta, sister by the mother's side to William the Conqueror." This clain of the Hussey family of descent from the Conqueror seems a little uncertain. "The mother of William the Conqueror," writes Mr. Edward Hussey, of Scotney Castle, "was Havlette, or Avlotta, daughter of Fulbert, a tanner of Falaise, said to be ancestor of the noble English family of Grey. Havlette, after the death of Robert Duke of Normandy, father of the Conqueror, married Herlonin, or Harlevin, seigneur de Conteville, and had issue Odo, or Eucles, Bishop of Bayeux, and Robert, Count of Mortaire, but I do not hear of any daughters being mentioned. Probably several of the name of Hussey came over at the Conquest. Gautier Heusè is mentioned in 'Les compagnons de Guillaume a la Conquête de l'Angleterre en 1066,' by De Lisle, and in the 'Nobiliare de Normandie,' by Le Vicomte de Magny. Hubert Huse, who married the daughter of Richard III., Duke of Normandy, and is said by Segar to be ancestor of the Lords of Harting, is also mentioned in Norman records."

The Harting branch of these powerful barons, the 
Husseys, usually bore the royal name of Henry, and, curiously enough, the family lasted here from the days of the first King Henry to the last.

We have seen that the Saxons made a home here, and gave the place a name: the Norman baron made here his mansion and park, and grew his vines, in Normandy fashion, against the slope of the hills.

In Henry the Second's reign, and probably at the date which Leland gives, I I69, the first Henry Hussey, Lord of Harting, founded the Abbey Church of St. Mary the Virgin and St. John the Baptist at Durford, on the banks of the Rother, and also in connection with this Premonstratentian Abbey a house of lepers, called the House of St. Lazarus of Harting. There is a local tradition that this latter house stood in the Culvers at South Harting near the Vicarage, and that its extreme western point is still marked by a thorntree. Although, however, some foundations are still traceable in this field, it is probable that the only house here was the "Culver" * or Dovehouse mentioned in the Survey of Harting made I 347 (of which mention has already been made, and of which a transcript will be given below), and that the Lazar house was near to, and in connection with, the Abbey of Durford. It is not likely that the lord of Harting would have brought the lepers to South Harting, and thus to his own door.

The history of Durford Abbey has been excellently written in the pages of the Sussex Archæological Journal, to which the reader is referred. It was a place of considerable importance, and had a daughter monastery in Wiltshire.

After that its original endowment by the first Henry Hussey had been endorsed by Hallary, and subsequently Seyffrid, Bishops of Chichester, it had a

" "Culver" is the old English for "Dove." In Wyclif's translation of the Bible, Gen. viii. 8, he wrote of Noah, "He sent forth a culver," for "dove." 
royal charter from King Henry II. undated, but attested by witnesses which prove its date to have been between II 8 I and II 89.

The possessions of Durford Monastery in the parish of Harting never seem to have comprised more than about 100 acres at Ryefield, Upperton, Canon Land, and Millcroft. With these lands, and much other property, the second Henry Hussey, ${ }^{*}$ confirming his father's gift, endowed the monks, and "with the wolle of the tithe of cheese," as he says in his charter of gift, "coming from the pasture land of my demesne at Harting (i.e., the grass lands near the Church) except one piece, which belongs to the Church at Harting." (Præter unam peisiam casei quæ ad ecclesiam de Hertinges pertinet.) This is an important entry, as it shows that there was a Church at Harting prior to I 80 , and therefore more ancient than the present early English Church.

The leper house also had a charter from Henry II., granting it a fair of three days yearly at the Feast of the Nativity of St. John Baptist. This charter, also undated, is witnessed by "the Chancellor, and William, my brother." Probably the Chancellor means Thomas à Becket, and if so, the document must be dated before his death in I I 70 .

The reign of Henry II. would seem to be the time of general settlement in this neighbourhood. The terraces of Nursted, of Petersfield, were now for the first time tilled by the monks. Philip le Bel endowed Durford with Ditcham. $\dagger$ The lowlands of Liss were also pastured by another convent, but Selborne Priory was only founded in the reign of King John.

And now the sturdy little borough of Petersfield drew its first breath. The charter of Hawisa, Countess

" "Henricus Hosatus secundus," as he is termed in the charter of Bp. Seyffridd, almost in royal style.

$\dagger$ Ricardus le Bel of Peteresfeld. Grant to Church of Durford of all his land, "De Dicham in Manerio de Mapuldreham," Charter of Durford, f. 89. 
of Gloucester, to the burgesses of Petersfield, is witnessed by Henry Hussey, whose name stands between those of Gwidon, Prior of Sanwich (Sandwich) and William, Abbot of Durford; sixteen witnesses in all. So early was the friendship between Harting and Petersfield, that the former may be said to have had the honour of standing godmother for the gallant little borough.

The next document to be cited is one of yet more considerable interest. It is nothing less than a cheque of King John's, written in the fourth year of his reign, I 203, and drawn upon a certain William de Wilek, his banker, for $£ 20$ in favour of Henry Hussey. Norman Roll, 4 John, m. 6:- "The king to Richard de Willek, We command you to make Henry de la Huse secure (quietum) of $£ 20$, which he owes to the Jews, and that ye cause the bond for the same debt to be given up to the said Henry without delay. Witness the king at Sage (Sagium), 28 January (1203)." * This cheque was no doubt a Magna Charta to Henry Hussey, and it must have been a stupendous wrench to have raised $£ 20$ from King John. Professor Stubbs contrasts Henry III. with his father, King John, in these words: "Unlike his father, who was incapable of receiving any impression, Henry was so susceptible of impressions that none of them could last long. John's heart was of millstone, Henry's of wax." $£^{20}$ in King John's reign may be taken as worth twenty-six times as much now, or $£ 520$ of our money, a royal gift. It is likely that the building of Durford, and the commencement of the Church, and repairs of the mansion at Harting, $\dagger$

- Norman Roll, "Rex Ricardo de Wilek, Mandamus vobis quod quietum esse faciatis Henricum de la Huse de $£ 20$ quas debet Judæis, et cartas de eodem debito ipsi Henrico reddi faciatis sine dilatatione. Teste Rege apud Sagium 28 Januarii."

+ Letter of Rev. W. Morgan, Vicar of Harting, to Sir. W. Burrell, I777, describes Harting place as a dwelling at even an earlier date. "In the time of Henry II. Henry Hussey lived at Harting place, the house near the Church." Burrell MSS., 5689, p. 187, B. M. 
involving extensive work, brought the lords of Harting into the hands of the Jews, the usual bankers of those days, by whose money Cathedral and Castle alike throughout England were built or rebuilt. On the other hand, Henry Hussey's claim on King John would doubtless arise from services to be rendered to the king in his unfortunate Norman war, the order being dated from Normandy. King John assembled his forces for Normandy in this immediate neighbourhood, and, in fact, they embarked from Portsmouth. The king having stopped the mouths of the voracious Jews, Henry Hussey set out on his foreign service, but never returned alive. He would seem to have died in the French war, probably after the disaster on the heights of Les Andelys.

Hayley (Collections of MSS., Sussex II., p. 60I, Add". 6344, B. M.) has the following entry: "In the I 3 th of John (I2I2, the fatal year of John's dethronement), 'Hugh Hose brought to Matthew, Abbott of Durford, ye Testament or device of Henry Hose, his brother, who, with tears and grief of heart at his death, repented that he had disquieted the Monastery, and with tears also begged their pardon, and earnestly besought his heirs that they should permit the monks to hold their lands in peace, whereof discord had been beforetime with them; of this device the said Hugh was a most faithful witness, having the said device of his brother sealed with the seale of Jocelin, the queen's brother, who, by the king's command, brought the body of the said Henry into this land, and ye said Jocelin had the device sealed." This extract shows the special regard for the lord of Harting shown by John and his family, and taken in connexion with the Norman Roll above cited, would tend to show that Henry Hussey was in some office of constant attendance and close personal relationship to the king, much as in after years another lord of Harting, the Secretary, John Caryll, enjoyed the friendship of the exiled James II. 
at the Court of St. Germains. It is interesting, too, to see that John's heart of millstone could sometimes do acts of kindness for his followers. As to the dispute between Henry Hussey and the monks of Durford mentioned above, it would seem to have arisen from the neediness of the Monastery, and, in fact, to have been a contention as to the possession of lands. At an early period the monks had much litigation, and thirty-three years after (33rd Henry III.) were cast in a suit at Lewes brought by one Walter, who claimed to continue his tenancy of Upperton.*

There is a third Henry Hussey at Harting in the reign of Henry III. At this time the narrow old Norman Church in our village seems to have been enlarged into its present Cruciform shape, the round pillars being cut into an octagonal form, and the lanceshaped arches projected. The upper half of a Purbeck marble coffin lid found by Mr. Frank Buckland near the North Porch in 1874, would appear to be of this period. From the fact that there is no ecclesiastical habit about the figure, we may assume it to have belonged to the shrine of the third Henry Hussey, founder of the restored church, but there is no direct evidence of a positive kind. There is a complaint in

- Carta de Dureford, Cotton, MSS., Vespasian E. xxiii., p. 138 :- "Abbas et conventus de Dureford capitales dni. de villẩ de Uptone cum suis ptibuz in mañio de Hertingges ex donacione et concessione Prioris St. Lazari de Hertone, et prædictus Prior feofatus fuit per quendam comitem Arundell, priusquam Henricus Huss vel aliquis antecessorum suorum feofati essent de Manerio de Hertinges. Contigit autem quendam de tenentibus mori, nomine Robertum de Upton. Defuncto Domino Roberto prædictus Abbas tanquam capitalis dominus intravit et dictam terram cum suis pertinentibus seysivit et in manu suâ retinuit. Deficiente hærede ad dictam terram non ven (ditam) postea venit quidam Walteri nomine asserens se esse filium et hæredem prædicti Robi. et tulit breve more antecessorum v. prædictum Abbatem coram justiciariis factum apud Lewes in com. Sussex Anno r. r. Henrici filii Johannis tricesimo tertio : et conquievit prædictum placitum (anglicè, 'gained ye said plea')," \&c., \&c. 


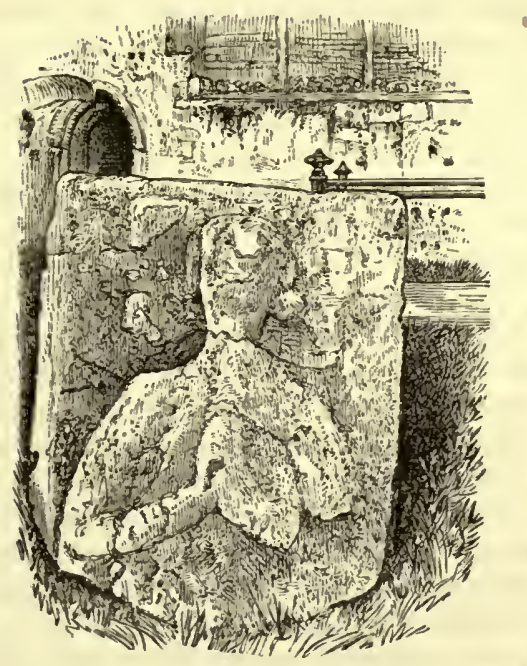

this reign (Rot. Hund. Hen. III, p. 2I2) that, for five years past and more, "Henr' Heusee has obstructed the king's highway in the town of Hertyng to the damage of king and state of $\mathrm{xx}$ shillings a year." This looks as if a good deal of building were going forward, the mansion and church being probably rebuilt at the same time. It is likely that what was soon afterwards known as Harting Place was in its full splendour on July 18, 1225, when it was honoured by a royal visit. The young king (Henry III., in the 9 th year of his reign) had spent the previous day at Bosham, and stayed the I8th of July at Harting on his road to Winchester, where he arrived on the Igth.*

" (Close 9 Hen. III.) “T. R. apud Herting xviii. die Julii." The king dated two charters from Harting on this day. I. Ships of John Wissand and $\mathrm{Ph}$. Glenand of Gravening, laden with wine at Rochelles, seized by Thos. de Haya and Reginald 
It is pretty certain that Hen. III. passed through Harting also once more, in his old age, 44 years afterwards, in 1269 on the 7th and 8th of August, on his way from Guildford to Chichester, probably on a begging expedition. At this time the king's lieges were glad enough to hear of him being anywhere else in his dominions than at their own doors, for he always proclaimed himself the poorest man in the realm, and levied black-mail. In I 269 the king would be entertained by the monks of Durford. Henry Hussey had been in disgrace. Four years before this (1264) he had taken the popular side under Simon de Montfort at the battle of Lewes, ${ }^{*}$ and was " in arms against the king." The treason, however, was soon forgiven, for Henry III's disposition was facile ; and, according to Professor Stubbs, "his heart was of wax." Probably too, the loyal death of the former lord of Harting was not forgotten. In the fiftieth year of Hen. III. (the year following the battle of Lewes, I265), the king granted permission to Henry Huse and his heirs "to build a house, enclose it with a ditch and stone wall, fortify and crenelate or embattle it, wherever they please in the manor of Harting." + Thus Harting Place, or the Park of Tullecombe, as it was also called, $\ddagger$ was rebuilt, fortified with battlements, and

de Bernevall and his brother Thom. Templar, are to be restored with their cargoes.

II. Concerning the Forest of Axiholt. The king's lieges of Aulton (Alton) to have their full pasture rights, secured from trespassers in the forest.

- Burrell MSS. Some land in Harting was called "Mountfort " (vide survey of Harting, I349), probably in remembrance of the Victory of Lewes.

\section{† Close Roll. 50 Hen. III.}

$\ddagger$ Close 6 Ed. III. Hen. Husee and Isabella held a Park in Harting called Tullecombe, belonging to the manor of Harting," with a water mill in the said park. (Probably at Dn. Park.) 
also made formidable with the terror of a prison or dungeon forty-seven years even before Petworth itself, for Henry de Percy was licensed to embattle Petworth only in the second year of Edward II. (Pat. II. Ed. II.)

The first mention of Rogate is in the last year but four of Hen. III., when Henry Huse and Robert de Rogate have the grant of a fair at Rogate on the eveday and morrow of St. Bartholomew, patron saint of the church. (Charter 52, Hen. III.) Mr. Lower thinks that Rogate was anciently North Harting, the compliment of the divisions of South, East and West Harting. But I have never been able to meet with any document containing the name of "North Harting"; and, at least as early as the reign of Henry III, Rogate appears in its proper name, and gives the usual local surname to one of its sons, Robert de Rogate. We may therefore suppose that Rogate was the usual and well ascertained name of our good neighbour on the north long before the reign of Hen. III. But though Rogate was never called "North Harting," there is abundant evidence that it was included in Harting Parish originally. Harting extended to Harting Combe, and so late as Mary Stuart's reign, the living of Rogate is called the living of Harting, and said to be in the king's gift. Also there was a like confusion with regard to the manors of Durford and Rogate, which in King Henry the Eight's reign were given to Lord Fitzwilliam, grantee of Durford Monastery, at its dissolution, and are called the "Manor of Hartinge and Rogate."

Rogate was the rib taken out of the side of the Adam of Harting, and subsequent history will show that it was an iron rib, too.

There had been a very ancient grant (temp. Hen. II.) to the lords of Harting of two fairs and a market at Harting. The Rev. D. Morgan writes (Burrell MSS.) Ap. 28, 1777, "The fairs are held the first Wednesday 
in June* and Oct. 28, but the market, which was on Wednesday, has been long discontinued." Will any adventurous spirit revive our Wednesday market?

Simon de Stanbrugg (i.e. of Standbridge near Petersfield) is mentioned by Dalloway as the first parson of Harting, 1 284. His Ordinary would be the great Bishop Richard de Wych, St. Richard of Chichester, of whose hiding place in Harting there is still a trace in "St. Richard's Hill," as Mr. Harting thinks-now profanely called "Dick's Hill," near Hemner.†

In the reign of Edward I. the Husseys continue to support the popular side; for the first member for Sussex, summoned to the Carlisle parliament, I307, is Henry Hussey, lord of Harting. Previous to this, however, Henry Hussey had been in disgrace again. Before the first parliament (18 Ed. I. Riley Placita Parliament, 23), John, Bishop of Winchester, brought a suit against him for poaching and causing his foresters to trespass, when constable of the king's castle of Pierrecester (Porchester ?) on the free warrên of the Bishop of Winchester. And in the same year (18 Ed. I. I 292) a Patent Roll says, that Robert de Burnedissh (was he a warming-pan?) was presented by the Crown to the Church of Harting, "the lands of Henry Husee being at that time in the king's hands" or confiscated. It must have been a bitter grief to the lord of Harting to have lost his patronage so soon after he had built his church. It is about this time also that the Lords Camoys, of Trotton, seem to have had temporary possession of the manor of Harting. Possibly the Jews may have been at high pressure again, and no royal benefactor to appease them.

In August, 1324, another royal progress brought Ed. II. through our borders, the route being from

- Now on Whit Monday, the Old Club anniversary.

$\dagger$ St. Richard in the time of his deprivation went about his diocese as a gardener, working for his daily bread. 
Tunbridge, viâ Petworth, to Porchester. On this occasion the king was entertained at Durford for a day, when his expenses amounted to $£ 10: 6: 0$. (Pat. Rolls.)

The reign of Edward III. is, perhaps, the most interesting to us as a village in all antiquity: It is the reign from which the rise of the great middle class is dated; and the annals of Harting are somewhat rich in materials for a local survey of this epoch. The measures of land and of money become now identical with our own; and the parish, with its inhabitants, industries, and church, happens to be defined with unusual clearness and detail in the ancient records. I have therefore determined to quote at some length. The materials disclosed will be interesting, not only as a standard of comparison with the present time, but also with the previous surveys of Ed. Confessor and Domesday.

I34I (I 5 Ed. III.) In the Nonæ Roll a return is made for Harting at Chichester, on the Wednesday after St. Gregory, March 12. The Rector of Harting is here stated to have a messuage or house, worth annually 30 shillings, and pasture or glebe sufficient for I2 oxen, \&c. The Vicarage, a remarkable appendage for so early a date, has a house and garden, value one mark. No less than five men of independent means are then living in Harting, at this time a considerable place: Lawrence Dorkyng, Egid Lylemot, William Smith, John Wycher (a name still extant in the neighbourhood), and Thomas Atebred.

I344 This year is remarkable as seeing three parsons at Harting. We learn this from an entry in Bishop Adam de Orleton's Register at Winchester, for our Chichester Registers do not commence till I399. Richard de Newebury, rector of Hartynge, exchanged livings with the great William de Edyndon on the 23rd of May, who again exchanged Harting with Mr. (dominus) John de Crocford for the prebendary of 
Tymberbury in the church of Romsey, on the 22nd July, I344* Thus for two months Harting had the distinguished honour of having for its rector William de Edynton or Edington, afterwards Bishop of Winchester, first Chancellor of the new order of the Garter and also Lord Chancellor of England. Milner says of Edynton, that "he was a prelate only inferior to his successor, William of Wykeham, in virtues and talents." William de Edynton (i.e. born at Edinton in Wiltshire) was the patron, ordinary, and pattern of William of Wykeham. Edynton's saying, when as Bishop of Winchester he was offered the Archbishopric of Canterbury, is well known, viz.: "that Canterbury was the highest rack, but Winchester the deepest manger." $\mathrm{He}$ commenced the rebuilding of Winchester Cathedral, and the great William of Wykeham professes in his will to have completed Edynton's work. Edynton's beautiful shrine is on the north side of the nave, immediately under the choir screen at Winchester; and his effigy, in full pontificals, is set over the extreme point of the west end of the longest and most stately of all England's Cathedrals. He thus presides over one of the chief examples of the perpendicular style, of which he may be said to have been the father. He was also chief Almoner in the terrible plague, the Black Death of I $349,+$ when one half of England, nine-tenths of the Clergy and three Archbishops were swept away, and Oxford, from 30,000 scholars in 1300 A.D., was reduced to 6,000 at the time when Wykeham's college was opened. (Lives of Wykeham, Waynflete, and More.) Bishop Edynton died at Waltham, 8th Oct.

* Bishop Orleton's Register, Winchester Cathedral, Tom. II. fol. 103-104. Communicated by Mr. F. Baigent.

$\dagger$ It is characteristic of Edward the Third's levity, that he celebrated his great feast on the institution of the Order of the Garter, of which Edynton was first prelate, in the midst of the Black Death. See Stubbs, Vol. II., "Constitutional History." 
I366, and was succeeded by William of Wykeham. It would seem as if some of the Bishop's family still lingered hereabouts, for (Pat. I2, Rich. II.) John de Edyndon was appointed to the Parish Church of Bury, near Amberley. In like manner, in our own immediate neighbourhood the living of Buriton was held by John, probably the nephew of William of Wykeham, to whom Wykeham left in his will $£ 50$ for his degree in Theology.*

In connection with this notice of the educational movement in this neighbourhood, it is very interesting to observe that William of Wykeham's first head master at Winchester College was Richard de Herton, 'venerabilis et discretus vir Richardus de Herton grammaticus,' as he is called in a deed dated I 373 , wherein he binds himself to William of Wykeham to teach the College boys at Winchester School for ten years, in the parish of St. John upon the Hill. $\dagger$ "Richard de Herton, schoolmaster," would in modern form undoubtedly be "Richard Harting," for "Herton" is the current name for Harting at this time. It was the invariable practice of men of mark to drop their family name, and to adopt that of their birthplace. Thus we have William de Wykeham, William de Waynflete, Simon de Stanbrugge, Richard de Torrebury, Adam de Beriton (Vicar of Boxgrave, Pat. 23, Ed. III.), and so Richard de Herton, or Richard of Harting. Is it possible that through Edynton's connection with Harting this Richard, when a young man, may have shared Edynton's patronage, and, once a fellow student with Wykeham, have been selected by the latter's well-known practical discrimination as the first Master of the famous School?

* "Item lego magistro Johanni Wykeham, Rectori Ecclesæ de Biriton pro inceptione suâ in Theologiâ and aliis actibus scholasticis L (fifty) libras."

† Lowth's Life of William of Wykeham. Appendix 360. Idem. pp. 94, 191. 
I 345. The neighbourhood of Harting is unquiet at this time. A Patent Roll shows that Edward Prest of Durford has the king's pardon for the death of John Carpenter of Rogate, whom he had killed, not in malice, but in self-defence. The rising value of Sussex iron, which dates from this period, no doubt brought many to the neighbourhood of Durford, where, in connection with West Harting Pond, I 80 acres of which are said to have been "flowed at pleasure," there were some of the largest iron-works in the county, an unlimited supply of forest wood being available. It is very probable that the village of Rogate sprang up on the banks of the Rother as a home for the workers in the iron foundries.

I349. Oct. I7. The Dowager Lady Katherine Hussey has an apportionment of her widow's thirds from the Harting estate. Henry Husee, fourth of the dynasty of that name, has died in Harting, leaving his son, another Henry, his heir. The assessors are Sir John de Bohun (Midhurst), John Haket, Ed. Trenchaunt, Geoffrey de Sedes, John Emmori, John Tille, Tho. Husee, Joseph Atte Burgge, and others.

\section{[Document No. I.]}

\section{Harting Place.}

The widow receives the third of a capital messuage or mansion at Harting, viz. : All chambers at the west gate and extending beyond it, except the prison or dungeon (domus prisone), which is reserved to Hen. Husee, the heir. The third of 2 dovecots with houses annexed to one of them. A bakehouse and kitchen for use of cooking, baking, and brewing, untill the said Henry shall have built her at his own costs a suitable house for the said offices at the west gate. A house between the great and little barn (grange) called the "Chaff-hous" (Chaff-house); a little house called the "Carterestable" (Carter's stable); a little house near 
the dove-cot called the "Hyne-lıous" (servant, or Hinde's house)* with a stable in it; a certain house called the "Pressour-hous," $\dagger$ at joint charges; a house called "Hogge-hous;" a place (placia) called Pundfold. Part of the South gardin (now "South gardens") on the west; 3 rd of the garden of Lawence's gardin towards the south ; garden of Gonnyldsmele ; garden of Barry; garden at Wexe on the west side of the lane (venelle) there ; a place at Alayne's ; garden called Est Gardyn (East garden) at Alayns.

Land.

Arable in the North cleye (North clay) on the east of the field . . . . . . . 3232 I

Lands lying in the Cumbe (Harting Combe) at west of Godinet's $\$$ land. . . . . . 324 At Langpatch, extending from the King's highway to the Cumbe .

A. R. P.

Three Buttes near the above at Langpatch, containing . . . . . . . . . . 030

In field of Rede lond (Red land, now Pays

farm) at the east . . . . . . . . 29 I O

In field of West cleye at north . . . . . . . $\begin{array}{lll}27 & 3 & 2\end{array}$

At Ekenefield (now Eckenfield), arable . . 39028

Third part of South sheep farms (berca) or

enclosures, at Ekenefield . . . . . o 03

In the "Bircham" at south . . . . . . . O I 3

In the Forlang $\S$ of Hoddeston (Hodson

lane, near Up Park ?) on north, arable . I6 I o

- Hyne, servant of Piers Plowman, Prologue, 39 : "Qui turpilogium loquitur is Luciferes hyne." "He who speaks slander is Lucifer's servant."

† "Pressour-hous." The press probably for cider or wine. The Husseys had a vineyard extending up the hill at the southwest of Harting Church. No. 630 (Tithe Map) is "The Row in the Vineyard Copse." No. 63I is "The Vineyard," I2 a. 3 r. o p. $\ddagger$ Godinet, a tenant, see list following.

$\S$ "Forlang," proportion of land lying in a common field. J. V. Harting, Esq. 
In the field of Holforlange on south, and

A. R. P. extending from south to north . . . . In Middel forlange . In field called "Maydene's dene" (Maiden's dell ?), 2 forlanges at $\mathrm{Rudh}^{2} \mathrm{~m}$, containing I4 320

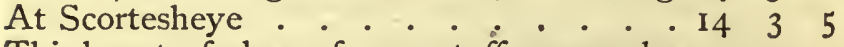
Third part of sheep farms at foxecoumbe on north (Foxcombe) $\cdot \cdot \cdot \cdot \cdot \cdot \cdot \cdot$ down) to the west, towards the Conyers (Conies, or rabbit's warren, now called "The Wârren")

On Mayndon ("Maindown"), in divers plots

(diversis partibus)

900

5 I 20

$0 \quad 02$

At Merlonde, on south.

Do. on north. . . . . . . 524 On the Conyere (or "Warren") on the west I4 0 o Above the Conyere to the east, near Moun ford* . . . . . . . . . . I $30^{*}$ On Akermaincouret on the north . . . . 300 In olde orchard to west, arable ... . . . 200 In Poukeput (probably now "Poppetts," near S. Harting) 4 pieces of arable land, and one butt on east, and one elna of land in the same field near the haya of Richd. de Torrebury, containing in all . . . . 220 One piece of Pasture, near Poukeput, in a certain meadow of Hertyng, on east, near a garden .

Third of the Bercarie (sheep farm) in afore$\begin{array}{lll}9 & 1 & 22\end{array}$ said meadow S. of Poukepot . . . . 3316 Three pieces of meadow at Wexe on west . $\begin{array}{lll}2 & 0 & 5\end{array}$ Alaynesmed, near ffronks (Fronks, near Rogate Station) . . . . . . . . . . I I I3

\section{- See p. 7, Note.}

† See Chap. I., p. 6. It is possible that there is a connection between Akermain coure and Eckenfields, where Roman coins were found, 1876 . 
A. R. P.

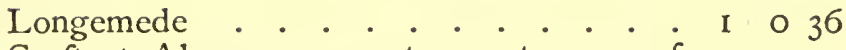

Croft at Alaynes on west, near tenancy of

Peter atte Halle • • • • • . . . . . 4 I 4

One Helna of land lying in Est Wexe near

la Ocke (the stream, E. Harting) . . . I $\mathrm{O}$ o

Lands not measured, probably about 8 acres.

Third of the Longe acre on the north.

One helna of land near the bound of Elnested ("sepem de Elnested") Elsted, I R.

At la Snape.

One butt on east of Shodwell.

One butt extending beyond the bound of Elnested.

One acre at the Burghe (Borough, query Petersfield ?).

One helna in the east at the Cumbe.

One helna on the south in the Bere croft.

One helna at Laperithe in the Smale lond.

One acre at the Goret (corner of a field or gore).

One acre upon "the oure," sup' la oure (probably Up Park, or "oure. park").

Common rights, Woods, \&c.

Third of mountain pasture of Ekenefeld (i.e., Lady Holt Park).

Third part of pasture of Merlonde.

Third part of brushwood and pasture in wood of the Conyere at east side, and third part of the rabbits of Ekenefield and the Conyere there.

Third of wood in Hertyng cumbe and Nywode on west side.

Third of profits of fairs of Harting and Rogate yearly, Katherine finding third part of expences. 


\section{Rents and Services.}

Rents and services of tenants and tenements undernamed as rendered to Isabella, wife of Hen. Husee, deceased, and mother of present Hen. Husee.

Thomas At Halle, Thom. Gyles, Rich ${ }^{\mathrm{d}}$. Aleyn, Robt. de Torrebury, widow of Shepherd Stephen Hunt, Hen. Lenechild, John ffesaunt (Pheasant), Mrs. Atte Brugge Widow Illori, Ten. Anguevyn (house named Anjou), Widow Copyn, Thos. Pollard, Egid Lylemot (Tend. Bosse), John Trentemasse, John Atte Croft, William Whatelygh, Hen. Fraunk (Ten. Page), Walter atte Lidegate, William de Herting (or "Harting"), John Musard, Garriesrude (query Gallygrove ?), John Wyse for I cottage. Christemasse $=$ (Christmas), Mr. Smith (Fabri), Thome Clement, John Jaket, $\mathrm{W}^{\mathrm{m}}$. atte Fourde, Simon Norman, $W^{m}$. Skynnere, $W^{m}$. Bigg, Peter Waldere, Walter Lucas, Thom. Langlyne, John Pyte, Nicholas le Whene (nicknamed "the Wen") Henry the Combere, Walter Coleman, Henry Waldere, Widow Le Boy, Robert Nyman, Robt. Cubbe, Walter Sampson, John Sampson, Peter atte Nashe, Henry "in the Lane," Hubert Blakewhit, John the Hayward, Thom. Tannere, Hen. Godynot, Robt. Stepline, William Senane (als. Cynnery) senior, and John Atwod.*

\section{Other Revenues, \&c.}

Third of profits of the Hundred of Dempford (Dumford), Kath. finding third part of expence.

The flock of Hertyng, on the north part of the town of Hertyng (pecus de Hertyng ex parte boreali ville de Hertyng), except one pond adjacent to a water mill. The said Henry to make at his own cost a fence between the said flock or cattle and the pond.

- Forty-nine names of tenants, whereof three still survive in Harting : At Halle-Hall ; de Herting-Harting ; WaldereWalder. The latter name is probably the equivalent of Archer, or Forester, "Sagittarii Waldenses," required by King Henry V. from Sussex for French wars. 
Third of profits of water mill situate near $s^{\text {d. }}$ pond (iron mill connected with West Harting Pond and Down Park), Kath. finding third of costs.

Third of eels caught in said pond, or at its channel of exit (exclusa = penstock).

Reasonable estover (estordium), viz.: Firewood in the park of Hertyng called the Ourpark (Up Park), on the south side of the aforesaid town of Hertyng, to be taken without waste, sale, or damage.

Third of a meadow called Chalnec ${ }^{\mathrm{T}}$ oft med (Chalnecroft mead) on west, containing 5 acres.

Third part of a wood called Chalnegove (Chalngrove, probably Chilgrove) on the north, containing 5 acres.

Third part of profits of rabbits of the warren (conyere) on the heath ( sup $^{\mathrm{r}}$ brueram) near Wenham.

Advowson of Pulbergh (Pulborough)* in lieu of her share of advowson of Hertyng and Ruggewyk.

A certain well called Typut $\uparrow$ : water thence to be common to Henry and Katherine.

Such was one part only of the large dower of Lady Katharine Hussey, widow. Yet even with all this good fortune she seems to have got into trouble. Pat. Roll, 7 Ric. 2 : "The king gives to Thomas Atte Lee the fine of $£ 40$ which Ankaretta (probably a pretty variation for Katharine) widow of Hen. Hussey, pays for having married again without the king's license," (Mr. Sharp, Record Office), the king being the domineering, worthless Richard II. Ankaretta is styled "uxor Henrici Husee senioris."

The foregoing specification of the manor of Harting represents one-third of the estate, the dower of Lady Katherine Hussey. It so happens that twenty-one years after (1370) there is a document which represents the

- The Hussey family held the manor and advowson of Pulborough : and it is interesting to note that the ancient fonts in the churches of Harting and Pulborough are very similar, and seem to have proceeded from the same hands, the Husseys being in each case the donors. 
remaining two shares of the manor held by Henry Hussey. Again the lord of Harting is in debt. Perhaps the immediate cause was the heavy dower allowed to his mother-in-law. There was an inquisition and valuation for the Exchequer for Henry Husee's debts (44 Ed. III. Ist No. 74), and the report is as follows :

\section{[Document No. II.] $£$ s. d.}

At Hertyng a capital messuage and three gardens ...

A square pigeonhouse, annual value Rents of assize*

Water mill + ...

Customary holdings of two parts of manor of Hertynge

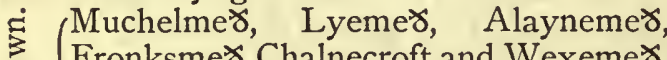
Fronksme $\gamma$, Chalnecroft and Wexeme $\gamma$, in all $3 \mathrm{I}$ acres of pasture (2s. per acre) Arable under the Downe, Redlon\}, Northcley and Southcley, and Pokeput, 2 I 5 acres (Is. per-acre)

... 10150

Near the Park on the Downe, $90 \frac{1}{2}$ acres (6d. per acre)

200 acres of pasture at Elknesfeld and $45 \quad 3$

Manydown and la Conyngber (warren) $\left\{\begin{array}{lllrl}\text { (Pasture above hill 4d.) } & \ldots & \ldots & 66 & 8 \\ \text { Fordoune (Foredown) pasture } & \ldots & 3 & 4\end{array}\right.$ A certain park called Le Upparke, $\begin{array}{llllll}\text { with pasture and wood } & \ldots & \ldots & 100 & 0\end{array}$

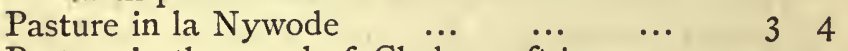
Pasture in the wood of Chalnecroft $\begin{array}{llll}\ddagger & \ldots & 3 & 4\end{array}$ Hog run (an evidence of great woods) $\quad . .4 \quad 40 \quad 0$

- Redditus assizæ-Quit rents to Court, \&c.

$\dagger$ "Watermill." Probably that mentioned in No. I, at Down Park.

$\ddagger$ Chalnecroft, a common name. The croft of the lime kiln. Thus there is a Chalnercroft at Pagham. (Ing. 51 Ed. III, Ist M., No. 42). 
Profits of Hundred of Dempforde and

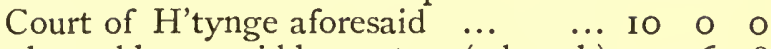
40 cocks and hens, paid by custom (2d. each) $0 \quad 6 \quad 8$ I40 hen's eggs, by custom (about $\frac{1}{2} \mathrm{~d}$. per dozen)

Total value of this manor, consisting of two parts $\quad . . \quad £ 7$ I $\quad$ O II

Assuming $£ 7$ I : o : I I to be two-thirds of the total value of Harting manors, their full annual produce would be $£$ I06 : i I : 5 .

Taking Hallam's multiple of 24 for present equivalent of money in Edward the Third's reign, we have the following results :-

Lands of Harting. Assessment (Edward the Third's time) adjusted to present value.

Pasture land under Downs Lady Holt Park Arable under Downs Arable above Hog run ... Hens

Eggs... Total worth of manor $(£$ I06: I I : 5) $=£ 2,557:$ I4 : o.

But it must be remembered that money in Hallam's time was. worth twenty per cent. more than it is in 1875 , and therefore we ought to add $4 \mathrm{~s}$. in the pound to obtain an exacter calculation of the present equivalents.

Putting the two documents together, the whole manor would have an extent of about 900 acres, arable and pasture; of which, in round numbers, Katherine took 300 . The downs seem to have divided this into half; but the chief bulk of the property, and the best of it, lay under the downs in the plateau surrounding South, East and West Harting. The 
pasture land under the downs commands a rent of 2 . per acre, whereas the pasture of Ekenfeld (Lady Holt park) is only set at $4 \mathrm{~d}$. Probably the reason of this was that there was no water on the hills. The arable land under the downs is also assessed at double the value of the arable above: the former being Is., the latter $6 \mathrm{~d}$. The lands are farmed by some fifty families, as appears in Document No. I. As there were 216 male population in Harting at the survey of Domesday, there would seem to be a slight increase now. Probably, including servants, and the five families living on their own goods and chattels according to the Nonæ Roll, there were 350 at least within the borders. We may note that North of Harting, e.g., at Nywood, Rogate and Harting Combe, the woodlands seem to have been cleared only in small and scattered patches. The forests are dense and extensive: the hog run is valued at 40 ., a large sum. The pheasant has arrived at Harting even in 1350 , and gives his name as a soubriquet to one of the Hussey tenants."

The English fancy for nicknames seems as strong then as now. "Jack Pheasant" no doubt exchanged compliments with "Hal in the lane," "Henry the Comber," "Jolnn the Hayward," and "Nicholas," surnamed from a personal disfigurement. "the wen." Robert de Torrebury has already taken his name from Tarberry Hill the place of his abode.

After this orderly time succeeds a period of nearly 200 years of war and entanglement, from which few and scanty documents survive. Even the handwriting it is said degenerates from the beautiful manuscript of Edward the Third's time, and does not regain its finish till the time of Henry VIII. The French wars and Civil Wars succeeded one another, and left but little local history in so humble a spot as ours. At the culminating point, however, of the Hundred Years' War (I336-I43I) the name of our village curiously appears in the news from the seat of war in Normandy. 
A Patent Roll (Norman. 7 Hen. V. m. 38) shows that the then Knight of Harting, Sir Henry Hussey (sixth of that name), was with the flower of English chivalry at Agincourt, and was appointed to the high post of guarding the town of Rouen when Henry the Fifth had won it after the terrible siege of six months in I4I8. It may be said that there was good policy in setting Sir Henry Hussey to guard Rouen, as we have seen that his family originally came from that neighbourhood.

The Patent Roll above mentioned says, "Sir Henry Husee, Knight of Herting, being in the king's service in the company of the king's uncle, Thomas, Duke of Exeter, captain of the town of Rouen, and abiding in that town for its safe custody, has letters of protection (the king's passport) for a year."

Three years afterwards (Norm. Pat. Io Hen. V., m. 20), May 22, I42 I, Henry Husee has another similar protection from the king, as he is commanding the camp at Gaillon. Doubtless many a brave Șussex yew bow was bent at Agincourt, and the county was specially requisitioned for sheaves of arrows and Sagittarii Waldenses.* The Walders, and Halls, and Hertyngs would be as retainers at their lords' backs, and doubtless there was a troop of Harting men at Agincourt.

The last "Knight of Harting" was Sir Nicholas Hussey, brother of Sir Henry, who died in Henry the Seventh's reign leaving three daughters only. Two of these died young, and the hope of the ancient house centred in Constance who married twice and had one

* See Liberate, I2 Edward III. Sheriff of Sussex, Wm. Vaughan, supplies 6,000 arrows (240 sheaves, each sheaf containing 25 arrows) of good dry wood, with heads well sharpened, called "Dogebil"--to be put into a cask and sent from Horsham to Tower of London, at I 4 d. per sheaf. (48 Hen. III. 3): King's letter to Nich. de Handlo, of Winchelsea-"Mandamus vobis quod trescentos de melioribus sagitariis waldensibus qui sunt super graveram maris inter Rom' (Romney) et Winchelsea, \&c., \&c., to be set for defence." 
child only, a daughter. Constance Hussey's first husband was Henry Lovell, next Sir Roger Lewknor ; * and as Lady Lewknor she presented Reginald Pole, afterwards the great Cardinal, to the living of Harting, I 525, through her commissioner and neighbour "Henry Pole, Lord Montague," the future Cardinal's brother. $\dagger$ Constance Hussey was a kinswoman of Cardinal Pole through the Pakenhams.

Elizabeth, the only daughter of Constance Lovell and sole heir, married Sir Anthony Windsor, brother of Lord Windsor, who lived at Down Park, West Harting, in a moated house, traces of which still remain, a contiguous field being called "Parlour field" to this day, and the direction of the drive, as Mr. Weaver informs me, being visible in dry weather.

The monastery of Durford, with its lands, was given by the Crown (29 Hen. VIII.) to William Fitzwilliam, Admiral of England, who again aliened it to Henry

* West Harting Leager ; also, Dr. Wilkinson, "Notes of Genealogies"; also, Bishop Storye's Register Chichester Archives, 1502, May 31.

$\dagger$ Register of Bishop Robt. Sherburn, p. 52 : “Ap. 10, 1526, Reginald Pole, clerk, admitted to the Rectory of Harting, Chich. Diocese, vacant by resignation of William Gibson, last rector ; patron Henry Pole, Lord Montacute, acting as commissary for Sir Roger Lewknor and Lady Constance his wife, patrons of the Church for this turn." It further appears, p. 78 of the same register, which is written "in the most elegant hand" of Bishop Sherburn, that, Ap. 13, I526, three days after his institution, Reginald Pole made a pension of $£ 24$ out of the fruits of the Rectory of Harting, in part for the salary of Warblyngton dio. Winton. All this favours the well-known tradition that Cardinal Pole was born at Racton (See Athenaum, 8th Oct., 1874). Reginald Pole is described as Rector of Harting in Valor Ecclesiasticus (1535).

It may be added that the local tradition that Cardinal Pole was Rector of Harting is recorded in the early part of the last century. Thus Mr. Tench, Rector of Harting, Jan. I8, I7 II, writing under feigned name of "Jacob Hudson" (Caryll MSS. Addl. 28, 229, p. 358), says: "The Rector (of Harting) has always presented ye Vicar ever since Cardinal Poole's time who was Parson of Harting." 
Windsor, son of Anthony Windsor and Eleanor his wife, who, in 38 Henry VIII., sold it to Edward Ford.* A daughter of the Windsor's married Sir Ed. Mervyn, "vice-admiral of the narrow seas." The family of Windsor, however, were unfortunate in heirs, Henry Windsor being an idiot. (Surveys $\mathrm{I}-7 \mathrm{Ed}$. VI. fol. I 36, I20; also, West Harting Leager.)

In the third year of Edward VI., I550, Sir Henry Windsor (son of Sir Anthony and Eleanor Windsor his wife) sold their estate, apparently in West Harting, to Edward (sometimes called Edmond) Forde for $£ 1,600$, on the morrow of All Souls, or Nov. 2nd. $\dagger$ Counting money at that time as worth fifteen times its present value, Harting fetched at its first sale $£ 24,000$.

Thus the family of Hussey lived and died with our Henries.

* Memoranda of Exchequer Michas. Terme, 3 Elizæ. Roll. 3 I.

† Ibid. 


\section{CHAPTER IV.}

\section{The Fords of EAst HaRting. \\ Sir EDWARD FORD.-FORD LORD GREY.}

THE Ford (1549-1746, eight generations) was from Devonshire. Erasmus, the father of Edmond Forde, purchaser of the manors of Harting, is described* as " merchant of the Staple," a wool broker or merchant of the Staple Company, whose object it was to bring as many foreigners as possible to the towns where wool was sold. The steady rise in the price of wool between I 5 I 5 and I 53 I led to the introduction of sheep farming on an enormous scale; $\uparrow$ and the great Thomas Cromwell was wool merchant at Middleborough at nearly this same date. It seems likely that Erasmus Forde may have been brought here by the markets for fine wool of the Southdown and Hampshire ranges, which constituted part of the traffic between Portsmouth and Spain, and the memory of which still lingers in the venerable name of "The Spain " at Petersfield, and the approach to the old square, called to this day "Sheep Street." $\ddagger$

Edmond Forde bought Harting for a pretty penny. When called upon to show his title to the manors of Nutborne and Harting, which apparently were sold by the Windsors as one estate, he pleads that in 1546 he gave Henry and Elinor Windsor $£ 280$ for Nutborne, that in 1549 he paid them $£ \mathrm{I}, 600$ for Harting manor, the larger or West Harting manor; and in 1560

* Philipot's Visitation of Sussex, 1634, Gough MSS., Sussex. Bodleian.

† Green's "History of England," p. 320.

$\ddagger$ Edmund Forde, Gent., resided at Petersfield. (Evidence of Petersfield Electors, Charter of Hawisa.) 
(2 Elizæ.) he gave Thomas and Constance Ryche (née Windsor) and Sir John Hussey $£ \mathrm{r}, 320$ for their shares in the manors of Harting and Nutborne. The document in which this appears is at the Record Office, and the transcriber, H. Goldsmith, Esq., assures me that he never copied one of greater interest. The three several sums paid by Edmond Forde amount to a total of $£ 3,400$, which, if adjusted to its present value by a multiple of I 5, would represent $£ 48$,000 of our money. Not less than $£ 40,000$ of this would seem to have been paid for the manors of West, South, and East Harting : and at the same time the purchaser pleads that with Nutborne they are one and the same estate, held under John Appesley, Esq., as of his manor of Walderton, and are distinct from the manor of Durford, granted by the Crown on the suppression of monasteries to Lord Fitzwilliam. The latter manor was transmitted by Lord Fitzwilliam to the Mervyns, and thence to the families of Bettsworth and Ridge. In the grant to Lord Fitzwilliam, 29 Hen. VIII., and in the court rolls of Queen Mary's reign, Durford and Rogate are loosely styled as "Harting manor;" and hence, probably, Ford was glad to use Nutborne as a screen to show that he was the real possessor of the ancient manors of Harting.

The sums paid by Edmond Forde for the Harting lands certainly seem to have been exceptionally high. He would purchase first the chief interest, the demesne and mansion of Harting Place, which was the capital seat of the West Harting manor, from Henry and Elinor Windsor, the eldest representatives of the Hussey, and then would have to buy up collateral interests in the neighbourhood at a still higher rate. At this time the chief house connected with East Harting was at East Harting itself : for though there was an ancient park at Up Park, as we have seen, so early as the I 4 th Century (and there must have been a considerable house there), yet there can have been no 
house on the Downs worthy of being called a mansion till at least after the time of Queen Elizabeth.

In I440 Sir Henry Hussey's trustees leased to Robert Legge, of London, draper (20 Nov., I9 Hen. VI.), Up Parke and Down Parke, but there is no mention of any messuage of note at the former place. (West Harting Leager.) Up Park and Lady Holt were farmed as ordinary separate sheep-farms to near 1600. See Special Commissions of Sussex. 33 Elizæ. (I59I), No. 232I : "John Smyth, farmer of Up Park, for $\mathrm{p}^{\text {te. }}$ of his rent, which he deteyneth by order given to him by the Officers of her Maties. Courte of Wardes and Liveryes (during the nonage of Sir Wm. Ford, then I 7 years of age), to be there answered to her Highnes' use, vil. xiiis. viiid. Stephen Hayward, for the half-yere's rent of certain land pcell. of the Lady Holt, late in his occupation, due Michaelmas last, xxxiiis. iiiid." So also in 1624 , "Wm. Broman, the sonne of John and Dorithy Broman, dwelling at Up Park, bapt. Aug. 5, 1624." (Harting Register.)

On the other hand, Sir William Ford, I643, as we shall see, inhabited Up Park, and Ford Lord Grey, in his "Secret History of the Rye House Plot," I685, speaks about his house in Sussex, evidently Up Park, where the Duke of Monmouth was "to be privately a week before the rising;" and, in I682, Lady Berkeley gives evidence at the Court of Queen's Bench: “My Lord Grey's wife, my daughter Grey coming down to Durdant's (Lord Berkeley's house near Epsom); he (i.e. Lord Grey) was to go to his own house at Up Park in Sussex, and thence to call at Durdant's again, believing that he was not able to go to Up Park in one day from London." The present Up Park was built in I686. My conclusion is, that between I624 and 1643 the chief branch of the Ford family went and lived at Up Park. There is a deed at Up Park, Mr. Weaver tells me, dated 1654, signed by Sir Edward Ford and Ralph Grey, of East Harting, his son-in-law, 
who would, in all probability, be occupying the original seat or manor-house* at East Harting. It would further seem conclusive that Ford Lord Grey, baptised I655, was born at East Harting. It is possible, however, that "East Harting” designates Up Park.

At all events, then, we cannot be far wrong in concluding that, at the time of Edmond Ford's purchase of the Harting estates, there was no very considerable residence at Up Park. This makes the high price given for the lands still more remarkable.

Nor was the Church of Harting in a very flourishing condition in Queen Mary's reign. July 27, I 554, immediately after the removal of the Protestant rector, Lawrence Nowell, $\uparrow$ Edmund Ford appointed Dr. John Seton to the Rectory at Harting. This Dr. Seton figures considerably in Foxe's "Book of Martyrs." At Oxford he disputed with Latimer in 1554 and with Bradford in 1555 . "Here Mr. Doctor waxed hot, and called Bradford arrogant, proud, vainglorious, and spake like a prelate." And in the last year of the Marian persecution, I 558, the "dreaming and doltish Doctor "willed the people not to pray for Benbridge at Winchester unless he would recant; and was answered from the stake: "Away, Babylonian, away!" Afterwards Dr. Seton drew up Articles of Recantation, which Benbridge, released from the flames, signed on a man's back. The Sheriff was sent to the Fleet for the reprieve which he had given, and Benbridge was burnt again. $\ddagger$ Here Seton acted for Gardiner.

Immediately on his entrance to the benefice of Harting, Dr. John Seton executed a lease of the tithes of Harting, for the period of his incumbency, in favour of Edmond Ford, under a bond of $£ 40$. This interesting document, with the seal of John Seton affixed, is

- Perhaps at Tye, or Tye-Oak, where servants were kept, 1585.

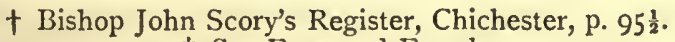
\$ See Foxe and Froude. 
preserved in the British Museum. Edmond Ford covenants to "yerly mainteyn the chancell of the Church of Hartynge in all things necessary, forasmuch as the charges of the reparacions of the said Rectory and parsonage hath heretofore, and hereafter is likely to be so chargeable unto the Person of the $\mathrm{s}^{\mathrm{d} .}$ Rectory."

Hence Edmond Ford's broad purse had to sustain a dilapidated Church in his new purchase. In Queen Elizabeth's reign, and probably in Edmond Ford's lifetime, the Church of Harting was destroyed by fire, an event recorded in an entry in the first register, which states that the Feoffees sold some acres near the Leeth (a hill, as the name signifies, and in the direction of Petersfield) to rebuild their parish Church. Probably the tower of the Church was struck by lightning, as was the tower of the neighbouring Church of St. John Baptist, Durford, in I4I7, when the eight bells, the largest of which weighed $14 \frac{1}{2}$ cwt., were fused. In like manner the tower of Buriton was struck in I7I4, towards the restoration of which John Caryll of Lady Holt, stout Roman Catholic that he was, gave Dr. Lowth, Rector, the sum of $£ 2: 3: 0$.* Of late we have had none of these old fatal thunderstorms. Probably the constant shaving off of forests, and the comparatively drier soil consequent upon this denudation, and above all the progress of drainage, have caused the modern thunderclouds to take the line of the Southdowns, and thus to be innocuous.

At any rate the chancel and south transept of Harting Church seem to have been burnt at this time, and to have been, with the tower, restored and re-roofed in 1577 , as is cut upon the finials of the timber in the chancel, a very fine specimen of its date-the Tudor rose marking the time of Queen Elizabeth. This remarkable chancel is of itself a complete answer to Dalloway's very gratuitous assertion that the style of Harting Church is "of the coarsest parochial archi-

- Caryll's Account Book, May 4, 1714. 
tecture" ; * but the reader of Dalloway must not expect accuracy. Like the Irish penitent whom St. Columba absolved on condition that he would speak the truth once out of seven times, about one-seventh of what Dalloway says may be considered worth verification.

The completion of this great work of Puritan restoration took place in the year 1577 , in the time of John Ford and Francis Fortescue, Esqs., sons-in-law of Edmond, and joint lords of Harting. It was probably effected by general subscription, as we have seen that the Feoffees took their part. At the same time it cannot be doubted that another member of the Ford family took great interest in Harting Church. William (?) Ford, of Hartyng, by his will dated I 568, now at the Record Office, $\uparrow$ first provides that he shall be buried in the south side of the chancel of his parish Church. He then bequeaths certain legacies: first to his wife, and then, to quote his own words, "Item, I give and bequeath to the Vicar of Hartyng for the tyme being, to pray for my soul and other Christian souls, and especially every Sunday in his bede-roll, over and above his mortuary, 20 shillings. Item, I give and bequeath to the Parish Church of Hartyng, towards the buying of a fair cope to go in procession (the yearly walking of the bounds on Rogation day in May), and a fair vestment to sing mass in, or other ornaments most necessary, if the law will not permit the others, Io pounds." This is curious, as showing that the much-contested law of vestments was not settled in the reign of Elizabeth, and the passage has been used in controversy. Whether the cope or vestments were bought for Harting Church or no, it is certain that they would soon disappear in the long incumbency of the Puritan Vicar, Ralphe Dear, who succeeded, from 1587 to 16 I I. But we may conclude that William

- Dalloway's Sussex; I., I97.

† Lecture by Hon. C. L. Wood to the English Church Union at Brighton, April 2, I868. 
Ford was one of those who have helped in the rebuilding of our Church, and his bequest is, to a certain extent, an evidence of its poverty and need at that time.

What, then, if there was but a single large mansion on the Harting soil at this period besides the moated house of Sir A. Windsor at Down Park, and if, moreover, the Church and buildings were so chargeable to the new Squire, could have constituted the value of $£ 40,000$ of our money paid upon Edmond Ford's entrance to the manors of Harting?

Probably the great and increasing value of the iron forges at West Harting and Nyewood, supplied as they were with abundant fuel from the contiguous forests of the lowlands and Harting Combe, the coal of the period; while the same tracts sent timber for the Queen's navy of good sturdy oak and ash, the southern direction of which stream of supply is still perhaps marked by the sign of the Ship inn at South Harting. It is curious that at Cowdray the inward central shaft of a winding staircase is formed of a ship's foremast-one of several indications of the prevalence of the shipbuilding trade which was fed in this neighbourhood.

In 1591* there was a special inquiry concerning the woods in Harting Combe and iron-works in Rogate, and a certain iron mill called "Hammer or Iron Hammer Myll." $\dagger$ The supplies for the navy were falling short, while Rogate, which represented the northern or iron industry, was taking more than its fair share of wood for smelting, and one Richard Michelborne was alleged to have committed "great spoile and waste of sounde tymber trees of oke (oak) in Harting Combe and Nywood. $\neq$ The witnesses were of Rogate,

- Inquisitions, 33 Elizæ. No. 2305. Record office.

+ Children of William Barber, servant to John Alwyn of "The Hammer," baptized 28th May, 1630 . Harting Register.

$\ddagger$ "Nyewood silver," 6/8, half a mark, still paid to East Hart- 
Robert Slowman, George Puttock, \&c.; "and one Robert Chase of Rogate, husbandman of the age of 30 yeares or thereabouts, sworn and examined, saith :'that he hath felled and cutt in peeces, within the compas of these two yeres now last paste, in Harting Cōme. and New Wood aforesaide, a greate deale of wood for the use of the iron-woorkes aforesaide; but (he adds with characteristic Sussex caution) what oken tymber (the main point) he doth not now remember.'", These extensive iron-works doubtless furnished a large source of revenue to the lord of the manor,*

ing Manor, is a relic of the fourteenth century practice of insuring certain payments in coin, such as "malt silver," "wood silver," "larder silver"; such payments, the earliest form of the modern rent, taking the place of the older personal service on the Court Rolls.

- Many of the Sussex manors were held by curious service. Thus Rogate manor (as was Sompting or "Sontingge," in the time of Queen Elizabeth) is to this day held by a red rose presented annually at Midsummer; Hemston, a sub-manor of Half-naked or Halnaker, was held by a pair of gold spurs on the death of the tenant ; Fittleworth by two pounds of cummin ; Stopham by half a pound of pepper. The manor of Woolbeding was held in Edward the Second's reign by John Peynel, by the service of carrying the king's gonfanon, or banner, on foot when he came into that country in time of war, from the bridge called Schytesbregge (Sheet) to the bridge called Wulvardsbregge (Woolmer's bridge), or the contrary (Inq. a. q. d. 1o Ed. II., No. 12). But in Inquisition Roll of 25 Eliz. No. 170 (1585), one William Ayling dies possessed of the same manor, his service (perhaps grotesquely altered by Queen Elizabeth as part of her Cowdray feats) being to carry before the sovereign "a cross-bow without a string and an arrow-bolt (tirbolum) without feathers, when the king comes to these parts ; for instance, if he shall pass towards the county of Southampton by the bridge near Midhurst, Sussex, called Wolversbridge, to the bridge of Sheete, in the county of Southampton." The bridge is now called Woolmersbridge, but its ancient form Wulvardesbregge, shows that it had to do with the wolfward and the tax on wolves (compare Woolmer's forest, Woolbeding, Wool Lavington), not with any compound of Wool (Verified for me by H. J. Sharpe, Esq., Record office ; to whom I sent the foregoing extract from Rawlinson, MSS. B. 458. Bodleian).

In a document contained in our first register, there is evidence 
in the days when the deep tenor bell of Durford Abbey boomed its curfew over the waters of West Harting pond, and the long low meadows of Downe Park and the black forest of Nyewood, and sent home the swarm of tired sons of Vulcan to Rogate, Terwick and Trotton; for these operatives seem to have settled near the course of the Rother. Rogate seems to have owed its growth almost entirely to the iron-factory hands.

In the Registers of Harting, which commence in I567, we have not a single entry of a worker in iron, though there are several trades-the mercers, shoemakers, mynstrels - and withal several resident gentry. The last "mynstrell" was John Smith of East Harting, who was buried 27 th Oct., 1583.* The first

that in 1604 there "had been a cow left time out of mind by some well disposed person to maintain (i.e. by sale of milk) a bridge called Rother Bridge in East Harting Tithing" (Query Haben bridge). At the date of the document, 1604 , there are four bridges in Harting parish, and probably in East Harting alone, which the said cow is to bear on her back so far as the "overplus of the said cow will stretcheunto," viz.:-Wix bridge, Elvers bridge (Elsted sheepwash), and Eastbrook bridge. This is clear evidence that the roads of Harting were much extended, in fact, four-fold, since the useful bequest was made, - - a sure sign of increasing cultivation and prosperity. Latimer names the building of bridges as one of the seven works of mercy, and the tradition is that at Trotton one sister built the church and the other the bridge.

- "Mynstrells." One or two Welsh names in our early registers, such as Davie Joanes (Oct. 22, I592), and "Christr. Gowdridge, or Cowbridge, Mynstrell," 1580, may possibly have come to us as those of minstrels. There is a very interesting letter, containing the earliest notice of any music meeting in England, in which a Welsh harper and player upon a dulcimer is commended to Sir Philip Sidney:-London, 7th Feb., 1583. Sir Arthur Basset writes to Sir Edward Stradling of St. Donat's Castle, near Cowbridge, Glamorgan, on whom, according to Camden, he attended,--asking for Sir Edward Stradling's "servante Thos. Richards .... and to cause him to bringe with him bothe his instruments, as well that wch ys stringed wth wyar stringes as his harpe, both those which he had when he was last in Devon. "I have given commendacions of the man 
registers contain several entries of nurse or midwife baptism, which was duly allowed, and of which the noble family of the Cowpers of Ditcham seem at one time to have availed themselves.*

The farmers of Harting were well established and well-to-do even in the time of Henry VIII. Here is the will of one of them :-I549. Will of Richard Sylvester of Hartynge. "In the name of God. Amen. The iiiith $^{\text {th }}$ day of September in the year of our Lord God a thousand five hundred forty and nine (1 549). I Richard Sylvester, of the parish of Hartynge, being holde (whole) of mind and of good remembrance, do make this my last will in mañer and form following : First, I bequeath my soull to Almighty God, to our blessed Ladye Saynte Marye, and to all the blessed company of heaven, and my body to be buried in the church lyten ('lidden,' still vernacular for 'churchyard') of Hartyng. Item, I bequeath to the Hyght Aulter (High Altar) of Hartyng ii ${ }^{\mathrm{d}}$. Item, to the Mother Church of Chichester ii $^{\mathrm{d} .}$ Item, to my son Rich ${ }^{\mathrm{d}}$ vili $^{\text {xiiis }}$ iv $^{\mathrm{d}}$ ( $£ 6$ I3s. 4d., or ten marks) and my great capake (query cassock?); after the decease of my wyfe, my beggeste (biggest) brass pott and my greate cheaste (chest); all these to be delivered when he cometh to the age of xxiii yers (years). Item, to Agnes my daughter $v$ marke sterlinge, to be delivered when she is xviii yers of age, and eche (each) of them to be the other's heire of this my legacye. Item, to

and his instrument with wyars unto sundry of my good friends, namely, to my cosen Sr. Phillippe Sydney, who doth expect to have yor. man at Salsbury before the viith of Marche next, where there will be an honorable assemblye and receyte of many gentlemen of good calling." Robert Sydney, brother of Sir Philip, and afterwards Earl of Leicester, married a Glamorganshire heiress, Barbara Gamage, of whom Sir Edward Stradling was guardian. (Sidneyana, Nichol, Shakespeare Press, 1837.)

- Dec. 13, 1583. Margaret Cowper. Baptizata erat domi $\mathrm{p}(\mathrm{er})$ obstetricem. 
bothe my brothers ii yewes a pyce (piece). Item, to my servant John Smyth one yew lambe (ewelamb). Item, to John Parker one yew lambe. Item, to my godchild Richard Shallow a trye lambe.* The residue of all my goods,-my debts paid, my will performed,-I give to Agnes my wyfe (wife), whom 'I do ordeyn my soyll (sole) executrix, and Rich ${ }^{\mathrm{d} .}$ Salter and Joe Smith my oversears, and they to have for their paines $\mathrm{xx}^{\mathrm{d}}$ a pice (a piece)." In witness Nicholas Kennedem (Vicar, who has made the will), John Walshe, Nicholas Collins, and others. $†$

Thus a Harting farmer in I 549 left stock and household goods as legacies, and a sum of about $£ 150$ in money.

I 549. Nicholas Faireman, of Hartynge.

"Item to the great alter of Hartynge for tythes forgotten, iiijd. . . . Item to John, my sonne, ii steeres, ten shepe, a horse colt of ii yeres old, and a quarter of barley. Item to Johann, my daughter, a cow, vi shepe, and 'a quarter of barley." Rest to wife Joane: Witness, Nicholas Kennet (Vicar), Thomas Barton, John Welche, and others.

8th Nov., I 540. Will of Nicholas Pytt, Hartynge. "To the high alter of the $\mathrm{s}^{\mathrm{d} .}$ Church for tythes and

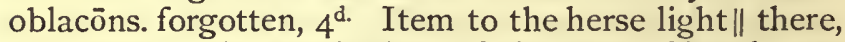
$4^{\text {d. }}$ Item to the brotherhed of the same Church, one bushel of wheat, and to the brotherhed of Petersfield as much in malt."

- Trye : an old English word for choice, excellent ; from French trier to choose, select.-Chaucer, Sir Thopas, B. 20, 46.

"They fette him first the sweete wyn,

And mede eek in a maselyn,

And royal spicerye ;

And gingebred that was ful fyn,

And lycorys and eek comyn,

With sugre that is so trye."

$\uparrow$ Vol. II., Wills, Consistory Court, Chichester, p. 94.

+ Vol. II., Wills, Consistory Court, Chichester, p. I 49 .

$\|$ Herse light $=$ funeral lights. 
William Smith,* husbandman of Hartynge. . . . . . "My bodye to be beryde (buried) in the pish. Churche of Hartynge before the auter of our Lady and Gabryell."

John Pen, of the pish. of Hertyng, 23 March, I 544.

"I bequeath to the hey altr. of Hertyng viiid. Item, I bequeath to the coppanions of the Churche of Hertyng vis. viiid. It (em), I bequeath herse light in Hertyng, xiid. It(em), I bequeath to the Matrict of the Brothers of the holy crosse and Saint Mychaell the archāgell vis. viii d."

It should here be mentioned that one family of yeomen, whose name occurs in the foregoing list, seems to have enjoyed peculiar privileges. Their head, John Pytt of Upperton (sometimes cited as Thomas $a$ Pit of West Harting), is always styled, from the time of Henry VIII., "the heire of Harting;" and local tradition records that two knights from London came down to honour him in his stronghold of Upperton, and that he had free licence to hawk and to hound as far as the liberty of Arundel Castle, for some signal service in battle. John Pytt is also called the "freeholder." Another family of the same name are styled "Pitts of Newbury," but they seem to have come into Harting about the beginning of the 16 th Century. The date carved on the stone of the fine chimney-piece at Upperton is 1634 .

After enjoying his property at Harting for twentytwo years, Edmund Ford was buried 5th December, I 568, leaving two daughters, Magdalen and Dorothy, coheiresses. Hardly was the breath out of her father's body, in fact it was just two days after his funeral, when Magdalen was married to her distant cousin lawyer John Ford, who became afterwards Protonotary of the Court of Common Pleas. Shortly afterwards Dorothy Ford married Francis Fortescue, of Fawkes-

- Vol. V. Wills, p. 24.

$\dagger$ Matric $=$ "Matrix ecclesia," or the Mother Church. I. M. H. 
bourn in Essex : and in 1582 a division of the manors was made which ultimately severed the Hartings into two chief holdings, one, the Western, Roman Catholic, and, to use a later nomenclature, Tory; while the Eastern manor, joined with the South, pursued a Protestant and Liberal policy; a state of things which lasted for nearly two centuries. By the agreement Francis Fortescue was to write all the demesne lands and tenements on two papers with a manor to each, and John Ford was to pay him $£ 40$ and take his choice.* John Ford took the manors of East Harting (including Up Park) and South Harting. To Fortescue there remained the lot of the manor of West Harting and all the lands therein, together with the Royalty of the hundred of Dumford. The advowson of the Rectory seems to have gone to the holder of the West Harting estates; but the tithes were divided into two moieties, each lord taking one. $\dagger$

Neither of the two brother-in-law squires lived long. John Ford died in 1584, and was buried among the Benchers in the Temple Church, leaving his son William, aged ten years, to succeed him in the East Harting estate. In 1597, at the age of twenty-three, this son married Ann, the daughter of a new comer, Sir Edward Caryll, and formed the only union between

\section{- Deed at Up Park.}

+ Mr. Weaver has in his possession a beautiful posy-ring of this date, which was found in grubbing a hedge at Casey's, East Harting, near the Beacon, and bears the legend engraved within :

\section{"If vertue I finde, \\ My choyse is to my mind."}

This may have been the betrothal ring of John and Magdalene Ford, of East Harting. Sir Jervoise Clarke Jervoise, of Idsworth, has a very similar posy bearing the legend-

$$
\begin{aligned}
& \text { "If love can merit, } \\
& \text { I shall inherit ;" }
\end{aligned}
$$

which Sir Jervoise thinks might have been given to some fond supporter of his Sacred Majesty when hiding in these parts preparatory to his escape. 
the two great families of Ford and Caryll. Their son was Sir Edward Ford, who, according to Camden and Coxe, was born at Up Park, but this seems doubtful.

Sir Francis Fortescue died I 586, the same year as Sir Philip Sidney; and this coincidence seems to have given rise to Dalloway's mistake that the illustrious hero of Zutphen died possessed of the manors of South and West Harting, which I have corrected in the "Athenæum" of July 22, 1876. - Ample as the Sussex possessions of Sidney were, they did not extend so far west as our Ultima Thule of the county. The nearest approach that Harting ever made to the great Sir Philip Sidney was when one Henry Burch christened his daughter "Walsingambe" in honour, perhaps of Sidney's wife, 5th June, 1608. The three sons of Francis Fortescue's large but sickly family having died without issue, ${ }^{*}$ the West Harting estate was sold to Sir Edward Caryll (son of John Caryll of Warnham, the attorney of the Duchy of Lancaster to Queen Elizabeth, noted by Fuller as a worthy of Sussex, and knighted by Queen Elizabeth at Cowdray in 1584). Sir Edward Caryll was resident in Harting in the spring of 1596 , as the registers show.

Thus the noble but unfortunate family of Carylls came here, $\dagger$ lasting from about the accession of James I. to the accession of George III. (in fact, not long after Culloden), coeval with and ruined by the Stuarts and Pretenders. It is remarkable that the second quotation of the name of Caryll in the Harting Registers contains a clue to the friendship, almost like a feudal tie between lord and dependant, which existed between one of this family in after times and Alexander Pope, the poet. Year I 597. "Item, Mercie Pope, servant to Edward Carell, of Hartinge, Esquiar, was buried the

* Burrell MSS.

+ Sir Edward and John Carylls, grantees of West Harting, in cap. 7 , Jas. I. Carylls, grantees of Harting, circa 29 Eliz. Tanner MSS. 
two and twenty day of September, I 597." To show that this was a person of no ordinary mark as a servant, there is a colophon of a hand to point the spot in the vermillioned parchment, though there is no such embellishment to denote the burial of a fellowservant, Raphe Woolven, who died in 1596 . So much has been written about the ancestry of Pope that it is hazardous to say more than that his grandfather appears to have been a clergyman in Hampshire,* who would be glad, doubtless (as a Vicar of Harting, John Newlyn, a century after), to place his daughter in the service of so distinguished a family as the Carylls, and that this domestic bond of fealty between lord and servant, the strength of which we cannot in these days measure, would account for the mutual accounts of debtor and creditor which existed between Pope and John Caryll and their fathers before them. $\dagger$

The family of Caryll (Carrell, Carrill, Caryl, monument of Forde, Harting Church) came here from Warnham. I am in this particular much indebted to the patient research of the late William Tanner, Esq., of Rye, whose marriage with Anna, second daughter of William Curtis, Esq., of Harting, connected him, during his short but active life, with our village. Mr. Tanner, at my request, made the origin of the Caryll family his particular study; and, fortunately, from a paper found amongst his detached MSS., which cover a very interesting and wide field of observation, I am able to quote what seems to be his conclusion. Noting that

* "Athenæum," 1857, p. I45 I. Mr. Potenger, M.P. for Reading, who claimed kindred with Pope, said, "Mr. Pope's grandfather was a clergyman of the Church of England in Hampshire." Register of Thruxton, near Andover, Hants, Feb. 21, I645 :"Alexander Pope, minister of Thruxton, was buried." Hunter, too, says that the Rev. A Pope of Thruxton was Pope's grandfather.

† The servants of Sir Edward Caryll usually bore good names. Thus, "Tutcher Charleton and Martha Chiverell, servants to Sir Edward Carrell, knight of Hartinge ; they were married 6 Aug., I609." Another is Thomas Apslye, servant to Sir Thomas Carrell, I6Io. 
the first appearance of the name of "Carrell" is to be found in the Calendar to Pleadings of the Dutchy of Lancaster, 38 Hen. VIII., the last year of that king, or I 547 (where the king, on the information of $\mathscr{F}$ ohn Carrell, Attorney general of the Dutchy, pleads against Henry Ashelye, Deputy Keeper of the Forest and Chase of Holte Park and chase of Kingston Lacye, Dorsetshire), he proceeds to add that Dalloway thinks that the name of Caryll descended from the Irish name O'Carroll. He continues: "At this date (sixteenth century) it is well known that the English were wont to migrate to Ireland, but instances of a counter migration of Irish families to England are most rare: and certainly an Irishman of that date is not likely to be found as a Professor of the law. I am led, therefore, to think that the Carylls of Sussex were an offshoot of the great Kentish family of Crioll, of whom Ireland tells us in his history of Kent, but whose ancestor was described in the Roll of Battle Abbey as Kyriell. Four centuries after the battle of Hastings we find that Sir Thomas Keryell, Knight of the Garter (an undoubted descendant of Bertram de Crioll, who was Governor of Dover and Rochester Castles in I6 and 26 Hen. III), being taken prisoner at the battle of Bernard's Heath, near St. Alban's, was beheaded, leaving two daughters his co-heiresses. I note this as showing that Keryell was considered by some, and possibly by the more knightly branches of the race, as the proper surname."

The zenith of the fortunes of the Caryll family at Harting was reached in I6I0, when Sir Edward Caryl1*

- The inscription in the chantry said that he married three wives; his only surviving son being Sir Richard, the son of the third wife, Elizabeth Wootton, daughter of a rich London merchant. The date of the mortuary chapel is fixed by the will of Sir Richard Caryll of Hartinge, dated 20 Aug., 1616 [ $\operatorname{Add}^{\mathrm{l}} 28$, 250] "My Bodye to be buried in ye chapell in Hartinge Church, nevuly built, where my father was buried." He gives $£ 20$ to the poor of Hartinge, and to "Margery, my loving wife," $£ 600$. 
died possessed of ten manors, of which West Harting, including Trotton, Elsted, Treyford, Didling, Iping, Chithurst, and Rogate, is the last.* He had married his daughter Cicely to Sir John Morley of Halnaker, or Half-naked. Of the two detruncated effigies in the ruined chantry at Harting (which was built in I609-10, and marked the summit of Caryll prosperity), that on the east side would seem to be Sir Edward's, the other being that of his successor, his last and only surviving son, Sir Richard. Thomas Carill was vicar of Harting, I6r2. Dame Margery, widow of Sir Richard Caryll of Harting, son and heir of Sir Edward, lies buried in some splendour at Greatham, Hants.

Some idea of the wealth of the Caryll's of Harting may be gathered from the good cheer at a bountiful old rate which is described in some curious "recytes of store" or kitchen bills of fare in the old Account Book at Harting Place. $†$ They stand at the beginning of the volume, and have been dated by the Museum authorities as I6I 5 ; however, as I find no entry of the year, and as the cook or manciple occasionally heads them "the declaration of yo. worship's expenses," a title so far as I know accorded in our Registers only to Sir Edward, I prefer to think them a little earlier.

"Dynned (i.e. dined) on Sunday, the xxii of January. 1 Beefe, boyled; 2 Marybones (marrow bones) boyled; ${ }^{3}$ Porke, boyled ; ${ }^{4}$ Beefe, rost ; ${ }^{5}$ Pigge, rost, I (mess or dish) ; ${ }^{6}$ Veale, rost, I (mess); ${ }^{7}$ Goose, rost, I ; ${ }^{8}$ Rabbets, rost, iii; 9 Woodcocks, ii. In y pler (parlour) my Lo(rd) Cursen, Sir Ger. Cowp(er) and Mr. Cottens." [These were the guests-Lord Curzon of Parham, an old neighbour, when Sir Edward was at Warnham, one of the Cowpers of Ditcham, and one of the Cottons of Warblynton, kinsfolk of the Caryll's.] "In $\mathrm{y}^{\mathrm{e}}$ hall serving men and extra psons. (persons) $\mathrm{xx}$."

- Rawlinson MSS., Bodleian, B 428.

$\dagger$ Household Books and Accounts of the Family of Caryll, 1615-1730. Add. 28, 240., B.M. 
“Supp : (supper). ${ }^{1}$ Mutton, boyled, i mess ; 2 Sliced beefe ; Sowces*; ${ }^{3}$ Sallet (salad) of South (?); ${ }^{4}$ Trippes (Tripe), fryed ; ${ }^{5}$ Mutton, rost, 2 mess(es) ; ${ }^{6}$ Capons, rost ; 7 Rabbets, rost, iii ; 8 Woodcocks, rost, ii ; ${ }^{9}$ Phesont, rost, ii ; ${ }^{10}$ Cold baked meat. In $y^{\mathrm{e}}$ pler. (parlour) ut supra : in $\mathrm{y}^{\mathrm{e}}$ hall serving men, 2I."

We may notice the unusual preponderance of fresh meat in January, when the fare of ordinary houses was salt Martinmas beefe.

"If one knew how good it were

To eat a fowl in Janiveere (January),

Had a man fifty, or had a man ten,

He'd leave but here and there a hen "-

was an old proverb in expression of the luxury of tasting fresh meat, after so many days of salt fare. Another point to be noted is the very large supply of meat : but the number of serving men (of which each guest brought his proportion) has to be remembered. There is nothing that represents our pastry, and not a single taint of French cookery: it is English fare simple and guileless.

On other occasions the guests were Mr. Cotton, Mr. Mitchell (who resided at Harting), Mr. Dering, Mr. Browles and his wife (probably of the family of Bowles, or Bolds, connected with Nursted).

On Fridays the lord of Harting kept his fast.

"Dynned on Friday, the xxvith of January.

Butter and egge

Earbe (herb) pottage

Sallets

Roots, buttered Salt fish, buttered Eggs, buttered
(Another dinner.)

Rabbett ................ xi ${ }^{\mathrm{d}}$

Sinomond (cinamon) viiid

Pigg ................ ii in $^{\text {iiid }}$

Salt fish, ii cupple v

Oatmele, a pecke ...... $\mathrm{x}^{\mathrm{d}}$

"I am told that "Sorvce" is still the current Sussex for "pig's feet, ears and tail, in fact anything pickled in salt."

"He that can rear up a pig in his house

Hath cheaper his bacon and sweeter his souse."

TUSSER. 
(Dinner No. I.)

Pudding, baked

Cood (codd) boyled, ii fishes

Apple pyes baked
(Dinner No. II.)

Eggs and yest ........ vi ${ }^{\mathrm{d}}$ Butter $\mathrm{xi}^{\mathrm{ib}}$

iiiis $^{\text {iid }}{ }^{\mathrm{d}}$

Drinking this week $\mathrm{xliii}^{\mathrm{s}} \mathrm{ix}^{\mathrm{d}}$ "

The chief item of all was the ocean of beer consumed; in fact it would seem that at that time more beer was drunk in a month in the single house of Harting Place, than in all the parish with its five public houses now. Over 1000 gallons disappeared from the store in one calendar month; and of the total expense of the household for one month from Jan. 6th to Feb. 2nd (Twelfth day to Candlemas), $£ 45:$ I $5:$ I I in all, the highest item is for 20 hogsheads of beere at 9s. the hogshead, $£ 9: 0: 0$. It must be remembered, however, that in those days beer covered the space now occupied by tea, coffee and cocoa, and all lighter drinks as well as wine and spirits ; it was nearly the sole beverage for all classes and sexes. And further the account is for a Christmas time. Still when all these allowances are made, we cannot doubt that to get rid of 20 hogsheads of beer in a month Harting Place must have wallowed in drunkenness. Other items of the month's bill of store were " 30 bushels of wheat at 3 s. 4 d. $=£ 6: 2: 4$; Beef, I Io nayles, at I3d. the nayle,* $£ 6: 7: 3$; Muttons (sheep), I $3 \frac{1}{4}$, whereof 5 at 10 . ye peece, 8 at 7 s. ye peece, $£ 6:$ I I : $0 ; 4$ turkies, 20 capons, 20 rabbits, 2 flitches of bacon, butter, 17 nailes at 5 d. the nayle, $7 \mathrm{~s}$. Id. ; I80 eggs, 9s. ; old ling (salt fish), iiii at $3 \mathrm{~s} .8 \mathrm{~d} .=14 \mathrm{~s}$. $8 \mathrm{~d}$. ; stock fish, 7 at $8 \mathrm{~d}$. the cupple, $2 \mathrm{~s} .3 \mathrm{~d}$.; codd, 12 cupple at I6d. ye cupple, I6s."

"Sum. totlis. of $\mathrm{yo}^{\text {r. }}$ wo $^{\text {ps. }}$ (worships) expenses of household for one whole moneth, that is to say from the sixth January untill the second of February, being the space of one moneth, besides wine, spice, woode and coole (coal) —£ 45 : I 5 : II."

- The "nail" is still known in Sussex as a measure for eight pounds of meat. 
Such were the palmy days of the Carylls.

- But the sky was soon overcast ; and (as if to throw a shadow of coming sorrow over the village) in $160 \mathrm{I}$, about Michaelmas, a murder is recorded as having taken place in the wildest part of the parish, the scene a century afterwards of another murder, the memory of which is still fresh. "I60I. Item this yeare about the Feast day of St. Michaell th'archangell or shortly after, the bones and apparell of John Roche of Estmeane (East Meon), was founde in Hale wood (near Lady Holt), within the parishe of Hartinge, which John Roche was suspected to have been kylled there by William Torner, who was hanged at the next Assyse (assize) at Estgrinstead for the same facte, and other roberyes. Also, the sayd bones weare buryed in the place where they weare founde by the appoyntment of the Crowner (Coroner)." (Harting Register No. I.)

In the troubles of Charles I. heavy times swept over the lords of both East and West Harting. Cousins as they were, Sir Edward Ford's mother being Anna Caryll, they seem to have held together in politics.

Parson Ralphe Deare, whose prim and puritanic handwriting* is a marked feature of the venerable register quoted above, dates the baptism of "Edward the sonne of William Ford, of Harting, Esquiar," on April 22, 1605. This was the future Sir Edward Ford, whose eventful and honourable life lasted $6_{5}$ years.

He entered Trinity College, Oxford, as a Gentleman Commoner about the year 1620 , the year in which the famous William Chillingworth obtained his scholarship at that College. $†$. Edward Ford did not take a degree,

- Examples of his precision :- "Thomas Harding and Godly Somer were joyned together in matrimonye the sixe and twenty day of January, I 588 ; the man of Esborne, the woman of Hartinge." His own marriage - "Item, Raphe Deare, of Hartinge, and Alice Packe, of Rogat, were joyned together in the estate of holy matrimony the twentie-seventh day of Januarie, I604."

+ Chillingworth the divine, born at Oxford: Scholar of Trinity 
but doubtless developed in early life the mathematical and mechanical powers for which he was still more famous than his tutor Chillingworth. As Sir Edward Ford, lord of East Harting manor was born, lived, and was buried at Harting, we must closely follow his public career.

The autumn of 1643 ushered in the second of the four years of Civil War. The king and his rival Parliament was at Oxford, and what may be called his depot, under Lord Hopton at Winchester: Parliament in London, and their officer, Sir William Waller, at Farnham. The county of Sussex was one in which "the king had hitherto had no footing"; * but a message was sent from some Sussex loyalists by Sir Edward Ford, who had been knighted at Oxford and made Sheriff of Sussex, and who commanded a regiment of horse in Lord Hopton's troops, begging that Arundel Castle, might be seized for the king before the winter set in. Charles having heard that Kent was on his side, and wishing to unite Sussex with Kent, approved of the scheme. Lord Hopton marched from Winchester to Chichester, and his cavalry passed through Harting, while the infantry attacked Lord Lumley at Stanstead. "The exceeding hard frost," as Lord Clarendon says, " made his march more easy through those deep dirty ways than better weather would have done." Arriving at Arundel by surprise, he took it on the third day, Saturday, Dec. 9th, and left it in Sir Edward Ford's keeping, in fulfilment of the ancient service rendered

College, Oxford, June 20, 1620, Fellow I628: became Roman Catholic, but was converted again to the Protestant faith by Laud at Oxford, 1631, when he wrote a book against Rome. He was a staunch Royalist, and helped the king's troops at Gloucester, being an eminent engineer. He accompanied Lord Hopton's troops as Chaplain, died after the siege of Arundel, 1643, and was buried with insult from the Puritan clergy, in Chichester Cathedral. $\mathrm{He}$ is the author of the well known saying: "The Bible, the Bible only - the religion of Protestants." 
by the lord of Harting manor from the time of Henry II., which bound him to defend the castle for the king in time of war. One month afterwards (Jan. 6, I643-4, at 9 a.m.) Arundel Castle changed owners again.

The Royalist garrison of Arundel under Sir Edward Ford numbered 200 men ; ${ }^{*}$ but the number of officers was large, many being fatigued with the late marches, and preferring to winter on the spot. The great William Chillingworth, who had accompanied Lord Hopton, stayed behind in Arundel Castle, "being indisposed by the terrible coldness of the season." Sir Edward Ford, adds Clarendon, was "a man of honesty and courage, but unacquainted with that affair, having no other experience in war than what he had learnt in these troubles." The garrison neglected Lord Hopton's injunction before he parted on his return to Winchester, viz: that they should get in provisions so as to be able to receive reinforcements, and stand a siege. They further resisted authority, and became factious under an Irish officer, Colonel Bamford, or Bamfield, who "set himself up." Meanwhile Waller, having gone to London, had obtained reinforcements from the London train-bands, and marching upon a "great village called Alton," surprised it, and slaughtered Colonel Bowles at the head of the Wallingford regiment in Alton Church. He was killed by a blow from the butt end of a musket. Waller then pushed on south by east, via Hazlemere and Midhurst (the November frost continuing) to retake Arundel. Sir Edward Ford stood a siege of twentythree days and surrendered, "the men being sick from continual alarms for three or four days together." Arundel Castle was thus retaken by the Parliamentarians on Jan. 6, I643-4: Chillingworth, mobbed by the Puritan clergy, died within a few days of the fall of his refuge, and was buried at Chichester; and Sir Edward Ford, with his garrison, were sent as prisoners

- For this account see Clarendon's Hist. of the Rebellion, Book VIII. 
of war in bitter snow to London. A sad winter for Sir Edward, as he had buried his daughter Anne in Harting Church on the I $3^{\text {th }}$ November. The loss of Arundel was " an inward bleeding wound to Lord Hopton."

We have a most interesting bit of old English history, in connection with the taking of Arundel, in a single line of our oldest Parish Register. "There were 3 souldiers buried Nov.24, I643." Following up this clue, and assuming from the loyalty of the village that the three "souldiers" were King's men, I have discovered that there were two encounters at Harting about this time, and have been fortunate enough to hit upon the account in one of the King's Royalist newspapers* of a battle at South Harting on the 23rd Nov., I643, as detailed by the "Special Correspondent" of that time. It will be observed that the date of the fight is just the day previous to the interment. The Earl of Crawford (Ludovic Lindsay, I 5th Earl of Crawford in Scotland) had three troops of horse (King's), with part of which he was on his way to Arundel, having probably come* from that stronghold of loyalty, Basing House, where Waller the Parliamentarian General was repulsed about this time. The Royalist cavalry entered Harting first, and took up their quarters, in all $\mathrm{I} 20$ men. Some 400 dragoons under the Parliamentarian General, Colonel Norton, a sort of flying squad of Waller's, whose object was to harass Lord Hopton's cavalry on its way to Arundel, according to the favourite device of the Covenanters at Alton, Adderbury, Reading, and elsewhere, caught the King's men asleep in South Harting. But the officers were equal to the occasion, and sallying out from the Knight's house near the Church, they passed along Typper lane, thus placing themselves between the hills and their enemy, and gave the signal, "Follow! Follow!" which in the darkness would convey the impression to the Parliamentarians that some of the

- The "Mercurius Aulicus," or Court Mercury, one of the first newspapers ever published. 
King's forces on the way to Arundel had been signalled back, and were coming down the hill behind in overpowering numbers.

The local tradition that there was once a fight in the Culvers, South Harting, is thus remarkably verified.

The Court Mercury of Sunday, December I0, I643,

p. 707, says :-

"This day I was certainly informed by an eyewitness of credit of one of the noblest pieces of cowardice that ever attended a bad cause and conscience. It happened on Thursday, the 23rd of November last, that in the dead of night about six score of the Earle of Craford's Regiment came into a village in Sussex called South Harting (a place sufficiently knowne by reason it is the constant seat of the noble Knight and brave housekeeper, Sir John Carell): They entered the village very farre spent with travell, want of sleepe and food, and extremely weather beaten with a rainie stormy night. These their sufferings and indispositions caused them presently to quarter themselves in the severall houses of the towne; onely six of the chiefe officers and one boy lay in the knight's house. Within lesse then an houre after (when all of them were now taking their rest) the famous Colonell Norton of Hampshire enters the village, not knowing (til he was in the towne) that any of the King's souldiers were there, but having notice thereof, and of the assurance (by taking them utterly unprovided for defence) that he might safely show a brave proofe of his valour, he caused his men to rank themselves ten and ten, and so to make good every door and house of the Towne that none might escape ; which being done the rebels cry 'Horse, Horse,' in the street, which the King's souldiers mistaking to be the call of their owne commanders offered in diverse places to come forth, but were presently shot or killed, so that seeing no possibility of bringing forth themselves or their horses into the streete, almost all of them fled by backways on foote to save themselves, leaving the Rebells outragiously domincering 
in the Towne, shooting into all houses, and at all persons, and barbarously using such of the King's men as their valour enabled to make any opposition.

"In this hurly-burly word was given to the sixe Officers in the Knight's house how the Towne and their souldiers were surprized by the Rebells. These six men with one boy presently tooke horse, rushing out by a back lane upon the 400 Rebels (for so have some of their owne company since protested to have been their number) and crying out, 'Follow, Follow, Follow" (as if they had already chased them), charged in upon them with so much fury and undaunted courage, that they routed them and presently drove them (killing and wounding them) quite through the towne, forcing them over hedge and ditch, killing as many as the Rebells had done of theirs (that is, some half-a-dozen), taking two Prisoners (one of which being the Trumpeter), wounding very many; having but five or six of theirs and but one of these much wounded (the Earle of Craford's own Cornet), but not dangerously, and brought off all their own Armes and divers of the Rebells' Horse, with all Captaine Betsworth's* sute of Armes, \&c."

"The Rebells having since been faithfully acquainted with the truth of their beating, and how that their 400 Horse and Dragooners were so lamentably beaten and chased away by only 6 men and a boy (but when they were in their chase and flight here and there 2 or 3 soldiers stept out of their places where they lay hid and lent some blows to their fellows), one of the Rebells swore solemnely in these true and remarkable words-" By heaven, we deserve all to be chronicled for the veryest cowards that ever lived!"

The parish of Harting at that time might rival Basing, of whom its stout old defender, the Marquis of Winchester, said when it was taken, that "Basing House was called Loyalty." Harting then contained five squires, a parson and yeomen, who were united in - Probably Bettsworth of Milland. 
their devotion to their unfortunate king. Father and son at Up Park, Sir William and Sir Edward Ford; the Carylls, father and son, at Harting Place, near the Church ; and Major Cowper (who, according to Dalloway, fell afterwards fighting for the King when Cromwell took Winchester Castle) at Ditcham, were our five loyal squires, securing our east and west, and above all the heights at Up Park on the south, for the king: and Colonel Norton's dragoons would have had a hard day's work before them, before they could have reached the summit of the Harting hills.

Before the month of December, I643, was over, however, the soldiers of Sir William Waller, "William the Conqueror" he was now called, were successful here as elsewhere.

In the Caryll Correspondence it is expressly said that the Rebels sacked Harting Place, the old mansion near the Church, and we learn from John Caryll's pleading when he compounded and paid his fine to Parliament at the end of the war, that South Harting was made by Lord Hopton "a garrison for the king."* There was a similar garrison for the king at Petersfield, $\dagger$ probably at the Castle House. The Royalist line of communication with Arundel had for its basis Oxford and Winchester: Petersfield and Harting were thus essential posts, that were fortified for the time. Caryll's plea at the close of the civil war, already quoted, shews this. He pleads, "That y" Petitioner being at his father's house, called Harting, in Sussex, wch. is in the midway direct from Winchester to Arundell, and $y^{e}$ King's forces having made a garrison in the said house about December 1643, Sir Ralph Hopton coming thither w $w^{\text {th }}$ part of his Armye commanded $y o^{r}$ petr. to attend him to Arundell, where he deteyned yo ${ }^{\text {r. }}$ petr. untill $\mathrm{y}^{\mathrm{e}}$ castell was taken by Sir William Waller." $\ddagger$

" Royalist Compositions, Vol. II., p. 240. Record Office.

+ "Perfect Diurnall," Saturday, Dec. 16, x643.

$\ddagger$ Hopton hung six persons at Salisbury for not joining him. 
As the strength of the Parliamentarian forces grew on all sides (from London Train-bands, and the Kent, Surrey, and Sussex contingents), until at last Waller had an army before Arundel of 8,000 men, Harting and its garrison began to suffer terribly. Just before Christmas Day, Lord Hopton made a vigorous effort with 4,000 Horse to relieve Arundel, but his forces were outnumbered by Waller, and he "made a nimble retreat towards Winchester." Having lost a battle south of the downs, he had to fight his pursuers all the way over the hills, and reaching the foot of the northern side of the downs at Harting, found a second battle awaiting him on the north, where the inexorable ColonelNorton, of Hampshire, was crouching like a panther, his dragooners anxious to set at rest the laugh about the "six men and the boy."

Thus the second battle at Harting was fought, and this time the king's forces were totally defeated. Its date was close on Christmas Day, as may be seen by comparing the following evidence: it was again a cavalry engagement; and between 200 and 300 of the Earle of Crawford's horse, a detachment of Hopton's retreating arny, were taken prisoners.

Among the State Papers (Domestic) of 1643 is one dated 28 th December, written by a royalist of the name, real or assumed, of Harrison, to a Mr. Jean Bradley, English gentleman, of the College of Tournay, Paris.

" $28,10^{\text {br. }}$ 1643. . . . Sir William Waller was bravely repulsed and soundly beaten from Basing about five or six weeks ago, with the loss of the best part of a thousand of his men, and the diminution of

- "Perfect Diurnall," 8th Jan., 1643-4 :- "There is certain newes come this night to the Speaker that Arundell Castell was surrendered this day, about 9 of the clock, to Sir William Waller .... And further, that Sir Ralph Hopton is hemmed in between Chichester and Winchester, and that he can hardly escape Sir William's forces." 
his credit with the citizens. But since, it hath been his fortune (he being four or five thousand strong and the other but weak for number) to surprise at unawares, and after firm fight, with the slaughter of more of his side, to take two or three hundred of my Lord Crawford's men, who were brought to this town (Farnham or Guildford?) in triumph about a week ago from South Harting (so I think the place is called) in Sussex. He is said to be now before Arundel Castle, and, as the citizens say, likely to carry it, being strong by an addition of Kentish, Sussex and Surrey men come to his aid."

The following is evidently another account of the same affair. It is from the "Perfect Diurnall" (Parliamentarian) of I 5 th Jan., 1643-4. The lateness of its date may be accounted for by the "bitter snow" of the early part of January in that year. "There was also a malignant report spread about the City (London) this week of a great defeat given to Colonel Norton by the Hoptonians: The summe of which defeat by a letter to his Excellency the Earl of Essex this day amounts to no more than this. That upon the retreat of Colonel Norton from following the Hoptonians' whole body upon their seeming attempt to relieve Arundell : the Colonell entering of a towne called Harr, met with two regiments of Dragoons under command of the Lord Crafford and Colonell Ellis, both which (after a short skirmish) he forced to retreat, with the losse of a Captaine and a CaptaineLieutenant of the enemies, besides many of them wounded and divers taken prisoners : he performed this service with onely fifty horse, of which he lost onely two or three men, the rest of the forces being got safe to Chichester, whither he sent the prisoners he took (?), and afterwards went himselfe with the rest of his forces to Portsmouth."

Under all this rough usage Harting suffered terribly. The king's soldiers in the garrison had been short of 
provisions, and plundered the cottages of the villages far and wide for bread. The enemy, having taken their 300 prisoners at South Harting, proceeded to sack Harting Place and the Church.

John Caryll, Pope's friend, writes, Oct. 29, I709, that his father thought that their title-deeds were lost in the time of the civil wars, when 'Harting House (Harting Place) was plundered several times.' * Most probably the ancient Church was denuded and ransacked on these occasions, and turned into a stable or hospital as the case might be. The Caryll monuments could scarcely have escaped their first desecration at this time. There are still local traces of the fights. A cutting which crosses the two roads at the foot of the warren near South Gardens is due in popular belief to "Oliver," i.e. Waller's cavalry officer, Colonel Norton. It is probable that this escarpment formed part of the hasty intrenchments of Harting on the north side, the shallow depth of which in most places was doubtless owing to the extreme rigour of the frost, which, according to Lord Clarendon, set in early and held on for a long time. Traces of these scratches in the ground to form lines may be traced on the north side of Tarberry, on the western slope of Bohemia Hill, at Upperton meadow, on the summit of West Harting Down, and on the north side of Up Park, under the Tower. The raised road between Hemner and Tarberry is probably due to this time. The "White Road" towards Chilgrove is trenched at intervals of the ascent where it faces the north, and small bastions for the use of such small cannon as the "saker drakes" and "murderers" of the day. At the summit of the "White Road" where it reaches the downs, the trenches are more perceptible, and close by, three mounds immediately facing the Up Park palings, near the Two Beech Gate, are un-

- Caryll Correspondence, Addl. 28, 227. Vol. I., p. 82. 
doubtedly the graves of the dead, three skeletons having been found there some years ago, and two more last year (1876) as the workmen were digging chalk to mend the road at the gate immediately opposite. About a quarter of a mile further over the downs towards Chilgrove, in the direction of Arundel, there is a regular encampment on the left hand, flanking a little coombe approached by another pass in the downs immediately opposite East Harting, near Beacon Hill, a road familiar to huntsmen as it saves much of the steep ascent of their way to Chilgrove or Compton. Near this battery the main road passes "Kildevil" lane, whose euphonious name proclaims its descent from the Cavaliers. There is a large green mound south of Up Park House, in which, tradition says, a number of horses were buried, and there is a similar tumulus further to the south at the fern beds between Compton and East Marden called "Solomon's thumb." *

A record of Lord Hopton's march from Winchester to take Arundel was perhaps discovered at East Meon not long ago, when four bodies were found buried in an upright posture (like Ben Jonson in Westminster Abbey) under a stone bearing the mysterious legend, "AMENS PLENTY." The lettering is very plain and precise, and might pass for a very modern effort; but it is almost identical with that cut on the grave of Shakespeare's wife Anne at Stratford-on-Avon, Aug., I623. Let the imaginative believe that four "Psalm-singing knaves" were killed on their way through East Meon into Sussex, and buried in grim jest as a quartett to sing "Amens plenty" without interruption. At all events this is only one of the many hazards as to the remarkable stone, and still more remarkable interment.

The poor Royalists of Harting were taken as fish in a prawn net when Arundel Castle fell. Old Sir William Ford, seventy years old, "aged and sickly," was at large, but his son, Sir Edward, or Colonel Ford, the Sheriff,

"Alias "Baverses' Thumb." 
and his kinsman, Captain Ford, were taken in arms and marched off "in the bitter snow" to London House. Poor John Caryll of Harting, "a Popish recusant," was taken, together with two little land owners of West Harting, Crasswell, or Crassweller, and Pay of Upperton, among the "gentlemen that bore not armes." Thus five luckless sons of Harting (including the three squires) got into the clutches of the Parliament as prisoners at the fall of Arundel. John Caryll paid Sir William Waller at once $£ 600$ " for his peace," and afterwards lent $£ 500$ to the Parliament towards suppressing the rebellion in Ireland. He had to plead hard, and at length (his petitions extend over IoO pages of the Records) to be allowed these deductions in the fine of $£ 2980$ that the Parliament set him in I649. There is evidence that Sir William Waller stood his friend and acknowledged the receipt of the $£ 600$ at Arundel. Caryll pleaded that he was forced by Sir Ralph Hopton to accompany him to Arundel, and yet that he had been sequestered and imprisoned, that his estate at Harting was entailed, and worth, after deductions, only $£ 732$ a year, and that "he had resolved to reconcile himself unto the Protestant religion, which sithence he hath really performed." He was allowed to pay his fine in two parts, and discharged at once $£$ I $322:$ IO : 0 . His voluminous petitions extend to December 2, I65 I, when he pleads, " $\mathrm{Y}^{\mathrm{r}}$. petitioner, by husbandry of watering many grounds, hath very much improved the sayd manor of Hartinge since his composition, and desires the value of his estate to be certified as it was at the date of composition." By this policy of delay he would almost seem to have tided matters over till the Restoration. His father, Sir John Caryll, did not die till I654. Nevertheless the fine actually paid doubtless impoverished his estate.

Parson Caryll, though a Protestant, seems to have fared no better than his relations the squires. His living was sequestered by Parliament, and he too had 
to pay the fine of loyalty for his concern with the Arundel expedition. One Richard Shallett, who had been a servant at Oxford for seventeen years, and owned a copyhold at West Harting (a principal tenant of the Caryll family), having been in arms against the Parliament at Winchester Castle, was fined 40 shillings a year for life. Old Sir William Forde was taken prisoner at Chichester, and henceforth his existence seems to have been embittered. He was marched off to London with his son, Sir Edward, for ten months' imprisonment. When he was exchanged and came home, his neighbours, the Parliamentary Committee of Chichester, worried him sadly by ordering " 2000 coards (cords) of wood in Harting Parke (Up Park) to be sold and taken away ... for satisfaction of wrongs done to certaine countrey people thereabout by some parties of Colonell Ford's (his sonne's) Regiment." About this time, as we shall see, Sir Edward Ford had gained interest with the Parliament, and the comparatively small fine of $£ 500$ was all that was laid upon Up Park.* The old man is shrewd enough to throw all blame upon his son, now in favour, and to make capital of him.

24th Oct., I645. " $\mathrm{Y}^{\mathrm{r} .}$ Petr. humbly begs that Parliament $w^{d .}$ not punish him (the father) for the sonne's faults," but enforce the composition; and is sorely aggrieved that since his composition in October last the Chichester Committee " have caused many of $\mathrm{y}^{\mathrm{r} \text {. }}$ petitioner's Trees to be cutt downe close about his house which standeth upon a hill." They also seized the furniture, stock and goods at Up Park. In a fuller petition of the same date, Sir William Ford pleads that "being sickly and aged he was at Chichester with

- For the composition Sir William Ford returned his Harting property as worth gross $£ 340$, nett $£ 283$. All is entailed. The "Up Park demeanes" he values at $£$ I 20 (let by the Committee for $£ 80$ ). Mayndownes, $£ 40$. Nywood's Meads, Lyemeads, Bonescrofts, $£ 40$. Also three yards of land called Neyers, \&c. Royalist Compositions, Ser. I, Vol. XXV, p. 353-36I. 
his eldest son, Edward Ford (whom the King had made high Sherieffe of Sussex), from whence he was carried away prisoner with his sonne to London House. After ten months' imprisonment, being exchanged, he moved the Earl of Essex, then General, to give him his " passe to go to Hartinge in Sussex, where his land lay, and there to abide." His Highness refused this. "Two years since he was forced to go into the King's Quarters, his land being sequestered, his house spoiled, and his personal estate taken from him.... And being at Winchester when $S^{r}$. Ralfe Hopton marched into Sussex with his Armie, $y^{\text {r. }}$ Petitioner went along with him to see yf he could gett any Rent of his Tenants, but none of them payd him any money, yet he procured as many as spake unto him protections; and at the return of the Army (Hopton's retreat from Arundel) the Souldyers wanting bread were appointed to fetch the same from the countrey men's houses, but they fearing to be plundered of their goods under colour of fetching bread, divers of the countrey came to $y^{r .}$ Petitioner and intreated him to be a Meanes that they might send some Bread, and not to have the Souldyers to fetch $\mathrm{y}^{\mathrm{t}}$, and according to their desire he sent a note to have $\mathrm{y}^{\mathrm{t}}$ done soe (for their good), and he had not any of his Tenants taken prisoners, nor any of their cattle taken away for his Rent behinde, as he might have had. And yor. Petitioner being at Winchester when Lieutenant Generall Cromwell lately tooke the same Towne and the Castell there, his passe was made for him to goe to Oxford, but he desired to have a passe to goe to London, and he noblie granted him a free passe, not forcing him to go into the King's Quarters."

I have quoted this interesting document at length, as giving a graphic picture of the sufferings of all classes at Harting in the fatal winter of 1643 :- the country far and wide ransacked for bread, rents unpaid, two sets of hungry soldiery in turn masters, Church, cottage, mansion, and park alike pillaged, the squires in gaol, the parson and the farmers fined. 
When we next hear of Sir Edward Ford he is found to possess interest and favour with Cromwell and the Parliament. It is probable that from his father's side he would inherit the traditionary popular instincts of the Ford's: and from his mother, the Caryll, a loyalty for King Charles. He appears probably from this cause to have had high friends on both sides; but he has never been charged of being a Trimmer. "Runegado Foord," as the Roundhead newspapers dubbed him at Arundel, simply meant that he had been imprisoned early in the war, and had managed to escape. He had married Sarah Ireton, sister to Ireton, Cromwell's lieutenant,*a Derbyshire heiress, and when Henry Ireton married Cromwell's daughter, Sir Edward Ford afterwards became connected by family ties with old Noll, the Protector himself.

King Charles I., sold by the Scots for $£ 400,000$ (1646), was given up to the Parliament and kept prisoner at Hampton Court (1647). A Ashburnham, who was helping the king's escape to Tichfield, on the way to Carisbrooke, communicated with Cromwell and Ireton through Sir Edward Ford, "who had married Ireton's sister, but had been himself an officer in the king's army from the beginning of the war, and was a gentleman of good meaning, though not able to fathom the reserved and dark designs of his brother-in-law," Ireton.

Sir Edward Ford, however, was best known to his immediate posterity as an engineer, machinist, and ardent disciple of the Baconian philosophy. Camden calls him "an ingenious mechanical gentleman;" and Wood in his "Athenæ," $\dagger$ enlarging upon Camden, in some measure repays the debt which the succeeding generations of Londoners felt to be due to Ford. "Edward Ford of Up Park was a most ingenious mechanist, and being encouraged by Oliver, and invited by the citizens of London, in 1656 he raised the Thames water into all the highest streets of the

* Clarendon, x. 128. † Wood's "Athenæ," I, 469. 
city 93 foot high in four eight inch pipes, to the Wonder of all Men, and the Honour of the Nation, with a rare Engine of his own Invention, done at his own charge, and in one year's time. He also built the great Water Engine near Somerset House, which supplieth the inhabitants of the Strand and adjacent parts with water. He made divers other proposals for the Advantage of the Nation, and would certainly have done great matters for the Public Good, had he not been discouraged for what he had done, and thwarted by the Great Ones in his further Designs, which Death put an end to. He died in Ireland Sep. 3, 1670, and his body being brought to England was buried in the Church of this place (Harting) by (i.e., near) his Ancestors. He printed some Books containing his projects in 1641, 1666, and 1663 , which have never been regarded since his death."

In these treatises he appears as an intelligent advocate of the Paper currency; and in one of his papers he proposes to bring the river of Rickmansworth into London in order to supply the Londoners with pure water. Had he succeeded in doing this he would have surpassed a similarly humane gift of pure water for which Sir Francis Drake is commemorated by his townsmen in the stained glass of the new Guildhall of Plymouth, where the artist has skilfully represented the hero as pouring water out of a pitcher for wondering children and maidens.

The notices of Sir Edward Ford in Pepy's Diary are amusing.*

"1663. 22 September. This day my wife showed me bills printed wherein her father, with Sir John Collidon and Sir Edward Ford, have got a patent for curing of smoking chimneys. I wish they may do good thereof."

" I664. 3 December. To a committee of the Fishery: 
there only to hear Sir Edward Ford's proposal about farthings; wherein, oh-to see almost everybody interested for him ; only my Lord Anglesey, who is a grave serious man. My Lord Barkeley was there, but is the most hot fiery man in discourse without any cause that ever I saw, even to breach of civility to my Lord Anglesey in his discourse opposing to my Lord's. At last, though without much satisfaction to me, it was voted that it should be requested of the king that Sir Edward Ford's proposal is the best yet made." It is curious that the chief parties in this quaint scene were, with the exception of Lord Anglesey, all more or less connected afterwards with the Ford or Caryll families: Lord Barkeley, as we shall see, married his eldest daughter to Sir Edward Ford's grandson, and Lord Baybrooke, the descendant of Pepys himself, sprung from the Carylls on his mother's side. The invention of Sir Edward Ford's about which so much heat was shown, at a time when Charles the Second's patronage of the Royal Society made such questions fashionable, was a new way of making farthings, "by which the inventor made demonstration to the king and council so that they were satisfied that the coins could not be counterfeited, and that one farthing could not be like another, but that they should differ in some little thing." Prince Rupert* is said to have prevented Ford's obtaining a patent for England, but one was granted him for Ireland, whither he went and died in I670, before his plan could be established. $\dagger$

Had Sir Edward Ford not been absent in Ireland at the time of the Plague and the re-building of London after the Great Fire, $\ddagger$ it is probable that his name,

- Prince Rupert himself invented mezzo-tinto, " and from him is named that curious bubble of glass which has long amused children and puzzled philosophers." - Macaulay, Book I, iii., p. 406.

$\dagger$ Wood, quoted by Dalloway.

\# Harting Church contributed for the re-building of St. Paul's 
unaccountably passed over in the "Lives of Great Engineers," would have become national. He was certainly "First Lord of the Works" to Cromwell and Charles II. As it is, while we look at his arched tombstone in our chancel, which perhaps a severe spirit of Puritanism has never allowed to receive its recumbent figure, we may think of him resting, after a well spent life of sixty-five years, in honoured peace in the place in which he was born;--a man of universally high character and usefulness : called to take a high part in civil war, but with strong sympathies to either side-the king's soldier and fellow-sufferer, and yet a kinsman to Cromwell- the college friend and mathematical pupil of Chillingworth, and yet the husband of Sarah Ireton-the unfortunate and yet stainless defender of Arundel-a man who could satisfy even so strong a partisan as Clarendon that he "was of honesty and courage and good meaning," honoured alike by Charles I., Cromweill, and Charles II., because his guileless and simple nature lent itself to no intrigue-a patriot who, when the king's cause failed, and the fine for unswerving loyalty had been paid, cheerfully devoted the energies of his active and practical mind under Cromwell and the Restoration to the material welfare of the people-an enlightened advocate of pure water supply to London as the best preventative of the terrible Plague-a practical philanthropist in the dandy days of Charles II.-a benefactor for many generations to the poor of London-a man who lived to sixty-five, and yet never had an old age.

Of all the sons of Harting there is none whose rest is more honourable than that of her old master, a simple-hearted gentle toiler for the many, Edward Ford.

after the Great Fire the sum of Thirty shillings, 24th May, I687. See Register of Briefs at the end of Register No. II, which also contains other curiosities, viz., collections or Briefs made for the refugees after the Revocation of the Edict of Nantes, and for redemption of Christians enslaved by the Turk. 
His body was brought over from Ireland, where he had died Sep. 3, and buried at Harting Oct. 1 5, 1670.*

The grandson of Sir Edward Ford was still more famous in English History than his grandfather for brilliant talents, high station and leadership, but lacked his grandsire's honest name. Though Lord Macaulay has softened some of the more repulsive features of his character, and said at least something in reply to the bitter and contemptuous invective of Fox (C. J.), yet no one can make a hero of Ford, Lord Grey. Perhaps the best palliation that can be offered is that the worst crime of his life, his incestuous intrigue with his sister-in-law Henrietta or Harriet Berkeley, aged 18 , was committed when he was but 27 years of age, and that he suffered for it during most of the remainder of his 47 years, near the average term of the short lived Fords. But if we excuse Ford Lord Grey, on

- The following is a list of Sir Edward Ford's schemes, or such at least as have been handed down. They are sufficiently varied to denote the extensive range of his scientific observations.

Under Charles I. :-I. River to be brought from Rickmansworth, Hertfordshire, to St. Giles' in the Fields, near London. London : I64I. 4to.

Under Cromwell :-2. Raising Thames water to higher streets of City. 1656.

3. Engine at Somerset House for Strand.

Under Charles II. :-4. A defence of Bill Credit. I663.

5. Cure of Smoky Chimneys. 1664 .

6. Method of Coining Copper Money, for which he had a patent for Ireland. I664.

7. Experimental proposals for collection of the King's revenue and rebuilding of London. 1666. (Hugh James Rose, Biographical Dict., I848.)

It may be noted here that there are strong grounds for believing that the water engine, which by an overshot wheel throws water from a pond near South Gardens, at the base of South Harting Hills, to Up Park, was Sir Edward Ford's workperhaps a design posthumously executed. 
the score of youth, justice requires us to remember that 3I years only were sufficient to complete the full lustre of the life of Sir Philip Sidney. When men come of age and deliberately take upon themselves the consequences of a false step, it is dangerous as well as immoral to plead their youth : as they make their bed so they must lie.

Sir Edward Ford had "married" his only child and heiress Catherine to Lord Culpepper, at the age of 12 years, and after "his soon death" to Ralphe, Lord Grey of Werk, and son of the Speaker of the House of Lords in the Long Parliament. Hence their son Ford (afterwards Lord Grey) was likely to inherit a Whig and Protestant policy. It must have been a new thing for Harting when a peer of the realm came to reside, as did Ralphe, Lord Grey of Werke, at East Harting. Ford, Lord Grey, was born probably at East Harting, and was baptized at Harting Church 20th July, 1655.* Ralph Grey's influence on his son would be religious. His initials R. G. with the Ford Arms, are upon the handsome Paten used to this day in Harting Church. But he was buried June 24, 1675, leaving his son Ford twenty years of age, and henceforth with little good influence. As, like Sir Edward Ford, Lord Grey was brought to our Parish Church first and last, I must throw myself upon the reader's indulgence if I enter somewhat fully upon his history.

Bishop Burnet (History of his own Times) never mentions Ford, Lord Grey, without some implied joke about him, due no doubt to what often served him in good stead-his youthful gaiety. In the year I680 the parliament had passed a very strict act for the due execution of the Habeas Corpus; it was carried by an odd artifice. Lord Grey and Lord Norris were named to be the tellers. Lord Norris

- By obvious mistake "Forde the soñe of Ralph Grey, Esq., was buryed (for "baptized") 2oth July, 1655."-Harting Register, No. II. 
being a man subject to vapours, was not at all times attentive to what he was doing; so, a very fat lord coming in, Lord Grey counted him for ten, as a jest at first; but seeing Lord Norris had not observed it, he went on with this mis-reckoning of ten; so it was reported to the House, and declared that they who were for the Bill were the majority, though indeed it went on the other side, and by this means the Bill passed.*

But the time of jest and merriment soon passed. Thursday, 23rd January, I682, disclosed a scandalous suit at the Court of Queen's Bench. Ford, Lord Grey of Werke, was tried and found guilty of carrying away his sister-in-law Henrietta or Harriet Berkeley from the house of her father the powerful Earl of Berkeley, at Durdants, near Epsom, Surrey, during the month of August, I682. " A scene unparalleled in our legal history took place. The seducer appeared with dauntless front accompanied by his paramour." On the other side appeared his father and mother-in-law " moved to transports of rage by the sight of him. The old Earl of Berkeley poured forth reproaches and curses upon the wretched Henrietta. The Countess of Berkeley gave evidence broken by many sobs, and at length fell down in a swoon." † Ford, Lord Grey, was defended by his lawyer kinsman Henry Ireton, and prosecuted by Sergeant, afterwards the famous Judge Jeffries on behalf of the Crown. $\neq$ Lord Grey's lawful wife was the Lady Mary Berkeley, described in the trial as 'goodnatured and religious,' and willing to forgive her sister. The Countess of Berkeley had sent down Mr. Craven to Up Park as a spy and guard upon Lord Grey, who proposed to get the lady out of the way, and to send her to a nunnery in Calais or Dieppe. "One day at Up Park we went out a shooting, as we did several days together: Mr. Craven, says

- Burnet I., 485. + Macaulay I., 525.

$\ddagger$ Trial of Lord Grey at Kings Bench. B.M. 
he, I will tell you the whole matter," and then confessed. At the trial* Lord Grey proposes to send the Lady Harriet to his own sister who had married a Mr. Neville. He makes "a long discourse," as the Chief Justice characterized it: "His honour lies at stake: he has suffered a fortnight's close confinement, and been most unhappy." He tries to avoid the evidence of abduction. Lady Henrietta, in her turn, exculpates Lord Grey of abduction, and when she says "I have been very much reflected upon here today, and my reputation suffers much by the censure of the world," is silenced by Justice Dolben and the Lord Chief Justice. In the last stage of the trial after a verdict of guilty against Lord Grey, Lord Berkeley claims his daughter. Lady Henrietta : " I will not go to my father again." At the same time she declares herself married to a Mr. Turner. Sergeant Jeffries shows that as Mr. Turner is already married this is bigamous. Then ensues the scene which Lord Macaulay describes as "unparalleled in our legal history.'"

Lady Henrietta : "I will go with my husband."

Earl of Berkeley, (her father): "Huswife, $\nmid$ you shall go with me home."

Lady Henrietta : "I will go with my husband." Earl of Berkeley: "Huswife, you shall go with me, I say."

Lady Henrietta : "I will go with my husband."

Earl of Berkeley to Lord Chief Justice : "My lord, I desire that I may have my daughter again."

Lord Chief Justice: "My lord, we do not hinder you, you may take her."

- One witness swore that Lord Grey was sometimes for two days together secreted in a cupboard of Lady Berkeley's house, with nothing but sweetmeats to eat.

† "Huswife" or "hussey," always a term of reproach. For respect-

" ' Goody,' ' good woman,' ' gossip, ' n'aunt forsooth,'

Or 'dame,' the sole additions she did hear."

(Shenstone's "School-mistress.") 
Lady Henrietta : I will go with my husband."

Earl of Berkeley: "Then all that are my friends, seize her, I charge you."

Lord Chief Justice : "Nay, let us have no breaking of the peace in the Court."

"The Court broke up, and passing through Westminster Hall there was a great scuffle about the lady and swords drawn on both sides; but My Lord Chief Justice coming by, ordered a tipstaff that attended him to take charge of her and carry her over to the King's Bench." Harriet Berkeley and Mr. Turner were then committed to the Marshal's House, afterwards the debtor's prison, and liberated the last day of term. The next term the suit was compromised.* The worthless Harriet Berkeley seems before this to have been so heady as to get into trouble. Lord Berkeley wrote to Pepys, Feb. 23, 1677-8. "As for Mrs. Henrietta," ("Mrs." being the old style for "Miss") "she is extremely troubled in anything that gave you offence, and though she did not in the least intend it, yet she begs $y^{\text {r. }}$ pardon." $\dagger$

Even in those days this scandalous trial for incest left a stain upon Ford Grey's name which men never forgot : and later, though the Whig party upheld him, the stricter Puritans to their credit never forgave the dishonour. Having lost his name, Ford Grey attempted to redeem it by desperate risks. He had met the Duke of Monmouth in the Charlton hunt, near Goodwood, in this neighbourhood, $\ddagger$ and determined to share and guide his fortunes. In the very next year (1683) he was imprisoned for his share in the Rye House Plot, which was to have put the Duke of Monmouth, natural son of Charles II., in the Protestant interest on the Throne.

It is curious that in the original design of the Rye House Plot, Up Park was to have played a prominent

- Trial of Ford, Lord Grey.

$\ddagger$ Mr. Bennett's Memoir of Charlton Hunt. 
part. In his confession made afterwards to James II.,* Ford, Lord Grey, says, that the scheme was that $£$ Io,000 should be lent to My Lord Argyll with all speed, that, if possible, the Scotch rising might begin before the end of June (1683), and that a messenger should come from Scotland, as soon as ever they were in arms, to London, where one should be ready to carry the news " to the Duke of Monmouth at my house in Sussex, where he was to be privately a week before the rising, that he might not be secured (i.e. arrested) if there were any suspicion of it, and they would be ready on the first notice to ride away to Taunton," the rendezvous.

The charge against Lord Grey before the Council, was that four-score guns were found in his London house (Soho). He pleaded that they were only bought with intent to furnish his three houses in Essex, Sussex and Northumberland. When the plot was discovered Grey was sent to the Tower, but succeeded in making his keepers drunk. $\dagger$ Burnett records, "An order was sent to bring up the Lord Grey, which met him coming up (i.e. from Sussex, where he was in May); he was brought before the Council, and he behaved himself with great presence of mind. He was sent to the Tower. But the gates were shut; so he staid in the messenger's hands all night, whom he furnished so liberally with wine that he was dead drunk. Next morning he went with him to the Tower Gate, the messenger being again fast asleep. He himself called at the Tower Gate to bring the Lieutenant of the Tower to receive a prisoner. But he (Ford Grey) began to think he might be in danger. He found Rumsey was one witness, and if another should come in he was gone, so he called for a pair of oars and went away, leaving the drunken messenger fast asleep." $\ddagger$

* Grey's Secret Confession of the Rye House Plot, p. 58. British Museum.

$\dagger$ Macaulay. $\quad \ddagger$ Burnet, Vol. I., 549 . 
Thus Grey escaped for the first time out of the hands of James II., and in the latter end of June, 1683, sought the protection of the Dutch Elector of Brandenburg in Holland, whither Monmouth, as soon as he was pardoned, followed him. As a Protestant refugee in Holland, Grey's life seems to have been miserable enough. Did the Calvinistic or Fatalist motto of his family help him: "Che sqra, sqra," "What will be, will be." It is strange to hear of the lord of a great London house and three country seats undergoing poverty. "I thought of going to Switzerland, where I heard I might live cheap, which was a very necessary inducement to one in my circumstances, who had little for support and less to expect from the Duke of Monmouth..... I was at this time in as sad circumstances as can well be imagined: I had before me the prospect of being always a vagabond and that a poor one too: no place to hide my head in except a garret at Amsterdam." *

Then came the proposals for Monmouth's expedition to England, in which Grey says that his cousin Henry Ireton who had come over about private affairs, but "in a very unfortunate time for him," was implicated : and word was brought that "if the Duke of Monmouth landed anywhere in England with a switch in his hand, he might with safety march to Whitehall," and dethrone James II., " there was such an universal longing for him." Grey further urged to Monmouth that Henry VII. had landed with a smaller number than his, and had succeeded in making himself king and dethroning Richard III. $\dagger$

Three Dutch vessels arrived at the Port of Lyme Regis June II, I685, and among the 80 men that landed first were Monmouth and Grey. Their blue flag was set up in the market place with the cry,

" Grey's "Secret Confession," page 9 r.

+ Burnet, I., 631. 
"A Monmouth! A Monmouth! The Protestant religion!" Grey being the only peer or person of note, a's Macaulay says, who joined Monmouth's army, he was appointed to command the raw cavalry "consisting of yeomen and tradesmen mounted on carthorses or post-horses. Day labourers, small farmers, shopkeepers, apprentices, dissenting preachers, flocked to the rebel camp; but not a single peer, baronet, or knight, not a single member of the House of Commons, and scarcely any squire of sufficient note to have been ever in the Commission of the Peace."* Evelyn notes, $\uparrow$ " Most of Grey's party were Anabaptists and poor clothworkers of the country, no gentleman of note being come unto him."

Grey, however, at the head of his motley hunt, attacked King James' militia at Bridport. C. J. Fox says that in this engagement "Grey left his troops to conquer, and sought his personal safety in flight;" and quotes Ferguson, one of the rebels, to the effect that when after Bridport Monmouth said to one of his officers "what shall I do with Lord Grey?" the other replied, that " he was the only general in Europe who would ask such a question;" intending no doubt to reproach the Duke with the excess to which he pushed his characteristic virtues of mildness and forbearance. Even Macaulay, $\ddagger$ strong Whig champion as he is, is obliged to characterise Grey as "intrepid everywhere except when swords were clashing and guns going off around him."

Once, however, Grey showed himself brave, and bore himself better than at any other moment of his life. After failing to secure Bristol, the Duke of Monmouth in a fit of despondency would have deserted his peasant followers but for Grey's firmness. Grey saved his unhappy master from the moment of perfidy and baseness: and when news came that the

- Macaulay. † Evelyn's Diary, Nov. 22, 1687, p. 245. $\ddagger$ Macaulay, I., 597 . 
marsh-men near Axbridge had risen in defence of the Protestant religion, the whole body of the rebels turned aside to Wells in order to effect a junction with them. Arrived at Wells, they shewed their hatred of bishops by tearing the lead from the roof of the Cathedral, defacing the ornaments of the Church, and "drinking many villanous and unseemly oaths at the Altar." * Bishop Ken, "Preacher, Patriot, Poet, Pastor," author of the simplest and most beautiful of all evening hymns, $\dagger$ was at that time Bishop of Bath and Wells. On this occasion it is said to his honour that Ford, Lord Grey, in the midst of his wild crew defended Bishop Ken's altar from insult, standing before it with his sword drawn. Ken afterwards, when their day was lost, visited the poor rebels in prison, and "retrenched from his own episcopal state to make some addition to the coarse and scanty fare of those who had defaced his beloved Cathedral."

On Monday, July 6, I685, the Battle of Sedgemoor, the last on English soil, was fought; and though five or six thousand colliers, weavers, and ploughmen, some armed with scythes fastened to poles (still shown in the armoury of the Tower) kept the King's Regulars in check for an hour-and-a-half, they were soon cut down, and the cause of Monmouth perished. In this battle Mew, or Mee, Bishop of Winchester, fought for James as a gunner, and put his carriage horses to the cannon. The rebel cavalry under Grey came up to the Bussex Rhine, or dyke across the moor, apparently not knowing of its existence, received one volley from the regulars, and fled.

Grey was taken the following day, Tuesday, July 7, by his own county-people, the Sussex Militia under Lord Lumley, about five in the morning near Holt

- "Account of Fights and Skirmishes in the West, and Manner of Taking Ford, late Lord Grey, and late Duke of Monmouth, I685," p. 3 .

† Ken's Evening Hymn, "Glory to Thee, my God, this night." 
Lodge in Dorsetshire, four miles to the west of Ringwood, in the attempt to reach the New Forest.* "Since we landed," he said, "we have not had one comfortable meal, or quiet night." At eleven o'clock on Wednesday, July 8, the Duke of Monmouth himself was taken by one Henry Parkin (one of the Sussex Militia) in a ditch covered with fern, disguised in a shepherd's dress; and it is recorded that some raw peas, gathered in the rage of hunger (though it is strange that field peas should have seeded by the 8 th of July, even if we allow for the variation of style), were found, together with the decoration of the George, given him by his father, Charles II., in his pocket.

On the road.to London for his trial Grey showed great spirit: "He was not only calm but cheerful, talked pleasantly of horses, dogs, and field sports, and even made jocose allusions to the perilous situation in which he stood." Monmouth, who showed the greatest degradation of cowardice, begged his life of his uncle, King James II., even at the cost of becoming a Papist: Grey was "more ingenuous," said the king (which probably means "made more discoveries"), and never once begged his life. Both prisoners, condemned, were sent by water to the Traitor's Gate of the Tower. Monmouth was beheaded after five strokes of the axe by Jack Ketch the hangman. Grey, as his estate was large and strictly entailed, $\dagger$ was spared, as he would bleed a large ransom, and also would turn king's evidence.

It has been thought by a recent writer that Grey's part had been that of wilful treachery to his friends at Bridport and Sedgemoor, and that hence James $I$.

" "Account of Fights and Skirmishes, 1685," page 6.

$\uparrow$ Grey's property would have gone to his brother, Ford Ralph Grey, who became after Ford Grey's death "Lord Grey of Warke," but survived his brother only five years. He was younger than Ford Lord Grey by seven years, being born in I66I. 
pardoned him as the betrayer of rebels. But there is no trace of this in the records of the time, nor does such a theory agree with the fact that the Whigs immediately advanced Grey when they returned to power three years after Sedgemoor. A man who had betrayed his party in battle would not have been made Earl of Tankerville by that party a few years afterwards. This suspicion of treachery, then, is a purely modern invention: Whigs and Tories alike smiled at the man who led the simple folk to the enemies' line and then turned tail; but there was no charge of wilful treachery. Further, the purport of Grey's secret Confession to James II. shows him to have been true to the rebel cause while it lasted, though at the same time weak, like his grandfather, Sir Edward Ford, in the field. Stating that his Majesty's command for the confession has been delivered by Lord Lumley-as though it were to his Sussex neighbours and captors that he owed his life-he makes a full statement of his concern in the Ryehouse Plot and in Monmouth's rebellion, and concludes in these piteous words :-

“.... If the shedding of my blood can be for your Majesty's interest, I shall be very willing to part with it: and only desire I may have the satisfaction to know that it will be an atonement for the crimes I have committed against you : but if $\mathrm{y}^{\mathrm{r} .}$ Majesty out of $\mathrm{y}^{\mathrm{r} .}$ great clemency shall think fit to save me, I hope you will believe that (beside the ties of honour, justice, and gratitude) my own inclination will ever oblige me to sacrifice the life you give to your service when you please to command it. I lie, Sir, at your Majesty's feet, where, though I cannot expect, yet it is a pleasure to beg for mercy. The consideration of myself destroys all hopes of that kind, but the observation of your Majesty's universal goodness affords me many. I pray God bless your Majesty with a long and happy reign 
over your people: and may all those perish that ever

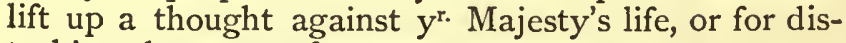
turbing the peace of your government.

"Your Majesty's most unfortunate Subject, "FORD GREY."

Thus out of two nooses, the Ryehouse Plot and the Sedgemoor Rebellion, did Ford Lord Grey extricate his neck, the second time by a barleycorn, in the space of two years. He was fined heavily. Rochester the prime minister had $£ 40,000$ from him, or as Burnet says, $£ 16,000$. Evelyn enters under Jan. I, 1687: "A seal to confirm a gift of $£ 4000$ per annum for 99 years to the Lord Treasurer out of the Post Office, and $£ \mathrm{I}, 700$ for ever out of Lord Grey's estate." Others had smaller slices out of Lord Grey. He gave his evidence to the king on express condition that no one should die on account of it.

It is probable that at this time Judge Jeffries, .just in the height of his work at the Bloody Assizes, determined to make a grab at Up Park. Burrell* says, "I found in the Surveyor General's Office, letter 2, p. 54, a petition from Lord Chancellor Jeffries to the Crown for the grant of Up Park in the county of Sussex, forfeited by Lord Grey. But no notice appears to have been made in consequence of that petition." And in another three years time another Up Park had arisen for Lord Grey in a triumph of its own; and Jeffries' head (who died from the treatment of the mob and from internal disease) was lying with Monmouth's in St. Peter's Chapel at the Tower!

Henceforth the life of Ford Lord Grey was peaceful, and, as soon as the Revolution of 1688 brought in the Protestant and Dutch ascendancy, exalted to high honour. Meanwhile it is not a little remarkable that the very year following his Sedgemoor downfall and

" Burrell MSS., 5705, page 22. 
fine, he was able to build. In 1685 the present Up Park was built from the designs of Talmar, a pupil of Inigo Jones. Its builder seemed as if he almost wished to crown himself on Sussex soil, and to show the Sussex militia that their prisoner had suffered little at their hands. But whence came all the wealth for such building ? Had it accrued during the absence of the great Lord? Did his wife's portion help him?

Under William III. Ford Lord Grey's tarnished name was exchanged for the style of Earl of Tankerville and Viscount Glendale. In 1696 the House of Lords listened to his eloquence as he pleaded that William was "rightful and lawe ful King of England :" the stress of the debate being upon the word "laweful;" and on another occasion he spoke with his usual ability in favour of disbanding the army. In 1696 , when "his constitution was so broken that he was fitter for flannel and cushions than for a laborious office at Whitehall," he was made Lord Privy Seal in Lord Godolphin's ministry.* Macaulay shows that though there was left upon the moral character of Lord Grey a stain at which even libertines looked grave, so capricious was public opinion, and so low the standard of morality in those days, that no allusion was made to the vices and misfortunes of the new Cabinet minister. "It is probable that his infirm health and his isolated position were his protection. The chiefs of the opposition did not fear him enough to hate him," says the historian, adopting Martial's famous epigram, sometime applied to Louis Napoleon when in power:-

"Vis quantum facias mali videre?

Vir justus, probus, innocens, timeris."

"Would you the cause of all this hatred know?

O spotless saint! The dread of you's your woe."

* Macaulay styles Lord Tankerville First "Lord of the Treasury," but "Lord Privy Seal" is on his coffin, and so says Smollett. Probably the two offices were held together. 
And yet Ford Lord Grey, now Lord Tankerville, was not more than forty-seven years of age when he died. He had gained the summit of his ambition, and his restless mind and brilliant vivacity carried him just far enough for his goal. He died 24th June, I 7or, the same year as that in which James the Second died, and the year previous to that in which his master William the Third's delicate and consumptive frame yielded also.

In $185 \mathrm{I}$, when the large vault in the chancel of Harting Church was opened, a coffin bearing the following inscription was disclosed :

"The Body of the Rt. Honble. Ford Grey, Earl of Tankerville, Viscount Glendale, Baron Grey of Werke, and Baronet, Lord Privy Seal,* and one of the Lord's of his Majestie's Privy Council, who died the 24th June, I7OI, aged 47."

The lid of the coffin was partially open and disclosed a plain Dutch clay pipe, grasped in the right hand,

* It is a curious coincidence that, as Harting supplied the first member for the county in the first beginning of popular government-Hen. Hussey of Harting being sent to the Carlisle parliament-so in the first modern ministry (Green, 68I) which brought down the popular government to its present form (i.e., the ascendancy of a committee of a party in the House of Commons who for the time enjoys the confidence of the people), Harting had the honour to supply a principal member of the Cabinet, a First Lord of the Treasury, nearly at the time of the commencement of the National Debt, and of the Bank of England. Few traces of Lord Tankerville still remain. Perhaps the fields called "The Great Dukes" and the "Little Dukes" commemorate the unfortunate Duke of Monmouth, just as Hen. Hussey called a field of his "Mountford" after Simon de Montfort. The earl's coronet with the strawberry leaf, in duplicate, denoting the two Earls of Tankerville, is still to be seen on the door of the smithy on the East Harting side of South Harting Street, belonging to Mr. G. Blackmore. The forge is generally the oldest of village curiosity shops, and also the rustic Music Hall. Doubtless the old smith of 1700 (R. Wakeford) was proud to mount the new Earl of Tankerville's arms, and thanks to the chiaro opscuro of dust and soot, they have escaped a good many eyes, and are in their way curiosities to this day. 
and lying by the side of the corpse. Was this the pipe with which he had consoled himself in the garret at Amsterdam, and in the marshy wastes of Sedgemoor?

\section{CHAPTER V.}

The Carylls of West HaRting and Lady Holt.

John, Lord Caryll, Secretary.

WHAT, in the mean time, was going on the other side of the way, on the opposite side of the street of South Harting, or, in other words, in the West Harting Manor? Full of historical interest as the eastern and Protestant segment of the parish was in the latter part of the sixteenth century, the western hemisphere, which included the Church, and which, was under Roman Catholic sway, could well match it in every particular. One of its rulers was in high favour at the Court of James II., both in England and in exile. West Harting was confiscated by William III. ; it was restored again to its owners; when its captivity was turned, it saw a great mansion, almost the rival and twin sister of Up Park, sacred to the English muse, rising in a new park of its own on the southernmost point of its extensive range from Harting Coombe and the intervening iron lands to the slopes of sunny Lady Holt.

Few places are so rich in the highest literary associations as West Harting. The whole estate was handled at one time by Sir Richard Steele. In the early part of the last century Lady Holt was the country home of Alexander Pope, the summer retreat of Gay; while the Parsonage connected it with James Bramston, and later still with William Collins. Nor 
were the Carylls themselves unknown to the literary world ; one was a writer of plays, and another is immortalized by Pope as having suggested the Rape of the Lock.

"I sing-this line to Caryll, Muse, is dueThis, Belinda may vouchsafe to view."

Thus West Harting is as wealthy as East in historical records at this time, while in literary subjects and domestic sketches of the period it may be said far to surpass it, and to have copious annals of its own.

And as the main guide which we shall now have to follow is the large collection of "Caryll Correspondence" given, together with many Charters and other MSS., to the British Museum, in I870, by Sir Charles Dilke, perhaps it may not be amiss to give a description of this mass of evidence, copied from a periodical of I869. The Caryll MSS. are stated to contain letters of King James and his Queen, The Dukes of Berwick, Beaufort and Norfolk, Dryden, Wycherley, Pope, Sir Richard Steele, Sir Roger L'Estrange, St. Evremond, and other celebrities of those times. Pope's letters (to John Caryll, of Lady Holt), which begin at an early period of his life, alone number I 50, and are the more interesting from the fact that they have not, like his published correspondence, been improved by their author into mere literary essays. A curious history attaches to these papers, which were left behind when the last of the Carylls took service in the French army in 1767 , and were accidentally discovered some years ago, together with a mass of other documents, stowed up in boxes, rotted with damp and preyed upon by vermin.*

Following Sir Edward Caryll, who, as we have seen, purchased West Harting of the Fortescues in the

- Daily Telegraph (or News), Monday, October (or September) 23rd, 1869. In the Recess. 
latter part of Queen Elizabeth's reign, we may number successively five John Carylls of Harting, four of whom attained some eminence, while the remaining scion of the noble house died of smallpox at a comparatively early age. In Elizabeth's reign the Carylls had inherited the wealth of Richard Colyer, of London, mercer. Their estate, however, as we have seen, suffered greatly in the time of Charles I., when their mansion was twice sacked and title deeds destroyed; and John Caryll of Harting I., the eminent loyalist, had to pay the Commonwealth a heavy fine. As some set-off, doubtless his wife Catharine, daughter of Lord Petre, brought wealth and considerable influence to the Carylls of Harting. John, their eldest son,* of a family of seven, whom for designation we shall henceforth call "Mr. Secretary" (as he afterwards became Secretary and Master of Requests to Queen Mary of Modena, the second wife and Queen of James II.), succeeded to the estate in this parish, as John Caryll of Harting II., and was from his early days a personage of some mark. He had fame as a man of letters before the conclusion of Charles the Second's reign, as Pepys testifies, though in qualified language. " 7 th March, 1667. To the Duke's Playhouse, and saw 'The English Princesse, or Richard the Third,' a most sad melancholy play and pretty good; but nothing eminent in it as some tragedys are: only little Miss Davis did dance a jig after the end of the play." Richard the Third, the best known of Mr. Secretary Carylls productions, consists of a heavily-rhymed set of thoroughly English verses, much like the cumbrous armour of the Tudor times; the play owed its brief popularity to the acting of Betterton. Much of the thought and manner of the piece are borrowed from Shakespeare. For example, there is an imitation of

- Baptized at Harting-“"John, the son of John Caryll, of Hartinge, Esq., was baptized the Second of November, $1625 . "-$ Harting Register, No. I. 
the Ghost in the last scene but one of Shakespeare's Richard the Third. In Caryll's play* King Richard, before Bosworth, is presented in a distracted state, newly risen from his bed, and walking in his dream dagger in hand, for he is surrounded by the ghosts of those whom he has killed. When Henry VI. appears Richard says-

"Saint Henry! get thee hence to thy cold bed : So tame, alive ; so fierce now thou art dead."

It must have required all the friendship of Dryden and Wycherley to have kept this cumbrous and turgid play afloat. Another of Mr. Secretary's compositions was a comedy in imitation of Molière's "L'Ecole des Femmes," which he published in 1671 , under the title of "Sir Salomon Single ; or, the Cautious Coxcomb."

Macaulay says that "Caryll's pieces have long been forgotten, but what Caryll could not do for himself was done for him by a more powerful genius. Half a . line in the Rape of the Lock has made his name immortal." This, however, is incorrect : the person thus distinguished by Pope is, as we shall see, his nearest friend, another John Caryll (third of that name), the Squire of Harting, a nephew of Mr. Secretary. (Athen. May 8th, I858.) The Secretary himself never saw Pope at all, and died in I7II, while the Poet made his acknowledgments to John Caryll the Squire in I7 I4, as the originator of the Rape of the Lock, a poem called by De Quincey the most exquisite monument of playful fancy that universal literature affords. $f$

- Caryll's Richard the Third, Act IV., Scene IX., p. 49.

+ Pope had only withholden the name of Caryll from the first edition, I I I I, because his friend was a Roman Catholic. The first edition was called by Addison "Merum Sal" =" pure wit." John Caryll II I., the squire of Lady Holt, proposed the subject to Pope with a view to putting an end, by this piece of playful ridicule, to a quarrel that had arisen between the two noble families of Lord Petre (Caryll's second cousin, and introduced to Pope by Caryll) and Miss, or according to the style of those days, Mrs. Arabella 
Towards the end of Charles the Second's reign, in the year 1679, John Caryll II. (afterwards Secretary) was sent to prison on suspicion of being concerned in the Popish Plot, at the time when the infamous Titus Oates was informer, but was afterwards discharged on bail.* In January, 1686, he was put out of the Commission as a Magistrate for Sussex on account of his being a Papist. $t$ On the other hand, early in the reign of James II. he rose to high favour, and for the first half of the three and a half short years of that monarch, he was English Ambassador at Rome with Pope Innocent. Lingard says, he was " too timid for the Roman party in England in I686"; while Macaulay says in his praise, that he was an enemy of violent courses, and a sound statesman. "Caryll acquitted himself of his delicate errand at Rome with good sense and good feeling. The business confided to him was well done : but he assumed no public character, and carefully avoided all display. His mission, therefore, put the Government to scarcely any change, and excited scarcely any murmurs." In 1685, John Caryll II. was recalled to England to make room at the Pope's court for Lord Castelmaine, a more fiery spirit ; and as soon as he reached England Caryll was made Secretary of Requests to Mary of Modena, Queen of James the Second, whom he had married after the death of the first wife of that king. Anne Hyde, Lord Clarendon's daughter. It is possible that Caryll

Fermor, on the trifling occasion of his having cut off a lock of her hair. "In this more solemn edition, Pope wrote to Caryll III., (Feb. 25th, I7 I4,) I was strangely tempted to have set your name at length, as well as I have my own." In the poem, the Baron is Lord Petre and Belinda Miss Fermor; Thalestris, Mrs. Morley (also of a Harting family, and connected with the Carylls); Sir Plume, her brother, Sir George Brown, of Berkshire (Wharton).

- Narcissus Luttrell's History of State Affairs, I., 259, under date of 2 Ist May, 1683, where he says the imprisonment was "four years ago."

$$
\text { † Ibid., I., } 392 .
$$


owed this position to his kinsman, the Jesuit Father, Edward Petre, who had been received into the Cabinet of James II., and bore the greatest part, it has been said, in the ruin of the house of Stuart. Having, however, once obtained the post, Caryll remained on the closest terms of intimacy with James and his Queen to the end of their lives. It was about this time that the building of Lady Holt was projected, though, in the event, certainly completed, at least, by the succeeding John Caryll. Hayly* says, that James the Second had planned for himself a residence on the South Downs, though the situation is unknown. It is not at all impossible, when we consider the warm affection that existed between James II. and his Queen and their friend the Secretary, abundantly proved by many royal letters now in the British Museum, that at one time there might have been a thought of making Lady Holt a royal seat. To these letters I shall refer, quoting extracts, a little further on.

I688, 9th Dec., Mary Beatrice of Modena quitted Whitehall for ever, taking her little son with her; and, leaning on Lauzun's arm, started for Gravesend, whence they crossed to Calais. A fortnight afterwards James II. made his second attempt to reach France from Rochester, and landed at Ambleteuse on Christmas Day. Secretary John Caryll accompanied the King and Queen in their exile.t By special request of the exiled monarch, $\ddagger$ the West Harting estates were exempted by William from confiscation. As a further

- Hayly and Burrell MSS., 5706, p. 767._-"King James II. marked out a seat on the Downs of Sussex. Query where. T.H."

† "James II.," by Col. Townshend Wilson.

$\ddagger$ Burrell, 5689, p. I91. - " Lord Caryll had, by his adherence to King James, forfeited this estate (West Harting), which was granted by William to Lord Cutts ; but, at the particular request of King James, it was restored to the Caryll family on the payment of $£ 1, \infty 00$ (should be $£ 6,000$ ) to Lord Cutts. This anecdote Mr. Caryll told my uncle, Sir Merrick Burrell, from whom I heard it. W.B." 
mark of royal favour, James created the exile Secretary a Baron, by the style of Lord Durford. It is probable that John Caryll chose this title partly as not clashing with the pretensions of the other Harting manor, and partly from veneration for the old monastery of Durford and its saints. It is curious that at Durford House at the present time, there is the only local record of a member of the Caryll family now in existence, the Portrait of Peter ("Father Alexis") Caryll,* younger brother of the Secretary.

In I696 William III. discovered that John Lord Caryll was plotting his life, and as this fact cancelled all former lenity, the West Harting estates were at once confiscated and given to Lord Cutts, a soldier of distinction and high command at the Boyne and Steinkirk (I693), whence "he hobbled home on crutches to his rich and pining wife." He was nicknamed Jack Cutts "the Salamander," and was the soul of every forlorn hope. His greatest distinctions were gained at the head of the British Grenadiers at Namur and Venloo, and when he led the cavalry and opened the Battle of Blenheim. $\dagger$

Luttrell, under date 23rd May, I696, writes:- "On Monday Lord Cutts goes to take possession of Mr. Caryll's estate in Sussex (Secretary to the late Queen), which his Majesty permitted him to enjoy, tho' beyond

- Baptized at Harting, 28th October, 1631.

+ (Wyon's "Queen Anne.") At Venloo the Guards, headed by Cutts, who had been the soul of every forlorn hope during ten years, rushed up the glacis, I Ith Sep., I702.

The division under Lord Cutts first crossed the Nebel at Blenheim, when Lord Rowe was killed, I704. Lumley, to whom Cutts appealed for succour, sent across the Nebel help; but the contest was too unequal, and the Allied horse fell back to edge of a rivulet (p. 262).

In a debate in Parliament against occasional nonconformity"A division between our two houses at this moment," urged Cutts, who had returned from abroad with a halo of glory surrounding him only inferior to Marlborough's, "would be as great an advantage to the French king as we won from him at Blenheim." 
the sea, till 'twas discovered he gave Sir Geo. Barclay $£ 800$ to buy horses and arms, \&c., in order to assassinate him." (i.e., William III.)* Luttrell, who represents the gossip of London at the time, adds in another place $\dagger$ that the West Harting estate was valued at $£ 2000$ a-year, but this puts it four times too high. Six years before this the Secretary's nephew and heir, John Caryll, from West Grinstead, had settled, apparently as his uncle's agent and receiver, at Lady Holt in 1689. The accounts of the year I694 are in his own handwriting, and the sum of all his accounts for the year is $£ 366: 2: 0$. In 1720 , when he had improved the property, we have the following return :Tax :-

I720. How my lands were rated to the Land

Lady Holt Park and Harehurst (now Harris

Wood

Harting Pond

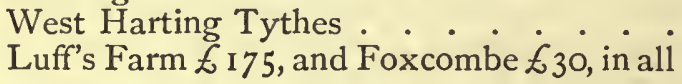

$£ 57$

107

205

$£ 378+$

Further, to show that Luttrell's valuation of West Harting at $£ 2000$ a-year is beside the mark, the most authentic document must be quoted :-

"The King (William III.) on the 29th July, I696, grants to John Lord Cutts, Baron of Gowran, Ireland, the manor of West Harting, county Sussex. Capital messuage called 'Harting Place,' of annual value of 40 shillings; a dovecote, garden, and orchard thereto pertaining in co. Sussex, annual value 20 shillings. Capital messuage called 'Lady Holt;' a stable, orchard, pasture, or park, called Lady Holt Park, containing I 50 acres, value $£$ I 5 per annum; I 20 acres of

- Narcissus Luttrell, "State Affairs," iv., 62. † Ib., iv. 5 I.

$¥$ Account Book of Jo. Caryll, Esq., of Lady Holt, and lord of the manor of West Harting, 1694-17 16. 
wood, called Harris Wood, value £ $\mathrm{I} 6$ per annum; messuage called Westbrooke, barn called Down Parke barn, barn called Sandyside, I 56s.; acres arable ; 48 acres pasture, 3 acres called Luffat's Pollard, 3 acres Whittington's meadow, 20 acres of Hill house land (now Hill Ash; Phil. Caryll afterwards lived there), 50 acres of Down Park, messuage Russell's, Pondhead piece, Ryfield farm, and Hill House, \&c., which have fallen to the King by reason of the attainder of John Caryll for high treason. Also a certain portion of the tithes, in part, of Harting aforesaid of the annual value of $£ 100$ during the term of the lives of John Caryll, Richard Caryll, Esq.." (of West Grinstead,) and John Caryll. Rent for all the premises by year, I3s. 4d. Total annual value, $£ 570$ : I 5 : $0 . "$

This very interesting document shows exactly what was granted to Lord Cutts, and disposes of Luttrell's fancy valuation of West Harting at $£ 2000$ instead of $£ 600$ per annum. But it does not take notice of the fact that King William had no power over the estate after the death of the outlawed Secretary. In those troublous times no one could say whether what was loyalty one year might not be treason the next, and accordingly few lands were suffered to be without the protection, as necessary as the modern insurance to present property, of an entail. And as in 1686 its entail saved East Harting under James II., so in 1696 its entail saved West Harting under William III. John Caryll, the outlawed Secretary, was old, and his life interest proved to be all that could be taken from him, so after all Lord Cutts found the $£ 2000$ a-year melted down to about $£ 600$ (say $£ \mathrm{I}, 800$ of our present money) for ten years, and the gilt was taken off the gingerbread. Meanwhile in April and in the May of this year I696 John Caryll III., nephew of the Secretary, and Pope's friend (henceforth to be called the "Squire," as he was

- Richard Caryll, younger brother of the Secretary, was baptized at Harting, 2oth Sep., 1635. He was the father of Pope's friend. 
our resident squire for about forty-seven years, and connected with Harting for fifty-four), was in gaol at Chichester and Horsham eleven weeks in all, on suspicion of being concerned in the same plot of Sir Geo. Barclay's for which his uncle was outlawed. As soon as the Squire was liberated he compounded with Lord Cutts for the purchase of his uncle's life interest, and eventually purchased it for $£ 6000$, a high sum, ${ }^{*}$ seeing that his uncle was at that moment severty-one years of age, and also very infirm. But the entrance of a stranger would doubtless have been disastrous to the property, the new house and its furniture would have been ruined, and the large woodlands of Lady Holt and West Harting would have suffered by the alien's axe.

The completion of this compromise took place in May, 1697, as appears pleasantly by the entry in the "Squires" account book: "Given the ringers at Harting upon $y^{e}$ Composition with Lord C., $£$ I : 2 : o." At that very time Steele was acting as Secretary to Lord Cutts; and Mr. Elwin thinks that Steele was thus brought into close personal communication with John Caryll "the Squire," whose genial nature and literary taste at once made a friend of him, and who was thus able to introduce to Steele his friend Pope, a service which Pope acknowledged in an early letter to Caryll. It is thus a fact of breathless interest to our parish of Harting that Pope owed his introduction to Sir Richard Steele, and hence to Addison, to the settlement of the West Harting estates in 1696 . But for West Harting "Ye Nymphs of Solyma" might never have appeared in the "Spectator." $†$

Another pleasant reminiscence of this transaction is, that the East Harting squire, Ford, Lord Grey, at this time high in power with William III. as Lord

- Luttrell says $£ 8000$ under Nov. 9, r697, but Caryll (the squire) himself writes $£ 6000$ in his letter to his uncle. Caryll Correspondence, I., p. 492.

† See "Athenæum," May 8, 1858. Elwin's "Pope," vi., 144. 
Tankerville, a zealous Whig and Protestant, seems to have used his influence to screen his rivals the squires of West Harting, though of the opposite religion and allegiance. A letter in the Caryll Correspondence,* addressed to one Southam, "the Squire's" lawyer friend, says : " 20 August, I696. I suppose it is newes to you that my Lord Cutts is the person to whom the King hath made a grant of $\mathrm{y}^{\mathrm{r}}$. friend's estate. There was a neighbour of yours near Stansted (Lord Scarboro' ?) who, I am told, did endeavour to beg it ; but ye other (as one in greater power) was more prevalent..... Did my Lord Cuts know that all he can legally hope for, is but an estate for life in that of Harting (deed made I652), and that $y^{\mathrm{e}}$ life by which he holds it is already superannuated, I cannot think his Lordship would look upon it as a matter of such mighty moment. . . . . I I am just come from Madame Caryll, who is put in great hopes of success by my Lord Tank (erville)."

A further circumstance which made the Harting property undesirable to Lord Cutts, was that only the West Harting moiety of the Tithes was in Caryll's hands. The East Harting Tithes (afterwards purchased by the Squire, and valued by him at $£$ I 20 per annum), were at that time possessed by the Fords, apparently according to the partition made in Elizabeth's reign, and then belonged to Lord Tankerville.

So the Squire had his own again, and reigned in all 47 years at Lady Holt, and set Harting bells a ringing. The old Secretary henceforth was severed from Harting, and doubtless saw with much composure his heir taking possession of his estate during his life time. Lord Cutts really did enter for a time, and the Squire, July I 8, I697, entered in his account book that he paid one Thomas Alnutt (Lord Cutts' lessee) “for Tythes due for $y^{e}$ Parke (Lady Holt) and Harehurst, \&c.,

* Caryll Correspondence, I., 2I. 
during the time $L^{d .} C$. had ye Estate, $£ 12$ : 0 : 0." This was in the Squire's own liberal vein: "Lord Cutts had the estate for a few months only, and his memory has gone like that of the guest that tarrieth but a day. No Harting peasant, I will venture to assert, has ever heard his name. But, though the composition was made with Lord Cutts, the outlawry still remained for nearly twenty-five years after; and it is not till 2 Ist Nov., I724, * that John Caryll receives congratulations on its removal that day, by order of George I.

As he has ceased to have any longer connection with Harting, I shall now take my humble leave of Mr. Secretary Caryll; but, before I do so, it may not be amiss to give the reader some extracts from the interesting letters received by him from James II. and his Queen during their exile at St. Germains, $†$ on the strength of which I have already remarked that it was quite possible at one time that the trio might have lived together at Lady Holt instead of St. Germains.

In these letters the royal handwriting is coarse and somewhat vague, the only exception being the looped initials of $J$. R., which long practice had evidently made perfect, and which it would have been hard in those days to forge. The spelling is scarcely that of the third standard in our present schools- "fower" for "four," "hether" for " hither," and a capital C for a capital $Q$ in "Queen," occur in our extracts-but it must be remembered that those were days in which Marlborough was so poor a scribe, that he wrote to his wife of whom he was passionately fond, "Of all things, I do not love writing" : to plan a campaign, it has been said, being far easier to him than to pen a despatch.

The first letter from King James II. to John, Lord

- Caryll Correspondence II., 160.

$\dagger$ Twenty-three letters of James II. and his Queen to John, Lord Caryll, 1692-1710. Addl. 28, 224. 
Caryll, is dated Boulogne, April 29, 1696. . . . " I see no manner of reason for my staying any longer, now that the world must find the decent is laid aside for the present." This apparently refers to some last hope of regaining England, which the next year, 1697, was disposed of by the Peace of Ryswick, wherein Louis XIV. finally surrendered the cause of James II., his cousin, as hopeless.

The Queen writes from La Trappe (her usual retreat in times of great stress), June 5th, 1696, of the illness of her son the Pretender. ... "If no accident happens-of which we have had good store since we left you : the worst has been last night, that by the carelessness of one of the grooms one of their stables was sett on fire and all burnt with four of my horses. But we shall mak a shift and go back, for all that, on thursday morning as $\mathrm{i}$ intended. It was a great mercy the whole convent was not burnt." .... The doctors are not to leave her son (in the smallpox, of which his sister Mary, William the Third's Queen, died in 1694) night or day. "Mrs. Stafford has my child and her owne. .... Pray bid her embrace my poor girle for me and the King, and keep her from her brother till he is quite well. .... We are here in a terrestriall Paradise, yett i don't at all forgett my friends, at the head of $w^{\text {ch. }}$ without wronging any, i putt Mr. Secretary Caryll. Maria R."

"Fontainebleau, Oct. 15, 1696. I approve intirely all that you have done concerning your niece, you may at all times with safety make use of my name, when it is to do you or yours any good, for you may be sure $\mathbf{i}$ shall always be ready to do that.-M.R."

This is followed by a letter from James, who says :

"Fontainebleau, Oct. I7. I have read the letter you sent me from the fish wife (apparently a plot from England), and had one part translated, and gave it to the king (Louis XIV. of France), out of precaution ; you did very well to informe E. Perth (Duchess of 
Perth, a staunch Jacobite) of the contents of it. . . . . You will have heard of the Queen's having had the colick these three or fower days last past, $\mathrm{w}^{\mathrm{ch}}$ continues still upon her, $w^{\text {ch. }}$ makes me send for $S^{\text {r. Will: }}$ Waldegrave,* he knowing her constitution, $w^{\text {ch. }}$ those of his profession do not. . . . You need not be alarmed at my sending for $\mathrm{S}^{\mathrm{r}}$. Will : for $\mathrm{i}$ hope by that tyme he can gett hether (hither) she will be quite well. J. R. $-8^{\text {ber. }}$ 17, /96."

The next letter of James' shows that though he was blamed for cowardice in a precipitate flight after the battle of the Boyne (1690), he had considerable stoutness of heart when he too suffered at the same place, Fontainebleau, at the turn of the leaf two years later, I698:-

"Oct. I 5, 1698, Font. I left my will with $\mathrm{S}^{\text {r. }} \mathrm{R}$. Nagle. $t$ I had in the night a little heat and unequalness in my puls $\mathrm{w}^{\text {ch. }}$ did not hinder my sleeping; all Mon. Faggon (Louis' physician) ordered me was to drinke some The (Tea) and ly some tyme in my bed, $\mathrm{w}^{\text {ch. }} \mathrm{I}$ did till ten in the morning; dined with the king (Louis XIV.), and have not found further inconvenience, only did not go out with the Cueene to the salut at the Lodg, it being somwhat cold; hoping in God to heare no more of this little distemper, and to be able to go a hunting to-morrow," \&c., \&c.

The king hunted " 3 days togeather," 2 Ist Sep., 1699, at Fontainebleau: so the exiles evidently paid the French king a yearly visit in the autumn. Apparently about the same date as the last is the following letter of Queen Mary about their prospects with Louis. "This king has been but once in privat with us, and $\mathrm{i}$ find that he thinks the P. of Orange (William III.,

- Henrietta, natural daughter of James, by Arabella Churchill, and sister of Duke of Berwick, married Sir Henry Waldegrave, created Lord Waldegrave.

+ Sir R. Nagle advised James to leave Ireland after the Boyne. 
James's nephew and supplanter) is not well, he is as civill and kynd to us, as he uses to be, and wee as modest and silent as to anything of business." (This is after the Peace of Ryswick, when Louis XIV. finally yielded up the cause of James II. as hopeless.) The Grand Monarque had welcomed his unfortunate cousin, James II., at St. Germains nobly. In taking leave of his guests he said: "Voici votre maison; qu'and j'y viendrai vous m'enferez les honneurs, et je vous les ferai, quand vous viendre $z$ a Versailles"- " As a king and politician Louis XIV. is liable to grave criticism. As a gentleman befriending a forlorn relation he is without reproach." Louis gave James a sum equal to $£ 24,000$ at once on his landing, and allowed him 50,000 francs a month. (Col. Townshend Wilson's James II.) - “Now I will only assure you that as long as $\mathrm{i}$ live $\mathrm{i}$ shall have a real esteem and sincere friendship for you, as indeed $i$ owe you upon a thousand accounts. M.R."

"Bourbon," Ap. 19, r701. i thank God the king grows better everyday then other, his goutte is quitt gon. ...... if the waters do but never so little good, he must go back quitt well. . . . . there is few of the whole traine that have kept so well as myself." (She was much younger than James, and, as we have observed, a second wife.) "It has cost poor Berkenhead very dear, or to say beter (better) he has purchased heaven very cheap, for i hope in God's mercy he will have it, being dead with all the sentiments of a true Christian and a good Catholick, \&c. She must write to Madame de Maintenon (Louis's creature) as usual."

Here is another letter from Queen Mary of Modena full of kind feeling for John Lord Caryll. It is further interesting as showing that the Secretary kept up his literary pursuits, and had in hand the private life or memoir of James II., afterwards published by James himself.

- After his Good Friday faint in chapel (170I) Dr. Fagon sent James to drink the waters of Bourbon de l'Archimbault. 
"Bourbon, May 19, I70I. I have putt off writing to you in hopes still every post to receive a lrē (letter) from you, but $\mathrm{i}$ find what $\mathrm{i}$ thought impossible, that you hate writting yet mor then I do, since you can hold out longer without writting to me than I can to you, for without any manner of compliment i may tell you that it has realy been uneasy to me to be so long without hearing from you, and even without writting to you. .... The king $w^{\text {d. }}$ have me putt you in mind of his memoires, but Mr. Inett (?) has assured us that you are hard at worke about them, so that nowe wee can only owe you thanks, begging you to go on till you perfect the work. I hope you have kept $y^{\text {r. }}$ health as well as $i$ have kept mine, and that wee shall find one another when we meet as well as when we parted, and as good friends. Mor (more) of me you cannot desire, for it is impossible to augment either the esteem or the kyndnesse $i$ have had for you ever since $i$ knewe you well. M.R."

The two last letters of Queen Mary's that we shall cite are dated from the. Monastery of Chaillot, to which Macaulay says she left the treasured whip or "discipline" wherewith James had vigorously avenged her wrongs on his own shoulders in penance for his amours with Catharine Sedley* and Arabella Churchill. The heart of James was left to this convent when he died, I6th September, I70I, and afterwards, in the first crush of her grief, Mary retired there.

"Chaillot, May I9, I7-. (I have lost) the satisfaction of seeing you, instead of $\mathrm{w}^{\text {ch. }} \mathrm{I}$ have willingly putt myself to the trouble of writing, a thing you know I am not fond of : but i find i can do it easyer to you than to most people in the world," \&c.

"Chaillot, May 31, 17-." (Page 29.)

"My daughter and $i$ are very well, and easyer in this place (the convent) than in any, when wee know 
that the king may be in danger" (perhaps this was the Pretender, for whom Mary's entreaties had won from Louis the title of James III., "seul reste de tant de grandeur." Some words of James to Mary before his death were treasured: "Songez, Madame, que je vais être heureux a jamais"). "I am glad to hear you are so well as to have no ailement but the goutte, which is a diseas i cannot pitty you for at your age, but wish you may have it som years yett, and no others. M.R."

The sturdy old Sussex gentleman* nursed his goutt to the age of eighty-six, having outlived his royal master, James II., by nine years. Like that master he had ceased to have any possession in England since 1695, and was under the ban as an outlaw to the time of his death. He continued to live at St. Germains, and subsequently in "Paris, where he died, Sep. 4, I7II, eighty-six years from the time that he first drew breath at Harting Place. He was buried near his master, James II., in the church of the English Dominicans at Paris of which he was a benefactor. He died a rich man, leaving $£ \mathrm{I} 8$,000 in cash besides estates to his nephew, the squire of Lady Holt, his heir. No doubt James's proverbial kindness to old servants enriched him. In reward for this last good deed of the Secretary's life, Pope wrote the Secretary's epitaph, the first six lines of which he afterwards fitted up for Sir Wm. Trumbull, and the whole of which he re-cast, as a similarly clever undertaker's job, for the Countess of Bridgewater. The suit, however, may be supposed to fit its original figure best, and therefore may be quoted here at length.

Epitaph on John, Titular Lord Caryll, I7II.

"A manly form : a bold, yet modest mind; Sincere, though prudent ; constant, yet resigned. Honour unchanged : a principle profes't : Fix'd to one side, but mod'rate to the rest.

* "Old Mr. Caryll of Sussex," as Kennet styles him. 
An honest courtier, and a patriot, too ; Just to his prince, and to his country true. All these were joined in one, yet fail'd to save The wise, the learn'd, the virtuous from the grave. Ye few whom better genius does inspire, Exalted souls informed with purer fire ! Go, now, learn all vast science can impart ; Go, fall'n nature, take the heights of art. Rise higher yet; learn even yourselves to know, Nay, to yourselves alone that knowledge owe. Then, when you seem above mankind to soar, Look on this marble and be vain no more."

Elwin's Pope Letters to Caryll, Vol. VI., p. 156.

- It may be doubted whether, if the following clever Jacobite verses, sent to Lady Holt by one James Tooker, had been divulged, a little more would not have been wrung out of West Harting Estate.

Fable.

"In Æsop's Tales an honest wretch we find Whose years and comforts equally declin'd. $\mathrm{He}$ in two wives had two domestic ills, For different age they had and different wills. One pluck't his black hairs out and one his grey, The man for quietness would both obeyTill all the parish saw his head quite bare, And said he wanted brains as well as haire."

The Moral.

"The Parties, henpeckt William, are thy wives,

The hairs they pluck are thy prerogatives; Tories thy person hate and Whigs thy power, Tho' thou much yieldest, yet they tug for more ; Till this poor man and thou alike art shown, He without hair, and thou without a crown."

London, April 9th.-

Caryll Correspondence I., p. 472. 
CHAPTER VI.

John Caryll of Harting iII., The Squire; AND FRIEND OF POPE.

JOHN CARYLL III. was the son of Richard Caryll, Esquire, of Harting, and afterwards of West Grinstead, and was born about I666.

As we have seen, he was his uncle's agent from the time that the latter was called to high affairs of state, his successor to the West Harting estates in 1696 , and subsequently, in I 7 I I, his uncle's heir.

His married life, of which he had a jubilee or golden wedding in 1735 , was spent, with one brief interval of six years, at Lady Holt.

It is singular that large as is the collection of Caryll Papers and Accounts (numbering 30 volumes, and some of them very bulky collections), there seems to be no direct evidence of the exact date of the building of Lady Holt mansion. For six years the Caryll Papers have been at the British Museum, and as yet they are unindexed, nor is any information, beyond the mere numerical title of each volume, to be obtained by the student. One is thus at great disadvantage, and as the task of search becomes laborious on the one hand, so, on the other hand, the risk of incomplete survey is enhanced. With some diffidence, therefore, I set before the reader the only data that I have found for an approximation of the exact date of Lady Holt.

There is a document which is headed "Inquisition for outlawry of Jo: Caryll, Esq., who is outlawed Monday next after Lady Day, I695."

It shows that the Secretary's whole estates in Sussex, including the Castle of Winchelsea, Higham Manor, Sontinge, Drayton, Oving, Merston, \&c., as well as 
West Harting Manor, amounted to a yearly rental of $£ 2,155:$ I I : 2 .

"Feb., I $695-6$.

Yearly value.

Jo. Caryll is seized of Hundred of Dumpford, worth...

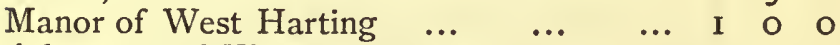

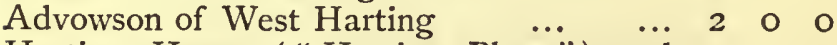

Harting House ("Harting Place") and Gardens

Of Lady Holt House, a Stable, Orchard, and a Park containing 150 acres

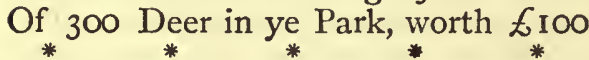

$£$ s. d.

Of Harting Pond (West Harting), held by

Peter Mee, together with the other lands

and farms ...

It also adds-" For six years next before $y^{e}$

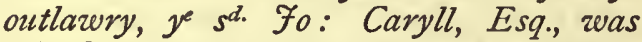
seized in fee of Lady Holt house and park, and all that time John Caryll the younger was Bailiff to his Uncle for $\mathrm{y}^{\mathrm{e}}$ same, and had $y^{e}$ care and reciñg (receiving) the rents thereof, $w^{\text {ch. }}$ have amounted to $£ 280$, and $\mathrm{w}^{\mathrm{ch}}$. he, the said Jo: $\mathrm{y}^{\mathrm{e}}$ son of Rich ${ }^{\mathrm{d}}$.

(i.e. the Squire) has in his hands... $£ 280: 0$ : :*"

Lady Holt house was, therefore, complete as to its main building and stable, six years before the outlawry, or in I689, as nearly as possible the very year in which the present Up Park first saw the light. To empark Lady Holt the Carylls disparked the ancient Park near the Church-the Home Park of Harting Place, still traceable in the name of "Pond Field," in the old grass land intersected by the road from South Harting to Petersfield. Harting has had at one time or other four, if not five parks : in the lowlands, or its

* Addl. 28, 250, Law Papers of Caryll family. Page 145. 
ground floor, Down Park; on its first story, the "Old Park" near the Church, and Mr. Lever would add a Park at East Harting near Turkey Island; on its second story, on the Downs, Lady Holt Park and Up Park.

It seems most probable that Lady Holt was built by John, Lord Caryll, the Secretary, and that, though he may never have taken possession of it, it was built by his money in the reign of King James his patron. The Secretary's accounts for the estate, and also for the widows of Dame Puckering's (a Caryll) charity, in which it appears that he apprenticed, among other orphans, a girl, ${ }^{*}$ at a premium of $£ 2: 0: 0$, to one Thomas Russell, I674, show that he was an active resident landlord at Harting. Among the curious lists of affidavits of burial in woollen of the year $I 68 \mathrm{I}, \dagger$ is an entry which shows that he buried his mother at Harting. "Sep. 13. Al: Cotton and Arthur Phillips for Jo: Caryll, Sen., Esq." We shall see that Mr. Arthur Phillips was his steward at Harting, and as he is called "Jo: Caryll, Sen.," it would seem as if his nephew the Squire, then "Jo : Caryll, Jun.," must have been upon Harting soil even in I68I.

In I683, a total inventory of goods at Harting Place, with directions for their removal to different houses in London was made, and shows I4 furnished rooms in the mansion. $\neq$ In 1696, the Squire was, as we have

- Addl. 28, 240, p. 52 . Household accounts of Caryll family.

† Harting Register No. I., End.-A curious entry of burial in woollen of the Rector of Terwick, is made by his successor S. Wormell : "I687. "Ubi desinit .N. Love I B I Incipit S. Wormell, Rectr. Indignissimus.' Mem ${ }^{\mathrm{d}}$. that my predecessor, $\mathrm{Mr}$. Love, receiving hurt by the fall of a loose lidd of a chest into which he, $\mathrm{y}^{\mathrm{e}}$ said Mr. Love, unfortunately (then, on 15th April) looked for his spectacles, he soon after dyed of a gangrene and feaver. ' Nigro carbone notetur ille dies.' Of his burial in woollen (viz., of Mr. Love), affidavit was made and dated the 2nd day of May, in the 3I year of our sovereign Lord King Charles ye 2nd, 1679." (Register of Terwick.) 
seen, in gaol on suspicion, I4 days at Chichester, and nine weeks:at Horsham, while the sheriff's charges at Newgate alone were six guineas. The ultimate bargain with Lord Cutts appears (p. 149) in the Squire's handwriting.

" Lord Cutts to have in all May I 3, I697, paid him

Of my own

Borrowed Caliswood

Do. Marewood

Mr. Hugh P., deceased, being the money of his master, J. C. ... 100

My money taken of Mr. Smith $y^{e}$ Priest

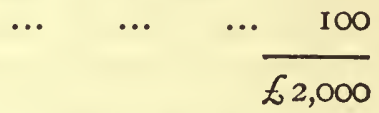

Lord Cutts received $£ 2,000$, and 2 'morgages' for ye rems. $£ 4,000 . "$

I quote this document to show the burthen which the composition with Lord Cutts entailed upon the Squire's property from the outset of his entry upon it. Nor did he succeed without domestic troubles at Harting. Robert Randall, one of the chief tenants, who farmed Eckenfield and other lands at a rental of $£ 80$ per annum in 1682 , turned rogue, left Harting without paying his rent, and actually crossed the sea to France to impose upon the old Secretary at St. Germains. There is a piteous letter from the Secretary to his nephew at Lady Holt, dated June Ist, I699, in which the old man says that Robert Randall had come over and "picked his pocket of ten pounds, saying that he had fled from the pillory for having drunk King James' health," whereas he had robbed his master at Harting, and run away and changed his name to Ansell and lived at Paris. In the same letter the Secretary gives his nephew permission to take 
down the goods, books, and letters left in his house in "Lester Square," London, to Lady Holt. " As to your taking into $\mathrm{y}^{\mathrm{r} .}$ own hands Randall's farme, $\mathrm{y}^{\mathrm{r} \text {. }}$ best way is to follow $y^{\text {r. }}$ father's advice $\left(\right.$ Rich $^{\text {d. }}$ of West Grinstead), who understands matters of husbandry better then I do. Tell $y^{r}$ father his friend D. Biddle (probably Biddulph, who accompanied James II. from Rochester), tho' he has $y^{\text {e }}$ gowt by inheritance, still rides stag hunting and wolf hunting, $\mathrm{w}^{\text {ch. }}$ chaces in this country continue $\mathrm{y}^{\mathrm{e}}$ whole year round, and walks without a staff by $\mathrm{y}^{\mathrm{e}}$ vertue of $\mathrm{y}^{\mathrm{e}}$ milk diet and of feeding only upon knuckles of veale; I wish $y^{\mathrm{e}}$ same management may have $y^{\mathrm{e}}$ same effect upon my brother." As to the Squire's "coming over to these parts," the uncle adds, "You cannot do better than follow the advice of your powerfull neighbour" (Lord Tankerville).*

In I 706 the young Squire of Lady Holt had another contretemps. Parson Tench, who held the sinecure Rectory and Vicarage of Harting, the former being the key of the latter, resisted the renewal of the lease of the tithes held by the Carylls, and in a subsequent lawsuit the unhappy Squire had to pay him $£ \mathrm{I}, 450 \dagger$ for a new lease, after all the expenses of law. The parson even went so far as to claim the "Canon lands" as Church property. The Squire consulted his uncle the outlaw in his French refuge, on the subject; and was answered in a letter which shows that the exile had not forgotten Harting. The names on both sides are feigned.

"J. South (Secretary Caryll) to Honble. Mr. John Southwell (the Squire), Lady Holt. Jan. 24, I705-6. Dr. N(ephew), I am sorry that I am not able to give you any account of $\mathrm{y}^{\mathrm{r} .}$ Canon Lands. They were purchased about 40 yeers ago, when I'did not live at

* Addl. 28. 226, pp. 103, 105.

† Caryll Correspondence, Vol. I., p. 492. 
Harting, nor do I remember ever to have rēcd $y^{e}$ writings concerning them : but it appears to me very certain that they must have been left in the custody of Mr. Phillips : so that his chamber at Harting sh. be well searched: as also the closet within my father's chamber there in $\mathrm{w}^{\text {ch. }}$ he used to keep many of his writings. I cannot possibly imagine upon what grounds your troublesome adversary (Parson Tench) should come to pretend any title to those lands : for tho' before Harry $y^{e}$ 8th they may possibly have been Church Land, yet their very name shews they could never belong to $y^{e}$ parsonage of Harting $w^{\text {ch. }}$ is a parochial Church and never had Canons belonging to it : and I beleeve those lands formerly belong'd to $y^{e}$ Abby of Durford wch was of Canon Regulars. Now, since you are in possession, he must shew his

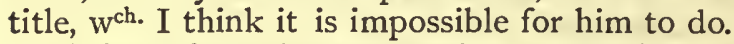

"I have been in some paine concerning $y^{\mathrm{e}}$ young gentleman (the elder Pretender?) who I formerly told you was going into Italy because he was to go part of journey by sea, and $\mathrm{y}^{\mathrm{e}}$ season has been very stormy, nor did I hear any news of him in three weeks or a month's time : but last night I received a letter $w^{\text {ch. }}$ tells me that he was safely arrived at Genoua after having 'scap'd great danger by sea; when he is at his journey's end I suppose you will hear from him. Comend me kindly to all $\mathrm{y}^{\mathrm{e}}$ family, and believe me to be, "Yrs. always, "J. SouTH."*

A vigorous letter for an old gentleman of fourscore: written in a clear upright hand, without a mistake. The Parson's claim to Canon lands seems to have been disposed of.

Parson Tench was always in difficulties. His creditors interrupted him, apparently on his way to Church, and in 1711 he offered his resignation to the 
Bishop. To his honour the Squire here gallantly interposed, though in a friendly letter Bishop Thos. Manningham remarks that " $y^{\mathrm{e}}$ paying of debts is not the use that spiritual benefices were designed for." Caryll's part in this matter shews how completely his sweet disposition had forgiven old scores. But the parsons of Harting were hardly worth preserving in their cures till they were men of a different stamp. There is a letter in the Caryll correspondence which states that Tench's predecessor as Vicar of Harting, named Francis Salisbury, "suffered death for coining." * I have not been able to verify this, but it is certainly remarkable that the only break in the Registers of Harting, occurs between the years I68I-I692, the entries of the former years being in Francis Salisbury's handwriting, and Mr. Tench succeeding probably as Curate at first in 1692. The Bishop's Register at Chichester, shews "Thomas Tench, Rector of Harting, Oct. 28, I695-Patron, John Caryll. Thomas Tench, Vicar of Harting, 1697-Patron, pro illa vice tantum, $\dagger$ Archdeacon Oliver Whitby, on the death of Francis Salisbury." As the vicarage of Harting was in the gift of the sinecure Rector, the object of Tench was to procure his own appointment to the vicarage through the Archdeacon, and he is quoted (in the next generation, 1739) as having written to Oliver Whitby, Sen r., that he "had placed so much confidence in him as to convey to him his right of presenting to the vicarage when it should be next void-which it will be soon," he adds, "by the deserved punishment of the present Vicar (who suffered death for coining), assuring himself that the Arch dn. $w^{\mathrm{d} .}$ use that right for his (Tench's) advantage only." $\ddagger$

It is right to say that this statement about the capital punishment for coining, rests only on the authority

- Caryll Correspondence, Adl. 28, 229, p. 358. † "For that turn only."

$¥$ Caryll Correspondence, $\mathrm{Ad}^{1}$. 28, 229, p. 358 . 
of another black sheep among the clergy of that date, Rev. Jos. Sager, prebendary of Salisbury, who was afterwards prosecuted by the Chapter for embezzlement. Sager is at the time one of the two rival vicars of Harting, and is writing to his rival, to whom he wishes to make the post at Harting disagreeable. It is hardly possible moreover, that if a Vicar of Harting were hung for coining within the last 180 years, there should be no local tradition to that effect, unless indeed he were non-resident. It is also but fair to remember that statements damaging the Protestant clergy would be very likely to find their way into the collection of the correspondence of a strict Roman Catholic family, such as the Carylls were, though we must not conclude from this fact that the Carylls endorsed their correspondent's views. It is just possible that the following "copy of a letter of the late Mr. Tench, sent to a gentleman whose son was lately entered into orders and wanted a Benefice," may be a true instance of the infamous traffic in the cure of souls that was often . practised in those days.

Copy of a letter writ to Captn. Hudson.

$$
\text { "Jan. I8, I } 7 \text { I I. }
$$

"Sir,-Since my return I have met with my friend Mr. Tench, who has the disposal of the vicarage of Harting, Sussex; the right of presentation is undoubtedly in him, and upon agreem ${ }^{\mathrm{t}} \mathrm{y}^{\mathrm{r} .}$ son may receive his presentation whenever he pleases and take Institution, and so he will enjoy it for life. I am very well satisfied that it is a noble living. . . from London, 45 miles (!), from Chichester, 8 miles (!), from Portsmouth, 14 (!), from Petersfield, 3 (!), from Midhurst, 5 (!). There are two noble parks in the parish Io miles about, and tho' the greatest parish in the county, yet but one church and one sermon a day. Mr. Caryll is only Patron of $\mathrm{y}^{\mathrm{e}}$ Rectory $\mathrm{w}^{\mathrm{ch}}$. Mr. Tench cannot 
dispose off; besides it is an insignificant thing, being only 40 marks a year, a sinecure; and all the advantages besides upon the accidents of fines. The Rector has always presented $y^{e}$ Vicar ever since Cardinal Poole's time, who was Parson of Harting, and enjoyed both the great and small tythes,* the former of $w^{\text {ch. }}$ is now in Mr. Caryll's hands, let by lease by the abovementioned Mr. Tench. The particulars of the small tythes you have on the back of this letter, with an endowment of $£ 90 \mathrm{p}$. ann. clear of all taxes, as are all things settled upon the Vicarage. This ought to be transacted by a third person, and by any but $\mathrm{y}^{\mathrm{r}}$. son, who $\mathrm{sh}^{\mathrm{d}}$. not in prudence be acquainted with it." . . . \&c. Suggests that "any clergyman of age or experience, or anyone of Doctors' Commons, should

"Oblige $\mathrm{y}^{\mathrm{r} .}$ friend, "JACOB HUDSON.

"An account of the Vicarage of Harting.

Impr. $£ 90$ p. ann. free from Taxes $\quad \ldots \quad \ldots \quad £ 90$ These were re-

corded in the 6,000t sheep kept in the Parish 100 Exchequer in 200 cows at 9 s. a cowe $\quad \ldots \quad 90$ 1705 , and not 400 young beasts at 2 s. a piece 40 contradicted I,500 load of haye at $2 \mathrm{~s} . \quad \ldots \quad$ I 50 by Mr. Caryll.

Meuse Platts at $£ 50$ p. ann. $\quad \ldots \quad \ldots \quad \ldots \quad \ldots 50$

$\begin{array}{llllll}\text { The Vicarage Glebe } & \ldots & \ldots & \ldots & \ldots & 5\end{array}$

$\begin{array}{llllllll}\text { Piggs } & \ldots & \ldots & \ldots & \ldots & \ldots & \ldots & 12\end{array}$

$\begin{array}{llllllll}\text { Calves } & \ldots & \ldots & \ldots & \ldots & \ldots & \ldots & 15\end{array}$

(Total) $\ldots . \quad \ldots \overline{£ 552}$

"Besides fruit, hopps, poultry in general, colts, 400

- Not true. Cardinal Pole was Rector only.

$\dagger$ There are not 4,000 sheep in the parish at present, 1876 . 
horses, beans sett, gardens lett at $£$ Io per ann., fish, wood in abundance, for none of the farmers buy any; Lord Tankerville and Mr. Caryll's wood may be computed to be worth at least $£$ I0,000. All Surplice Fees with a house and garden, containing an acre of ground well planted with all sorts of fruit. No manner of taxes out of this."*

Modern advertisements are naked veracity compared with this audacious document. The Vicarage of Harting had a very early endowment, and was augmented in the hard times during Mary's reign; but its resources were always humble. It is here made to be worth in our money, over $£ \mathrm{I}, 000$ a year.

Yet it would seem that the unscrupulous Mr. Tench was successful in disposing of his appointment; for the Bishop of Chichester's register shews that Thos. Tench resigns the vicarage of Harting, and appoints Robert Sully, Vicar, June I, I7I6; but himself dies before the end of the year. Just in time.

The squire of Lady Holt had married Elizabeth Harrington, by whom he had a large and sickly family of eight children, five sons and three daughters. The eldest son "Jack" (John Caryll) was born in 1686, and was educated at the Secretary's expense, near St. Germains. His great uncle writes of him, 1703, that he is thriving as to health and study, and that his "issue has been stopt up this twelve month past." His father before him had been educated in France; and he was in the country of other relations; Mary Caryll, the Secretary's sister, was Abbess of the Dominicans at Dunkerque, and her niece and namesake Mary the squire's sister had joined her, and with Queen .Mary's approbation took the veil, Lady Day, I699. The Secretary's nieces, Mrs. Cope, deserted by her husband (afterwards Pope's "unfortunate lady") and her sister Mrs. Blewett, whose name is old in 
Harting, were the bêtes noirs of the family. "She has great experience of the world and wants no witt, and I hope has attained to so much discretion as to govern herself suitably," wrote the Secretary of Mrs. Cope, in I787 : adding, "to ask me to lay down her portion, who have been for so many years quite owted of my estate in England, would be the same thing as to ask me to fly without wings." Nevertheless, the old man seems to have remembered her in his will, and her annuity of $£$ IO per ann. was charged on the Harting Estate.

Meanwhile "the Squire" was living quietly with his young family at Lady Holt. He was now leading and glazing the house, raising the outbuildings, planting elms and ash and chestnut on the downs, in soil that was too thin for them, setting "hopps" on the clays, deepening his great well, and furnishing the mansion with damask bed and chairs bought for him out of the royal bedchamber at Old Windsor, by his friend and cousin Mr. Tooker, of Idsworth. For this the Lady Holt team went up to Windsor. Sometimes he would kill a stag at Petersfield with Batt Starr his doctor, and spend $£_{3}$ IOs. $6 \mathrm{~d}$. on the junket; sometimes he would go-a-hawking at Nutley in Ashdown Forest, his old neighbourhood, and spend $£ 44$ Is. on the sport exclusive of $£ 5$ to the Grinstead servants; at home, the Lady Holt falconer had $£ 8$ a year,* and was a potentate at Harting. In I TOI, on the death of the Squire's father, Richard, the West Grinstead property came to him; and the family coach went up from Lady Holt to town to be put in mourning. The gradual raising of a sum which the Squire annually gave to the poor on "St. Thomas his day," from $£ 2$ in I697, to $£_{4}$ I 5s. 9d. in I7 I4, marks the corresponding increase of his income.

- Ap. 22, 1700. Paid Jones ye faulconer a year's wages, ending Lady Day last, $£ 8$. Caryll's Account Book, Lady Holt. Add. 28, 245. 
Before his death in Paris, the old Secretary seems to have heard with distress that his nephew "the Squire" at Lady Holt was in debt. There are two drafts of the critical letter, in which the Squire makes a statement of his affairs to his uncle. The most perfect copy is marked June I 5, I7 I8, but cannot have been later than I7II, the year of the Secretary's death, and probably the real date is I7 IO.*

"I have received a letter from worthy Mr. Jones, wherein he tells me $y^{r}$. Lordship seemed surprised I $\mathrm{sh}^{\mathrm{d}}$. be in debt. Wherefore, my Lord, I think myself obliged in duty, to give you in as short a manner as the thing will bare, an account of the present state of my affairs, $w^{\text {ch. I }}$ will faithfully include under two heads, one, as shewing how I came to be in debt; and the other, what means I thank God I have still in my hands of clearing myself one time or other.

"As to the first, your Lordship may please to remember that by the compision with Lord Cutts, we were to pay him down $£ 6,000$, that then you were so generous to give the thousand $\mathrm{p}^{\mathrm{ds}}$. morgage you had on Marchell's land, and about eleven hundred pounds of cash of $\mathrm{y}^{\mathrm{rs}}$ there was in my hands, to which were added about $£ \mathrm{I}, 200$, raised by $\mathrm{y}^{\mathrm{r} .}$ order for sale of timber from Har. (Harehurst or Harris Wood, near Lady Holt), $\dagger$ towards discharging itt. The remainder was forced to be charged upon $\mathrm{y}^{\mathrm{r} .}$ estate. After that, to skreen itt the better from Trouble Times, Worledge, a Protestant attorney, was put in by my father to receive the rents of itt; but before I could gett him to deliver up his accts. he was run I, IOO and odd pounds in our debt; for which, however, I got from him a land security, but 'tis in reversion after an old woman's death. After that, the next thing that followed was an expensive lawsuit with $y^{e}$ Parson, which there was

- Addl. 28, 227, p. 492.

$\dagger$ Perhaps "Har." is "Harting," but Caryll's usual abbreviation for this is "Hart." 
no avoyding off, and then it cost me fourteen hdd. (hundred) and fifty pounds* to take a new lease of the tythes. Some time after I gave $£ 2,400$ for Mr. Buning's share of Winchelsea, which I bought purely because I knew it to be a very improveable estate, and the greatest part of itt being alreddy (for reasons you know) in my possession: I could make more of itt than another. Itt has proved allreddy to my expectation, for I have been offered considerably more than itt cost me; butt I am sensible 'tis yett capable of a far greater improvement. I have further, as my conveniency led me in Harting and Grinstead, purchased severall odd parcells of land, some of a near relation, in the whole to the value of $£ 400$.

"My Lord, I have portioned out two Dâturs, after maintaining and breding up a great number of children, $\dagger$ all att my own expence, except Jack, whose education indeed was wholly owing to your bounty.

"I have been liable to pay $£$ IOO a-year in annuity to my wives' relations, and fifty pounds to Mr. Inboro', nor did any of them drop till about two years since, tho' now indeed they are all dead. I also paid some years $£ 50$ p. ann. to my Cōsn Cope by $y^{r}$. direction till such time as she marry'd. I suffer'd by Robert Randall when he ran away, and had a considerable losse by Waldegrave when he broake : great part of the expense has been all along double tax'd.

"Having now laid before your Lordship the occasions of my debts, give me leave to observe to you the course I may take to clear 'em. First I shall inform you $\theta$ f the prom's wife will bring him. . of Winchelsea, and the other things I purchased among them, $w^{\text {ch. }}$ are halfe $y^{\mathrm{e}}$ Tythe of Hart. (ing), for we have now the other moiety also $w^{\text {ch. }}$ was in $y^{\mathrm{e}}$ Ford family,

- $£ \mathrm{r}, 450$-about $£ 4,000$ of our money. The lease obtained was for two lives. P. 494 .

† "I have brought up ten children." Duplicate draft of this letter.-Ibid. 
butt I hope never to be necessitated to (part with'?) itt, for I bought 'em with a design to augment the Estate of the family, and I think I shall have very ill luck if we get not Portion enough with a wife for my son to goe clear our debts. Besides, my Lord, I have a great deal of Timber upon my Estate, for 'tis well known my

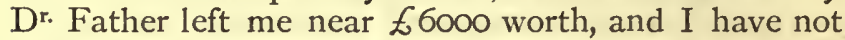
cutt yett to value of two.

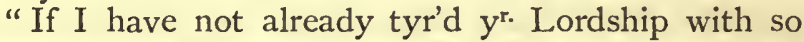
long a detail of matters, give me leave to add a word or two more--that I need not go about to vindicate myself from any assertion of extravagance, \&c., for no body can accuse me of Gaming or any other Unjustifiable Expences. The only thing that I have been att that has not been precisely necessary has been Horses and Hounds " (kept at Harting, also a stable at Charlton), " $w^{\text {ch. }}$, besides that they contribute both to the Health as well as to the Diversion of my son and of myself, perhaps might have saved us from running into greater Expense in other places. I ever design'd, so soon as I had settl'd my son, to live beyond seas for some years to save for younger children, and in $\mathrm{y}^{\mathrm{e}}$ mean time you may please to observe that I have constantly resided near half $y^{e}$ year att Grinsted as a cheaper place, of less resort and thinner neighbourhood than Lady Holt.

" Here my $L^{d}$. I have faithfully lay'd before you the true state of my affairs: I wholly submitt itt to $y^{\text {r. }}$ judgment; and with all humbly beg $y^{r}$. directions where you think $\mathrm{me}$ in $\mathrm{y}^{\mathrm{e}}$ wrong either in what I have done, or what I design to do. . . . The Small Pox breaking out at Lady Holt, of which a ser. (vant) dyed, drove us away from here sooner than we design'd.

I must not forgett to add that if a peace come I will not faile, God willing, of kissing $\mathrm{y}^{\mathrm{r} .}$ hands in person soon after, and hope to find you in as good a condition of health as is possible......"

This letter, a model of simple honesty, shows exactly 
the state of the Squire of Lady Holt's fortunes, and the cheerfulness with which he struggled, spite of dishonest servants, a burdened estate, and a large and sickly family-flanked by poor relations on either side - to complete and furnish a new mansion. Would he not have done better in the old home at Harting Place? But probably sickness and the insecurity of the times drove him to his hill fortress of Lady Holt, where, peace loving and religious as he was, he might be safe in moments of suspicion from espionage, and have his private chapel and resident priest. Beside borrowing from others, in I7IO, the year of the foregoing letter, he borrowed $£ 200$ at $5 \frac{1}{2}$ per cent. from his friend Alexander Pope's father.

The two next events of his life eased his shoulders from burthen, at all events for the time: viz., the death of his uncle, I7II, and the marriage of his son Jack (John Caryll of Harting No. IV.) in the following year to Lady Mary, daughter of Kenneth, fourth Earl Seaforth, of Salterns, Devon.

The Secretary left "little Jack" the "rents in the Town House of this place," Hotel de Ville, Paris ; his. will also contained bequests to several members of the Caryll family, to the Jacobite Scot College in Paris, and to several charities. The Squire, as Légetaire Universal, or Residuary Legatee, found $£ \mathrm{I} 8,000$ in cash, and a rental of $£$ I 2,966 : Io : 0 . No doubt these sums represented the liberality of James II. and Queen Mary, and the thrift of the old (bachelor?) man. Mrs. Ann Cope was left $£ 300$ a-year out of the estate for her life.*

-Addl. 28, 227, p. 103. In Caryll ("Squire's") writing. LEGACIES.

Ready Cash ........ £ $£$ r8,000

8,500

$£ 9,500 a b^{t}$
Burial .................... £400

Others................... 8,100

$£ 8,500$

June 2, I7 12. 
The Squire calculated that he received $£ 9,500$ in cash, and an income of $£$ IO, I $6:$ IO : o all paid. But the mouths were many and ravenous.

From this time we are able, through Pope's letters to Caryll, to trace an intimacy that no doubt had long existed; and as these letters number I 50 (from I 7 I I1735), and were most of them sent to Lady Holt, we have the honour of claiming Pope as the historian of West Harting for near a quarter of a century. In the original editions Pope's letters to the "Squire" are headed "to Hon ble. J. C." The name of Caryll was that of a well known Jacobite, and hence the initials only were given, as in the line which acknowledged Caryll as the originator of the "Rape of the Lock" because Caryll was a Roman Catholic, and Pope, though he owned himself a "poor Papist" to Caryll, was no bold professor of his faith. To Caryll, whom he honoured specially for his unaffected piety, Pope sent in the first instance all that he considered most virtuous in his compositions. Thus, "Vital Spark of Heavenly" Flame," "just warm from the brain," though a dressing up of some lines of Flaxman's, was sent to Lady Holt

Total of the several Contracts per ann $£_{66}$ s. $d$. Total of Rent charges per ann. .......................... 2,850 a

Remains coming in clear ................. £10,116 10

Perpetual Rent Charge.

Newport Paish.(?) ...... £150 To ye Scot College* ... 450 To London …............ 550

$$
\text { EII50 }
$$

For Life only. To Bat. C................... £500 To young P. C. ......... 500 To Mrs. Ann C. ......... 300 To Mrs. Cath. C. ..... 400 $£ 1700$

* A Jacobite stronghold in Paris. Charles Edward set sail to Scotland, 1745, as Scot College student. Probably "Little Jack's" school. 
for Caryll's revision in $1713,{ }^{*}$ while the same copy was sent as bran new to Steele in I730. So the "Thoughts on the Vanity of Man," "Good God! what an incongruous animal," \&c., were sent as an ordinary letter to "J. C." in I7I3, and afterwards to Addison. Caryll and Lady Holt are Pope's first thoughts after the loss of his mother, at which the latter was much touched, twenty years after; and it is to Caryll that he defends the infidel doubt which he had written to please Bolingbroke :-

"If to be happy in a certain state-

What matter here or there, or soon or late;"

suggesting that "if" here does not imply a doubt, but assuredness, and that thus it is equivalent to "since."

It is said that there are three who should never give witness of a man-his parson, lawyer, and physician, for they respectively see him only at his best, worst, and weakest. To judge from the letters of Pope to Caryll, Pope in them always appeared at his best ; and if Pope ever had an approach to a confessor, it would be John Caryll our Squire.

In the letters of Pope that have been preserved he has recorded four visits to Lady Holt, extending over a space of twenty years; but there is evidence that he was a constant visitor, expected usually viâ the "Three Tuns," at which hotel in Guildford (now the marketplace) the Lady Holt coach met him. Sometimes he would plan twice in a year for a Sussex holiday, and "the serenity and lively good humour" of the countryseat of his oldest and best friend.

The "Squire's" son, "Little Jack," married Lady Mary Mackenzie, on I 5 th July, I 7 I2. The bride and bridegroom were honoured by a visit from Pope, who

* Pope tells Caryll, to whom he sends "Vital Spark" for criticism, that it was "struck off at a heat one morning in Dec., 1712." It was clearly suggested by the "Spectator" of Nov. 10, 1712 , No. 532, which contains a prose translation of these Latin lines of the Emperor Adrian. 
accompanied them after their honeymoon to Lady Holt.* In his letter of congratulation to the Squire Pope says- "To conclude as no happiness comes without alloy: so it seems that the young gentleman must carry me down with his fair lady": and he tells Gay (I3 Nov., I7I2) that "he had passed 2 months in Sussex." Lady Mary at once charmed Pope, as she witched all the world. To the proud father he writes: "If you could get every man as good a wife as you did for your son ..... the very satirists and wits would be the first to apply to you, and even I, myself, should entreat you to seek out some shepherdess about the hills of Lady Holt for the felicity of your humble servt." The Squire doated upon his daughter-in-law. Every year he seems to have made her some present on his son's wedding day. In I 7 I 3 the token was a repeater watch of sixty guineas (a third of the present value), and in I7I4 a silver teakettle of forty guineas. These were bought at a shop in town interesting to Harting people at the time, for it was kept by one Hatton, who had married from Lady Holt Park. Pope is here our chronicler: "I am lately fallen acquainted with Mr. Hatton, watchmaker, whose clocks speak, strike is too boisterous a word :

'From hour to hour melodiously they chime,

With silver sounds, and sweetly tune out time.'

$\mathrm{He}$ is likewise curious in microscopes. . . . . He married the daughter of Peter My or Mee (for historians spell it variously), keeper of the beautiful park of Lady Holt, and flourished in the beginning of the I8th century in Duke Str., near Lincoln's Inn Fields." We have already heard of Peter Mee as holding West Harting Pond under the Squire, valued by the inquisition for the outlawry at $€$ Io per annum. Peter Mee

* A shady lane, now a coppice, leading to the Downs near Foxcombe, in the direction of Lady Holt, is called to this day "Lovers' Lane." 
lies buried on the left or north side of the west door of our Church, under a plain slab with death's head and bones and the inscription " $\mathrm{R}$ in pace." I707. The Squire always sought out Hatton's shop when in town,--twice a year in his gay days,-and bought trinkets for his kinsfolk at home and in France. Sometimes, including the expenses of his horses at "Foxhall" (Vauxhall), he would spend $f^{20}$ in a day. The Squire's wife stood godmother to Mr. Hatton's child in I7I3, and presented it with two guineas. Pope was now approaching the height of his fame, and the Squire was proud to help his friend in procuring subscriptions for the translation of Homer's Iliad. Three Harting men joined the list of subscribers: the Squire,* his son Jack, and Richard Caryll, another son, who had a place at West Harting, and farmed "Crookes and Fowlands and $\mathrm{y}^{\mathrm{e}}$ Fullen Mill." The Edward Carylls who were settled at Compton (Littlegreen), to be near their uncle, were also contributors. In all Caryll collected from his tribe forty guineas towards Pope's great venture, by which the great poet made $£ 5$,000; a success which caused Voltaire to be astonished at the English love of literature. "I look upon money," writes Pope to the Squire, "to be one of the least things to be obliged to you for, and I should be heartily ashamed to thank you for forty guineas, after I had enjoyed $y^{r}$. friendship with silent satisfaction for many years Assure $y^{\text {rself. }}$ and the united families of Lady Holt of my faithful service."

Twice during the translation of the Iliad did Pope visit Lady Holt, and doubtless much of the work was done there, though it was finished at Stanton Harcourt in 1718 , as he himself inscribed on a pane of glass with a diamond.

In I7 22 the winter was too cold for Pope to make

- The Squire also subscribed a guinea thro' Pope for Tickell's translation of Lucan, and through Mr. Tooker for a new edition of Chaucer. 
a second journey to Lady Holt. Dec. 2r. "I cannot express how thoroughly I am penetrated by the sharpness. I feel nothing alive but my heart and head: and my spirits, like those in a thermometer, mount and fall thro' my thin delicate contexture just as the temper of air is more benign or inclement. In this sad condition I am forced to take volatile drops every day: a custom I have so long continued that my doctor tells me I must not long expect support from them, and adds that unless I use certain prescriptions, my tenement will not last long above ground. But I shall not prop it, rotten as it is, with his rotten fulciments. If it falls, as the honest Hibernian said of the house, I care not, I am only a lodger." Pope was then forty-eight years of age. In I7I4 he was more successful in his attempt to get a holiday at Harting. "Nov. I9, I7I4 As soon as I can collect all the objections of the two or three noble judges, I shall fly to Lady Holt as a proper place to review and correct the whole for the last time. I fully purpose to be with you at the beginning of December, and to stay till Christmas." Mr. Elwin notes, "Pope paid this visit to Caryll;" and that they returned together appears from Caryll's account book at Lady Holt. "Dec. 22. I went this day with Mr. Pope to Whiteknights ; we lay at Odiham."

In I715, Pope and Gay seem to have come to Lady Holt together ; and before their arrival they wrote the following joint note to their hosts :-

"Mr. Pope and I (Gay) have thoughts of doing ourselves the honour of making you a visit to Sussex as soon as he has ended this year's labours with the bookseller : where I promise myself the greatest pleasure and satisfaction. May the gout be favorable to you, that we may walk together in the park; Mr. Pope will make his conditions, before he will venture into $\mathrm{y}^{\mathrm{r}}$. company, that you shall not allow him any of your conversation in the morning. $\mathrm{He}$ is obliged to pay this self-denial in complaisance to his subscribers. For my part, who do not deal in herocs or ravished 
ladies (Helen of Troy to wit), I may, perhaps, celebrate a milkmaid, describe the amours of your parson's daughter, or write an elegy upon the death of a hare : but my articles are quite the reverse of his. Let Mr. Pope and Homer keep company together. I $\mathrm{sh}^{\mathrm{d} .}$ think that ancient gentleman a good companion in a garret in London, but not in one of the pleasantest seats in England, where I hope next month to have the happiness of good company." "Thus far Mr. Gay," Pope adds, "who in his letter has forestalled all the subjects of raillery and diversion." $\mathrm{He}$ adds that Richard Steele, Esq. (to whom, it will be remembered, Caryll had introduced him) is now Sir Richard Steele." *

Gay's remembrance of Lady Holt is pleasantly chronicled in his congratulatory ode to Pope on completing his work, and a "safe return from Troy,"

"I see the friendly Carylls come by dozens:

Their wives, their uncles, daughters, sons and cousins."

It was these "dozens" that contributed to the impoverishment of the Caryll family, and singularly enough in another sixty years the whole of the numerous family seems to have died out. In 1716 , Pope did not come down for Gay was ill. But in 1717, June 7, he made another effort to gain the inspirations of Lady Holt. "I made a party with Lord Jersey last week to have run away and seen the Isle of Wight and Stanstead (Lord Scarborough's). He thought it a mere ramble; but my design lay deeper to have got with you. ... I must go abroad to follow my business, and if Lady Holt's shades afford me protection, it is there Homer's battles must be fought.

" ' $\mathrm{O}$ qui me gelidis in vallibus $Æ m i$

Sistat et ingenti ramorum protegat umbrâ." †

- Elwin's Pope V. 226, Letter 43.

$\dagger$ "O who will set me in cool Hœmus' glade, And shield me with a canopy of green?"

Virgil, Georg. II. R. D. Blackmore, Esq. 
But alas! June 30, I7I7. . . "That one of us disappointed the other is evident, and which of us it was the shades of Lady Holt can witness which saw you there and not me." *

In August, Pope, who was distinguished as a painter as well as a poet, had caused some of his pictures to be framed for Lady Holt. One of these was a "Madonna and Child" for the altar of the private chapel. $\dagger$ The squire paid for his share of it, $£ 2$ IOs., probably for the frame. In 1694, another set of pictures had now been finished by Pope, and he writes, Aug. I8, I7 I7:- "When my pictures are done be pleased to order them down to Ladyholt by the Stanstead carrier, who inns in Gerard Street." At the same time, perhaps, that the cases might not go back empty, Pope hints_- "when a hogshead of good French wine falls into Ladyholt Park, whether out of the skies or whatever element that pays no customs, you would favour me with about twelve dozen of it at the price you give." It is sad to note that this sort of reckless dealing with smugglers led thirty years after to the Lady Holt murder, as we shall see. No doubt such Jacobites as Pope and the Squire were sorely tempted for three reasons to patronize the smugglers; first, in order to evade the unlawful taxation as they thought it of the line of Hanover, secondly, to stop its supplies, and, thirdly to take some set off

\section{- Elwin's Pope, Vol V., p. 246.}

$\dagger$ In return for Pope's Madonna, Caryll sent him some Emsworth oysters.

"Now as your Lady is pleased to say of my present that St. Luke himself never drew such a Madonna, so I may say. of yours that the Prince of ye Apostles himself, tho' he were a fisherman all his life, never eat so good oysters." "You'll be the cause that I shall obey a precept of the Church this Lent," \&c. Pope to Caryll, 17 10-11.

Pope's Aunt and Godmother, Christina, was wife of Samuel Cooper the great miniature painter of European fame."Athenæum," July 18, 1857. Hence Pope's early love of painting. 
against the petty laws which prevented a Roman Catholic from having a horse of more value than $£ 5$.

The twelve dozen of good French wine ordered from Lady Holt, were delivered to Pope in London as seven dozen; several of the bottles were broken, and the Stanstead carrier, J. Hart by name, got his scolding, but might doubtless plead bad packing, or the roughness of the Sussex ways. However, Pope paid for his not very honourable purchase, Dec. 28, 1717. "When Socrates lay a dying, some of his last words were that he owed about nine pence to his friend Æsculapius. Now to compare myself in the only instance that I can to that just man, I owe you for seven dozen of wine and bottles." (Pope to Caryll.)

But in 1718 , the pleasant times at Lady Holt ceased, and a bitter affliction befell the Squire. His son, Jack (the fourth John Caryll of Harting), was, as the Secretary noted, weak in his childhood, but at the time of his marriage appeared to have been full of vigour, and afterwards hunted the Harting hounds. On the failure of the French Funds in which he had invested, Pope playfully wrote that he thought he should go and live upon Mr. John Caryll, but he adds, "I have lost all my hope since he had a child, unless he will maintain me as his huntsman." This child was born, Dec. 13, I7I3, as Mr. Tench enters in our register, and the Carylls desiring to give a special mark of their religion to the future heir of the house, christened the boy "John Baptist Francis." Doubtless the name "John Baptist," was in memory of "St. John Baptist's Abbey of Durford, and of the Secretary's title as Lord Durford." John Baptist lived only four years. But in April, I718, this sorrow was eclipsed by one far greater. The scourge of the age, the smallpox, had been fatal at Harting and Lady Holt before; Lady Holt well may have been in fault as before, when a dead dog was fished up out 
of it;* but however this may be, smallpox carried away the Squire's eldest son at the age of thirty-six, and Lady Mary was left a young widow after but six years of sunshine at Lady Holt. The Squire was heartbroken, and entered in his diary the touching lines-“1718, Ap. 6. Being Palm Sunday, my dear son, never to be forgotten, died of the smallpox. Sweet Jesu, grant me resignation, and to him eternal rest." After the funeral the family went abroad for six years, and Lady Holt was let to Edward Roper, Esq., of Eltham. $\dagger$ Oct. I8, I 7 r8.

Pope had already characterised Mr. Roper ... " he has the reputation of keeping the best pack of foxhounds in England, and will visit the ladies in a hunting dress." Elwin says that he was connected by marriage with Caryll's neighbours, the Butlers of Sussex. He afterwards rented Lady Holt, and in 17 8 took a lease of Caryll's stables and kennel at Findon. He adds:- "The announcement of the death of $\mathrm{Mr}$. Roper in the Historical Register for 1723 , is in keeping with Pope's description. Feb. 27-'Ed. Roper, Esq., of Eltham, in the county of Kent, died of the hurt he received by a fall from his horse, as he was hunting a fox. He was eighty-four years of age, and had all his life been a keen sportsman.' $\mathrm{He}$ was a good tenant of Lady Holt; for with characteristic couleur de rose the Squire notes, March 25 (I729):- “I think 'tis very happy if a man can keep up and emprove his own house with other people's money, as I did at Lady Holt whilst I let it." $\ddagger$

- Squire's Account Book, June 7, I714. "To Tupper (who sunk Lady Holt well), for fetching a dead dogg, 'Emperor,' out of ye well. . . . 2s. 6d."

f Pope seems to have stirred himself on Caryll's behalf, not only writing him a letter of condolence, but also endeavouring to let Lady Holt for him, Oct. 18, 1718. "Before I could see my Lord Burlington who was as much upon the ramble as myself, I heard Mr. Pultney had agreed for Lady Holt."

$\ddagger$ Caryll Correspondence, 1729 . 
It is probable that during the stay of the family in France, Lady Mary gave posthumous birth to the last John Caryll, of Harting (No. V.).* This child being in its infancy "very tender," was brought up like its father and grandfather in France; and as it was the Squires only direct male heir, he lavished much affection upon the boy. When he was twelve, the old gentleman, then long ago back at Lady Holt again, trotted out his best Latin and French in the following playful note to his grandson, who had written him a Latin letter. $\dagger$

"Lady Holt, 8 Kal Novbris., I730." " Jucundissima mihi fuit, mî Filî, epistola tua; et pergrata Elegans illa tua scribendi norma. Linguam Latinam, ut video, jam calles, et tibi respondere eôdem Idiomate (ut prius in Animo fuerat) non valeo; imparem me oneri jam sentio; nam a quadraginta quinque annis ne ullum quidem verbum Latinè scripsi!- Me voyla donc au bout de mon Latin! C'est pourquoy Je vous prie deprendre le reste en François; Langue que J'ay plus cultivèe que l'autre, quoyque Je l'ay appris toutes deux en même Têms, et au même College (? Scotch College) on vous êtez a present.

" Nous voyla de rétour a cette heure a Lady Holt, Grace a Dieu, Tous en bonne santè ; et pour moy, je m'occupe principalement a embellir Le Parc et les Avenues, dont J'espere que vous jouisez bien d'annees apres ma mort, et peutêtre même avant qu'elle arrive. En attendant, contez qu'il n'y rien au monde que Je souhaite plus ardenment, que le plaisir de vous revoir. ... Je suis bien aise que vous vous appliquez a la Musique aussi bien que L'étude; et Je ne serois pas fachè (si $M^{\text {de. votre }}$ Mere le trouve bon) que vous

- As he came of age in 1739 , he wd. most probably be born in 1718 ; and as there is no entry of his birth in Harting Registers, it $w^{\text {d. }}$ be abroad.

t Caryll Correspondence ii. 427. J. Caryll to his grandson in Paris. 
reprenniez le Violon (the younger Pretender was a good violoncello player, and fiddled his part in Corelli's Notte di Natale, in the concerts at Rome) qui est plus en usuage parmis les gens de qualitè en ce pays-ci que Le Claveçin: et votre Taille est a present si bien formè qu'il n'y aura plus de Danger de ce que nous apprendions autrefois. Et puisque vous montez quelque fois a Cheval, Je ne manqueray pas de vous envoyer un joli Bidet, pour les vacances de l'annèe prochaine.

"A Madame-Madame Caryll, [a son hotel] dans la rue de Cheval vert proche L'Estragade A Paris."

This letter is written in the colossal handwriting of an old gentleman, and has been partly burnt by candle light. It doubtless took some time in its composition.

When the paragon was fourteen, his verses were sent by the fond grandfather to Pope, who pronounced them " extraordinary;" but added-“" I would rather see him a good man than a good poet."*

Before I730, Lady Mary put off her widow's weeds, and took for her second husband Sir Francis Sempill, probably the same person as the Lord Sempell, who was agent for the young Pretender at Paris, in I 745. While she was in Paris, the poor Parson of Harting had a sore grievance against her for making his daughter a Roman Catholic. The cry that attends the religious hawk or kite has often been heard before and since; but never without awakening sympathy. We shall all therefore enter into the case of the poor father of Mary Newlin, and share the sorrows of an old home at the Vicarage. To understand the following correspondence, it must be said that Parson Newlin was appointed by the Squire's Trustee, one Trevanion, to the living of Harting, and that Mary, Newlin's daughter, "eleven years old," would be just 
the same age as Lady Mary's son, the Squire's heir. Probably little Mary Newlin may have been needed as an English child, a playfellow for the last cadet of the house of Caryll, who might keep up the boy's English. Lady Mary passes on Mr. Newlin's piteous letter to Mr. Caryll, one of the Shipley family, a cousin of the Squire's, now in France, who answers in a tone of scorn and cruelty that contrasts much with the dignity and good feeling of the Parson of Harting.

"I4th March, I726-7. A copie of a letter from a Parson in England to Lady Mary Caryll at Paris, who was so good and charitable as to take one of his nine daughters off his hands to breed her up and provide for her."

\section{"Chalton, $\uparrow$ March $y^{\text {e }} 14^{\text {th }} 1726$, O. S.}

"Honoured Madam,

"I have just now rec d. a letter from Mr. Caryll from Dunkerke (Phillip Caryll) with part of another inclos'd subscribed Mary Anne Caryll, in $\mathrm{w}^{\text {ch. }}$ are these words-" "My. (Mary) Newlin is to make her first communion next Easter." I have been often reproch'd for letting of her go, and as often told that she was only decoyed away and sent to Bruges in order to be perverted; but I depended most assuredly upon your Ladyship's honour, that nothing of that kind wou'd be attempted without my consent, and sure a child of ten year old is in no way capable of determining for herself in so weighty a busieness as is $y^{t}$ (that) of her soul.

"Madam, I am a clergyman, and therefore ought to be presumed to know $y^{e}$ foundation of my relligion, and as I don't think it good manners to reflect upon

- Heading in Philip Caryll's handwriting.

† Caryll Correspondence II., 194. - Like Dr. Bramston who succeeded him at Harting, John Newlin was Incumbent of Harting and Chalton. 
those $y^{\text {t. }}$ differ from me, so neither cou'd I ever yet see reason to change my own principles, and consequently can never consent that any belonging to me shou'd; since, therefore, $y^{e}$ case stands as it does, tho' it cost me more to fitt her out in one year, then it must in two if she stayed at home, whatever expence $y^{\text {r. lady- }}$ ship have been at on her account I will honestly repay to $\mathrm{y}^{\mathrm{r}}$ orders, and I beg my child may be sent home again forthwith. And as it was by $y^{r}$. Ladyship's order that she was sent to Bruges, and likewise on $y^{r}$. account $y^{\text {t. }}$ she was entertained there, I entreat $y^{\text {or. Ladyship }}$ would immediately write to my Lady Lucy Herbert to send my child to England by $y^{\mathrm{e}}$ very first opportunity, for I would not part with her upon those terms to have her made a Dutchess, thô otherwise I shd. have

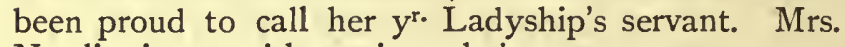
Newlin joyns with me in makeing $\mathrm{y}^{\mathrm{e}}$ same request as well as in duty to $\mathrm{y}^{\mathrm{r}}$. Ladyship, to whom I am

"A most obed". and obliedged humble servant, "JOHN NEWLIN."

P. 195, Vol. II.- " A copie of a letter from Mr. Caryll at Dunkerke to $\mathrm{y}^{\mathrm{e}}$ Parson in England, upon $\mathrm{y}^{\mathrm{e}}$ subject of his letter to Lady Mary Caryll:"-

"Sir,-I have had lately transmitted to my hands a copy of a letter you writ to my Lady Mary upon $\mathrm{y}^{\mathrm{e}}$ receipt of my last to you, wherein I sent $\mathrm{y}^{\mathrm{ou}}$ inclosed some few lines $\mathrm{w}^{\mathrm{ch} .}$ I had $\mathrm{rec}^{\mathrm{c} .}$ from Bruges, where

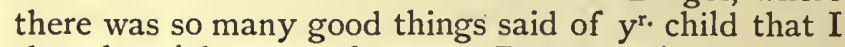
thought $\mathrm{w}^{\mathrm{d}}$. be a comfort to a Parent to hear. I am sorry it proved otherwise to you : but I find you are so unfair as to take notice of nothing therein but $y^{e}$ last words, viz.: that she is to make her first Communion at Easter, $w^{\text {ch. }}$ words doe so extreamely alarm you as to make you run into strange extravagant expressions of her being decoyed away in order to be perverted, \&c. You say, also, as you are a clergyman 
$y^{\text {ou }}$ ought to be supposed to know $y^{\mathrm{e}}$ foundations of $\mathrm{y}^{\mathrm{r}}$. Relligion, \&c.

"Now, Sir, you will think it hard to be told by one who is no clergyman $\mathrm{y}^{\mathrm{t}}$. if you realy think as you now write you do not know $y^{e}$ foundation of any Relligion, for I am sure that ever since I have heard of $y^{e}$ name of Catholick and Protestant, $y^{\mathrm{e}}$ later, especially $\mathrm{y}^{\mathrm{e}}$ Church of England, have always mightily boasted of their great and extensive Charity in allowing salvation to all Relligions as well as their own; when, at $\mathrm{y}^{\mathrm{e}}$ same time, the Roman Catholick is reproched for not having the same extensive charity, especially by those who cannot, or, at least, will not make distinction between material hereticks and formal hereticks, $\mathrm{y}^{\mathrm{e}}$ Later of $\mathrm{w}^{\mathrm{ch}}$ are such as do continue perversely and obstinately to live and die in an error, even contrary to $\mathrm{y}^{\mathrm{e}}$ conviction of their own consciences (and I fear $y^{\text {t. }}$ there are to many such in $y^{\mathrm{e}}$ world), those, indeed, $y^{e}$ Church does condemn. But of all the knowing, sincere, honest clergymen $y^{\text {t. }}$ I have heard talk on this subject ( $w^{\text {ch. }}$ are not a few), I never met with any that deny'd salvation to $\mathrm{y}^{\mathrm{e}} \mathrm{R}$. C. Church; therefore, $\mathrm{Sir}$, as this is $\mathrm{y}^{\mathrm{e}}$ case, give me leave to conclude, that if $\mathrm{y}^{\mathrm{r}}$. child or my child, or any one's child (who is not in very opulent circumstances) shd. meet $\mathrm{w}^{\text {th. }}$ a friend, so kind and good as to take 'em off our hands and breed 'em in such a way as they may save their souls and also be decently provided in this world, I think we have no reason to be uneasy and clamorous. Moreover, cou'd you be so weak as to imagine that when $y^{\text {ou }}$ sent $y^{\text {r. }}$ daughter to a monastery, that she was to be there taught $y^{e}$ Protestant Relligion? If so, I am very sorry for this, as well as all other infirmitys $\mathrm{w}^{\text {ch. }}$ you complain of in $\mathrm{y}^{\mathrm{r}}$. last, and wish $\mathrm{y}^{\text {ou }}$ well rid of 'em all.

"Who am, Sir, your well wisher, \&c., "P. CARYLl." 
John Newlin, Rector of Harting, to Phil: Caryll, Esq., of Dunkerque.

$$
\text { "9 May, I727, O.S. }
$$

"Honoured Sir,-I had the favour of yours last night at Lady Holt. As to $\mathrm{y}^{\mathrm{e}}$ charge of unfair dealing by $\mathrm{y}^{\mathrm{e}}$ paper you sent, I thank God, I always was and hope I always shall be a stranger to it. In the first place, I never mentioned or gave the least hint to any one breathing that I had from you any acc. at all, and, therefore, I hope, was not guilty of unfair dealing in betraying a friendly correspondence; and as to my omitting the foregoing part of the paper, I cannot yet see, upon the strictest review, the least shadow of unfairness, the foregoing neither weakening nor confirming the latter, but $y^{\mathrm{e}}$ latter, if anything, illustrating the former: However, the whole, and specially the words quoted out of it, were sufficient to convince or alarm me as you are pleased to speake, that my child was to be forc'd into the Comunion of a Church which, in some things, I cannot in conscience comply with, and that too before she was of competent age for soe solemn an undertaking, and before confirmation. I allways did and doe hope and believe that many, thousands and millions that live and dye in the Romish Com̃union will be saved, and God forbid that all of you shou'd be of the damming side, tho' you know noe argument has been more frequently made use of among silly people than this-

Protestants own Papists may be saved ;-But, Papists deny that Protestants can.

Ergo Papists are of the surest side.

How strong the consequence, or how great the charity that this argument carrys with it, I shall not observe to a man of Mr. Caryll's acute parts and excellent understanding.

"And now; since you are pleased to question whether I know the foundation of my Religion, I'll 
frankly tell you what it is ; and here, by way of preliminary, I shall beg leave to assert, that none but God himself cou'd shew man the way to heaven, for $\mathrm{He}$ only cou'd tell upon what conditions $\mathrm{He}$ wou'd be pleased to admit us into it, and, therefore, those conditions must be known by Revelation, which $\mathrm{He}$ has graciously don' in the Gospel of His Son, which Gospel the same blessed Son tells me is the Way, the Truth, and the Life, in $\mathrm{w}^{\mathrm{ch} .}$ Way of truth I beg the H. Spirit to direct you and me to walk that we may both meet in life eternal.

"And now, Dr. Sir, why all this stir to make a little child of eleven years old a Papist? I only askt the favor of a servant's place in her Ladyship's family, to wait on the young Ladys, or whatever her Ladyship thought fit; if it had been to clean their shoes I should not have thought much of it ; and this every girle that's kept by the parish has a right to petition for, and some have obtained. And why a Protestant girle might not make as good a servt. as a p: I cannot comprehend. You must know I ask'd the favor in the first place for my eldest, who was of age and capacity to earn her bread. But her Ladyship was pleas'd to make choise of this, and it was she that sent her to Bruges, and not I. And you yourself tolde me she was to be in the convict* (not in the nunnery), which I took by your discourse to be of the nature of a boarding school, where I presumed she was to learn such work as her Ladyship thought proper for her service. And I know that in those places of education there was the finest work in the world, wch. made me not only satisfied, but delighted that she was to spend some time in a place of soe much virtue and improvement; for you can't have a greater respect for their discipline and conduct than I have: but whilst I am perswaded in my conscience that I can not hold communion in some

- The Boarding house of a monastery was called "the Convict." 
things with the $\mathrm{Ch}$. of $\mathrm{R}$., it would be $\sin$ in me to let my child doe it. Because to act against conscience is a sin, even when 'tis an erroneous conscience. I grant $\mathrm{y}^{\mathrm{t}}$. whoso is led by an erroneous conscience ought to labour to get rid of his errour; as in great pity to my understanding you tell me you hope I will; and I assure you $S^{\text {ir }}$ it hath not been my fault hitherto, nor shall it be for the future. And whoe knows what $\mathrm{y}^{\mathrm{r} \cdot}$ skill in casuistry may doe for a weake Xtian? In the meane time, I am sorry to find $y^{r \cdot}$ stile (style) soe altered at top and bottom; but that as you please. However, I shall allways be as I allways was to my poor ability, Mr. Caryll's sincere ffriend and

\section{"Very humble servant,}

JOHN NEWLIN."

This letter is written beautifully in an upright hand, quite clean still, and without a fault.

It is interesting to note in this correspondence the humble position in a gentleman's family sought for by a clergyman of the eighteenth century, on behalf of his daughter. To be sure Parson Newlin numbered near a score of children, including his nine daughters, and $\mathrm{Ph}$. Caryll asks in another letter "what sort of figure he cuts with his numerous retinue?" But it is impossible not to admire the honest English sentences of the Parson, or to censure sufficiently the subterfuges of the cruel adversary who has no pity for the poor man's ewe lamb. We cannot believe that under any circumstances the gentle hearted old Squire would have written as his cousin Philip did. The correspondence seems to have been referred to him, but in all probability Mary Newlin never saw Harting Vicarage again, and lived and died in France a Papist.

A little before this the verses of the Vicar of Harting, Dr. James Bramston (instituted I725), a satirist, became famous. He wrote "The Art of Politics," and the "Man of Taste." A specimen of his verses is to 
be found in Campbell's British Poets. His best known couplet was in allusion to Charles I. at his trial :-

"So Britain's Monarch once uncovered sat,

While Bradshaw bullied in a broad-brimmed hat."

His satire on the Budgets of the Ministers of his day is amusing :-

"From folios of accounts they take their handles,

And the whole balance proves a pound of candles:

As if Paul's cupola were brought to bed

After hard labour of a small pin's head!"

The "Man of Taste" is a dandy like Lord Dundreary, but who sometimes hits hard :-

"I gaze with pleasure at a Lord Mayor's head, Cast with propriety in gilded lead."

As a parody on Phillip's "Splended Shilling," Bramston wrote the "Crooked Sixpence," or the sorrows of an old maid. Its motto is :-

"Sing maiden muse-

Sixpence, hoop-petticoat, and Church on Fire."

It was the fashion for lovers to divide a crooked sixpence, in token of betrothal; but for Bramston's heroine

"No Jolly Joe or Sober Sam

The matrimonial question ere proposed,

Or crooked sixpence offered to divide."

Dr. Bramston was of Christ Church, Oxford, and became Vicar of Chalton, Lurgashall and Harting; he was presented to Lurgashall by the University of Oxford, as the appointment had lapsed through the inability of the patron, Sir - Browne of Cowdray, who was a Roman Catholic. He gave the Communion plate to Lurgashall Church. Pope writes to Caryll, Feb. 6, I730. "The art of Politics is pretty: I saw it before it was printed." Elwin notes, that this was probably through Caryll's introduction.*

The Squire returned from France in 1722 , for in

* Elwin's Pope, Vol. VI., p. 326. 
the August of that year he together with Pope visited Bp. Atterbury, who was imprisoned in the Tower for conspiring to bring in the Pretender. The conspirators in Atterbury's Plot intended to bring the Foreign Legion to the shores of Sussex, King George being abroad. Caryll, as a Sussex Jacobite Squire, therefore, shewed some spirit in visiting Atterbury, when in disgrace. But Caryll knew well enough what it was to be in gaol.

In 1726 , after the death of Mr. Roper, Caryll is again at Lady Holt. "I really long," writes Pope, "to see a true patriarch, the lappet of whose shoes I am not worthy to unloose (alluding to the Squire's gout), and to observe once more before I die, the increase of all your herds, flocks, and plantations at Lady Holt." The Squire was now farming on a large scale for those times. He had planted his belts of trees from the house at Lady Holt, and avenues across West Harting Down and Foxcombe, reaching nearly to Harting Church itself. $\mathrm{He}$ had 300 red deer in his park, the produce of which, "Mrs. Patty," Duke of Richmond, and three succeeding orthodox Protestant Bishops of Chichester, the latter not seldom guests at Lady Holt, pronounced to be the best venison in the world. Nor were his two parks at Lady Holt and East Grinsted unremunerative. In one of his Account Books he has entered the following:

"Copy of the note I sent Mr. Bentley to sign.

“Ap., I730. I doe promise to take of Mr. Caryll twenty brace of fatt Bucks in this next ensuing season, viz., thirteen brace of Grinsted, and seven brace from Lady Holt, at the rate of five guineas (now about $f$ I 6 ) per Buck: and to stand to $\mathrm{y}^{\mathrm{e}}$ whole caredge (carriage) of those from Grinsted, wch. I am to take upp at the Lodge there, and to allow 5s. per Buck towards the caredge of those from Lady Holt.

"Witness my hand, 
Mr. Hipkin, deerkeeper, Up Park, has horns of Red Deer that undoubtedly come from Lady Holt, and are of extraordinary size :-Round burr, Io inches; Total length, 36 inches; Branch of antlers, 30 inches; six tynes on antlers.

Caryll's method of farming his lowlands was by irrigation; thus, under 24 July, I727, he enters "Paid $\mathrm{W}^{\mathrm{m}}$. Wooldridge for his half-year's watering the Downe Parke farm, due last May day, $1727, £ 6: 0$ : 0."

Out of the present miry wastes of West Harting Pond he made a good speculation. In the days of our forefathers, when little beside salt fish could be had, Sussex carp were thought the finest in England.

$$
\text { "Mē̄̄um, May, i720. } € \text { s. d. }
$$

Jones paid to Mr. Cole for 2,100 store carp

for Harting Pond at 8s. p. cent. . . . . . $8 \begin{array}{lll}8 & 8 & 0\end{array}$ Item to Mr. Yalden (Blackdown) for 800 at

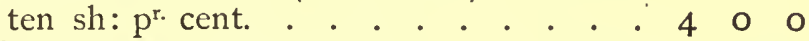
Given to $\mathrm{y}^{\mathrm{e}}$ two servants . . . . . . . . . o 46 Jones' expence being twice to both places $\begin{array}{lll}0 & 5\end{array}$

$$
£ \longdiv { £ 2 1 7 \quad 6 }
$$

Putt in by Jones (as appears above) 2,900 carps."

" 20 April, I724. The said Pond was fished and about 2,400 carp taken out, of which. Southwell bought 2000 at $£ 5: 5$ : o per hundred. 220 odd Pack* putt into $y^{\mathrm{e}}$ little Pond at West Harting- 100 large ones were reserved (as usuall) for my own eating and the rest given away.

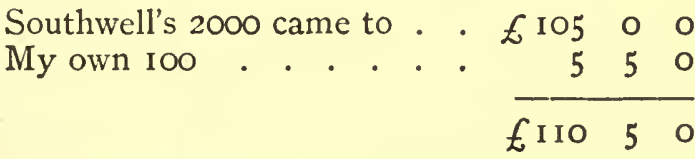

- John Pack is still one of the West Harting names. 
Stock cost . . . $\underset{12}{E}$ s. d.

Caridge of stock

4 years' Rent had $y^{e}$

Pond been lett $w^{\mathrm{d}}$.

have been

Charge of Fishing .

By all which allowances it appears that I gained above fifty pounds by keeping the Pond in my hands.

Sometimes he paid a prodigious price for stock carp thus :

"March I, I730. I bought 50 carps of 20 inches and upward for six pounds of Mr. Biddulph of Burton, and putt 'em into the stews at Harting." Each carp, therefore, before it reached the Harting waters cost 2s. 4d., or about seven shillings in our money; but they were very big fish. The running streams were stocked with trout.

The Squire had in Harting and Rogate thirty-six tenants. Two of them were of the family of Collins, and, as Mr. Moy Thomas says, were probably related to William Collins the poet. Their name still survives at West Harting in "Collins' Lane." + One of the West Harting tenants supplies the Squire with wool, and an anker of wine at $£^{2}: 15: 0-$ suspicious items, as wool was smuggled out of England, and wine in return into it: and hence the farmers as well as the squires were much compromised with the smugglers. One Widow Gaile pays her rent in part by a hogshead of beer at $£ 4: 0: 0$ in 1733 , for which in 16 Io nine shillings only would have been charged-so much had the price risen. In 1733 hay is a guinea a ton; wether

* Account Book of Jo: Caryll, Esq., of Lady Holt, Addl, 28,245 Flyleaf. 
sheep 9s. to Ios. a-piece; a coach horse $£ 20$; wool I7s. per todd; wood I4s. a cord; and fagotts $7 \mathrm{~s}$. Oak timber in the Harehurst, Is. per foot; ash, 8d.; other wood, 6d.; a labourer's pay per day, Is.; a woman's, 6d. Thus, "Goody Whitington and her gang, for haying in the Canonlands for 3 I days," are paid by the Squire the modest sum of I5s. 6d. Salt at its cheapest was $5 \mathrm{~s}$. the bushell ; within the memory of man $£ \mathrm{I}$ : O : o per bushell has been paid for it in Harting: "To be worth your salt" was in these days to be of no trifling value. Tea an almost unknown luxury at $£^{2: 2: 0}$ a pound. In September cheese was bought wholesale at St. Giles's fair, Winchester. At Christmas the "moresque dancers" are not forgotten; and " 4 parcel of Wasling boys" (still called "Wassailers," or carol singers) are entered in the account book as receiving 8s. For corn he dealt with "my Cobden"* of Midhurst.

The Squire seems to have been a visitor at every house of note in this part of England; and doubtless so susceptible a man was glad to have some change as a relief from sorrows at home and trials in his family.

In I 725-6, Feb. 3, he buried another son, Richardnot Henry, as Mr. Elwin notes on Pope's letter No. 91,where Pope says, "Upon the most violent strokes one rather faints than groans." In the March following young Bluett was just saved from transportation, and two guineas were paid by the Squire to save him a public whipping. The scapegrace was finally settled at St. Omer under one Captain Dunn. Poor Mrs. Cope had a terrible operation for cancer at Paris in I 728, towards the cost of which the Squire sent her $£ 25$. She died shortly afterwards. Sometimes John Caryll would receive begging letters from some worthless kinsfolk or namesakes: as when Mrs. Elizabeth

- This Richard Cobden, malster, was Churchwarden of Midhurst as early as 1709. Another of the same name in 174I. I am indebted for this information to Rev. W. Haydon, Vicar of Midhurst, Rural Dean. 
Carroll, evidently an Irishwoman, wrote from the Marshalsea Debtors' Prison that "she was a gentelwoman and well born, lying upon the Cold Boards." "Great and all knowing God, that knows the secrets of all hearts, knows that I am a gentelwoman and worthy of your Lordship's favours," \&c.

The Squire never seems to have saved money, or perhaps to have been able to do so. It is certainly suspicious that though he kept a careful register of his accounts, he never added up a page; and such entries as $£ 50$ for a raffle are not to be defended. But these ventures were the fashion of his day. There are some touching lines of his, written on the back of a page of one of his account books, in which two voices are heard, and of which the conclusion is characteristic.

"1724. A serious Thought of my own Concern in Rhyme:-

"Born in an Isle (so hard has been my fate !)

Where rich I never dar'd to be, nor great;

Yet sixty years of life I've nearly run,

Submitting still to see myself undon!

But my good God unto my lott has cast

Joys more refin'd and of sublimer taste.

He blest me first in those that gave me birth,-

A pair more worthy never breath'd on earth.

Next in a wife (the pattern of her state)

That well deserves a more deserving mate :

Then with such children from her vertuous womb

As ne're cause grief, but when layd in their tomb.

Next farther yett, by an united stock

The fairest yeild of great Mackenzy's flock :

And hence an offspring that such charms display

As speak the glorys of a future day.

Whilst grandsire pleas'd, exults with joy to see

His youth renew'd in a third progeny.

Then, gracious God, let me still grateful prove For all these tokens of Thy wondrous love : And Thy great mercyes lett me still adore, Since heaven is all that I can wish for more." *

The last thought is in the vein of Addison.

* Caryll's Account Book, I724, p. 218. 
With these lines we may couple one extract from the Squire's religious treatises, written towards the close of his life, where dealing with the end of man he puts forward "this great and undoubted truth, that I was borne butt to be saved."

To the end of his life Pope was on the closest terms of intimacy with him. Lord Petre, Pope's hero in the Rape of the Lock, shewed such confidence in him that he made him Trustee of his will. He was godfather to half the county-the Tichbornes of Tichborne, the Lacys, the Blounts of Mapeldurham, the Bluctts, the WVells', the Dormers, as also to the Hattons, and to humble "Nan Hutching's child," to whom he stood in Harting Church. I'ope had two afflictions, in 1732 , when he wrote to Caryll, "Poor Gay has gone before, and has not left an honester man behind him"; and in 1733 (June 25), when his mother Editha Pope died, aged 93, he wrote again to his oldest friend-" my attendance upon her living was not virtue, but only duty, and my melancholy for her dead is not virtue, but weakness. I thank God her life was innocent, her death easy, and her state I doubt not happy. May yours and nine be just the same. To see you at Lady Holt was the first thought I had upon this coent: but as it is a great and new era of my life, and upon which the whole course of it will in a manner change, I must pause awhile and look about me. In the first place $\mathrm{I}$ am acting like one that may die myself and settling all that belongs to me, or that thro' me may affect any others. I am paying all I owe, and disposing all my papers, \&c., before I leave this place (Twickenham), to which I have no intention to return for a good while, it has become so melancholy to me. . . I rather think to come to you from Southampton (Lord Peterboro's) in a month or less." In the same year, Sep. 4, I733, he wrote-" God willing, I will be at Guildford on Sunday night or Monday morning the $9^{\text {th }}$ inst., at 
the Three Tuns (whither Caryll's chariot was to be sent). I cannot pretend to express how pleased I shall be to be at Lady Holt." Pope speaks of the hearty and friendly reception that he met with in this visit, which showed that he looked upon Lady Holt as a sheltering home, sacred to the most holy sorrow that he experienced in his life.

This, however, was probably not the last visit that Pope paid to a place

("Some safer world in depth of woods embraced")

whose surroundings doubtless inspired many of his poems; for in Ap., 1734, just two years before the good old Squire's death, he writes to him about the house which he almost counted as his own"Please to send me the draught of your staircase whenever it is convenient to you. It would be a great pleasure to me to contribute to the ornament of Lady Holt;" and again in July 7, 1734, writing from Cirencester, he says to his friend-" I have a great desire once more to pass some days at Lady Holt, and settle your staircase plan." "In this world," he adds, about this date, alluding to their mutual afflictions-" we live only upon the terms of compassionating and lamenting one another by turns. It must be a better place where all tears are wiped away." Pope's last letter to his friend the Squire is dated July 17,1735 . So far as this can we trace the friendship of the two, as unbroken and close, as that of Jonathan for David.

In Feb. I7, I735, the Squire and his wife Elizabeth hảd been married fifty years, and a friend from Racton writes- "I give yourself and lady joy of your Jubilee. I heartily wish the happy pair many more pleasant years." *

That eventful half century represented a happy married life, full of useful and genial influences among

- Caryll Correspondence, Vol. III., p. 75. Add1. 28,229. 
the simple folk of Harting, few of whom could have been living to remember how the old man of seventy had once brought his bride to Lady Holt in the year of the Great Fire. He had built and fortified with every rustic improvement the mansion of which he had laid the first stone; and now his life's work was done. The date of the Squire's death is 1736, and he was buried in the Mortuary chapel at Harting, by Parson Newlin, on Ap. I 7th. Mr. Carruther justly characterizes him as "liberal, tolerant and accomplished:" we may add that his life was unblemished in a corrupt age, and that his worth is remembered to the present time in that unwritten but most faithful history, the tradition of some five generations of village folk. To this day the Harting peasant remembers that the Caryll was good, and therefore "we always looked," he says, "that he would come back again." This is the village hind's version of the celebrated couplet:-

"A wit's a feather, and a chief's a rod :

An honest man's the noblest work of God."

Had Pope been asked when he wrote those words to point out an honest man in the flesh, he would have sent his inquirers to Lady Holt, to make the acquaintance of John Caryll, fifty years Squire of West Harting. 


\section{CHAPTER VII.}

END OF THE Fords AND CARylls of HaRTing.

When Ford, Lord Grey, Earl of Tankerville, died at the summit of his fame and magnificence at $U_{p}$ Park in I 7OI, he left one only child, the Lady Mary Grey, as his heiress. She had been married in I695 (July 3) to Charles Bennet, and Lord Ossulston, whose seat was at Ossulstone in Middlesex, and never did Mr. Tench see so grand a wedding at Harting Church. "At the time of the marriage a guinea went for 30 s. : and there being but four bells at Harting, the bridegroom first gave the ringers four guineas, and then, dipping his hand into his pocket, brought up thirty-six more and gave to the Rector (Mr. Tench), who, as soon as the new married couple were gone, said'Plague upon his little hand! if it were as big as, some folk's hands, it might have brought up as many again!'"* The bells at Harting are now six in number, having been recast in 1785 by Mears, a duplicate, it is said, of the Westbourne peal. This wedding at the new mansion of Uppark must have been a considerable event for this part of the county. We can think, too, that the goodnatured Fords would consider the news just received, that their neighbours the Carylls would not lose West Harting, as heightening the auspices of the occasion.

In I702, Oliver Whitby, whose mother was a Ford, died. His father was the Archdeacon of Chichester who, as we have seen, befriended Mr. Tench. As to the Carylls Harting is indebted for the widows' charity founded by Lady Puckering, so to the Fords is owing the interest which Oliver Whitby took in our village. $\mathrm{He}$ died at the age of forty-two, and left the lease of the tithes of Wittering, which he held, for the foundation of a Bluecoat School at Chichester for the instruction - Burrell MSS. 
of sons of poor parents in Harting, Wittering and Chichester in the principles of the Established Church, and further directed that they should be taught Navigation. The original foundation was for 12 boys, but now Harting alone sends 9 out of a total of 45. "No Parliament man or Dissenter" is to have the privilege of sending his son to this Bluecoat School: and Mr. Lower has a story to the effect that when Oliver's father, the Archdeacon, was preaching in Petworth Church he was shot at by a Puritan, who fired a pistol at him ; and hence, out of filial piety, the son Oliver (forgetful of his namesake Oliver Cromwell) excluded the children of Covenanters, "Parliament Men," or Dissenters from his school. This school has been of the greatest advantage to the good folk of Harting for near two centuries, and its wise management in the present day, secures to many a poor home, in the midst of all the quickening influences of a town, a good training for its eldest sons in religion, manliness of character, industry and thrift.

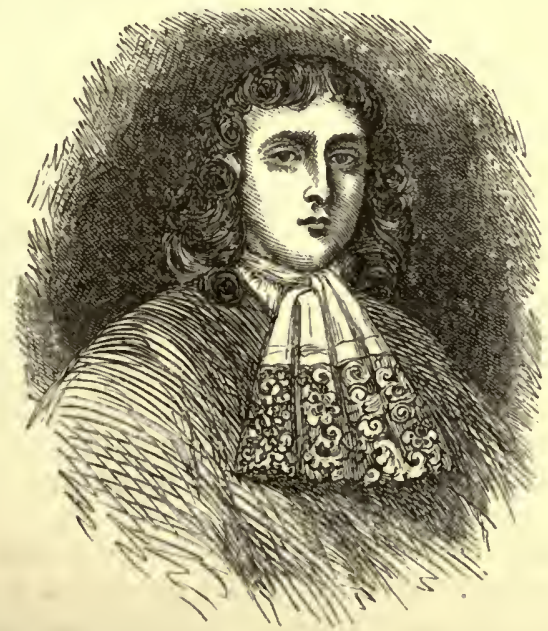

Oliver Whitby, jun., Founder of Blue Coat School, Chichester, Aged 18, 1678. 
I have been fortunate enough, through the kindness of Professor Bell, of Selborne, to obtain an engraving of his noble picture of Oliver Whitby, as he was approaching his manhood. The picture itself, a model of grace, is, with the other heirlooms, in the house of Gilbert White, and is much in the style of Sir Peter Lely. Oliver Whitby, through Ann Holt his niece, was a great uncle of Gilbert White, and like that illustrious naturalist, had possession of land in Harting, at Nyewood, and kinship with the East Harting Squires. Mr. Weaver remarks- "Oliver Whitby was at one time possessed of certain lands at Nyewoods, these he willed to his sister, Ann Holt (wife of Rev. - Holt, of Streatham), she left them to her daughter, Anne White, of Selborne, who was the mother of Gilbert White." The derivation of "Nyewoods" is uncertain. Along it passes the present road to Rogate, maintained by the Longstock charity. It is said that a poor traveller once found hospitable shelter here at. the Parish Receiving House, at Champs, and in his will remembered the place, and out of some 500 bequests, appropriated $£ 20$ a year for ever to the maintenance of the hospitable road. (Smith's charity.) To us residents in Harting, Oliver Whitby is best known as the donor of the handsome and capacious silver chalice used to this day in Harting Church.*

Lord Ossulston, in right of his wife Mary, succeeded to Uppark and the East Harting Manor in I702. In I706, just when John Caryll, "the Squire," was negotiating for the purchase of the East Harting Tithes, Lord Ossultone, so far as can be decyphered from a slovenly and ill-spelt note, full of broad provincialisms, in the Caryll Correspondence, was in some trouble about his estate, and on the point of going to law. He writes to Caryll :-

"London, Nov. $y^{\mathrm{e}} 6^{\text {th }}$, I708. $S^{\mathrm{r}}$. I am pleaged (plagued) again $w^{\text {th. }}$ Ford, and I am to ha' a tryall att

" The inscription is "Harting. Donum Oliver Whitby." 
$y^{\mathrm{e}}$ Queen's Bench barr. on Munday, $\mathrm{y}^{\mathrm{e}}$ sis $^{\text {th }}$ inst., and if it suited $w^{\text {th. }} y^{\text {r. }}$ conveniency, I should be very glad to speak $w^{\text {th. }}$ you before. $\mathrm{Y}^{\mathrm{e}}$ matter upon $\mathrm{w}^{\text {h. I }}$ would be glad to discourse you about, is concerning $y^{\mathbf{e}}$ manner of East Harting, wh. was bought by $\mathrm{y}^{\mathrm{r} .}$ ancesters.

$$
\begin{aligned}
& \text { "I am, Sr., } \\
& \text { "Yr. most Humble. Servant, } \\
& \text { "C. OssulstoNe." * }
\end{aligned}
$$

In I7I4 Lord Tankerville's title was revived, and given to his son-in-law at Up Park. The latter died 2Ist May, I722, and was succeeded by his only surviving son, Charles, who afterwards married Camilla, Lady of the Bed Chamber to Queen Caroline. The 3 rd Lord Tankerville was known at Winchester College (with which the Fords were probably long connected, as a branch of the family lived at Winchester, and one of the Fords was master at Winchester College) as Charles Ossulstone, Viscount (1730), and was a favorite commoner pupil of Dr. John Burton, the head master. Lord Ossulstone, on quitting the school, left his portrait to the head master, and it is to this day among the pictures at the second Master's house. Dr. Burton was much loved by his pupils, who, when he died, attached Latin verses to his bier. $\dagger$ Lord Tankerville, when he was Viscount Ossulstone, must have been at school with the Chichester lad William Collins, and as Collins was at the head of the school when he left, the young heir of Uppark would be sure to know him, and appreciate the rising fame of his county neighbour.

At that time the boy-commonwealth of Winchester was divided into two factions, the Jacobites and Hanoverians, who fought in earnest for George or Prince Charlie. Lord Ossulstone would be, according to his family traditions, Hanoverian. Lord Elcho, another

$$
\text { * Addl. 28,227, p. } 63 .
$$

† Mackenzie Walcott's "Memorial." It is curious that Caryll, too, educated his sons at Winchester, but being a strict Papist, he sent them to the private care of Father Dicanson. 
of his contemporaries, was a staunch Jacobite. Collins, the quiet-loving, indolent, irresolute boy, in appearance almost an Albino, and delicate, at the head of the roll in I740, would choose neither side. At this time, according to Lord Elcho's diary, there was little discipline at Winchester. The boys played cards, haunted taverns, and their morals were entirely neglected. "We did not learn Latin and Greek," writes Lord Elcho, "as well as we should have done had we been placed with a private tutor, but we were taught how to live as men of the world, and made acquaintances which, if cultivated, could be very useful to us in after life." Among these contemporaries of Lord Ossulstone at Winchester College were the sons of the Dukes of Hamilton, Devonshire, and Queensborough, and the Earls of Exeter and Coventry.*

Collins must have known Harting well, as it lay almost half-way from Chichester to Winchester, and subsequently, when he was scholar of Magdalen, Oxford, where he took his degree in I743, it must have been a first stage on the coaches. And though the old road would take him from Chilgrove across the outskirts of Uppark, and along Hemnor to St. Richard's Hill, where it left the downs for Petersfield, yet from first to last of his life he had many calls to visit our land-locked lowlands at South and West Harting. Mr. Moy Thomas, in his excellent Life of Collins, $\uparrow$ has noted that "several Collinses, who," he believes, were connections of the poet, "lived at Harting." The name of Collins is as old at Harting as the time of Henry VIII. In I724 James Collins was clerk of the parish Church. Henry and Richard Collins were tenants of the Carylls, and their possession is recorded, as has been said, by the still current name of "Collin's Lane" for 240 years in West Harting. $\ddagger$ In

- Ewald's "Life of Prince Charles Stewart," i., 76.

$\dagger$ Life of Collins, Aldine Edition.

$\ddagger$ “Colline's land and Buckland's Hill," W. Harting Leager, 1635. "Collins' Six Acres." No. 509, Tithe Map, 1841. 
1739 Lord Brudenell recommends to the last Caryll "Mr. Collings as tailor, Mr. Fairhills as grocer, Mr. Galtgate, jun., as a hatter, my firm friends at Chichester." * This "Mr. Collings" the tailor is the father of William Collins the poet, and Caryll's grandfather, the old Squire, usually bought hats of him. In the last line of the ode by Collins to a lady whose husband was killed before Tournay (Fontenoy), I 745-6, Collins mentions our village :-

"Even humbled Harting's cottaged vale Shall learn the sad repeated tale, And bid her shepherds weep."

Collins' college friend was Tom Warton, and the ode in which these lines occur was first published together with some of the poems of Warton. In a letter of Warton's, May, I746, he says that he has met Collins at Guildford Races, and that they have determined jointly to publish odes. "You will see," he adds, " a very pretty one of Collins's on the death of Col. Ross before Tournay. It is addressed to a lady who was Ross's intimate acquaintance, and who, by the way, is Miss Bett Goddard." Warton further states that she resided at or near Harting in Sussex. The name of Goddard is native at Harting: for example, the last entry of our first Register Book runs thus: "Ruth, the Daughter of Joseph Goddeard, was baptized I 3 th Nov.," I653. Now, Collins might have met his young lady at several houses in Harting, but notably at two: at Uppark, where his Wykehamist schoolfellow, Lord Tankerville, lived, who did not sell the estate to Sir Matt. Fetherstonhaugh till two years after, $\mathrm{I} 745$; or at the Vicarage, where lived Dr. Durnford (Thomas Durnford, jun., successor to his father as Vicar of Harting), who married Collins's sister Ann for his second wife. Dr. Durnford's exquisite penmanship, which commences in April, 1745, in our Registers, shows that he was the resident parson of

* Caryll Correspondence, III., 347. 
Harting under the Tankervilles for thirty years.* The true reading of the line "Humbled (not 'humble') Harting's cottaged vale" would show that the lady was resident here, and well known to all our village folk; and the mention of the shepherds of Harting probably refers to the Vicar, and would point to the Vicarage as the place in which the lines were written. It is said that Miss Elizabeth Goddard had rejected Collins; and that, as her birthday was a day before his, he used to say that he was born "a day after the fair." "If Warton's recollection were right," adds Mr. Thomas, "the poem originally contained the line "If drawn by all the lover's art;" but if Collins had really been in love with this lady, Mr. Thomas thinks it is difficult to believe that he would have addressed to her a poem of condolence on the death of his rival. But, on the contrary, surely we may think that sympathy with the fair on such an occasion was a very clever piece of wooing, and that he who wished to be "next best" could not do better than praise in a feeling poem the best now that he was removed from the arena, and the prize not yet awarded. Shakespeare makes Richard the Third, the murderer of Henry VI. and of his son Edward, the successful suitor to the Princess Anne, young Edward's widow, as she is following her father, Henry VI., to the grave at Chertsey, and cursing his murderer. Richard mingles with praises of the lady his best words for his dead victims. Edward was fitter, he says, for heaven than earth, and Henry is the "noble king whose grave he will wet with his repentant tears." And the Lady Anne gradually yields to him whom she has cursed and scorned throughout a long scene, and whom she has offered to stab with his own sword.

"Was ever woman in this humour woo'd? Was ever woman in this humour won?" $\dagger$

- Dr. Durnford was afterwards tutor to Sir Harry Fetherstonhaugh.

† "Richard III.," Act I., Scene 2. 
Shakespeare at least thought that the praise of a dead rival, combined with flattery without stint, could transform a "hated wretch" and "diffused infection of a man" into a second husband of his victim's widow. And if Shakespeare be in this famous scene, as usual, true to nature, is there anything wonderful in Collins's politic condolence with his Harting lassie for the man to whom she had preferred him?

Another indication of Collins's associations with this neighbourhood is his poem on the death of Otway, who also was educated at Winchester, and who was born at Trotton. Among the few lines of Collins that remain, there are several that doubtless describe his memories of Harting; and one may think that somewhere near the site of the present tower at Uppark, commanding one of the most beautiful landscape views in England, he must have caught sight of the evening which he has made immortal in a lay that, like every, syllable that this poet left, "wins the harmonious ear."

\footnotetext{
"Or if chill blustering winds or driving rain

Prevent my willing feet, be mine the hut

That from the mountain's side

Views wilds and swelling floods

And hamlets brown, and dim-discovered spires ;

And hears their simple bell, and marks o'er all

Thy dewy fingers draw

The gradual dusky veil." 。
}

The allusions to Uppark under the Tankervilles to be found in the Caryll Correspondence are few and unhappy. In 1737, Lady Mary Caryll, writing from Lady Holt to her son, describes in her prattling gossip an impromptu wedding at Uppark, which might rival the memories of Gretna Green. The bridegroom is a Mr. Pierssen or Pearson, a connection of Lady Tankerville's, who seems to have had some management in the Uppark estate, and the lady, a Miss Jedes,

* Collins' Ode to Evening. 
a niece of a rich neighbour. "Yesterday, Lady Tankervill sent two livery men to Mr. Bruerton's (who it seems was gone to Chichester), and took up behind them his niece (Miss Jedes) and her maid, and brought them to Uppark; when my lady made all the servents in the house assemble in the great hall, and be witness to Miss Jedes saying she wou'd marrie Mr. Pierssen, which accordingly was done in their presence (by a parson Lord Osleton (Ossulstone) brought down from London the night before in a coach and six, and gave the coachman eighteen shillings more than his fare to make hast);

they had a very great supper, and to-morrow they say are to have a ball, and so the farce is to end, which it is thought will be a tragidie to the young woman. It seems Bruerton is her uncle and guardian, she it is said has about seven hundred a year. Pirsson's father (tho' my lady's brother-in-law) has $£$ I 50 a year, and is my Lord Tankervill's steward. in the north (Chillingham Castle, Northumberland). Bruerton intended the girle for his son, and wou'd never trust her out of his sight till fatal yesterday. I think it so base a thing in my lady, that I have no patience with it, and I believe she wont find it add to her credit. Our Keiper (keeper-gamekeeper) was att it."

In consequence of this, "Lord Ossulstone, with three servants and Mr. Piersen, were put into the King's bench" on a charge of abduction.* This disgraceful frolic, for the purpose of enriching a poor kinsman at the expense of some Sussex neighbours, was but a sorry jest, and gives no pleasant impression of the second Lord Tankerville. The report of his death, 2 Sep., I 738, gives no brighter prospect. "There is just now an account of Lord Tankerville's death : his madame that is with him sent over a courier,

* Caryll Corresp., Vol. III., p. 169. Addl. 28, 229. 
to desire that my Lady and Lord Osleton shou'd go over immediatly, for my Lord had a violent fever and convultions, and they believ'd him dying, others say he is dead. I sent to Uppark, and they are all in tears believing him so. A melancholy thing to reflect in whose company he is taken off. I wish his son may lead a better life." This son, the contemporary of Collins at Winchester College as we have seen, sold the Uppark estate to Sir Matthew Fetherstonhaugh, in 1747, and thereupon closed the connection of the Fords with Harting. The name survived in our village till the end of the eighteenth century, and the last Harting person of the name of Ford is buried with the pauper cross affixed in the register.

The price paid by Sir Matthew Fetherstonhaugh for Lord Tankerville's estate in the parish of Harting, was $£ 19,000$; and it is usually added by the chroniclers that the wood in the park in which there was then much oak, was computed to be worth the whole purchase money. But Mr. Weaver has ascertained that the whole of the property then sold did not exceed a thousand acres, viz. :-

The Park and Paddock

A. R. P.

Hodston Farm and Copse

Nyewood Meads

\begin{tabular}{cccc} 
& A. & R. & P. \\
$\ldots$ & 680 & 2 & 2 I \\
$\ldots$ & II9 & 3 & I 3 \\
$\ldots$ & II6 & 2 & 23 \\
\hline & 917 & O & I7
\end{tabular}

At the same time it must be remembered that in 1747 , the burdens upon land in the shape of taxes for constant wars were very great; and in the latter part of the eighteenth century, Sussex land paid even $5 \mathrm{~s}$. in the pound for poor rate alone in the year. Thus Sir Matthew Fetherstonhaugh, in a letter to the last

- Caryll Corresp., Vol. IV., 95. 
John Caryll, after the purchase of Lady Holt, dated 8 April, I768, states that the parish had charged him for the poor rate that half year to Lady Day, I768, at $2 \mathrm{~s} .6 \mathrm{~d}$. in the pound.* When all these burdens are considered, the price of $£ 19,000$ for Uppark and I,O0O acres of land, does not appear insignificant or disproportionate; for it must be remembered that it would be equivalent to at least $£ 40,000$ at present.

Having now completed the records of the Fords of East Harting, I have only to describe the few remaining years of the Carylls. From the death of the old Squire, in I735, the voluminous correspondence religiously preserved in the British Museum is little else than a mass of dunning letters; and each year up to the finale of the MSS. in I768, marks the steady advance of the tide of debt, misery, and ruin. It would seem far more respectful, not to say humane, towards an ancient and honourable house to have destroyed, or at all events suppressed from public gaze, the monotonous records of its degradation; and if a Caryll were to re-appear now-a-days, he might justly complain that many have brought the rake and few the broom. No doubt much is nationally interesting, as relating to a family connected with James II. and with Pope, and other great men : still at least the story of the end of the Carylls might have been told far more shortly, and those who believe it to be a duty to destroy letters, may be fortified in their opinion by a perusal of the last six volumes of the Caryll correspondence. How such a collection of trash, as much of it is, could have been admitted to the shelves of the British Museum, is passing strange.

In April, 1736, Lady Mary heard from her brother that John Caryll, the Squire, was dead, and had left no will, but that a letter was found in his pocket which was intended to be sent for one to make it. "Master

- Caryll Corresp., Vol. IX. Add'l. 28,235, p. 398. 
Caryll" (for our modern style in designation of one still a minor is used) was the heir of the intestate, in the place of his father. The young man came of age and married two years afterwards.

With his mother, he came over to England, and received an enthusiastic welcome in this neighbourhood. His first friends are Mr. H. Legge, a young barrister of the Temple, and Mr. Bonham, of Petersfield, who join him in a yachting expedition at Portmouth, the latter "bringing a cold pigeon pie in token of his wife's housewifery." * His French education serves the young Squire ill enough in his first essays at the old English game of cricket in May, I737. He has received a kind of horse kiss from a cricket ball, and Mr. Legge writes- “I congratulate you. Bruises and strains, and cuts, and thumps and knocks were the acts by which Pollux and Hercules immortalized themselves, and no man has ever arrived at any superior degree of heroism whose features have all dyed in their beds." About this time he seems to have offered his hand to Lady Arundel (daughter of the Duke of Norfolk), and, to the indignation of his grandmother, to have been rejected, the young lady preferring some one of larger estate. Soon after, he was more successful. The London "Daily Post" of May 15, 1738, trumpets the announcement of the marriage of the last John Caryll of Harting, in the most fulsome terms :-

"We now hear for certain that the Hon. Mr. Caryll, of Lady Holt, in Sussex, a Gentleman of a most antient Family and fine Fortune in that county (commonly called Lord Caryll), is married to Miss Molyneux, second daughter to the Right Hon : the Lord Viscount Molyneux, of Lancashire, a Lady of real Merit, Beauty and Fortune : and no less admired for her Humility, Generosity, and affable good Nature,

- Addl. 28,229, p. 77. 
than her present agreeable Consort, whose most engaging Behaviour to People of all Ranks, renders him the Darling of his County; so that it may be truly said this happy Couple, so exactly united, are real Stocks of their noble ancestors, whose Extraction and Characters are already too universally well known to need any additional Account of them."*

Lady Dolly Molyneux brought eventually a dower of $£ 6,000$, but does not seem to have possessed the strength of soul that the last of the Carylls needed to sustain his own inherent weakness. The first letters of the bride, in March and April, 1738, are full of headaches hysteria and cockfighting, an ominous combination. Thus, she writes to her husband :"Little Owlton (near Preston, Lancashire, Lord Molyneux' seat), April 7. I shall only tell you that you are a little out of pockett ; wors cocks never was than those his Honour fought: tho' you had ye good luck to win by them, but $y^{\mathrm{e}}$ feeder's bill was large." The burthened acres of West Harting and West Grinstead were not likely to be eased by such a lady as this. At first the marriage was kept secret : Lady Molyneux owned it to Lady Westmoreland and her brother, Lord Brudenell, under a pledge that they would not divulge it.

Meanwhile, Lady Mary is at Lady Holt, preparing it for the reception of her son and his bride. She is at this time a curious mixture of gaiety and embarrassment. "It is unaccountable that there is no money to be had in this country ... If there be not some better method taken we must be starved." Nevertheless, though constantly suffering from a kind of nervous fever, or ague, the widow gaily cheers up on her son's account, and through all her gossiping prattle about this neighbourhood, shows a brave and affectionate mother's-heart. Dec. 21, I737, Lady Holt is smarten- 
ing up for the wedding; furniture is ordered from Hazard's in town, and from Chichester; and the oldfashioned arrangements of the grandfather are set aside for a newer style. There is to be a cavalcade to meet the bride and bridegroom from town "in great forme"; and all the country expects to be invited. We may quote Lady Mary's letters at this time somewhat fully, as they have considerable local interest.

She has no doubt consulted a fortune teller for the following directions which she gives to her son about his wedding ring :- " I hope you won't forget a gold ring, the measure is not to be broken, but you must finde out the size by some stratigam; there must be a purse of gold and a little silver in it, I have a very fine one for the purpose, if I cou'd tell how to convey it. Major Battin (of East Marden) has got the fine Cistern yesterday in Jernager's Lottery, two people came down from London to acquaint him of it, and the bells at Compton have rung all day on that account. Your health and the young lady's is drunk every day, and your sisters sing 'Roger come to Polly's window.'" Meanwhile, I90 trees on the Lady Holt property are marked in one day for their fall.

Parson Newlin, forgetting old scores, is friends with Lady Mary again, and writes his respectful congratulations in a last letter within two years of his death.

“Jan. I6, I 737.--Honoured Madam, I heartily wish you joy, tho' I was not able to wait on you at Lady Holt. I am sensibly affected with the pleasure it must, of course, raise in your Ladyship's breast to have so fine a gentleman for your son, and to see him one-and-twenty. Long may he live to add new honours to a brave ancient family, of which the approaching marriage gives the most promising hopes, and opens a new scene of joy and pleasure to your Ladyship. That it may long continue and encrease. 
to him and to you, is the sincere wish and earnest prayer of, Madam, your Ladyship's most dutiful and faithful servant,

\section{"JohN NEWLIN."}

The happy day on which the young Squire came of age was January 12, 1737-8. And here is the proud mother's account of the festivities at Lady Holt. "I may say I believe you are the best belov'd by all sorts of people, from the highest to the lowest of any man in the county. Farmers and wives dined 3 and 20 yesterday, and danced and drunk till two in the morning. . . . To-morrow I have the workmen of all sorts and my brother's servants with ours, who are to have a ball alsoe; they dine in their hall, and afterwards are to dance and play in the drying-room and new infirmiry (a sick ward, needed in case of smallpox). On Monday I am to have the tradespeople, with their wives, and all the secondrate gentry in the neighbour-* hood, which is to be turner (?) ball : and then, I think, we may rest till you come home; for I'me sure ther never was such true merryment in this country before, the people are all charm'd with it, and I am as tyred (tired) as a dog, but I don't repine at that." Then follows a suggestion that the Dukes of Norfolk, Richmond, or Lord Petre, should be asked to be trustees of the settlement. But, as a set off for this general good will, there is one person that poor Lady Mary cannot abide at Lady Holt. This is a Mrs. Jones, wife of Caryll's agent, who gave herself airs. "Mr. Joans and his fine Madame came down two days before your birthday and expected to lye in the house, but as I apprehended the consequence of letting them begin so, I made an excuse for want of roome by expecting company, and sent them to Guold's (Arthur Gould married Kate Caryll, and lived at Harting Place), where they stayed two nights. I invited them the next day to dinner and they came, but the day 
following Madam huff'd (I believe), for she went away to Barnard's and wou'd not so much as see the desert (dessert) ; however I don't repent it, he has been here at all the merryment, and I believe you'll find it better to keep them at a civill distance than other ways, for she seems a high dame and not very good humoured, for she has been sick ever since of the Mulygrubes, and I hear, by-the-bye, she depended upon being my companion. . . . T Tarquin, your good gun-dog, went melancholy mad last week, and was obliged to be killed yesterday. I sent all the rest to sea, for fear they should have been bitt."

It is plain that Lady Mary was a formidable character, and would share her throne with no daughterin-law. Therefore, no doubt at his bride Dolly's request, Caryll had the old house at Harting Place surveyed in May 1738 , as a second residence, by "Mr. Minchin, of Petersfield." The roof had given away, but if it were restored at a cost of $£ \mathrm{I}, 200$, and some useless parts pulled down, the surveyor reported that there would be a fine uniform shell of ninety-six feet in length, two fine fronts, and fifty feet broad, giving much more room than at Lady Holt, and a house as good as one that might cost $£ 6,000$, while sufficient materials would be left to build another. "This my Lord," writes his brother-in-law, A. Goolde, "is a true state of the case, and without any uncertainty or post expence the whole can be compleated in four or five months time, or six at most, with good weather, and provided with submission, you dont consult too many people, which occasions strange interruptions like the breaking the thread of a man's discourse, or the chain of his thought tho' before ever so well formed." It does not seem, however, that the young Squire took this hint or repaired the old house. Its sole occupants after this time

- Caryll Correspondence 28,229, p. r87. 
were a pack of harriers, and an old schoolmaster named Exall, who lived there rent-free, and kept a school in the old rooms fearless of the tottering roof. Mr. Goolde concludes his letter by announcing the discovery of an Iron Mine in Harting Comb, probably one of the old pits, the memory of which Sussex tradition with its characteristic slackness has allowed to drop. A Mr. Butler, who bought all Lord Montague's ore at Cowdray, surveyed the spot in Harting Combe, June 7, I738. Lady Mary wrote to her son in some excitement. "This day they begin to dig for oare. God send them a good increase of it, for you are at no expence, and he (Mr. Butler) gives twelve pence a load. . . . . Mr. Butler said he believed there was coale in the same grounde, which he shu'd find out by diging for the oar, and if it proves so will be a prodigious advantage to you. He says there was a Litle in Lord Montague's land, but they made nothing of it, I hope you'll have. better Luck." It would be 'interesting to see if any traces remain of this search for coal in Sussex (as ineffectual as that made about I 50 years later), and to what depth the borings were carried. It was natural that as Sussex found her old trade in iron superseded by the coal of the North, she on her side should be searching for coal, to save her custom. Lady Mary next passes with her usual abruptness to note the death of odious Mrs. Jones. "Mr. Jones' wife dyed on Sunday, just as she lived, an Independant, and wou'd have no parson with her, because she sayd she cou'd pray as well as they.* $\mathrm{He}$ is making a great funerall, but I believe not in much affection, for he was all night at a merry bout two days before she died."

Next follows an inventory of the wine in the cellar 1738 .

- She was buried by Mr. Newlin in Harting Church, June, 
at Lady Holt, after the great run upon it at the festivities. It is an interesting record of the wine which a country gentleman would store in the carlier part of the last century, and doubtless had in a great part been smuggted through the hands of Robin the postman and other worthies, into Lady Holt Park.

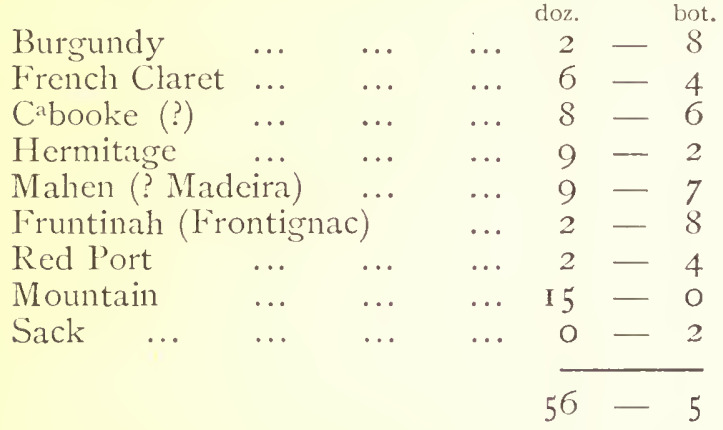

"So" continues Lady Mary-" I have ordered one hogshead of Red Port, and one of French White, wh., with these two that we expect from France, and the half hogshead you bespoke of hermitage, will I hope be enough for the present. You kill every year eleven braces of bucks the keeper tells me, and three braces of them goes each year in presents." . .

Next follows mention of another or two of Lady Mary's little quarrels. "Mrs. Peacham has given me leave to go thro' her field to Uppark, but in so ungentle a māner, that I have writ her word I wou'd not accept of it." A second grievance of a more serious character concludes this interesting letter. The reader will note that it is caused by one of those bêtes noirs, the Jones, who seems to have started a general Harting row, by her pranks with the boys cricketing on the hill, on Sunday, June 5,

C. C., 28,229, p. 223 . 
1738 (Whitsuntide Club Feast). "Now I must tell you of a most provoking thing in Mary Jones. You must know that on Sunday last, when the boyes were playing at ball on Harting Hill" (Hemner Down), "she came out in one of her ill humours, and I supose they plagued her as usuall, upon which she took a tyle and threw it at one to break his head ; he was carried to Lardner's" (the village apothecary at Harting, whose assistant was Nick. Turner, surgeon), "and he said the sckul was broke, or at least fractured; he dyde (died) away severall times that day: she thinking (I believe) that she had kil'd him, came running up here to complain to me how they had abus'd her; but instead of pitying her both I and all the house chid her: upon which she said I upheld them, and went to Major Battin for a warent (warrant) against seven of the boyes, among whom are Dick and Paul Kelly (sons of Caryll's bailiff); and yesterday while I was at Ned's (i.e., a dinner party at the Edward Carylls, at Compton, Littlegreen), the constable came up and serv'd the werent against them, and was to have carried them away (i.e., from Lady Holt), but out of civility and good-nature left them till to-day. The constable said he was very sorry to doe it, for he thought a warrent against her was more proper, for the wounded boy was more likely to dye last night then live. However, I think the Major has acted a very unhandsome part to grant a warrent against the children of my old servent, and two people that are actually working in your house, which I shall take care to let everbody know; and the more that his man saw what happened at Harting, and said he believ'd the boy kill'd: but Major Battin has a grudge at old Paul, and I sopose (suppose) was glad of this occasion. I have this morning sent Hew (Hugh, a servant) down to Mary to threaten 'her, and try if we can make her return the warrent, if not, I think she shou'd be 
forbid this house, for this affair will be both a great losse of time and an expence to the poor people. The boy belongs to Bartlet the miller, not ours, but the other of the name. I fear I have quiet tyr'd you with this Long History, but I am out of patience to see things as they are at present, for we have so much ill humour at present among us, that it makes me grow pivish (peevish). You are to have a whole load of complaints . . . . again." The young Carylls are wanted at home "now they have been marryed so long."

One is staggered in reading this letter at the startling power of the womankind of Harting in 1738 . Even if she were wholly in the right at the commencement of the squabble, Mary Jones cannot be defended for imitating the lady of Thebez among the Harting boys, and then wheedling Major Battin so as to bring down the law upon their heads also. Among the deaths about this time in the Harting Register is that of "John, $y^{\mathrm{e}}$ son of Benj. Bartlett, junior," but whether this were Mary Jones's victim or not cannot be ascertained.

Early in 1739 old Parson Newlin, sometime Rector, but still Vicar of Harting, died ; and the appointment of his successor caused no small stir. The old Squire, fearing disqualification as a Roman Catholic patron, had conveyed the right of presentation to a Protestant friend of his, one John Trevanion, of Kerhayes in Cornwall. The Carylls treated this as a mere nominal trust, and believed the patronage to be still to all intents and purposes their own (as in the former case of Parson Newlin). Accordingly, a year before Newlin died the younger Caryll sold the next presentation to the Vicarage of Harting to Lord Clancarty. Mr. Trevanion was probably one of the many creditors of the family of Caryll; and as soon as he heard that the living of Harting was vacant, recouped himself by appointing to the sinecure Rectory of Harting the 
Rev. Joseph Sager, or Seager, Prebendary of Salisbury, who thereupon relinquished a benefice "nearer home," i.e., nearer to Cornwall, in favour of Trevanion's brother. Seager instituted (May 20, I735) as Rector of Harting forthwith on Parson Newlin's death, appointed himself as Vicar, the patronage of the Vicarage of Harting being annexed to the sinecure Rectory.

Meanwhile, all unknowing, Lord Clancarty had appointed a nominee of his own to the selfsame preferment, Rev. Henry Magill, Reader or Lecturer of St. George's Church, London. And to mark his satisfaction with the Carylls, or, possibly, to give. Mr. Magill a good introduction at Harting, Lord Clancarty had presented Caryll's sister, Kate Goolde, with a beautiful little yatch (March IO, I738-9).

Accordingly, there were now, to all intents and purposes, two rival Rector-Vicars of Harting, and another of the many Church battles about these benefices was fought with surprising sharpness for two years. Caryll is at once at law with Trevanion; Sager and Magill cross each other with quare impedits caveats; the lawyers talk pleasantly of "being fellow-labourers in the vineyard of Harting;" two bishops step up to second the two combatant clerks, Dr. Hoadly of Winchester for Magill, the Bishop of Chichester for Seager; Magill even invokes the aid of the greatest General of his day, John, Duke of Marlborough, in his eagerness to be Vicar of Harting. But all to no avail: step by step the Caryll and Clancarty side grew fainter; Seager proves from the registry at Chichester kept by Mr. Dear, and the Bishop's decision, that the Rectory carries the patronage of the Vicarage ; Lord Clancarty swears freely at the Parsons, "who will always plague," and thinks the whole affair "a strange confus'd piece of business ;" Lady Mary considers the knot "inextricable," and adds, "ther' is but one more in England of the same kind." As a last chance Magill and his friends offer 
to allow Seager as Rector provided he will cede the Vicarage ; but to this his clever answer is an exchange of the Vicarage of Harting with Dr. James Bramston, who already held Lurgashall and Charlton. By Nov. 9, I739, the Bishop of Chichester had collated Bramston to Harting, and Caryll, Clancarty, and Magill were checkmated.

But Magill was not wholly unavenged. On the I9th June, I740, he wrote to Caryll: "I'm told that my worthy friend Sager is fall'n into $y^{\mathrm{e}}$ Hands of the Dean and Chapter of Sarum for Forgery concerning some lease belonging to them, and that the matter is to be tried at Doctors' Commons next Thursday, after $w^{\text {ch. }}$ he is to fall into the hands of the Bishop. It is not impossible that this may make something in my favour. Sager will not dare show his face . . . . Some think he will be degraded or rendered incapable." What an astonishing vitality must the Church of England have possessed to have survived such corruption amongst her ministers in the eighteenth century! But the records of her past miseries in this respect must raise in any generous mind even without her pale a sense of veneration, and a chivalrous foe will show some tenderness for the ship that has weathered such storms as these.

In June, I739, Lady Mary turned out of Lady Holt to make room for her son and his wife. Her last letters still present her usual characteristics: the irritability of an invalid, and the affection of a doting mother. "June 20, 1739. A Cheshire gentleman named Brooks (who went all over Lady Holt) call'd the Park the 'garden of the world,' but I fear it would not be long so, for they drove quite down the middle of the Lawn, and backwards and forwards as if it had been the king's highway, $w^{\text {ch. }}$ you know provokes me beyond all patience. John Varndell (carpenter, son of West Harting farmer) has promised me to put up one of the gates to-day, and as soon as that is, I'le fasten up the 
park that it may not be so trampled upon...... Somebody has stolen all the Iron, and broke down the Maple Gate upon West Hartin down. I can't imagine who it is, but I fancy it must be the same that rob'd Lordington house of all the Iron bars and locks last week." These thefts were usually set down to the gipsies, who were the terror of the country neighbourhood at this time.

Lady Mary adds that she is going to show her daughters over Cowdray, and after that to "Hartin," and thence to the great Salterns in Portsea Island, near Portsmouth, Hants. They probably went to the Salterns for health.

".... Now, my dearest, I can say no more at present, having something of my fever again, but at all times and in all conditions ever imploring the Almighty to grant you all blessings on earth, and an eternal crown of glory in the world to come, I am, my dear, $\mathrm{y}^{\mathrm{rs} .,} \& \mathrm{c}$., \&c."

By 9th September, I739, Caryll and Lady Dolly seem to have taken up their abode at Lady Holt. On the happy Thursday South Harting street was unpeopled, the ringers and a Scotchman being all that were to be found. All Harting turned out to meet the young Squire and his lady in the road from London, and conducted them safe home "with the upermost satisfaction" (as Paul Kelly, the bailiff, wrote) to Lady Holt. Caryll, however, found his place no palace. "He had been left," Lady Mary said, "without a bed to lie upon, or a spoon to eat with, but what he paid for;" and when his grandmother, aged 78, wrote from the Salterns begging that her husband's debts might be paid, adding, "I have doon $w^{\text {th. }}$ this world, and never more seek for any diversions," the young squire answered kindly that "it was true that he had promised to see his grandfather's debts paid, but that he had come into an estate whose every farm was to pieces, and into a house almost ready to fall on his 
head. Nevertheless he would consider that promise as a sacred thing." As a curious mixture of dignity and respect for the young head of the family, the old lady always signed herself to her grandson, "Your affectionate grandmother and very humble servant, E. Caryll." To crown the young squire's woes, the Land Tax for that year was 4s. in the pound.*

The Rev. Henry Magill, still hoping against hope for the benefice, continued to write pleasant letters to Lady Holt. "London, Dec. I I, I739. I am doomed to live in a Town $w^{\text {h. }}$ is Reckoned the centre of Pleasure, But I must own I could think myself much happier situated in your neighbourhood at least att this time. For I think $y^{e}$ Town is empty, and has but a dull and Melancholy aspect. There now and then comes out a Stupid Play or Farce. And $y^{\mathbf{e}}$ only agreeable entertainment $\mathrm{y}^{\mathrm{t} .} \mathrm{I}$ hear of is Lord Middlesex Concert in $\mathrm{y}^{\mathrm{e}}$ Haymarket, for $w^{\text {h. }}$ he will be above two thousand Pound out of pocket. And Hendal's (Handel's) operas are sometimes performed att Lincoln's Inn Fields. . . . The day of humiliation, 9 th of January next, is like to be looked on as a Lord Mayor's shew. Sir Robert (Walpole) has been well roasted this Sessions, but notwithstanding some of $\mathrm{y}^{\mathrm{r}}$. second sighted people see a concern and gloominess Through the vizard, I think he laughs on and graws fat and kicks $y^{\mathbf{e}}$ world before him.'

It had been Lady Mary's earnest wish that she might live to see her son's offspring. This, however, was denied her. She grew worse at the Salterns, and, on her removal to London, died there April I4, I740. Her funeral took place at Harting Church, and she was interred in the Caryll chapel. Her life had been a sorrowful one since her sudden widowhood in 1718 , and her second marriage seems to have been unhappy; but as the mother of a young and only son, she showed

* C. C. Addl. 28,230, p. 420 . 
great energy and acuteness of mind. Her bluntness doubtless made her some foes; nevertheless her feeling disposition, affability, rank, and purity of character must have endeared her to a good many more. Her death was the signal for a violent outbreak of dunning letters from all quarters. The Duke of Norfolk claimed $£ 500$ lent for Caryll's education, and adds that "Lady Mary died insolvent." Mary Lowth (wife of the Rector of Buriton, and mother of Bishop Lowth) wrote from Winchester, April I3, I741, that she had now, by Lady Mary's death, but a single security for her Bond debt of $£ 400$, and asked "by Michäs (as bond securities are liable to great hazards) to be paid off, or to have the debt changed for a land mortgage at 4 per cent." It is sad to contrast with all this misery the funeral pomp which young Caryll's vanity loved to assume in Paris. The following printed form of invitation is preserved among the Caryll records :-

“ [1740.] Vous estes priez d'assister au Service pour le repos de l'Ame de Haute et Puissante Dame Madame Marie Mackenzie, Veuve de My lord CARYLL Baron de Dunford, Seigneur de Lady Holt et autres Lieux, Pair d'Angleterre, decedée a Londres le $14^{\mathrm{e}} \mathrm{du}$ present mois ; qui se sera Mardy 26 Avril, 1740, a neuf heures du matin en Eglise du College des Ecossois, sossez S. Victor.

"Messieurs et dames s'y trouveront, s'il leur plaist. "Un de profundis."*

Perhaps young Caryll already felt that he should soon be driven to seek shelter in France again. The small pox broke out a second time at Lady Holt in 174I. Edward Caryll, the uncle of the present squire, wrote from Crompton (Little green) that it was at East Marden in April, and that in consequence the 
Battine family* were absent, and that Miss Roberts had it at Iddsworth, that Iddsworth House was shut up, and so for the present the match between young Squire Roberts and Miss Hugony (Hugonyn) of Nursted was put off till next year. Young Caryll himself caught the disease by the end of May, and had it for the second time in his life: "a terrible distemper," as Mr. Towneley of Towneley noted in his letter of congratulation on Caryll's recovery, "to undergo twice. They (i.e., small pox) are still much in our neighbourhood." It must have been very depressing to the young squire to have suffered this plague in the same house where, twenty-three years before, his father died of it, and where several servants had also been swept away from the same cause.

The year I 744 was a disastrous one for the Caryll family. Caryll's sisters had run into debt to such an extent that the Sheriff's officer seized them. They in turn sued Caryll, who had neglected to provide for them. It was arranged that the Grinsted estate should be made over to them for sale. Meanwhile Caryll, at the commencement of this exposure and infamy, left England for France, and was at Dunkerque in June, "penetrated with gratitude for the honour which his R(oyal) Highness (the Pretender, Charles Edward, then at Gravelines) had done them." It is strange that he did not join the Scotch expedition of 1745 ; perhaps his health, or the fear of compromising his wife's relations, the Molyneux family, saved him from Culloden. At any rate in August he was at Lady Holt again, but from this time seldom made any stay there. Caryll's conduct towards his sisters seerns to have been considered cowardly; and even an old friend such as Mr. H. Legge, now a M.P.,

- The first mention of the Battine family of East Marden shows them to have been connected with the navy, and on the Parliament side. In a list of those commanding the fleet in Cromwell's time, I found that John Battin commanded the "George." 
"hopes that Caryll will have the courage to live privately now on the spot where he has lived in so publick a manner before." Apparently, it is in answer to this appeal that Caryll writes from Lady Holt, Aug. 6, 1744:- "The unnatural usage I have received from them (his sisters) is too affecting for me to dwell longer on the $\mathrm{y}^{\mathrm{e}}$ subject. They have given irrevocable power to a woman who is like to abuse them as she has made them abuse me." Caryll adds that he has not given her the slightest provocation, "unless ordering her out of my house is such. ... She is endeavouring to find a person who $\mathrm{w}^{\mathrm{d} .}$ swear that I left England on purpose to avoid prosecution from my sisters. ....... I am well assured, Dr. Sir, that you at least are one of the few sincere friends I have remaining (for the number of those who used to appear so dimineshes ev'ry day)." To suit his present circumstances he is "breaking off all acquaintance: and for $\mathrm{y}^{\mathrm{e}}$ future will live entirely retired-being liable to public abuse again while he owes a farthing."

It was high time for Caryll to return, however ignominiously from France. As he did not at first appear to the Bill brought against him by his sisters, a copy of Commission of Rebellion had been issued, and a neighbouring magistrate (J. Page, of Watergate) speaks of a capital case as likely to ensue, and expresses himself guardedly as to judgment. The sale of the Grinstead estate, and probably other loans, enabled Caryll to meet this crisis, and to silence the clamours of many creditors ; but, from henceforth he seems to have been alone, and the few letters from members of his family are bitter and stinging. All things were preparing Lady Holt for its last siege of debt and shame.

Matters now pressed so hard upon the outlaw, that it was doubtful whether he might keep a horse. To

* Caryll Correspondence, 28,230, p. 256. 
this question Major W. Battine replies from East Marden :-“ " 28 Oct., I745. I don't apprehend a Roman Catholic convict has a right to keep a horse of the value of 5 pounds or upwards, but then I don't conceive that anybody but magistrates, or such as they shall empower, have a right to meddle with such horses." Pope had said upon a similar occasion, when threatened with the loss of a horse because he was a Roman Catholic, "Deus dedit, Diabolus abstulit."

At the end of the year the panic of the Pretender's invasion reached the south of England. Mr. Page, of Watergate, as a Chichester magistrate, demanded that all the arms at Lady Holt, as the house of a Roman Catholic, should at once be given up; and adds, in a friendly letter to Caryll, that "Lord Vernon, with two ninety-gun ships, was gone to the Downs."

Caryll entered in his own handwriting :-

"The arms sent to Watergate, 26 Dec., I745, areTwo bullet guns, one rifled, the other plain ;

Two Carabines;

Three shot guns, one silver mounted;

One bullet gun-the keeper's ;

One shot gun-his ;

Five pair plain livery pistols ;

Five pair screw-barrell'd do."

These arms were seized by order of the Ministry. Lady Holt was not unduly armed, though probably it had its secret means of offence and defence. The local tradition is that there is an underground passage from the site of Lady Holt house to Eckenfields, a quarter-of-a-mile south : the large quarry at the northeast of the park, near Starr copse, would be capable of concealing with great advantage a troop of men; and at Hucksholt there is an old house with a bacon chamber over the chimney, which doubtless did service in Royalist days as a hiding place. 
A handsome letter from Mr. Page acknowledged the receipt of the arms from Lady Holt.

\section{"Watergate, 26 Dec., I 745.}

"Sir,-I am favoured with $y^{\text {r. }}$ letter, and have received the arms you therein mention, $w^{\text {h. }}$ I shall restore to you with a Thousand times the Satisfaction I received them. Sir Rich. Mill and Mr. Battine are here, and join in saying that they have not gone thro' a more disagreeable business a long while than that of this day, and that you behaved with great propriety and politeness.

$$
\text { "J. PAGE." }
$$

Caryll's horses and arms were re-delivered to him on the I 5 th Feb. 1746.

From the spring of 1746 Caryll seems to have found this neighbourhood too hot for him, and therefore removed to London, and the north. His chief correspondent from Lady Holt was his Roman Catholic Priest, Dr. Thomas Hunt, whose letters are always amusing, and who takes up the thread of Lady Mary's local gossip. He describes himself as a person with "a mountainous red face," strolling about the woods of Lady Holt with a pig in a string. Sometimes he must have looked grotesque enough.

“ Nov. 29, 1746. I ventured out just to look at my garden to-day for the first time, but such a Figure I cutt, that the Gipsyes (who infest these parts att present, and have done some and attempted more mischief) tho' sixteen, had all been frightened. . . . . My head was covered with a Hat, my Face $w^{\text {th. }}$ a great dab of Scarlet Frieze, the remains of a pair of Britches, my neck with a silk neckerchief and neckcloath (concealing his Ruffle $w^{\text {h. }}$ the Biddy the Parrot had torn), and my Body, besides other Cloaths, $w^{\text {th. }}$ my Fidler's Coat. 'Qu'el chien de Figure ?'" It was happy that he did venture out, or all the orange Trees would have been 
lost. The seven younger orange Trees had rotted in the 'wet mousy weather,' but 'the Pentioner myrtles have escaped.'" The does of Lady Holt Park at this time fetched about a guinea or twenty-five shillings a-piece, being probably in very poor condition. With much honest affection Hunt ends by begging his master to keep a good heart if he finds disappointments in London. "I beg and intreat you for God's sake, your own and Lady's and all Friends' sake, not to let troubles work too much upon you, I am sure many of $\mathrm{y}^{\mathrm{r}}$. illnesses proceeded chiefly from $\mathrm{y}^{\mathrm{r}}$ interior vexations.*

\section{"Thos. F. HunT."}

A Petersfield neighbour, J. Jolliffe, Esq., having twice appealed to Caryll in vain for repayment of a debt, pleading "the charge of a large Building that he was then concerned in (9 Jan., I 745), and the circumstances of his estate at Petersfield which, tho' extravagantly bought, is very ill paid," + sent the Sheriff's officers to Lady Holt. Faithful old Father Hunt describes their arrival. "Mr. Rookes was here last night at 6 a'clock, and came on purpose from Petersfield to serve you. I said-'Hum! you was much obliged to him and $\mathrm{y}^{\mathrm{r}}$. other friends.' He look'd a little down in $\mathrm{y}^{\mathrm{e}}$ mouth, but as Mr. Peace (Caryll's local lawyer) desired me to be silent, so I was, and accepted an Invitation to dine $\mathrm{w}^{\text {th. }}$ him on Thursday next, but my stomach was full and so it will be on Thursday, but i'le either spew or swallow, for speak I will not till I see you." $\ddagger$ He adds that a shoulder of mutton a-week is now all the meat ordered at Lady Holt.

On Fridays the diet of the household was severe enough. Which of our luxurious domestics now-a-

\section{- Add1. 28,230, p. 342.}

† Addl. 28,230, pp. 305-307. $\ddagger$ Do. page 339 . 
days would endure the following fare? Feb. 2I, 1747. "The constant dinners of the servants hitherto upon Fasting days have been Pudding or Apple Py, and now and then Cabbage; but that will not do for Lent, so I should be glad if you $\mathrm{w}^{\mathrm{d}}$. send down some dry Salt Fish and some red Herrings, $w^{\text {th. }}$ orders how often you $w^{\text {d. }}$ have the servants have Salt Fish or Herrings, and whether they should not have Eggs on Egg days; they are now I believe about twelve a groat. As for Sturgeon, if you are so good as to send one little piece for me, I shall be obliged to you."

(Doctor Hunt to Caryll).

- How great the contrast between this point of starvation and the fat days of Harting Place under Sir Ed. Caryll, in 1610 ! It is quite possible that much of the illnesses at Lady Holt proceeded from want of food. In this very year, however, the young . Pretender, Charles Edward, a fugitive from Culloden, was living for days on roots, and when dressed up as Betty Bourke, Lady Flora Macdonald's maid, would doubtless have gladly exchanged fare with the servants of Lady Holt.

Still in spite of all this scarcity the Harting hounds were not put down. "They eat and kill, not at least for you," wrote Father Hunt, piteously. "Few of your hounds will stay att Quarters (in Harting). They are continually up here. I tell Isaack to whip them away." In April, I747, the poor chaplain of Lady Holt is afraid that all the Squire's rents will go up to London without allowance for his salary. And so Dr. Hunt continues- "Now, my dear Sir, if you order all the money upp without any deduction what must I do? for I have none. ... I must say with the steward in the gospel-fodere non valeo; mendicare erubesco. ("I cannot dig: to beg I am ashamed'): but I have not his salvo 'scio quod faciam 
('I am resolved what to do'). For to borrow, if I cared for it, I have not one person hereabouts of my acquaintance who is in a condition of lending: I sent for Mr. Biggs and hoped to have got a guinea or two of him upon my note, but instead of that he begged me to lend him a couple of guineas to be paid by you: that stopped my mouth: I made a leg, and assured him itt was not in my power. Mr. Hawley (butler at Lady Holt) says there is no meat for the dogs, and as he is ordered not to take anything from the tenants, they will cat one another in a few days time. Oats in the stable there has been none this week past." July I I, I 747. Sir Matthew Fetherstonhaugh writes to complain of these dogs the pest of the neighbourhood. Mr. Phipps (now at Littlegreen since Ed. Caryll's death) had shot one of them; and Sir Matthew says that they had torn down a wire window and eaten a buck at his keeper's lodge. "Besides which, they are continually night and day hunting by themselves, and as I am informed kill a great many of the young hares." Eventually, in Dec., 1747, Lady Holt was let to Mr. D. Matthews, of Dean Street, Soho, who took the hounds and made agreement with a farmer of Harting to keep them for $£ 40$ a year in one of the cellars of the old house at Harting-Harting Place.

Sometimes the hungry denizens of Lady Holt fished the ponds and feasted. Dr. Hunt gives an amusing anecdote of Sussex simplicity in his

\section{" History of $y^{\mathrm{e} .}$ Fishing of the great Pond (West Harting), Ap. I 3, I 747 .}

"I arrived att the Pond between 6 and 7 (for I went on Foot), but when I came I was told it was all over, for the Penstock was done, and not one soul in the Pond. Mr. Hawley and Mr. Rooks arrived $\mathrm{w}^{\text {th. }}$ melancholy countenances, the latter (for he also 
had watched all night) swore most terribly that there had been much Roguery (before $y^{e}$ Fishing) last Summer and last spawning time. Mr. Hawley look'd very blanck, and said they had not got one Watercart of Fish: all the Fishermen were either swearing, cursing, or looking quite out of countenance. I went to look at the Fish in $\mathrm{y}^{\mathrm{e}}$ stew and found it as they said, but now and then they got a Flashet out of $\mathrm{y}^{\mathrm{e}}$ Thrashing hole ( $\mathrm{I}$ think they call it) below the Pond, where the water was so muddy it kill'd the Perch and Trout. I could not comprehend that the Pond could have been robbed in so strange a manner; so I advised immediately to let down a Flash of water through the Trunck, and $w^{\text {th. }}$ that water there came some hundreds of Fish, which made us all alive and merry again, and so made a tollerable Fishing of it, tho' not like last time; but, as I said before, the water in that hole being so muddy and it could not be lett off, kill'd a vast many Trout and Perch, and allmost all the Fishermen too, for they were obliged to be many more hours in $\mathrm{y}^{\mathrm{e}}$ water than usuall; and the Potts in the Brook and att $\mathrm{y}^{\mathrm{e}}$ end of this Hole were too wide, so that they let out a great many Eels and some small Tench; I wanted some Eels alive for the Harehurst Pond, but they foolishly put some straw into the little pool they were kept in and killed them all, so there was not one came home alive. So much for this dry account of this wet fishing.**** Thursday night the fishermen were allmost killed with snow and rain. But let the weather change as itt will I am always the same-that is, $D^{r}$. Sir, entirely $y^{\text {rs., }}$ T. F. HUNT. P.S.-Money: Coat."

On the 9th May, 1747, Lady Holt Park being in the height of its beauty, "The Duke of Richmond, My Lord and Lady Kildare, \&c., were to see ittwo coaches and six."* The Duke's letters show

$$
\text { * C. C., 28,230, Vol. III., p. } 403 \text {. }
$$


that he prized highly the Lady Holt venison. But alas! the Park and its red deer were but the fair outward show of their owner's misery. That rent day the sheriff's poundage (represented even at Harting Pond by Mr. Rook's presence) came to $£ 26$ i Is. Six years later the good Petersfield folk were avenging their attack upon Caryll by setting on the lawyers against themselves; and Hunt wrote, March 7, 1753 :"As news, Mr. Gibbon (the father of the historian, living at Mapledurham, a frequent correspondent of Carylls) and Mr. Joliffe are going to law about Petersfield great Pond, each claiming it as their own; but the valiant Mr. Gibbon has cut down the Pond Head, and publicly fished him, as also removed all Mr. Joliffe's Bound stones, set thereabouts as Boundaries to and about the Pond."*

During Mr. Matthew's tenancy of Lady Holt, the terrible murder by the smugglers occurred there, and seems to have given the death blow to the place. It is singular that though it happened on Harting soil, not one Harting man was principal or accessory to it. Caryll's gardner, William Comberleach, a name still surviving in its shortened form of Bleach, was tried as we shall see on a remote charge of being an accomplice, but the trial failed. It is a remarkable coincidence that (as apparently in the case of the other murder near Lady Holt in 160I) the murderers were strangers, and some in fact came from another county. But by whomsoever a murder is committed, in the issue it is the place in which the deed is done that suffers the stigma of guilt. And the memory of the smuggler's murder at the Harehurst or Harris Well of Lady Holt is vivid still, though near I30 years have gone since 1748 .

The county of Sussex, from one end to the other, at this time favoured the smugglers, who procured for the landlord his wine and spirits, and for the * Vol. IV., pp. 147-8. 
tenant-farmer a higher price for wool, the export of which was protected by a duty. A gang of smugglers having secured the two witnesses, Chater and Galley, at Rowland's Castle, tied them upon horses and whipped them for miles along the road towards Rake, untill Galley fell dead. He was buried at a place on Caryll's property, which by curious coincidence was called Gally Grove* for more than a century before. The smugglers had obtained possession of their enemies through the treachery of an innkeeper's wife at Rowland's Castle; and upon their bodies were found letters, containing their evidence, addressed to Major Battine, of East Marden. One, John Greentree, of West Harting, swore at the trial that he had picked up the packet for Major Battine, in a great coat lying on the road beyond Harting Pond. Thus the smugglers seem to have entered Harting on the southwestern extremity, and to have passed near Lady. Holt and Foxcombe, avoiding South Harting on their way to Rake. Poor Chater was still more inhumanly tortured than Galley; and after having been chained up for three days in a turf-shed at Rake, was led, after the most revolting cruelty, to the Harehurst Well (now "Harris Well") in the wood, 200 yards below Lady Holt House, where he was hung over the edge and stoned to death. The well seems to have been a dry pit, probably excavated by Caryll as a second resort for water, while the boring for Lady Holt well was unsuccessful. Finding that after Chater had hung for some time over the well he was not quite dead, the smugglers went to Lady Holt House and borrowed a ladder from old Wm. Combleach, the gardener; it was, however, found to be too long for their purpose, and they despatched their victim with stakes and stones.t After the

- Gally Grove occurs several times, once with Fyning Wood. West Harting Leager, 1632.

† Harting Church Register, Sep. 19, 1748. "Buried Wm. Chater." 
murder, about 2 a.m., the smugglers retreated to Pescod's Barn, in Caryll's property, the usual resort of vagabonds for shelter; but Ann Pescod did not admit them, as her father was ill. The murder was not discovered for some time after, when one of the gang tried for another charge, turned king's evidence. As a mark of the spurious sympathy felt by some for the smugglers on this occasion, and of the terror that they inspired in others, it is stated that only two magistrates ventured to attend at the Chichester examinations, and to take evidence against them. The two heroes were the Duke of Richmond and Mr. Wm. Rickman, grandfather to Mr. John Rickman, Clerk of the House of Commons.* Sir Matthew Fetherstonhaugh was foreman of the grand jury that tried the prisoners. Six of them were hung in various placeson the Broile, near Chichester, on Selsea Bill, and on Rake Common.

We may now trace the history of Wm. Combleach, as it is detailed in the Caryll Records. He was gardener to Caryll, and had continued at Lady Holt when Mr. Matthews took it. After the murder, he imprudently told Joseph, a servant at Lady Holt, that when Jackson and Carter called him in the night, they said "they had met with two men who had a mind to kill them; but that they had made an end of them, and being wearied and fatigued, they desired to lie down upon his (William's) bed for awhile, which he permitted 'em to do, as they were men he had known from a child." As this tale, which probably originated in William's desire to obtain

* Mr. John Rickman, Clerk of the House of Commons, Author of the Census, and of the present system of voting in the House; married a young lady of Harting, in 1805-Miss Postlethwaite. The Register of the marriage referred to, shews that "John Rickman, Esq., and Miss Susanna Postlethwaite, were married at Harting Church, 3 Oct., 1805. WitnessesJos. Postlethwaite and Mary Anne Tourle." The Postlethwaite family appear to have settled at East Harting, about the year 1802 . 
notoriety, soon reached Major Battine's ears, the Lady Holt gardener was arrested on the ugly suspicion of being an accomplice and harbourer of the murderers, and spent his Christmas in gaol to his great misery. Caryll sent Father $H$. Hoghton, the R. C. priest of West Grinstead, probably as Father Hunt was too old or too much of an invalid for the task, to visit the poor victim of his own vanity in the prison. Hoghton reported, that in his journey to Chichester, Combleach was loaded with a great pair of irons, and put into a cart with the other smugglers: where, besides the shame, he was entertained all along with their reprobate language. When arrived at Chichester, he was thrown into the dungeon, where he remained seven days on straw. Combleach describes the scene in Chichester gaol the night before the execution. One or two of the smugglers were bewailing their fate; Carter praying most earnestly: the rest swearing and revelling, and not yet believing that they should be hung. It seems that to the last they were in hopes of a rescue from their comrades. Hoghton adds- "This usuage (towards Wm. Combleach) has been, I think, a most severe punishment for a crime, $w^{\text {ch. }}$ I think can scarce be called a crime, considering $y^{\text {t. }}$ if Combleach had discovered this at first, he wou'd have run great risque of his life; and secondly, as he says himself, he cou'd not believe $w^{\text {ht. }}$ they said to be true, for it was $y^{\mathrm{e}}$ part of madmen only to go and kill a man, and then come and tell him that they had done it. $\mathrm{Y}^{\mathrm{e}}$ gaol-keeper told me $\mathrm{y}^{\mathrm{t}}$. he had spoke to $y^{e}$ Duke of Richmond, to know what he should do $\mathrm{ab}^{\mathrm{t} .}$ Will, who made answer he was sure Will knew more, and therefore $y^{\text {t. }}$ he shou'd take him back to gaol."* After the executions, Combleach was transferred to Horsham gaol, and liberated after the March assizes, I 749.

- C. C., Vol. V. Addi. 28,231, pp. 29, 31, 35. 
In $1754, \mathrm{Wm}$. Combleach was still at Lady Holt, and like the rest of the dependants there wanted money. Within a few years of the murder, Lady Holt house became an Aylmer's field, and was razed to the ground. On all sides Caryll was pressed for debt. From the Abbey of Dunkerque his aunt wrote him the following letter, the sting of which must have been severe :-

“Dearest Nephew,

"The dismal account I've a long time had from all hands of your past conduct and present circumstances, go as you may imagine, too near my heart to enlarge upon it: soe can only add, that I pray for you night and day, and beg in return for my affection and solicitude, that you will no longer differ, but pay $\mathrm{y}^{\mathrm{e}}$ first moment you are able, $\mathrm{y}^{\mathrm{e}}$ ten pounds that I borrow'd for you of Mr. Keetin, $w^{\text {ch. }}$ he so obligingly then lent (and I so often repeated to you), as no one is secure of a moment of life; and should Allty. God deprive me of myne before this debt is discharged, I shall dye in Debt and guilt ; and as this is contracted for your sake, shew you have some compassion for me that has ever had soe true a love for you, as to stile myself to my last breath, your most affectionate tho' most afflicted Aunt,

\section{BEN. (edicta) CARYLl.}

"I told you in some of my letters $y^{e}$ necessity poor Romana (her sister) and myself was in for a little money to supply our necessarys, and finding $y^{\mathrm{e}}$ want of tea and snuff prejudiciall to our healths; but my still greater concern is your long-continued debts to My Lady (Dame Mary ?), it having forced her to contract many, depending on your payment. As this house was begun by our name, a hard stroke for me to live to see you help to bring it down; besides, my dearest nephew, remember that Justice is an absolute vertue to salvation." 
It is curious that the foreign monasteries with which the ladies of the Caryll family were connected, seem to have shared their ill-luck. The convent at Ghent, says Mr. Harting, Sen., of which Dame Mary Caryll (noticed before as first Abbess of the Benedictines at Dunkerque) was a member, had lent large sums to King Charles the Second on his embarkation for England, at the restoration under General Monk.

In hopes of recovering the loan, Dame Mary Knatchbull and Dame Mary Caryll, came to England in $\mathrm{I} 662$. The king received them very graciously, and gave them a $£ \mathrm{I}, 000$, promising also an annual payment of $£ 500$. This was "constantly payde, as long as my Lord Famont livde (some four years);

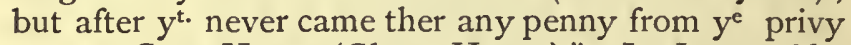
purs to Gant House (Ghent House)." In June, I663, Dame Mary Caryll came again to England on the same business, but with no success." *

Caryll paid his debt to Benedicta by Oct. 23, I 749. About this time he petitioned Parliament for the reversal of the entail of the Lady Holt and West Harting estates.

Perhaps the last crowning stroke of misfortune causing the speedy sale of the Harting estate, was the failure of his wife's relations in Lancashire. His mother-in-law, Lady Molyneux, wrote as follows :" 26 Oct., I 753, Woolton. I am sory to acquaint $\mathrm{d}^{\mathrm{r}}$. Mr. Caryll that last Wednesday night there came a Bailife to arrest me from Doctor Angier, but being

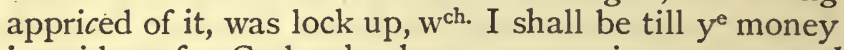
is paid, so for God sake have compassion on me and hasten the sale of $y^{e}$ estate, my unhappy situation will,

- NotE.-Dame Mary Caryll founded the Abbey at Dunkerque. Her brother Peter (Father Alexius) was Architect of the New Convent ; and her father, John Caryll ("the Squire"), provided the principal staircase, which was prepared at Harting from oak felled at Lady Holt, and sent out for fixing. 
I fear, be all over the country. My blessing atends all ; my head is so distracted I cannot answer my dearest child's letter. . . . . I am, dear Mr. Caryll,

" $\mathrm{Y}^{\mathrm{r}}$. affectionate Mother,

"M. Molyneux.

" $\mathrm{Y}^{\mathrm{e}}$ Bailife say'd he was to come again on another account $\mathrm{w}^{\text {ch. }}$ is Harper.

"For Mr. Caryll, at Lady Holt, near Midhurst."

The starved garrison of Lady Holt still held out. Mutton, Hunt wrote word, was $3 \frac{1}{2} \mathrm{~d}$. a pound, for there was a terrible mortality among the sheep in 1754 . $^{*}$ Butter was $7 \frac{3}{4} \mathrm{~d}$. per pound, and boiling peas (the usual diet of the poor from the days of Piers Plowman) 8s. per bushell. The discreet shopkeepers of Petersfield began to limit the credit of Lady Holt. "M Meace will let us have a few candles and some soap, but she has a very small quantity, the reason is as she told me as she can't get tallow, nor any other persons in Petersfield, the cattle being so poor. She begs your Hon ${ }^{\text {r. }}$ will please to order her money, for she is in great want." Yet Caryll was ordering fifty ton of hay of Farmer Blackmore at 40s. per ton, as they sold it in Harting.

Mr. Weaver computes from documents at Uppark, that between the years 1746 and 1762 , the debts of John Caryll amounted to upwards of $£ 30,000$, and that 53 judgments were entered in the King's Bench against him. The first sale of the Caryll land took place in 1755, after an Act of Parliament had been obtained, which reversed the entail. Caryll had no male heir. Lady Dorothy's only children were a son who died young, and a daughter, who never married.

s The sheep "dye very fast and some of them fatt, and most in good case. Farmer Barnard has sent above a score here for the doggs : Farmer Clarke, a week ago, had lost upwards of 100 more than during 17 years he had held the farm. Many fawns and young deer have died at Lady Holt."-Hunt to Caryll, April, 1754 . 
Thus the direct line of the Carylls became extinct, and the recklessness of the last John Caryll of Harting may in part be accounted for by the fact that there was no heir apparent for whose benefit he might save. Lady Dorothy Caryll died at Lady Holt in I760, but was not buried at Harting. Gentle old Father Hunt, with careful nursing and "duddling," lived on till May I 77O, and, having died according to tradition at Brightwells, is buried in Harting Churchyard. The last Caryll burials at Harting were those of Edward Caryll of Compton, in I766, and Miss Elizabeth Caryll (John Caryll "the Squire's" daughter) in 1767.

Sir Matthew Fetherstonhaugh purchased the Bohemia lands in I755; the Home Farm, "Ffoxcombs," the disparked Park near the Church, and Tarbarrow or Tarberry Hill in 1761 ; the capital Manor or Mansion House of West Harting, the Mill, Mill Pond, Trout Stream, \&c., in I76I; several Farms, together with Harting Great Pond, the little Pond and the Clay Pond, the Hundred of Dempford and Manor of West Harting, "these being purchases formerly made by Mr. Jolliffe from Mr. Caryll previous to the Act of Parliament," in I76I. It thus appears that $\mathrm{Mr}$. Jolliffe's claim upon Caryll on account of which the bailiffs were sent to Lady Holt in 1746, was satisfied at the time by Caryll's giving a mortgage on part of his land, which would afterwards seem to have been foreclosed; and thus Sir Matthew purchased from Mr. Jolliffe. Last of all, in the year 1766-7, after his wife's, uncles', and daughter's deaths, the unhappy solitary sold Lady Holt itself to the Duke of Richmond, who assigned it to Sir Matthew Fetherstonhaugh. It is styled in the deed of sale "The Mansion House and the Beauty thereof at Lady Holt."

Before 1770 every stone of Lady Holt house was removed; and nothing but turf remained to mark the site so dear to Pope and Gay. 
In Aug. I768,* Sir Matthew built a house at Foxcombe, which afterwards being castellated attained the name of Castle Farm: probably some of its materials may have been derived from Lady Holt, as afterwards the bricks from the high garden walls served for the kitchen archway at Uppark when the Front was erected, as it is said, after a design by Beau Nash. So hasty is Dalloway, that he pitches upon "Castle Farm," a name not half a century old at the date of his Book, as the site of the ancient "Harting Place." To this day the older villagers prefer the venerable name of "Foxcombe" to the modern grandeur of "Castle Farm."

Before I 800 the old house at the Church was also dismantled. In its last days, as we have seen, it had been appropriated to a parish school, and afterwards a workhouse, while in its old dungeon the poor old Harting hounds starved, and must have made dismal music for the paupers above. A letter of one John Exall to Caryll, wherein the petitioner, a Roman Catholic schoolmaster, asks not to be turned out of the "great house at Harting," shows incidentally the early interest taken by the family of Fetherstonhaugh in the improvement of the Harting poor by means of schools. It is dated Sunday, 25th February, I749, $\dagger$ two years after Sir Matthew's purchase of Uppark.

Exall begins by reminding Caryll that last time he was at Lady Holt, " as soon as I entered the Room, you was pleased to fill up a large glasse of wine, and desired me to drink it up, and then took me by the hand and said, 'so long as my name is John Caryll and your name is James Exall so long shall that room be yours (except I pull it down).' Now, one William Cumbridge is his enemy. "I wonder he should covet that room from me, contrary to God's express command (Thou shalt not covet thy neighbour's house),

* The Caryll Correspondence closes in 1768 . C. C., IX. Addl. 28,235. 
when there are two or three rooms lies void in the house. . . . . This suited mee best because of the largeness of the windows to give light, I being between 60 and 70 years of age, and my eyes dim.

"I remember, Sir, the last time I saw you at Lady Holt you was pleased to ask me what school I had. I answered but small, and that one of $y^{r}$. Tenants opposed me. 'You said you would speak to him yourself, which I find you was so good as to do the next day, but I think had not the desired effect, for a little after $S^{r}$. Matthew Fetherstone and his Lady came, and their two Brothers, and the 2 latter vewed the Room in order to allow me $£ 15 \mathrm{p}$. annum to teach a certain number of Poore Children, but the same Farmer tould the Lady I was Idle, \&c., shee excused it by saying 'Poverty makes some people worse: it may be for want of Incorrigment;' another reported he doughted I was to much Romishly inclined. One was for this man to be Schoolmaster, another was for that man, the Gent. said he thought they troubled themselves with what they had not to do with. So the desine dropt, and it was not done." James Exall was buried, I777.

This document carries with it its own evidence as to the bad scholarship of one who was probably our first schoolmaster, but it is also an interesting record of the gentle-heartedness of Lady Sarah Fetherstonhaugh, a daughter of the Lethieullier and Ironmonger family, whose piety is still remembered at Harting. Probably in order to prevent its becoming a permanent Poor House, Harting Place was shortly after demolished: and thus the two mansions of the Carylls passed away with the family's downfal, and the Mortuary Chapel, which was built at the time of their best days, has long become, in its decay, a symbol of their worst.

John Caryll, after the sale of Lady Holt, retired to France, where it is said that he lived with some pretension at a château ("Maison sur Seine") near Paris, and died in the army of France in 1780 , aged 63. 
Always averse to change, the poor to this day have their legend that the last Caryll was only dispossessed of West Harting through treachery; while at the same time the bounty of Lady Holt to all comers is still remembered by some of our old minstrels. "When the Carylls were at Lady Holt there was an archway, something like Uppark, for the servants and travellers; and there was always a large cask of beer in this passage with a chain on it and a harn (horn): every one that went there had to help themselves, and then he (the horn) was filled again. . . . . Sir Matthew let him (Caryll) have the money to pay his score off. Sir Matthew went to London, and Caryll started after with the money to pay the mortgage, and Sir Matthew paid the postboys to keep Caryll back: so he came too late to London, and the mortgage was closed." So the Harting cottager sings what is to him the fall of Troy. He has no ill will against anyone, but he cannot believe that what he does not like has been done without wrong. Another tale is, that Caryll drove two of his own horses dead on the road to Guildford in this journey to London, and could get no more. All this is merely the legendary leave-taking of a favourite and hero of a century ago, whom every one pitied for his misfortunes. The documents at the British Museum show that the sale of Caryll's property for a twenty-five years' purchase was in every way fair, and, indeed, advantageous to Caryll.

Thus, almost in the year in which the second Pretender died without an heir,* did the last of the Carylls, whose destiny had been so closely connected with that of the Stuarts, pass away from this village after a reign of nearly two centuries. No doubt the fines imposed on the property by the Commonwealth and by William the Third were the main causes of the ruin of the house: but the race from the commencement of the

- Pretender died Jan. 30, 1788. 
eighteenth century became sickly and dwindling; and the last John Caryll seems to have been a man strong neither in mind or body, spoilt in childhood, effeminate in manhood, from first to last overwhelmed with debt, but happily not in a coarser sense immoral.

\section{CHAPTER VIII.}

\section{ODDS AND ENDS.}

THE year 1767 , in which Lady Holt was sold, may be considered as forming the conclusion of the antiquities of Harting, which it has been my object to trace. The more recent history of our village will doubtless one day be handled by a far more able chronicler, who will show how here, as elsewhere, the old order ceased, yielding to the new, and how the new in its turn soon became old. I shall use this last chapter, therefore, as a postscript, and shall store it, after the manner of gentler writers, with miscellaneous materials.

And first in point of interest, we must record the connection of Harting with Rev. Gilbert White of Selborne, the father of Modern Natural History. For at least forty years (I754-1792), Gilbert White was an East Harting Squire. The bulk of his property was at Woodhouse and Nye Woods, on the northern slope of East Harting, and bounded on the west by the road to Harting station. The passenger from Harting to the Railway has on his right, immediately 
opposite the "Severals" * wood, Gilbert White's Farm, extending nearly, to the Station. White had also other Harting lands. These were upon the Downs, viz.,- - a portion of the Park of Uppark on the south side, and a portion of Kildevil Lane, on the North Marden side of Harting Hill. Gilbert White was on his mother's side a Ford : and these lands had been transmitted to him through his great uncle Oliver Whitby, nephew to Sir Edward Ford. Thus the little estate in East Harting was part of the family property of Gilbert White, and showed that he was kinsman to the great Squires of East and West Harting, as the Carylls and Fords had intermarried. An interesting entry in his Account Book marks not only that he was intimate with the Clergy here, but that in all probability he knew Harting at a very early period of his life.

"Feb. 2, I754. Gave Dr. Durnford's servant at Harting 3s.: Mrs. Newlin's maid 3s." He was here evidently staying two nights in Harting; and for one of these resided at the house of the widow of honest old Parson John Newlin. It is pretty certain, therefore, that he must have known old Mr. Newlin himself, who lived at Harting from the commencement of his incumbency as Vicar, I731, $\uparrow$ to the time of his death, 1738. We may assume further, that, no doubt, in

- "Severals," not an uncommon name for a piece of land severed and enclosed from the Common. In "Love's Labour Lost," Act II. Scene I. In the Mask.

"Boyet.-No sheep, sweet lamb, unless we feed upon your lips. Marg.-You sheep and I pasture, shall that finish the jest? Boyet.-So you grant pasture for me. (Offering to kiss her.) Marg.-

My lips are no common, several though they be."

$\dagger$ John Newlin was presented by Trevanion Caryll's Trustee to Harting Rectory, 1716. He resigned the Rectory in $173^{\circ}$, and becoming Vicar of Harting in 1731, continued his residence here to the time of his death. 
consequence of his family connections, Gilbert White was quite at home in Harting from an early period of his life, and that his facts relating to the South Downs were mainly collected here.

The following draft of a codicil to the will of Gilbert White is preserved in his own handwriting. . . . "Whereas I, the Revd. Gilbert White, of Selborne, in the County of South'ton, Clerk, have duly made and executed my last will and testament in writing, bearing date the second day of November last, and whereas since executing my said will I have suffered a recovery of my estate at East Harting, otherwise Harting, in the County of Sussex, now I do hereby give and devise unto my all that, my Messuage, Farm Lands, Tenements and Hereditaments, with the Appurtenances situate and being in the Parish of East Harting, otherwise Harting, in the County of Sussex, called or known by the several names of Deane's, Boyes', Woodhouse and Maxwell's, or by whatsoever other name or names the same or any part thereof is called or known. To hold unto him my said his Heirs and assigns for ever. And I do declare this to be a Codicil to my said Will, \&c., \&c. Dated the - day of January, I792.'

It is quite possible that one object of Gilbert White's visit to the Vicarage of Harting during the period of the Incumbency of Thos. Durnford, jun., D.D., was to inquire after Durnford's brother-in-law, the ill-fated poet Collins. Gilbert White wrote a letter to the Gentleman's Magazine, I78I, wherein he states all that he had been able to collect with regard to the madness of Collins, with whom he was connected both by County and College. It is curious that White says in this interesting paper that he did not know where Collins was buried, though in fact it was no further than St. Andrew's, Chichester (1759).

Dr. Durnford's union with Ann Collins, younger sister of the poet, proved unhappy, and they separated. 
Mrs. Durnford* died at Chichester, and is also buried at St. Andrews. From his christening one of his children "Stillingfleet," it may be inferred that Dr. Durnford was an admirer of that celebrated bishop. Like his father he had been appointed to the Vicarage of Harting by Rev. Joseph Sager.

There are still amongst us a few cottage tales which offer a glimpse or two at some scenes of humble life in Harting at the end of the last century. The accompanying sketch is from a crayon or mezzotint picture

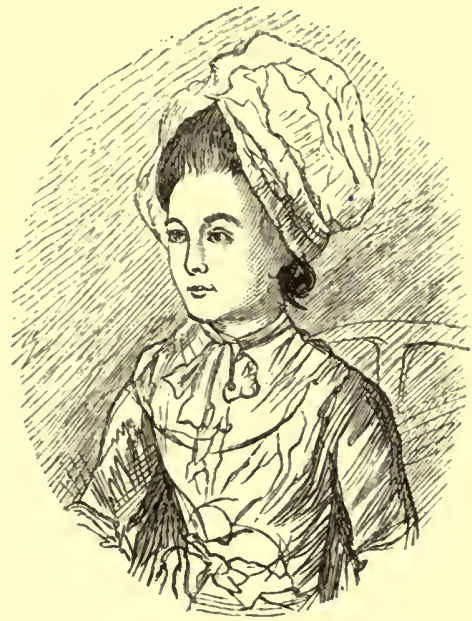

of the Harting Miller's daughter, aged 18 in 1780 . This blooming young maiden in the mob cap, Mistress Sarah Hall, as she would be called in those days, was the daughter of John Hall, who bore a name even at that time 400 years old in Harting, its first recorded

- Dr. Durnford continued to live at Harting till 1774 , the date of his last entry among the marriages, after which a Welchman named David Morgan, became the last of his many Curates, and was in charge here till near 1800 . Dr. Durnford held the living till 1792. 
owner being the first of the Hussey tenants, about the time of the battle of Cressy. "John" was a name much cherished, partly, perhaps, as being safe from the political associations of Charles, Edward, James, George, or William, partly from the jingle of honest Fohn, which always had a good sound, and was on the whole better than "jolly Joe," or "sober Sam," or "fidgetty Phill." John Hall was a thrifty man, and it was his boast, that when he came to Hurst Mill and had paid justly for his first load of wheat, he had only one farthing left in his pocket and his wife only a halfpenny. In the end he saved enough to retire and to live in a house of his own at West Harting, now belonging to his descendant Josiah Oliver. Sarah Hall (Sarah - a name much in vogue since Sarah Duchess of Marlborough, but now never chosen) was his only surviving daughter. The portrait was taken at Portsmouth, where Sarah Hall was visiting; she complained that she had stayed so long away that her friends at Harting would not know her; on which a gentleman at the table made an impromptu sketch, adding that it did her little justice, and told her to send it to her mother. The original, a real work of art, was hanging in the cottage of her grandson, Joseph New, a shepherd at Hurst Farm, in 1876. Sarah Hall was married first to John Wild by license, Jan. 29, I784 ; and the signatures of bride and bridegroom are unusually good. The name of John Wild is also a very old fixture in Harting; as a landholder, one John Wild, sold Fleetsholt, W. Harting, to Sir Edward Caryll, in 1608.* The gallant bridegroom's (I784) posy-ring contained the legend-

\section{"I will have her}

Love the giver,"

and he must have had no fear of a blue stockingfor the tradition amongst her descendants is, that Sarah Hall had read Josephus through at twelve

- Addl. 28,529, p. 45. A John Wild lived at the Crose or Cross, East Harting, now East Harting Farm, 26th Dec., 1624. 
years of age. On the death of John Wild, Sarah, his widow, married another Harting man, John New, Oct. 23, 1794, also by license, and having two large families by each husband, she became the ancestress of the wide-spreading houses of Wild and New, with whom almost all Harting proper may be said to be related. One hundred and fifty-seven souls are known to have sprung from her in Harting, and from her extensive motherhood she may be said to have well earned her patriarchal name of Sarah.* She lived latterly at Hill Ash, and was buried on the south chancel side of our church-yard, Jan. I9, I8 I 5, aged 5 I.

A curious entry appears in our Register, dated Nov. 25, 1794. "Bap.-Harry Matthew Thomas William Stag, son of Joseph and Ann Stacey." There was a Stag-hunt in Lady Holt Park in 1794, on which occasion the last of the famous Red Deer was killed. The hunt consisted of Sir Harry Fetherstonhaugh, Matthew Day, Esq., Thomas Welch, Esq., and Major William Battine, of East Marden; one, Joseph Stacey, was part of the retinue, and afterwards Park-keeper. During the hunt it was announced to Joe, that a son was born to him at Lady Holt. The gentlemen present proposed to become sponsors to the infant, who in consequence received their four several Christian names, that of the noble stag being added for good luck.

- Sarah Hall's family.-Children, 8 : grandchildren, 42 : greatgrandchildren, 94: great-great-grandchildren, 22. Part of the issue is not known, as one branch of grandchildren went to Australia. (Communicated by Miss Sarah Griffin, a descendant of Sarah Hall in fourth generation.)

\section{Epitaph of SaRah New, née Hall.}

"Sarah New, Wife of John New, fell asleep the 15 th Jan., I815, and was laid in this bed, a last resting-place till the Resurrection, aged $5^{\mathrm{I}}$ years.

Weep not for me, the Ashes cry:

The Spirit sings with Saints on high.

Be wise, and live the life of Faith,

Or thou shalt die the Second Death." 
Henry Matthew Thomas William Stag Stacey, had the utmost credit at Uppark (where he was Brewer, \&c.) for his honesty, and dying Ap. I7, I875, aged $8 \mathrm{I}$, was buried at Compton.* Rev. David Morgan, though doubtless a voluble Welshman, must have found a difficulty in pronouncing this string of names in one breath at the font.

An old man, aged 82, now living, gives the following graphic picture of a Harting labourer's work and fare at harvest time, at the end of the last century :- "Out in morning at four o'clock. Mouthful of bread and cheese and pint of ale. Then off to the harvest field. Rippin and moën (reaping and mowing) till eight. Then morning brakfast and small beer. Brakfasta piece of fat pork as thick as your hat (a broadbrimmed wideawake) is wide. Then work till ten o'clock: then a mouthful of bread and cheese and a pint of strong beer ("farnooner, i.e. forenooner, "farnooner's-lunch" we called it). Work till twelve. Then at dinner in the farm-house; sometimes a leg of mutton, sometimes a piece of ham and plum pudding. Then work till five: then a munch and a quart of ale. Nunch was cheese, 'twas skimmed cheese though. Then work till sunset: then home and have supper and a pint of ale. I never knew a man drunk in the harvest field in my life. Could drink six quarts, and believe that a man might drink two gallons in a day. All of us were in the house (i.e., the usual hired servants, and those specially engaged for the harvest): the yearly servants used to go with the monthly ones.

"There were two thrashers: and the head thrasher used always to go before the reapers. A man could cut according to the goodness of the job, half-an-acre a day. The terms of wages were $£_{3}$ IOs. to 50s. for the month.

"When the hay was in cock or the wheat in shock,

- For this anecdote I am indebted to Mr. Weaver. 
then the Titheman come (came): you didn't dare take up a field without you let him know. If the Titheman didn't come at the time, you tithed yourself. He marked his sheaves with a bough or bush. You couldn't get over the Titheman. If you began at a hedge and made the tenth cock smaller than the rest, the Titheman might begin in the middle just where he liked. The Titheman at Harting, old John Blackmore, lived at Mundy's (South Harting Street). His grandson is blacksmith at Harting now. All the tithing was quiet. You didn't dare even set your eggs till the Titheman had been and ta'en his tithe. The usual day's work was from 7 to 5 .

"An old man once come up to me at nuncheon, a kind of half-starved independant old man, used to sponge about, and he sidled up to me and says, looking aside at me (it is impossible to give the old man's perk), a stamping and staring at me with my shirt collar all open:- 'You've got a pretty neck for a halter.' 'Ah! but when the ropemaker made yours, he told me there wer'nt hamp enough (hemp) left to make me one!' The old man's name was Newlen." This was, without doubt, one of the last of our old friend Parson Newlin's " numerrous retinue."* One of the daughters married Farmer Gayger, but the rest seem to have gone down rapidly; and the son of the courtly old Rector of Harting became at last "a kind of half-starved independent old man, who used to sponge about," and was the butt of the merry harvest field. The repartee is certainly far above the average of ordinary Sussex wit. The Sussex swain is, however, not without certain talents of his own. His womankind have unusually quick powers of utterance, and he himself though but a trifle slower, is often a wonderful mimic; and thus his yarn is broken up into a constant parenthetical drama, very cleverly acted, while the nimble tongue casts off the historical appendages of, "says he," "said I," and the alteration - The mother of William Ansell, sen., W. Harting, was a Newlin. 
of tone and gesture carries at once the speaker's personality. In this respect he has almost the vivacity and imitative powers of his neighbour the French peasant. On the other hand, one of the Teutonic elements is much wanting: he has very few proverbs, no native songs, such as the Celt delights in-absolutely no literature or trace of cultured conversation, and hence unusually few local traditions. He is a much-enduring, passive, easy-going, home-loving specimen of humanity; and if we consider the crowded hovels and wigwams that for centuries he has inhabited, and the constant intermarriage of which he is the result, it is a wonder that his nineteenth century appearance is so good as it is. Mr. Phillips told me that on his arrival at Harting some fifty years since, there were but six families in the place, so compact was the affinity, though the population was over I,200. There are two views of the place, the outside one, "never come near it:" the inside, "never leave it." The truth is of course between the two; but it may be said that nine out of ten emigrants catch the Harting fever in their absence, and return.

It has been said that the pronunciation of our peasantry is very rapid. At the same time it must be allowed to be remarkably faithful. It is not till Henry the Eighth's time that "er" is transformed to "ar." For instance, Harting first appears as the spelling and pronunciation of I 526 . Before this it was Herting or Herton. The common people talk of going to "Hiertan" still; and "garland" still has its Spenserian sound of "girlonde."

"John Martin" would still be rendered by some of us "Joänn Mertan"-the latent o in the first name faithfully recording the long Omega of the Greek Joannes, crushed into the English single syllable "John." As to the sirname "Mertan" for Martin, it is the identical pronunciation of 300 years ago. Thus, Harting Register, spelling phonetically or by sound, records that " Roger Murtan, of West Harting, 
husbandman," was buried in 1584. "Kenshutt" is entered for "Kinsholt" about the same date, and had thus the same popular sound as in 1877. At that time too nicknames in Harting were as common as now. Thus we have "Thomas Aylinge, alias Wysedom (Wisdom), I 585," while another, probably a man in debt, is called "Owyn" (Owing) Silver, or Sylvester. The old spelling of Brighton, by the way, is remarkable. "Henrie, the son of John Hankocke (Hancock), of Brighthemson, buried at Harting Church, July 2, I 589."

The following curiosity is an example of the varied correspondence of a country Parson:-

[Nov. 3, 1872.]

" I9, South Grove East, Mildmay Park,
"Islington, North London.

"Rev" Sir.

"I enclose you twelve Postage Stamps, which I trust will reimburse you for any trouble you take in the Matter, the more especially as this Letter is written for no Legal Purposes whatsoever, but for an almost Insurmountable curiosity to know the Exact date of Death of a Man who appears from some conversation amongst kinsfolk to have been both a Gentleman and a Great Lover of the More Natural Sciences, but by his Poorer Neighbours a Wizard or Sorcerer.

"I understand there is a Monument in West Harting Chancel to this 'Timothy Luff, of Kent House, Harting ;' and from Circumstances told me in Ordinary Discourse I cannot but imagine this Man possessed what was then seemingly unknown to Ignorant folk -the Mesmeric Power. Certain 'tis he could cast Nativities and horoscopes. Now from Many Cir-. cumstances I am led to believe this Man lived about I 748 or thereabout, and should feel truly obliged if you would give me the Inscription on that Man's Tomb, for I cannot help believing him to be a disciple 
or Follower of the Celebrated Mesmer, and I wish greatly to ascertain that point, as I have been given to Understand that he "could transfix immoveable a Waggoner, Waggon, and 4 Horses, like to the Sun at Ajalon.' I merely wish to Ascertain if he lived before or after Mesmer.

\author{
"I remain, Rev" Sir, \\ "Yours very respectfully, \\ "M. W. HARRISON,
}

"A descendant of his Nephew, my Gt. Grdfthr."

Timothy Luff was chief tenant of John Caryll "the Squire," and held the present Church Farm, and "old Park," at South Harting. His monument is on the north wall of the Chancel of Harting Church, and he was buried June $27,1727$.

With regard to the black arts, local tradition still declares that hot flints were rained at East Harting House (now Mrs. Luff's) in Squire Johnny Russell's time by a fortune-teller. This lady was discoursing to a servant girl about her destiny, when, being summarily ejected by the mistress, she in retaliation witched the girl, and broke all the windows by hot flints rained from the Downs.

Item, that old Mother Digby (née Mollen), who lived at a house in Hog's Lane, East Harting, had the power of witching herself into a hare, and was always, like Hecate, attended by dogs. Squire Russell of Tye Oak always lost his hare at the sink-hole of a drain near by the old lady's house. One day the dogs caught hold of the hare by its hind quarters, which escaped down the drain; and Squire Russell, instantly opening the old beldame's door, found her rubbing that identical part of her body in which the hound had seized the hare!

With this queer tale we may compare an old imposture of I726, when Mary Toft of Godalming (doubtless a harmless maniac had she lived in these 
days) pretended that she bred rabbits, and so imposed on many, among others, upon Mr. St. Aubyn, the King's physician, that he espoused her cause. Pope laughed at this tale in one of his letters to Caryll; and Pope and Pulteney celebrated Mary Toft in a joint satire.

Public opinion generally was lenient with the witch if there was a joke about her story. If, however, fear rather than laughter were appealed to, the wise woman had a hard time of it, and stood in danger of ducking or burning.

The Jury of the Court Leet held for the hundred of Dumford, April I 5, I 747, made the following entry :-

"Also we present the Hon ble. John Caryll, Esq., Lord of this Mannor, for not having and keeping a Ducking Stool within the said Hundred of Dumford according to law, for the ducking of scolds and other disorderly persons."

Other humourous lovers of the black arts at Harting had the wonderful power of teasing people in a solemn way-making loads of hay fall off in the streets near quagmires; turning swarms of bees upon their creditors and Sheriffs' officers ; and, of course, bewitching small pigs, as in "Macbeth" :-

\section{Act I., Scene iii. \\ "Ist Witch.-Where hast thou been, sister? 2nd Witch.-Killing swine."}

The power of an evil eye and illicit pig-killing are still articles of faith among some of the outlying poor. But when witches kill pigs they become serious, and may expect to be burnt in substitution for the pig that they have swooped upon.

I have not yet been able to identify the entry of the burial of Emma Stanley, Queen of the Gipsies, who died at Bohemia Hollow in 1848, and who, it is said, was baptized and buried in Harting Church : nor of the marriage of one Bryder with his sister-in-law, for 
which offence both were made to do penance by wearing white sheets during service one Sunday morning in the early part of this century. When the service was over Bryder had the wit to say to a byestander, still living in Billingsgate, alluding to the white sheets as surplices, and the unusual congregation, "that a many people came to church that day to hear the new parsons."

The superstitions of the Sussex aboriginal have generally some sensible tendency. For instance, it is supposed to token death within a year to you if you gather apples from a tree that has a blossom upon it : the object here being to protect the unripe fruit from young hands. Also to bring May-blossom (white thorn) into the house is forbidden, the object again being to save the fruit for the coming winter for the birds, a lesson of humanity that may have come from the Monks. In like manner, if your plough turns up a mouse's nest, you must stop it, or be undone. The Humane Society would doubtless support this last superstition. Some years ago a man, grubbing a fence near Compton down, pulled up an ash stump that disclosed a nest of silver pieces of the time of Queen Elizabeth, no doubt hidden there in the time of civil war. He ran away in terror, for to find a treasure signifies that you belong to Mercury, the god of death as well as the god of luck in the old pagan creed. Recovering himself he told the cause of his fear to another, who at once accompanied him to the spot, and the two soon shared the spoil. The love of money is stronger than any superstition.

The population of Harting has very slowly increased to its present size. In two years of the early part of the seventeenth century Harting would seem to be fast emptying if we take the following summaries in the Register for our guide :-

"From the 25th of March, 1612, to the 25th of March, 16r3, were- 
Christened-Children. . . 22 Buried-Persons . . . . 30 Married Couples . . . . 6 Mr. Thos. Carill,* Vicar."

"From the 25th March, I6I3, to 25th March, I6I4, were-

Christened-Children . . . 20

Buried-Persons . . . 3I

Married Couples . . . 6"

The burials in these years are nearly 75 per cent more than those of the present time; for the last ten years the annual average has been I 8, or I4 per I000. There are several entries in the old Registers which show a devouring mortality, many being buried together from one house. The small pox was the great destroyer. Still, judging by the number of deaths and the unusual bulk of the Registers, it must be allowed that for nearly 300 years it is probable that Harting has contained over 500 souls. Some even go so far as to calculate, from the antiquity of the majority of the houses that ten thousand children have been baptized in the venerable font of Harting Church. first :

The following are the results of the Census from the HARTING CONTAINED-

\begin{tabular}{|c|c|c|c|c|c|c|}
\hline Year. & Males. & Females. & Total. & $\begin{array}{c}\text { Inhabited } \\
\text { Houses. }\end{array}$ & $\begin{array}{l}\text { Uninhabited } \\
\text { Houses. }\end{array}$ & $\begin{array}{l}\text { Houses } \\
\text { Building. }\end{array}$ \\
\hline I80I & 451 & 412 & 863 & & & \\
\hline I8II & 504 & 443 & 947 & & & \\
\hline 1821 & $55^{8}$ & $5^{14}$ & 1072 & & & \\
\hline 1831 & 677 & 613 & 1290 & & & \\
\hline I $84 \mathrm{I}$ & 640 & 627 & 1267 & 238 & 5 & I \\
\hline 1851 & 660 & 670 & 1330 & 255 & 3 & o \\
\hline $186 I$ & 644 & 603 & I 247 & 264 & 7 & I \\
\hline I87I & 660 & 617 & 1277 & 255 & 10 & 0 \\
\hline
\end{tabular}

" The head of the family wrote his name "Caryll," as in a deed in my possession of 1627 . 


\section{Note in Census of I85I.}

" $182 \mathrm{I}$. The increase of population in Harting is attributed to the return of the poor to their own Parishes from the scarcity of agricultural employment." Subsequent figures, however, tend to show that since I82 I there has been genuine growth not due to any single or temporary cause. Probably this results chiefly from better medical attendance, wiser charity for the sick, and increased attention to the laws of health. There has been of late years no such epidemic, we may record with thankfulness to the Giver of Health, as that which carried off forty-two persons at Harting in the single year I 853 .

The following is a list of Nonagenarians in Harting since I 820 :-

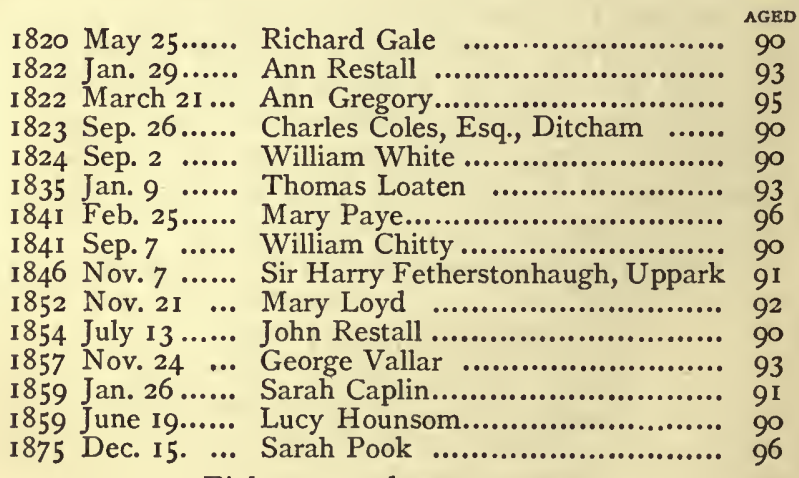

Eight men and seven women.

Oldest man living (I 877), John Love, 89; oldest woman, Sarah New,88; Mr.John Bowstead, Uppark, 88.

The meaning of old names is a dangerous speculation. It is with some tremor, therefore, that I append the following ventures:-

"Uppark," "Ourepark," or "Overpark" (I370), is evidently so called in distinction to the two lower 
parks, the old or "Middle Park of Harting" by the Church, now Mr. Brockhurst's farm, and the "Down Park" or "Netherpark" of West Harting lowlands.

"Lady Holt" is a name first occurring about the time of the Reformation. In the fourteenth century, Lady Holt Park is the "pasture of Eckenfield." The equivalent of Lady Holt, would be "the wood ('holt,' akin to German 'holtz') of our Lady." In that wild part of the parish, which was the scene of murders and haunts of ghosts, they would be likely to give a religious name by way of charm. So we have also "Hale or Holy (hallow, hallidome) wood," near Lady Holt, where a murder occurred, as mentioned before. The first mention of Lady Holt by name, is in the Deed of partition of the Manors in 1557, before the Carylls had settled at Harting. It is here called "Ladaies Holt." * In 1635, West Harting Survey describes (p. 169) "Ladie Holt Farm, late percell of $\mathrm{y}^{\mathrm{e}}$ Jointer (parcel of Lady Margery Caryll's jointure), contayneth a competent Farmehouse, two Barnes, and other outhouses, orchards, gardens, and gates, and nineteen enclosures.-24I A. : I R. Rent £40. Valor p. annum-£44 i7s. rod."

The suffix "holt" (raised, high, wood), once common, is now somewhat rare in Sussex, but appears in Hucksholt (once called "Gobbies," or "Holte Farm"), Alice Holt, Fleetsholt, West Harting, and Lady Holt. The name of Hurst also denotes woodland; and the preponderance of these forest names, such as Woodhouse, Padswood, Alderswood Pond, the ancient name for West Harting Pond, Maydenes dene or Maiden's grove, the dene being deep wood, still points to the extent of the old Harting timber-land. "Nywoods," in its most ancient form, "Nywode" (I349 and 1370), in its degenerated style, "Nere Woods," is a name

- "All those lands, teñts, pastures and woodes, called or knowen by the names of Westholte, otherwyse Ladaies' Holte, Baker's Holte, Fleet's Holte, Harehurst," \&c. 
that seems to be almost identical with "Nytimber," a hamlet of Pagham, near Chichester, also mis-called, "Nerw timber."

"Great Rivals" and "Little Rivals," the current names of fields and farm at Lower West Harting, near the course of the Midhurst and Petersfield Railway, have no connection with strife or rivalry; but are corruptions of peaceful "Ryefield." The word "Rye" anciently meant a ridge, heap, or mound. Hence, Rye the town in the East of Sussex, and with us the greater and lesser Ryefields, or fields of the ridge, and Black Rye or "Blackery" Pond, near Down Park, so named from a mound of peat.

The termination "Putt" or "Pit," meant a place dug out for shelter. So Lambput signified the place dug out for Lambs, now Lamputts, near the Down, East Harting. "Poppetts"- variously called "Poukeput" (1349), “Pokeput" (I 370), "Pulpitts" (1632), may possibly signify the Black Pit from Norman French Pochée. In addition to its mysterious name, Poppetts is singular in its localisation, and belongs to the Manor of South Harting, though firmly embedded in the West.

To judge of some of our names, one might think that Harting was laid out by our forbears as a map of the world. South Harting itself being the Metropolis, had its "Billingsgate," a venerable pleasantry for "Barn's gate," from the old Tithe Barn that once held 400 quarters of wheat per annum.

The rest of the parish contained other rude lessons in Geography. Thus, in West Harting, we have "Canada," "Clayhill," or "Quebec," now by a smash of both names (well known to the readers of the Author of "Alice in Wonderland"), "Claybeck:" on the North of the Downs the "Nores" or "Noahs," and at Huxholt Farm, "Northumberland:"* in the vale, "Bohemia" or "Bohemy hollow," sacred to gipsies: near our station and the Rogate sand, "The

- So called with reference to Huxholt or Ladyholt. 
Red sea :" * in the immediate East, "Turkey island." This dry island is a triangle or delta, formed by the sections of the East Harting Roads, and owes its name to the Turk's head of thorn or yew, anciently trimmed in its frontage. Similarly in Milton, a village in Oxfordshire, an old Turk's head of yew once matched the name of the neighbouring tavern, which still survives as the "Black Boy." There is a good example of a thorn "Turk's Head," opposite the pretty seat of J. V. Harting, Esq., at East Harting, to which he has given the revived name of Ladymead.

On the southern hills there is a field, next to Maindown, and north of it called "Cessan Beech Field." There was once a clump of trees here, visible in a remarkable picture at Uppark, by Tilleman, of the date of I720. Here, says Mr. Weaver, was one beech under which the Lord of the Manor was in the habit of receiving petitions or applications or complaints from his Tenants, on his road from Lady Holt to Harting. It is quite possible that this venerable tree, now long gone, was a representative of the old moot-hill and sacred tree, round which, in the first English villages, the whole community met to administer its justice and to frame its laws; where the field was passed from man to man by the delivery of a turf cut from its soil, and the strife of farmer with farmer was settled according to custom. $\dagger$ The field is still called in the Tithe Map "The Beech Field" (No. 799-about sixteen acres), though no Beech is there, and was just on the borders of the Caryll's property, as Maindown belonged to the Fords. Mr. Weaver would derive "Cessan Beech" from "Session;" but I think it more likely to be a Sussex slip for "Procession Beech," in connection with the Procession on Rogation days which walked the boundaries of the various Lordships. $\ddagger$

- Near Sandhill, G. H. Seward, Esq.

+ Green-History of English People, page 4.

$\ddagger$ “. . . a long spongge or p'cell of Mr. Cooper's land, lyinge 
In East Harting "Tye oak," if originally "Tryeoak," would exactly represent "trye" or choice, and be the "Fair Oak" of Henry the Eighth's time.* "Hampshire Farm" may very probably have designated what was once really part of Hampshire. Crossing our borders, Buriton, anciently Beriton, was the "town of bere or barley," as we had in Harting in I349, a "Berecroft" or "Barley-hill." Ditcham is the ham or place of the "dykes," the old mansion being on the lowlands. Rogate or Rothergate is so called from the Red River-the Rother.

One of the chief curiosities in the Parish is the great well in the chalk at Lady Holt. $\dagger$ It is remarkable that it is to a foot exactly of the same depth as. that of Carisbrooke; it has also, like Carisbrooke, a great wheel, formerly turned by a donkey. Its total depth is $240 \mathrm{ft}$. The wheel of Carisbrooke is $16 \mathrm{ft}$. in diameter, with a drum of $6 \frac{1}{2} \mathrm{ft}$. all made of chestnut; at Lady Holt the wheel is $12 \mathrm{ft} .8$ in diameter, and made of oak. The boring of the Lady Holt well, which is stained for $6 \mathrm{ft}$., is most beautifully regular and shapely, and few sights are more charming than that of the rapid descent of some tapers let down in a tin dish, the starlike coruscations of whichsometimes golden, sometimes blue, sometimes green, in short almost a rainbow-reveal everywhere the true circle till the water is reached, and a bed of $40 \mathrm{ft}$. of water too, even after a dry season. Two measurements were made for me by William Marsh, one on Dec. 6,1876 , shewing $40 \mathrm{ft}$. of water: the other on Jan. 27, 1877, after unprecedented rains, marked $82 \frac{1}{2} \mathrm{ft}$. The Foxcombe well had risen from $54 \mathrm{ft}$. to $84 \mathrm{ft}$. in the same time. There is a tradition that when the lavant breaks out at the New Barn on the

between ye Tumemere or ye pr.cession bounder of Hartinge and Mr. Cooper's close, called Doale Field." W. Harting Leager, 1632 , p. 105.

- See page 62.

$\dagger$ Lady Holt well was made by an old man named Tupper, 1702. Its new rope cost $\oint_{2}$ I9s. 6d. in 17 I 4 . 
road to Hurst in the lowland, it is the overflow of Lady Holt well, but this theory may be taken to represent popular respect for the deepest well in the neighbourhood. It is probable that the water in all the upper Harting wells is held up by the gault clay beneath the chalk, and not by the chalk itself. On June 7, I7 I4, Caryll, "The Squire," paid, aswe have seen, 2s. 6d. to his well-sinker Tupper, who made Lady Holt well, for fetching a dead dog "Emperor" out of it. History repeats itself: for in January, I877, a cat in play sprang at the rope, as the man was letting down the bucket, missed her hold, and falling into the depths below was drowned. Probably both accidents occurred in the same way.

Seven Wells of Harting Downs in Upper Chalk.

\begin{tabular}{|c|c|c|c|c|c|}
\hline & $\begin{array}{l}\text { Total } \\
\text { Depth. }\end{array}$ & $\begin{array}{l}\text { Depth to } \\
\text { Water. }\end{array}$ & Depth of Water. & $\begin{array}{c}\text { Dia- } \\
\text { meter. }\end{array}$ & Remarks. \\
\hline I Lady Holt Well & $240 \mathrm{ft}$ & $200 \mathrm{ft}$ & $\int 40 \mathrm{ft}$. Dec. $6, / 76$ & & Perfectly rour \\
\hline 2 Eckenfields ... & 200 & 162 & $\left\{82 \frac{x}{2} \operatorname{Jan}_{38 \mathrm{ft} .} 27, / 77\right.$ & $\begin{array}{lll}5 & 11 \\
4 \frac{1}{2} & \eta\end{array}$ & $\begin{array}{l}\text { Stained } 6 \mathrm{ft} \text {. } \\
\text { Shapely. }\end{array}$ \\
\hline $\begin{array}{l}3 \text { Down Place } \\
\text { (W. Whitehouse, Esq.) }\end{array}$ & $170 "$ & $137 \%$ & 33 & $5 \%$ & Brick stained. \\
\hline 4 Padswood ....... & $16 \mathrm{I}$, & I 46, & $15 \%$ & $3 \mathrm{ft} .3$ & $\begin{array}{l}\text { Brick stained. } \\
\text { Muddy at the } \\
\text { bottom. }\end{array}$ \\
\hline 5 Foxcombe ....... & I5I" & $97 "$ & $\left\{\begin{array}{l}54 \mathrm{ft.} 6 / 12 / 76 \\
84 \mathrm{ft.} 27 / \mathrm{r} / 77\end{array}\right.$ & $6 \mathrm{ft}$. & $\begin{array}{l}\text { Brick stained. } \\
\text { Sand at the } \\
\text { bottom. }\end{array}$ \\
\hline 6 Hucksholt ....... & I 35, & I I I , & $24 \mathrm{ft}$. & $4 "$ & $\begin{array}{l}\text { Oval at bottom, } \\
\text { and rough. }\end{array}$ \\
\hline $\begin{array}{l}7 \text { Deerkeepers' } \\
\text { Well, Uppark. }\end{array}$ & I 31, & 116, & $15 \%$ & $\cdots$ & $\begin{array}{l}\text { Very rough, and } \\
\text { through clay, }\end{array}$ \\
\hline $\begin{array}{c}8 \text { Harris Well } \\
\text { (Harehurst) } \\
\text { Lady Holt }\end{array}$ & dry & and & filled up. & ... & \\
\hline
\end{tabular}


The measurements of the well at Carisbrooke are said to be as follows :-Gross depth, $240 \mathrm{ft}$; t to the water, I $50 \mathrm{ft}$. ; depth of water, $90 \mathrm{ft}$.

In some places in this neighbourhood, owing to faults in the strata, it is impossible to sink a well successfully. Thus at the Rev. G. Tasswell's, Stonerhouse, near Petersfield, a shaft was driven to a depth of $200 \mathrm{ft}$. in the year I870, through Upper Greensand, but no water was reached. Here the gault clay was inaccessible.

On the west, the boundary between the Counties of Sussex and Hampshire is now said to pass through an oven at old Ditcham House. The survey of Sir Edward Caryll's land in I632, is not so particular on this point. "From the Lyth (i.e. the hill or 'Leith,' as at Selborne) $y^{e}$ said Bounder passeth Northward in $y^{e}$ Procession way or Tumemere (perhaps Tunemere or town-boundary, round which the procession walked on Rogation days), between $y^{\mathrm{e}}$ Parishes of Hartinge and Berryton aforesaid, directly without and neare $y^{e}$ west side of Mr. Cooper's (Cowper's) close called Dalefield and Ditcham House orchard, bounding this Manor Parish or Tything. From Ditcham Orchyard hedge Corner aforesayd or $y^{e}$ west end of $y^{e}$ crosse lane called Dole lane, leading to Richard Cobb's house, late Widow Lipscombe's, being $y^{e}$ Lords of this Manor." This last apparently is Hurst Farm.*

The Cowpers or Coopers of Ditcham settled there in the 15 th century, and always appear to have held other lands in West Harting. John Cowper of Ditcham was one of the Feoffees of Harting in I604, and from the interment of his family in the South Transept of Harting Church, that part of the edifice has been called "The Ditcham Aisle." A monument

- West Harting Leager. Bounds of West Harting Manor, page 70. "Total circumference of West Harting Manor I 4 miles, 7 furlongs, and 30 perches." 
with three effigies, remarkable for its elaborate dress, marks the spot. Dalloway says that Major John Cowper lost his life in Winton Castle in the service of King Charles the First, and was plundered and sequestered of all he had by the Rebels. The Cowpers were connected by marriage with the Lewknors of Leigh in Kent, Palmers of Parham, Unwins of Horton, Morleys of Halfnaked, Drewrys of -Watergate, Bolds of Nursted. William Cowper, "the celebrated anatomist," was the fourth son of Rich d. Cowper of Ditcham, who died I695, xt. 70. Richard Cowper is said to have purchased the estate of Paulett, co. Somerset, and to have become the ancestor of the Earls of Shaftesbury. The identification, however, seems

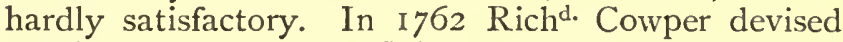
Ditcham to his cousin John Coles of Putney, whose grandson, Captain Cowper Phipps Coles, perished on board the "Captain" (I870), which foundered in the Bay of Biscay. One of his brothers, Colonel Coles, served with distinction in the Indian Campaign, I857; and another, Colonel Richard Coles, commanded the Ist Regiment (Royal Scots) for many years. The only surviving member of the ancient Ditcham family is Mrs. Hornby, wife of Admiral Phipps Hornby, K.C.B., Commander of the Mediterranean Fleet. The Ditcham Estates were recently sold to Chas. Cammell, Esq., the present proprietor.

Near Ditcham Lodge a young oak tree about seven feet in girth was struck by lightning in 1868 , and was apparently unhurt, save that a very minute fissure was seen in the centre of the bark proceeding from the fork, about five feet high, and running vertically down to the ground. On examination the tree was found completely split through as a child would split a hazel wand. The inmates of the house within a few feet from the tree were stunned, and on recovery, said that the lightening appeared blue.

On the road between Tarberry and Ditcham (Peters- 
field road) a double beech tree is passed near a stile called Pitt's stile, on the left-hand of a little hill on the Petersfield side of Tarberry. About six feet from the ground the divergence of the stems forms a natural bowl, so deep and so ensconced in shade that it is a never-failing well, there being always fifteen inches of water in it (Mr. Tickner assures me) even in the dryest summer. It may just be reached by a person standing on the stile: and Mr. Tickner says that in the recent Tichborne trial, it was stated that the putative Sir Roger used to lift up his dogs to give them water at this tree on the road between Harting and Petersfield. The present road, however, between Harting and Petersfield is new nearly to Hurst, and the late Sir Roderick Murchison used to say that for many years of his acquaintance with Harting, the carriage road to Petersfield lay through Rogate. It appears by the Parish Records that there were $24 \frac{1}{4}$ miles of roadway in Harting in 1845 . Now there are more than 30.

In 1782 the four bells of the Harting Church peal were recast, together with those of Westbourne, by Mears and Co., when an exact duplicate (a beautiful peal of six) was produced. The Church spire, anciently of shingle, was covered with copper about 1825 ; and the weathercock has served as a target for some wild riflemen, as appears by some holes in the metal on the north side, which can be detected by curious eyes. Sparrow heads and hedgehogs cost the Church rate in 1827 about $£ 5$. The Fast of 1808 , after Austerlitz, and the Prayer "Books for Peace," in I 813 , are duly chronicled in the old Vestry Book.

Some among us still remember the fear of a French invasion in the early part of this century, which was, of course, very sensibly felt here in the neighbourhood of Portsmouth and the South Coast. These good gossips tell, not without a thrill even now, how ovens were measured to see how much bread each village could bake, how waggons were appointed to take the 
women and children out of the way when Mounseer should come, and how one valiant Harting family (the Scardefields, ${ }^{*}$ former bailiffs of the Carylls) set to and drank all their wine, that the French should not have it. Mrs. Scardefield was a French Protestant refugee, and had probably seen how these things were done in France. About this time the military road behind Down Place was thrown up, an escarpment for cannon being still traceable. The Tower of Uppark had a peaceful origin-to commemorate the coming of age of Sir H. Fetherstonhaugh, 1778. It was burnt down in 1830.

The relief of $18 \mathrm{I} 5$ is still more vividly remembered. The children and old wives stopped at home to mind the house. Beer ran in the streets, and the men strutted about wearing gilt laurel leaves in their hats. The London coach road from Ramshill to Petersfield was illuminated.

In 1816 , before the purchase of Strathfield-saye, the great Duke of Wellington had some idea of choosing Uppark as the nation's gift to the conqueror of Waterloo. The late Duke of Richmond married a daughter of the first. Marquis of Anglesey in 1817; his mother, a daughter of the fourth Duke of Gordon, Duchess of Richmond, wrote to Sir H. Fetherstonhaugh (in I 816) asking him if he could find out whether "Sir Jervoise Clarke's place is to be sold, or Stansted, as she is anxious to have the Duke of Wellington in either of these places, which might be purchased for him out of the Grant made to him by the Nation."

- Mr. George White, tailor, is a descendant of the Scardefields. The name of Scardefield has disappeared at Harting in company with those of Sherlock, Crossweller, Chantrell, Argentyne, and Talenter. To the searchers for rare female names, the following from the old Registers may be interesting. Petronell (1605), Annice or Annis (common), Barbaire (Barbara), Sysley or Cicely, Phillis, Jellyan (Gyllean), Em. (for Emily), Margerye (Valour sert. and dr. in law to Rich. Rickman, I 584), Ozeman (1594). Boys names :-Myles, Eustance, Raynold and Raphe. 
This led to the Wellington Correspondence preserved at Uppark, in the course of which the Duke assured Sir Harry, "from all I have heard and know of Uppark, I should prefer to have that place to any other." The terms named were for the house alone $£ 90,000$; for the estate, exclusive of the house, " 30 years' purchase on a new valuation of the farms, and the timber at an additional valuation."

In conclusion, let me say that the compilation of the preceding pages has been a pleasant holiday task for the last thirteen years, and that the work, imperfect as I well know it to be, will have amply succeeded if it add in any degree to what was so near the hearts of many in all generations that have gone before us," and is felt at present by so many of her children far and near, the true love of Harting.

H. D. GORDON.

Feb. 3rd, 1877.

- For this interesting information I am indebted to Mr. Weaver. 


\title{
SKETCH
}

\author{
OF THE
}

dytural distory of dyatimg.

GENERAL FAUNA. 



\section{CHA P T ER I.}

\section{QUADRUPEDS.}

Although the area included within the three Hartings is very limited in extent, its richly wooded uplands, picturesque hangers and fertile valley, abound in natural productions; and the enthusiastic naturalist may here find ample scope for a life-long study of its Fauna and Flora. Indeed the subject is so comprehensive, that we may well be excused if we confess that we approach it with diffidence; fortunately, however, the numerous publications specially devoted to the several branches of Natural History are so easily obtained now-a-days, that we feel relieved of the necessity of attempting any formal description of the different species that may come under our notice, or of entering into the already published details of their history. We propose, therefore, to indicate briefly, some of the animals and plants which we know are to be found here, and taking them in their natural order, we shall introduce a few occasional remarks which may occur to us, and which we hope may not be deemed misplaced.

We commence with the Mammalia, and first on the list are the Bats ; our acquaintance with these remarkable animals is however so imperfect, that although the species may be more numerous with us than might be supposed by a casual observer, we can speak of three only,- the Long-eared Bat (Plecotus communis), the Noctule (Noctilinea altivolans), and the Barbastelle (Barbastellus communis). There may be, as we have intimated, several other species, but we profess to give those only which we have identified. In the day time, their season of repose, we find them 
occasionally in great numbers in holes in decayed trees in the Park, and in no one instance has the condition of their retreat appeared to us entitled to a favorable report from the Inspector of Public Nuisances. That of the Noctule is especially remarkable for a very unpleasant, pungent odour, arising from an accumulation of the deposits of the animal. The ease and certainty with which bats pursue and capture their insect food among the branches of trees and other impediments in the twilight, must have struck the least observant of Naturalists with astonishment, and the result of cruel experiments on the poor animals has led to the conclusion that they are not so much dependent on vision for this wonderful faculty, as on the extraordinary development of the nervous system in their wing membrane. A blind bat turned loose in a dark room, across which strings are stretched in various directions with rods suspended from them, is capable of winging its way among them for a long time without coming into contact with one! Those who have only seen a bat on the wing, would be amused with its performance on foot, on a flat surface especially its mode of progression is singularly awkward and laborious, it is more at home, however, in climbing a tree or a wall, and, curiously enough, it accomplishes this feat upside down. The female does not appear to be very prolific, often producing one only at a birth, probably never more than two, and, strange to say, the young cling to the mother from the moment of their birth till their power of flight is fully developed, never leaving her during the interval, whether she be suspended by the hooks of her hind feet in the usual attitude of repose, or actively engaged in her hunting excursions.

Night in some latitudes is said to disclose more beauties than it veils; but as applied to our temperate zone, this statement is not to be accepted without modification. In the autumnal months especially, on 
clear moonlight nights, a most harrowing note often startles the silence of our parks and fields. Many a solitary traveller on hearing it, has felt "each particular hair to stand on end, like quills upon the fretful porcupine," and has hurried home under the conviction that a deed of violence has been perpetrated on some "unprotected female." This note, which startles the unaccustomed ear as a sudden screeching yell, more easily remembered than described, is in reality the cheerful voice of the Vixen, or bitch fox! We have seen the animal in the act of uttering it in the open fields, and again heard it at intervals of a few minutes, gradually becoming fainter and fainter, until it was lost in the distance. Curious tales are told of the effect of this most discordant cry on many persons who never heard it before, but we refrain from repeating them. We need only add that from its frequency, we may reasonably conclude that foxes are numerous in our covers, indeed we have other evidences of this fact, as sundry owners of poultry and preservers of game willingly admit, and everyone in the parish knows that Reynard not only affords frequent sport to the patrons of the "Noble Science" who hunt the district, but now and then to some of them, an opportunity of technically "coming to grief!" Innumerable anecdotes, illustrative of the cunning of the fox are related, many of them no doubt highly coloured; but the following, which we have never seen in print, may be depended on, and if necessary, corroborated by one or more of the eye-witnesses of the incident here given, who are still living in the parish. At a battue in the Old Copse, many years since, a gentleman who was stationed in the Forty Acres at the edge of the cover, shot a hare, immediately afterwards a fox started out of the cover, deliberately made his way towards the game, "lifted" it, and bore it off in triumph. The gentleman referred to, being a well-known M. F. H., as well as a first-rate 
shot, enthusiastically cheered the fox with an energetic wave of his hat and a ringing "Tally-ho!" In those not very remote days, Foxes were very unscrupulously dealt with on similar occasions; and an old keeper who witnessed the occurrence, emphatically declared that this one "knowed a precious sight better than to turn up within shot o' e'er a one o' t'other guns," encouraged by such high authority therefore, we give the incident as an additional instance of sagacity or cunning on the part of the fox. With this brief notice of the crafty Vulpes vulgaris, we pass on to the other Ferce natura, and next on the list the Weazels claim our notice.

Of this sanguinary family we are acquainted with three undomesticated members only, the Polecat $(P u$ torius fotidus), the Weazel (Mustela vulgaris), and the Stoat (Mustela Erminea) - the first of which is very. rare. It is about a score of years since the last two. polecats of which we have any recollection were trapped here, and, to the person who incautiously skinned them in a very small unventilated apartment, they afforded ample proof of the fact that they had by no means degenerated in one at least of their family characters. It may not be generally known, perhaps not even suspected, that the insufferably offensive secretion of the polecat, if sufficiently diluted, is capable of affording to some olfactory organs a gratification little inferior to that derived from musk. It is, however, a fact, the discovery of which, like many other additions to our knowledge, was the result of accident. The knife which had been used in skinning the polecat was unintentionally wiped on a pocket-handkerchief, and imparted such an intolerable stench to it that for many weeks afterwards the least fastidious person would have found it impossible to apply it to its legitimate use without a feeling of unmitigated disgust. After innumerable washings and airings, however, it gradually lost this offensive character, and eventually 
became not only tolerable, but sufficiently agreeable to answer the purpose of a sachet in the linen chest ! The weazel and the stoat are found here in tolerable numbers, notwithstanding the attentions of the keepers. Like the polecat, they are very destructive creatures, killing many more victims than they can possibly require for food, their prey consisting of rats, mice, moles, and even birds, birds' eggs and frogs, to say nothing of hares and rabbits, the latter of which they regularly hunt by scent, sometimes singly, sometimes in packs. The fur of both the weazel and the stoat undergoes a change of colour in winter, but we have only met with examples of this in the stoat, which, by-the-bye, is only another name for the celebrated ermine. Specimens of stoats in their winter suit of yellowish white, the tail retaining its usual dark tuft, might have been seen not many years back in more than one cottage in the parish, and we once shot an individual in Park copse, in the early part of March, the head and cheeks of which were so thickly covered with enormous ticks, that it presented a very singular appearance.

The Badger (Meles Taxus), although no longer a member of our community, was not unfrequently found here in byegone years; and some persons are still living who may recollect that one individual of the species once took up its quarters in the Leith, from which place it paid frequent visits to the neighbouring pig-sties, a practice that indirectly led to its destruction. This occurred about fifty years since, and an old gamekeeper on the estate had the circumstance painfully impressed on his memory by a "scratch" from the tooth of the animal, which nearly cost him his arm!

The Otter (Lutra vulgaris) is not unfrequently met with in the Sheet river, and sometimes makes incursions in our Harting waters. In the autumn of I 873 a fine young one was killed among the sedge at the tail of the Great Pond, and since then other young 
ones have been seen by the keepers and other persons in the Pond itself-these were probably part of a litter that had been reared in the spring of the same year in the "Slips," one of the East Harting meadows, at a considerable distance from any large stream from which their supplies could have been obtained. In all probability, however, as their habitation was close to a large cover, their fare did not exclusively consist of fish, the otter being an expert hunter on land as well as in the water, and having no objection to a rabbit in the absence of other animal food. Buffon, in his "Natural History," appears to have drawn anything but a flattering picture of the otter in its young state, particularly dwelling upon what he terms its heavy, stupid expression, as contrasted with the appearance of the young of many other animals, and its awkward, sluggish movements. The accomplished author of "La chasse à tir en France," in a paragraph, of which we give the substance, protests against this libel of the great naturalist. "If I venture," he says, " to differ on any subject with so high an authority, it is because I have made independent observations on that subject. So far from the otter which I saw (a tame one belonging to a gentleman at Verdun) being awkward and sluggish in his movements, he was, on the contrary, particularly graceful and lively, reminding one of the activity of the squirrel. Playful as a kitten, he would twist and turn his lithe and supple body in all directions with the greatest ease and agility, more like a lizard than a less sprightly creature. It was a rare treat to see him gambolling with Don, a brown and white setter belonging to the same gentleman. The tail of this setter was very conspicuously tipped with white, and any white object was particularly attractive to the young otter. If a white handkerchief, for instance, were waved in his presence, he would immediately bound towards it, he would never even pass by a white stone without curiously examining it: it naturally 
followed, then, that in all his games with Don the white-tipped tail was the constant object of his attention. Don, taught by experience, would take especial pains to guard it against the otter's playful attacks, and the antics of the two, whenever they joined issue on this trying question, were for a long time ludicrous beyond description. At last the otter whose teeth were decidedly sharp, and whose notions of fair play were somewhat hazy, would succeed in getting the unfortunate tail in his mouth and making a very painful impression upon it. Don would instantly resent this, and the game was at an end for a time, but only for a time; after brooding a few minutes over their mutual punishment they would resume their playful exercise, and continue it till another successful attempt on the white tip brought it again to an abrupt close."

This young otter was an expert climber, and he never neglected an opportunity of exercising his skill in this way on the legs of any one he came in contact with, especially if said legs were encased in white stockings. On one occasion he had been fishing for his master in the Meuse, when a number of young school boys, who were out for exercise, were attracted by his appearance and stopped to watch him. One of them, unfortunately for himself, displayed an unwonted interval of white stocking between his shoes and the lower extremities of his nether garments, which he appeared to have considerably outgrown; this phenomenon caught the quick eye of the otter, who instantly dashed off with sportive intent towards the poor lad. The latter in the greatest alarm took to his heels and an exciting race between the two ensued; but it proved to be a very unequal one, and the owner of the otter was eventually obliged to interfere and rescue the white stockings from the muddy paws of his playful pet. If, at any future period of his existence, this youth should undertake to write the natural history of Lutra vulgaris, it may safely be 
predicted that he will never think of describing it as an "awkward, sluggish animal."

The common Mole (Talpa Europoea) is almost as common as the worms on which it preys. It is a wonderfully powerful animal, and as voracious and ferocious as it is powerful. Instances are on record of fierce and deadly battles between two males of this species, in which the life of one of the, combatants was sacrificed and his body partly devoured by the victor. The mole has so powerful a scent that dogs have often been known to "wind" it at a great distance, when its "run" was very near the surface; on East Harting Down we have more than once seen moles hunted and. caught in this way by a spaniel. We have somewhere seen it stated that the mole was once popularly known as "the little gentleman in black velvet"; this phrase had a political significance at the time, but the description is by no means inappropriate ; we have, however, seen more than one individual of the species to which it would not apply. We have never met with the orange-coloured specimens which the professional mole catcher so often promised to show us, but one was once caught in the park, the fur of which was of a light tawny shade on the upper surface, and gradually deepened to a reddish buff on the under side; another which we saw, was of a uniform dingy cream colour.

Another little animal, not much unlike the mole in its appearance and some of its habits, is the Shrew (Corsira vulgaris). Its food consists of insects, larvæ, and occasionally earth-worms, and, that it is not uncommon with us may be inferred from the number of dead specimens we find every autumn on the ground where there is nothing to conceal them. It gives out such a rank unpleasant odour that, although a cat will readily kill it, we have never heard of a cat eating one. This odour is not unlike a compound of garlic and musk, and may, not improbably, have given rise to the popular belief that the shrew is venomous. Not 
only is its bite considered by our fellow parishioners capable of producing very serious consequences to man and his domestic animals, but even simple contact with any portion of its body is dreaded. Fortunately for the present and future generations, our earlier Naturalists have left us simple instructions for the successful treatment of all genuine cases of shrew-bite - a live shrew, an auger, a plug of wood, and a sound growing ash tree, are all that is required for the purpose; a hole is bored in the body of the tree, the poor shrew securely plugged in it, and from that moment the branches and leaves of the "shrew-ash" acquire the wonderful property of neutralizing the venom of any number of shrews! Will it be needful to add seriously that the bite of this little animal is perfectly harmless to man?

The common Hedgehog (Erinaceus Europaus) is so well known here, that in the game preserves and poultry yards it ranks as "vermin," and, we believe, with some reason. It is a very voracious animal, and appears to be omnivorous ; it is said that insects, grubs, worms, larvæ, snails, eggs, milk, birds, young rabbits, vipers, snakes, lizards, frogs, fish, roots, and fruit are included in its ordinary bill of fare. The most wonderful fact in the history of this animal, is its power of resisting the action of the most deadly poisons ; prussic acid has been administered to it without producing the least apparent effect, baits seasoned with arsenic it will devour with impunity, and it is utterly indifferent to the bite of the viper. We give this on the authority of the Rev. J. G. Wood; but a contributor to Hardwick's Science Gossip informs us (Vol. II. p. I66) that "Battle's Vermin Killer" is speedily fatal to it. The Reverend gentleman's statement must, therefore, be taken cum grano; it is certain, however, that the action of prussic acid on different species of animals varies considerably. On one occasion we administered, on a small piece of sponge at the end of a wire, about 
half a dozen drops of prussic acid to a spaniel of the Goodwood race, and the effect, as a first experiment, was too startling to be forgotten in a long life time. The saturated sponge was gently introduced into the dog's mouth, which was held open for the purpose by a second person, and no sooner had the deadly poison come into contact with the mucous membrane of the gullet, than the animal, with a faint shriek, instantly fell paralyzed, to the no small dismay of the assistant, who had never heard of the possibility of so rapidly producing death by poison. A similar dose of the same preparation was tried a few days afterwards on the Great Noctule, but with a very different result. A few seconds after it had been given a perfect swarm of fleas languidly, and with difficulty, made their way out of the coat of the bat, and were actually dead before the animal they had infested. The latter resisted the action of the poison more than five minutes. More recently, we have seen a cat disabled in a very few seconds by a dose of prussic acid, but on opening its body twenty minutes afterwards, we found its heart in full beat. The quills of the young hedgehog are, as may be supposed, very soft at first and very thinly distributed ; they gradually harden, however, soon after birth, and in the course of a few months become much more numerous. We have often found their neatlybuilt nests, composed of soft dried grass and moss, thickly surrounded with dead leaves, among the fern, in rabbit burrows, between the roots of large trees, and sometimes in cavities in decayed stumps, and, in all cases, they appeared to be thoroughly weather proof, however rainy the season might have been. Those who have had the courage to cook and eat the hedgehog, assure us that its flesh is far preferable to that of the rabbit, though somewhat less delicate. It is said to form a favourite pièce de résistance with the Gipsies, whose recipe for dressing it is not to be found either in Ude or Soyer. After killing the 
animal, they surround the body with a tolerably thick coating of clay or loam, and, without further preparation, place it in a fire kindled for the purpose, which is kept up until the experienced "artiste" knows that the delicious morsel is sufficiently baked. When the covering is removed, with the skin and quills adhering to it, nothing more is required by those who are about to partake of the dainty, than that "digestion wait on appetite and health on both." Fragments of these casts have been more than once found on Bramstead Heath, near Kill Devil Copse, a favourite camping ground of the gipsies in our younger days, and have puzzled us not a little.

The brown Rat (Mus decumanus) is too well known to need more than a passing notice. It is a very daring, very wary, very prolific animal, and wherever there is an accumulation of animal or vegetable offal, it is undeniably a most useful scavenger, fully entitled to our thanks. It cannot be denied, however, that it is very far from being a general favourite, our allusion to it, therefore, will be limited to the simple assertion that in our larders, our hen roosts, our barns, and our hedge banks, it is much more "free than welcome."

The common Mouse (Mus musculus) is equally numerous with the last species, and although it is a much more gentle animal, its depredations in granaries, barns, and corn ricks, are sometimes very great. Everyone has seen the pretty Albino variety or White Mouse, exhibited in numbers by wandering Savoyards and intelligent organ grinders, and many persons have kept white mice as pets, but it has fallen to the lot of few to meet with an individual of the species, of any colour, addicted to musical exercises; yet we learn from good authority, that on one occasion a whole family of young mice vied with each other in their attempts to imitate the song of a canary, and that one of the number, whose organ of melody was probably more fully developed than those of its companions, eventually succeeded tolerably well! 
The Field Mouse (Mus sylvaticus) is another mischievous little animal, and very abundant in our gardens, fields and copses, where it burrows in the soil or under moss. We have many times explored its storerooms, and have been astonished at the result of its labour; it is not an unusual thing to find in one of these receptacles quite a large handful of nuts, which must have been brought from a distance of many hundred yards -in the middle of the park for instance. Nuts, however, are not the only stores laid in by the long-tailed field mouse. Towards the end of the summer of $187 \mathrm{I}$, a farm labourer, in ploughing up a patch of land in this neighbourhood, laid bare two nests of this species, and in each of them he found three ovate masses of a dark colour and a somewhat yielding consistence, which he gratuitously informed us were young truffles, but as the materials of which they were composed afforded evidence, to more senses than one, that they were derived from a locality where cattle "most do congregate," we at once suspected they were the cocoons of an insect. Three of them were about the size of thrush's eggs, and the other three smaller. We kept them through the winter, and the following season we had the satisfaction of ascertaining that they were the cocoons of Copris lunaris, a rare beetle with us, which we had never met with before.

The Harvest Mouse (Micromys minutus), which appears to have been unknown to Naturalists as a British species down to the time of Gilbert White, is not at all uncommon in our cornfields in the summer months, and our corn ricks in winter. Its more or less globular nest, which is attached to the corn stalks several inches from the ground, is composed of blades of grass reduced to the finest fibres in the interior, but coarser on the outside. At first it is constructed with a lateral opening near the top, and when the time for converting it into a "procreant cradle" has arrived, 
the young are deposited within it, the fibres round the opening are re-adjusted so as to completely close the structure, and the parent mouse is supposed to suckle her infant family through the interstices of the outer covering, which being of a somewhat loose texture, is sufficiently elastic to expand with the growth of the nurslings. The discovery of these nests is an every day occurrence in our harvest fields, and during the last week of the harvest of 1874, after all the wheat had been housed, we had no less than nine of them in our possession, these were cut out in three fields only, and as many more nests might have been obtained there in the same time if we had expressed a wish to have them. The full-grown harvest mouse is a very pretty lively little creature, very restless, very shy, very voracious, and, under certain circumstances, a decided cannibal, $\rightarrow$ of this latter fact we have had direct evidence this very season. A nest was brought to us containing one young one only, the others having escaped in the field, this we secured in a dormouse cage, and a day or two afterwards a full-grown female was caught and placed with it ; on examining the nest the next morning, we found she had left nothing of the young one but a few fragments of skin and bone! This discovery, however, did not lessen the interest with which we noted the dexterous use she made of her paws and prehensile tail, as she climbed over the bars of her cage, and her graceful attitude while cleaning her head and face with her fore feet; this she did regularly after her breakfast of bread and milk, to which she always applied herself very eagerly as soon as it was offered to her. Of the other food we placed within her reach, she seemed to give the preference to dry bread and grains of barley. One incident illustrative of her instinct may, perhaps, be worth recording: as soon as she had the cage to herself, she rearranged the materials of her nest with great care, and, before many days had passed, produced a young 
family, after which she neatly turned a kind of loose arch immediately under the opening in the roof of her nursery, through which the interior would otherwise have been visible from above.

The Water Vole (Arvicola amphibius), commonly called the Water Rat, is found on the banks of our streams and ponds; and it has the credit of being a much more harmless creature than the common brown rat. We had, until very recently, been under the impression that it subsisted exclusively on vegetable diet, chiefly aquatic plants and roots; and that, with the exception of its censurable habit of burrowing in the banks of the ponds, and a few unimportant pilferings at no great distance from its habitation, very little mischief could be justly laid to its charge. We have now, however, been assured by competent observers thàt water voles have frequently been seen to pursue and attack very young ducklings in the South Garden ponds, on the banks of which several of the aggressors have been shot. On one occasion an unusual commotion was noticed among a brood of the Decoy duck on one of these ponds, and the parent bird was seen to rise up in the air repeatedly with loud angry quackings, and pounce down on the water at some object that was only partially visible to the observers. This continued for several minutes, after which the excitement seemed gradually to subside, and the duck appeared to be engaged for some time longer in violently striking with its bill and shaking some dark-looking struggling mass under the surface; it then quietly rejoined its young family, which by this time had found shelter among the flags. The sequel may be anticipated, it was a water vole, about three-parts grown, and not a brown rat, that was left floating in a disabled state on the water where the conflict had taken place, and a retriever, belonging to one of the persons who had witnessed the extraordinary scene, plunged in and at once brought it to land, when it was identified beyond 
the possibility of doubt. These facts, and others of similar import which come to us from what we deem good authority, have somewhat shaken our belief in the innocence of the water vole, more particularly as nine or ten out of every successive brood of newlyhatched ducklings on these ponds (where the vole abounds) have regularly disappeared every season. Water voles are a favourite prey of the otter, and many dogs that will not touch a common rat, except to kill it and leave it, will greedily devour the vole; we have seen retrievers and spaniels do this repeatedly.

The Short-tailed Field Mouse, Field Vole, or Campagnol, is as common with us as the long-tailed Field mouse. We are under the impression, however, that among the scores of short-tailed mice that have passed through our hands there are two distinct species, Arvicola agrestis and $A$. riparia, but as they were all caught in one of the up-hill covers, and the home of the latter is said to be in low-lying wet pastures, we have some doubts on the subject. These little creatures are very destructive, and when they are numerous the havoc they make in underwoods and plantations is incredibly great. Not many years have passed since a number of them made a raid on the jessamine plants in the shrubbery at Uppark, which they very nearly destroyed on the occasion by barking the stems from the ground upwards to the height of four or five inches; but this was a trifling misdeed as compared to that with which they are charged in "Jessie's Gleanings." It is there recorded that in Dean Forest in Gloucestershire, and the New Forest in Hampshire, nearly all the young plants over an extent of many hundred acres were destroyed in one season by the Field mice, which swarmed there to such an extent that in Dean Forest alone, between the months of September and the following January, nearly thirty thousand were caught in holes dug in the ground for the purpose, but as it was calculated that a much 
greater number were trapped, poisoned, or devoured by cats, dogs, foxes, and birds" of prey, "the total destruction of mice in the two forests in question would probably amount to nearly two hundred thousand;" and of those that were actually "counted out and paid for by the proper officers" of the forests, the shorttailed mice outnumbered the long-tailed species in the proportion of fifty to one. It is not at all unusual to find the little compact nest of the campagnal among the herbage and wild plants in the Park, the covers and the low-land meadows. We once met with one in a decidedly swampy locality, within a very few yards of the stream running into the Great Pond, this was built of coarser blades of grass than those we had seen among the fern in the Park, but differed from them in no other particular.

The Hare (Lepus timidus) and the Rabbit (Lepus cuniculus) are not quite extinct within the boundaries of the parish, although unremitting exertions are made season after season to reduce their numbers. The hare is well known to travel a long distance in search of food, so that if all the hares on the Manor were to day killed "at one fell swoop," they would very shortly be succeeded by others from other localities. This, however, cannot justly be said of rabbits; their colonies are numerous in the Park and on the Downs, and their wonderfully prolific nature enables them to hold their own in spite of traps, wires, guns, dogs, ferrets, stoats, weazels, hedgehogs and foxes. Other means of destruction have yet to be resorted to for the purpose of subduing them, and we are enabled to state that the ingenuity of man has been already successfully exercised in this direction. Not many years since, in one of the Eastern counties, extensive works were carried on in a locality where rabbits abounded close to the sea-shore. The men engaged in these works, yielding to their natural instincts as sporting animals, hit upon a novel expedient in rabbit hunting, the idea 
of which, not having been secured to the originator by registration, may fairly be considered public property, we therefore feel at liberty to make it more generally known. In the absence of dogs and ferrets, they pressed into their service a species of crab which they found plentifully on the beach. Provided with a number of these unpromising animals, they sought the rabbit burrows and, by means of a lump of clay, or a spot of tallow, they affixed to the back of each crab an inch or so of candle-end, the bits of candle were then lighted and the astonished crabs turned into the burrows. As may be anticipated, the progress of the unwilling torch-bearers soon produced a startling effect on the rabbits-they scampered away in all directions, and in their endeavours to escape from the general illumination at their several "bolt-holes," fell an easy prey to their captors.*

The pretty little Dormouse (Muscardinus avellanarius) is tolerably common in our copses, and is probably the best known of our smaller Mammalia, it is so frequently kept as a pet. In its wild state it is wonderfully active among the branches and twigs of the underwood in which it resides, and we often meet with its well-built nest, round as a ball, in low thick bushes, and occasionally in a fork of a young hazel, five or six feet from the ground, in the covers and hedgerows. We have also met with their young in the early summer months, and again as late as October, so that they probably have more than one brood in a season. Nuts, when they can be obtained, are a favorite article of diet with the Dormouse; but when its winter store of these and other fruits and seeds is exhausted, it necessarily has recourse to other kinds of food, and one of its dainties in season at this time, consists of small bird's eggs "au naturel." In the beginning of June '7 I, a nest of the common wren,

- This was written in 1866 . 
containing six eggs, was discovered by a little boy near one of the entrances to the park. On the following morning a seventh egg was added, and a very few days afterwards the youthful naturalist made another discovery, notwithstanding the short time that had elapsed since the deposition of the last egg, he found the nest full of young ones! Such astonishing precocity on the part of the wren family, naturally puzzled the child's sister, who was old enough to appreciate such an unusual phenomenon. Assuming, therefore, that either the birds or the birdsnester had made some mistake, she examined the nest herself, and found it tenanted by a plump little Dormouse, indulging in a sound nap after having feasted on the eggs.

It scarcely need be said that we have no difficulty in finding the Squirrel (Sciurus Europaus), or that hunting the squirrel was a favourite pastime with the rising generation in byegone days. In later times, bordering on the present, dogs have spontaneously taken to the sport, and not far from the village there were two,--Rover, a spaniel, and Jessie, a retriever, that singularly excelled in it, each in his way. Those who have paid attention to the habits of the squirrel, are aware that when one is surprised feeding on the ground, he rears himself on his haunches at the least alarm to reconnoitre, and if the danger that threatens him appears to be very pressing, he bounds off with all speed to the nearest tree; but instead of making straight to the body of the tree, he invariably directs his course to one side or the other, so as to run up it in a spiral direction, and put the tree between himself and his pursuer. Jessie was as well aware of this as the most experienced naturalist, and instead of attempting to overtake the fugitive on the ground by running directly after him, he would dash round one side of the tree, while "Scug" was attempting to escape round the other, and in this way he has very 
often met his game at the back and brought it down. If, however, he failed to do this, and he very rarely did, Rover would then take up the hunt and, unless the foliage was very dense, would keep his eye upon the squirrel, where the branches were upwards of seventy feet from the ground, and follow him from tree to tree for many hundred yards, giving tongue all the while, until at last poor "Scug" was brought down by a shot. In extenuation of this tragic dénouement, we ought perhaps to add that the squirrel makes such sad havoc among the tender shoots of the chestnut and other trees in the spring, and takes so much more than his fair share of wall fruit in the autumn, that the owner of plantations and gardens, who strongly objects to these proceedings, necessarily has recourse to severe measures for checking them.

Rats, mice, hares, rabbits and squirrels, are known in works on Natural History as rodents or gnawing animals, from their four long chisel-edged incisors, two in each jaw. In the economy of the animals of this order, these instruments are made to perform such severe work, that if there were no provision for keeping up their efficiency, friction would soon blunt their sharp edges and render them comparatively useless. This contingency is effectually guarded against in two ways ; in the first place, the outer or front surface of each tooth is considerably harder than any other portion, so that the inner side is the first to be worn away and, as a natural consequence, the front plate of enamel always forms the cutting edge, the back portion being bevelled off by the opposing tooth. In the next place the teeth themselves are constantly growing, and this last fact sometimes leads to a very curious result. If by any accident the incisors are prevented from coming properly into contact with each other, so as to keep up an amount of friction proportionate to their rate of growth, they are gradually pushed forward till they protrude from the 
mouth like enormous tusks more or less irregularly curved. We once found the skeleton of a rabbit's head, in the upper jaw of which was an incisor that had grown so long and with such a sharp curve, that it might easily have been worn on the finger as a ring, and a squirrel was some years since shot in the shrubbery at Uppark with two of its incisors, one in each jaw, so curiously produced, that the person who picked it up was for a moment under the impression that worms were issuing from its mouth. Notwithstanding the great inconvenience which this animal must for a long time have experienced from the apparently utter uselessness of these most important instruments, with any but the most succulent food, its unusual weight, size and accumulation of fat, afforded good presumptive evidence of the efficiency of its grinders.

\section{CHAPTER II.}

\section{BIRDS.}

OUR list of birds is longer, but does not include any rare species among those permanently resident with us. We take them in the order and with the nomenclature adopted by MacGillivray, in his Manuals of British Ornithology, published in I840. The common Buzzard (Buteo fuscus) visits us occasionally, and in the summer of 1860 , nested in one of the high fir trees in the park, one of the parent birds and two of the young ones having forfeited their lives in the rash attempt to do their appointed work within gunshot of 
our vigilant keepers. Since then a wounded specimen has been picked up in the Westwood. The roughlegged Buzzard (Buteo lagopus) is still more rare, but one fine specimen was shot a few years back close to the park. In the winter of 1863-4, the Sea Eagle (Haliaetus albicilla) paid us a visit of several weeks, during which it had many a narrow escape from Walker's patent shot and the hands of the taxidermist; and in the year '24, a young specimen of the Osprey (Pandion haliaetus) was shot on the estate, and may still be seen in a glass case in Uppark House.* The Peregrine Falcon (Falco peregrinus) is met with much more frequently than either of the buzzards, but as an occasional visitant only. Several individuals have been shot or trapped in the neighbourhood, and are preserved in some of our local museums. The Kestrel (Falco Tinnunculus) and the Sparrow Hawk (Accipiter nisus), tho' "few and far between," are permanently resident here, and their eggs are met with every season in the deserted nests of Crows and Magpies. The Marsh Harrier (Circus anuginosus) pays us an occasional flying visit; and in the year '27, one adult individual was shot in one of the fields on Hucksholt Farm. The Brown Owl (Ulula aluco) and the Screech Owl (Strix flammea) are also permanent residents, chiefly frequenting the wooded parts of Uppark and Lady Holt Park, where they rear their families in cavities in old decayed trees. $\dagger$ The Long-eared Owl (Asio otus) is rare, but we have found its eggs in a crow's nest on West Harting Down, and now and then the bird there in winter. The Swift (Cypsehus murarizs), the Swallow (Hirundo rustica), the House Martin (Hirundo urbica), and the Sand Martin (Hirundo riparia), are punctual to their spring appointments, and return to their respective nesting places with us in great numbers. The

- This is now in the collection of the late Bishop Wilberforce.

+ We once found an egg of the Brown Owl in a rabbit burrow. 
"Jarring" of the common Goat-sucker (Caprimulgus Europous), of which Gilbert White has given us such an astonishing account, may be heard in all our woods any fine evening in the early part of summer, and its beautiful marbled eggs are frequently found on our downs as well as on West Heath, where they are deposited in a little depression in the turf or the soil without any nest.

The well-known Cuckoo (Cuculus canorus) generally announces its arrival about the middle of April, and in fine warm weather may often be heard "from morn to noon-from noon to dewy eve," and far on into the night. No fact in Natural History is better authenticated than the singular habit this bird has of neg-. lecting to build a nest of its own, and depositing its egg in that of another species. We have met with its egg in the nests of the Thrush, the Robin, the Hedge Sparrow, the Redstart, the Grasshopper Warbler, the Pied Wagtail, the Sky Lark, the Meadow Pipit, the Tree Pipit, the Yellow Bunting, and the Cirl Bunting; but it most frequently patronizes the Meadow Pipit and the Pied Wagtail and, as the latter is a familiar bird and frequents shrubberies and gardens, it is no uncommon thing to see a pair of them in the act of feeding the young cuckoo. In a garden in the village, a few years since, a remarkable instance of this came under the notice of a family occupying premises there. A pair of wagtails, having built their nest not far from the house, had successfully carried on the business of incubation, and in due time it became known to all the members of the family that the sole tenant of the nest was a young cuckoo. As they were much pleased with this discovery, they took every precaution to prevent the destruction of the interesting group, and the incredible labour of the wagtails in working out the task that had been imposed on them, astonished the observers not a little. At length the cuckoo left the nest, and an unforeseen difficulty at once presented 
itself. The old birds, hitherto accustomed to see their protégé only in his cradle, had no doubt underestimated his real bulk and dimensions, so that when he stood confessed a gigantic nursling, ravenously clamouring for food with enormous gape and shivering wings, they questioned his identity, and were actually afraid to venture near him. Each, with a dainty morsel in its bill, would alternately flit about from side to side and alight at a safe distance from the monster, eyeing him most suspiciously the while, and garrulously demanding of its companion an explanation of the phenomenon. At intervals one or both would hang on wing a few seconds in the air over the cuckoo, and take a "bird's eye" view of him; but for a long time every fresh appeal from the famishing one seemed to increase their perplexity. The dilemma might have resulted in serious consequences to the poor cuckoo, had not one of the wagtails, more courageous or more fertile in expedients than the other, after many feints and attempts, fairly settled on his back, and hastily dropped a supply in his upturned bill, the other after some further hesitation, followed the example of its mate, and in this way did they continue to feed him till he was able to cater for himself.

The Kingfisher (Alcedo Ispida) frequents our streams and ponds in small numbers, and not uncommonly rears a brood here. "Have you ever seen a nest actually built by this bird?" asks a local observer, copies of whose letters are before us. "The circumstance which induces me to put the question is this: during the spring of ' 53 , I directed the attention of some farm labourers to a pair of kingfishers, which I had seen more than once frequenting a brook at Down Parks, and in a few weeks afterwards was much pleased at receiving a message from one of them to the effect that a nest had been found. I lost no time in going down, but what was my surprise when, after having been conducted into a barn close by the brook, 
I was assured by my guide that a kingfisher had several times been seen by himself, and the other labourers quietly occupying a nest that was pointed out to me in the thatch close to the Ridge-pole. I soon climbed up to the spot, and found a simple cavity lined apparently with moss, but containing no eggs. I then perceived that the bird, in order to find its way to this nest, had to pass entirely through the thatch on the opposite side of the ridge, and the hole which it thus converted into a passage was such as might have been made by a rat. I am sorry to say that this eccentric trait of the kingfisher had no further consequences, as far as my observations extended; but my informant being an intelligent man and worthy of. belief, I think it right, as a humble admirer of Captain Cuttle's systematic mode of dealing with remarkable discoveries, to 'make a note of it.' The kingfisher's eggs, which I have recently become possessed of, were taken from an excavation in the bank of a stream. They were seven in number, and with them was brought quite a museum of fish bones, so many indeed, that the accumulation of them must, I fancy, have been the work of more than one season. I suspect they were the rejectanea of one or more broods of former seasons. They consisted chiefly of gill-plates and vertebræ, with a few shells of aquatic molluscs and wing-cases of small beetles; but I could not detect any scales among them. Some years ago I had an opportunity of examining one of these habitations, in which I was told a brood of young had been reared, and found scarcely a vestige of their family records in the neatly rounded extremity of their burrow."

The Red-backed Shrike (Lanius collurio) is sparingly distributed among the few hedgerows that are left, and the Grey Flycatcher (Muscicapa grisola) is generally dispersed in our woods, orchards and gardens. The Raven (Corvus corax) rears a family with us every 
season, and is permanently resident, as the following extract from a letter written some years since will show :-

"I have a strong suspicion that the raven-our raven-was rehearsing his love song on the morning of New Year's day. The weather was not very inspiring certainly, as you will perhaps have no objection to admit when I tell you that it was under cover of one of the densest of cold fogs out of London, that I approached the foot of the tree on which he was soliloquizing. I remained an unsuspected listener for some minutes, during which I had an opportunity of convincing myself that the raven really had 'music in his soul.' 'From the date of this discovery, that immortal bird of the fable stands excused in my estimation for having, under a sudden impulse of pardonable vanity, yielded to the insidious flattery of the fox; and I very sincerely regret that he should have sustained so severe a loss as he is recorded to have done on the occasion. I think, however, the raven of my acquaintance, notwithstanding his vocal talents, would have behaved with more discretion; he is unequivocally shy of every member of the canine family, otherwise I might have heard more of his song than I did ; but an unlucky repetition which he made of a short monosyllable in falsetto, resulted in such a correct imitation of the bark of a dog, that one of the spaniels my companions, took umbrage at it, and the vocalist instantly took flight.

"In a work recently published, 'Murray's Handbook for Kent and Sussex,' it is stated that the only pair of ravens in this county is at Parham Park, this is an error, and for the honour of this favoured spot I can fearlessly assert against all comers that the ravenhood of Uppark is a time-honoured institution, the origin of which is only to be guessed at, and may, for aught I know, date from the days of Gilbert White, or a more remote period. At all events it is a fact familiar to almost every person of observation hereabouts, that 
the parent birds year after year send their young families out into the world vi et armis to seek their fortunes. Last year it was long past Midsummer when this annual event took place, and, as it involved no small amount of angry demonstration and unmusical croaking evening after evening among the trees nearest the house, I was a frequent witness of their domestic squabbles long after twilight had marked the close of 'parting day,' and more exemplary birds had retired for the night. With the last generation of keepers the ravens bore but an indifferent character: they were deemed guilty of frequent infringements of the Game Laws, especially that of helping themselves liberally to pheasants' eggs-poaching them in fact. As a natural consequence a war of extermination, extending over many years, was waged against them, and in those days many an unlucky raven, old as well as young, was sacrificed; but it is as well and as widely known here as any other fact in Natural History, that the survivor of the pair, after disappearing for a time, invariably returned with another partner. A few years ago I took their eggs, but in an incredibly short time afterwards they had another nest not two hundred yards from their favourite clump, and succeeded in rearing their young-so that it would seem to be a difficult affair to expel them, even if such an enormity were now attempted; but I am happy to say that the lady of these acres will not allow them to be molested on any consideration whatever-accordingly, she is rewarded every spring with the satisfaction of seeing how jealously they guard their clump at nesting time.*

- Alas! the kind-hearted Lady here referred to, the late Lady Fetherstonhaugh, ended her exemplary life in January, 1874, some years after the above sentence was penned. Her gentle memory is fondly and justly cherished by those who knew her best, and would most assuredly be more generally appreciated than it is, if her numerous acts of benevolence and charity had not been too unostentatious to be as widely known as they deserved to be. 
I myself have watched them year after year, as they swooped down, with right good will and many angry complaints, among the chattering jackdaws that ventured to intrude on their privacy.

The note of the Carrion Crow (Corous Corone), easily distinguished from the rich croak of the raven and the caw of the rook, is heard here occasionally throughout the year, and its nest is frequently found with us; but very few individuals escape the fatal attentions of the keepers. Its congener, the Hooded Crow (Corvus Cornix), now and then pays us a visit, but does not meet with a more kindly reception.

To say that our rooks are innumerable is almost superfluous, as everyone is familiar with the fact that in autumn and winter the "music of the woods" is supplied almost exclusively by them, in concert with the jackdaws, and that there are several well stocked rookeries within a few miles of each other, two of which are in the Park. This useful bird (Corvus frugilegus) in a state of maturity is destitute of feathers all round the base of the bill, from which peculiarity it is known in some works on Ornithology as the "Barefaced "Crow. It will not be difficult to show that he is equally barefaced in another sense. Till within the last few years, it had been a question with preservers of game hereabouts, whether the rooks were or were

- In the early part of 1866 a furious hurricane from the southwest passed over the country and uprooted hundreds of trees in the Park. Unfortunately one of the latter in its fall crashed into the very tree in which the ravens had established their home. The destruction of their nest under such startling circumstances was the last $d r o p$ in the cup of the poor birds, whose ancestors had experienced and disregarded the persecutions of keepers and others for so many generations-we have never met with their nest in the Park since. It would seem, however, that even now they are not quite proof against the charm of old associations, as they have more than once paid us a visit extending over two or three days, and their rich mellow croak, as they loudly remind each other of the past, is still occasionally heard in their old familiar haunts among the beech woods. 
not destructive of pheasants' eggs, now, however, the closely-trimmed hedge banks, with their occasional fringes of quickset, have settled the question with a vengeance! The pheasant will too often select a very exposed situation for its nest, and when it begins laying before the leaf is expanded, as it generally does, there is nothing out of the covers and hedgerows to conceal the eggs from prying eyes, not even " a friendly crop of weeds;" the consequence is that the rooks have yielded to temptation, and in carrying out "the good old rule-the simple plan, that they shall take who have the power," they have latterly devoted much more of their attention than they formerly did to this source of their supplies; and they have actually learnit to beat along every hedge bank so systematically and perseveringly, that a pheasant's nest must be very cunningly concealed indeed to escape them. A hundred and thirty eggs and upwards have been known to be thus discovered and carried off by the rooks, in three or four fields where the fences are trimmed within strictly agricultural limits; and a few years ago a rook, whose photograph ought to have found a place in every keeper's album, was absolutely seen to take an egg from under an unresisting hen pheasant, as the latter was sitting on her nest, which the impudent thief was known to have visited before. Another instance of this, in an aggravated form, occurred no longer ago than last spring, when a rook was seen to alight on the back of a pheasant in. her nest and violently tear out her feathers with his beak till she fled from her assailant, and of course left him to help himself leisurely to her eggs.

Next in point of numbers, as well as in ornithological order, comes the cunning Jackdaw (Corvus Monedula). This is a very common bird here, and it would appear that nearly every individual in the parish makes his home in the Park; some of the reasons for this may be gathered from the following extract from a letter written in 1860 . 
"Our beech trees are for the most part so far past their prime, that they are in a condition to afford excellent accommodation in the nesting season to our resident jackdaws, as well as to many of their friends and connections, who are not slow to perceive the eligibility of the locality, indeed, so very numerous are they at this time, that their frequent raids in the surrounding gardens have brought them into exceedingly bad odour with those heads of families whose frugal aspirations have a special object in abundant crops of peas and beans. To remedy this unsatisfactory state of things, nothing has been deemed more effectual than an occasional 'exhibition' of No. 5 shot, and this involves a greater amount of difficulty than a stranger, casually strolling through the wood they frequent, and not carrying a gun, might suppose.

"Towards the end of April, when they are engaged in exploring and selecting their nesting places, or desperately fighting to retain possession of them, I can occasionally get a shot at them by cautiously approaching the trees in which they have established themselves, and Rover, who most astonishingly remembers from year to year where they lodge, and invariably directs his attention to every tree in which a hole is visible, has more than once been just in time to settle a dispute among them by a decision against which there is no appeal. One morning this very last spring, for instance, he might have been seen anxiously endeavouring, by repeated bounds up the mossy trunk of an old tree, to reach a hole some twenty or thirty feet high, in which a noisy conflict was going on, and at the same time he was making the wood resound with his impatient summons to the invisible combatants to make their appearance. After disregarding his invitation for some time, they at length emerged from the hole, when their individual and collective appearance, not only betokened their power to 'disguise fair nature with ill-favoured rage,' it also afforded indisputable evidence of the fact that they 
had been struggling in a cavity half full of water. Their wings were so clogged with wet and dirt, that three of the number came fluttering helplessly to the ground, and only one escaped to tell of the fate of the other two. After the adjustment of these differences, other contingencies, incidental to the important business in which they are engaged, have to be met, and their arrangements directed to this end are very efficient, their vigilance especially is very wonderful. While one of a pair is engaged in the hollow of a tree, the other mounts guard among the branches above, and, at the least evidence of danger, sounds a note of alarm so expressive, that even to me, who am unversed in jackdaw dialect, it is sufficiently intelligible, and, of course, the object of solicitude instantly escapesliterally 'hops the twig.' After the labours of the day, they frequently congregate on the tree tops in small detached parties to pass the evening in social chat; if, when they are so engaged, I endeavour to approach them with the gun, I scarcely need say that they very provokingly repel my advances, and melt into thin air, right and left, as I proceed. How often have $I$ at such times seen one of the fugitives, after a short flight, suddenly turn back and make a hurried circuit high above the tree he had just left, to give a friendly warning, repeated again and again if necessary, to an individual that had imprudently remained behind! How frequently, too, have I been amused at their behaviour when they are collecting their building materials. Just at that time of the year when the fallow deer is doffing his winter suit to assume a new one-technically 'shedding his pens'the jackdaw finds it convenient to appropriate the rejected materials, as the best he can find in sufficient quantity, for the lining of his nest, and his proceedings on the occasion are characterized, in some individuals at least, by a singular absence of ceremony. Not content with the scattered tufts, which with a little 
industry he might collect from the trunks of trees, the fences, or any other object against which the deer has been rubbing himself, he actually has the supreme effrontery to tear off fragments of the worn out coat from the very person of the owner, the latter, meanwhile, calmly watching the process of denudation as if it really ministered to his comfort. It is not unusual here in the nesting season to see from the drawing room windows, several jackdaws at a time busily engaged on the backs of the deer, as they leisurely chew the cud while basking in the sunshine, and it is only when three or four of them, alighting on an old buck, pick a quarrel with each other and try conclusions on the spot, that they get a gentle admonition from one of the horns of the animal. For several seasons a pair of stock doves had occupied a spacious cavity in an old beech tree in the park, and probably succeeded in rearing their young there, but on examining the tree this season, I found it tenanted by a pair of jackdaws, and as the interior was very wide and deep, they had resorted to a most ingenious expedient for excluding any intruder larger than one of their own species, they had defended the entrance with a perfect chevaux de frise of sticks, leaving an aperture just large enough for the passage of one bird, the nest and eggs being a foot or eighteen inches below. Among other curiosities of my nesting experience, I am tempted to mention another jackdaw's nest, which was built in an old disused chimney. The sticks which formed the foundation of this bulky affair were so judiciously selected for their length and strength, placed so horizontally, and fitted in to such a nicety, that it was exceedingly difficult, almost impossible, to remove them without breaking them, and the effect might naturally have suggested the idea that among the first measures taken by the architects, when about to erect their mansion, the importance of duly testing the timbers on which it was to rest was not overlooked by them." 
More recently we have met with an instance of such astonishing perseverance exhibited by a pair of these birds in their labours of nidification, that we cannot refrain from adding it. A thatched and ivied cottage on the Uppark estate had been untenanted and undisturbed for several months during the year 1868 , and in the following spring preparations were made for putting it in substantial repair for the reception of a future occupant. A hundred years back it was a farmhouse, chiefly remarkable in its internal arrangements on the ground floor, for its primitive and spacious fire-place, totally innocent of grate or any other modern innovation, and this with its characteristic chimney corners, still occupies nearly the whole of one side of the apartment. On entering the cottage towards the latter end of April, the workmen were surprised to find this wide space completely choked up with sticks, twigs and scraps of wood, and on looking up the chimney, they found that this also was crammed with similar materials from bottom nearly to top. It was evident that a pair of jackdaws had projected an establishment in the chimney, and, in endeavouring to carry out their intention, had failed at the outset to appreciate the very serious engineering difficulty, considering their limited resources, of lodging their nest inside the upper part of a perpendicular shaft gradually widening downwards. Nothing daunted, however, by the repeated subsidences which their treacherous foundations must have undergone, they had persistently continued the accumulation of building materials until, as we have seen, the lining of the nest when completed would have rested on a pile of scraps some fifteen or sixteen feet high! Assuming all this to have been the work of two birds only, we look upon the result as a very astonishing one; but if the jackdaw is not an exception to the general rule, that the hen bird takes upon herself exclusively the business of nidification, it is quite wonderful. With 
every disposition, however, to make the most of this curious incident, we cannot ignore the probability that two or three rival pairs of these birds had been engaged in the performance, and if so, the valour of the first comer must have been often and sorely put to the test in the defence of his hearth and home.

The Magpie (Pica melanoleuca) and the Jay (Garrulus Glandarius) are important and beautiful members of our feathered community, and would no doubt be more numerous than they are in the woods and covers, if they were capable of disregarding the allurements ostentatiously thrown in their way by the keepers. For the jay particularly they are careful to erect, in a conveniently open part of the underwood, a small platform supported by slender rods, on which they know how to conceal a gin baited with eggs of the blackbird or thrush. This device has naturally been suggested by the jay's well-known habit of plundering the nests of smaller birds, and many an innocent "squab" has it been the means of saving from a premature end. Every one knows that both the magpie and jay, when tamed, are frequently taught to articulate words and sentences more or less distinctly; the latter bird especially, even in an undomesticated state, has so often been heard to imitate the notes and cries of other birds, that by some naturalists it has been called the "British Mocking Bird." In the Starling (Sturnus guttatus), which is another of our commonest birds, this talent is remarkably developed also, and we have heard it almost daily and at all seasons, with the exception of a short interval in winter, introducing into its own apology for a song variations from the rook, the jackdaw, the blackbird, the thrush, the house sparrow, the yaffle, the lapwing, and, occasionally, the whistling donkeyboy. It is no uncommon thing to meet with highlyeducated starlings capable of whistling one or two simple airs in a very pleasing style; but perhaps many 
of those who have heard them do so, have yet to learn that these docile birds are not only remarkable for their musical talent, but for their proficiency in languages also, and even their classical associations. We extract the following from the Article on Starlings in the Cyclopædia of Natural History:- "Their aptness to imitate the sound of words was not unknown to the ancients, for Pliny alludes to the starlings which were trained for the amusement of the young Cæsars, as being capable of articulating both Latin and Greek." Again, "It is mentioned that when Monsieur Gérardin visited his friend, Monsieur Thirel, in Paris, he was agreeably surprised and astonished by hearing a starling articulate a dozen consecutive sentences, with the same precision as if they had been spoken by some person in the next room; and when the bell rang for mass, the same bird called to its mistress by name, 'Mademoiselle entendez-vous la Messe que l'an sonne? Prenez votre livre et revenez vite donner à manger à votre polisson'-'Miss, do you hear the bell ringing for mass? Take your book, and make haste back to feed your saucy pet." " An accomplished individual of this species not long since died in the kitchen department at Uppark, after having entertained his mistress with his little eccentricities for the long period of thirteen years.

The Ring Ouzel (Turdus torquatus) visits our downs in October, on its way to its winter quarters, and again in April on its return; but no well authenticated instance of its nesting here has come to our knowledge. Of the Blackbird (Turdus merula), the Missel Thrush (Turdus viscivorus), and the Song Thrush (Turdus musicus), we have quite a different tale to tell, the numbers of the blackbird and the song thrush, especially are proof against every thing but a severe winter. From a letter written in 1859 , of which we possess a copy, we extract the following :- "blackbirds and thrushes have been and still are innumerable, and 
so persevering have been their attentions to the fruit trees, that the most grotesque scarecrows in the orchards and gardens have been laughed to scorn by them, as indeed they richly deserved to be ; and with reference to the wages to which these birds may consider themselves entitled for useful labour performed by them at other seasons, they have most unscrupulously taken the law into their own hands. I know of many a cherry tree which last spring blossomed and fruited for these pilferers alone, I have seen many a currant tree, many a gooseberry bush, that at one time gave promise of a luxuriant crop, totally deprived of the power of keeping that promise, as far as the owner was concerned, by these wary depredators. It is impossible to walk a field of turnips, or beat a hedgerow, or a patch of fern in the park, without putting up quite a 'bouquet' of them at frequent intervals, in short I never before knew them to be swarming as they are now, and I never before saw so many of their eggs and such a variety among them as I did during their last nesting season. Many a mile have I walked for nests and eggs, which I had been urgently requested to believe were neither blackbird's nor thrush's, tho' something like both, and which I once or twice faintly hoped might prove to be the ring ouzel's; but which, after all, were only varieties of those of the former birds." We have only to add that albino and pied specimens of the blackbird, have not very uncommonly been met with here; and a beautiful dovecoloured variety of the thrush, which was shot on the estate, is still preserved somewhere in one of the villages. The Redwing (Turdus iliacus) and the Fieldfare (Turdus pilaris) are our guests, in numbers varying with the mildness or severity of the season, from about the middle of autumn till the following spring.

The pretty little Hedge Sparrow (Accentor modularis) is never absent, and often favours us with its cheerful song, even when the gardens and fields have "put on 
their winter robe of purest white." It is needless to say that the ubiquitous Robin (Erithacus rubecula) is as familiar with us as elsewhere, and may often be seen studying horticulture under the very eye of the practical gardener, when he is engaged turning the soil in early spring. To snatch a hasty morsel within a yard or two of the spade and disappear with it, is not at all an uncommon feat in the practice of the robin. Every school boy knows where to look for the nest of this bird, and can readily identify its eggs when he finds them; but sometimes they puzzle more finished Oologists. In one or two localities in the parish, perfectly white eggs of the robin have been found repeatedly season after season. The song of the robin is as well known as the personal appearance of the bird, and any allusion to it might be deemed superfluous; but we have seen a few lines on the subject which we are tempted to quote. "This season (I 86I) I have had an opportunity of making a curious and unlooked for addition to my Ornithological experience. Every fine day since the latter end of September, I have heard a very unusual note of a small bird, always on or near the same tree, and for a long time I was under the impression that the often quoted 'occasional and rare visitor' was among us at last; but after many attempts to get a sight of the bird and many failures, I succeeded last Thursday in bringing him within the focus of a first-rate Voigtlœnder, when the prospect of addressing 'Mr. Editor, of the West Sussex Gazette,' on the discovery of a species new to this locality, at once resolved itself into a blank! The highly gifted and punctual assistant in the dairy and poultry department here, possesses the rare faculty of producing between his front teeth a shrill melody of an original, and I should think, indescribable character; and it is chiefly when he summons the half-dozen cats on the premises to dinner, that he exercises his musical talent in this 
way. The series of notes that have so long been exciting our curiosity in the shrubbery, are a rude imitation of this cat-call, and the common robin is the author of the not very discreditable performance."

The Whinchat (Fruticicola rubetra) is one of our summer visitors, but is comparatively rare within the parochial limits, altho' it is met with in greater numbers in surrounding localities. The Stonechat (Fruticicola rubicola) is a much more common bird, and not only nests among the heath and furze of our downs, but may often be seen throughout the winter perched on the top of a bush, and uttering, with a jerk of its wings and tail, its well known note, which more resembles the sound produced by striking two pebbles together than anything musical. The Wheatear (Saxicola onanthe) is thinly dispersed on our downs during the summer months, and often selects a hole in a bank for its nesting-place. In allusion to this bird, our local observer gives us the following note :"From a hole, resembling a rabbit burrow, in a chalky bank, I one day saw a wheatear make its exit, and on exploring the interior I found a nest containing one egg. Just beyond it my hand came in contact with a cold clammy yielding mass, which puzzled me for an instant, but under a little further examination with the tips of my fingers, and a not very exhausting mental process on my part, it gradually resolved itself into a full-grown toad, in the enjoyment, as I trusted, of robust health.' I had no doubt he had travelled thus 'far into the bowels of the land,' and established himself in his hermitage uninfluenced by any other feeling than the wish for solitude under cool and humid circumstances, before the birds had laid the foundation of their rest, so that his occupation of the same dwelling with them must have been accidental; but it would also appear to have been very peaceful, as he retained his position close to the nest from the day I first came in contact with him, until 
his companions had obeyed the universal law to the extent of adding half a dozen full-fledged individuals to the feathered community." The flesh of the wheatear is almost as highly esteemed here as that of the Ortolan in France, or the Beccafico in Italy; and at the period of their autumnal migration, a great many of these birds are noosed on the downs in the neighbourhood of Brighton.

The Redstart (Ruticilla phonicurus) is widely but sparingly distributed, and its nest and beautifully delicate blue eggs, to the number of six or seven, are found in old ivied walls in gardens, or in a hole or a fork of a tree, sometimes even on the ground under heath. For several seasons in succession, it has been known to make its home and rear its family on the plating of a wheelwright's shop at Uppark, within a few feet of the block on which the heaviest work was carried on day after day. An unusual speckled variety of its eggs has been taken in the park and on West Harting down, on three separate occasions. These eggs are still in existence, and are not the least curious specimens in a collection which has been made for the purpose of illustrating the Oology of Harting. Incidentally, however, other curious eggs have found their way into this collection, as the following extract from some copies of letters in our possession will show :- "As one instance, among many that I could give you, of the interest taken in Oological pursuits here, I may mention the fact, without I think being guilty of making an indiscreet revelation, that when visitors have been staying at Uppark, I have more than once been requested by them to exhibit my collection. On one of these occasions when, in deference to a drenching downfall of rain, the gentlemen had postponed their operations in the field, an incident took place that may perhaps be worth relating. One of the party, an enthusiastic sportsman, whose Ornithological studies had probably been 
limited to the stubbles in September, and the covers and hedgerows the remaining months of the shooting season, banteringly challenged me to show him an egg which he would be unable to identify. I accordingly ventured to test his Oological skill with a specimen I had not long before received from Valparaiso. After having feigned a long and critical examination of it, he with a meaning smile, pronounced it to be a ... hen's egg! I shook my head dissentingly as if it were utterly impervious to the joke, which in truth was obvious enough. 'Not a HEN's egg!' was his exclamation of unmitigated surprise. 'No,' I replied. Glancing archly at the company, who with the delicacy of good breeding were endeavouring to suppress a smile at my apparent simplicity, he deliberately repeated, and with increased emphasis. - 'Not a HEN'S egg!' 'No.' 'Well, that is odd! Isn't this a hen's egg ?' pointing successively to several eggs in the collection, 'and this? and this? and this ?' To each of which questions I of course replied in the affirmative. 'And yet you wish me to believe that the one I hold in my hand is not a hen's egg!' 'You have most accurately represented my meaning,' I said. 'Well then,' he persisted, 'I should like to know by what process of reasoning you can make it appear that it really is not a hen's egg.' 'By simply assuring you,' was my final answer, ' that it was laid by an alligator!!' I may add that the laugh this time was in my favour, and that the astute Oologist who had conducted the enquiry, joined in it as heartily as the rest of the company." Our Ornithological reminiscenses extend over a period of perhaps thirty years, be the same more or less, as the lawyers say; and during that time two specimens of the rare Black Redstart (Ruticilla tithys) have, to our knowledge, been shot in the parish. We also suspect that other individuals of the species have been seen here, from the fact that a few years since, two or three juvenile naturalists were on one occasion in eager pursuit of an alleged Black Robin. 
The Nightingale (Philomela Luscinia) visits us in great numbers, and is generally distributed; but it appears to prefer the damp woods and groves of the valley to the upland covers and hedgerows. The nest is a somewhat massive structure of dead leaves (chiefly oak), and the eggs very much resemble those of the pheasant in colour. Of our Warblers, which arrive about the same time as the nightingale, the Garden Warbler (Sylvia hortensis) and the Black-cap (Sylvia atricapilla) are so remarkable for the general resemblance of their notes, their nests and their eggs, that a casual observer would find it more than difficult to distinguish either from those of the other, although the birds themselves are sufficiently dissimilar. The male and female of both species, as we have often seen, take an equal share in the business of incubation, during which their delightful song is seldom heard. It is resumed, however, abobut Midsummer, when they are making preparation for a second brood. We have never met with any marked variation in the eggs of the Garden warbler; but the Black-cap has supplied us on two occasions with a remarkable and beautiful rosecoloured variety. The Greater Whitethroat (Sylvia cinerea) is more common than the two latter, and is chiefly heard in the lowland hedges and underwoods. The Lesser Whitethroat (Sylvia garrula) is found in the same localities as the last, but is not so numerous.

The Dartford Warbler (Melizophilus provincialis) has been rarely seen here. We can record but two instances of its appearance in the parish, one among the heath and furze on East Harting Down, the other at West Heath ; but its nest has been met with at no great distance from us. We learn from a gentleman who has had rare opportunities of practically studying the habits of this bird, that it is not uncommon on the heath-and-furze-covered wastes between Liphook and Godalming, where he has discovered many of its nests every season. His mode of proceeding is to take an early stroll on the waste, so early, indeed, that he not 
unfrequently greets the rising sun. On such occasions he sometimes gets a glimpse of a little bird darting rapidly upwards out of a tuft of heath or furze, and as quickly dropping again after a short flight. This is the cock bird at his morning orisons, or what "Rusticus of Godalming" terms his "fiz-gig of a song." After the lapse of a minute or two, he makes a second fitful and brief aerial excursion from another tuft several yards distant from the first; and sometimes, after a longer interval, he indulges in this short course of gymnastics a third time. If the observer has remained in the same place from the first appearance of the bird, and carefully noted the spots from which he emerged, he has seldom been disappointed of finding a nest in the proper season, after a patient examination of the heath and furze between them. We may well believe that a less systematic exploration of an almost interminable waste would be all but hopeless. The hen is seldom seen except during the period of incubation, and even then, when intruded upon, she drops noiselessly from her nest, and is quickly lost to sight. In May, I859, we had an opportunity of taking three nests of this bird; and we were struck with their great resemblance to each other in every detail, not even excepting their exterior decorations, which consisted of numerous white silky cocoons of some tiny insect, that had evidently been attached to the stems of grass before these had been selected for building purposes. Each nest was suspended from slender upright twigs of heath (not furze) by its margin, with only an occasional and slight connection at the sides, the lower part being quite free; and this we were told is generally the order of architecture of the Dartford warbler.

The Wood Wrens make their appearance among us very early in spring. The notes of the Willow Wood Wren (Phyllopneuste Sylvicola) and the Chiff Chaff Phyllopncuste Hippolais) are often heard in March, 
those of the Yellow Wood Wren (Phyllopneuste Trochilus) a little later; but their curiously-arched nests, which are cunningly concealed, are seldom found before May. That of the Yellow Wood Wren, lined with hair, usually on the ground in the beech woods; those of the other two, lined with feathers, in low bushes and brambles in the valley.

The hardy little Golden-crested Wren (Regulus auricapillus) is tolerably common in winter and summer, but its note is so feeble that it may often be heard unnoticed in a country ramble by any but those who are well acquainted with it. Although this is our smallest bird, its nest, which is usually suspended from. a branch in the Spruce fir or the yew, is much more bulky than that of many larger birds. The talented author of "Ornithological Rambles in Sussex," a work which is deservedly admired by all who have had the pleasure of reading it, is of opinion that, from the great similarity of the Fire-crowned Kinglet (Regulus ignicapillus) to the better known species, the probability is that it has been overlooked in localities frequented by the latter, and that it may be found here. We have never, to our knowledge, seen the bird; but a nest taken at Petersfield this season contained an egg. so unlike that of the Golden-crest, that we venture to ascribe it to the Fire-crown. This nest, composed of moss, wool, and hair, and lined with feathers, was placed on a branch of a yew tree, and not suspended. The only egg saved out of several which were found with it is white, with small, dark grey and light grey spots sparsely distributed over the larger end, while those of the Golden-crest are more or less brownishwhite, darker at the larger end, and without spots.

The Grasshopper Warbler (Sibillatrix Locustella), though generally dispersed, is a very unobtrusive bird; and more frequently heard than seen. Its note much more nearly resembles the chirp of a cricket than the song of a bird, but it is more continuous, and varies in 
intensity during its progress with a regular crescendo and diminuendo movement. This bird is stated by authors to build in low bushes near water, and so indeed it does occasionally; but as a general rule, in this locality at least, it does not do so even where an experienced bird'snester can see no reason for its absence: for instance, out of nine nests of which we have an authentic record, seven were found in flat grass meadows, and only two in bushes. The first we ever saw was the uppermost of a series of nests in a low, scrubby blackthorn; and it seemed as if the bird, after having reared one family in this bush, had made use of the first nest as a foundation for the next, and so on for five or six successive broods or seasons. With one other exception, however, all the remaining nests we have taken of this bird were built in little natural depressions in the soil between the roofs of high meadow grass-under which circumstances they were of course brought to light by the mowers when they cut the grass for hay. It will be obvious, then, that we never had the opportunity of seeing the nests that were mowed out in this way till after the crop was down, so that we can only describe them as having consisted entirely of blades of grass, a trifle finer inside than out, and so loosely put together, that it was not possible to remove either of them without leaving a considerable portion of the building materials behind. More recently, however, we have seen a nest of this bird in a meadow before the scythe had done its work. It was as perfectly concealed as if the builder of it had taken a lesson from the wheatear and placed it in a rabbit burrow; and there was no visible way to it except through a distant entrance, the bird obviously gliding unseen under the grass, like a mouse, to reach it and leave it-we say obviously, because the tunnel to its domicile was the very cause that led to its discovery!

The Sedge Warbler (Calamoherpe phragmitis) is 
tolerably common, but confines itself to the neighbourhood of water, where its lively song may be heard among the aquatic plants and bushes fringing the pools and water courses in the meadows, sometimes long after sunset. The Reed Warbler (Calamoherpe arundinacea) is rare with us; we have met with its nest and eggs but twice : once among the small twigs of a willow overhanging a stream near the Pond-tail plantation, the other in a thick patch of reeds, growing, oddly enough, in the " Red Sea!" In this latter structure the stems of the plants were converted into the supporting columns of the edifice by being brought forcibly together and skilfully enclosed within a neat. band of fine grass, which was designed to form the exterior of the nest. Its song, like that of the sedge warbler, is often heard late at night, and its eggs are not much unlike those of the Dartford warbler. On the authority of J. E. Harting, Esq., author of the charming "Ornithology of Shakespeare," and several other well-known works on Natural History, we may add another species of warbler to our list. In the summer of 1870 we met with a nest containing three eggs which were new to us. We were fortunate in having an opportunity of submitting them to $\mathrm{Mr}$. Harting, who at once identified them as those of the Marsh Warbler (Calamoherpe palustris), a bird of such rarity as a British species and an occasional visitant, that Harting may well be congratulated on the distinction of having, once at least, afforded it a nesting place.

The Common Wren (Anorthura Troglodytes) favours us with its presence summer and winter, and not improbably builds its nest in almost every old thatch in the Parish. It occasionally nestles also in sawpits, in hedge banks and in old walls overgrown with ivy. Its song is surprisingly loud for so small a bird, and may be heard occasionally all the year round.

The elegant Pied Wagtail (Motacilla Yarrelli) is 
common, and may often be seen near every shallow pool of water, engaged in running down the insects which swarm in such places; occasionally it pursues them on the wing, and after every capture gives a lively chirp, as if in exultation at its success. The Grey Wagtail (Motacilla Boarula) visits us in winter only, from which circumstance it is known locally as the Winter Wagtail, retiring farther north in March or April to attend to its domestic affairs. We have never met with its nest here, but this season, for the first time, we have taken its eggs in the neighbourhood of Petworth.* The beautiful Yellow Wagtail (Budytes Rayi), sometimes called the Summer Wagtail, is much more rare with us than the other two, but its nest has been found within a few yards of the Blackrye Pond at Down Park.

The Meadow Pipit (Anthus pratensis), which is so frequently victimized by the Cuckoo, and the Tree Pipit (Anthus arboreus) are common and generally dispersed. The latter is chiefly remarkable for the great variation in the colour and markings of its eggs. We possess no less than eight varieties, many of them so unlike each other, that a scrupulous collector would hesitate to label them on his own authority without having seen the parent bird sitting on them. The Sky Lark (Alauda arvensis), "whose notes do beat the vaulty heaven so high above our heads," in the season of song, is as numerous as the corn fields in which it builds its nest, and is too well known to require any lengthened notice here. Immense flocks of these birds are among the "Common objects of the Country" in the autumn and winter months, during which those who do not find their way into the London and other markets, are industriously clearing the fields of the seeds of wild plants, which, in his

- Since this was written we have found its nest and eggs near "The Hatches," in the rocky bank of a stream formed by the waste water of Hurst Mill pond. 
harvesting operations, the farmer has scattered over the surface in profusion. The Wood Lark (Alauda arborea), whose song is more highly esteemed by many persons than that of the Sky Lark, is not uncommon with us, but it is much less numerous here than the latter species, and much more local. Scarcely a season passes but we meet with its nest on the ground among grass in Uppark and Lady Holt Park, at which time the bird may, of course, be frequently seen and heard; but we have particularly noticed that, although in its musical soarings it not unfrequently passes and repasses the boundaries of the parks, it seldom strays far from either in the breeding season. On the other hand, large flocks of them may be seen towards the end of winter, before they have selected their several summer homes.

Our Tit family is represented by five species: the Ox-eye Tit (Panus Fringillago), the Blue Tit (Parus caruleus), the Coal Tit (Parus ater), the Marsh Tit (Parus palastris), and the Long-tailed Tit (Mecistura longicaudata), all, except the last, very similar in their nidification and habits. The Marsh Tit appears to be less numerous than its congeners; but the Ox-eye, whose song in spring so charmingly emulates the exhilarating sounds produced by sharpening the teeth of a saw, must not be dismissed without an extract from the letters already alluded to, in one of which we find the following reference to this species :- "I need not say that the Great Tit is, here, as elsewhere, a very important member of Ornithological Society, whether among the beechwoods in the Park, the scattered ash and thorns of the Upland waste, the orchards in the valley, or the willow stumps bordering the ponds and streams; and that he frequently shows himself independent of the simple instinct which appears to limit the choice of nesting places in many other birds. A decayed tree, a hole in the wall or thatch, an old hat on a scarcecrow, a space under the eaves, suit him 
equally well ; on one occasion well remembered here, he unceremoniously established himself under an inverted flower pot in the garden, within a few yards of a melon frame, which, of course, was visited by one or other of the gardeners daily, and I have known him, once at least, not indifferent to the accommodation afforded by an old magpie's nest; I have even found him in possession of a nest neatly built of moss and lined with hair and feathers, near the extremity of a branch of yew, but I never, till this season, knew him devote himself to the cares of a family under such singular circumstances as those which have recently come to my knowledge : Twelvemonths ago a pair of these birds took lodgings in a thatched brick-shed in the valley, and there in due season they, creditably to themselves, reared a numerous family. Early this spring I found that a pair of Robins had made their bed in the same recess, but on returning a week or two afterwards, I was surprised to see the Tits again in possession, the hen actually sitting on a batch of its own eggs and six of the Robin's! At my last visit to the nest it was so full of young ones that, in the expressive language of the (late) brickmaker, it was 'a'most ready to run over.' Since then, I am sorry to say, some mischevious urchin has terminated the experiment very much to my dissatisfaction." The nest of the Long-tailed Tit, alias Bottle Tit, is a wonderfully beautiful structure of an oblong form, composed chiefly of moss and lichens neatly felted together, lined with feathers, and having near the top a small circular doorway which is often partially closed, as if by accident, by one of the feathers of the lining. In his notice of this bird, our local observer says :- "You may probably not have forgotten that last season I told you I had met with a nest of the Bottle Tit containing white eggs, and I well remember that I gave you no description of that nest, although I now think its remarkable appearance would have 
justified my doing so. It is quite fresh in my memory as I write-a large mass exactly resembling a complete double nest, and each portion finished off apparently with equal care, as if the future progenitors had inaugurated their matrimonial career with a miff, and followed it up with a mutual determination to use separate beds. But on closer examination, I found that one division only of this example of a new architectural design was a true nest, its counterpart consisting of a somewhat compact mass of the usual building materials without aperture or cavity. This discovery led me from my first impression to the supposition that the building instinct of the architects had not been quite satisfied by the erection of the true edifice, or that the anomaly was simply the work of a 'prentice han'. What I have now to add, will, I think, make this curiosity more striking. In the same hedgerow, and not many yards from the same bush in which this double nest was found, I last spring met with another Bottle Tit's nest, with its supplement, exactly similar to the one of the previous season, and that also contained white eggs!" We may add to this extract, that a third nest of the bottle tit, of precisely the same composite character as the two here alluded to, and with white eggs, has since then been found in the same locality.

The curiously unmusical and harsh notes of the Corn Bunting (Emberiza Miliaria), a plain coloured, common bird, about the size of the skylark, may be heard any day in spring in open pastures and cornfields, where also its nest is found on the ground. The Yellow Bunting (Emberiza Citrinella) is equally common; and as it is a more gaily-coloured bird than the last, it is perhaps more generally noticed. Its song is also more pleasing than that of the corn bunting, but at best it is a somewhat doleful ditty. The Cirl Bunting (Emberiza Cirlus) is not nearly so numerous as the last species, or the next; but we have 
met with many of its nests, which are generally built in low bushes, while that of the yellow bunting is more frequently on the ground, or under a bush. We have no doubt that the eggs of the two species are often confounded, there is so great a resemblance between them. The Black-headed Bunting, or Reed Bunting (Emberiza Schoniclus), during the breeding season, is met with commonly among the bushes, reeds, flags, and rushes growing near water; but in the winter it visits the farmyards in company with the other buntings, greenfinches, chaffinches, and sparrows.

The Chaffinch (Fringilla calebs) is a very common bird, and almost as familiar as the house sparrow. Like many other small birds, it is seen in large flocks in the autumn and, during the winter months in longcontinued severe weather, sometimes, indeed, before hard weather has set in, it is often accompanied in great numbers by another member of the same family, the Brambling (Fringilla Montifringilla), a beautiful bird about the size of the chaffinch, which, however, is only an occasional visitant. The elegant Goldfinch (Carduelis elegans) is too highly prized by professional bird-fanciers to be very numerous anywhere except at the dealer's; it is, however, a common bird, and generally nestles in gardens, orchards and shrubberies, where its pretty, neat nest may be found in any of the trees growing there. As its principal food is the seed of thistles, which plants are here nearly as "thick as autumnal leaves in Valombrosa," its wholesale capture after the breeding season is much to be regretted. The Brown Linnet (Linota cannabina), which, by-thebye, is much more gaily-coloured in summer than in winter, is common on the Downs, where its nest, occasionally provided with a snug lining of seed-down, is generally found among the furze bushes; it is not so frequently met with in the valley. We scarcely know whether we should be justified in including the Lesser Redpole (Linota Linaria) in our catalogue; 
but large flocks of them put in an appearance in autumn at so short a distance from us, that they can scarcely fail to visit the birch clumps of West Heath. The Hawfinch (Coccothraustes atrogularis) in severe winters visits us in small parties, and at long intervals remains till after the breeding season-some young ones having been shot in the village in the summer of I 829 , and others on one or two occasions since. At no great distance from us, however, in an easterly direction, a few pairs are permanently resident; and our local observer has had more than one opportunity of seeing their nests, their eggs, and their young. "The nest of this bird," he says, "with a strong family resemblance to that of the bullfinch, is built of much coarser materials. The one in my possession consists of a very scanty foundation of twigs, above them grey lichens, and, lastly, a lining of not very fine rootsaltogether a slovenly structure, with very little more concavity than that of the ringdove; and it was somewhat insecurely lodged in a fork among the upper and smaller branches of a plum tree in a garden. It appears that these birds are frequently found nesting in that locality, to the no small. disgust of the owner of the premises, who assured me that he would gladly dispense with his many opportunities of studying their habits. In proof of this he had laid violent hands on several specimens and, adding insult to injury, had imprisoned them in glass cases in such elaborately unnatural positions, that their nearest of kin, if put to the test, might well fail to recognize them as ordinary members of the family!" * The Greenfinch (Chlorospiza Chloris) is not uncommon, and is generally distributed both in the uplands and the valley. It frequents gardens, orchards, and shubberies, where its nest is often found. In the autumn it associates with other

* In I863 we met with a nest of this species in the Park, and, more recently, a young hawfinch was caught in the shrubbery near the mansion. 
small birds in search of grain and seeds in the stubbles, and during the winter months it may be found in flocks in the farmyards. The House Sparrow (Passer domesticus) is common everywhere, and finds work to do in every garden in the parish; but its value is not generally recognized. Its food is so various that it may be regarded as one of our minor scavengers; but it is accused, and we believe justly, of committing considerable havoc in the cornfields about harvest time. Its nest is placed in any suitable recess about a building-often among thatch; occasionally it may be found high up among the branches of a tree, when it is provided with a comfortable, though not very neatly constructed, arched roof. We have only met with the Mountain Sparrow (Passer montanus) during the winter months on two or three occasions. The Bullfinch (Pyrrula pileata) is well known here, and is not a local bird; but it does not appear to be very common. It scarcely need be said that, like the goldfinch, it is a great favourite with bird-fanciers; and when it has been taught to "pipe" it commands a high price; but the gardener, aware of its partiality for the tender buds of his fruit trees, does not admire it.

The Little Brown Tree Creeper (Certhia familiaris) is one of our permanent residents, but confined to the wooded districts, and not very numerous. Among the beech woods on the uplands we have frequent opportunities of seeing it clinging to the mossy bark in search of the insects on which it feeds. While so engaged it is quite indifferent to the presence of an observer, and will deliberately continue its progress, which consists of a succession of upward starts, between each of which it appears to press its tail against the tree as a support. We have often found its nest and eggs in a hole in a tree; or in a convenient fork, and quite as often in the mortice of a post in the park fence.

The Hoopoe (Upupa Epops) we fear cannot be 
ranked among even our casual visitors, but it has been shot more than once so near to us that we are disposed to record the fact. We can also state, on our own authority, that an individual of this species in immature plumage was obtained not many years since on Petersfield heath, from which we infer that it occasionally breeds in the neighbourhood.

The Nuthatch (Sitta Europoea) is another of our local birds, chiefly inhabiting the beech woods on the uplands, where it breeds in holes in old trees. It is a very pugnacious little fellow, and when it has taken possession of a suitable nesting-place, it resolutely defends it against all feathered aggressors. If the entrance happens to be larger than necessary, it carefully and neatly contracts it with a cement of loam; but it is not over-fastidious in its choice of building material, and in default of loam it often finds a delicate substitute in the droppings of sheep or deer. It lays six or seven glossy white eggs, blotched with light red.

The Greater Spotted Woodpecker (Picus Pipra) and the Lesser Spotted Woodpecker (Picus striolatus) are found in the same localities as the nuthatch, but in smaller numbers. The remarkable note of one or both is heard almost every spring among the beech woods on the hill, and sometimes in the birch groves of West Heath; and is quite distinct from the sounds they produce when "tapping the hollow beech tree," which are not audible at any great distance. Of the note of the larger species our local observer writes:- "When I heard it last April it was from a distance of five or six hundred yards, and yet it seemed to proceed from the tree nearest to me, which I approached, to find that it was as evidently from the next, and so on from tree to tree through a part of the Garden Wood with the same result, until I emerged from the Forest of Beech into an open glade, and as distinctly heard it a hundred yards further on. I now began to fear that it might turn out to be vox et preterea nil; but was at 
last led by the ear to an old stag-headed ash tree near the park fence, and took every precaution to obtain a sight of the bird. In this I very soon succeeded, but not till it had first caught sight of me; and, after a mutual look of enquiry, we abruptly parted for the season." Both species lay their white glossy eggs in the bottom of holes of their own boring in the trunks of decaying trees. The Yaffle, or Green Woodpecker (Gecinus viridis) is another beautiful denizen of our beech woods, more common than the last two species, and similar to them in its habits; but its loud cry differs remarkably from theirs. When the yaffle is engaged in preparations for nidification, one might imagine that he looks upon the whole affair as a rich joke, he is so perpetually making the woods resound with hearty shouts of laughter; as a very natural consequence he is sometimes spoken of as the "laughing Satyr." His neat circular borings are very numerous in the old trees in the park; and sometimes they may be seen where there is not the slightest evidence of decay on the exterior of the tree. In the season of I86I a yaffle was almost daily engaged from the latter end of April till the beginning of May in perforating the trunk of a beech tree which, under close examination even by practical hewers, presented no symptom whatever of disease or decay. Not a flaw in the bark could be detected; the very chips produced in the process of boring were quite fresh and green ; still, on it laboured assiduously until a pair of unprincipled starlings set up a counter claim to its intended domicile, and so rudely backed their pretensions that the poor yaffle, reluctantly sacrificing the fruits of its labour, after several days of contention retired in disgust. It must have proved a barren acquisition to the starlings however, as the yaffle, whose wonderful instinct after all had not misled it, had only just reached the decaying interior of the tree, after having driven a tunnel horizontally through three or four inches of 
sound living wood. The Wryneck ( Yunx Torquilla) is not a common bird with us; and, although its hawklike cry in spring is sure to betray its presence wherever it may have established itself, it is difficult to obtain a sight of the bird. It was heard, and its white eggs were found two or three consecutive seasons, in Lady Holt Park when the ant-hills were very numerous there; but, since the gradual destruction of the latter, it appears to have betaken itself to "fresh fields and pastures new."

The Ring Dove or Wood Pigeon (Columba palumbus), is generally distributed in the nesting season, places its platform of loosely arranged scraps of wood among the branches of high trees, sometimes as early as February, and rears several broods in a season. In the winter months it congregates in large flocks, and frequents the park in astonishing numbers when the beech mast is plentiful.

The Stock Dove (Columba anas), which is not the original of our domestic pigeon, as its trivial name might be supposed to imply, is common enough in the park, where it generally deposits its eggs in a hole in an old tree, in a convenient space in a dense mass of ivy, or in an old building, without a scrap of anything to indicate even the commencement of a nest. The gentle cooings of the pretty Turtle Dove (Columba turtur) are heard in all our coverts throughout the summer months, and several pairs of the bird breed here. We have no recollection of ever having met with its nest in high trees; it is a somewhat neater structure than that of the Ring Dove, and is usually placed among the taller growths in the underwood, sometimes in a bush not many feet from the ground. Its eggs only differ from those of the other Columbida in being smaller.

Little need be said of the Pheasant (Phasianus Colchicus), which, not being an indigenous bird, would very probably soon disappear if quite left to its own 
resources, notwithstanding the great abundance of the wire worm, which, besides many other insect-enemies to the farmer, it destroys in great numbers; we pass on then to the Red-legged or French Partridge (Perdix nubra). In the year 1776 , the late Sir Henry Fetherstonhaugh imported from France several sittings of the eggs of Perdix rufa; and in the subsequent correspondence between him and his mother, we learn that the hatching was perfectly successful, several coveys were bred in the walled gardens attached to "Harting Place" and in the park; but the experiment to establish them here permanently appears to have failed. We have a recollection of some forty years, during which we never heard of a single specimen having been found on the estate; and when, about the year I860, one of the keepers discovered several eggs of the species on Castle Farm, he brought them to us as the eggs of "some furrin bird," the like of which he had never seen before. Since then we have not only met with several in the warren and on East Harting farm (some deposited in nests of the pheasant), but many of the birds have been shot on East Harting down, where it has been no uncommon occurrence to put up a covey or two several seasons in succession. The species is said to be tolerably common in the neighbourhood of Butser Hill, but a gentleman who occupies land there, does not speak favourably of the sport it affords, or of its claim to a high rank among the delicacies of the table; on the contrary, it is within the bounds of probability that he never misses an opportunity of emphatically putting his foot on a French Partridge's egg when he finds one.

The common Partridge (Perdix cinerea) in favourable seasons is sufficiently numerous in the stubbles, the clover and the turnips, to constitute what the keepers term "a pretty fair sprinkling;" but as a rule 
it appears to be more abundant on two or three of the adjoining estates than with us. Of the appearance of the migratory Quail (Coturnix dactylisonans) here, we can record but one solitary instance, although we have seen its eggs. from the neighbourhood of Petersfield, Catherington and Alresford; and last August a perfectly fresh egg was picked up in one of the corn fields on Castle farm. The Black Grouse (Tetrao tetrix) is equally rare, one or two stragglers only having been shot here within the memory of middleaged sportsmen.

. Our Water Birds and Waders will not detain us long, for two reasons, - the species are not numerous, and we have not had many opportunities of studying the habits of any, but the most common among them. The Stone Curlew (Edicnemus crepitans) visits the open tracts about Lady Holt Park and West Harting Down, where its eggs are found almost every season, deposited on the bare ground without any nest. The Golden Plover (Pluvialis aurea) is occasionally seen in our open fields and meadows in tolerably large flocks in mild weather, during the winter months; and a few individuals find their way to the larder, where they rank nearly as high as the Woodcock. The Lapwing (Vanellus cristatus) is common with us winter and summer, being more generally dispersed during the breeding season than at any other period. The eggs of this bird are so highly esteemed as a luxury (and in our opinion justly so), that they are imported from the continent, chiefly from the low countries, in fabulous numbers, and early in the season, according to the London poulterers, one shilling and sixpence represents the marketable equivalent of each! By a domestic economist this might be deemed an extravagant figure; but what would such a person think when told that more than twenty pounds have been given for the egg of the Great Auk (Alca impennis); and 
that in all probability the same egg, before it is twenty years older, will have considerably increased in value.* Of the Black-tailed Godwit (Limosa melanura) we know no more than that a specimen was shot at the Blackrye Pond in the autumn of 1858 .

The Green Sandpiper (Totanus ochropus) we have more than once in autumn flushed and shot in a meadow near the Brick-kiln Copse, through which a shallow stream from the Great pond flows, with many curves and windings, towards the "Red Sea;" and we have repeatedly seen the Common Sandpiper (Actitis hypoleucos) on the banks of the pond after the middle of May. On one occasion especially, we had been watching a pair of these birds through a binocular, and endeavouring to approach them as noiselessly and stealthily as we possibly could. The dark brown undulations and other details of their glossy plumage, their eyes, bills and legs, the singular movements of their bodies, we could make out almost as distinctly as if they were within arm's length of us, and we were mentally indulging a hope that, for once, they might forego their annual visit to the north, when . . they were suddenly put to flight, and sent skimming over the water by a very undignified splash that we made in stepping unexpectedly knee deep into a stream that intervened between us. We had not forgotten this stream, which we were well aware was flowing from the pond-head across our path; but in our un-

- Since the above was written, we have seen an egg at a dealer's in London, labelled "Egg of the Great Auk, price $£ 40$," but this is a trifle as compared to the sum required for another Oological celebrity, the egg of the Dinornis, an extinct bird of New Zealand. In Hardwicke's Science Gossip, Vol. II. pp. I4, 15, we read the following:- "We were led into an error in our last number (p. 282) in stating that the Moa's Egg was sold for \&120. It is true that this was the highest bidding, but there was a reserve beyond that sum, and we are told that the egg is to be repacked and sent back to New Zealand, as its owner is not disposed to part with it at that price." 
divided attention to the birds, we had imagined it to be still some yards further on, when our unlucky ducking startlingly undeceived us.

The Common Snipe (Scolopax gallinago) not only affords us a frequent delicacy in winter, but often supplies us with its large richly blotched pyriform eggs. Its nest is found in the little islets of coarse grass in the Brick-kiln Copse, among the rank herbage on West Heath and near the Blackrye Pond. The pretty little Jack Snipe (Scolopax gallinula) is also a frequenter of the same locality, but does not breed there. It is not nearly so numerous as the common species, but to an indifferent shot it is infinitely. more interesting. Its flight is so short that it may be flushed, shot at, and ... missed, many times in the course of a few hours, and in this way it is said to have tested the skill of many an incipient sportsman for a whole day, and escaped at last! The Woodcock (Rusticola sylvestris) visits us about the beginning of October, but not in great numbers. It is flushed in some of the Uphill and Downhill covers throughout the winter months, and sometimes later, an occasional pair even remaining to breed with us. We have met with three or four of its nests here; and in the year I822, a beautiful pied specimen, now in a glass case, was shot in the parish. We are indebted to this bird for an opportunity of recording an incident illustrative of the observant character of the "tender thought," before the young idea has been taught "how to shoot," and we may add that it was duly appreciated by those who were present at the time and place of its occurrence. Among the technicalities of Battue shooting, it is well known to the initiated, that the lads who are stationed at various points on the outskirts of a cover, for the purpose of preventing the birds rising at inconvenient distances from the guns, are called "stops." On one occasion several years since, when a party were shooting in the Brick-kiln Copse, a woodcock was 
flushed and shot at, but as it did not fall, although it was supposed to have been struck, a stentorian chorus in all possible keys at once, of " Mark that Woodcock! Mark that Woodcock!" immediately followed the shot. The woodcock, however, appeared to escape being marked; but as its line of flight was forward in the direction the beaters were following, the party quietly continued their progress through the cover, till they reached the station of a juvenile "stop," who was "whistling (perhaps) for want of thought," and at the same time improvising an accompaniment to his inspirations with a stick between the bars of a gate. "I say, young un," shouted old Barton the keeper, "have ye. sin e'er a Oodcock come over this way?" “No, I ha'n't," was the straightforward answer of the lad, whose unfledged appearance, by the bye, pointed to the probability that his study of Ornithology was as yet in the elementary stage. A suspicion of this may perhaps have occurred to Barton, who after a moment's reflection supplemented his first question with another of a more general aim. "Ha'n't ye sin ne'er a bird than?" "Ees, there's one gone over yender with a girt long stick in his mouth (!)" Whether this lucid reply led to the collapse of the questioner, or to the eventual bagging of the woodcock, we are not in a position to state.

The Water Rail (Rallus aquaticus) is found in the ditches and watercourses in the lowland meadows every winter, but we have only twice met with its nest, once among the meadow grass near the Great Pond, and, on another occasion, in a solitary tuft of heath near the Blackrye Pond.* The Corn Crake (Crex pratensis) is generally distributed, but not numerous; it does not appear to confine itself to the moist meadows, but more frequently makes its

- In a third instance we took its eggs in early spring, on the site of Sir Anthonie Windesor's "moated house," near the Parlour-pond at Downparks. 
nest among corn, clover and grass in the Uplands, where its curious cry, so nearly expressed by its generic name, is often heard during the summer. We have a homely recipe for so accurately imitating this cry, that the bird has often been deceived by the imitation and lured within gunshot. Any one who may be curious to try the experiment, is advised to provide himself with an ordinary short-toothed comb, and draw it rapidly, once backward and forward at regular intervals, across the thin edge of a large bone. Of course, to be enabled to do this with the proper effect, the experimenter must consent to take a lesson from the bird itself. The Moor Hen (Gallimula chloropus) and the Coot (Fulica atra) are common in all the West Harting Ponds, and, although not webfooted, they are excellent swimmers. We have often seen the moor hen, after a sudden dive on being disturbed, quietly anchor itself among the flags and rushes, with its body under the water and its bill only above the surface, in which position it would remain a very long time, if not further molested. Both these species build very large nests among the flags and rushes growing in the water. The Bittern (Botaurus stellaris) is seldom, if ever, heard "booming in the fallow" here; it is only a very rare visitor, some three or four individuals probably having been seen, and one shot in the meadows near the ponds, within the last thirty years.* The Common Heron (Ardea cinerea) is frequently seen at Down Park, sometimes in parties of five or six, but they are no doubt stragglers from their well-known establishment at Parham Park. Two instances, at least, of the discovery of a heron's nest, one in the fir clump on West Heath, the other on a tree at the Pond-tail, are well authenticated, but the nests and eggs were unfortunately destroyed. The Wild Goose (Anser

* Another was shot in January, 1875. 
brachyrhyncus), the Hooper (Cygmus musicus), and the Shieldrake (Tadorna Vulpanser), only visit the ponds in very severe weather. We have seen several specimens of the two former species shot here, but never more than two of the latter.

The Wild Duck (Anas Boschas) is a permanent resident, and its nest is often found in the hedgerows, in the covers, and among the heath at some distance from the water, but not so frequently as to account for the great addition to the numbers of this species which we notice in the winter season. Our local observer, after a successful expedition some years since in quest of the eggs of the wild duck, tells us that they "were deposited on a very bulky collection of nesting materials--grass, moss, bits of fern, heathtops and leaves - all in a state of humidity, and concealed amongst the densest heather on a swampy waste, not many yards from a large pond." After some further remarks, he goes on to say, "I subsequently met with two other nests in which the building materials were reduced to a minimum; they were situated on high and dry banks, where the leafless oak trees, at the foot of which they were placed, had in no degree contributed to their security from the keen eye of the marauding crow, a resident pair of these scavengers having anticipated $m e$ in the discovery of the eggs, and practically asserted their claim to the lion's share of them." From a letter addressed to the writer of the latter remarks by a gentleman of the highest rank as an Ologist, we take the liberty of quoting the following anecdote:- "With respect to your observation that the wild duck nests ' high and dry,' I can confirm your remark by stating that many years ago I flushed a wild duck from a pollard willow, whilst fishing in the-River Avon, and on examination, found a nest in the crown of the tree with ten eggs in it, which, when I had done fishing, I carried home on horseback in my pocket handkerchief 
full eight miles and substituted for the eggs of a sitting hen, and at the expiration of a fortnight had ten wild ducks. The tree grew on a high bank, so that the young birds would have had to descend ten feet into the water!" The Common Teal (Querquedula Crecca) is very abundant in the winter, and a few pairs breed among the birches of West Heath, where we have more than once seen its cosy nest full of eggs. The Widgeon (Mareca Penelope), the Tufted Duck (Fuligula cristata), and the Red-headed Pochard (Aythya Ferina) are sometimes numerous at the ponds, and the beautiful Merganser (Merganser Castor) has been occasionally shot there.

The pretty little Dabchick (Syllbeocyclus Europœus) is one of our well-known residents, more numerous at the Hurst Mill Pond than at either of the others, and sometimes even seen and heard at the Engine and South-Garden Ponds. This bird is a wonderful diver, fies under the water almost as easily as over it, and constructs a very remarkable nest. Our local observer says: "My success with the Little Grebe was more complete, and of this I must give you some details. It was on a very cold evening early in May that I embarked in a small craft on one of our neighbouring Mill Ponds-a long narrow winding sheet of water, fringed here and there with flags and sedge, and having on each side a high steep bank covered with copsewood down to the water's edge. As I knew that the dabchick frequented this charmingly secluded spot, the discovery of its nest was my especial object, and I was not disappointed; I found three before I landed again. When I say, with reference to the first, that I had never to my knowledge seen one before, I purposely abstain from adding one word in extenuation of the surprise with which I found that a shapeless raft of dead flags, the very 'counterfeit presentment' of an unstudied entanglement of floating weeds, was the unassuming structure I was.in search 
of! Out of any number of individuals casually glancing at such an isolated mass, rising and falling with the miniature swell caused by our boat, not one would have suspected it to be what it in reality wasa literally warm bed, as well adapted to the purpose for which it was designed, as the most downy couch is to the most luxurious requirements of man. The boat was soon brought alongside, and while one at the stem and another at the stern kept it stationary by means of the oars, I proceded leisurely to pick the nest to pieces. To an investigator thus engaged, there was nothing at first sight to indicate the presence of eggs, particularly as two thirds, at least, of the materials were under water; but after I had removed quite a thick stratum of flags, I discovered a carefully concealed store of three only, and, to my further edification, they were unmistakably warm-a natural consequence, as I surmised, of the evolution of heat from the decomposing vegetable matter surrounding them. The eggs in the other two nests were in the same condition, and the nests themselves were precisely similar to the one I have just been describing. As they were in deep water, several yards from the bank of the pond and quite clear of the border of sedge, they must, of course, have been retained in their positions by some cunning device; but although after I had secured the eggs, I submitted each nest to a careful scrutiny, I failed to discover it. I could only infer, from seeing here and there the stump of a flag under water, that some of the materials of which the nests were composed had probably been only partially severed from their stems."

The Green Cormorant (Phalacrocorax Graculus), the Gannet (Sula Bassana), in inmature plumage, the Herring Gull (Lams argentatus) and the Kittivake (Rissa tridactyla), are the only other birds of which we can record the accidental appearance here on good authority. 


\section{CHAPTER III.}

\section{Reptiles AND Fishes.}

WE now come to a class of animals, the personal appearance of which is so little in their favour, that scarcely one of the number can show itself without incurring imminent danger of assault and battery from those who are imperfectly acquainted with their character and history-we allude to the reptiles. If it were more generally known than it is that, with one exception, our Harting reptiles are perfectly harmless to man, in an aggressive sense, and that our only venemous one will, on all possible occasions, carefully avoid him, unless roused to anger by some act of provocation, they would be spared much undeserved persecution. In their internal organisation these animals differ greatly from the mammals and birds; but, like the latter, many among them are oviparous; some species in their early stage breathe by means of gills like fishes; and most of them present an analogy to insects in the periodical casting of their skins.

The Common Lizard (Zootoca vivipara) is our first example, and is not at all uncommon among the heath and furze on East Harting Down, where we have seen and caught several specimens. It is five or six inches in length; of various shades of brown, with a dark line down the middle of the back, and a band of the same colour on each side-the underside being of a lighter shade and spotted. It is an elegant, active, little animal, and wonderfully expert in capturing its insect prey. On one occasion we saw one engaged in this way on the upper bar of a field gate, and, on being disturbed, it darted over the head of one of the posts "like lightning" into a closely-trimmed quickset hedge, 
among the intricacies of which it seemed to have no difficulty in making its way for some distance before it reached the ground. The Blind Worm, or Slow Worm (Anguis fragilis), is another of our lizards, although its undeveloped legs are only to be found on dissection. It is so well known that any description of it will be unnecessary; but one feature in its history is so remarkable that a brief allusion to it may not be out of place even in this short notice. If it be rudely disturbed, or any attempt made to capture it, it becomes as rigid and unyielding as a glass rod; and in this state often astonishes the would-be captor by voluntarily snapping off its tail. No sooner has it performed this extraordinary feat, than the rejected portion assumes an unwonted degree of energy and liveliness, jumping, twisting, and coiling about as if in a state of convulsive agony, while the head and body of the animal quietly glide away to a place of security. The loss of the tail, however, appears to be only temporary, as this curious animal is said to possess the property of partially reproducing it. Examples of a similar reproduction of lost members are not uncommon among the crustacea: lobsters and crabs, for instance, are often brought to our tables with one claw considerably larger than the other; in all such specimens the least of the two claws is a second edition of a former one; but reproduced members never attain to the size of those which they have replaced.*

- It appears that voluntary decaudation (if we may coin the word), followed by gradual reparation of the injury, is occasionally practised by the common lizard also, but although, reasoning from analogy, we might have suspected the fact, we have handled many specimens of this reptile without meeting with an instance of it ; and we did not know that it really was so until we read the following in "Hardwicke's Science Gossip" (Vol. II., p. 79) :"If caught by the tail these reptiles (common lizards) snap that appendage off, deeming it better to lose their tail than their life. Many other species do the same. If broken off the tail begins to grow again in exactly two months, and is complete in another month, unless broken off very late in the season, in which case it does not grow again till the spring." 
The Common Snake, Ringed Snake, or Grass Snake (Tropidonotus natrix), is common enough in the lowland covers and hedgerows; particularly among the fern on West Heath, and in the vicinity of water. As it preys chiefly on frogs and newts, its partiality to the haunts of these animals is easily accounted for; we have taken two large frogs from the body of one snake. It is no uncommon thing to find a batch of snake's eggs in a manure heap, or a sunny bank, where they are deposited and left to hatch without any further care on the part of the parent reptile. These eggs are not provided with a shelly covering, like those of many other reptiles; they more nearly resemble little yellowish vesicles, a little larger than the eggs of the common robin, attached together by a glutinous secretion. A "snąke in the grass" is no rarity in any of our damp meadows; neither is it unusual to see one in the water; we have had more than one opportunity of witnessing its very graceful serpentine mode of progression among the duckweed on the surface of a pool of water. We have also often found its slough between the stems of dead fern and other rigid plants, but until very lately we were quite ignorant of its value. We now know that many persons suffering from headache have used it as a bandage across the forehead for the purpose of "charming away" the pain!

The Common Viper, or Adder (Pelias Berus), is often met with among the heath and furze on the Downs, in Kill Devil Copse, and the adjoining covers, and not unfrequently in the patches of fern in the Park. We have had some startling experiences with this dangerous reptile; but, fortunately for us, we have come out of them "more scared than hurt." In three separate localities contiguous to each other, Padswood Copse, Kill Devil Copse, and the belt of trees between the Down and the Park, we have met with the rare jet-black variety; the first on a sunny day in Marchthe last on a warm day in November. On one occasion 
since then we have seen a dirty brick-red variety on the sand at West Heath; but in the greater number of instances the ground colour of our viper is greyish brown. As this is the one reptile to be carefully avoided, and it may easily be confounded with the perfectly harmless snake, it may be proper in this place to point out the characters by which they may be most readily distinguished from each other. To say nothing of the difference in size, form, number, and arrangement of the so-called scales on the heads and other parts of the two reptiles-which, indeed, would scarcely be appreciated at a glance by any but a professed herpetologist-we can point out one obvious character by which any person of ordinary observation may be spared the very dangerous consequences of petting a viper by mistake. The viper has an unbroken band of dark lozenge-shaped spots, like a chain of black diamonds, running from the head to the tip of the tail down the whole length of the back; the snake has no such band, but is spotted all over, and has a patch or two of yellow on each side of the neck. In other respects they resemble each other generally; but the chain of diamonds is the danger signal; and, as this is sufficiently conspicuous, we need not enter into further descriptive detail. The viper preys on mice, birds, frogs, and, we believe, toads also, as on one occasion we accidentally disturbed a viper in the act of attacking a toad which appeared to have received several wounds from the fangs of its aggressor. We have intimated that, under ordinary circumstances, the viper when intruded upon by man will endeavour to beat a hasty retreat; but, if any attempt be made to thwart its praiseworthy intentions, it is not slow to retaliate: we have seen one strike viciously and repeatedly the barrel of a gun that was pointed to within a few inches of its head, and the blows were sensibly felt by the person holding the gun by the stock.

The Common Frog (Rana temporaria) is very 
plentiful and generally distributed, its spawn and tadpoles swarming in spring in every pool of stagnant water in the parish. The history of this animal in its early stages of development is very curious and interesting. It deposits its eggs in water, and at their extrusion there is nothing strikingly remarkable about them; but in a very short time they increase so enormously in size, that they form a mass a great many times larger than the animal that laid them. In a few weeks the little black tadpoles are liberated, and at this stage of their existence they are each provided with little tufts of fine thread-like processes on each side of the head, these appendages are external gills, which enable them to breathe in the water like fishes. In their further development, these external gills first become internal; and subsequently are replaced by true air-breathing lungs appropriate to the change of habits of the young frog, when it has become a terrestrial animal. Its mechanical functions of inspiration, however, are due to the pressure of the tongue against the integuments under the lower jaw, while the mouth is closed, and strange as it may appear, a frog would as inevitably die of suffocation if the jaws were permanently propped open, as the respected reader of this would, if both mouth and nostrils were hermetically sealed up.*

The well known Common Toad (Bufo vulgaris) differs little from the frog in the history of its reproduction. The spawn of both is frequently found in the same pools together; and the distinction between them is that the toad's is deposited in long double chains, while that of the frog is in irregular masses; we know of no striking difference between their respective tadpoles. Much has been said and written on the alleged venomous character of the toad, some naturalists assuring us that it is a most dangerous reptile;

- Encyclopædia of Natural History, article "Batrachia." 
while others implore us to dismiss such a notion as an idle prejudice, we believe the truth may be found somewhere between the two extremes. The skin on the back of the toad is thickly dotted with small glands, which secrete a fluid so acrid, that we have many times seen Rover playfully and unsuspectingly "lift" one of these animals, and, as if he all at once became conscious of having made a mistake, instantly drop it again with a grimace expressive of the most intense disgust. But he was not to be let off thus easily, for more than half-an-hour afterwards he would champ his teeth, foam copiously at the mouth, and violently and repeatedly shake his head and paw his muzzle to get rid of the offensive matter. When we know that the larger glands at the back of the head of the toad under pressure, can be made to spurt out the fluid they secrete to some distance, we cannot be surprised at Rover's experience, we may even accept the fact as an excuse for the popular notion that the toad "spits," although we have never seen it do so. Our independent observations end here, but we may add that if the acrid secretion from the glands of the toad be introduced under the skin of some other animals, a condition which can never occur through the instrumentality of the toad itself, fatal consequences ensue in a longer or shorter time, according to the size of the animal operated upon. This fact is said to have been elicited in a course of experiments carried on by eminent French naturalists. On the other hand, it is not difficult to show that the toad possesses no offensive weapon with which it could inflict a wound; and we have heard of toads being repeatedly handled with perfect impunity by persons in this country, including tender-skinned ladies, who have kept them as pets, and from all accounts found them very interesting ones. With these facts before us, we certainly cannot deny that the toad secretes a very irritating fluid; and perhaps we should not be 
justified in rejecting the testimony of those experimentalists, who assert that under certain abnormal conditions (and possibly in a warmer climate than ours) this secretion possesses dangerous properties; but as we believe it to be a provision for self defence only, we are disposed to acquit this animal of the majority of the charges brought against him. Another vexed question in connection with this and the preceding species, which we are only qualified to touch upon incidentally, is their longevity. If we may credit half the tales related of the occasional discovery of one or other of these animals in a solid block of granite or limestone at a considerable depth below the surface, we are led to the astounding inference that many of the specimens thus brought to light again, must have been in existence some thousands of years!!

The Common Smooth Newt, or Eft (Lophinus punctatus), is the only other reptile with which we have to deal. It is found in great numbers in almost all our stagnant waters, where it may be seen in its various stages of development, the youngest individuals without legs, but provided with the branchial appendages which save them the trouble of rising to the surface of the water to breathe, the older ones now and then wriggling up for a fresh supply of air, and quietly disappearing again. Their eggs, unlike those of the toad and frog, are said to be laid singly.

\section{FISHES.}

In these days of Pisciculture, we might be expected to have a great deal to say on the subject of fishes; but the science is not yet practically known at Harting, and our indigenous fishes are too limited in the number of species to justify a lengthened notice of them, it will be seen, however, that in one instance at least, our want of variety is amply com- 
pensated for. To the gorgeously coloured nestbuilding little Stickleback (Gasterostens aculeatus), which any person desirous of studying its very interesting habits and possessing an aquarium, may be glad to know is readily caught in any of our meadow streams with a worm simply suspended by a thread. The Loach (Cobitis barbatula), the Miller's Thumb (Cottus gobio); we may add the Perch (Perca fluviatilis), the Eel (Anguilla), the Pike (Esox lucius), the Trout (Salmo fario), the Carp (Cyprimus carpio), and the Tench (Tinca vulgaris), all of which, except the trout, thrive in the South Garden Ponds, the Harting Great Pond, and the Blackrye Pond, while the Trout is found in the Engine Pond, the Mill Ponds, and the streams they supply. In the autumn of 1858 , the Great Pond was fished, and in the following short extract from a letter written a few days after the event, a casual allusion is made to the general result :-

"After a fortnight of unusual excitement and fatigue, during part of which I have been breathing an atmosphere redolent of fishy effluvia, I feel it quite a relief to be able to devote a quiet evening to the pleasure I have long anticipated of again writing to you on a subject much more to my taste than my recent occupation, although $I$ have been gratified with the sight of nine hundred fine carp, one of which was of the extraordinary weight of twenty-four pounds and a half; three hundred tench, more than a thousand gold fish (from a puddle in the park), and at least a ton weight of eels; not to mention a jack weighing twentyseven pounds and a half, and in the act of digesting two carp, four pounds and two pounds weight respectively. When I have added that nearly all the accommodating natives of the three villages temporarily became ichthyophagi to do honour to the occasion, three hundred of the finest carp having been sacrificed by Lady Fetherstonhaugh, as a means to this endI gladly wash my hands of the whole affair." 
For the accuracy of this statement we can vouch, and, if our own testimony as to the monster carp required endorsing, we might produce that of several gentlemen who were present when it was weighed.

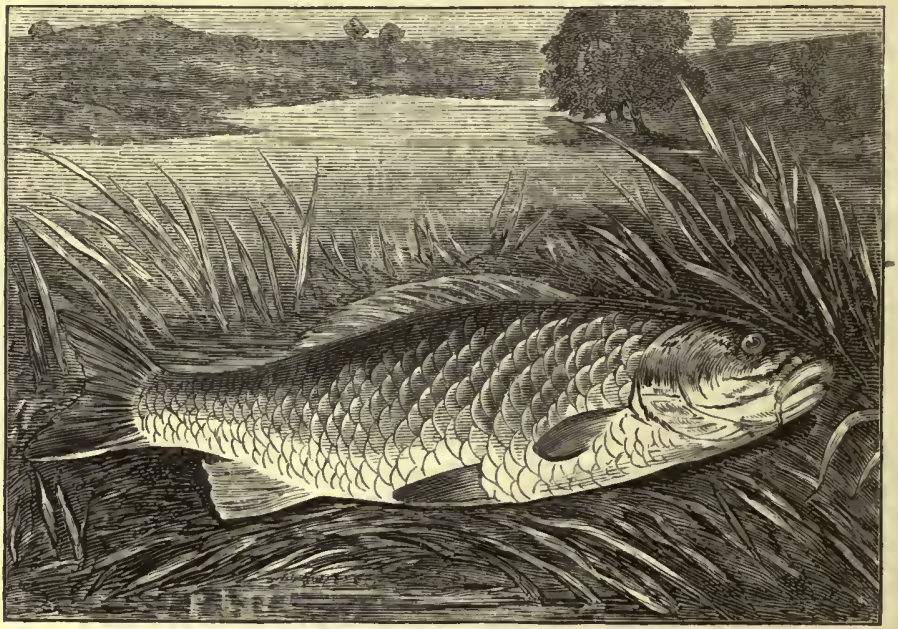

The length of this extraordinary specimen was thirtyfour inches, exclusive of the caudal fin, and many of the scales on its flanks behind the pectoral fins were larger than half-crown pieces; a faithful representation of it in oil is still in the possession of one of those who saw it taken out of the water by a noble lord, one of the guests at Uppark at the time. Harting, we believe, has long been celebrated for its fine carp, and doubtless a goodly number of them found their way to the Refectory of the Holy Fathers of Durford Abbey in the sixteenth century, when the Great Pond extended over an area of probably thirty acres. It was reserved for the present age, however, to make the grand discovery that Harting was capable of producing a finer 
specimen of the genus than any other taken in British waters of which we have an authentic record. Yarrell, our great authority on "British Fishes," says in his second edition, page 352 , "Though not so rapid in their growth as some fish, carp have attained three pounds weight by their sixth year, and six pounds weight before their tenth year. The largest I can refer to, are thus noticed in Daniel's Rural Sports: 'Mr. Ladbroke, from his Park at Gatton, presented Lord Egremont with a brace that weighed thirty-five pounds, as specimens, to ascertain whether the Surrey could vie with the Sussex carp.' In 1793, at the fishing of the large piece of water at Stourhead, where a thousand brace of killing carp were taken, the largest was thirty inches long, upwards of twenty-two inches in girth, and weighed eighteen pounds. At Weston Hall, Staffordshire, the seat of the Earl of Bradford, the painting of a carp is preserved which weighed nineteen pounds and a half. This fish was caught in a lake of twenty-six acres, called the White Sitch, the largest of three pieces of water which ornament this fine estate." It will be seen from this that our carp exceeded in weight the largest alluded to in "British Fishes" by five pounds! In 1862 the Great Pond was again fished, and on that occasion, although the largest jack did not exceed eighteen pounds, and the largest carp thirteen pounds, upwards of twenty-two hundred weight of carp and tench were taken and nearly eight hundred weight of eels. Among the tench many were pronounced good specimens, but we have seen equally fine ones taken from very unpretending pieces of stagnant water in other localities in the Parish.

The Engine Pond has supplied us with very fine Trout; not many years since, when the Engine was under repair and the pond was allowed to run dry, more than forty fine trout were taken, one of which, selected at random, was upwards of two feet in length; 
it was not, however, supposed to be of any extraordinary weight, as it was not in first-rate condition. With few exceptions, these fish were returned to the pond as soon as the repairs to the Engine were completed, but we have reason to believe that after having long baffled the skill of more than one experienced angler, both before and since the circumstance related, these patriarchs of the deep, at their final exit from their native waters, fell into the hands of persons who were anything but fair sportsmen.

We have reason to believe that the (Ammocotes branchialis) may be found in all the tributaries to the Rother that pass through our Harting lowlands; we know it is not uncommon in the deeper parts of the stream running through the meadows in the occupation of Mr. William Wild of East Harting, and some of the water courses in the Down Park meadows. We also know that those who have fished it out of the streams and have yet to learn that it is distinguished by a high sounding name, call it the "Nine eyes." Others who are more familiar with it, call it Stone Grig, Sand Pride, and Mud Lamprey, the latter name being the most appropriate to our Harting individuals. These are of an eel-like form, about the thickness of a goose quill, from six to eight inches long, with seven respiratory orifices on each side of the neck, and their bodies are annulated like that of the common earth-worm, though less conspicuously. As they obviously make their way from the Rother, in order to reach the streams in which we have met with them, they must cross the roads over which these streams flow. Here; when seen in great numbers, they would be readily mistaken for young eels, or "elvers," by non-pisciculturists, who, in primitive days, would probably be under the necessity of fording the streams in the absence of other means of crossing them. Later on, when the march of improvement invaded Harting, and bridges came to be thrown over the different fords and water courses in 
the Parish, a very appropriate name for one of them would be "Elver bridge."

With the Fishes we dismiss the Harting Vertebrates, every species of which, with two or three exceptions, has, to the best of our recollection, been noticed. In the remaining divisions l'embarras des richesses will be so overwhelming, that a bare synopsis of the species included in them would exceed the limits we have prescribed to ourselves; we shall, therefore, necessarily omit the greater number of them, although in doing so we shall have to deal with l'embarras du choix. That this is no trifling affair, may be gathered from the fact that for every plant in the Parish we may reckon on an average at least half a dozen species of invertebrated animals that either directly or indirectly derive their sustenance from it.

\section{CHAPTER IV. \\ Slugs and SNaIls.}

* SNails and Slugs in the abstract, are not very attractive objects to the million, at least this may be justly said of the few species to be found at Harting ; but if we were to limit our observation to those natural productions only which have a pleasing ex-

* The many extracts from this chapter to be found in Mr. Harting's "Rambles in search of Shells," published some years after our manuscript was submitted to that gentleman, will probably astonish those who may have an opportunity of comparing the two; but their surprise can scarcely exceed that which we felt on finding ourselves so highly complimented by this well-known author and naturalist. Wé need scarcely say that we fully appreciate his flattering testimony to the merits of our unpretending sketch; and we take this opportunity of tendering him our thanks. 
terior, how many of the most interesting pages of nature's great book of wonders should we pass over unread! How little, for instance, should we know of the commonest of our molluscous animals, beyond the generic and specific characters of the habitations of the shell-bearing species, except that they remorselessly devour our cabbage and other cultivated plants, or disfigure them with their slimy trails as they crawl over them; if the comparative anatomist, undaunted by their repulsive appearance, had not by means of skilful dissection learnt something of their wonderful structure, and given us the result of his investigations ! In the early days of Conchology, it was held sufficient to study the shells only of these animals, and the possessor of an extensive collection of such shells might have been intimately acquainted with the name, geographical distribution and proper place in a systematic arrangement, of every species in his cabinet, without necessarily knowing anything of the mollusca themselves. Now, however, the Conchologist has given place to the Malacologist, and this gentleman, not content with examining, describing and naming the shell independently of its inhabitant, curiously questions the latter as to its habits and internal structure; and in the case of those which possess a single shell (univalves) he literally learns the relationship of each species from the animal's oum mouth. In this way we come to know, among other things, that as a rule slugs and snails are more liberally provided with teeth than any other animals in the parish; one of our slugs, for instance, actually possessing no less than twenty-eight thousand, they are not, however, all in use at the same time. The dental apparatus of our univalves may be described as a tube lined with teeth set upon flattened plates, collectively called the lingual ribbon. One extremity of this ribbon is open, and spread out like a tongue, teeth upwards, on the floor of the mouth, so as to occupy in fact the same relative 
position as the tongue in the mammalia, and the roof of the mouth is supplied with a horny plate, against which the open end of the ribbon can work backwards and forwards, so as to rasp and triturate the food between them. The tubular portion of this lingual ribbon is contained in a cavity behind the mouth, and as the teeth in use become worn or broken down, it is conjectured that they are absorbed, and a fresh set from the reserve in the tube is pushed forward to take their place.

The body of every mollusc with which we are concerned, except those of the slug family, is contained in a membranous sac called the mantle, which not only serves as a model on which the shell is moulded, but is liberally provided at the edges of its open end with the glands that secrete the shelly matter. To this set of glands alone are due the coloured bands and other markings in the shells, as may be seen in the case of a fractured specimen that has been repaired by the tenant, in this the new matter thrown out by the mantle under the fracture is always colourless. Respiration in the animals of this class is carried on by means of a rudimentary lung in each member of the terrestrial division, the aquatic species, with some exceptions, being provided with gills. In the air-breathing molluscs the air is admitted into the pulmonary cavity, not by the mouth, but by an aperture which may easily be seen in slugs at the edge of the convexity on the back formed by the mantle, and in snails just within the mouth of the shell, in both cases on the right side. We are all tolerably familiar with the fact that one essential character of the vertebrated animals is their possession of a brain and spinal cord, from which proceed those numerous

"Tracts, along which the mysterious will Is conveyed by a process on which fancy lingers With awe, from the brain to the tips of the fingers" 
(or their analogues), and other portions of the animal frame; in the animals under consideration, this plan is considerably modified, and instead of one cerebral mass governing the whole system, we find half a dozen ganglionic centres from which the nervous threads radiate to the organs of sight, smell, hearing, and touch, which appear to be well developed, and the important systems of digestion, circulation, respiration, reproduction and locomotion. When we have added to this faint outline of the internal structure of snails and slugs, that these animals are essential agents in checking the redundancy of vegetation, removing decomposing matter, both animal and vegetable, amd supplying dainty food to many other members of the animal kingdom, we have perhaps said enough to shew that they possess a high degree of interest.

If we next make a passing allusion to the Pearlbearing Mussels, or Unios, it is chiefly with the object of expressing our regret that they have not a single representative in our Harting Fauna that we are aware of. Many rivers and streams in the British Islands, however, are, or have been, rich in them; and nearly two thousand years ago, Britain was celebrated far and wide for its pearls, so much so, indeed, that according to trustworthy historians of that remote period, we are indebted to these precious objects for the first hostile visits of the Romans to our shores, on which occasions in the words of a very humorous modern writer-Cæsar "broke in upon the natives with considerable energy." Several rivers in the British Islands are noticed in works on the subject, as having been at one time the seats of pearl fisheries. We gratefully record the fact that we not long since received a valuable present of Scotch pearls from a gentleman, who at the same time sent us the following extract from the Cornhill Magazine (No. 80, August, I866):- "One pearl is on the average found in every thirty shells, but as only one pearl in every ten is sale- 
able, it requires the destruction of a hundred and thirty shells to find that one gem." "Mr. Unger, of Edinburgh, is the chief dealer in these pearls, the best kinds range from five pounds to fifty pounds each."

The Common Swan Mussel (Anodon Cygneus) is abundant in all our ponds, in the mud of which we find it deeply sunk, with the posterior end only of the shell, where the respiratory syphon is situated, above the surface. Like the Pearl-bearing Mussels, this species produces eggs which it retains within its shell until they are hatched, but the young are at first so unlike the mature individual, that, as they have been frequently found adhering to the bodies of fishes, they have been erroneously regarded as parasites. The largest specimen we have met with in the Great Pond at West Harting, measures six inches in length by three in width; it is of a yellowish green colour, which deepens into a dark brown towards the posterior end. We have also seen others in the same water much smaller and much thinner than this, of a somewhat different outline and with a beautiful glossy grassgreen epidermis, crossed by a few delicate striæ of the same colour, but whether these are a variety or young individuals of the same species, we do not know. " Ploughing the deep," in a literal sense, is one of the occupations of this animal, and the large foot with which it performs this operation is admirably developed for the purpose, its numerous furrows in the mud are distinctly visible. The smaller Bivalves inhabiting the Great Pond and the streams issuing from it, are the Cyclas cornea and Cyclas lacustris, the latter in great abundance, and associated with them is the Pisidium amnicum, which is also widely distributed along the water courses traversing the Down Park and the Nyewood meadows. Pisidium cinereum is another species inhabiting the streams in the East Harting district, and Pisidium obtusale is tolerably plentiful in a shallow water-course in a meadow known as 
“ Pannel's hole." Among our Aquatic Univalves common in the Great Pond, we may specify Valvata piscinalis, the shell of which is a quarter of an inch long, of a yellowish horn colour, and having a circular aperture, closed when the animal is at rest, by a shelly operculum. This species is still more plentiful than the Cyclas lacustris.

Our Slug Family is represented by the Black Slug (Arion ater), the Garden Slug (Arion hortensis), the Large Slug (Limax maximus), the Yellow Slug (Limax flavus), and the Field Slug (Limax agrestis). The two first, as the gardener assures us, have an unpardonable weakness for his plants and fruits, a weakness which. he visits with capital punishment as often as he has an opportunity of doing so ; they also vary their diet with earthworms and other animal matter, living and dead, sometimes even indulging in cannibalism. Arion ater, however, is thought by many persons of easy belief to be endowed with a valuable property, in which may be found a slight compensation for its depredations. In the destruction of warts on the human skin, it has the credit locally of having been eminently successful long before the application of acetic acid to this purpose. The living slug, after having been carefully rubbed over the parts affected, is to be securely impaled on a thorn in some secluded place and there left to die. If, from the commencement of this experiment, the warts do not gradually become "fine by degrees and beautifully less," until they finally disappear, the operator has failed in one or other of the two conditions indispensable to success -implicit faith or strict secresy! The Limax maximus and Limax flavus frequent our houses, and assiduously take upon themselves the duties of scavengers during the hours of darkness, retiring to obscure damp places, drains, \&c., in the daytime. They are not, however, confined to our buildings, they may be found also under stones in damp situations and in the decaying 
stumps in our woods. The Limax agrestis is the pest of the farmer as well as of the gardener, and may be met with in his cornfields in such abundance, that even the willing pheasant finds it no sinecure to keep its numbers within safe limits.

The popular belief that slugs are only snails that, for some reason best known to themselves, have temporarily vacated their shells, is not sanctioned by the observations of Malacologists, who, on the contrary, have long been aware of the fact that slugs are really possessed of shells of their own, of which, to put it in the simplest form of language, these animals would find it remarkably difficult to divest themselves. We have already alluded to the prominence on the back of the slug, this is the mantle on the under surface of which the calcareous secrection is spread out in the form of a thin plate, and the latter, from its position, is no doubt designed as a protection to the important organs beneath it. This plate, as may be anticipated, varies in the different species, and in Testacella, a sluglike animal which we have never found here, it becomes external, and is situated on the back near the tail. Intermediate between the slugs and true snails we find the Vitrina pellucida, in which the general form of the slug is associated with the spiral shell of the snail. Among the decaying leaves under the beech in the Park, among damp moss in the covers and hedgerows, we have found this species in a state of activity when nearly all the other molluscs are in their winter quarters, although its thin greenish transparent shell is much too small to contain the whole body of the animal. Our largest specimen of this pretty shell is about a quarter of an inch across.

- The Cellar Snail (Helicella Cellaria), shell a pale horn colour; the Garlic Snail (Helicella Alliaria), shell nearly or quite transparent; the Crystalline Snail (Helicella crystallina), a minute species inhabiting a transparent shell with a high polish; and the 
Top-shaped Snail, or Fulvous Snail (Helicella fulva), are all found under stones, among moss and moist decaying leaves in our upland and lowland covers, hedgerows, gardens and pastures, the two first occasionally in damp cellars; and whatever difficulty there may be in identifying the different species of this genus, the Helicella Alliaria speaks for itself, very often, at the slightest touch, it gives out such a powerful odour of garlic, that it cannot easily be mistaken for any other species.

The Common Snail (Helix aspersa) may be found plentifully in all the gardens in the parish at any time between its hibernations, particularly after a shower of rain, and in the majority of cases it is no sooner found than it is crushed under foot. If, however, it should be so fortunate as to escape a fatal accident before it has arrived at maturity, each individual deposits upwards of a hundred eggs, and if its value in the French Pharmacopœia is really as great as it is asserted to be, many a sufferer from pulmonary disease has good reason to rejoice at its prolific nature. It is from this species that the valuable Helicine is obtained, but it can scarcely be deemed a recent discovery. Without having the faintest suspicion that this now celebrated specific was ever destined to be introduced to the Medical Profession under a scientific name, Materfamilias, at Harting and elsewhere, has been in the habit of administering it for generations past, with the happiest results, in cases of whooping cough. The formula according to which she prepares it, no doubt differs materially from that of the eminent Physician under the sanction of whose name it has taken so high a rank in the Materia Medica. She simply strings a dozen or so of living snails together, by passing a needle and stout thread through the shell and body of each, these are next suspended festoon-like over a dish or pan containing a layer of coarse brown sugar, on which the mu- 
cilaginous fluid exuding from the snails is allowed to drop. The resulting compound is a "Syrup of Snails," of which she prescribes two teaspoonfuls pro dos: twice a day. We cannot but suspect that in this instance science has taken a hint from her!

Probably not one in a thousand of those who are familiar with the common snail would ever imagine that, under any circumstances, it is capable of becoming musical, we happen to know, however, that this phenomenon is an episode in its history. One stormy evening in autumn some years since, while engaged with a book in an apartment, the windows of which were directly exposed to the wind and rain, we were startled by a sound so sweet, so unlike anything we had ever heard before, and so peculiar, that we were not only puzzled to assign a probable cause for it, but actually unable to form a guess as to the exact spot whence it proceeded. It was often repeated at irregular intervals during the evening; occasionally three or four times in the course of as many minutes; and although it was not loud, and did not continue many seconds at a time, it was distinctly audible notwithstanding the noise occasioned by the beating of the rain against the windows, and the discord of the wind in the "Pandæan pipes" on the chimney stacks. Several months elapsed before we had an opportunity of hearing it again. At this second performance the rain was falling as before, but the shutters of the room were not closed, as they had been in the first instance; and we were enabled distinctly to trace the mysterious sound to one of the windows. A light held near this window at once revealed the fact that the musician was no other than our friend the Helix aspersa. It appeared that the friction of its foot or shell - we could not satisfactorily determine which-against the wet glass had caused a vibration in the pane on which it was travelling, and in this way had produced a note of the same character as that which we all know may be 
brought out of a drinking glass by the friction of a wet finger on the rim. We have heard this sound many times since, and more than once enjoyed the mystified expression of other persons whom we had summoned to listen to it.

The Wood Snail (Helix nemoralis) and the Garden Snail (Helix hortensis), the most gaily-coloured and prettily-banded of all our snails, and vernacularly known here as "snags," are common throughout the parish; but of the Hybrid snail (Helix hybrida), so nearly related to the last species as to be ranked by some authors as only a permanent variety of it, we have only found five specimens here-three in Pads-wood Copse, and the other two in a hedgerow on Hucksholt Farm. The Zoned Snail (Helix virgata) and the Wrinkled Snail (Helix caperata) are met with chiefly on the thistles, nettles, and herbage of the sheepwalks on East and West Harting Downs, Hemner and Torbury; and in some other localities they are so numerous, that they are presumably credited with the property of fattening and flavouring our South-down mutton. The Kentish Snail (Helix Cantiana) is also a Harting species, and may be found not uncommonly on the wild plants growing in hedgerows on the hill as well as in the valley. Omitting any lengthened reference to the Rufous Snail (Helix rufescens) and the Bristly Snail (Helix hispida), both of which are common here, we may specify the pretty little Prickly Snail (Helix aculeata), the shell of which measures about the tenth of an inch in breadth, and the same in height. We meet with this not uncommonly under fragments of chalk and among decaying leaves under the beech trees in the Park. The distinguishing character of this curious shell is that the epidermis with which it is clothed rises at frequent and regular intervals in the middle of each whorl into sharp teeth or points, so as to present under $a$ lens the appearance of a very elegant spiral of bristles. 
Of the Apple Snail (Helix Pomatia), the largest of British snails, we have never met with a living example here, and the only reason we have for assuming that it ever did exist in the neighbourhood, is the discovery of a dead shell of the species in one of the Lady Holt covers many years back. Since then a tender solicitude for the length of our catalogue of natural productions has induced us to import some fifty or sixty specimens of this fine snail into the parish. These were obtained from Preston Candover, where about thirty years back they were plentiful, and we made an impartial distribution of them between Padswood Copse, the Warren, the hedgerows on either side of Love Lane, and Lever's Copse at the foot of the Fore Down; but the experiment to establish them here signally failed; we never saw one of them afterwards, and if, as we suspect, the hedgehog found them toothsome, the fact speaks volumes for the discriminating palate of our erinaceous friend, who in this instance only emulated certain epicures among our Gallic neighbours. With the latter a dish of Escargots is a recognised dainty, and in the summer months may be obtained at the restaurants in many large towns in France as readily as whitebait at Greenwich in the proper season. Some idea may be formed of the estimation in which these snails are held there, from the fact that Burgundy and Champagne send no less than a hundred thousand of them daily to Paris alone. In our younger days we have seen gangs of Breton sailors, from the merchant craft in the Seine, collecting them in the gardens and orchards on the banks of the river, in utter defiance of the rude reception they were certain to meet with if discovered in their occupation by the owners of the premises on which they trespassed. The hostile attitude of the latter, on such occasions, was no doubt stimulated by a tolerably well founded apprehension that the fruits then in season might offer too great a temptation to the conchologists to be resisted. A few pages back 
we had occasion to allude to the wonderful property possessed by members of the lizard family of restoring a lost tail; if any one, reading that statement, has been disposed to receive it with a smile of incredulity, how shall we hope to induce that person to believe that any other animal in Creation is endowed with the still more extraordinary privilege of reproducing a head? We have often heard of the impossibility of "putting an old head on young shoulders," but we learn from the experiments of Spallanzani that the resources of the apple snail are actually equal to the rare difficulty of putting on a new head after the absolute removal of the old one, and this, he tells us, is accomplished in the course of a few months.

The Shrub Snail (Helix arbustorum) is not generally distributed; we have found it plentifully among nettles by the road-side and near water in the village of South Harting, and elsewhere in the valley; but, although in other localities it is said to occur at a great elevation, we have never met with one here on the hill. Of the White Snail (Helix pulchella), on the contrary, we have collected all our specimens under fragments of chalk in the Park and on East Harting Down. The Rock Snail (Helix lapicida) is a common species with a depressed and carinated shell, in shape not much unlike a double convex lens, and is often found in wet weather ascending the smooth trunks of the young beech trees in the Park. The Cheese Snail (Helix obvoluta) is such a local species, that it is supposed to have been accidentally introduced here at no very distant date. As an inhabitant of Ditcham Wood, near Buriton, it was first discovered by Dr. Lindsay, at one time a resident in the neighbourhood. We have found it there also among moss at the roots of hazel; and we have a keen recollection of the fact that the pleasure with which we picked up our first specimen was considerably damped by a sudden deluge of rain, from which we found it impossible to escape. 
We have since found it in another locality nearer $U p$ park, where, within the last dozen years or so, they were so plentiful that we have collected as many as thirty or forty specimens in less than three hours on several separate occasions. If we refrain from indicating the exact spot where these treasures have been found in such abundance, collectors, will, we hope, kindly refrain from censuring our reticence, particularly as we take this opportunity of informing them that we shall be happy to exchange shells of this species for others which we have not found here. The rosecoloured mouth of this rare shell differs from those of all other known British Helices, and during the period of the animal's hybernation we find it closed with a rather thick calcareous epiphragm. The shell itself is of a reddish colour, and thickly studded with short hairs.

The Heath Snail (Helix ericetorum), inhabiting a flattish white and banded shell, is the common snail of our downs, and is often put in requisition for decorative purposes by our tender-aged rustic beauties, who mount a number of the dead shells as necklaces and bracelets, by stringing them together. The Radiated Snail (Helix rotundata) is common in most of our covers and under our beech trees, among moist decaying leaves, wood and bark, the latter, by the bye, we have often found an excellent bait for many of our smaller snails, particularly the Helix aculeata. The Wall Snail (Helix rupestris) we find in the crumbling joints of old walls, and on the moss-covered tiles on the roofs of buildings, and the Pigmy Snail (Helix Pygmaa), which from its minute size is difficult to discover, is not improbably generally distributed. We have collected several specimens in more than one locality from the underside of recent chips of wood, left on the open spots where large trees had been felled.

The Dull Twist Shell (Bulimus obscurus) is very 
common during the summer and autumn months, on the trunks of the beech trees in the park, and at other seasons under stones, moss, and fragments of wood in the surrounding covers, but when very young it often escapes notice as a shell. The following extract from a paper by the $\mathrm{Rev}^{\mathrm{d}}$. Mr. Sheppard, in the Linnzean Transactions (No. I6, I66), will explain why: "These shells, particularly in their young state, shew great sagacity and ingenuity, by covering themselves with a coat adapted to the different situations in which they are found, and when so covered, it is almost impossible for any other than a conchological eye to discover them. If its abode be on the trunk of a tree covered with lichen, then is the epidermis so constructed as to cause the shell to resemble a little knot on the bark of the tree covered with such substance. If on a smooth tree, from whose bark issue small sessile buds, as is frequently the case, it will pass off very well for one of them, and on a dry bank or the lower part of the body of a tree splashed with mud, its appearance will be that of a misshaped pointed piece of dirt." Of course when the shell is fully developed, this disguise is less perfect, although the coating of extraneous matter is still conspicuous. The Common Varnished Shell (Zua lubrica), a very glossy little oblong shell of various shades of brown, is frequent in the same habitats as the last. The Glossy Trident Shell (Azeca tridens) we have found in company with the Zua lubrica, but one specimen only is all that we possess of this rare species, a few others, however, have occasionally been met with in the warren. The Umbilicated Chrysalis Shell (Pupa umbilicata), the Margined Chrysalis Shell (Pupa Muscorum), the Toothless Whorl Shell (Vertigo edentula), and the Pigmy Whorl Shell (Vertigo pygmaa), all very minute shells, are found among stones, chalk and moss, on old walls and tiled roofs of old buildings in the park and elsewhere. The 
Fragile Moss Shell (Balea perversa), one of our commonest, may be collected in great numbers on the mossy bark of the old beech trees in the park.

The Epiphragm, where it is found in the Helicida, is a thin plate accurately fitting the mouth of the shell, and secreted by the animal for its protection during periods of inactivity, but is cast off at will when no longer required. The Operculum, as in the Common Winkle for instance, is a plate of a horny character (in some Genera it is calcareous) permanently attached to the back of the animal's foot, and naturally closes the aperture of the Shell when its inhabitant has retired within it; but the next genus we have to notice is characterized by the possession of an apparatus for (partially) closing the last whorl of the shell within the mouth, which is neither epiphragm nor operculum. It consists of a valve attached to the pillar of the shell by an elastic hinge, and "When the animal wishes to protrude itself, it pushes the plate on one side into a groove situated between the inner plait and the columella (pillar), where it is detained by the pressure of the body of the animal, leaving the aperture free, and when the animal withdraws itself, the plate springs forward by the elasticity of its pedicle and closes the aperture."-(J. E. Gray, F.R.S., \&c., in Zoological Journal I. 2I2.) Of this singularly gifted genus we possess three species,- - the Laminated Close Shell (Clausilia laminata), about three-quarters of an inch in length, very common on the trunks of trees, on fences and among moss, in and near the park; the Rugose Close Shell (Clausilia rugosa), half-an-inch long, equally abundant with the last on walls, fences and trees, among moss and under stones in the same localities; and "last, though not least," the rare Clausilia Rolphii, which with us is nearly as plentiful as either of the other two species, but more local and less easily discovered. Not far from Uppark, within the manorial boundaries, we have more than once or 
twice gathered quite a harvest of them in the course of a few hours; this sentence is specially dedicated to collectors, whose cabinets are rich in all the other British shells but this.

The elegantly delicate and transparent minute Needle Agate Shell (Achatina acicula), may not improbably in the transactions of future .Conchologists, be recorded as anything but a rarity in the parish; but hitherto we have not been so fortunate as to discover its favourite habitat. It is presumed to be chiefly subterranean in its habits, but it may occasionally be found at the roots of grass, under stones and decaying wood. The only specimen we ever met with, a living one, was under a block of chalk resting on turf at the foot of East Harting Down.

The Common Amber Snail (Succinea putris) is plentiful on plants growing near the ponds, water courses and ditches in our lowland meadows, and its thin deep-amber-coloured shell is really a very pretty one. The Minute Sedge Shell (Carychium minimum) occurs in abundance in the park under fragments of chalk, among moss and moist decaying leaves. Our Pond Snails are the Wandering Mud Shell (Limnoea peregra) and Var. ovata, both found in the South Gardens Middle Pond, the West Harting Great Pond, and some of the water courses in the meadows; the Lake Mud Shell (Limnoea stagnalis), confined to the Great Pond (of this species we possess a specimen having a faint white band on the last whorl); the Marsh Mud Shell (Limncea palustris), in some of our stagnant waters; the Small. Mud Shell (Limnœa truncatula), a very rare species here; the Stream Bubble Shell (Physa fontinalis), generally distributed; the River Limpet (Ancylus fluviatilis), in the Great Pond; the Contorted Coil Shell (Planorbis contortus), generally distributed; the Flat Coil Shell (Planorbis vortex), not common in the parish; the Flattened Coil Shell (Planorbis marginatus), common in all our ponds 
and water courses; and the White Coil Shell (Planorbis albus), generally distributed. We have seen specimens of the Keeled Coil Shell (Planorbis carinatus); and the Streaked Coil Shell (Planorbis lincatus), said to have been found here, but we have never been so fortunate as to collect any of either species ourselves.

Returning to the Land Shells, we find that our list of mollusca appropriately closes with an operculated species, the Cyclostoma elegans. This is provided with a purple-tipped, prettily-banded, brownish-grey shell, about half-an-inch long, and having a circular mouth, from which latter character its generic name is derived. It is generally, but not plentifully distributed in our covers and hedge rows, and appears to be particularly unwilling to encourage the familiarities of the Conchologist, at the least alarm it suddenly drops from the plant on which it may be engaged, hurriedly withdraws itself into its mansion, and securely closes the door.

We do not flatter ourselves that the fact incidentally revealed to us by this species is destined to lead to any very startling or even useful results, we nevertheless venture to make a note of it here, although it might with more propriety be included in the geological section. In a little spring, at the foot of one of our downs, we have, season after season, for many years past, met with specimens of the dead shells of the Cyclostoma, of the Helix rufescens, and of the Helix hispida, thickly and uniformly coated with a hard calcareous deposit, similar in appearance to that on the so-called Derbyshire petrifactions. In all probability this deposit is very slowly formed, otherwise more perishable substances than the shells of snails would be found encased by it, but shells are the only objects we have noticed in this condition, and we have hitherto seen them in no other locality in the parish. 


\section{CHAPTER V.}

\section{INSECTS.-BEETLES.}

THE next division of invertebrated animals exceeds all the other classes in numbers of species and individuals, variety and elegance of outline, and beauty and richness of colouring and clothing. It includes all those articulated forms of animal life which the earlier systematists grouped together under the general designation of Insects-so called from the insections of their bodies into annular divisions or segments. The outward covering of insects is more or less firm in the different species and, like the internal skeleton of vertebrates, affords the requisite points of attachment for their muscles, the number of which is so great that we have nothing to equal it in the higher animals. From the immortal Lyonnet, whose study of the anatomy of a single species was carried on with rare patience and perseverance for many years, we learn that the caterpillar of the Goat moth, for the due performance of all its various functions, requires not less than seven times the number of muscles that are found in man!

The transformations of insects are among the most interesting wonders in Natural History appreciable by the unassisted eye-first an egg, deposited under conditions unerringly calculated by supreme intelligence to ensure its protection; then the Grub or Larva, which, on leaving the egg, finds itself at once surrounded by an abundant supply of the very food on which it is destined to thrive ; next the pupa, securely lodged in a silken cell, which it has already constructed as if in anticipation of its future use ; and, lastly, after a longer or shorter period of repose, during which other important changes are in silent progress, the 
perfect insect with all its parts complete, the gorgeous butterfly, or the brilliant beetle. There is no insect so small as not to afford ample space within its external crust for the unobstructed performance of all the vital functions. The most minute of beetles possess the same number of segments and jointed organs as the most gigantic; and perfect systems of digestion, circulation, and respiration are common to them all.

The function of respiration in true insects is carried on by means of a remarkably complex apparatus; instead of lungs they are supplied with an incredible number of wonderfully-constructed air tubes called trachea, running through every part of the body like a fine network. Each of these tubes, however minute, is kept in a state of distension by a fine elastic thread wound round and round from end to end like a spiral spring, and the air is drawn into them through several openings in different parts of the body called spiracles, or breathing pores, which some insects have the power of opening and closing fifty or sixty times in a minute. These breathing pores, where they are not protected by wings or wing-cases, have most of them a provision for filtering the air that passes into them, so as to exclude the finest floating particle of dust which might otherwise be drawn into the air tubes and cause an obstruction. The construction of this filter is not limited to one plan; in some insects it consists of an elastic fringe attached to the inner border of the spiracle, the free ends of which meet in the centre, so as to leave no part of the opening undefended. In others it is a delicate membrane stretched over a framework fitted across the aperture and pierced with minute holes like perforated zinc. Other forms might be described, but these are sufficient to show that the members of this class have been in the habit of wearing respirators from time immemorial.

In the typical forms of the most perfect insects we find six legs fitted for various modes of progression-. 
walking, running, leaping, burrowing, and swimming ; wings for flight, and wing-cases to protect them. The most perfectly-furnished insect mouth is made up of twelve principal moveable pieces-upper lip (Labrum), under lip (Labium), a pair of upper jaws (Mandibulce), a pair of under jaws (Maxilla) working horizontally between the lips, and six feelers (Palpi), four of which (Maxillary Palpi) are attached to the under jaws, and the remaining two (Labial Palpi) to the under lip. All these may be easily seen in large beetles; but in many other insects some of the pieces are wanting altogether, and the others are found under very different forms, according to the character of the food they are designed to act upon. The most conspicuous organs, however, in the majority of our local insects are those wonderful articulated appendages projecting from the space between the eyes and the mouth, called the antennæ. That these are exquisitely sensitive organs there is ample evidence to show; but whether they are the seat of a simple or a compound sense appears to be as yet an unsolved question. Some insects use them as tactors to explore the surface on which they are walking; others as instruments of discovery when the object they seek is so well enclosed in a carefully-constructed cell deeply concealed in wood, that the antennæ cannot possibly touch it. A wasp confined in a wine glass inverted over a drop of turpentine or collodion on absorbent paper, after a few frantic struggles to escape, quietly settles down to devote especial attention to its antennæ by carefully and repeatedly passing its fore feet along their whole length, as if to free them from the annoying effect of the vapour-query, odour?* In many insects the

- In the "Chichester Magazine" for June, I837 (a periodical long since defunct), there is a short article bearing upon this subject, which we quote :-

"I once imprisoned a few small predacious beetles in a close box having a glazed lid, with some camphor; and I kept my eye 
antennæ of the males appear to be keenly alive to other influences so utterly imperceptible to us, that we can only surmise the fact of their existence from the behaviour of the creatures affected by them. This will be again adverted to when we come to treat of the moths. In size, length, form, and other particulars, antennæ vary so much that Messrs. Kirby and Spence, in their admirable "Introduction to Entomology," have devoted several octavo pages to a description of them alone.

The organs of vision in insects are so largely developed, that in many species they present the appearance of two fixed hemispheres nearly covering the head, one on each side. Under a lens the surface of these prominences is seen to be divided into a great number of hexagonal spaces, each of which is found on dissection to be the base of a prism, and a distinct eye of itself. The number of such eyes in different insects ranges from about fifty to between twenty and thirty thousand, and, wonderful to relate, a distinct branch of the optic nerve is allotted to each! As the

intently fixed on them for some time. After their first struggles to escape, unequivocal symptoms of uneasiness exhibited themselves in the antennæ. The little animals frequently and adroitly brought down each of these organs under one of the anterior tarsi alternately, and drew it back in such a manner that the latter passed along its whole length, as if to free it from some extraneous matter. After an interval they would convulsively start backwards, forwards, or sideways, holding down their heads in the meantime, and evidently endeavouring to conceal the antennæ. In a few minutes more they showed evident signs of intoxication, often turning round and round, running rather rudely against the walls of their prison, and against each other, fixing their bodies in the most grotesque positions, and rolling over on their backs, while they suffered one or other or both of their antennæ to drag powerless along, having apparently lost all controul over them.

"The first time that I witnessed this scene I was struck with the analogy between the effects of camphor on insects and that intoxication which is produced in man by the smell alone of spirits." 
prisms in each compound eye radiate from a common centre, and are isolated from each other by a coating of dark pigment, an object to be seen by the insect must be in a strictly direct line with the axis of one of the prisms and, as this cannot happen with the same object to more than one prism on either side at a time, it is not difficult to comprehend that our own vision, with two eyes only, may not be more free from a confusion of images than that of an insect with its thousands; and that the aggregation of so many similar organs, placed at all angles, may in reality have been designed as an admirable compensation for their immobility. Many insects possess one, two, or three simple eyes in the form of very convex lenses (sometimes of unsurpassed brilliancy) fitted into the central space on the head not occupied by the compound eyes; and it has been conjectured by Messrs. Kirby and Spence that the range of vision in the former is upwards, while that of the compound eyes is more or less horizontal. For further details of the general and particular structure of insects we cannot refer to more delightful and instructive works than Kirby and Spence's "Introduction to Entomology," and its sequel, Westwood's "Introduction to the Classification of Insects."

We have already stated that the organs of manducation (parts of the mouth) in beetles* are more fully developed both as regards number and structural character than those of other insects; beetles, therefore, in modern systems of classification take precedence of all the other orders. Their numbers are so great that Stephens, in his "Manual of British Entomology," published in I839, has described upwards of three thousand species; and, without doubt, many others have since then been added to the list. The Cicindelida

- Order Coleoptera-from the Greek Koleos, a sheath and pteron, a wing-wings in a sheath. Wings four ; the upper ones (Elytra) corneous, without veins, and covering the under ones. 
take the first rank among beetles, and as they are among the most active and ferocious insects of prey, they are very appropriately named Tiger Beetles. They so readily take wing, and are so fleet footed, that not only do their luckless victims find it almost impossible to escape them, but they themselves are not easily captured by the entomologist. The only species we have met with here, chiefly on the highway known as Tarbury Knap, and occasionally in the sandy district, on bright sunny days in spring and summer, is the Cicindela campestris, a beautiful rose-scented, silky green beetle, with white spots on the wing-cases, and a tinge of copper on other portions of the body. In its larval state it is a horrid-looking grub, nearly all head and jaws, inhabiting a deep vertical burrow which it makes in the soil. It is provided with two hooks on the back, by means of which, with the assistance of its six legs, it can anchor itself just within the mouth of its pit, which it then closes with its large flat head. In this position it is capable of suddenly seizing any unwary insect that may be passing within reach, and dragging it down to the bottom of its charnel house, where it quickly devours it.

The next group of predacious Land Beetles (Carabida) is a very large one, no less than four hundred and fifty species having been described as British. The members of this division may frequently be seen running about highways and pathways, or found concealed under wood, bark and stones, in hedgerows and other places, and their office is to assist in keeping within numerical bounds the hosts of other insects which, in their most voracious stage, commit such havock on the roots of our herbage and the green leaves of our trees and plants. The Cychrus rostratus, Carabus violaceus, Carabus catenulatus, Carabus nemoralis and Carabus monilis are among the larger species engaged in this work, and are generally distributed hereabouts. The smaller Nothio- 
philus aquaticus, Elaphrus cupreus, Elaphrus riparius and Bembidium flavipes, we find more frequently near water, particularly on the dried mud at the edges of ponds. Zabrus gibbus occurs in our cornfields, $A b a x$ striola everywhere, and of the pretty little Brachinus crepitans we have met with several specimens under stones, \&c., in the hedgerows on Hucksholt and Castle Farms. We had often read of the Bombardier Beetle, long before we had an opportunity of identifying the insect, but the first specimen we captured fired off such a volley of "stern chasers" when we put it into a wide-mouthed phial and gently stimulated it with a straw, that notwithstanding all we had learnt from ${ }^{\circ}$ books on the subject, we were quite taken by surprise. This then, we thought, is the prudent individual that never travels without his pocket revolver, and makes such excellent practice with it when called upon to defend himself! The ordinary occasions on which this artillery is played off are when the Bombardier, which is less than half-an-inch in length, is closely pursued by other and larger insects of prey; if it finds itself about to be overtaken by its assailant, it astonishes the latter with such a loud explosion, accompanied by a wreath of blue smoke and a very pungent odour resembling that of nitric acid, that the pursuit is checked for a few seconds, the chase is soon renewed, however, to be again interrupted by a wellaimed shot, and so on a dozen or twenty times in succession if necessary. So caustic is this volatile ammunition, which is expelled from two reservoirs near the posterior extremity of the body, that if its effect on the sensitive antennæ of insects resembles the burning sensation it produces on the skin of the Entomologist, the frequent escape of the Brachinus from its enemies need not excite our surprise.

The Pelobius. Hermanni, Colymbetes maculatus, Acilius sulcatus, Dyticus marginatus, Dyticus circumflexus, and Gyrinus natator are among our com- 
monest Water Beetles, inhabiting most of our stagnant waters. To these we may add Berosus luridus, Hydröus piceus and Hydroechus Caraboides, met with in our ponds and ditches. The male of the Dyticus is distinguished by a remarkable expansion of each of the two anterior tarsi, the underside of which, under the microscope, is a very beautiful object, and proves to be a very efficient apparatus of suckers, by means of which the insect is enabled to hold on to a flat polished surface very securely. We have seen the Dyticus circumflexus anchored at arm's length, by means of these organs, long after death, in a flatbottomed glazed vessel nearly full of water, the body at the same time swaying to and fro as often as the vessel was moved. The Gyrinus natator is that little black shining gregarious beetle we so frequently see in fine weather sportively whirling round and round, in a maze of circles, on the surface of the water with astonishing rapidity.

Sphoridium bipustulatum and Sphoridium Caraboides frequent the droppings of herbivorous animals, and Scaphidium quadri-maculatum we have found in a rotten stump in the beech woods in the Park. The Burying Beetle (Necrophorus Vespillo), whose singular economy has deservedly been the theme of many a writer on Entomology, finds frequent opportunities here for the exercise of its admirable instinct. In its perfect state it feeds on carrion, and it is also careful to provide a larder, well-stocked with the same kind of fare, for its young. This is the appointed sexton for all the dead rats, moles, mice and small birds it may find about to undergo decompositon on the surface of any loose mould or sand. No sooner is a carcase discovered by this sanatory official, than the work of giving it a decent interment immediately begins. With or without the assistance of others of the same species, it laboriously scoops out the earth from under the dead body until the latter gradually 
sinks into its grave; the little ridge of mould, which by this time has been thrown out round the excavation, is then neatly levelled over the defunct, and the interment is complete. In a few days afterwards, the individual, on whose remains so much patient toil has been bestowed, is swarming with the young larvæ of the burying beetle. Other species of this family which we have taken here in decomposing animal matter, are the Oiceoptoma thoracica, Silpha obscura, Nitidula bi-pustulata and Nitidula discoidea. Under bark, in rotten wood and in fungi, we meet with Micropeplus porcatus, Mycetophagus quadri-pustulatus and Mycetophagus atomarius.

Dermestes lardarius, as may be inferred from its specific name, yielding to the temptation of bacon in our drying lofts, visits our houses in great numbers, and appears to enjoy the food of its choice when the latter is in that stage of flavour locally known as "hammy." Dermestes murinus may frequently be shaken out of the bodies of the dead moles that are so conspicuously gibbeted on the twigs of bushes and trees near the scene of their capture. Anthrenus Museorum seems to prefer the dried skins of stuffed birds and other animals, when they have not been made sufficiently ungrateful to its palate by the Taxidermist, not even despising the specimens in our Entomological collections. Byrrhus pilula, so called from its singular habit, when alarmed, of packing its legs and antennæ so closely to its body as to resemble anything but a living insect, and thus remaining motionless till the danger that threatened it is passed, is common enough on our dusty and sandy highways and pathways. The dung of animals again, in our meadows and pastures, supplies us with Onthophilus striatus and many species of Hister.

Almost everyone is familiar with the large Stag Beetle (Lucanus Cervus), sometimes two inches long. This insect is armed with such formidable protruding 
jaws, that when their strength has been unintentionally tested by the Entomological finger, the incident has generally left a lasting impression on the memory of the owner of the latter. Rotten wood is the food of its larvæ, we accordingly meet with the perfect insect not uncommonly in the timber-yard, or in old sawpits where an accumulation of sawdust has lain undisturbed for a long time. Dorcas parallelipipedus we have often found in similar habitats, and Sinodendron cylindricum is common in decaying ash trees and stumps.

Among the true Dung Beetles we have taken many Onthophagi, Typhous vulgaris (at Downparks), Geotrupes stercorarius, and several species of Aphodius. The Geotrupes, alias common Dor, or Clock, or Blind Beetle, is that large beetle, black above, violet underneath, that " hath rung night's yawning peal" any fine summer's evening ever since the days of Shakespeare, and occasionally brought its "droning flight" to an abrupt check against the person of any one indulging in an evening stroll, as if it really were blind. It soon takes wing again, however, and resumes its course, which is generally in a direct line to a recent deposit of cow dung, under which it disappears, and at once sets about boring perpendicularly downwards into the earth. It then partially fills its tunnel with the dung, commits an egg to it, and repeats the operation several times, thus materially aiding in the dispersion of masses of offensive matter which would otherwise injure the herbage and poison the air. We have often seen this useful scavenger infested with a very annoying parasite, an active Mite (Gammasus Coleoptratorum), one of the privileges of which is that of securely defying the utmost unaided efforts of its victim to dislodge it. When, however, the discomfort of the beetle from this cause has become intolerable, it has _recourse to a singular expedient for ridding itself of its unwelcome companions. It seeks a convenient heap of loose earth, plunges headlong into it, and rapidly bores its 
way through, so as to rub off its parasites by main force and, before those that have escaped being crushed in the process have had time to recover from their surprise at the rough treatment, it hurriedly takes to it wings and leaves them behind! Further on, we shall have to record the still more remarkable proceeding of another insect that is subject to the attack of the same species of mite.

Trox sabulosus we have taken on West Heath near the line of Railway, and among the destructive chafer family we have met with numerous specimens of Serica brunnea; Rhysotragus Solstitialis (the Midsummer Chafer); Melolontha vulgaris (the Common Cock Chafer); Phyllopertha horticola and Hoplia argentea. The beautiful Golden-green Rose Chafer (Cetonia aurata) we have found less frequently. In the catalogue of insects that, as Larvæ occasionally injure our herbage by devouring the roots, and in the perfect state now and then make a clean sweep of the foliage over large tracts of our woodlands, we scarcely need say that Melolontha vulgaris, Phyllopertha horticola, and Hoplia argentea, are very notorious. In Kirby and Spence, some astounding passages in the history of Melolontha vulgaris are given, which far surpass anything of the kind that has ever come under our own notice. Of the depredations of Phyllopertha horticola however, we can speak from actual observation. From a letter written in 1858 , we extract the following notice of this insect:- "When I began my letter it was my intention to say something of the rooks, in continuation of my strictures on their conduct last year; but if I state in passing that, here and elsewhere in the adjoining parishes, they are chargeable with the serious offence of materially influencing the marketable value of mushrooms, I must in common fairness admit that they are well entitled to a goodly share of this comestible, in consideration of the great good of which they are the instruments this very 
autumn. They have been turning up acres and acres of turf to an extent, that I, the impartial chronicler of their deeds, never saw before, in the parks at Uppark and Lady Holt, in the lowland pastures and on the sheep downs, in quest, as I have good reason to believe, of the larvæ of Phyllopertha horticola, an insect that abounded here so astonishingly last summer, that it darkened every growing plant with its numbers, dissected the leaves of the hazel and other underwoods in the copses, leaving nothing but unsightly botanical skeletons on the young shoots, remorselessly disfigured the roses in the garden, and lastly made a most wanton attack on the ferns in my collection. In short, they seemed to be endowed with such an unsparing appetite, and so accommodating a digestive apparatus, that they found a repast in almost every green leaf on which they alighted, with the exception perhaps of those of evergreens; but hundreds perished in the rash attempt to rifle the sweets of the blossoms of the Tulip tree (Liriodendron Tulipifera), which probably contained a poison as fatal as it was attractive to them. A similar visitation, attended with even greater destruction, is remembered by the patriarchs of the village, as having made one year of their local history remarkable, and then, as now, the rooks had their autumnal feast the following season, scarcely a yard of the turf on the lawn at Uppark was left untouched by them, and great was the dismay of the then park-keeper at the loss of such an extent of pasture; but the following spring did more than compensate for this temporary damage, thanks to the rooks the grass sprang up in greater vigour and luxuriance than before, and for a few seasons afterwards the lawn looked fresher and greener than any other part of the park where the surface had not been disturbed."

Several species of Elater (Skip-jacks) are common with us, and as their larvæ are the well known Wire- 
worms that infest the young wheat plants, were it not for the useful pheasant, the rook and the jackdaw, they might perhaps be deemed too common. Drilus flavescens, which as a larva preys upon the common snail, we have occasionally met with both in its winged and apterous states, the former being characteristic of the male, the latter of the female. We have also taken one specimen of Dyctiopterus minutus on an oak tree in the park, and so rare was this insect deemed as an undoubtedly indigenous specimen by the late eminent Entomologist, Mr. Curtis, that he thought it worthy a place in his cabinet. It scarcely need be said that the Glow-worm (Lampyris noctiluca) lights up its lamp every summer nearly all over the parish, and sometimes even keeps it burning as late as November; we have frequently seen instances of this on the Fore Down and by the roadside in the open part of the warren. We have also a distinct recollection of having once seen near the warren stile a luminous insect on wing, in all probability the male of this species, which, however, among these "stars of the earth and diamonds of the night," shines less brilliantly than its mate.

Telephorus fuscus, Malthinus flavus, and the pretty little brassy-green Malachius aneus we find in abundance, the two first on plants and flowers, particularly the blossoms of the hawthorn, the latter chiefly among the meadow grass. Tillus oblongus we have taken on palings and dry fences; Thanasimus Formicarius under the bark of an old ash tree felled last winter in the park, and Corynetes violaceus in unoccupied wainscoted rooms in the house and in outbuildings.

In old houses the sleepers and joists on which the floors are laid, are often "honeycombed" by a host of small Timber-boring Beetles,-Ptilinus pectinicornis, Ptinus Imperialis, Mezium sulcatum, Anobium tesselatum, and others. Of those we have enumerated, with the exception of Ptimus Imperialis, we have taken 
many specimens here, of the latter not more than three. Although many species of this family produce a distinct ticking noise at certain seasons of the year, as a signal to their companions, the Anobium tesselatum is the death-tick or death-watch par excellence, and for ages past has been listened to by the superstitious with a feeling of awe. To any one, who in these days of enlightenment, still entertains the belief that the object of this ticking is to foretel the death of a member of the family then living in the house where it is heard, we have much pleasure in submitting the result of a simple experiment which we have more than once gone through very satisfactorily. We have placed one of these beetles on an uncovered table, and with the point of a pencil we have gently tapped the table ten or a dozen times in rapid succession, and repeated the tapping several times with a pause of a few seconds between each. In very little more than a minute we have seen the death-tick bring its legs nearly together close to its abdomen, raise the anterior part of its body to an angle with the surface it stood upon, and obligingly shew us how the real ticking is effected. At every stroke it brings its mandibles into forcible contact with the table, by using its feet collectively as a pivot, on which the whole body in a rigid state is made to work rapidly up and down, and this performance it willingly repeats as often as it may be called upon to do so. Scolytus destructor and others of the family to which it belongs, which we have collected in the timber yard, carry on their operations chiefly in old elm and ash trees, between the bark and the wood, without penetrating far into the latter. They are said to be very destructive insects, but we believe that they seldom, if ever, attack perfectly healthy young trees; and that their office is simply to hasten the decay of unsound ones.

Another family, and a very extensive one, of truly destructive beetles, is that of the Wecvils. It includes 
some of the most elegant forms among the whole insect tribe, and many species are clothed in such gorgeous costumes, that one need not be an Entomologist to admire them. The Calandra granaria, which for its subsistence throughout the whole period of its larval stage is satisfied with a single grain of wheat, is abundant in our granaries, and often does much mischief there. Cionus Scrophularice, Cionus Verbasci, Cionus Blattaria, with their slimy larvæ, are not uncommon on the plants from which the two first derive their specific names. Ceutorhynchus Erisimi and Cryptorhynchus Lapathi we have not so often seen. Orchestes Fagi is very conimon, and pierces the buds of our beech trees just as they are about to burst, to such an extent, that the delicate green leaves when fully expanded, are found to be disfigured with innumerable perforations like pinholes. Balaninus Nucum, Balaninus Glandium, and Balaninus villosus, we have taken not unfrequently in Padswood Copse and other covers. The first gives birth to." the little red-capped worm that's shut within the concave of a nut," and has not the most distant resemblance to its larva, which every one who has cracked a "maggotty" nut must be familiar with. The perfect insect is provided with a curved rostrum, nearly as long as its body, and as fine as a needle, with which it perforates the outer integument of the nut before it has become hardened into a shell, and there deposits an egg. Anyone who has the curiosity to carefully examine a few nuts while they are in their growing state, may detect the scar of this perforation in nearly every specimen that has been attacked by this weevil; the little round holes we so often see among the nuts we have stored up for winter use, are the work of the full-grown larvæ, which thus gnaw their way out of their nurseries in order to undergo their next metamorphoses. The economy of Balanimus Glandium, which commits its eggs to the acorn instead of the 
hazel nut, is in all other respects similar to that of the nut weevil. Among the other species of this family which we have met with here, we may specify Grypidius Equiseti, Molytes coronatus, Hylobius Abietis, Phyllobius Pyri, Phyllobius argentatus, Phyllobius Mali, and Cleonus sulcirostris, all in the park; Lixus paraplecticus on aquatic plants, between the Springhead in Brewhouse piece and the Kennels, and Panus barbicornis in hedges and covers. Phyllobius argentatus is the pretty little beetle so remarkable in our Entomological career, as the very first insect we ever examined under the microscope, and an indescribably beautiful object it is, so resplendent with brassy-green scales, that although much less dazzling than the South American Diamond Beetle, which looks as if it were studded with precious stones, it may be regarded as its Harting representative. It is a very common species and generally distributed.

The elegant but minute pear-shaped weevils forming the genus Apion, which attack the seeds of various plants after the example of the nut weevil, are very numerous, specifically and individually, and one which is not uncommon here is the Apion frumentarium. This is about a quarter of an inch in length, and under a lens presents the appearance of a most exquisite miniature carving in red coral, with jet black eyes. Rhynchites pubescens, which we have taken in Padswood Copse, is another weevil of a different form and a rich shining blue, thickly clothed with short stiff hairs, and a still more beautiful species inhabits the same locality, Rhynchites Betula, a brilliant metallic green, blue, violet, or purple beetle, with a rich golden gloss on the rostrum and legs. Apoderus Avellance is of more sober colours, and frequents most of our upland covers. The food of its larva is the leaf of the hazel, which the parent insect knows how to convert into a neat pendulous lodging for its young, in which the latter is enabled to consume an ample stock of 
provisions, and undergo all its changes secure from any ordinary accident. We have unfolded many of these cases, which, to the best of our recollection, are seldom more than an inch long by three-eights wide, but they vary in dimensions according to the size of the leaf out of which they are fashioned, the smaller ones containing one egg only, the larger ones frequently two. The first step in the formation of this curious nest, appears to be the weakening of the nervures in a straight line across the leaf, about midway between the stem and the free extremity, as if to facilitate the next operation, which consists in lapping over the upper half on to the lower half, the two sides are next folded inwards, an egg is attached to some part of the interior, and the whole is so compactly rolled up and so ingeniously packed in at the ends, that when completed it has the appearance of a truncated cylinder closed at each end, and suspended about its centre by the stem of the leaf. On examining an empty case after it has served its purpose, we find that the young grub has been careful to feed on the inner loose folds of the leaf only, leaving the outer portion untouched, until it was ready to emerge in the perfect state. Bruchus Pisi belongs to this division, and appears to enjoy the green peas in our gardens as much as we do ourselves, the maggots we so frequently find in the pods are its larvæ. Anthribus albinus has a preference for the Spharia Fraxinea, which sometimes dots the dead branches of old ash trees in the park, where we have found it.

The Long-horned Beetles follow the weevils, and among them we find some very interesting examples here. Prionus coriarius, a large leathery looking insect, occurs occasionally in the wooded parts of Uppark and Lady Holt Park, and Aromia Moschata, a very beautiful beetle with so powerful a perfume, resembling that of otto of roses rather than musk, that its presence may often be detected by this alone, 
before the insect itself is seen. It is often more than an inch in length, of a glossy coppery-green colour, occasionally tinted with blue, and inhabits old pollard willows. Tretops prausta, a very small beetle, deriving its generic name from the singular fact that its antennæ are inserted in such an unusual position, that they appear to divide each eye into two distinct ones, we have discovered on the hawthorn in the park. Callidium violaceum is not unfrequently found sunning itself on the park fence, and Clytus arietis, which to a non-entomological eye, presents at the first glance some resemblance to a wasp, is partial to the blossoms of the hawthorn. On dead fences we have taken many specimens of Rhagium bifasciatum, one of which, a well-marked variety, is still treasured by us as a rarity, and Leptura quadrifasciata is common on the blossoms of the hawthorn and other wild flowers.

A few species of the beautiful Genus Donacia, belonging to another division of beetles, may be seen on the flags and rushes bordering the ponds and water courses in the Down Park and West Harting meadows. Donacia protous, the most common species, has a beautiful metallic splendour, and varies so much in tint in the different individuals, that it is difficult to find two exactly alike in this respect, we have seen them of a deep blue, a light blue, purple, violet,.brassygreen, grey, yellow, and several shades of red. Crioceris Asparagi in favourable seasons is plentiful on the asparagus in our gardens; Cassida Murrea, Cassida viridula, and other species of tortoise beetles, we have found on various wild plants in the fields and meadows. Galeruca Tanaceti appears to be very local, we have found it in abundance, season after season, in one spot on the herbage on East Harting down, and in no other locality, and Luperus flavipes is not at all uncommon on the blossoms of the hawthorn and other flowers. The Genus Haltica is made up of those innumerable minute leaping beetles of which we hear 
so much, under the name of "the fly" among the young turnip plants in our fields, where Haltica nemonum, among others, is so busy in dry seasons, that it has often been the cause of much loss to farmers, by entirely destroying crop after crop. The claims of Mniophila Muscorum to our notice are of a much more innocent character.

"The shapely limb, the lubricated joint, Within the small dimensions of a point,"

are here proved to be no poetic fiction; we have shaken more than one specimen out of moss gathered in the Westwood, and the largest of them did not exceed the twentieth part of an inch in length. Cryptocephalus sericeus, a brilliant golden-green gem, we have taken frequently among meadow grass; Clythra quadripunctata on hazel under oak in Padswood Copse; Timarcha tenebricosa (the bloody-nose beetle) in many places on wild plants, particularly the different species of galium; and many beautiful species of Chrysomela, among which we need only name the Chrysomela polita we find inhabiting our hedges.

Coccinella is the generic name of the very common little Lady Bird, which in our days of innocence we have so often heard affectionately enjoined, in the language of a defunct poet, whose effusions have survived his name, to "fly away home;" but why it should have been stimulated to do so by the unfounded statement that its "house" was "on fire," and its "children at home," we have never been able to understand. We have met with several species red, with round black spots, yellow, with round white spots, and glossy black with red blotches, and we know that they are a most useful tribe of insects, passing the whole of their growing stage in destroying the different species of aphis that infest and injure so many of our plants. Of the Endomychus coccineus we several years ago discovered quite a colony under the bark of an old 
decaying beech tree in the Park, but we have never seen a single specimen of the species since. Tenebrio Molitor, the progenitor of the well known mealworm, we have often found about houses where the consump-tion of flour and meal does not uniformly keep pace with the supply. Opatrum Sabulosum we have met with at Down Park, Blaps mortisaga frequently in the stables at Uppark, Melandrya Caraboides once under the bark of an old ash tree, and from the hawthorn we have more than once shaken Mordella fasciata, so nearly related to the remarkable Rhipiphorus paradoxus, which is sufficiently daring to enter the nest of the hornet for the purpose of depositing its eggs in the young grubs of this formidable insect. Proscarabens violaceus occurs not uncommonly on the herbage in the open part of the Warren, and we once made a post mortem examination of one large specimen, which we found to be infested with a species of intestinal worm. Edemera carulea and Pyrochroa nubens are common on the hawthorn, and of the pretty little Salpingus ruficollis we have taken several specimens on dead fences in the Park and elsewhere. A propos of this beetle, we venture to give an extract from a letter written at a period when we were most actively engaged in entomological pursuits :- "At the outset of my report for the first half of this season, I suppose I need not lay much stress on the discovery I made long ago, that the entomologist occasionally gets laughed at in his rambles, I am nevertheless disposed to record the fact that if at any future time during the term of my natural life my sanity should be called in question, I should be exceedingly loth to leave the issue to any one of the group of intelligent haymakers I accidentally encountered to-day in a field in this parish. They were at their symposium, literally. "sub tegmine Fagi," when I entered the field and quite unexpectedly found myself in their presence. Their employer, a burly specimen of the race, in rude health 
and spirits, with a wholesome contempt for any pursuit unconnected with pounds, shillings, and pence, at once displayed his readiness to "trot" me "out," in a figurative sense, for the recreation of his employes. 'And pray, my friend,' was his ironically-polite opening address, 'if it's not an impertinent question, where may the butterfly-net be?' 'Oh, in my pocket; but I'm not looking for butterflies now, I'm bound for yonder cover.' 'Indeed! and shall I be too inquisitive if I ask what you expect to find there?' 'Well, to tell you the truth, and (lowering my voice) I shouldn't like it to go any further, you know.' 'All right.' 'I hope to meet with Salpingus ruficollis.' 'Sall who, did you say?' 'Salpingus.' 'Pingus! Pingus! never heard of the family before-new comers, I suppose ?' 'That's it. Good day!' The chorus of humorous comments and unrestrained laughter that followed and continued, as long as I was within hearing, may be easily imagined by any one who has carried a fly-net through a Harting field or meadow in busy haymaking or harvest time, and perhaps even you will laugh when I tell you that these brawny sons of the soil cannot find a more euphonious name for us than 'Buttervlee Ketchers'! "

The remaining division of beetles, consisting of several hundred distinct species, to say nothing of varieties, includes some of the most minute ones, such as Pselaphus Herbstii, Euphlectus pusillus, and their relatives, several of which we have discovered at the roots of grass, and in moss gathered in damp places. The larger Rove-Beetles, Trichoderma nebulosum, many species of Staphilinus and Goerius olens, we have seen running about in pathways in fields and gardens, or found under dead carcases; Prederus riparius and Stenus biguttatus, with which we close this imperfect notice of beetles, we have more frequently met with in damp situations under stones and wood. 


\section{CHAPTER VI.}

Insects.-Earwigs, Cockroaches, Crickets, GRASSHOPPERS AND LOCUSTS.

PASsing lightly over the next Order of Insects,* which includes the Earwigs, only two species of which we are familiar with, the Forficula auricularia and the Labia minor, the latter swarming on the wing in the vicinity of dung-heaps on every sunny day in spring, in early summer and in autumn, we come to the Cockroaches, Crickets, Grasshoppers and Locusts. $\dagger$

Blatta Orientalis is the domestic nuisance so generally and so abundantly represented in our dwellinghouses, that no description of it need be attempted here. One peculiarity of this insect, which has long been known to Entomologists, may, however, have escaped the notice of those who view the family with too much disgust to study their habits with any higher object than that of lessening their numbers, and that is its mode of oviposition. The eggs are not dropped singly, or attached to any particular substance fitted for the food of the young as soon as they are hatched; they are, on the contrary, enclosed in a graduallysecreted capsule, of a horny charácter and an oblong or nearly oval shape, having a slit extending from end to end on one side. This slit is at first soldered up by a glutinous substance, which the young are enabled to

- Order Dermaptera.-From the Greek derma, a skin, and pteron, a wing. Wings, four ; the upper ones (Elytra) coriaceous without veins.

† Order ORTHOPTERA.-From the Greek orthos, straight, and pteron, a wing. Wings, four; the upper ones (Tegmina) parchment-like and veined. 
dissolve as soon as they are capable of liberating themselves; but no sooner is this effected, than the elasticity of the capsule, resulting from its form, causes the two sides to close again, and the case resumes its original appearance. We have more than once caught a specimen of the female insect, with the egg-capsule protruding more or less from the extremity of the abdomen, and in nearly every capsule we have opened we have found eighteen eggs, each securely packed in a distinct division.

Immediately following the Cockroaches, and belonging to the same order, we find the House Cricket (Acheta domestica), whose musical performances throughout the summer months and occasionally in winter, are highly interesting to the naturalist, if not generally pleasing. To any one watching a cricket in the act of chirping, as it is termed, it cannot seem less than marvellous that such an ear-piercing effect should be produced by such simple means. We have actually heard the remark, that "a cricket must have a power o' wind to cherrup so loud ; " but there are few persons now-a-days who need to be told that the cricket is not a wind instrument. It has two wings which, when not in use, are closely folded longitudinally along the back and partially concealed by two wing-cases, or rather wing-covers. A portion of each wing-cover overlaps the corresponding portion of the other, and where the two are in contact, a system of ribs forming the frame-work of these organs is found to constitute the stridulating apparatus. The main rib of the upper wing-cover, being finely notched transversely on the under side, is made to act by a tremulous motion of both wing-covers diagonally across the upper surface of the main rib in the lower wing-cover, and the result is a shrilly audible vibration of all the divisions of the two organs. This description applies to the males only, the principal ribs or nervures of the wing-covers are so nearly parallel in the females, that these (ac- 
cording to Kirby and Spence), unlike other ladies who have noisy lords, are always silent! We have no reason for believing that these insects prey upon the living cockroach under ordinary circumstances, as we have had ample opportunity of seeing the two species occupying the same apartments and living together in perfect harmony, but we know that they do not disdain the dead carcasses of the latter in the absence of other food.

The Field Cricket (Acheta campestris) is a larger and much darker insect than the last species, and its louder chirp is somewhat more agrecable, probably from its associations. It burrows deeply in the soil, as the House Cricket does in the mortar near our fire places, and generally performs its serenade at the entrance to its retreat, into which it quickly vanishes on the slightest alarm. The Entomologist, however, has learnt from no less an authority than Pliny, that if a straw be introduced far enough into its burrow, the cricket will immediately seize it in its jaws, and retain its hold so firmly, that it will allow itself to be dragged out and captured.

The largest and most curious in appearance of our crickets, if, indeed, it be not the most remarkable of all our British Insects, is the Mole Cricket (Gryllotalpa vulgaris). Like the two last species, it is furnished with wings and wing-covers; but the minstrelsy of the male, which many have no doubt heard in the Brickkiln Cover and the "Severals," without having the faintest suspicion that it was the performance of an insect, is a low continuous purring, not much unlike the jarring of the Goat-Sucker in miniature. As may be inferred from its trivial name, it is a burrowing insect, and incredibly active it is in its subterranean operations; we once dropped a specimen on the loose mould of a newly made flower bed, and not only. was its disappearance under the surface almost instantaneous, but, although we lost no time in digging for it 
with a stick, we were actually unable to recapture it. Its strength, too, is amazing; the whole length of the insect is less than two inches, and yet, when on one occasion we had several specimens in a large tin vessel, we saw one of them push aside, with apparent ease, a mass of clay weighing very. little less than nineteen ounces. It was in the act of burrowing between the tin on one side and the clay on the other, that it displayed this wonderful strength, and, at the same time, its mode of using the extraordinary and efficient tunnelling apparatus with which it is provided. This consists of the forelegs, so different in structural appearance from those of other crickets, that the purpose of the modification is self-evident at a glance. The tarsi appear to be comparatively useless and insignificant, but the tibiæ and the femora are very much enlarged and flattened, each of the former especially being deeply notched on the outer edge, so as to present a striking resemblance to the hand of the mole; this resemblance is further increased by the character of their articulations, the result of which is, that when the hands are brought into use their action is necessarily outwards at the best possible angle for insuring the attainment of the purpose for which they were designed. It will scarcely be needful to add that the outer integument of these very powerful limbs, as well as that of the head and thorax, are as hard and unyielding as a shell, or that they are clothed, like the skin of the mole, with a fine soft silky anti-friction pile.

In the Grasshopper family we notice, not unfrequently after a storm in summer, but chiefly in autumn, many specimens of a delicate green species, the $M e$ conema varia, crawling up the mossy trunks of the beech trees in the Park; this species no doubt passes the summer months among the foliage on which it feeds, and is dislodged in great numbers by the Equinoctial gales. The more remarkable Great Green 
Grasshopper (Acrida viridissima), unlike the last species, is very musical, and in this particular emulates the field cricket; but, although it stridulates by means of its wing-covers, these differ in their reticulation from the same organs in the crickets, the difference, however, is too unimportant to be dwelt upon here. A very few individuals of this species may be met with in some seasons in the lowland meadows, particularly those near the water, but it is not of sufficiently frequent occurrence to afford us many opportunities of testing the accuracy of the Ettrick Shepherd's Couplet :-

"Elate on the fern branch the grasshopper sings, And away in the midst of his roundelay springs."

It does not, however, require a minute examination of its powerful hind legs to be convinced of the fact that it is quite capable of taking an extraordinary leap; but, although it can at the same time bring into play a pair of wings more than three inches in expanse, it generally soon alights again, and certainly does not appear to be equal to so continuous a flight as some of the species in the next family.

The Migratory Locusts, for instance, one remarkable species of which, the notorious Locusta migratoria, we once met with at Harting. It was caught by one of the farm labourers, and may, we think, have crossed the Channel as a straggler from a more or less numerous flight of these insects on the Continent. What gives colour to this supposition, is the fact that we obtained another live individual of the same species, and in the same season, from the vicinity of Petworth, and a few other dead ones were found about the same time washed ashore on the eastern coast. We may fairly claim this celebrated species, then, as an occasional visitant, and fortunate it is for us that it has hitherto put in so unostentatious an appearance amongst us. When we read of whole fields of growing 
corn having been completely devoured in the course of a few hours by these insects, we find it difficult to resist an impression that the statement must be an exaggeration; but if the armies of these devastators on wing could on one single occasion darken the air over an extent of surface equal to the whole length of England and Scotland together, and when, at length, they were blown or fell exhausted into the sea, and those that escaped being drowned were washed back again on the shore, their dead bodies formed a bank more than a yard high and fifty miles long, the stench from which could be perceived at a distance of a hundred and fifty miles (all which facts Kirby and Spence tell us are recorded on unimpeachable authority), the destruction of a few acres of verdure may be deemed a comparatively insignificant feature in their history.

The music of the locust band may be said to be of a more refined character than that of the crickets and grasshoppers; it consists of a more regular and rapid succession of notes and intervals of equal duration, and is more subdued and pleasing ; we allude, of course, to that of the smaller species we have so often listened to here, and watched during their rehearsals on a sunny day in autumn. In the production of these notes the wing-covers are again brought into play, not, however, by friction against each other, but by the rapid action of the hind legs alternately up and down across them, the inner edges of the femora being roughened for the purpose of producing by friction a vibration in the prominent nervures of the wing-covers with which they are brought in contact. A resounding cavity on each side of the abdomen, immediately underneath the wing-covers, partially closed by a drum-head and curiously fitted internally with a delicate membrane stretched across it, in a plane parallel to the drum-head, greatly increases the effect of this vibration. May not the inventor of the violin have 
been indebted to these "Entomological Fiddlers" (Kirby and Spence) for his first idea of that instrument, the notes of which are not only produced, but intensified also on exactly the same principle as their music?

Hitherto we have said nothing of the internal anatomy of insects of this order, but we may here note the fact that every individual cockroach, cricket, grasshopper and locust, possesses a gizzard of a much more complicated character than that of a bird. In the latter, various hard substances, from large fragments of metal or stone to pebbles and grains of sand, according to the size of the animal, are made to perform the functions of teeth on the food within the gizzard; but this wonderful apparatus in the insects under notice, is furnished with rows of permanent teeth, and it is highly interesting to find that the gizzard of the cockroach, laid open and mounted in Canada balsam as an object for the microscope, closely resembles a preparation for the same purpose of the lingual ribbon of a mollusc. We are not unprepared to meet with this resemblance between the two organs, when we know that their functions are the same-namely, the comminution of the food, in the one case before, and in the other after deglutition. Incidentally we may add that many other insects possess gizzards, which as may be anticipated, differ materially from each other in the character of their internal armature, some are provided with teeth, some with plates, some with horns, and others with bristles; but in every instance the apparatus is a very wonderful one. In a pretty little beetle, not uncommon in the parish, and with a name perhaps as long as any to be found in the parish register, the gizzard is about the size of an ordinary pin's head, and is lined with no less than four hundred teeth! If we are curious to enquire as to the number of muscles engaged in the effective working of this wonderful machinery, we are 
met by the startling information that in some instances it amounts to many thousands!

Among the remaining members of this family, all of which we do not profess to enumerate, we may include a host of individuals of the Genus Tetrix, a group of comparatively small unmusical locusts, containing more than one species; but as the specific characters laid down for them by one eminent entomologist are not recognized by another of equal eminence, we are perhaps justified in attempting to divert the reader's attention from our own inability to identify the different forms, with the usual convenient appeal in similar emergencies! " "Who shall decidê when doctors disagree ?"

\section{CHAPTER VII.}

INSECTS.-Thrips, LACE-WINGEd FliES, MAY FLIES.

THE order, which in Westwood's classification, immediately follows the Grasshoppers and Locusts, ${ }^{*}$ is made up of such very minute and generally little known forms, that we deem any detailed allusion to them out of place in this simple outline. With the exception of the professed entomologist, who studies their structure and economy, no one is more familiar with them, or perhaps more unaffectedly disposed to anathematize them than the gardener, and when the latter sees the curled up shrivelled petals of his choicest exotics, the drooping flabby leaves of his melon and cucumber plants, his vines and his peach

- Order Thysanoptera. - From the Greek, thysanos, a fringe and pteron, a wing. Wings four, all with fringed margins. 
trees, he does not require to be told that the almost invisible puncture of the Thrips is the source of all the mischief. The progress of entomological research, and the consequent discovery of new forms of this insect, have naturally led to the subdivision of the original Linnæan genus into several other genera, subgenera and species, all subsequently grouped together under a distinct order, specially framed for their reception. The botanical young lady who is carrying home a bouquet of wild flowers for identification after her morning ramble, is fortunate if, on the occasion, she escapes a very unpleasant sense of irritation on her delicate skin, for which she can assign no reason. The probability is that this annoyance will be one of the results of her devotion to her favourite science, and if a knowledge of the immediate cause of it would afford her any gratification, we can inform her, without a personal interview, that the little black Thrips, which she may see swarming in the corollas of her specimens, is the offender. In a white flower, particularly the Convolvulus sepium, they are sometimes very conspicuous, although individually they are finer than a hair, and often less than the twelfth of an inch in length. They possess four membranous wings, delicately fringed all round their free margins, and differ from all our hitherto noticed insects in wearing a vesicle on each foot, by means of which it is conjectured that they are enabled to produce a vacuum at each step in walking or skipping on a smooth surface; Thrips physapus derives its specific name from this character. We have met with several species of the order, but the enumeration of them would scarcely be interesting to the general reader.

Our next Order* is not an extensive one in point of numbers of species, but it includes some remarkable insects of large size that by superficial observers have

- Order Neuroptera-From the Greek neuron, a nerve and pteron, a wing. Wings four, all with numerous reticulations. 
been strangely misunderstood. Perhaps when we learn that "Dragon-flies," "Scorpion-flies," and "Snakeflies" belong to this group, we may naturally be prepared to meet with some of the most formidable of insects; but our apprehensions will vanish when we become acquainted with their anatomy and history. Dragon-flies are quite harmless except to the smaller insects on which they prey, and although they are popularly known as "Adder-spears" and "Horsestingers," these names must have been conferred on them on the principle of "lucus a non lucendo," as they possess neither poison-fang nor sting of any kind. They may be seen any fine day in summer insect hawking, for which pursuit their four powerful reticulated wings, efficient jaws, and long slender abdomen, which acts like the tail of a bird in flight, specially fit them. In the bright sunshine they are very brilliant objects while performing their easy and graceful evolutions over or near a pool of water, from which their living insect food is being constantly liberated. Now they are poising themselves in the air for a few seconds, now darting off at any angle with lightning-like speed in pursuit of their quarry, and again gliding and skimming to and fro over the water, with wonderful command of wing, at one moment within a few inches of the surface, and the next soaring far above the overhanging branches of the highest trees.

In their preparatory stages they are entirely aquatic. We have often seen the female insect in the act of oviposition on the surface of the water, upheld by the vigorous action of her wings alone-her abdomen curved downwards and lightly striking the water each time she deposited an egg-her body at the same time gently advancing and retiring in concert with the extrusion of the eggs. This operation is not a slow one : we have counted, on more than one occasion, upwards of seventy such movements of the body and abdomen, 
indicating the deposition of as many eggs in one minute.

The larva, like the perfect insect, is predacious, but, unlike the latter, it is very sluggish and insidious in its movements; as a compensation, however, for this inactive habit, it is provided with a prehensile apparatus of a unique character. The under lip is unusually developed, transversely hinged at its base, and again about midway between that and its extremity, which is armed with a pair of articulated toothed, or acutely pointed forceps. This apparatus, when not in action, is folded back, joint upon joint, so as completely to conceal the mouth and part of the face; but no sooner has the truculent owner stealthily brought itself within range of its intended and unsuspecting victim, than, dropping the mask, literally as well as figuratively, it suddenly dashes out the whole apparatus at the doomed animal. This it seldom misses, and having seized it in its labial forceps, it brings it to its mouth and there retains it in a position to be conveniently operated upon by the jaws, which make very short work of it. The hinged lip is then refolded, and its various parts are applied, as before, closely over the mouth and face until another opportunity of making a similar capture presents itself.

Another peculiarity distinguishing the larva of the dragon-fly is its mode of respiration, which is also subservient to locomotion. At the extremity of the abdomen is an orifice or spiracle, closed by a valve and several plates; when these are opened a quantity of water is admitted into the body of the insect, and the valve is closed. The water then undergoes a deoxygenising process, and, as soon as this is completed, the valve is again opened and the effete water forcibly expelled in a jet two inches or more in length. The immediate effect of this discharge is a sudden forward propulsion of the animal itself. In its next stage of development it exchanges this system of respiration 
for a totally different one, and at last, bidding adieu to its native pool, it ascends the stem of some aquatic plant and there fixes itself in a favourable position for undergoing its final metamorphosis, the details of which we need not give, although they are singularly interesting. Through a slit in the pupa-skin it liberates itself complete in all its parts, with the exception of the wings - these are at first very small, very flabby, moist and soft, but they grow so rapidly that in the course of an hour or two they become quite rigid and dry; the perfect insect is then prepared to enter into the active enjoyment of its new phase of existence, and takes its first flight.

Among the other families of this order we find the well known may-flies, and the beautiful lace-winged flies; but in the system of classification which we take as our guide, that which first claims our notice is not yet known by any other than its scientific name, this, however, is not important, as we purpose dealing with one species only of those that are included in it-we mean the Atropos pulsatorius, a very minute, nearly transparent creature, with such tender and delicate tissues that it is impossible to capture it uninjured without the most careful manipulation. Among old books and papers, neglected collections of insects, dried plants, and dilapidated paper-hangings, the "papermite" is sometimes sufficiently common to be very destructive; but its chief claim to notoriety is the alleged fact that it shares with the death-watch the faculty of producing an "ominous" ticking noise. This is alluded to by Kirby and Spence, and by Westwood in his more recent work on the classification of insects, without one word of comment implying a doubt on the subject; but the author of a monograph of the British species of this family, and who may therefore be assumed to have studied them attentively, does not believe it possible that so minute an insect as Atropos, with such a soft body, can be capable of producing 
any sound whatever appreciable by the human ear. Other entomologists go so far as to express a doubt that the ticking of the true death-watch is in any way unconnected with the action of the mandibles of the insect while the latter is engaged in gnawing the wood, this, as we have shown in our notice of Anobium, is certainly an error. Anobium tesselatum is the only bond fide table-rapper we believe in, and he is not at all unwilling, under favourable conditions, to give an instructive séance unassisted by any "medium," but the ticking which we have always ascribed to Atropos is of quite a different character from that of Anobium. It is slower, not so loud, more regular, and more uniformly continuous; we have often heard it at night in a room hung with paper on canvas several minutes consecutively without a break, and found the insect there at the same time, but we have never seen it in the act of ticking. On the other hand a contributor to "Science Gossip" (Vol. III., p. 29) asserts that he has actually detected an individual of this species, in a honeycomb in his possession, repeatedly striking its head against the wall of the cell in which it had taken up its lodging, and that the noise thus produced was "as loud as the ticking of an ordinary watch." Although this evidence, given on the authority of a careful observer (who used a lens on the occasion), might be deemed conclusive, it does not appear to have set the question at rest, and probably nothing that we could advance pro or con would have any weight in the matter, still we venture to suggest that, as the mandibles of Atropos are capable of cutting the substance of dried insects and plants, the same organs might possibly produce. a noise when struck against a sonorous substance.

There are several species of other genera belonging to this family, all very minute insects, which we have found on fragments of dead wood under the beech trees, on old wooden fences, and in situations similar to those frequented by Atropos. 
The second family is limited to several species of those four-winged flies so well known to the scientific angler, and, we are sorry to confess, so little known to ourselves. Like the Dragon-flies, they frequent the banks of our ponds and water-courses, in which they have passed through all their stages of development.

The May-flies are classed in the third family, the Ephemera vulgata being the typical form, and a great many of the species are associated with those of the preceding group in the angler's catalogue of "killing flies." The larvæ and pupæ of these insects are aquatic, living on decaying vegetable matter, and many of them residing in burrows in the mud, which they make themselves. The perfect insect, with its reticulated wings and three caudal filaments, is too common to need any particular description, it is chiefly in its habits that it is remarkable. After having undergone its change from the larva to the pupa, and emerged from the pupa-skin as an apparently perfect insect, it is not until it has divested itself of an additional garment, so fine that the fact of its existence might scarcely be suspected, that it is competent to take part in the social pastime these short-lived creatures indulge in. This, and the business of reproduction, are their only concerns in the perfect state, which, as a rule, does not extend beyond a few hours, during which they take no food whatever. Indeed the different parts of the mouth are so rudimentary, that they are utterly useless; even the mouth itself is so imperfectly developed that, according to Réaumur, it is simply represented by an inconspicuous vesicle. The fiat, therefore, has already gone forth, "edisti satis, tempus adire domum;" accordingly the female dies as soon as she has laid her eggs, and her companion either falls a prey to fish or the voracious dragon-fly, or quietly disappears in some other way from the scene of his ephemeral dance. Those of our readers to whom a sensational record of the occurrence 
of vast swarms of these insects would afford interest, we beg to refer to Kirby and Spence.

Libellula, the generic name conferred by one of their early sponsors, Linnæus, on the greater number of the species which make up our next family, that of the Dragon-flies, was suggested by the appearance of the insects when at rest. In this position, their four beautiful gauzy membraneous wings are extended at right angles to the body on each side the thorax, like the leaves of an open book, hence their name. Others of the family are popularly known in some parts of France as "demoiselles" (young ladies), from the beautiful proportions of their slim elongated bodies, their graceful appearance on wing, and their lovely colours; the latter, however, can only be appreciated in the living insect, as, unfortunately for the collector, they quickly fade after death. In Normandy we have heard dragon-flies, without distinction of species, called "Priests," from a fancied resemblance of their wings to some portion of a priest's surplice. This family is very fairly represented here, but we have only identified the CEshna grandis, a fine large insect, which we have not infrequently watched in the act of decimating the smaller insects under the trees in the Park, at some distance from the pool in which we have also found its larvæ. Libellula vulgata, Libellula depressa and Libellula quadri-maculata frequent the ponds in the valley, two or three species of Agrion the water-courses in the Downparks and East Harting meadows, and one beautiful species of Calepteryx (virgo?) we have taken on the banks of the Rother at Ryefields. This is the "demoiselle" par excellence, the two sexes of which differ so much from each other in their colours, that they may readily be taken for two distinct species, the male having a purple body and a large blotch of the same colour near the tip of each wing, while the female is uniformly green, with unspotted and transparent wings. 
The delicate Lace-winged-flies follow the Dragonflies, and one species, which we have frequently met with, the Chrysopa perla, is eminently remarkable for its beauty in the perfect state, its singular mode of oviposition, and the useful labours performed by its larvæ. To the fastidious collector, however, one of its distinguishing characteristics is objectionable to the last degree, it emits an odour which we imagine all the resources of Gattie and Peirce would be powerless to subdue or disguise. Kirby and Spence have most accurately defined it as resembling that of human ordure, -and our own experience, on many occasions, enables us to endorse their verdict most emphatically. Taking into consideration the diminutive proportions of this slender-bodied insect, not exceeding an inch in length, with the most filmy wings imaginable, and being aware of the fact that at no period of its existence has it subsisted on food of an offensive character, we cannot resist a feeling of amazement, not only at the potency, but the peculiarity also of its disgusting stench. This is the more striking, as some species of lady-bird, the food of which, in all their active stages, is exactly the same as that of the larvæ of Chrysopa, gives out a somewhat unpleasant smell resembling in nothing that of the latter.

The body and wings of the insect under consideration are a very delicate green, and its compound eyes, viewed through a lens, present the appearance of two very brilliant hemispheres of burnished copper, symmetrically reticulated by the numerous facets of which they are composed. Its eggs are deposited in small patches on the leaves of living plants, and many who have found them, without having any previous knowledge of the history of the fly, have very naturally mistaken them for a species of minute fungus. They are little elliptical bodies, elevated on very slender white pedicles, each of which is about half-an-inch long, and has its basal extremity planted in a minute 
speck of glittering matter attached to the leaf or twig. The substance of which these pedicles are formed, is a viscid secretion from the oviduct of the female, and, like the silk of the caterpillar, dries and hardens very quickly when extruded, so that by the time each egg is laid, the footstalk, of which it is a continuation, has become sufficiently rigid to support it in an erect position on a horizontal surface. In the insect world parasites are so numerous, and their attacks are so fatal, that entomologists regard this exceptional feature in oviposition as a special provision for the security of the eggs against their foes. We have often found these curious objects in clusters of from five or six to upwards of twenty, and those from which the larvæ had escaped, were not unlike the empty capsules of a species of moss, without the opercula and very regularly denticulated on their margins. In about a fortnight after the deposition of the eggs, the larvæ make their début, and without loss of time descend the pedicles to enter upon their avocations. They each possess six legs and a pair of enormous mandibles, and for the space of another fortnight or thereabouts, their activity and voracity enable them to commit such havoc among the plant-lice, that they become entitled to the popular designation of "AphisLions." They do not, however, restrict their appetite to Aphides alone, other small insects that come in their way are readily preyed upon by them, not even excepting individuals of their own species. They never masticate or crush their food, but extract the fluids of their victims by a process analogous to that of suction, rejecting the drier portions of their bodies as useless, and in this way they dispose of an incredible number of noxious insects until they are full-fed. They then become inactive pupæ, and in this form spend the winter in their cocoons, from which they burst forth the following summer in all the delicate beauty and with all the indelicate effluvium of the perfect lacewinged flies. 
The larva of another very common species of Lacewinged fly, belonging to the next family (Sialis lutaria), unlike the Aphis Lion, is aquatic, and differs from the other larvæ of this order in its mode of progression through the water. In addition to the normal six legs for walking, it possesses a series of fine articulated processes on each side of the abdomen, by means of which it can swim also, and its comparatively powerful toothed mandibles afford good presumptive evidence of its predacious habits. When about to assume the pupaform, it crawls out of the water and burrows in the soil, where it undergoes its final metamorphoses. It reappears as a dingybrown fly, somewhat sluggish in its habits, and may be found on the flags and rushes, or other aquatic plants at the edge of the water, here too, in conspicuous patches, it deposits its numerous eggs. These, like the eggs of a great many other insects, are very pretty objects, they resemble tiny cylindrical short-necked upright vases, and are closely ranged side by side in uniform parallel lines.

We now come to the Scorpion Fly (Panorpa communis), the type of another family in this order, and the only species we have met with. This we have found in many localities among the wild growths by the side of hedgerows, and particularly on the blossoms of umbelliferous plants, which it frequents for the purpose of preying on other insects generally to be found there. The perfect insect is not quite an inch in length, with four equal spotted wings and a long rostrum directed downwards, which is armed at its tip with small but sufficiently serviceable toothed mandibles. Its abdomen is elongated, and at its extremity wields an apparatus, which certainly has such a general resemblance to the last joint of the tail in the true scorpion, that very probably it has seldom been captured by the inexperienced collector without cautious hesitation. This, however, is needless, as the suspicious looking organ, which on close inspection 
proves to be a pair of harmless forceps at the top ofan enlarged segment, is in reality a character peculiar to the male alone, and therefore, in all probability, simply subservient to sexual purposes, the terminal segments in the female being developed into a slender tubular ovipositor. Of the history of this insect in its earlier stages, we believe, little or nothing is yet known.

The last family in this order is that of the Snakeflies, and these are of a less threatening aspect even than the Scorpion-flies. They derive their popular designation from the slender neck-like form into which the anterior part of the body is produced, the large head in which it terminates, and the peculiar active movements in all directions of which it is capable, quite independently of the thorax. The general appearance of the insect is that of a fly with its wings standing out about midway between the two extremities, and of one species about an inch long, the Raphidia Ophiopsis, we have occasionally netted an individual on the banks of the stream leading from Hurst Mill by the Pond-tail plantation to the Great Pond. The larva has been found under the bark of trees, and the structure of its mouth sufficiently indicates the fact that, like the perfect insect, it is predacious, but the record of its transformations is still incomplete. At this stage then we necessarily take leave of it, and turn our attention to the next order of insects.

This order* is made up exclusively of the Caddisflies, more generally known perhaps by the very curious cases in which the larvæ reside, than in the perfect state. Phryganea grandis is not uncommonly an evening visitor in our houses, evidently attracted by the flame of a candle or lamp, but in all its imperfect states it is aquatic. The eggs are attached

- Order Trichoptera.-From the Greek thrix, trichos, ha and pteron, a wing. Wings four, upper pair clothed with hair. 
in masses to some portion of a plant at some depth in the water, and no sooner are the larvæ hatched, than they set about the construction of their portable habitations. These are simply silken tubes open at both ends, and so accurately ballasted with a casing of various materials, that they do not impede the free progress through the water of the larvæ within them, being neither too buoyant for the bottom-feeding species, nor too heavy for those that seek their food nearer the surface. The head and legs of each larva project from what may be termed the mouth of its case, while the remaining part of the body is retained in it by means of a pair of articulated hooks at the extremity of the abdomen, so that it is difficult to eject the tenant from its tubular dwelling, the more so as the slightest alarm causes it to disappear wholly within it, as a snail retires within its shell. When, however, by one who knows how to set about it, a larva is extracted from its case unharmed, it is found to be a rather long tapering fleshy grub, with dark head and six comparatively short legs, in this form the angler finds it a very efficient bait for several species of fish. Its food is partly animal, partly vegetable, but in the perfect insect the total absence of masticating or suctorial organs, would lead to the inference that at this closing period of its career, it is incapable of taking any food whatever.

A complete collection of the cases of Caddis-worms, must be a singularly interesting one, some of the species will be seen to be botanists, others conchologists, and others again mineralogists, thus presenting in their economy a striking analogy to Onustus, an exotic genus of marine molluscs, which incorporate within the substance of their own shells, as fast as they secrete them, fragments of minerals, shells and other materials. One specimen in our own collection (Onustus conchyliophorus), when looked at in its natural position, has the appearance of a small conical heap 
of portions of shells and entire shells, thrown together in "most admir'd disorder," but so closely, that no part of the shelly substance in which they are embedded is visible.

The cases of the species of Phryganea proper, are formed exteriorly of portions of leaves ingeniously spun together in close spiral order. Those of Limnephilus flavicomis, so abundant in the South Garden ponds, are formed of empty shells, among which, however, may occasionally be found one still containing its natural living inhabitant, which, for the credit of the caddis-worm, we hope may have been thus appropriated by mistake. Other individuals of the same species encase their tubes with small seeds, or short lengths of tiny rushes or fine twigs, arranged either transversely or longitudinally. Limnephilus lunatus prefers a coating of grains of sand, but as the quantity of this heavy material increases with the length and diameter of its tube, which, according to Pictet, it enlarges gradually to keep pace with its own growth, it lashes on to one side or the other, or both, without any regard to symmetry, a spar or two of some lighter material, as if to lessen its gravity. Another curious case, which we have often dredged up in the conchological spoon-net, is that of Molamna angustata. This is entirely coated with fine sand, and instead of being tubular, like the others, is nearly flat, with a very oblique aperture at its larger extremity. Many other varieties of cases we have found, some of which, attached to the underside of stones, are very rudimentary, while some species of caddis-worm content themselves with cases almost exclusively formed of silk, and others even dispense with the case altogether.

When the larva has attained its full development, it spins a cable, with which it securely moors its case to a stone or some other firm support, and carefully closes the aperture at each extremity with an open network of silk. Through this network the water, 
indispensable to the respiration of the insect, passes in and out freely, while intruders are effectually excluded, and in due time the pupa makes its way out of the water to assume the perfect form.

\section{CHAPTER VIII.}

INSECTS.-BEES, WASPS, ANTS, AND ICHNEUMONS.

IF we were so ambitious as to aim at the production of an exhaustive local natural history, and were qualified for the task, we should necessarily devote a whole volume, and not a small one, to the Order* we are about to enter upon. Not only on account of the great number of the species included in it, but also from the fact that the histories of many of them are very wonderful, so wonderful indeed, that the entomologist who records them incurs the risk of being credited with a very elastic imagination. There is nothing in the whole known range of insect economy more marvellous than that of the social members of this group, the Bees, Wasps, and Ants; nor are there many more interesting facts than those which make up the lives of the majority of the solitary parasitic species, the Ichneumon-flies, Cuckoo-bees, and Sandwasps, to say nothing of the Mason-bees, Carpenterbees, and Leaf-cutters.

We assume it to be pretty generally known that a colony, of the Honey Bee consists of three distinct forms, the queen, the drone, and the neuter, each one

- Order Hymenoptera-from the Greek hymen, a membrane, and pteron, a wing. Wings four, nearly transparent. 
having special duties to perform distinct from those of the other two. The queen bee, for instance, is endowed with all the instincts and faculties of a perfect female capable of producing fertile eggs and becoming the parent of other queens, drones, and neuters; the drones are the males taking no share whatever in the labours of the community, and the neuters, commonly called "workers," are, speaking generally, imperfectly developed females. The latter are the indefatigable architects and builders of that wondrous structure, the honey-comb, the secretors of the wax of which it is composed, the untiring collectors of the honey and pollen with which many of the cells are stored, and the careful attendants of the larvx or young brood that are to be found in others. Although it is known to entomologists that there are two kinds of queens, a larger and a smaller one, two kinds of drones, of different sizes, and two kinds of neuters, the wax producers and the nurses of the young grubs, we limit our remarks on these insects to the outline we have here given, and to the following passage in their history. This is so startlingly suggestive of reflective faculty, foresight, and appreciation of their various proceedings, as evidenced in the intelligent application of the resources within their reach to a sudden emergency, that we cannot omit it. We have stated that three distinct individual forms are found among the social bees, in reality they consist normally of males and females only, but the industrious members of the community, in the ordinary exercise of their wonderful instinct, know how to check the development of the latter by a special treatment which results in the production of workers. If by any accident they are deprived of their queen, they not only soon discover their loss, but without unnecessary delay set to work in a very scientific manner to provide themselves with another. Who without a long entomological preparation could accept upon trust the statement that, to 
effect their purpose, they remove from its cell one of its larvæ which they were bringing forward as ordinary workers, place it in a royal cell specially constructed for it, supply it with food of a more stimulating property than that uniformly given to the larva of the worker, and thus in a few days develop it into a perfect queen? It reads more like a day-dream than a reality, yet it is an admitted fact! It is equally true that, notwithstanding the abolition of the slave trade in the British dependencies, for which we have paid so many millions, this nefarious traffic is still actively carried on by some species of ants, which periodically organize regular expeditions for the purpose, and, to make the analogy between these proceedings and those of the human slave-owners perfect, the slave-making ants are of a light complexion, while their slaves are black! Perhaps, however, it will be fair to add that this social blot is not to be found within the parochial boundaries of the three Hartings, if within the limits of the three kingdoms, but it is one of the astounding revelations brought to light by naturalists of great eminence, on whose veracity we may implicitly rely.

The most obvious characters of the typical representatives of this order are four unequal membranous wings, with fewer nervures than those of the Lace-winged flies, and further distinguished by a small dark patch, more or less triangular, called the stigma, on the anterior margin of the upper wings near the extremity. There is also a number of very minute hooks on the anterior nervure of the under wings, by means of which the two wings on each side are so closely held together, that during flight they cannot act separately or independently of each other. The mouth is furnished with a pair of cutting mandibles and a long rostrum, consisting of the maxillæ and lower lip, with their several appendages, applied closely together in the form of a tongue, with which they are said to lap their liquid food. This apparatus, which, 
like the mandibles, varies very much in its length and form according to the requirements of the different species, is capable of being bent back under the head, and is only exserted at the will of the insect. As a rule the legs are of moderate length and slender, and in the wood-boring and burrowing species, as well as those which collect pollen, they are provided with various suitable appendages, spines, hairs, fringes, and plates. The females are supplied with instruments for oviposition of different forms, severally adapted to the substances in which, or on which, their instinct teaches them to commit their eggs. Some carry saws, others borers, and in the social groups, as everyone knows who has incurred the active displeasure of a bee, a common wasp, or a hornet, the ovipositor becomes a weapon which is capable of inflicting an unmistakeably painful wound.

The family of Saw-flies is the first in this order, and contains many genera, several species of which we have found here. Their larvæ are sometimes very destructive, feeding on the leaves of various plants, like the caterpillars of moths and butterflies, to which they bear no little resemblance. The female of the perfect insect is provided with an ovipositor of a very complex structure, and as we possess a micro-photograph of a specimen, we will attempt a short description of it. It consists of two nearly-transparent narrow lamellæ, slightly curved upwards at their extremities, and crossed at regular intervals with fine sharp ridges, terminating on the lower edges in very minute denticulations. Each plate is divided longitudinally by a mid-rib running from one extremity to the other, the lower division is the saw-blade, the upper one the saw-frame, and the mid-rib itself contains the groove in which the saw-blade is made to work to and fro by appropriate muscles. These delicate instruments when at rest are applied, between two larger plates, closely to each other with their serrated edges downwards, 
but when they are brought into use, they are slightly separated so as to work freely and rapidly side by side alternately, and the saws are made to "clear" themselves, as the carpenters express it, by means of the transverse ridges on the outer surface of each-it will thus be evident that they act as saws and rasps at the same time. As may be anticipated, there are differences of detail in the ovipositors of the various species, but the general plan of construction is the same throughout the whole family. With these beautifully-finished implements, the flies not only make fine saw-cuts in the tender bark of trees, or the leaves of plants, but they afterwards delicately and surely guide an egg between them down into the incision they have thus made. A drop of fluid is then introduced into the wound, the probable effect of which is to keep it open till the larva is hatched out; in the meantime the egg, unlike those of the majority of insects, absorbs moisture from the substance in which it is deposited, and increases considerably in size.

Among the numerous individuals of this group which we have met with here, by far the most remarkable for its size and beauty, is the Cimbex lutea; this handsome fly is not much unlike a small hornet in general appearance, and we have taken three or four specimens, one of which is still in our possession. The larvæ of Trichiosma lucorum we have frequently shaken off the whitethorn in the now obsolete hedgerows, we have also found its cocoons in the winter and kept them, under the impression that they were those of a moth, till the perfect fly made its appearance and undeceived us. Abia sericea is a strikingly glossy brassy-green fly, with yellowish legs and antennœ, of which we have captured three or four specimens on the blossoms of umbelliferous plants, but we have never identified its larva. Hylotoma Rose is sufficiently common to have more than once brought down upon its larvæ the vengeance of the gardener; Allantus Scro- 
phularia and Allantus viridis we have netted in byelanes fringed with wild flowering plants, and the slimy larvæ of a species of Selandria, probably Cerasi, we have often seen on the leaves of pear trees trained against the garden wall. Of the pretty little blackand-orange coloured Athalia centifolice in the perfect state, we need scarcely say we have taken many specimens; but for every such capture we have certainly seen thousands of its larvæ, perhaps millions. This statement will probably take no one by surprise who has had an opportunity of walking across a turnip field infested by the notorious " niggers." Very fortunately for agriculturists, such opportunities do not present themselves often, but we have a recollection of two seasons in succession, if not three, when nearly every turnip leaf in the parish was devoured by the black larvæ of this species. Two or three attempts were made here and in the adjoining parishes, to destroy the devastating legions of these larvæ, but with such doubtful success, that the plague was not even checked. Salt and soot were liberally sown broadcast over the plants, and in one instance a flock of sheep was driven across a field or two, yet although no doubt thousands of the pests were on that occasion trampled into the mould, a sufficient number of them escaped to show the failure of the experiment. It was at last suggested that all the ducks in the parish should be invited to a succession of "nigger" banquets, but considering that these grubs were swarming all over the South of England at the same time, all the ducks in Europe, if "requisitioned" for the purpose, would have been unequal to the task of subduing them with sufficient despatch to save the plants. The inevitable result then of these visitations, was that the turnip crops, with very partial exceptions, were utterly ruined, and all, or nearly all, the turnip lands on this estate were ploughed up again. We have met with other species of Athalia, but neither of 
them capable of emulating centifolice in its destructive powers. The Gooseberry Saw-fly, Nematus Grossularice, is another very common species, in some seasons its larvæ swarm on the gooseberry, and we have seen long rows of bushes completely stripped of their leaves by them on several occasions. Although, as a result of these attacks, the fruit prematurely assumes the tinge of colour special to each variety when ripe, it is never fully developed, and is comparatively destitute of flavour.

The ovipositor in the insects of the second family, although presenting a strong analogy in each of its component parts to that of the saw-flies, is a very different instrument in its general form. It projects considerably beyond the extremity of the abdomen, is tubular instead of flat, and is very firm, rigid and powerful. It is termed a terebra or borer, and is capable of penetrating solid living timber, in which the female deposits her eggs. The larvæ, which are white fleshy grubs not at all resembling those of the saw-flies, eat their way into the substance of the wood, and in the course of their development, perforate it in all directions, sometimes to such an extent and in such numbers, that they are said to have more than once caused great destruction among the pine forests on the continent. In or about the year 1845 , a new floor was laid in one of the offices at Uppark, and the year following we had an opportunity of recording our first introduction to Urocerus $\mathcal{F}_{\text {uvencus, a specimen of }}$ which noisily attracted our attention as it buzzed against the window. During the next two or three weeks, many others made their exit from the floor through very neat circular perforations that remain to this day, and on several subsequent occasions, we have seen individuals of the same species in the timber-yard attached to the out-buildings.

Urocerus gigas, the only other species we have identified, is said to be a very rare British insect, but 
we have captured four or five specimens, and seen probably as many others which are equally entitled to the distinction of being included in our list. It may be objected that, probably all these were imported as larvæ or pupæ in the Norway deals that were occasionally stacked in the yard with timber of native growth; but although the greater number of our captures of this fine insect were made in the timberyard, a few were taken in Padswood Copse on the trunks of living Scotch firs. It is a fine large blackand-yellow fly, at the first glance suggesting some resemblance to a hornet, but of a more cylindrical form, about an inch long, with a borer from threeeights to half-an-inch more, and makes a loud buzzing noise during flight.

The Gall flies, forming the third family, have given rise, from a very early period in the annals of natural history, to some ingenious theories. The female insects, in the act of oviposition, introduce into the punctures they make in the leaves, stems, roots, and other parts of various plants for the reception of their eggs, an irritating fluid, which has the property of producing in a very short time those curious excrescences popularly known as galls.* The question on which speculation has been rife, and which still awaits solution at the hands of vegetable physiologists, is how these abnormal growths are effected, and what explanation can be given of the fact, that among the many distinct forms they assume, although all the result of the same simple process of oviposition, each one is peculiar to a single species of fly only. For instance, the little globular berry-like galls on the leaves of the oak are those of Cynips quercus folii;

- Another and more recent theory, which dispenses with the irritating fluid, is that the egg of the Cynips, being deposited in the cambium layer of a young shoot, acts as a spherical nucleus round which the sap courses, and thus causes the development of the gall. 
the well known spongy-oak apples springing from the young shoots are the work of Cynips terminalis; the pear-shaped imbricated tumours on the roots are caused by Cynips aptera, while the very remarkable reddish moss-like "Bedeguar," so common on the species of wild briar, results from the puncture of Cynips Rose, a fly about the twelfth of an inch long.

The egg, when deposited in a leaf, must obviously be at an inconsiderable depth below the surface at first, but as it becomes gradually enveloped by the morbid growth caused by the irritating fluid introduced with it into the wound, it is eventually found carried to some distance from its original position and in the centre of the gall. Here, like that of the Sawfly, it increases in size for a time; the larva, a white grub destitute of feet, is shortly afterwards hatched out and at once attacks the provender with which it is surrounded. Some of the species undergo all their transformations within the gall and only quit it as perfect insects, others gnaw their way out as soon as they have attained their full development as larvæ, and undergo their final changes in the earth. A species of woody gall, showing the little round hole through which the fly has made its exit, or the irregular breach made by the Blue Tit in his search for the insect before it had escaped, is very conspicuous here during the winter months on the young growths of the oak underwood in the covers. It is about the size of the common gall nut of commerce, so useful in the manufacture of ink, and is frequently found in clusters of five, six, or a dozen together.*

We now pass on to the Ichneumon Flies, under which general designation we include in one group the members of the four families immediately following the gall-flies. Their special province is to keep within due bounds the numbers of almost every other tribe

* These are the galls of Cynips lignicola, popularly known as "Marble Galls." 
of insects, particularly the caterpillars of butterflies and moths, not by openly preying upon them after the manner of carnivorous beetles, dragon-flies and others, but by an indirect mode of proceeding for which their instincts and the structure of their ovipositors pre-eminently qualify them. The venerable myth handed down to us by naturalists of other days, as a phenomenon in the history of the Egyptian Ichneumon (Viverra), is scarcely more incredible than the thousands of well ascertained facts in the economy of these flies. Instead of entering the mouths of their victims while the latter are sleeping, they attach one or more eggs to the body of each, sometimes on the skin, sometimes under it, and leave the work of actual destruction to their larvæ, which feed on the internal substance of the insects in which, or on which they are hatched. Eggs, larvæ, pupæ and perfect insects are all more or less subject to the attacks of these parasites, and among the species that oviposit in the former, there are some so very minute that, according to an eminent entomologist who has made this tribe his special study, one butterfly's egg contains sufficient provision for several individuals during the whole period of their existence as larvæ. Examples of almost every intermediate size between this microscopic form and Rhyssa persuasoria, an insect four inches in length, may be found in these families. Their ovipositors also vary considerably in length in the different species, in those which commit their eggs to naked external feeding larvæ, they are very short and scarcely visible beyond the last abdominal segment, while in others which are appropriated to larvæ that are concealed in galls, in wood, in artificial cases, or under the bark of trees, the ovipositors are much longer. By what extraordinary faculty the latter are enabled to discover their prey is one of nature's impenetrable secrets, but that it is by the agency of their antennx, which in the true ichneumons are in 
constant vibration, except during the hours of repose, is the conclusion of naturalists who have patiently watched the process of oviposition of several species.

In the first of the four families under notice, we find a very small curiously formed insect, Evania appendigaster, which is said to deposit its eggs in the egg capsule of the common cockroach. The abdomen in this species is so disproportionately minute, that at first sight it would appear to have been accidentally arrested in its development. We have a humiliating recollection of once placing a specimen of this fly under the microscope, and eventually rejecting it as an insect that, from some cause or other, as we erroneously thought, had failed to complete its growth. This is a reminiscence of our very early entomological course, another opportunity of examining one would find us better prepared to appreciate it. We have several times netted Fonus jaculator, another member of this family, with a compressed abdomen growing gradually larger towards the extremity, and a long ovipositor; it is parasitic on other species of its own order.

The species of Ichneumon proper which we have seen here and not identified are innumerable, but there are some so remarkable in their appearance, or for their association with other insects that have come under our notice, that we could scarcely fail to recognize them, either from verbal description or figures. Conspicuous among these is the Rhyssa persucasoria, the largest of the group, and the species of which we have taken the greatest number of individuals. It is parasitic on the larvæ of Urocerus juvencus, piercing with its ovipositor a considerable thickness of solid wood to reach its prey; accordingly we find both these insects in the same localities and under similar conditions. In the summer of 187 I, a large scaffolding, consisting of fir poles and deal planks, had been standing several weeks in an outbuilding here, where con- 
siderable repairs were in progress, and the workmen engaged in them secured no less than four fine specimens of this Ichneumon. in three days, after having allowed several others to escape through the open windows. It is, as we have already stated, quite four inches in length from the tips of the antennæ in their natural position to the extremity of the ovipositor, the latter extending an inch-and-three-quarters beyond the abdomen.

Pimpla manifestator, Pimpla instigator, Pimpla favicans, and other species of the same genus, we have taken in the timber-yard, on the Park and other wooden fences, and in fields on the blossoms of Umbellifere. The oviposition of Pimpla has been witnessed by more than one entomologist, and the rapid vibration of its antennæ while it is in the act of seeking the concealed grub to which it is about to commit an egg, particularly described. Some of these grubs reside in deep perforations in wood that are left open at the surface, into each of these openings the ichneumon introduces its antennæ for the purpose of exploring it, and the presence or absence of the object of its search is in this way ascertained after a very brief examination.

Ophion luteum, a pretty reddish-yellow fly about three-fourths of an inch long, we have bred from the larva of the Puss Moth, and subsequently caught several other specimens in the fly net. It has a compressed sabre-shaped abdomen, and an ovipositor so short that it is incapable of making a deep puncture in depositing its egg, we are not surprised, therefore, to find the latter on the surface of the skin of the larva it attacks, and the grub that proceeds from it, unlike the majority of these parasites, is always externally visible.

Microgaster glomeratus is the little parasite of which the yellow egg-like cocoons are so often found associated with the shrivelled skin of a very common 
caterpillar, that of the White Cabbage butterfly. These masses are often very conspicuous under the copings of walls, the bars of greenhouse lights, in tool houses and garden sheds, where the infested caterpillar has fixed itself preparatory to its final transformations, happily unconscious of the fact, we presume, that it contains within its own system a host of tiny foes that are only awaiting the appointed time to bring its "strange eventful history" to a close. In the early stage of their subcutaneous existence, these parasitic grubs subsist on the fatty matter alone of the caterpillar, without in any way impairing its appetite, or impeding its growth, but when the latter has ceased feeding, they unscrupulously attack its vital parts and speedily cause its death. They then make their way out through its skin, spin themselves up in their silken cocoons, and eventually become perfect four-winged flies, capable of repeating the process to which they owe their own development on the next generation of caterpillars.

Campoplex paniscus we have bred from the larvæ of a minute moth of which we shall give some account further on. Another genus of ichneumons is parasitic on the plant-lice, and is hence named Aphidius. The species of this genus undergo all their transformations within the skin of the aphides, which, after the whole of the interior has been devoured, becomes dry and rigid like that of an ordinary pupa, and, wonderful to relate, other parasites of the same order actually deposit their eggs through this skin into the body of the included parasite! The history of these insects abounds with similar examples, a phenomenon which has been immortalized by an anonymous poet in the following deservedly-admired couplet :-

"The little fleas that do so teaze,

Have smaller fleas that bite' em,

And these, again, have lesser fleas,

And so, ad infinitum."

The family of parasites immediately succeeding the 
ichneumons is that of the Peach flies, or Ruby tails, of which the genus Chrysis is the type, but in their economy and oviposition the two groups differ materially. The business of Chrysis is to watch assiduously the nidification of the insect on which it is parasitic, generally some species of solitary bee, and take the opportunity, in the absence of the latter, of entering its burrow or cell. It there deposits its egg in the store of provisions already laid up by the bee for the future use of its own grub; the parasite is the first hatched, and monopolizes the whole supply of food before the appearance of the other, which, as a natural consequence, is left to starve. Chrysis ignita is one of the most brilliant of our Harting insects-its head and corselet are a very beautiful rich shining blue, and its abdomen has all the dazzling splendour of burnished copper in the sunshine, with a tinge of the ruby. The rapid vibration of the antennze in Chrysis is incessant, and all the species are otherwise wonderfully active; but when an individual of either apprehends danger from another insect, it rolls itself up into a ball, leaving no vulnerable part of its body exposed. We have taken several in many localities, particularly on the garden wall among the trained fruit trees, on dry sand banks at West Heath, on old gate-posts, and on the flowers of wild plants.

Hitherto we have treated of the families of this order in which the ovipositor has no other function than that of conveying the egg to its proper nidus, in all the remaining ones this apparatus is connected, not only with the ovaries, but with poison glands also, and is thus converted into a sting as well as an instrument of oviposition. Some solitary species that provision their cells with other insects for the support of their own young, sting their prey to death before they thus dispose of them; others only disable them, without depriving them of life, so as to ensure a constant supply of fresh food for the future parasite as long as the latter may require it. Of the stings of those 
insects which live in societies, and the wounds they inflict, perhaps it may be superflous to speak at any length; almost every one has, at one time or another, had an opportunity of appreciating some of them. We have been stung by solitary bees, humble bees, wasps, hornets, and hive bees, and the agony caused by the latter we have found more intense than anything we ever experienced from the sting of either of the others.

The species of the genus Crabro make their cells in wood, which they bore for the purpose, and provision them with two-winged flies and other insects. We have taken several species, among others Crabro vagus, a small wasp-like fly, and Crabro cribrarius, or the sieve bearer, which derives its specific name from a curious concavo-convex semi-transparent plate on each of the anterior tibix of the males. The use of these singular appendages is unknown to entomologists, but from the fact that under a lens they are seen to be full of bright specks, not unlike minute perforations, they have been fancifully termed sieves. Ammophila sabulosa, a long black insect, with a reddish orangecoloured belt round the pedunculated abdomen, is not uncommon at the sand pit and the railway cutting at Westheath. It excavates its burrows in the sand banks, and, after depositing an egg in each, stocks them with the caterpillars of some species of moth.

The wonderful history of the Ant tribe, like that of the Honey bee, is so generally known through the works of eminent entomologists, and the individuals of many of the species are so widely and numerously distributed, that it will be quite unnecessary here to give a description of the appearance of these insects, or to enter into the details of their economy. We have seen colonies of the Horse ant (Formica rufa) under the trees on Scot-lands, near Bramstead heath, among the birch groves on Westheath, and in other localities. A confused heap of scraps of sticks, straws, and other materials forms the exterior covering of the 
huge nest of this species, but the underground tunnels and passages, which are carried to some depth, appear to be laid out with great regularity and order. If a breach be made in one of these nests, swarms of the ants rush out to attack the intruder, and they not only bite him severely if practicable, but almost suffocate him with the powerful and pungent odour of the formic acid, which, in their fury, they discharge in all directions. Another species, Formica fusca, which we have commonly found in the Park and on the Downs, makes its nest underground, and about Midsummer it is not an uncommon thing to see thousands of recentlydeveloped individuals airing their glittering and comparatively large wings in the sunshine on the exterior of their nest, from which they have just emerged. Later in the day they take flight and fill the air with their numbers, the sole object of this proceeding appears to be the union of the sexes, which is shortly after followed by the death of the males and the descent of the females. These immediately set about divesting themselves of their wings, and devote their energies to the foundation of other colonies, unless they should chance to alight on or near the nest from which they have taken their flight, in this case they are at once forcibly restored to their native home by the workers.

The social Wasps live in communities consisting of males, queens and workers, and the ardent student of their economy who would venture on the capture of an individual of either species without the aid of any entomological apparatus, a net for instance, or a pair of forceps, should be careful to try the experiment on the males alone. Several queens or perfect females are found in each nest, and, unlike the queens of the honey bee, they not only live in harmony with each other, but take their share in the labours of the establishment till the setting in of winter. The males and workers then perish, the queens disperse for the pur- 
pose of hybernation, and those of the latter that survive till the following spring found other families, each individual commencing its own nest, depositing its eggs, and rearing its young itself. In the early part of the season, workers only are produced in the new colonies, and their first duties are the preparation of the cells they have quitted for the reception of other eggs, the enlargement of the nests then follows and is continued throughout the summer months. The nests of the few species we have found here are essentially wooden structures, the building material is collected by the insects in very fine particles and, with the addition of a glutinous secretion from their mouths, worked up into a pulp which, when spread out in a thin layer and dry, resembles a more or less coarse kind of greyish or buff-coloured paper. These nests consists of hexagonal cells in single-series arranged in horizontal tiers, each tier suspended from the one above it by strong pillars, and the whole, when complete, enclosed in a general envelope of several layers. The entrance to the cells is from below, so that the position of the larvæ in them is with the head downwards, and in the nest of the common wasp the tiers are about half-aninch apart, in that of the common hornet the cells are necessarily larger and the spaces between the tiers wider.

The Common Wasp (Vespa vulgaris) nidificates underground, generally selecting a hedge bank for the purpose, and we have, late in the autumn, dug out many of its globular nests, some nearly a foot in diameter. Vespa Crabro, the Common Hornet, is the largest insect, not only of the genus, but of the whole order, the perfect female measuring an inch-and-aquarter in length, and the species is occasionally met with in great numbers, particularly in the valley. It builds in old hollow trees, in outhouses and barns, and in one instance, which we have reason to remember, we found a nest suspended from one of the laths in 
the roof of a thatched cottage near Ryefields. The occupants of this cottage were naturally very much alarmed at the daily visits of these dangerous intruders and had begged us to destroy the nest, accordingly one evening, accompanied by an assistant and provided with a large canvas bag, a bull's-eye and two helmets with masks improvised for the occasion, we repaired to the cottage. The entrance to the nest through the thatch was within a foot of the ridge, and our business clearly was to make a breach in the roof in order to effect an entrance. Unfortunately, in doing this we broke the lath from which the nest was suspended and the latter fell on the ceiling of the bedroom below. We lost no time in following it with the light, and after having carefully secured the huge mass in the bag, we turned our attention to the scores of enraged hornets, that had previously esçaped from it and were now swarming around us, or dashing furiously against us, with a deep booming chorus of which we retain a very lively recollection to this day, indeed we should probably never forget it in a long life-time. The next few minutes were anxious ones, but we succeeded eventually in destroying the stragglers and triumphantly bearing off the nest, which we subsequently measured and found to be twenty-three inches in diameter. In this exciting affair we were stung in the hand twice, through a thick buckskin hunting glove, but the pain we experienced, though very severe at first, was not of long duration, and we congratulated ourselves on having escaped a greater punishment. Before the end of the same season, we destroyed no less than seven other nests, and since then we have met with four or five in the Park. Vespa holsatica (Fab.) campanaria of other authors? is the only other species of the genus that has come under our observation here, and of this we have obtained two nests, one was suspended from the centre of the arched woodwork forming the canopy of Spit-head bench in the Park, and the other was 
discovered in the roof of an unfrequented shed in the gardens. Each nest was about two inches in diameter, of a more delicate fabric than that of vulgaris, with three distinct envelopes, the two inner ones enclosing the whole of the combs, with a large aperture at the bottom, the outer one embracing a little more than the upper half only of the nest and presenting the appearance' of an inverted cup.

We have also seen several specimens of the nest of another species, that of Vespa britannica (Leach), they were very neat nearly globular structures, six or eight inches in diameter, and attached to the branches of apple trees and shrubs; as, however, they were not found in our Harting district, we only incidentally allude to them. The food of wasps is various, they prey on other insects, infest butchers' shops, help themselves to any sweets within their reach, and feast upon the ripest fruit in the garden, but whether this general statement applies to all the members of the family or to a few only, is not quite satisfactorily made out, their specific distinctions and economy require further investigation.

The last great group of this order is that of the Honey-gatherers, in which we find the solitary bees, cuckoo bees and social bees. Among the first we have met with several species of Andrena, which no doubt are often mistaken for the common hive bee, but in their economy they differ from it essentially. They burrow in the ground, and with each egg they deposit, they store up a supply of pollen paste, just sufficient and no more, for the support of one larva during the period of its development. A favourite locality for one species of this genus (or of Halicta?) is the trodden slope, with a sunny aspect, leading to the Dog-kennel Pond in the Park, where we have found several of its burrows within a few inches of each other many seasons in succession.

The species of Nomada which we have met with we 
have not had the opportunity of identifying, but we have taken many of these pretty wasp-like flies, among others Nomada Marshamella, Nomada rufiventris, Nomada ruficomis and Nomada flava. As they are unprovided with apparatus for carrying pollen, they are supposed to have a cuckoo-like connection with other bees, probably Andrena, depositing their eggs in the pollen paste collected by the latter, and thus avoiding the labour of constructing nests of their own.

The Leaf-cutter bees form their burrows in decayed wood, and that of Megachile centuncularis, an insect also resembling the Hive-bee, we once discovered in an old gate-post in Hotston Paddock. It was eight or ten inches deep, and when laid open, disclosed a leafy tube accurately fitting the interior. On examination we found that this tube was formed of distinct cells, one above the other, the bottom of each cell closing the mouth of the one below it, and all filled with a thick dark coloured honey or pollen paste. We have often seen these bees during their nidification, engaged on different plants in the shrubbery, the rose especially and the laburnum. The insect fixes itself on the edge of a leaf, holding it on each side between its legs, and with its sharp mandibles clips out a circular piece so accurately, that when it has removed it, the leaf has the appearance of having had a neat little disk punched out of it, somewhat larger than the top of an ordinary thimble. If undisturbed in this operation, it proceeds very quickly without hesitation or pause, till it has accomplished its purpose, when it immediately takes wing and disappears with its load, still holding it between its legs. These circular disks are intended for the bottoms of the cells, the sides of which are formed of larger pieces of a different shape, principally oval. It will be evident that a considerable interval must elapse between the deposition of the first egg in the lowest cells of the series, and that of the last in the 
upper one, and that, as a natural consequence, the larvæ cannot all attain their development simultaneously. The first hatched, therefore, which is ready to emerge before the others have ceased feeding, gnaws a hole through the bottom of its cell, and makes its exit through the side of the post, the others all following the same route in succession. Another species of Megachile, at least we assume it is distinct from centuncularis, constructs its cells in cavities of old walls, we have repeatedly seen individuals of this species, with their leafy burden, enter the open spaces between the bricks where the mortar had apparently crumbled away, in the summer of 1870 there were three of these nests in the course of construction, at the same time, in the walls of the stables at Uppark.

Chelostoma florisomnis is a slender little bee, remarkable for its habit of coiling itself up and taking its siesta within the corolla of a flower, we have found scores of these drowsy creatures in the common blue bell (Campanula rotundifolia) in the park. We have also many times seen in the same localities, towards the close of an autumn day, quite a little family of another similar bee (a species of Heriades?) suspended together by their mandibles from the inflorescence of different grasses. The nests of both these genera are found in old woodwork, and the divisions between the cells are composed of fine raspings of the wood mixed with a viscid fluid secreted by the insects.

Eucera longicornis, which burrows in the ground, and Anthophora retusa, another burrowing species, we have several times netted, but we have never had an opportunity of identifying their nests. The first of the two is remarkable for the peculiar structure of its long antennæ, a peculiarity which we believe is not found in any other genus, the terminal joints of these organs appear under a lens to be composed of minute hexagons, like the facets in the compound cyes of insects. 
In the fact that Humble bees store their cells with honey and pollen paste for the support of their young, they differ from the wasps, but in other details of their economy they are very similar to them. Their colonies, which, like those of the wasps, are only for a season, includes males, females, and workers of different sizes, and the continuation of the species is entirely dependent on the few impregnated females that escape the rigours of the winter, each of these founding its own family in the following spring. Their nests are not very elaborate structures as compared with those of the domesticated bee or the wasp, they consist in the early part of the season of a rough kind of waxen dome thrown over a rude reservoir of the same material, filled with pollen paste, and containing several young grubs together. When the latter are fully developed, they separate, and spin oval upright cocoons side by side, from these they escape as perfect insects, and the empty cocoons are subsequently lined with wax and stored with honey. The nest of Bombus terrestris is underground in a carefully smoothed cavity, the entrance to which is through a long tunnel, that of Bombus muscorum is on the surface, and concealed by a neatly felted covering of moss, which is continued to some distance from the main structure, in the shape of a tubular passage intended for the ordinary traffic of the bees to and from their nest.

In our brief notice of the Honey-bee we have directed attention to the wonderful variation of instinct in that species, developed under a very unusual contingency, the accidental loss of a queen; the humble bee is not less remarkable for its faculty of accommodating itself to special circumstances. These insects are subject to the attacks of the Beetle mite (Gammasus Coleoptratorum), already noticed in connection with Geotrupes stercorarius as being particularly difficult to shake off, and they resort to a curious 
stratagem for the purpose of ridding themselves of their tormentors. An infested individual seeks an ant hill, on which it throws itself on its back, and sets up a loud buzzing noise, the ants soon take the alarm, swarm out of their nest, and at once fall upon the noisy cause of the disturbance, but the latter, with its legs now rigidly extended and motionless, as if it were simulating death, escapes molestation, while the soft bodied mites, hurriedly coursing over its body, are very quickly despatched, and the relieved Bombus, without the ceremony of apologizing for its trespass, gives itself a comfortable shake and flies away!

The next order* is composed of a single family of very minute insects, parasitic on wild bees and wasps in their perfect state, but as we are only acquainted with them through published figures and descriptions, we can only infer that from the general abundance of. the insects to which they are appropriated, these parasites may be by no means rare with us, although they escape the notice of the collector. The number of species hitherto described is not large, and beyond the fact that their attacks, unlike those of the parasites in the preceding order, are not necessarily fatal, little is yet known of their history.

* Order StRePSiPTeRA.-From the Greek strepsis, a turning or twisting and pteron, a wing. Wings four, the upper ones rudimentary and contorted. 


\section{CHAPTER IX.}

\section{INSECTS-BUTTERFLIES AND MOTHS.}

THE most gaily coloured of our insects are the Butterflies, Moths, and Hawkmoths; they are also those with which, in our tender years, we are most familiar -our experiments in entomology at that early period of our studies being generally directed to the capture, after an exciting chase, of every butterfly we see sporting in the sunshine. How often on such occasions, after having secured the coveted prize, have we had to deplore the total loss of its beauty under the incautious pressure of a finger and thumb! It is only at a more advanced stage of our entomological experience, however, that we come to learn the cause of this early disappointment. We then find that the wings of the majority of the insects in this order* are clothed on both sides with a fine powder, every particle of which, under the microscope, proves to be a very elegant scale or feather, each provided with a minute stem at its base, as if it were made to fit into a socket, which, indeed, it really does before it is removed from the surface to which it is at first attached. In butterflies, moths, and hawkmoths, with some exceptions, thousands of these sockets may be found on each side of the wings, and they are so arranged that the scales that are planted in them lie in very regular rows, each row overlapping a portion of the next, an arrangement similar to that of tiles or slates in the roof of a building. All the colours and beautiful markings on the wings of these insects are entirely due to the scales themselves, and if these are removed the socketed surface

- Order Lepidoptera-From the Greek lepis, a scale, and pteron, a wing. Wings four, all clothed with scales. 
beneath them will be as nearly colourless as the wing of a house fly. The fine dust, then, that glistens on our thumb and finger, when we have rudely closed them on the wing of a butterfly, is a pinch of beautiful scales, feathers, and hairs of curious and elegant forms and many different colours, and in a few of our insects these objects, when properly adjusted under a microscope, are so inconceivably splendid, that they are not surpassed by the most brilliant clusters of gems ever worn by a ball-room belle in anything but size and conventional value. Beautiful, however, as the butterfly is in its perfect state, it has passed through its preparatory stages under very different forms; hatchêd from an egg, which in many species is a marvel of beauty in itself, it enters on its active existence as a voracious larva or caterpillar, sometimes not very attractive in appearance. In this condition it is provided with a pair of powerful cutting jaws, which it plies incessantly, between its periods of moulting, on the leaves of the plant on which the egg has been deposited by its parent. After a few changes of skin it has completed its growth, and becomes an inactive chrysalis or pupa, to emerge in a few weeks or months as a perfect winged insect. Henceforth it mends its ways, instead of disfiguring the leaves of plants, it seeks its liquid food in the flowers alone, and the change that takes place in its habits is scarcely less remarkable than the modification that is effected in the different parts of its mouth. The jaws that formerly made such havock among the culinary and other plants in our gardens, are replaced by an elegant apparatus, outwardly resembling an elephant's trunk in miniature, which, when not in use, is carefully coiled up like a watch spring, and concealed under the head of the insect. This trunk, or tongue, consists of two distinct pieces, each of which has a groove channelled out all along its inner side, so that when they are brought together in close contact the two grooves 
together form a tube. In many species, and probably in all, the two halves are locked together by a set of hooks on the inner edge of each, which fit into as many minute notches in the other. With this apparatus the butterfly is enabled to reach the nectary of a deep tubular flower into which its newly-acquired wings would not allow it to enter bodily, and rapidly pump up the sweet fluid on which it now feeds. This fluid is drawn up the tube formed by the two grooves at the point of contact of the two halves of the trunk, and it is reasonably assumed that an air-tube inside each of the two halves has something to do with this performance. The length of this trunk varies greatly in the different species, in those that take no food at all in the winged state it is but slightly developed, but in some of the hawk moths, that feed as they hover over the flowers without settling, it is nearly two inches long, and in the majority of butterflies and moths its length is very little less than that of the body of the insect itself. The insects of this order possess compound eyes similar to those of beetles, a short description of which we have already attempted, and the number of facets varies in the different species from a few hundreds to several thousands in number. There is nothing very striking in the coloration of these organs, but those of a few species possess a remarkable property which should not be overlooked, that of becoming luminous in the dark; whether this phenomenon is under the controul of the insect or not we do not know. It is among moths, however, and conspicuously so in the males, that we find the greatest development, diversity, and complication in these elegant appendages, the antennæ; here also do we meet with those startling facts on which rests the assumption that these organs are the seat of a simple or compound sense, of which in the whole range of our own perceptions and faculties we find no analogue. We shall have an opportunity of giving an illustration 
of this further on, in the meantime we proceed to the enumeration of our butterflies, no very difficult task as the list is not long.

The Brimstone Butterfly (Gonepteryx Rhamni) is one of our earliest to leave its winter retreat, and may frequently be seen abroad in sunny intervals in the days of February, it is not generally regarded with favour, however, at that early season, the local impression being, we have never heard why, that we may expect as many frosts in May as there have been individuals of this species seen on the wing in February! "I can call spirits from the vasty deep_-But will they come?" Its caterpillar is found on the buck= thorn during the summer months, and the perfect insect is tolerably common in the autumn.

The Clouded Yellow (Colias Edusa) is one of our most highly prized and richly coloured insects, and so vigorous is its flight that it has often tested the agility of the young entomologist intent on its capture, and succeeded in escaping the net after all. In byegone seasons, when a race with a butterfly was a daily event with us, we have taken this beautiful species in the Park and on the Downs, and in later years we have seldom failed to see one specimen at least every season by the roadside near Honey Lane Field; but it is not common, and we have only once been so fortunate as to capture the female, although we have several times seen the caterpillar in the adjoining clover fields.*

The Black-veined White (Aporia Crategi) is less frequently met with here, but as the caterpillars are gregarious, when it makes its appearance it does so in

- This species appears to have very much increased in numbers since the racing days referred to in the above paragraph; this season especially (1877) it has been quite common. We have incidentally heard of the capture, by a youthful Harting entomologist, of as many as thirty specimens, and we saw no less than seven one morning towards the latter end of August, during a drive from Uppark to the Rogate and Harting Station. 
tolerable numbers. We have three times in our experience found its young family feeding under the shelter of a silken awning on a quickset hedge (the hawthorn) on Hucksholt and Church Farms, and on each occasion bred the perfect insect from them.

The Large Garden White (Pieris Brassicc), the Small Garden White (Pieris Rapoc), and the Greenveined White (Pieris Napi) are, we need scarcely say, always abundant, but never before nor since have we seen such an extraordinary flight of the first of these species as we did on one occasion in the summer of I868. For more than three hours did they swarm past the house and over the highest beech trees in undiminished numbers, always in a straight course from south-west to north-east, as if they were intent on keeping a general appointment at some distant rendezvous. It was on one of those tropical days in August for which that season will long be memorable, without a breath to ruffle the foliage, and a spectator, looking towards the south across the lawn, might at the end of the three hours have aptly exclaimed, "The cry is still they come." Legions of these butterflies were observed about the same time in other localities, but no allusion is made to their uniform line of flight in any of the records of the phenomenon which we have seen in periodicals.

The Orange Tip (Euchloe Cardamines) is one of our common butterflies, and a very pretty one it is, but its winged life appears to be of brief duration, seldom much exceeding a summer month, during which it may be seen on duty among the wild flowers fringing the hedgerows, by the woodside and in bye lanes.

The Marbled White (Arge Galathea) makes its appearance later in the summer than the last and is not so generally distributed, we have- met with it occasionally on West Harting Down, in Holkham Lane, and, more frequently, in Padswood Copse, in which latter locality the Speckled Wood Butterfly (Lasiom- 
mata Egeria) and the Wall Butterfly (Lasiommata Megara) are common, they also frequent the open drives in the covers, and the latter, especially, may be seen in the company of the Grayling (Hipparchia Semele) on the Fore Down and on the adjoining northern slope of the Tower Hill in the Park.

The Meadow Brown (Hipparchia Fanira), the Large Heath (Hipparchia Tithonus), and the Ringlet (Hipparchia Hyperanthus) are three very common insects, the two former frequenting the open Downs, the Park and dry pastures generally, the latter woods and hedgerows. Although the coloration in these three species is anything but lively, one very remarkable feature distinguishes the underside of the secondary wings of Hipparchia Fanira. The markings are, as may be. expected, more or less distinct in different individuals, but in some of the most highly favoured in this respect, a curious observer may detect, without the exercise of a very lively imagination, a tolerably good profile of the first Lord Brougham! Another very common insect frequenting the Park, the Downs, the Heaths and wastes generally, is the Small Heath Butterfly (Cononympha Pamphilus), a plain buffcoloured little species, much smaller than either of those hitherto noticed in this paper.

The White Admiral (Limenitis Sybilla), of which we have captured half-a-dozen specimens only in as many consecutive seasons, four in Padswood Copse and two on West Harting Down, although not so strikingly gay in coloration as many less rare species, is no sooner seen on the wing than it is at once recognized, far as the eye can distinguish it, by the experienced collector, its easy, graceful flight, as it appears to glide hawk-like, without an effort, through the sunny glades in the copse wood, is so unlike that of our other native species.

The high soaring Purple Emperor (Apatura Iris) is a noble looking insect, most difficult under ordinary 
circumstances to capture, and the few living specimens we ever saw, or succeeded in netting, were swept off the mossy turf on which they had settled within the ring fence surrounding the Tower in the Park. On all these occasions, without exception, our first attempts to approach their imperial majesties were discouragingly unsuccessful. They darted off so swiftly that any attempt to pursue them would have been simply ridiculous, but so powerfully did they appear to be attracted to the spot on which they were first seen, that after several rapid evolutions round, the building, at such a distance that they were sometimes lost to sight, they returned again and again until at last they were fairly bagged. At that time we were unacquainted with the fact, which has since been well ascertained, that the Purple Emperor has a decided penchant for animal food in an advanced stage of decomposition, but we have now reason to believe that, in the instances here recorded, it was to this weakness that he fell a victim.. Bands and spots of white on a rich purple ground are the distinctive markings of the male insect, the purple being sobered down in the female to a homely brown. The larva, which feeds on a species of sallow, is a curiously shaped smooth-bodied caterpillar, tapering gradually towards the posterior extremity, and furnished with two inarticulate processes on the back of the head like a pair of horns, it is of a lively green colour with yellow diagonal stripes on the sides.

The larva of the Painted Lady (Cynthia cardui) differs from those of all the preceding butterflies in the possession, along the whole of its upper surface, of a formidable looking array of branched and acutely pointed spines, which, however, can never be used individually as offensive weapons. - It is of a brown colour, striped with yellow, and feeds on the thistle and nettle. The pupa, like that of several other butterflies, is rich with spots of burnished gold, from 
which character the term chrysalis was, in the early days of entomology, applied to the pupæ of all butterflies indiscriminately, and collectors were known as aurelians. We have found the perfect insect generally distributed, but not common.

The rich velvety black and brilliant scarlet on the upper surface of the wings of the Red Admiral (Vanessa atalanta), delicately relieved near the margin with spots of white and blue, make this one of our most gorgeous insects, the underside of the wings, though less striking, is also exquisitely beautiful, and few more charming scenes greet us late in the autumn, than a number of these magnificent butterflies feeding, as we have seen them year after year, on the fallen fruit in the gardens, or rifling the sweets of the ivy blossoms in the shrubbery, and leisurely displaying the two surfaces of their wings alternately in the bright sunshine. While thus engaged, they are as fearless as they are beautiful, and we have on several occasions gently taken up a few of them by their closed wings and set them at liberty again, when they have at once returned to their feast, as if determined at all risks to enjoy the abundance set before them, all the more precious from the fact that the chilling fogs of November were so near at hand. The caterpillar is thorny, like that of the last species, feeds on the nettle, and changes to a gold-spotted chrysalis in August.

The Peacock Butterfly (Vanessa Io), so called from the resemblance of the four conspicuous spots on the upper surface of its wings to the "eyes" in the train of the peacock, is common and generally distributed. It makes its appearance on wing sometimes very early in the season, after its hybernation we have seen it in March, but the caterpillar, which is gregarious, spiny, black, dotted with white, and feeds on the nettle, does not assume the perfect form before the end of summer or the beginning of autumn. 
The Large Tortoiseshell (Vanessa polychloros), sometimes also called the Elm Butterfly, and the Small Tortoiseshell (Vanessa urtica) differ little from each other in their general colour and markings, but the latter is the brighter of the two, and, as a rule, the smallest. The caterpillars of both, like those of all the genus, are clothed with spines, and the golden decorations of the chrysalides are sometimes unusually splendid. The perfect insects, which are generally distributed, emerge in the early part of summer, and may not only be seen throughout the remaining montlis of the season till late in the autumn, but in early spring also, the specimens, however, which survive the winter have often lost their freshness, and present a faded, battered appearance. A remarkable fact in the history of Vanessa urtice came to our knowledge many years back, but although it was made known to the readers of a local periodical shortly afterwards, we have yet to learn that any other observer has witnessed a recurrence of the phenomenon, although we may reasonably assume that it is not an exceptional one in the economy of this insect, but that, on the contrary, it may be common to the whole order. The circumstance alluded to is related in the following extract from the "Chichester Magazine" for June, I 837 .

"In the month of May, I832, I was in pursuit of Lepidopterous insects in a beautiful green lane, or rather a wide foot-path between two hedgerows, where the rays of the sun were somewhat powerful at midday. Butterflies were flitting and zigzagging plentifully throughout the whole length of the lane. The Orange-tip and Small Tortoiseshell were the most abundant, the former in its undulating course displaying alternately the variegated green and white of the secondary wings, and the brighter orange cloud of the primary ones, and I was amusing myself in contrasting its desultory flight with the more vigorous 
onward course of the latter species, the more particularly as it had occurred to me that those butterflies whose wings were of a lax texture with slender nervures, displayed this particular means of avoiding their pursuers, of which those possessing stronger nervures with an apparently more tense membrane between them, would seem to have no need. While I was indulging my speculations upon this conjecture, two individuals of Vanessa Urticce that had repeatedly flown by me, now alighted on a broad blade of grass not a yard off, and I had ample opportunity of watching them for some time. One had fixed itself in an attitude, which though singular and perhaps not very graceful, is by no means unusual with this beautiful order of insects; I mean with its abdomen raised so as to form an angle with the thorax, its antennæ and wings extended and motionless. The other, about half-an-inch behind it, was displaying a most fantastical behaviour, and with as much agility as the narrow space on which it was moving would allow, traversing it from side to side, then closely approaching the inactive one and receding from it by sudden starts, and what more particularly arrested my attention, frequently striking its antennæ against each other so forcibly as to produce a click or snap distinctly audible to me as I stood upright, and I am no pigmy.

"At that time I had never heard the noise produced by the larva of Acherontia Atropos (Death's head Sphinx); but since then I have-though out of nine individuals that $I$ had the good fortune to obtain last year, one only produced the noise in questionand I am enabled to assert that the click produced by the butterfly (Vanessa Urtice) was by far the strongest. I remained watching three or four minutes, during all which time the scene I am describing continued without any interruption, the clicking being frequent and perfectly audible. On a slight motion I unintentionally 
made, that which had been so passive took wing, and was closely pursued by the other."

Among the Fritillaries, we have taken in Padswood Copse, in the park, at Lady Holt, on East and West Harting Downs, and in other upland localities. The Silver-washed Fritillary (Argynnis Paphia); the Dark green Fritillary (Argynnis Aglaia); the High brown Fritillary (Argynnis Adippe); and the Glanville Fritillary (Melitea Cinxia), all beautiful insects, distinguished alike for the rich golden brown of the upper surface of the wings, variously relieved with streaks, waves, and spots of black, while the under surface of light brown blending with iridescent green, is resplendent with brilliant undulations, festoons and blotches of silver. The caterpillars wear the family livery of spines, and the chrysalides are more or less decorated with yellow or white spots of a metallic lustre. The last of the four species leaves the chrysalis about the middle of May, and generally accomplishes its mission in the winged state before the appearance of the others.

The Hair Streaks are not abundantly represented here, we have met with two species only, the Purple Hair Streak (Thecla quercus), a pretty insect with the upper surface of the four wings varying from dark brown in one position, to rich purple in another, and the Green Hair Streak (Thecla Rubi), chiefly remarkable for the light green hue of the whole of its under surface. The larvæ are short, thick and smooth, somewhat tapering from the middle towards each extremity, and the perfect insects are generally distributed.

The Small Copper Butterfly (Chrysophanus Phlaas) is very appropriately so named, the anterior wings accurately resemble little films of burnished copper, tesselated and bordered with black, in the posterior ones the black predominates. It is a lively, splendid little fellow, not at all uncommon, and may be seen 
often sportively associating with the active little blues, of which we have met with three species,- the Azure Blue (Polyommatus Argiolus) in the Forty Acres Lane, Holkham Lane, and the skirts of the upland copses; the Bedford Blue (Polyommatus Alsus), and the Common Blue (Polyommatus Alexis), the latter as common as the blue bells among the herbage by the roadsides, in the parks, on the downs, and in the lowland meadows.

The Grizzled Skipper (Thymele Alveolus), the Dingy Skipper (Thanaos Tages), the Small Skipper (Pamphila linea), and the Large Skipper (Pamphila sylvanus), complete our list of butterflies, the locat occurrence of which we have noticed.

The next division of insects in this order includes the largest, the most full bodied, and the swiftest fliers, and when on the wing by twilight they are not unfrequently mistaken by casual observers for bats. The caterpillars are remarkable for their great size as well as the perfect insects, and from the position they assume when in repose, with the anterior extremity elevated and motionless, they are imagined to present a general resemblance to the fabled Egyptian Sphinx, from which peculiarity the perfect insects are called sphinges. They are also quite as often termed Hawk Moths, from the vigour and swiftness of their flight, during which the vibration of their wings is so inconceivably rapid that they produce a humming sound, and this again has suggested for them the further alias of Humming bird Moths.

Among the few species we have met with here, taking them in the order followed by Newman in his "British Moths," we begin with the Eyed Hawk Moth (Smerinthus ocellatus). We have never taken the perfect insect, but we have bred several specimens from the caterpillar, many of which we have found in an orchard in the village. The skin of the latter is 
rough to the touch, of a light green colour, finely sprinkled with white, and obliquely striped with white on each side. In the autumn they bury themselves in the earth about the roots of the trees, on the foliage of which they feed, and emerge in the perfect state the following June. The moth has two conspicuous eyelike spots on the posterior wings, from which it derives its specific name.

The Poplar Hawk Moth (Smerinthus Populi), and the Lime Hawk Moth (Smerinthus Tilic), we have occasionally taken in the perfect state at East Harting, but we have never met with the caterpillar of either. We have been more fortunate with the Death's-Head Hawk Moth (Acherontia Atropos), of which we have possessed both moth and caterpillar. This, the largest of our moths, supplied us on one occasion with no less than thirteen caterpillars found in a patch of potatoes in a neighbouring garden, and we had many opportunities of verifying the fact that the caterpillar when full fed, has the power of producing a sharp click when disturbed, while the perfect insect is still more remarkable for a prolonged stridulous note, almost startling to the young entomologist in his first attempt to prepare it for the cabinet. On two or three occasions since the one referred to, we have had many of these caterpillars from the gardens in the village, but we candidly confess that we have not always been successful in rearing the perfect insect. All the caterpillars we have seen, some thirty or forty, were yellow, elegantly banded obliquely on the sides with blue and white, from the upper to the under surface, but they generally became of a dull orange before they disappeared towards the end of summer in the garden mould with which we supplied them. Those which effected their transformation successfully reappeared in six or seven weeks, with magnificent velvety wings, the anterior ones nearly five inches in expanse when extended, deep brown, varied with shades and un- 
dulating bands of a lighter colour, the posterior ones yellow, set off with a transverse wavy black band about the middle of each, and a broader one parallel to it near the margin, elegantly scalloped between the nervures. Abdomen of the same colour as the hind wings, with a longitudinal stripe of blue down the middle, and transversely banded with black. But the most distinctive specific character of this fine insect is that from which it has received its name, the figure on the back of its thorax more or less suggestive of the human skull.

Of the Convolvulus Hawk Moth (Sphinx Ligustri), we once captured a solitary very much battered specimen, and about the same time we saw in the possession of a gentlemen at Petersfield an enormous dark brown caterpillar similar to one figured, as that of the moth in question, in "Wilks' English Moths and Butterflies." *

The Privet Hawk Moth (Sphinx Ligustri) is a common insect with us, scarcely a season passes but we meet with it in one or other of its stages, and we have found the caterpillars generally distributed wherever there is a supply of privet or lilac. The Small Elephant Hawk Moth (Charocampa Porcellus), and the Large Elephant Hawk Moth (Charocampa Elpenor), both eminently beautiful insects, we have bred from the caterpillar. On one occasion we found several caterpillars of the latter species feeding on the Clarkia pulchella in the flower garden, an exceptional case no doubt, as our native specimens are generally contented with more humble fare, although they are said to evince an occasional weakness for the fuchsia.

The most interesting members of this family, though not the most lively in coloration, are the Humming Bird Hawk Moths, and we imagine that very few of the least observant of our cottagers, who have access

- In 1875 we obtained another battered specimen of the perfect insect from a village within a few miles of Harting. 
to a flower border, can have failed to become acquainted with our commonest species,-Macroglossa Stellatarum, and to watch it with astonishment as it suddenly made a dash at the corolla of some gay flower, stop as suddenly with its head directed towards it as if for the purpose of testing its fragrance, and remain for a second or two apparently motionless, and horizontally poised without any visible support. This is its appearance when it is in the act of inserting its long tongue into the tube of the flower and lapping the sweet fluid stored up in its nectary. At the slightest motion on the part of the observer it vanishes with such magical speed, that it is utterly impossible to follow it, even by sight, in its course. The next instant it may be seen, again rigidly balancing its short thick body, with its outspread tufts of tail feathers, at the level of another flower, then another and another, until, if undisturbed, it has visited and revisited in this way as many as may suit its purpose, its wings vibrating with such astonishing rapidity all the while, that a faint filmy indication of their play is all that is perceptible to the eye, their powerful action on the air, producing at the same time a distinct humming sound. In I 866 we had many opportunities of watching as many as a dozen at a time, flashing in every direction with unerring aim from blossom to blossom in the flower beds in the shrubbery. On this occasion they did not limit their attention to the flowers alone, the silver-leaved varieties of geranium seemed to have some attraction for them, several individuals curiously and carefully exploring the irregular folds of the leaves with the tips of their tongues. The two other species, the wings of which are transparent with an opaque border, are the Broad Bordered Bee Hawk Moth (Macroglossa Fuciformis), and the Narrow Bordered Bee Hawk Moth (Macroglossa Bombyliformis). They are both occasionally met with here, and are equally remarkable with the common species 
for their swift darting flight and their practice of feeding on the wing.

Of the Clearwings we are familiar with three species only, The Red Belted Clearwing (Sesia myopoeformis), The Currant Clearwing (Sesia tipuliformis), the caterpillar of which we have found in great abundance feeding on the pith of the young shoots and the smaller branches of the red currant tree, and the Hornet Clearwing of the poplar (Sesia apiformis), which, from its close resemblance to a hornet in size, shape and colour, has no doubt often been mistaken for that insect. In the year 1869 we caught two specimens in one day on the flowers of Pedicularis sylvatica at Downparkes, with no other apparatus than a card box.

We have captured several specimens of the woodboring Leopard Moth (Zeuzera Esculi), both in the larval and perfect states, in an old orchard at the Parsonage which no longer exists, and the fine Goat Moth (Cossus ligniperda), remarkable for its delicatelymottled brown wings, elegantly and finely varied with short wavy streaks across the disk, is not uncommon with us. The caterpillar of this species is a ranksmelling, unamiable, repulsive looking reddish-brown grub, with a black head and very powerful mandibles, with which it is quite capable of punishing the entomological epidermis, and not slow to do so if incautiously handled, a fact which has been very disagreeably impressed on our memory. All the larvæ of this species that we have met with, and from which we have reared the perfect insect, were oak-wood feeders, and one of them we saw taken from the butt-end of an old gate post in the Park, a foot or more under ground.

The following extract from the copy of a letter to which we have access, refers to the next species in our list :

"Would you now have a genuine ghost story? I can give you one on my own authority, and if you should, as you may, not unreasonably, be disposed to 
do, wish for additional testimony to the truth of the statement I am about to make, I can refer you to three or four respectable and intelligent individuals in the village, who are quite ready to vouch for the actual occurrence of the incident here related. I was one of a party of aborigines who had casually met one fine evening last summer, and were indulging in a social chat. Among them was one, a local knight of the thimble, whose intellectual resources fell short of exciting the envy of his friends, although they appeared to be eminently satisfactory to himself. He was the authority on local traditions, and, his memory being well stored with village chronicles and domestic incidents of byegone days, he was so obtusely indifferent to the admission of new ideas on any other subject whatever, that he was wont to look with good-natured suspicion on any statement not within the range of his comprehension. I had just returned from London, where you know I had gone for the express purpose of seeing Mr. Curtis's rich collection of insects, and, having been much interested in the lectures and experiments at the Polytechnic, I was relating a few of the wonders of science I had witnessed there, as well as at the Adelaide Gallery a few years before. The chemical decomposition of water, for instance, in two invisible gasses, one of which was made to explode with such startling effect that 'a young man from the country,' who happened to be seated near the table on which the experiment was made, hastily sprung from his seat and loudly exclaimed 'ketch me drinkin water after that!' The Electric Telegraph, which was capable of transmitting a message to-day that should reach America some time yesterday! The Electric Flash, which showed distinctly and repeatedly that a spoked wheel in rapid revolution was actually at rest while the light was upon it! The cooking a piece of meat a hundred feet from any fire, by means of concave reflectors! Setting fire to water by throwing a piece 
of cold bright metal on it, as an illustration of the possibility of 'setting the Thames on fire'! Cutting a steel bar with a rapidly revolving disc of soft iron! - and so on. 'What d'ye think of that, Ned,' asked one of the party, who appreciated the incredulous smile that already sufficiently expressed 'Ned's' ideas on the subject, but the only response was a deliberate appeal to his snuff-box, accompanied by a cunning look at each individual present, and a mute assertion, as intelligible as words, of his steady resolve not to allow himself to be betrayed into the weakness of believing such tales on any account. "To change the subject,' I continued, 'you all know "Matthew's bush," where the murder was committed many years ago; well, last evening, as I was hurrying by there in the twilight, without bestowing a thought on the fearful associations of the spot, I suddenly saw a ghost, as distinctly as ever I saw anything in my life.' The hitherto incredulous snuff taker at once interposed with extraordinary solemnity 'Ah, that I wool believe,' thus implying that all the rest was not worth a serious thought. He was very much disappointed, however, and not a little laughed at, when, to his eager question 'what was it like?' I replied, that it more resembled a white moth than any other thing I could liken it to, and that it seemed to be mysteriously flitting up and down just above the grass, as it passed round the murderer's bush and disappeared. You, of course, will not care to be told that my ghost was nothing more supernatural than the Hepialus humuli." This is known to collectors as the Ghost Swift, and is so called from the silvery white wings of the male, and from its habit of fluttering over the herbage at dusk, probably in search of its dingy companion, now rising, now falling, without appearing to make much onward progress, unless when pursued. This common species is not the only one of its genus to be found here, but we have now reached a division of moths in which the 
genera and species are so numerous, that to notice them all would be beyond the scope of this paper, we therefore purpose limiting our further notes to the more remarkable only of those with which we are acquainted.

The Forester (Procris Statices) is one of these, it is not uncommon in the uphill district, and is a very beautiful insect, with lovely golden-green wings and body. The Burnet Moths are conspicuous for their crimson-spotted fore wings and crimson hind wings, but two of the species are so nearly alike, that we have probably confounded them and made out two species only instead of three, which are plentiful in the same localities as the last. The Red-necked Footman (Lithosia rubricollis), and The Cinnabar (Euchelia Facoboe ), we find in the valley commonly, and the caterpillar of the latter, with its black rings on a deep yellow body, is often a striking object on the Common Ragwort (Senecio Facoboa) in waste land near the Brick-kiln copse. The Clouded Buff (Euthemonia russula) we have taken on East Harting and West Harting Downs, The Wood Tiger (Chelonia Plantaginis) in and near Padswood Copse, and of The Common Tiger (Chelonia caja) we have had caterpillar and perfect insect from almost every garden in the three villages. The latter is that large moth with fine silky, dark brown, cream-coloured, red-and-blackspotted wings, so common in the early part of summer. The Ruby Tiger (Arctia fuliginosa) is the only other Tiger we have met with in the wilds of Harting.

The Muslin Moth (Arctia mendica), The Buff Ermine (Arctia lubricipeda), and The White Ermine (Arctia Menthastri) belong to our list, and, in connection with the first named species, we have not forgotten an incident that, at the outset of our entomological career, astonished us very much. We had secured a female specimen to the setting board, having, of course, previously killed it, as we believed, but on looking at it a few weeks afterwards for the purpose of removing its 
braces, we found that it had deposited several eggs in the groove containing its body, these had hatched and the tiny larvæ were actually feeding on the hind wings of their parent!

The Brown-tail Moth (Liparis chrysorrhea), the' Yellow-tail Moth (Liparis auriflua), the Satin Moth (Liparis Salicis), and the Gipsey (Liparis dispar) we have captured, and the Black Arches (Liparis monacha) we once reared in great numbers, having collected the caterpillars on the trunks of the old beech trees in the Park, from the foliage of which they had that season been dislodged by a heavy storm of wind and rain. On that occasion we were much gratified by the discovery among the perfect insects, when they emerged from the chrysalides, of a curious variety of the species, which eventually found its way into Mr. Curtis's cabinet in exchange for some other insect.

The Pale Tussock (Orgyia pudibunda), the Common Vapourer (Orgyia antiqua), with its wingless female, very little resembling a perfect moth in general appearance, and the Nut tree Tussock (Demas Coryli), we have bred from the caterpillar; the Pale Tussock especially in great abundance. In addition to those larvæ of the latter, which we have found here plentifully on the beech, we have received so many specimens from other localities that the species must be very generally known, in that stage at least when it is locally called a "Hop-dog," that caterpillar, we mean, with velvety-black body-rings, and several upright brushlike tufts of yellow hair on its back, so often met with in hop-gardens. One specimen only of the Dark Tussock (Orgyia fascelina) have we ever captured.

The Lackey (Bombyx neustria) we have often reared from the caterpillar, and one of our curiosities to this day is a batch of the eggs of this moth deposited and cemented in such regular and close order round a twig of blackthorn, as to form a very elegant little ring or tube of spiral lines.

The Fox Moth (Bombyx Rubi) was common on the 
Long Down adjoining the park, before the sheep-walk there was broken up and converted into arable land, and among the heath that flourished on the down thirty years ago, we have many seasons in succession, not only collected the caterpillars of this species, but succeeded without the slightest difficulty in rearing the perfect insect from them, yet very singularly, among all these we had never seen one male. Knowing however, from published figures of the species, that the sexes differed from each other in size and depth of colouring, we were naturally desirous of capturing a male specimen, and in order to accomplish this we had recourse to an expedient well known to entomologists as "sembling." On a fine calm day towards the latter end of May, or the beginning of June, having first secured one of the recently excluded females in a chip box with a gauze cover, we repaired net in hand to the locality in which we had collected the caterpillars, and although we were prepared for probable success (having tried a similar experiment before), our anticipations were so much more than realized, that the result appeared to us little less than marvellous. The path leading to the Long down passes through Padswood copse, a narrow strip of cover between the park and the down, and we had not proceeded a score of yards in the copse before a fine male made its appearance, fearlessly alighted on our sleeve, and, after impatiently fluttering up and down for a few seconds, eventually settled on the hand holding the box, and boldly sought admission to the imprisoned female. We then placed the box on the grass, and in the course of the next two hours it was no difficult matter to bag many more specimens than we could reasonably wish for. They hurried in from all points of the compass, sometimes singly; sometimes two or three fellow victims of temptation together, and, utterly indifferent to collector or net, or indeed anything but the object of their search, 
they allowed themselves to be captured on or near the box with the greatest ease, even by the hand, although under ordinary circumstances their flight is so swift, that in our subsequent experience we have found it no trifling exercise to run them down successfully. At the conclusion of this very satisfactory experiment, we gave the female her liberty, and returned to the setting-board with a full conviction that anything we had ever read on the subject of "sembling" was within the limits of probability.

In our introductory remarks on the antennæ of insects, we have incidentally touched on the hypothesis that these wonderful agents of communication betweer the sensorium and the external world, may fulfil their end by means of a complex sense which man is incapable of appreciating. Assuming that one of the several functions of the antennæ of the male is, not improbably, the perception of certain atmospheric influences emanating from the unimpregnated female, we can understand the object for which these organs are more deeply pectinated than those of the female in this and many other species. It is obviously to enable the insect to expose a more extended sensitive surface to the medium in which these emanations are diffused, but whether the faculty of perception on this extended surface, be identical with, or analogous to either of the human senses of smell, hearing, or touch, differing from these only in the possession of greater acuteness, or a blending of all three (if not a totally distinct sense of which man can have no conception) is matter of speculation, and will continue to be so until the special organ of each sense has been localized.

The Oak Eggar (Bombyx quercus); the Grass Eggar (Bombyx Trifolii); the Drinker (Odonestis potatoria); and the Lappet (Lasiocampa quercifolia), we have repeatedly reared from the caterpillars, found in the lowland meadows, clover fields and hedgerows, and of 
the very beautiful Emperor Moth (Saturnia carpini) we once, and only once, found a numerous family in the caterpillar state on one of the strawberry beds in the gardens. These caterpillars were much more beautiful after their last moult than in either of their earlier suits, and spun elegant flask-shaped cocoons, in which they passed the winter, months. When the perfect insects appeared, we took one of the females on a "sembling" expedition, but as we totally failed in our purpose, although we strolled over every part of the gardens from II a.m. to nearly 5 p.m., and repeated the attempt several days later with another female, but with equal disappointment, we came to the consolatory conclusion that we had probably secured all the brood, or at least all the males of that brood, when we collected the caterpillars the previous season.

Immediately following the last species is an extensive group of moths, upwards of two hundred and seventy of which are described, with illustrations, in Newman's fine work, from these we select the Swallowtailed Moth (Uropteryx sambucata), which we have bred abundantly from the caterpillar and taken in the perfect state, flying in the twilight by the side of the hedgerows that once added beauty to the lowlands, as seen from the Tower hill in the park, or reposing by day on the trunks of the beech trees in the gardenwood. The Brimstone Moth (Rumia cratcegata), which is common wherever the hawthorn flourishes; the Orange Moth (Angerona prunaria); the Light Emerald (Metrocampa margaritaria); and the Scorched Wing (Eurymene dolobraria), which we have reared from the caterpillar, taken from the beech. After the Thorn Moths, most of which may be included in our list, we notice the Peppered Moth (Amphidasis betularia), the caterpillar of which we have also found in the park; the Mottled Beauty (Boarmia repandata), not uncommon in the former orchard at the parsonage; the 
Small Engrailed (Tephrosia crepuscularia); the Engrailed (Tephrosia biundularia); the Grass Emerald (Pseudoterpna cytisaria); Papilionaria), a very beautiful insect; the Small Emerald (Iodis vernaria); the Lace Border (Acidalia ornata); the Latticed Moth (Strenia clathrata); the Common Heath (Fidonia atomaria).; the well known Currant Moth (Abraxas grossulariata); the Dark Umber (Scotosia rhamnata); and many other species of the same group.

Our next division of moths is the most remarkable of all for the extraordinary forms of its caterpillars, and we have been fortunate in meeting with some of the rarest of these and rearing them with success. Those of The Barred Hooktip (Platypteryx unguicula) we have taken abundantly, after the equinoctial gales in autumn, on the trunks of the beech, and, although they had necessarily been blown violently from their food leaves at a great height from the ground, very few of them failed to reach their final stage of development. The caterpillar of the fine Puss Moth (Dicranura vinula) we have frequently met with in the three villages, and fed on the aspen, as well as the elm and the poplar. In a state of repose, with its two extremities elevated, this is a curious looking object, rendered still more so by the angular hump on its back and the two horns on its caudal segment. These horns are, in fact, tubes, from each of which the caterpillar, when irritated, is capable of briskly protruding a slender filament of a pinkish colour, which it can direct to any part of its dorsal surface, and thus (according to some entomologists) sometimes "whip away" the Ichneumon (Ophion luteum), which is parasitic on this species, before it has had time to fix its egg on the skin. It is also provided with another remarkable defensive apparatus, this consists of a double syringe, issuing at the will of the animal from an aperture underneath the head, from which it ejects an acrid 
fluid in two distinct lateral jets, for the especial attention of its enemies. Its cocoon, which consists of particles of comminuted wood intimately mixed with a gummy fluid secreted by the caterpillar, becomes so hard and horny in drying, that to cut through its walls with a sharp knife would be no easy task. The first caterpillar of this species we ever saw was placed in a school boy's common oaken desk, and the next morning we found it necessary, before school hours, to wrench up the lid of the desk, the caterpillar having during the night spun its cocoon in one corner of it, partly on the lid, partly in the angle formed by the front and one side, so that the lid was firmly gummed down in its place, yet the soft downy moth, when ready to emerge, is provided with the means of liberating itself from this more than ligneous cell without the ruffling of a scale!

A still more curious looking caterpillar than that of the Puss Moth, is the caterpillar of the Lobster Moth (Stauropus Fagi), and of this we have met with one or two specimens in the season, several years in succession. All these we found in the Park under the beech, the leaves of which are undoubtedly their food in this locality, and we may here incidentally remark, that very many species of caterpillars, which in the experience of other entomologists are found on oak, birch, alder, poplar, whitethorn and other plants, the leaves of which are in all such instances their natural food, we have found among the beech woods, which, indeed, are the prevailing growth on the South Downs. Instead of one hump on the back, like that of the puss moth caterpillar, this one possesses two on several of its segments, four of its legs are elongated like those of a spider, and the two terminal segments, which when the animal is not walking are borne erect, are spread out as it were into a comparatively large mass, convex above, flat underneath, which is armed with two horns. The general colour of those we have seen was more or 
less a tan-colour, darker on the tips of the humps, and in several of our specimens, the curved horns and the legs (in part) had a tinge of steel-blue. We never succeeded in rearing more than three females of this species.

The Buff-tip (Pygara bucephala) is one of our commonest moths, and may be found reposing on the trunks of the beech in early summer, looking in this state very much like a short bit of dry stick recently broken off at both ends, for which, no doubt, it has often been mistaken to its own advantage. The caterpillars are so abundant, that when they are feeding on branches overhanging a chalk-dusty road, they often betray their whereabouts by the presence of an accumulation of stercoracious dottings underneath. The Coxcomb Prominent (Notodonta camelina) is another common species on the beech, the Pebble Prominent (Notodonta ziczac) we have reared from its curiously shaped caterpillar on the willow, and the Figure-ofeight Moth (Diloba caruleocephala) we have frequently bred on the blackthorn.

In the next great division, comprising more than three hundred species, we can claim the Buff Arches (Gonophora derasa), the beautiful Peach Blossom (Thyatira batis) on the bramble, the Grey Dagger (Acronycta Psi) on the beech, the Poplar Grey (Acronycta megacephala) taken in the net, and the Alder (Acronycta Alni) another species, the caterpillar of which we have several times found and fed till fullgrown on the beech, although one specimen only emerged safely from the chrysalis. All our examples of the caterpillar were alike velvety black, each segment being ornamented on the dorsal surface with a transverse squarish patch of shining bright yellow, resembling enamelled leather, and on each side with one hair, not unlike a flattened club, standing out laterally. The Knot-Grass (Acronycta Rumicis), the Scarce Dagger (Acronycta auricoma), the Light Arches 
(Xylophasia lithoxylea), the Dark Arches (Xylophasia polyodon), the Cabbage Moth (Mamestra Brassica), the Dot (Mamestra Persicaria), the Dusky Brocade (Apamea gemina), the Garden Dart (Agrotis nigricans), the True Lovers' Knot (Agrotis Obelisca), the Lesser Broad Border (Tryphona ianthina), the Broad-Bordered Yellow Underwing (Tryphoena fimbria), the Lesser Yellow Underwing (Tryphona orbona), the Large Yellow Underwing (Tryphoena promba), the Clouded Drab (Taniocampa instabilis), the Brick (Xanthia ferruginea), the Common Angle Shades (Phlogophora meticulosa), the Gray Arches (Aplecta nebulosa), the Sword-Grass (Calocampa exoleta), the Mullein (Cucullia Verbasci), the Beautiful Yellow Underwing (Anarta Myrtilli), the Gold Spot (Plusia Festuca), the Silver Y (Plusia Gamma), the Herald (Gonoptera Libatrix), which we never miss from its winter quarters in the subterranean passages leading to the offices in the house at Uppark, the Gothic (Nonia typica), the Old Lady (Mania Maura), often taken in a garden tool-house and other outhouses in the village, the Red Underwing (Catocala mpta), one only specimen taken on the wing at West Harting, and many other intermediate species, too numerous to find space in this short notice.

The last great division of moths, which we shall briefly invite attention to, is made up of all the most minute forms of the whole order, and includes, among many other objects of interest, the Leaf-miners, whose tortuous subcutaneous labyrinths in the leaves of the bramble and other growing plants are so conspicuous every season. The largest species of this group Halias prasinana, which we have found and reared on the beech in great numbers, is a most beautiful moth, with anterior wings of a delicate pale gireen, relieved with three diagonal silver lines across the disk of each. In our early entomological days we have collected many specimens of the caterpillar of this pretty moth every 
autumn, at which? season they spun their boat-shaped cocoons among their food leaves and emerged the following spring.

The caterpillars of the Rose Moth (Argyrotosa Bergmanniana) we have met with too frequently in the Rosary, where, as a "worm i' the bud," or among the tender leaves webbed together, it almost every summer commits great havoc. Carpocapsa pomonella (the Codling Moth) scarcely needs any introduction, it is a pretty little insect, but too partial to the apples in our orchards to be a general favourite. Every one is familiar with the "webby" fruit that falls prematurely in early autumn, the grub that is found in its interior is the objectionable larva of this insidious pest, which lays its egg in the "eye" of the apple in its very young state, and in some seasons these unscrupulous grubs are so numerous, that they commend themselves to our notice as the perpetrators of an immense amount of mischief. More plentiful sometimes than the last, is the little Green Oak Moth (Tortrix viridana), we have often seen both caterpillar and moth literally swarming on the oak, the foliage of which in the Park and the meadows in the valley they had-very extensively disfigured, if not nearly destroyed. The Ermine Moth (Ypomoneuta padella) is the parent of those speckled larvæ which we often find feeding gregariously, or grouped together in their cocoons, under the shelter of a silken awning set up by themselves on the whitethorn, the blackthorn and other growths. We have more than once seen such an extent of quickset hedge hung with the white fabric of these tiny grubs, which secrete their own materials, that, familiar as we are with many of the wonders of natural history, we have been lost in astonishment at the apparent disproportion between these diminutive artists and the result of their labours. Adela is our next genus, and Adela De Geerella, as well as Adela viridella, we have often netted. The antennæ in the first of the 
two species are developed to more than four times the length of its body, from which character it derives its popular name of "Long Horn," and a wonderfully beautiful object it is under the microscope.

The Clothes Moth (Tinea tapetzella) requires no description, as very few heads of families, we imagine, can be ignorant of the fact that it may be met with, and its economy leisurely studied in the best regulated establishments. It not only makes food of our garments, but, utterly indifferent to the caprices of fashion, continues to this day to cut out, make up, and wear its own apparel exactly as it has been known to do ever since it received its entomological name. Galleria cereana we have met with in the winged state, but for reasons of our own we have never sought, or even availed ourselves of an opportunity of intruding on the privacy of its larva. It is not often that we have been permitted to approach a well-stocked beehive in summer with impunity, but this dainty fellow actually passes the early stages of his existence among the bees within the hive itself, and there, literally surrounded by the "sweets of life" from his earliest infancy, he helps himself liberally until he has attained his full development. We have seen a portion of honey-comb containing several empty cocoons of this species, and so disfigured by the web spun by its larva, that it had been rendered quite useless to its lawful owners. We have been less scrupulous with the larva of the Turnip diamondbacked Moth (Cerostoma Xylostclla), as will be shown in the following extract from a letter of ours to the late Mr. Curtis, published in the "Journal of the Royal Geographical Society" in I842.

"The little moth which I have sent is one from a host of small green caterpillars, which have been exciting some surprise here this summer. About the beginning of August, I was directed to a field of turnips said to be infested by the 'niggers,' they 
proved, however, to be myriads of tiny larvæ, averaging perhaps half-an-inch in length each, slender, somewhat tapering at both ends, and of a green colour when full fed. They were exceedingly active, and on the slightest touch would wriggle themselves off from the leaf on which they were feeding, let themselves down by a silken thread, and remain suspended till the cause of alarm had subsided, when they would regain their former position. So incredible were their numbers, that on a single plant of moderate size and taken at random, I counted upwards of two hundred and forty! -and before the end of the first week in August, every leaf, for the space of more than an acre, was completely reduced to a parched-up skeleton: not a turnip escaped them, and by the middle of the month you might have looked in vain for the smallest vestige of a green leaf on the field of their depredations; and to this day (Oct. 29th, 1837) it is as bare as if nothing had been sown there. Similar patches from a like cause may be seen in two or three other fields in this neighbourhood, where a most excellent crop is yielded in every other part. On the 9 th they began spinning their cocoons, which are of the most beautiful net-like texture, some on the dried fibres of the turnip leaves and others upon the ground. The perfect insects emerged about the 2oth; but out of seventeen cocoons five moths only were hatched, while the remaining twelve produced the accompanying parasite."* The destructive powers of this moth will perhaps be fully appreciated, if we add that it does not exceed two lines and a half in length!

The last three species of this group differ from all our other moths, in the fact that their wings are so deeply divided between the nervures, that they present the appearance of several separate feathers or fringed rays standing out laterally on each side the body. They are known to entomologists as Plume Moths,

- This was Campoplex paniscus, an Ichneumon. 
and we have taken the three species here frequently: the White Plume (Pterophorus pentadactylus; the Stone Plume (Pterophorus lithodactylus); and the Twenty Plume (Alucita polydactyla). The Stone Plume, which by a casual observer might be taken for any other winged insect than a moth, is plentiful in its season among the herbage in the park and on the downs, and when disturbed flits away a very short distance to settle again immediately. The pretty little fan-shaped Twenty Plume, being of a darker colour than either of its congeners, is occasionally conspicuous on the white-washed walls in the stables and other outbuildings at Uppark.

In bringing this cursory review of our butterflies and moths to a conclusion, we scarcely need repeat that our list is very imperfect, we have purposely passed over many "Carpets," disregarded many "Wainscots," avoided many "Rustics," "Pugs" and "Thorns," and shewn indifference to the attractions of many "Beauties," had we allotted a few lines to each of the claimants of our notice under these several heads, we should in all probability have trebled the length of this paper, and "bestowed" a corresponding amount of tediousness on the courteous reader, "a consummation (not) devoutly to be wished." 


\section{CHAPTER X.}

\section{InseCtS.-Frog-hoppers, Plant Lice, Scale}

Insects, Bugs and Fleas.

THE next order* is composed of a few families of suctorial insects, the musical Cicada, the Lantern flies, the Cuckoo-spit insects, the Plant-lice and the Scale insects. In all these the different parts of the mouth are so modified in form, that they can only be recognized as the representatives of true mandibles and maxillæ, they assume the shape and functions of fine lancets working freely in a fleshy canal formed by the lower lip, and the palpi are obsolete. These insects live on vegetable juices, and it is needless to say that they are so injurious to the plants they attack, that the popular and comprehensive term "blight" is always associated with their presence. With the living individuals of the first two families we are not familiar, the greater number of them being exotic, but every one has seen the little saliva-like mass so common on almost every plant in the garden, and generally known at Harting as the Cuckoo-spit, in France it is called, with equal propriety, the Frog-spit. This is simply the secretion of the larva of Aphrophora spumaria or Frog-hopper, the object of which is no doubt to protect, the soft-bodied insect from the scorching rays of the summer sun. In the perfect fly, which is more remarkable for its leaping power (in which alone it resembles the frog) than for its beauty, the wings when at rest are deflexed, so as to form two sloping sides meeting in a ridge along the back like

- Order Homoptera.-From the Greek homos, alike, and pteron, a wing. Wings four, all entirely membranous. 
the roof of a building, indeed this is the character of nearly all the winged specimens of the order. Another species, the Scarlet-hopper (Cercopis sanguinolenta, now altered to vulnevata) is, on the contrary, a very pretty insect, upper wings bright red with transverse black bands, and it is not at all uncommon in the Park. In Padswood Copse we have more than once shaken from the branches of the underwood the curiously-formed Centrotus cormutus and Ledra aurita.

The well-known family of Plant-lice (Aphida) is a very numerous one, and the insects composing it may be found on almost every species of plant in the parish. Their office is to assist in checking the redundancy of vegetation, and their wonderful powers of reproduction enable them to do this effectually; indeed, if it were not for the Lady-birds, the Aphis-lions, and numerous parasites, to the attacks of which the aphides are subject, these would become terribly destructive. Some species have the faculty of secreting a sweet fluid of which the ants are fond, and the latter may frequently be seen associating with them for the purpose of gratifying this partiality, the same secretion may also be seen in little irregular shining patches on the leaves of the plants they infest, and in this form it is know as honey-dew. Curious that the saccharine product of plants, which is the favourite food of innumerable insects, should be sought for and collected by one tribe of social insects as an animal secretion, while all the others resort direct to the flowers themselves for it! The most astonishing fact, however, in the history of the aphides, is their anomalous mode of reproduction. A single impregnation of each female in the autumn, is sufficient for the fecundation of nine or ten consecutive generations of other females, and it is not till the latter end of the following summer that other males are produced and another union of the sexes is possible.

The Scale Insects are the next to be noticed, and 
where they are numerous they are as destructive as the plant-lice, but this in our latitude, is chiefly in the vinery, the stove and the greenhouse. The two sexes in the perfect state are strikingly dissimilar, the male possessing an elongate body with a pair of large upper wings, and two minute appendages representing the lower wings, but it is not provided with any suctorial apparatus whatever, so that, like many other perfect insects, it is incapable of taking food, while the female is always wingless and armed with a sharp rostrum. With this apparatus it pierces the stems and leaves of the plants on the sap of which it subsists; in its earliest stage it also resembles the other sex, but is eventually developed into an ovate tortoise-like form, without a trace of articulations, or the slightest evidence of vitality. It becomes, in fact, simply a scale distended with eggs, and firmly adhering, like a sucker, to the surface on which it is found. The deposition and hatching of the eggs take place underneath this shieldlike body, but the young do not emerge till after the death of the parent.

As it has fallen to our lot to meet with a few specimens of the true Cochineal insect on a species of Cactus formerly cultivated in the stove at Uppark, we feel justified in making a passing allusion to this most important member of the family of scale insects. It is extensively cultivated on the Opuntia Coccifera in the West Indies and Mexico, and is largely exported for dyeing purposes. Other species have long been celebrated for the scarlet dye they yield, for instance, the Coccus Ilicis, known to the Greeks, the Romans, the Arabs and the Persians, and the Coccus Polonicus, or Scarlet grain of Poland; but these have now given place to the more valuable Coceus Cacti (Psendococcus of Westwood) or Cochineal. insect, of which we are told that 150,000 pounds weight, representing a money value of $£ 370,000$, are annually consumed in England alone. Another species, the East Indian Coccus lacca, 
supplies us with the well-known stick-lac (from which a blood-red colouring matter is extracted), seed-lac, lump-lac and shell-lac, all different forms of the same secretion, and so useful in the manufacture of varnishes, cements and sealing-wax.

In the next order* we meet with the Water Boatman, the Water Scorpion, the tribe of Field Bugs, and, last though not least, the eminently unsavoury Bed Bug. The structure of the different parts of the mouth in all these insects is similar to that of the members of the preceding order, but many of them are predacious, and are capable of causing considerable irritation by the wounds they inflict. The Notonecta glauca is very common in our ponds and stagnant waters, and is remarkable, as its generic name imports, for the position it assumes in the water. It may frequently be found stationary near the surface, and if it be cautiously examined at these times, it will be seen to be resting on its back, with its two long fringed legs extended on each side at right angles with the body. These are the oars of the water boatman, and, on being disturbed, it uses them so effectually that it quickly disappears in the water. We have more than once caught a specimen on the wing, and on one occasion, after having captured one and removed it from the net, we were not a little astonished at receiving from it a very painful puncture in the finger, the effect of which was exactly as if a drop of scalding water had fallen on the skin; with this incident imprinted on our memory, we are not surprised to learn that the Notonecta will not only attack gold fish in an aquarium, but actually cause their death. In the same localities as the last we find the Water Scorpion (Nepa cinerea), a broad flat-bodied predacious insect, with two long

- Order Heteroptera.-From the Greek, heteros, unlike, and pteron, a wing. Wings four, the upper ones (Hemelytra) coriaceous at the base and membranous at the tip. 
filaments proceeding from the extremity of the abdomen, and the fore-legs adapted for seizing its prey. It is a darker coloured insect than the Notonecta, and less active in its movements through the water, a natural consequence of the different structure of its legs, which are not formed for swimming. Two other insects of the same family and of similar habits are also found here, the Naucoris Cimicoides and the Ranatra linearis, the latter, as may be inferred from its specific name, having a comparatively long and narrow body.

In our progress from the aquatic division of the insects of this order to that of the terrestrial bugs, we notice a very remarkable family of few species, belonging, curiously enough, to neither. It may be truly said of them, that, like the nondescript of the travelling menagerie, "they can't live in the water, and they die out of it." Many of these singular insects may be seen in calm weather on the surface of any stagnant pool in the parish, indeed they are such conspicuous objects, that they are widely and popularly known as Water Spiders, although the true Water Spider (Argyronetra aquatica) is a totally different creature both in its form and its economy. The species alluded to is the Gerris Paludum, the body of which is long and narrow, and so effectually defended underneath from the action of the water by a coating of fine silky pile, that even if the insect be purposely immersed when captured, it will be found, on examination, to be perfectly dry. Its forelegs are comparatively short, and although they are not raptorial, like those of the Water Scorpion, the Gerris may probably find them useful in seizing and retaining the insects on which it preys, the middle and posterior legs are very long, and it is by means of these that it is enabled to dart along the surface with such astonishing rapidity, the middle pair acting as the principal organs of locomotion. To a casual 
observer it would appear to be running on the water with as much ease and certainty as if it were on a solid surface, but on close inspection it will be found that the underside of the body is in actual contact with the water, and that in fact it is propelled along the surface like a boat. Another of our water bugs, nearly allied to Gerris, but much less active (Hydrometra Stagnorum), really does walk on the water. It is a much smaller insect than Gerris, with a body almost as slender as its legs, and may often be seen creeping among the plants growing at the edge of stagnant pools.

Among the Field bugs which we have occasionally swept off the herbage, the flowers of wild plants, and the foliage in hedgerows and copses, we may notice Reduvius personatus, a very predacious black fly, which in its perfect state is very fleet footed. During its earlier stages it is always found under a voluntarily assumed disguise of a very strange character, its body and limbs being completely covered with a thick coating of loose particles of dust. Under this mask, which it carefully renews after each successive moult, its movements are very slow and awkward, and, according to French entomologists, it is not too fastidious to feast on the Bed bug in preference to other insects of a less exceptional flavour. From this we may infer that the Cimex lectularius may certainly be found at Harting, but strange to say, we cannot from personal observation assert that it is so, we have never met with this entomological celebrity within fifty miles of the apartment in which we are penning this sentence. Notwithstanding this, we feel that it would be no very extravagant flight of imagination to assume that the experience of others in connection with the bed bug has been of a less negative character in the parish, and that where the masked bug is found, there also will its special prey be met with. The bed bug then we think may be 
safely included in our list of acquisitions, either as an occasional visitant or a permanent resident, but we can speak more explicitly of the Ploiaria, a species of which we have netted, as well as Lyganis apterus (Fab.), Coreus marginatus, Neiedes tipularius, and several species of the minute genus Tingis.

The last great family of this order includes a group of insects irreverently called "Bishops," by many of those who are unacquainted with their generic and specific names. The mitre-shaped outline of their bodies, as seen from above, is no doubt the only character that can have suggested this misnomer. Some of the species are of moderate size and prettily coloured, but many of them have the faculty of emitting a most offensive odour, to which no verbal description of ours could do justice, but which may be appreciated by any one who is familiar with the bed bug. They might with some show of justification occasionally offend us in this way, when they are under the influence of alarm or irritation, but they frequently do so without any apparent provocation, as many persons have no doubt experienced when they have been tempted to pluck and taste a raspberry, or other small garden fruit, recently flavoured by simple contact with the body of one or other of the species. From the structure of their oral apparatus, they, like all the other members of the order, are necessarily restricted to food in a fluid state, but although they subsist chiefly on the juices of plants, they are not strict vegetarians. We have captured Eurydema oleracea, Pentatoma rufipes, Pentatoma grisea, Pentatoma prasina, and many others of the family. The egg of a species of Pentatoma is described and figured in Kirby and Spence, we once discovered a patch of such eggs in the garden, and brought them home with the leaf to which they were attached side by side in close contact with each other. Curiously enough, while examining them under a lens, with a speck of sunlight thrown on 
them, we actually saw the lids of several of them fly open, and the young bugs make their way out. The group of beautifully glossy white empty shells, with their lids and spring hinges still adhering to them, we kept many years as a very interesting object for the microscope, but to our great regret we have long since lost sight of them.

It has been well said by an eminent writer on Entomology," that "nothing in nature that possesses or has possessed animal or vegetable life, is safe from the attacks of insects," the swiftest animals known to man cannot run or fly away from them, the most ferocious beast on the face of the earth cannot frighten them, and man himself, under certain not very rare conditions, finds his patience and endurance severely taxed by them. To say that the Flea is one of his special tormentors would be superfluous, but as the whole of the next order $\uparrow$ is monopolized by this wellknown insect, and as some account of its economy, apart from its phlebotomizing practices, might be new, if not interesting, to those who have never been on social terms with the family, we cannot wholly ignore its claims to our notice.

We learn then from Westwood and others, that the common bed flea lays ten or twelve roundish white eggs in the cracks in the floor, or amongst the hairs of rugs and carpets, particularly those on which dogs are accustomed to lie, or indeed in any dry corner in a dwelling where mops and brooms are unknown, not improbably even among the soiled "confidential garments" in households composed of individuals that are habitually indifferent to the virtue of personal

\section{* In Kirby and Spence.}

+ Order Aphaniptera.-From the Greek aphanes, inconspicuous and pteron, a wing. Wings four, represented by minute scaly plates. 
cleanliness. From these eggs are hatched, long, worm-like, very active, though footless grubs, the food of which does not appear to have yet been satisfactorily ascertained. Those which are hatched early in the season are full-fed in about twelve days, they then spin themselves up in small cocoons of silk and become pupæ, in this stage they remain about a fortnight longer, when they emierge in the perfect state. The later bred larvæ do not undergo their transformations till the following spring, but in either case the fully-developed flea is a marvel of muscular strength and activity. Many proofs of this are on record, and, to say nothing of the astonishing feats of flees broken to harness, or trained to military exercises and other public performances requiring enormous muscular power, it has been ascertained by Entomologists, that the common bed flea can clear a distance two hundred times the length of its own body at a bound.

More than twenty distinct species of flea have been discovered and described, the Dog flea (Pulex Canis) is specifically different from the Bed flea (Pulex irritans); Ceratopsyllus Talpe, the largest of the family, may be found on the Mole; Pulex Felis on the cat; Pulex Sciorurum on the squirrel; Pulex Erinacei on the hedgehog; and Pulex Vespertilionis is appropriated to the bat. For specimens of all these species, therefore, no distinct locality need be explored by any of our Harting readers, who might feel disposed to add to their intellectual recreations the practical study of this order of insects. 


\section{CHAPTER XI.}

\section{INSECTS-TWO-WINGED FLIES.}

THE last Order* of winged insects to which we shall devote a few lines is that in which we find the gnat, the crane fly, the house fly, and their allies. The oral organs in these are of the analogically representative character, of which we have seen so many examples in other orders, and they are more or less developed in the different genera according to the functions they are required to perform. A fleshy tubular suctorial apparatus, adapted to the passage of fluid food, is the common feature of the two-winged flies, but the gnats and Breese flies possess an additional set of fine sharp instruments, specially fitted for puncturing the skin of the animals on which they prey. This typical organization gradually becomes less and less perfect in other groups until in those individuals that take little or no food in the perfect state, both lancets and proboscis totally disappear. The two wings, in many species, are expanded at the base behind into small membranous processes called Alula, or winglets, and in the majority of them two tiny bulbs on slender footstalks, called Halteres or poisers, project horizontally from the thorax, one on each side close behind the wings-they are even present in those species that are wingless, and are therefore regarded as very important organs in the economy of these insects, but entomologists are not agreed as to their uses. Some are of opinion that they are simply the representatives of a second pair of wings, while others infer that they are subservient to the function of respiration, more particularly as a

- Order DipTera-from the Greek dis, twice, and pteron, a wing. Wings two, with winglets at the base. 
spiracle is situated at the base of each, and the poisers are often in rapid vibration even when the wings are at rest. The insects of this order are so numerous, both in species and individuals, and many of them are so persistently obtrusive in their habits that they are universally known, any attempt, therefore, to describe their nore obvious characters would, we imagine, be superfluous, even to those whose entomological experiences are limited to retaliatory measures on the insects that annoy them.

The family of Gnats is the first to come under our notice, and Culex pipiens, the typical form, is distinguished by a slender rostrum nearly half as long as the entire body of the insect, and enclosing no less than six fine lancets, barbed at their free extremities. When these are brought into use, an operation that is very insidiously performed, an irritating fluid is introduced into the wound they make, the unpleasant consequences of which are felt long after the insect has made its sanguinary attack. In their preparatory stages gnats are aquatic, the larvæ suspending themselves in their intervals of inactivity head downwards in the water, and carrying on their respiratory functions by means of a long tube projecting laterally from one of their terminal segments, and furnished at its tip with a star-like fringe radiating from a central spiracle. As often as a fresh supply of air is required this fringe is expanded on the surface of the water, and the breathing pore is thus brought into direct communication with the atmosphere. In the next stage there are two respiratory tubes, but as they are situated on the anterior part of the body, the position of the pupa in the water when at rest is exactly the reverse of that of the larva in the same condition. In about a month after the deposition of the eggs the perfect insect appears, with a further modification of its respiratory system, and, taking its stand on the skin it has just quitted, it securely floats on the suface 
until its wings are fully expanded and fitted for flight. There are few individuals who have not, when wooing " tired nature's soft restorer," been startled into wakefulness in the silence of night by the piping of the bloodthirsty gnat ; there are fewer still, probably, who could believe in the possibility of even approximately estimating the number of vibrations of its wings in a given time, while it is sounding this note of alarm, yet the solution of this problem has been attempted by natural philosophers. In elementary works on Acoustics we learn that the gravest note audible is produced by about thirty-two, and the sharpest by about fifteen hundred, vibrations in a second. As the piping of the gnat, when compared with the latter, is found to be in unison with it, it follows that this tiny trumpeter vibrates its wings no less than ninety thousand times in a minute, a velocity one would suppose sufficient to throw off the delicate scales with which the wings are fringed.

The family of Crane-flies is a very extensive one, and contains many genera as well known as the Gnats, to which indeed some of the smaller species bear so strong a resemblance, that they are often mistaken for them, but the structure of the mouth in the majority of them is less perfect than that of Culex. Chironomus plumosus, remarkable for the feathery character of its antennæ, is common enough here, and is gnat-like, both in its form and its economy. Its larvæ are those very active blood-red worms so often seen in stagnant water in pools, in uncovered cisterns and water-butts.

The economy of the Gall-gnats is similar to that of the Gall-flies among the Hymenoptera, the deposition of their eggs within the substance of different species of plants is followed by excrescences, irregular growths, and distortions of the parts attacked, and in these the larvæ feed and undergo their transformations. One of the members of this division, Cecidomyia Tritici, is 
often very injurious to the wheat crops, when the plant is in bloom it oviposits in the flower itself, and its larvæ are supposed to render the plants sterile by devouring the pollen. Another Gall-gnat deposits its eggs in the extremities of the young twigs of a species of willow, and very curious dense tufts of abnormal leaves subsequently spring out round the puncture made by the insect, these masses bear such a striking superficial resemblance to compound flowers, that botanists of bye-gone days actually named the plant on which they were found the "Rose willow." After the periodical cutting of the copse-wood in the covers, we often see among the early shoots of ash a curiously deformed specimen which we strongly suspect is due to a similar agency. One example in our possession is spread out into a wide spatulate, concavo-convex form, closely ribbed on both sides, the ribs terminating in buds, and the whole surmounted by a tuft of similarly flattened contorted shoots, standing out unsymmetrically in all directions. Psychoda Phalcenoides, a minute midge, by which designation it is popularly known, is often seen on our window panes, and when examined under a lens is a very pretty object. Its wings are so thickly coated along their numerous nervures, and so densely fringed with fine hairs, that to the unassisted eye it very much resembles a tiny moth with symmetrical dark bands and other markings on its upper surface, its larva is found in dung. We have also met with several other species of the genus less conspicuously ornamented than Phalanoides. Other members of this family are Rhyphus fenestralis, the larva of which revels in cow dung, and the true Crane-flies or Daddy Long legs, of which Tipula oleracea and Tipula crocata are typical forms. The apparent indifference with which one of the latter will sometimes part with two or three of his unwieldly limbs, leaving them between the finger and thumb of his captor, and flying away as if unconscious 
of his loss, must have been noticed by every one. In the perfect state they are incapable of resenting the liberties taken with them, as they are unprovided with any defensive organs, but as larvæ they are among the most destructive insects, often committing great havoc underground among the plants in gardens and the grasses in pastures. It is needless to say that they are not very showy insects, but the Pectinated Crane-fly (Ctenophora atrata), an allied species, is gaily ornamented with black and bright yellow, its larvæ reside in decaying wood.

Stratiomys Chameleon, a prettily coloured fly, is often found on our flowers, attracted by their nectar or basking in the sunshine on the leaves of plants in damp localities. Its larva is aquatic, breathing by means of an apparatus similar to that of Culex, but it has the additional faculty, when it is disposed to leave the surface, of curving inwards the numerous rays of its caudal fringe, till their points meet in the centre, and enclosing within the cavity thus formed a bubble of air with which it descends. When this is no longer required for respiratory purposes, its buoyancy enables the insect to float passively upwards again for a fresh supply.

Among the Gad-flies we meet with some of the most sanguinary of our insect tormentors, as they spare neither man nor beast. Tabanus Bovinus, also called the Breese fly, from the buzzing noise of its wings, the usual prelude to its dreaded onslaught on both horses and cattle, is a large fly nearly an inch in length, and as the parts of its mouth are equal in number to those of the gnat, and very much more powerful, the wounds it inflicts are very severe, we have learnt from personal experience that when it is disposed to test the temper of its-lancets on the human hand, it is capable of piercing an ordinary kid glove with ease and despatch. We have also often seen horses in that part of the park known as the 
"Forest," where the gad-flies and clegs abound, with the blood streaming down their sides in consequence of the attacks of one or more species of these formidable insects, and as each puncture is immediately followed by a hard irritating swelling, which does not subside for several days, the torture endured by the poor animals must be considerable. The only redeeming feature in the perfect Tabanus is the beauty of its compound eyes, which are conspicuously banded with golden-green and purple. Chrysops cacutiens, another member of this sanguinary family, is also remarkable for the dazzling beauty of its eyes, which resemble brilliant hemispheres of burnished gold, a character which is expressed in its generic name.

Bombylius major is closely allied to the gad-flies, but in its personal appearance and economy in the perfect state, there is little to indicate to an unexperienced observer any close affinity between them. In a state of repose it might easily be mistaken for a small humble bee, with an unusually long, exposed proboscis, but when it is on the wing its flight is much more rapid than that of the latter, and of a different character. Like the Hawk moths, it whisks from flower to flower, and sips their nectar to the humming music of its own wings without settling. We have met with many individuals of this species, and of Bombylius medius, while thus engaged among the wild spring flowers.

A group of very predacious flies follows the harmless Bombylius, including, among many others, Empis pennipes, Empis borealis, Empis tessellata and Asilus Crabroniformis, or the Hornet Fly. In these the body is long, the abdomen gradually tapering to a point, and the proboscis, with only four internal puncturing instruments, short but very powerful. We have more than once been deceived by the singular appearance of some of these insects on the wing, and have occasionally netted one under the impression that we had 
met with an entomological rarity, but, to our disappointment, we had simply captured an Empis or an Asilus with another insect nearly or quite as large as itself in its grasp-a beetle, a moth, or a fly-on which it was making its repast. It is recorded, on high authority, that Asilus Crabroniformis, which is a very conspicuous fly and one of the largest of the order, has been seen to pounce upon and carry off a hive bee, but whether a stingless drone or a neuter "deponent saith not."

Bee flies and Drone flies are very interesting in all their stages, the perfect insects are generally brilliantly coloured, wonderfully active on the wing, and they may often be seen in the bright sunshine stationary in mid air as if suspended by an invisible thread, their wings vibrating at the same time so rapidly that they are imperceptible. From this circumstance they are popularly known as "Hoverer flies," and if they are disturbed in their diversions, they vanish into space in a twinkling, to return again and again to the same spot. Sometimes they "hover" in this way above the flowers on the nectar of which they subsist, and they alight so gently and gradually, that the only indication of their coming into actual contact with the flower of their choice, is the sudden starting into sight of their wings when they have ceased to vibrate.

Syrphus Pyrastri, one of the family, is the parent of those curious larva so commonly seen on the leaves of plants that are infested with the Aphis. Strange to say these larva are totally destitute of both feet and eyes, yet they are carnivorous in their habits during the whole period of their growth, and capture their living prey without difficulty. To ensure this result the Syrphus deposits her eggs singly in the midst of the Aphides where they are most numerous, and the young grubs, when hatched, need only elongate their bodies from their point of attachment, to explore the space around them in every direction and 
thus seize their unresisting victims. When full fed each larva fixes itself, by means of a glutinous secretion, to the leaf on which, in less than a fortnight, it has completed its useful task, its body then contracts into a pyriform mass, and the usual transformations take place within its hardened skin, which thus serves as an ordinary cocoon.

The larva of the Drone fly is that curious creature well known as the rat-tailed grub, swarming in shallow stagnant water, turbid with fecal matter and other impurities. The constant position of this grub in the fluid it inhabits, is, like that of the larvæ of Culex and Stratiomys, with its head downwards, but as it differs from the latter in the sluggishness of its habits, its respiratory apparatus is modified to suit this condition. The external portion of this apparatus consists of two tubes, one sliding within the other like the joints of a telescopic tube, and capable of being lengthened out or shortened at the will of the animal, to suit the varying depth of the fluid from which it derives its sustenance. The spiracle at the extremity of the inner tube, which projects beyond the other, is always in contact with the air at the surface, and it has been ascertained by experiment that these tubes can be drawn out to twelve times the entire length of the body of the grub. When it has attained its full development as a larva, it leaves the water and passes its next stage in the earth, from which, in due time, it makes its appearance in the perfect state. Eristalis tenax, a living specimen of which is now on the table before us, presenting a sad contrast to its former self when revelling in the sunshine, Eristalis intricarius, Eristalis florens, all very much resembling the male of the hive bee, and many other species of the genus, are very common here.

Volucella pelluceris, a handsome insect with clouded wings and a transparent patch on the upper surface of its abdomen, is an example of the Bee fly. Its larvæ 
are found in the nests of humble bees, on the grubs of which they prey, and it is assumed that the striking resemblance of the perfect fly in shape and colour to the species of Bombus on which it is parasitic, enables it to enter the nest of the latter, deposit its eggs, and escape unnoticed and unmolested.

First among the true flies, as they are termed, a group composed of innumerable species, one of which is the common House fly, we meet with Conops flavipes, a long-bodied gaily-coloured slender fly, with the extremity of the abdomen curved downwards. This, and a few other species of the same genus, we have seen innocently feeding on the nectar of flowers, but in their larval stage they have parasitic relations with bees, wasps and humble bees.

We have all had so many opportunities of studying the habits of the common House fly, the uninvited sharer of our meals, where, in spite of frequent repulses, it unscrupulously helps itself to the gravy on our plate, takes the first sip from our glass and feasts on the syrup of our tarts before we can help ourselves, that little more need be said of this troublesome intruder than that it is the Musca domestica, and that its larva, less dainty than the perfect insect, is found in dung. It may not perhaps be generally known, however, that the term House fly, as popularly understood, includes several distinct species so much alike in shape, colour and other particulars, that it is very difficult to distinguish the one from the other. Anthomyia canicularis, Anthomyia pluvialis and Stomoxys calcibrans are the frequent companions of Musca domestica in our apartments, and the last named insect is the greatest plague of all, inflicting very sharp wounds upon us in showery weather, particularly towards the close of summer, a provocation that has led many a sufferer from its attacks to devote the whole tribe of harmless house flies indiscriminately to destruction. Another species, Anthomyia metcorica, is 
that troublesome fly that in sunny weather is perpetually swarming round the heads of horses and cattle. Every one who has taken a ride or a drive in summer must have noticed this phenomenon, and been struck with astonishment at the wonderful strength of wing and endurance which enable these insects to keep pace in this way with a trotting horse.

The well known scavengers, Sarcophaga carnaria, the Flesh fly, Musca Casar, the Bluebottle fly, and Musca vomitoria, the Meat fly, belong to this division. The first of these performs its task with such amazing expedition that three of them, according to Linnæus, would devour the carcase of a dead horse as quickly as would a lion. Taken in its obviously proper sense, as referring to the larvæ of the flies, this statement, which has been a thousand times quoted in entomological works, is probably no very great exaggeration, and it is quite certain that the work performed by them, under favourable conditions, would astonish any one who, for the first time, made himself acquainted with their proceedings by personal observation. In the first place, the delay involved in the laying and hatching of eggs would be avoided, and sixty thousand living and unmistakably voracious "maggots" would in a very short time be placed in a position to do justice to their fare. These would devour so much, and grow so quickly, that in the short space of twentyfour hours they would be two hundred times heavier than they were at their birth, and, assuming that this rate of rapid development continued four days longer, by which time they would be full grown, they would have increased in bulk a thousand-fold before they had ceased feeding. We once witnessed, in a not very distant private collection of Exotics, the result of what to us appeared a curious error of instinct in one of these flies, deceived by the carrion-scented blossoms of a species of Stapelia, which was there growing luxuriantly, it had deposited so many of its larvæ in 
them that every expanded flower was literally swarming with maggots.

Musca Casar and Musca vomitoria, better known as Blow flies, are oviparous, and, "taking time by the forelock," they commit their eggs to the fresh joints in our larder, or the carcases of any recently killed animals they may have access to, and as the larvæ are very soon hatched out, they not unfrequently consume a considerable portion of their provender before it has become offensive.

Scatophaga stercoraria is that common yellowishbrown fly frequenting the deposits of horses and cattle, to which it commits its eggs. The latter are curious oblong bodies furnished at one extremity with two short arms projecting diagonally, one on each side, the object of which is to prevent the eggs sinking too deeply in the soft matter in which they are lodged. There are several species of the genus, and many of them may be seen intent on their prescribed duties in cow yards and pastures from early spring till the approach of winter.

The Cheese-hopper, though literally without a leg to stand on, is capable of taking tremendous leaps, as we all know, and is ranked among the minor delicacies of the table by many who, strangely enough, believe it to be the spontaneous production of the cheese in which it is found, but we willingly confess that to us it is chiefly interesting as an entomological acrobat, whose curious performances are faithfully described by Kirby and Spence. The parent fly, Tyrophaga casei, is a little greenish-black shining insect generally found where the richest cheeses are stored.

The history of the Bot flies, our next family, though not a large one, is not less interesting.or wonderful than that of any other group in the order. These insects in the perfect state are totally destitute of oral organs, the mouth itself in the majority of them being obsolete, but their larvæ are parasitic on many 
of our domestic animals, principally the horse, ox, sheep, and fallow deer, other herbivorous quadrupeds are also subject to their attacks, and several instances are even recorded of their presence within the human body. Each species of fly is not only appropriated to one particular species of quadruped, but confines its attacks to special parts of the animal on which it is parasitic. For instance, CEstrus Bovis oviposits on the backs of cattle, and every egg so deposited, whether in the hide, as some assert that it is, or on it, according to others, is followed by a gradually increasing open tumour, in which the larva resides and subsists on the purulent secretion resulting from the constant irritation it occasions until it has attained its full development, it then forces its way out, and allows itself to drop to the ground, into which it burrows for the purpose of undergoing its final transformations. As many as thirty or forty of these tumours, each containing a grub, are sometimes met with in the back of one animal. Estrus Ovis (Cephalemyia Latr.) glues its eggs to the inner margins of the nostrils in sheep, in spite of the frantic attempts of the latter by running away, violently shaking their heads, or burying their noses in the herbage, to escape the infliction. The grubs, when hatched, make their way up the nostrils to the maxillary and frontal sinuses, where they complete their development, and when full grown, like the larvæ of Estrus Bovis, pass through their final changes under ground. It would be interesting to ascertain whether the maggots sometimes found making their exit between the eye-ball and the nasal duct, in the inner angle of the orbit, are the larvæ of this fly.

Another species of Estrus which we have not identified, although we have every season good presumptive evidence of its presence in the park, is a source of constant annoyance to the Fallow deer, causing them to snort incessantly in the day time. The larvæ of this fly have sometimes been found in 
considerable numbers in two large cysts situated in the pharynx of the deer. Those of another species of this family, the true Bot fly (Gasterophilus Equi), actually pass their growing stage in the stomach of the horse, and the establishment of its family by the parent fly in a locality so difficult of approach, is one of the wonders of insect economy. The eggs are deposited on the coat of the horse, not at random, as at first sight might be supposed by any one casually witnessing the act of oviposition, but on the anterior part only of the body of the animal, were it otherwise, hundreds of the young grubs, failing to reach their proper nidus, would infallibly perish in a few hours without taking food. The manner in which the eggs are deposited by the fly is thus described by Mr. Bracey Clark, in "An essay on the bots of horses and other animals," a standard work on the subject :"Suspending herself before the part where she designs to deposit her egg for a few seconds, she suddenly darts upon it, and leaves the egg adhering to the hair: she hardly appears to settle, but merely touches the hair with the egg held out on the projected abdomen : the egg is made to adhere by means of a glutinous liquor secreted with it. She then leaves the horse at a small distance, and prepares a second egg, and, poising herself before the part, deposits it in the same way. The liquor dries and the egg becomes firmly glued to the hair. This is repeated by various flies, till four or five hundred eggs are sometimes placed on one horse." In a few days the hatching takes place, and the attention of the horse being called to the fact by the titillation resulting from the uneasy movements of the larvæ amongst its hairs, the unsuspicious animal naturally licks the part affected, which, thanks to the wonderful instinct of the parent $\mathrm{fly}$, is never out of reach of the horse's tongue, the larvæ adhere to the latter, and are thus fairly on their way to the stomach. No doubt many 
perish in this dangerous transit, but sometimes as many as a hundred bots succeed in attaching themselves by means of their two anal hook-like processes to the mucous membrane of the stomach, chiefly near the pylorus. Here they remain till they are full grown, and as they are supposed to feed on the chyle, they are probably not productive of much discomfort to the horse or any material derangement of its health. When they are prepared to assume the pupa state, they relax their hold, are carried through the intestinal canal, and discharged with the frces. At this stage a few individuals once fell into our possession, these were placed in a vessel having a piece of net strained over the top, and a few inches of loose mould at the bottom, they soon disappeared in the mould to become pupæ, and before the end of the summer emerged in the perfect state. - In this way we first became acquainted with Gasterophilus Equi, a hairy fly of a dingy yellowish colour with a black patch on the thorax, transverse black bars on the upper surface of the abdomen and symmetrically clouded wings, and we have since then had many opportunities of watching the insect hovering near the horses in the Downpark meadows. Another species of the genus, Gasterophilus hamoroidalis, is also parasitic on the horse, and the latter, though no Entomologist, is quite capable of identifying his tormentor at a glance. It is on his lips that this fly seeks to deposit its eggs, and no sooner does it approach him for this purpose, than he endeavours to drive it away by violently tossing his head up and down, or gallops about to avoid it. Needless to say, that in spite of his resistance, the fly sooner or later accomplishes its object, and the after history of the insect is similar to that of the preceding species.

The members of the last important division in this order, as curious in their outward forms as in their economy, differ from all the other Diptera in their 
singular mode of reproduction. Collectively they are termed Pupipara, from the fact that their young, of which each female produces one only, are hatched and developed within the ovaries of the parent flies, until they become pupæ, in which state, enclosed in their cocoons, they are deposited in the form of comparatively enormous eggs, and from these the perfect insects escape without any further transformation. Hippobosca equina, the well-known Forest fly, is a winged insect having a short flat body, defended by an integument of such leather-like consistency, that any one attempting to crush it would be astonished at the enormous pressure it is capable of resisting. It is parasitic on the horse, and as it is provided with powerful limbs and stout hooked claws, toothed underneath, it has no difficulty in threading its way quickly and securely among the hairs of the coat, it has also the faculty of moving with equal ease and readiness in any direction, backwards, forwards, or sideways, like a crab, a character which we believe is common to all the species of the group. It does not appear that the punctures made in the skin of the horse by Forest flies are very painful, or that they are followed by such unpleasant consequences as those of the Tabani, indeed, many horses appear to suffer no inconvenience at all from them, we have often seen rough-coated ponies that had led a nomadic kind of life on wastes and commons, utterly indifferent to the swarms of these parasites with which they were infested, on the other hand a single specimen of the forest fly on the sensitive flank of a well-groomed hunter, will sometimes cause the latter to kick and plunge dangerously. This, however, is no doubt due to the excessive titillation caused by the firm foothold of the fly as it courses about on the thin coat, and any one who has felt one of these creatures crawling up his arm, and been compelled to throw off his coat in hot haste for the purpose of capturing the assailant, will perhaps appreciate the sensation. 
Craterina Hirundinis, another winged insect, bearing a close family resemblance to Hippobosca, infests the swallow, and we have found both the perfect fly and its egg-cocoon in the nest of this bird. On one occasion we picked up a dead swallow, the body of which was still warm, and while in the act of parting its feathers to ascertain if it had been wounded, we unexpectedly disturbed one of these parasites, in an instant it was on the back of our hand, and the difficulty we experienced in removing it even from the bare skin, left us in no doubt whatever of the fact that it would be absolutely unmanagable among the feathers of a bird.

The term "fly," in its general application to insects materially differing from each other in almost every external character, was no doubt originally intended to refer to those only that possess the faculty of flight. To any one who still understands it in this sense, a fly without wings would appear to be an anomaly, yet such an insect is our next and last example in this order-Melophagus ovinus. This parasite inhabits the woolly covering of the sheep, and it is evident that in such a dense tangle wings, would not only be useless to it, but would actually impede its progress. It is popularly known as the sheep-tick, or sheep louse, but, as we have already said, it is a true fly, though utterly destitute of both wings and poisers, in other particulars it is not unlike Hippobosca and Craterina, and it is so tenacious of life that it has been found alive in a fleece twelve months after the latter had been shorn. 


\section{CHAPTER XII.}

\section{Wingless Insects, Mites, Spiders And}

Cudworms.

ONE of the principal characters of the insects to which the next and last Order* is restricted, is their progressive development from the egg to the perfect state without undergoing any intermediate metamorphoses. Another important distinction is that they never acquire wings, a fact for which all of us, who are not indifferent to the comfort of immunity from the attacks of disgusting parasites, have reason to "rest and be thankful." We have never seen the once notorious Gregarine, we do not know what it is, but the other companion of the unwashed and unkempt is presumably no rarity in the parish, and if it were possessed of the faculty of winging its way from one human head to another, how vastly enlarged would be its sphere of annoyance! There is nothing particularly repulsive in the personal appearance of the "lively flea," but this cannot be said with truth of Pediculus cervicalis, the very name of which, apart from its scientific disguise, is proscribed in polite society. Entomologists, however, as may be anticipated, have not been restrained by any feeling of squeamishness from closely investigating the details of its structure and economy. Leeuwhenhoek indeed, a very celebrated Microscopist, is recorded to have tenderly nursed a pair of lice in a stocking, which he wore night and day for several weeks (examining its contents from time to time, we presume), for the express purpose of qualifying him-

- Order APTERA-from the Greek $a$, priv., and pteron, a wing. Wings none. 
self as their historian. As, however, the result of his experience on this occasion might possibly not be so interesting to the general reader as, we doubt not, it was satisfactory to the great naturalist himself, notwithstanding the personal discomfort involved in his course of study, we need not dwell on his discoveries. It will, perhaps, be sufficient to state that, although three known species, if not four, are parasitical on the human subject, the conditions under which they all flourish on the same individual are probably never met with at Harting, and that the species rescued from obscurity by Leeuwhenhoek is the only one that has ever come under our own observation. We have, however, seen many others of the family, for instance, Trichodectes Equi on the horse, Trichodectes longicornis on the deer, Hamatopinus piliferus on the dog, H. Suis on the hog, and the very remarkable Goniodes falcicornis, formerly known as Ricinus Pavonis, on the peacock.

Rook pie, which in early spring is esteemed by many as "dainty" a dish as the immortal one celebrated in nursery rhyme, is inseparable in our own experience from very unpleasant recollections of an insect nearly allied to the preceding genera, Nirmus argulus, swarms of which infest the rooklings, and instinctively make their way very expeditiously to the heads of those who are so rash as to handle the birds while yet warm. Many persons appear to be indifferent to the annoyance caused by these insects, but we have more than once found them exceedingly restless and troublesome bedfellows, the incessant titillation they occasion in their search for more congenial quarters, effectually " murdering sleep." A similar parasite, Menopon pallidum, is still more abundant among the feathers of our common poultry, and another species, the name of which is unknown to us, although, in byegone days of stubble shooting, it has gratuitously afforded us frequent opportunities of identification, infests the partridge. 
In the next great division of the order we find the Sugar louse (Lepisma saccharina), also called the Window Fish, a flattish very active little insect, tapering gradually from the head to the tail, furnished with three fine caudal hair-like appendages, and wearing a glittering suit of minute silvery scales. It is frequently found in old sugar casks, among damp parchments, disused linen, neglected books, and old papers. "Its immediate allies are the leaping Podure, or springtails, of which we possess several species. One great merit of this genus is that it has suggested to enterprising manufacturers of children's toys the bright idea which is illustrated in leaping frogs and mice. Indeed, the mechanical contrivance by means of which the leaps of these mimic animals are effected, is but a rude copy of the distinguishing character of Podura. This consists of a forked process at the extremity of the abdomen, which in its normal position is bent forwards under the body, but when the insect is disturbed, it suddenly presses the forked and elastic tip of this organ against the surface on which it is standing, and, forcibly unbending it, instantly springs upwards several inches and alights at a considerable distance. A very common species ( $P$. Aquatica), a tiny black speck of insect life, is enabled, with the assistance of this simple apparatus, to leap on the surface of water with as much ease and agility as the other species on more solid surfaces. Like the Lepisma, many of the Podure are clothed with scales, and the latter, mounted separately as test objects for the microscope, are well known to students of Natural History, but a magnified specimen of the insect itself, properly illuminated, is indescribably beautiful, the rich play of colours from its iridescent scales producing a gorgeous effect.

It will perhaps be recollected that the term Insect, as applied to an invertebrated animal with articulated limbs, simply implies one whose body is composed of rings or segments; but the class Insecta, as at present 
constituted, is founded on other characters in addition to these, for example, in true insects the head, thorax and abdomen are distinct, the number of legs is never more than six, the eyes are compound, and the respiratory apparatus consists of tracheæ and spiracles, or breathing pores. These conditions are so far modified in the few remaining subjects which will occupy our attention, that the establishment of other classes for the reception of the latter has been found necessary, and the first to come under our notice is that which is made up of Spiders, Scorpions and Mites.*

In true Spiders the antennæ, which, as we have seen, play such an important part in the economy of insects, are altogether absent, the body is divided into two segments only, the cephalo-thorax consisting of the head and trunk together, undistinguishable from each other and the abdomen, which is destitute of insections. They possess eight legs, two, six or eight simple eyes, and they breathe by means of pulmonary sacs and stigmata. Although it is well known that spiders prey on various insects, either by actively hunting them down, or by entrapping them in nets which they ingeniously hang up for the purpose, much difference of opinion exists among those who have investigated their structure and closely studied their habits, as to the anatomical details, uses and mode of action of the several organs with which they are furnished: Some doubt that spiders are venomous, and others believe that each of the fine threads, of which their webs are composed, is a single homogeneous line, but the preponderance of authority is in favour of the theory that spiders are really capable of injecting a poisonous fluid into the wounds they make, and that their threads are very complex indeed. Their offensive weapons, representing mandibles, are two-jointed organs situated above the mouth and technically called

- Class ARAChnida.-From the Greek, arachne, a spider, 
falces. Each falx consists of a perforated fang, articulated to a basal joint, which is itself articulated to the front part of the cephalo-thorax. Each joint has an independent motion of its own, and on the under surface of the basal one there is a longitudinal groove for the reception of the fang, which, when at rest, is bent back into its support, as the blade of an ordinary clasp-knife into its handle. Within each fang is attached, near the aperture at its extremity, a very fine thread or duct, which may be traced by careful dissection through the basal joint into the cephalo-thorax, where it terminates in a poison-bag and gland. There is, therefore, no internal passage between the falces and œesophagus or the stomach, through which any portion of food could be conveyed to the latter, so that, contrary to popular belief, the falces are certainly not instruments of suction. It would appear that their office is to seize and disable the prey, which they subsequently retain in their fatal grasp until the maxillæ, which are within the mouth, have acted upon it to the owner's satisfaction.

The eyes of spiders are situated on the upper surface of the cephalo-thorax, just behind the falces, and their positions, relatively to each other, are so uniform in closely allied species, that their mode of arrangement is an important generic character in the system of a well-known arachnologist.

The external spinning apparatus is at the extremity of the abdomen on the underside, and consists of four or six nipple-like processes or spinners, each of which is furnished with numerous minute tubes or spinnerets, very thickly distributed over the whole of its exterior surface, and a central aperture at the apex. From these spinners and spinnerets issues, at the will of the animal, a viscid secretion, which at first adheres to any surface against which it may be pressed, and subsequently dries up in the form of a thread, almost as rapidly as it is drawn out. As many as a thousand 
spinnerets have been counted on each of the nipples of one species, so that assuming them to be all in action at the same time, which, however, may not improbably be an exceptional condition, the thread of this particular species must be composed of no less than four thousand finer lines. It is certain that the common Diadem Spider has the faculty of emitting from its spinnerets a broad ribbon of web secretion, which may be distinctly seen by the unassisted eye, to consist of innumerable parallel lines, individually much finer than the ordinary threads of which its geometric web is formed. It is not unreasonable, therefore, to assume that these ordinary threads consist of finer lines that have coalesced immediately after issuing from the spinnerets, although it must be admitted that the most skilful and delicate manipulation has never hitherto surmounted the difficulty of separating the filaments from each other. We have more than once seen the diadem spider seize a large fly, whose frantic struggles were endangering the symmetry of its web, and, holding it between its fore legs, rapidly turn it round and round in contact.with its band of threads, and thus, in a few seconds, swathe it in a dense shroud of web, that effectually deprived it of all power of motion.

Spiders undergo no metamorphosis, but their changes of skin are frequent, they also possess the remakable faculty, in common with the crustacea, of casting off an injured limb or two and reproducing them at the next ensuing moult, a provision of inestimable value to a fierce animal, that when fairly dependent on its own resources, seldom meets one of its own kind without a desperate battle, often fatal to one or other of the combatants.

With the exception of our common House Spider (Tegenaria domestica), probably the Diadem, or Garden Spider (Epeira Diadema) is the most widely known. Its beautifully symmetrical, vertical net, consisting of 
straight lines radiating from a central point, and crossed at regular intervals by other lines concentrically arranged, is so often seen stretched between parallel bars of fences, or the branches of trees, with the spider in the centre in an inverted position, that it cannot have escaped the notice of the most indifferent observer. But something more than a casual glance at this beautiful structure, reveals the curious fact, that the radiating lines are perfectly dry and comparatively rigid, while the concentric lines, or cross bars, are very elastic and thickly studded with minute globules of viscid matter, which retains its fluid and adhesive property, for any length of time, in the driest atmosphere and the hottest sunshine. This secretion is sufficiently tenacious to effectually arrest and entangle any moderately sized insect on the wing, that may incautiously come in contact with it, so that the analogous process of liming twigs for the capture of birds, may possibly have been suggested by the daily practice of this spider.

"For thus to man the voice of nature spake :

Go, from the creatures thy instruction take."

We meet with two other species of Epeira, Epeira quadrata and Epeira scalaris, both very prettily marked. The first is a larger spider than the diadem, and makes its home in the furze bushes on East Harting Down. It may be known by its beautiful delicate-green abdomen, symmetrically ornamented on the upper surface with white spots, four of which are more conspicuous than the others.

Among our other weaving spiders with which we are acquainted, the Water Spider (Argyronetra aquatica) is the most interesting. Our first specimen we well recollect having found in early spring beneath an empty valve of Anodon, in a watercourse communicating with the Great Pond, and since then we have fished out others in the same locality, in the South Garden Ponds, in the Hurst Mill Pond and elsewhere, 
and kept them some time in glass jars partially filled with water. Under these circumstances, we had excellent opportunities of watching their proceedings in the manufacture of their wonderful mid-water diving bells, their mode of supplying them with air, their activity in pouncing upon flies thrown on the surface, and their beautiful appearance as they progressed through the water, each in a brilliant silvery envelope of air. Here, too; when they were in the act of glueing their lines to the inner surface of the glass, we could with the greatest ease examine through a lens the curious and complex action of their spinners, each of the latter working independently of the others, and each producing a distinct thread, which remained permanently separate from the main line when finished, a short but appreciable distance from the glass. As, however, these and other details of the economy of Argyronetra, if not widely known, are within easy observation of any one possessing an aquarium, we need not dwell on the subject.

Every one is familiar with the white flocculent masses of gossamer that on a fine dry day in autumn may be seen in greater or less abundance gently floating in the atmosphere, these are the first balloons of which there is any record, and, simple as they are, they are admirably adapted for facilitating the dispersion, or partial migration of spiders. Some naturalists believe that there is a distinct species of so called Gossamer spider, but many others assert that several species of different genera are engaged in the manufacture of this substance, which consists primarily of a viscid fluid expelled by them in such a position that, according to Mr. Blackwall, the eminent Arachnologist, it is "drawn out into fine lines by the ascending current occasioned by the rarefaction of the air contiguous to the heated ground. Against these lines the current of air impinges till the animals, feeling themselves acted upon with sufficient force, quit their hold of the object on 
which they stand, and mount aloft." Another theory on this subject is enunciated by a contributor to "Science Gossip" for I 868, in an article at page 124 . In this the motive power is attributed to "the downward rush of numerous threads from all the spinnerets at once against the current of air." " The application of a similar power," he adds, "in another element, is seen in the larva of the dragon fly". (see, our paper on the Neuroptera) and "the flight of the skyrocket, which mounts with astonishing force by the downward impulse of the escaping gases." In either case the threads, which are not adhesive, are gradually collected together into loose masses, either by the irregular action of the air, or by the aëronauts themselves, and eventually fall to the ground, or become entangled in the foliage of trees, or lodged against other objects that arrest their flight. Thomisus cristatus (one of the Crab spiders), and several species of the genera $L y c o s a$ (Wolf spiders), and Theridion (Money Spinners), are recorded on good authority among those that are accustomed to indulge in gossamer exercise. Thomisus citreus, another Crab spider, is not uncommon with us, and is often found in the blossoms of the wild carrot, wild parsnip, and other umbelliferous plants, patiently lying in wait for the insects on which it preys. Pholcus Phalangioides is very commonly found on the loose webs it spins in the angles of ceilings and windows in stables, out-buildings, and unfrequented rooms that are not often explored by the housemaid. Its resemblance to Phalangium, from which it takes its specific name, is in the great length of its limbs, which, being nearly transparent, give it a very frail appearance. It has a curious habit of rapidly quivering its body, and, in so doing, imparting a vibratory movement to its web, this is supposed by some authors to be for the purpose of more effectually entangling its prey. We have often seen the performance on suddenly approaching its web, when no prey was visible near it. 
Lycosa saccata and L. campestris are common members of the division of Hunting spiders, which are often seen among the herbage, or fallen leaves in gardens, in pastures, on the Downs, and in the covers; and the females especially may be readily identified by their packets of eggs. Each female envelops her eggs in a neat silken cocoon, more or less white according to the species, which she spins for the purpose, and, suspending it beneath her cephalo-thorax by means of two or three fine braces, retains it in that position till the young are hatched, even then her maternal solicitude does not cease, she literally, without cradle or perambulator, nurses her infant family, sometimes nearly fifty in number, until they are capable of catering for themselves. In the meantime her personal appearance is strikingly curious, her whole batch of nurslings thickly clustering over every part of her body. Many other species of spider enclose their eggs in silken cocoons, weaving them under stones, in crevices of walls, or the bark of trees, rolling them up in dead leaves of plants, or attaching them to various objects without any attempt at concealment. We have often found solitary cocoons, resembling small roundish pellets of mud, attached to bents of grass, stalks of plantain, and other low plants in the Park, by the roadsides, and on the Downs, particularly on Hemner, we believe them to be the cocoons of a species of spider, but although we have kept many of them a long time, the eggs have never hatched, and we have had no opportunity of ascertaining whether they are really those of a spider or not. In these cocoons the eggs are neatly and closely packed in a glistening white envelope of so close a texture that it resembles a fine membrane, and this is thickly coated all over with a dirty-white looking felt, composed of minute particles of earth compactly webbed together.

The Zebra spider (Salticus scenicus) is another common Hunting spider, seeking its prey. in the hottest 
sunshine on walls, fences, and trunks of trees. This species does not fairly run down its game as others do, but quarters the field, as it were, in a succession of irregular darting movements until it espies its intended victim, a fly, for instance, from that moment its motions are singularly cautious. Keeping its head steadily in the direction of its prey, it moves almost imperceptibly towards it, if the fly takes a few steps either way, the wily spider does the same, and at every such change of position contrives to lessen the interval between itself and the unsuspecting insect, until at last, quick as lightning, it springs sideways upon it and quickly despatches it. We have more than once seen this crafty hunter pounce upon a little projection above the level of its hunting ground, as if it had mistaken it for a living object, but its disappointment, if it felt any, did not appear to be of long duration.

Passing over the Money Spinners (Theridion linealum), frequently found on bushes and shrubs, and Theridion benignum, whose loose protecting nets are so liberally thrown over the grapes on outdoor vines in the autumn, that they can have escaped the notice of few observant gardeners, we reach the last section of the Arachnida, which is chiefly made up of Mites. In these there is no outward distinction between head, thorax and abdomen, and the respiration is carried on by means of tracheæ, as in true insects.

Occupying an intermediate position between the Mites and true Spiders, are found the Shepherd Spiders or Harvestmen (Phalangium), those long slender-legged spider-like creatures so common in autumn among the herbage in the Park and on the Downs. They are predacious, and it is interesting to note that, in the stilt-like character of their limbs, they are specially fitted, like the Daddy Long-legs found in the same situations, for making their way with ease over the impediments of a grassy surface.

The family of Mites supplies us with Acarus de- 
structor, too frequently found in our collections of insects and dried plants, where it does much mischief; Acarus Farina, so abundant in stale flour, and Acarus Siro, which not unfrequently swarms to such an extent in old cheese, that its numbers give it quite an animated appearance. Many species are parasitic on different animals man himself, not excepted, and most notorious among his Mitey assailants are the Harvest Bob (Leptus Autumnalis), and the Itch Mite (Acarus Scabiei), for the attacks of which, however, frequent applications of soap and water may be prescribed, as a probable remedy in the former case and a not improbable preventative in the latter. Dogs and horses are subject to the attacks of the Dog-tick (Ixodes Ricinus), which, indeed, occasionally fixes its barbed rostrum in the human skin also; other forms are met with on various birds, and not the least remarkable of these is the Sparrow Mite, one sex of which displays an enormous pair of lobster-like claws. Philodromus Limacum may often be seen rapidly coursing over the slimy bodies of more than one large species of slug, and we have repeatedly seen it run in and out of the respiratory orifice of Arion ater, even insects, as we have already stated, have parasitic mites appropriated to them. Gammasus Coleoptratorum is the pest of beetles and humble bees, Leptus Phalangii of the common shepherd spider, and (omitting many others) Uropoda vegetans infests several species of beetles.

Occasionally a specimen of the common Dor (Geotrupes stercorarius) may be met with oddly disfigured by masses of minute shining roundish bodies, each of which, on examination, is found to be attached to the underside of the beetle by a slender footstalk. On further and closer examination, it will be seen that these curious objects, although apparently growing like tiny fungi out of the integument on which they are clustered, are, strangely enough, furnished with 
legs, and that, in reality, they are living insects. This is the appearance of a family of the parasitic Uropoda vegetans, each individual, like the egg of Chrysopa Perla among the Neuroptera, being supported on a slender filament. There is, however, this difference between the two, the peduncle of the latter is solid, while that of Uropoda vegetans is a hollow tube, serving the purpose of an umbilical cord, through which the nutriment, extracted from the body of the beetle, is conveyed, first to the egg and subsequently to the fully developed mite. Although the agency is yet to be discovered by means of which the communication between the tube and the softer tissues of the beetle is effected, the result is the evident exhaustion of the latter when its parasites are numerous. These eventually detach themselves from their anal support, and, exchanging their pedunculated life for an active one, betake themselves to the important business of reproduction and the planting of other colonies.

Chelifer Cancroides is another curious Mite frequenting damp situations under moss and the bark of trees, where we have often met with it, it is also found in collections of dried plants, as well as among old books, and is there supposed to prey on other creatures smaller than itself. It is about the eighth of an inch in length, and of such a remarkable appearance, that it is scarcely possible to confound it with any other genus. Its legs are comparatively short and slender, but its projecting palpi, or feelers, are as long as its entire body, and each armed at the extremity with a pair of formidable-looking scorpion claws, with which it is capable of seizing its prey and firmly holding it. When disturbed, it moves equally well in any direction, backwards, forwards, or sideways, crab-like.

Among our representatives of the class Myriapoda*

- Class Myriapoda.-From the Greek, myrios, numberless, and pous, podos, foot, many footed. 
are several species of Wood Lice (Oniscus, Glomeris and Armadillo), of the cylindrical-bodied Millepede (Iulus terrestris), and the flat-bodied Scolopendra or Cudworm (Lithobius forficatus and Geophilus longicornis), but the most remarkable of all is the luminous, or Electric Centipede (Geophilus electricus), which may commonly be seen in the dark evenings of autumn and occasionally earlier in the season. Its phosphorescence is paler than that of the glow-worm, and the luminous secretion is not only diffused over the whole of its body, but is so easily detached from it, that in its nocturnal wanderings among decaying leaves under the trees and in gardens, this creature leaves a track of light behind it, sometimes two or three inches in length. This brilliant trail is more or less interrupted by the irregularities of the surface over which the animal passes, so that it is not always continuous, but on the smooth palm of the hand it is more perfect, and in either case, it remains visible for several seconds. If the conjectures of many naturalists, that the luminosity of insects is a provision for enabling them to discover their prey, in the absence of any other light, or to attract individuals of the opposite sex, be well founded, this property in the electric centipede must have been bestowed for a very different purpose, as the creature is utterly destitute of any organs of vision whatever.

In bringing our remarks on this division of the Natural History of Harting to a close, we anticipate the obvious objection, on the part of some of our numerous readers, that in almost every Class and Order we have reviewed, the individuals we have noticed are fewer in number than those we have omitted. Not only do we "own the soft impeachment," but we further admit that, in passing on at once from the Myriapoda to the next division, we are purposely leaving a wide hiatus for the reception, in our future editions, of a long list of creatures belonging to other 
classes, not even indicated here, that are not less interesting to the naturalist, if not to the general reader, than many of those we have specified. In the hope, then, that in due time these addenda will be made, and that our imperfect outline will, at the same time, be filled up, by one better qualified than we are to do justice to the subject, we take our leave of the Fauna to add a few general notes on the Flora of our favoured district.

\section{CHAPTER XIII.}

\section{FLORA.}

To those who have long resided in one spot in the country, and have become familiar with the principal features of the surrounding landscape, every deciduous tree appears, at the fall of the leaf, to shrink in its individual proportions, the far off hedgerows and hangers recede still further in the distance, and the whole country assumes a more open character. On the return of spring, all these effects are reversed, and when "th' umbrageous multitude of leaves" is fairly developed, the outlines are again filled up, the masses of bright green foliage appear to draw nearer to the eye and approach each other, and the glades and open spaces between them are sensibly diminished in area. This is one of the interesting experiences of rural life, and it is needless to say that we have it in perfection in the park, which from the mansion, looking south, commands a wide range of very charming 
scenery, and from the Tower Hill overlooks a panorama of unrivalled beauty and great extent.

It is, however, of the timber trees in the park that we have now to speak, and as we are in possession of a letter written in 1858 , in which some allusion is made to the subject, we begin with the following extract from it:- "It grieves me to write or utter one word in depreciation of this terrestrial paradise, but a tender regard for the truth will not allow me to leave you in uncertainty as to the fact that its oak timber is not the greatest of its beauties. The oak trees in the park are comparatively few, and the largest is but a trifle over ten feet, and a half in girth at about five feet from its base. The principal growth is beech, and, without doubt, the magnificent specimens of that tree that abound within the Park fence, are not wanting in beauty or variety, some dividing a few feet from the soil into innumerable and enormous spreading branches, each in itself equal to a very respectable tree, others sending up bare shafts, forty, fifty, sixty feet high, and ultimately rearing their heads eighty, ninety, a hundred feet and upwards. One of the latter, once a very conspicuous object and long known, I understand, to the people of Stansted as 'Sir Harry's walking stick,' was uprooted a few years ago during a hurricane that fatally 'shivered the timbers' of many other fine trees in the park, and in its fall it displaced a huge mass of chalk, which, being firmly held between the roots of the prostrate trunk, presented the appearance of a fragment of wall twenty feet high. This Brobdignagian walking stick was seventy-five feet from the roots of the lowest branch, and a portion of the trunk sixty-four feet in length, may, for aught I know to the contrary, be actually afloat at the time I am writing this, and doing duty as a collier's keel. Another beech, on the crest of a long ridge in front of the mansion, was wrecked about the same time, and in order to 
do justice to that, the hewers were under the necessity of borrowing a 'cross-cut' saw from an Emsworth timber merchant, their own, which had answered their purpose, under every contingency during a long experience in several counties, being found too short on the occasion. The diameter of the tree at its base was ten feet and a half, which was reduced by the process of 'setting in' to six and a half, before the borrowed saw was applied to it. It contained seven load of timber, and the 'lop and top' produced eleven load of stack wood, and six hundred and fifty-five faggots."

Many other remarkable specimens of the beech may be pointed out in the park, one especially on the lawn not a hundred yards from the mansion

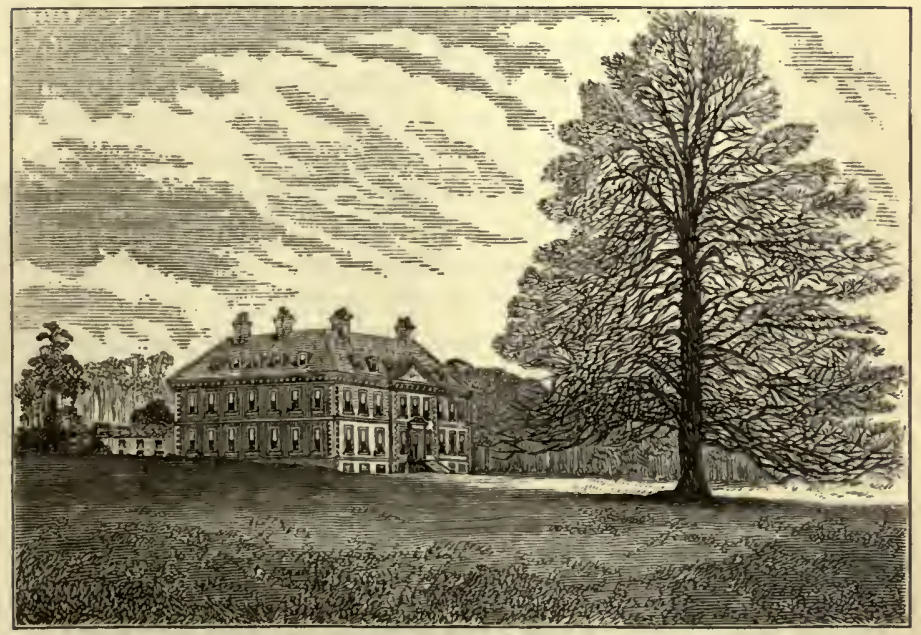

some of the branches of which, crossing each other in their ramifications at various angles, and at some distance from their origin, have in the course of their progressive growth, become so intimately united at 
the points of contact, that, collectively, they assume quite an anastomosing character. Another fine tree, near the Belt plain, known as "Rover's drinking fountain," has thrown out an enormous horizontal branch a very few 'feet from the ground, and in the angle between this branch and the parent trunk, is a natural rounded cavity nearly always containing a gallon or two of water, this discovery was made by a thirsty spaniel. In Padswood bottom, about a hundred yards from this, may be seen an ash and a beech, apparently springing out of a single bole, and in this instance we cannot but think that the "struggle for existence" will in all probability end, as it began, in a tie. We might easily extend our list of noble old trees in the park, many of which present some peculiarity of development, but we will only add one more. This stands in the Old Rookery near the park-keeper's lodge, a giant beech almost a grove in itself, the stem of which is divided into half-a-dozen colossal shafts.

The "Gothic Arches," an avenue of comparatively young beech, just within the southern boundary of the park, is locally interesting, from the fact that the land on which it was planted not quite a century back, was formerly part of the patrimony of Gilbert White, but it also has a special attraction quite apart from its historical associations. The over-arching terminal branches at one end of the avenue intersect each other at acute angles, so as to very fairly represent, when looked at from the opposite end, the elaborate tracery above the mullions of a gothic window, but obviously this effect can only be appreciated during the winter months, and when the trees are loaded with rime the effect is indescribably beautiful.

The graceful Beech, then (Fagus sylvatica), thrives well on the chalk, and is abundantly distributed over the whole of the uplands, including Lady Holt Park, East Harting Down, West Harting Down, and the 
slopes of the Warren and the Leith. In the marl and the clay of the low lands it gives place to the Oak (Quercus pedunculata), which ranges over the whole of the area from the Mill Hanger, through Goose Green, the Down park meadows, and the Nyewood plantations to the East Harting meadows, but it is not confined to these localities, the uphill covers are not without their young oak timber, and, as we have already seen, it is not wanting in the park. It is not improbable, indeed, that three hundred years ago, when "pannage" was one of the valuable appurtenances of wooded property, oak was very abundant here, and that the greater portion of it was felled when Sir Matthew Fetherstonhaugh purchased the estate. A few fine old specimens were no doubt left standing here and there, but these have nearly all disappeared from the more exposed parts of the Park, where the terrific gales from the south-west are sometimes terribly effective. As an instance of this we may mention that on part of the beautiful green slope now known as the Garden plain there once stood a grove of stately beech trees, and we have heard the late Sir Henry Fetherstonhaugh say that from the lawn he saw the whole of them, upwards of three hundred in number, levelled in a few minutes by a sudden squall!

Our notice of the oak would be very incomplete if we omitted to record a discovery that was made on one of the finest old specimens in the Park by the late Lady Murchison. Whether this particular tree is still flourishing or not we do not know, but the following, in her Ladyship's handwriting, is now before. us :-

"INSCRIBED ON AN ANCIENT OAK TREE IN UPPARK.

" 'Beneath this shade did antient Druids dwell;

My Grandsire with the Roman Empire fell ;

Myself a sapling when my father bore

Victorious Henry to the Gallic shore." "

- We had no doubt, when we transcribed this couplet, that it was an original effusion composed on the spot expressly in honour 
It would be an interesting feature in our History of Harting if we could discover in the poetical writings of Pope any evidence that he visited the domain of the Tankervilles and was inspired by its grand beauties. In the principal division of this work we learn that he was a frequent guest of his friend and correspondent, Caryll, at Lady Holt, and it is scarcely to be credited that he did not take many opportunities during his visits there of riding or driving over to Uppark. We are disposed to believe that he did so, but we have no authority for assuming that he was the author of these lines, and we think it is much to be regretted that he did not leave some memorial of the admiration he must have felt during his occasional rambles among these resorts of the "antient Druids."

There are some fine old clipped hedges of the Hornbeam (Carpinus betulus) in the Uppark gardens, forming two avenues that cross each other at right angles, and divide the garden into four equal quarters, but we are not aware that the species is met with in a wild state in the parish. These hedges are eight or ten feet in height, and for more than a century have weathered the heaviest storms, so that they have done good service in sheltering the garden crops from the high winds.

The Ash (Fraxinus excelsior) is pretty generally distributed, and in the Park especially rivals the birch in magnitude, but in our opinion it is not so graceful in outline. It is a valuable underwood in the covers,

of the tree on which it was afterwards found, but the following, which has been kindly handed to us by the Rev. H. D. Gordon, suggests something more than a doubt on the subject :-

“ 'In my Great Grandsire's trunk did Druids dwell ; My Grandsire with the Roman Eagle fell ; Myself a sapling when my Father bore The Hero, Edward, to the Gallic shore.'

"Quoted in connection with the Penshurst Oak in Mrs. Markham's History, Vol. II., p. 29o." 
where its "keys" readily take root, and it is curious to observe that among the many young plants that have strayed on to the commons and roadside wastes, very few individuals are met with without their protective armour of bushes or brambles by which they were "nursed" in their seedling stage. When its buds are bursting in spring the ash is vernacularly said to be "coaling," and those who are learned in "folk-lore" know under what conditions this process portends a coming wet or dry season.

A noble Plane tree (Platanus Orientalis) is still flourishing in the Kennel Gardens, where many successive generations of "Clumbers" and other sporting dogs have gambolled in the shade of its broad canopy of beautiful dense foliage; unfortunately much of its original beauty has been destroyed by the removal of some of its lower branches. Of the eccentric dogkeeper, Sam Phillips, many anecdotes are in the recollection of his contemporaries; one which we have from good authority relates to the latter portion of his career, after he had voluntarily left the kennels and turned truffle hunter. A gentleman who knew him well, casually meeting him one day, and being struck by unmistakable evidences of dilapidation in his hunting suit, good naturedly expressed a fear that truffle hunting had not turned out a very fortunate speculation. "Oh, I dunno s' much 'bout that, Sir," was Sam's reply, "I gits on middl'n well at it, but I dessay I med do better if I dint happ'n to light wi s' many o' they swing'n sign boords, do what I wool, I never can git by 'em!'

The Elm (Ulmus campestris) is not uncommon on the lowland marls and clays from the New Barn on Hurst Farm to East Harting. With a few exceptions, it is found in scattered groups originally planted, in all probability, in the immediate vicinity of old farmhouses, Hill Ash, for instance, Upperton, Weston's, Garrett's, Penn's at East Harting, and many of them 
are fine old specimens. The Broad-leaved Elm (Ulmus montana) is more rarely met with as a timber tree. This is one of the forms known as the Wych elm, and there are two very fine ones on the estate, one in the Park on Steel's Hanger, and the other in the Round copse at the foot of West Harting Down. It is also sparingly distributed as an underwood in the covers, and in this stage of its growth the woodmen call it the Wych Hazel.

There is a very fine and picturesque example of the Birch (Betula alba) in the park near Padswood, and a smaller one nearer Padswood bottom, but the home of the species is on the sand at West Heath, where it is found abundantly, it is also met with as an underwood in the covers on the chalk, and in one or two other localities.

The Scotch Fir (Pinus sylvestris); the Larch (Larix Europaca); the Spruce Fir (Abies excelsa), and other coniferous trees, may be included in our list, but as, with the exception of the Scotch Fir, they are cultivated plants, we need only say that they are well established with us, both on the chalk and on the sand, and if the monotony of a fir plantation is not always very pleasing to the eye, its valuable timber is fully appreciated.

The Field Maple (Acer campestris) is one of the most striking objects in our "fading many-coloured woods" in the autumn, and its rich golden-yellow foliage then stands out in bright contrast with the surrounding shades of dark green and russet brown. There is a very large, old, rugged specimen in the Deer Paddock, with a fine wide-branching head, the trunk of which, at three feet from the ground, measures ten feet and a half in circumference. Many others are found in the Park fence, between Bridger's Pond and the Little Green Lodge, in Lady Holt Park, in the Round Copse, on the eastern slope of West Harting Down, adjoining the Harting Crofts, 
in the South Gardens and other localities; but the most elegantly grown maple we possess, though not the largest, may be seen within the park not far from Bridger's Pond. As an ornamental indigenous tree this is eminently worthy of notice, it is nearly nine feet in girth, four feet up the stem, and, notwithstanding its size and age, the apparent soundness of its timber and its healthy foliage, hold out a promise that it may continue to be "a thing of beauty." for many years to come.

Instances of the Sycamore (Acer pseudo-platanus) are very few and far between, but what they want in numbers they amply make up for in individual magnitude and massive beauty. We know of four fine old trees in the parish,--one on the Marl in the garden to the west of the churchyard, one in the Four-acres on Engine Farm, and two on the sand at Downparks, one of which is a truly magnificent specimen; we also meet with a few scattered plants in the covers.

The Lime tree (Tilia Europea) of which a group is left standing near the site of the mansion of the Carylls in Lady Holt Park, is only found where it was planted. The Walnut (Fuglans regia), and the Spanish Chestnut (Castanea vesca), are met with under similar conditions, and we have a few of both species in the park, the latter especially being very fine picturesque old specimens.

The Horse Chestnut (AEsculus Hippocastaneus) is more common, and not only grows freely in the park and the south gardens, but produces seedlings in abundance where the parent tree stands in an enclosure. A pink flowering species, or variety ( $A$. $H$. rubicunda), has been not very recently introduced, which grows and blossoms as luxuriantly as the old kind, and is quite as easily propagated from seed. It differs somewhat in habit from the latter, is of a more dwarf character, with foliage of a deeper 
green, and, though not so striking in appearance, is really a very pretty object when loaded with its wealth of rich pink clusters, which it retains a long time. The chestnuts of both species are eagerly sought after in the autumn by the deer, and when the latter have picked up all the fallen ones, they know how to shake the lower branches of the trees for a fresh supply. The leaf scars, peculiar to the genus, which by a curious coincidence bear a tolerable resemblance to the hoofs of a horse, are found in both species, but they are less characteristic on the pink flowering form than on the other.

The Wild Cherry (Prumus Cerasus), which in early spring rears its compact snowy head in the Old Copse opposite the kennels, is not uncommon among the underwood in some of the covers and hedgerows, on the chalk, the marl, and the clay. It is found in Star Copse, the Hodson field row, on each side of Bohemia Hollow, and in the wheatrivers hangers, and rows. The Wild Apple or Crab tree (Pyrics Malus) is not unworthily represented in the park near the Little Green Lodge, in the Warren by the side of the Hollow on the chalk, and on West Heath, in Blackrye Copse and near Chase's Copse on the sand. The White Beam tree (Pyrus aria) is conspicuous in the park, Lady Holt, the Warren, and the Round Copse on West Harting Down.

Of the Alder (Alnus glutinosa) we have several fair examples, on the Marl, in the Cabbage Garden, and the little plantation between the highway and the private road to the South Gardens, on the sands near the hay barn at Downparks, at the tail of the Blackrye pond, and on the clay in the East Harting meadows. As an underwood we find it in the Alder Moor near Ryefields and in Chase's Copse.

We are not sufficiently acquainted with the Willow tribe to venture on an enumeration of all the species or varieties that are found here, but we may claim the 
Goat willow (Salix caprea), so well known as the "Palm Tree" that enlivens the hedges and copses with its welcome sweet yellow Catkins, long before the appearance of the leaf in the surrounding woodlands is general. For the Common Osier (Salix viminalis) we must go to Battine's piece, to a meadow at the foot of Upperton Hollow, to Champs, the Barracks, the Severals, Hill plantation, Pond-tail plantation, the Sheep-wash and other covers, while the one locality in the Parish for the Weeping Willow is the Vicarage garden and meadow adjoining, where there are two very fine specimens.

"The many twinkling leaves" of the Aspen (Populus tremula) were, not many years since, conspicuous between the village of South Harting and the Culvers, and have afforded us, in our entomological days, many a fine specimen of the Puss moth, but the only aspen now remaining in the village stands at the entrance to the Vicarage garden. Unfortunately it has been deprived of its head, but its roots are making ample amends for the loss by sending up, season after season, a host of vigorous suckers ; this is so characteristic of the species that if an old specimen be cut down to a short distance from the ground, the stump will, in the course of a very few seasons, become the centre of a thriving nursery. Other examples of the aspen are growing near the Hay barn at Downparks in the Three-cornered piece on the waste near the Nyewoods, and a particularly fine one is flourishing at the foot of Gutter's Copse.

The slender forms of all the Lombardy Poplars (Populus fastigiata) in the Parish may probably be recognized from the summit of Torberry, and it will at once be evident that they are not -numerous. The largest group is near Tye Oak, and a few others will be seen in the East Harting meadows, near Hill Ash, and in the Vicarage garden. Here we have more than once passed between two very fine specimens which 
were standing in our younger days, like twin giants guarding the entrance, and we have a very lively recollection of the fearful storm during which one of them was injured by the lightning, and one of the pinnacles of the Tower in the Park was struck and nearly reduced to ashes. Indeed, the whole building might have been completely destroyed on the occasion, but for some lads who had taken shelter under the arch in the front of the doorway, these were naturally startled from their concealment by the crash, and speedily gave the alarm.

The Yew (Taxus baccata) is found everywhere on the chalk where it is permitted to grow. There are several fine specimens flourishing among the deciduous trees of a hanger overlooking West Harting Bottom, a charming valley running from the Hop Garden Copse to the ridge of the Down, and here, as well as on Downley Brow and in the Park, they form a pleasing contrast at all seasons with the surrounding growths. A few solitary trees are also dotted about on the marl in the lowlands.

The Holly, or Holme (Ilex aquifolium) is more generally distributed, being found on the chalk, the marl, and the sand. It is usually spoken of as a shrub, but we have seen several specimens that had attained to the dignity of timber trees thirty feet high, with stems eight or ten inches in diameter. Locally this species is popularly known as the Holme (pronounced "Home") when the foliage is prickly, and Holly when the leaves are destitute of spines, but as we often find the two forms on one bush or tree, Holme and Holly are simply convertible terms applicable to the same species.

Passing on from the timber trees to trees of smaller growth, we come to the hedgerows, copses and waste lands, where among the earlier flowering species we find the Hazel (Corylus avellana) with its hardy catkins and wee crimson blossoms, and the Blackthorn (Prunus 
spinosa), the flowering season of which is locally known as Blackthorn winter. Later in the season we inhale the fragrance of the Hawthorn, or Whitethorn (Crategus oxyacantha), many fine old specimens of which are distributed over the Park, the. Warren, Booker's Down, West Harting Down, and other localities in the parish. Then follow the woolly-leaved Wayfaring tree (Viburmum Lantana) in almost every cover and hedgerow on the chalk, the Guelder Rose ( $V$.opulus) which displays its clusters of rich crimson glossy berries every autumn on the waste near the Severals, the common Buckthorn (Rhammus catharticus) frequent on the chalk, the Alder Buckthorn ( $R$. frangula) found on the clay and the sand in the Nyewoods, the Severals, and at West Heath, the Privet (Ligustrum vulgare), sparingly met with on the chalk in the Leith, and on the clay in the Corner piece on West Harting Farm, the Dogwood, or Wild Cornel (Cormus sanguinea), the purple and crimson foliage of which in the autumn is so constant a feature in all our hedges and thickets, the Spindle tree (Euonymus Europoea), not the least ornamental of our wild shrubs when loaded, as it often is in favourable seasons, with a profusion of its delicate pink-coloured angular capsules and deep yellow seeds long after the fall of the leaf, the Common Elder (Sambucus nigra), ranging all over the parish, and the Dwarf Elder (Sambucus ebulus) in more than one field on East Harting Farm, particularly in the Engine Barn Field on the south side of Tipper Lane, and in a meadow near the Hatches on Hurst Farm.

Intermediate between our wild shrubs and creepers, are the Brambles and the numerous species of Wild Rose, but we are very imperfectly acquainted with them. We have identified the common Blackberry (Rubus fruticosa), which often forms a large tangled mass of stout arched stems and young shoots, the latter bearing a profusion of pretty pink blossoms in summer and a rich crop of its well-known glossy black 
fruit in autumn; the white-flowering hazel-leaved Bramble (Rubus Corylifolius), a less striking species than the latter, and the Dewberry (Rubus coesius), a more humble and dwarf growing plant than either, this is scattered about the hedge banks, and produces a very delicious fruit with a bloom like that of a plum, but consisting individually of fewer grains than that of the commoner species. The most frequent examples of the Wild Rose which we find enlivening our hedges and wastes, are the Downy-leaved Dog Rose (Rosa tomentosa), the small-flowered Sweet Briar (R. micrantha), the still more common Dog Rose $(R$. canina), and the White Dog Rose (R. arvensis).

The climbing plants, which add so much to the beauty and variety of our native woodlands, are of three kinds, those which twine spirally round the stems and branches of the shrubs and trees to which they attach themselves, those which climb by their tendrils or leaf petioles, and the Ivy (Hedera Helix), which climbs by means of fibres, springing laterally from its young shoots. Among the twining plants, we find the Sweet Woodbine, or common Honeysuckle (Louicera Peryclimenum), the gay, sweet blossoms of which decorate, throughout the summer months, almost every bush and tuft of bushes on the downs and wastes; the glossy-leaved, white trumpet-flowered Convolvulus, or Great Bindweed ( $C$. Sepium); the Small Bindweed (C. arvensis), as frequent in the corn fields as in the hedges; the Black Briony ( $T a-$ mus communis), deriving its trivial name from the colour of its root; and the Woody Nightshade (Solanum dulcamara), the flowers of which have an unmistakable family likeness to the potatoe blossom. The other climbing plants, that do not twine, are the Virgin's Bower, or Traveller's Joy (Clematis vitalba), abundant everywhere on the chalk, and particularly conspicuous in autumn and winter, when its persistent gray tufts of feathery seeds shroud the plants they 
have taken possession of in large patches; and the Red-berried Briony (Bryonia dioica), the root of which was, in byegone days, the British representative of the Mandrake.

Our other shrubs which do not range themselves under either of the heads we have glanced at, are the Fine-leaved Heath (Evica cinerea), and the Common Ling (Calluna vulgaris), widely and abundantly dispersed over the chalky downs and the sandy wastes; the Cross-leaved Heath (Erica Tetralix), at Downparks, near the Blackrye Pond; the Juniper ( Funipenus communis), a frequent and very elegant shurb, on part of East Harting Down; the Furze, or Gorse (Ulex Europocus), still more common in the same locality; the Bilberry, or Whortleberry (Vaccinium Myrtillus), which we find on West Heath, but we have never seen it in fruit there; the Butcher's Broom, or Knee Holme (Ruscus aculeatus), in two or three localities on the chalk, the Killing Wood especially, and the parasitic Mistletoe (Viscum album), common on the White Beam tree and the Hawthorn in the Park.

The number of our herbaceous flowering plants, or wild flowers, as they are popularly termed, is so great, that although we do not give a tithe of them, we restrict our further remarks to a few only of those we include in our list. If we were to attempt to do justice to them severally, we should far exceed the limits of a confessedly simple sketch, for which only this, our notice, is intended. We propose, therefore, to group the different species we have identified under the heads of their respective habitats, without, in all cases, indicating their localities, and, in carrying out this plan, we begin with those which abound in

Hedges, on hedge banks and by road sides :Veronica Chamadrys (Germander Speedwell). Valeriana officinalis (Great Wild Valerian). Dipsacus sylvestris (Wild Teasel). Galium cruciatum (Cross-wort). 
G. verum (Common Yellow Bed-straw).

G. Aparine (Goose-grass or Cleavers).

Cynoglossum officinale (Common Hound's-tongue), found also in the park.

Campanula Trachelium (Nettle-leaved Bell-flower).

Viola hirta (Hairy Violet).

$V$. odorata (Sweet Violet).

Verbascum Thapsus (Great Mullein).

$V$. nigrum (Black Mullein).

Torilis Anthriscus (Upright Hedge-parsley).

T. infesta (Spreading Hedge-parsley).

Anthriscus sylvestris (Wild Beaked-parsley, Wild-

Chervil, Cow-weed, Cow-parsley).

Conium maculatum (Common Hemlock).

Angelica sylvestris (Wild Angelica).

Heracleum Spondylium (Cow-parsnep, Hog-weed).

Polygonum aviculare (Common Knot-grass).

Stellaria holostea (Greater Stitchwort).

Sedum Telephium (Orpine or Live-long).

Agrimonia Eupatoria (Common Agrimony).

Potentilla argentea (Silvery or Hoary Cinquefoil).

$P$. reptans (Common Creeping Cinquefoil).

P. Fragariastrum (Barren Strawberry), often mistaken

when in flower for the Wild Strawberry.

Chelidonium majus (Common Celandine).

Helianthemum vulgare (Common Rock-rose).

Verbena officinalis (Common Vervain).

Calamintha officinalis (Common Calamint).

C. Nepeta (Lesser Calamint), East Harting.

Lamium album (White Dead-nettle).

L. purpureum (Red Dead-nettle).

Stachys sylvatica (Hedge Woundwort).

Ballota nigra (Black Horehound).

Clinopodium vulgare (Common Wild-basil).

Linaria vulgaris (Common Yellow Toad-flax).

Cardamine pratcnsis (Ladies' Smock).

Sisymbrium officinale (Common Hedge Mustard).

Erysimum Alliaria (Garlick Hedge Mustard, Jackby-the-hedge). 
Geranium Robertianum (Herb Robert, Stinking Crane's-bill).

Malva sylvestris (Common Mallow).

Ononis spinosa (Thorny Rest-harrow).

Lathyrus sylvestris (Narrow-leaved Everlasting Pea).

Vicia Cracca (Tufted Vetch).

$V$. sepium (Common Bush Vetch).

Ervum hirsutum (Hairy Tare).

Hypericum hirsutum (Hairy St. John's-wort).

Prenanthes muralis (Ivy-leaved Wall-lettuce).

Lapsana communis (Common Nipple-wort).

Arctium Lappa (Burdock, Clot-bur).

Cnicus lanceolatus (Spear Thistle).

C. arvensis (Field Thistle).

Artemisia vulgaris (Mugwort).

Pyrethrum Parthenium (Common Feverfew).

Achillea millefolium (Common Yarrow, Milfoil).

Arum maculatum (Cuckow-pint, Wake Robin, Lords-

and-Ladies.

Humulus Lupulus (Common Hop).

Cultivated fields are rich in :-

Veronica Buxbaumii (Buxbaum's Speedwell).

$V$. montana (Mountain Speedwell).

Scabiosa arvensis (Field Scabious).

Myosotis arvensis (Common Field Scorpion-grass).

$M$. collina (Early Field Scorpion-grass).

Anagallis arvensis (Common Scarlet Pimpernel).

Viola tricolor (Pansy Violet, Heart's-ease).

Chenopodium olidum (Stinking Goose-foot).

Cuscuta Europaea (Greater Dodder).

Scandix Pecten-Veneris (Needle-Chervil, Shepherd's needle, Venus' comb).

Daucus Carota (Wild Carrot).

Aithusa Cynapium (Common Fool's-parsley).

Pastinaca sativa (Common Wild Parsnep).

Polygonum Convolvulus (Black Bind-weed). 
Silene inflata (Bladder Campion, White Bottle). S. noctifiora (Night-flowering Catchfly). Agrostemma Githago (Corn Cockle). Spergula arvensis (Corn Spurrey). Papaver Rheas (Common Red Poppy). Mentha agrestis (Rugged Field Mint). Galeopsis Ladanum (Red Hemp-nettle). G. Tetrahit (Common Hemp-nettle). Stachys arvensis (Corn Woundwort). Acinos vulgaris (Common Basil Thyme). Linaria spuria (Round-leaved Toad-flax). L. Elatine (Sharp-pointed Toad-flax). L. Minor (Least Toad-flax).

Scrophularia nodosa (Knotted-rooted Figwort).

Orobanche minor (Less Broom-rape).

Thlaspi Bursa-pastoris (Common Shepherd's-purse).

Sinapis arvensis (Field Mustard or Charlock). Malva moschata (Musk Mallow).

Fumaria officinalis (Common Fumitory).

Sonchus arvensis (Common Sow-thistle). Anthemis Cotula (Stinking Chamomile). Euphorbia helioscopia (Sun Spurge, Wart-wort). E. exigua (Dwarf Spurge).

In woods and thickets we meet with :-

Circoa lutetiana (Common Enchanter's Night-shade). Asperula odorata (Sweet Woodruff).

Lithospermum officinale (Common Gromwell), found most frequently by roadsides on the clay as well as the chalk.

Primula vulgaris (Common Primrose).

Lysimachia nemorum (Wood Loose-strife, Yellow

Pimpernel).

Viola canina (Dog's Violet).

Sanicula Europaea (Wood Sanicle).

Bunium flexuosum (Earth-nut, Pig-nut).

Allium ursinum (Broad-leaved Garlick, Ramsons). 
Hyacinthus nonscriptus (Harebell, Wild Hyacinth). Convallaria multiflora (Common Solomon's Seal). Epilobium angustifolium (Rose-bay, Willow-herb), in dense patches in Hodson copse and in a wood near Kill Devil Copse.

Paris quadrifolia (Herb Paris, True-love, One-berry). Adoxa Moschatellina (Tuberous Moschatell). Oxalis acetosella (Common Wood-sorrel). Fragaria vesca (Wood Strawberry). Geum urbanum (Common Avens, Herb Bennet). Aquilegia vulgaris (Common Columbine). Anemone nemorosa (Wood Anemone). Ajuga reptans (Common Bugle). Galeobdolon luteum (Yellow Weasel-snout). Betonica officinalis (Wood Betony).

Geranium dissectum (Jagged-leaved Crane's-bill). Hypericum Androscemum (Tutsan, from Toute-saine). $H$. perforatum (Perforated Common St. John's wort). Hieracium sylvaticum (Wood Hawkweed).

Gnaphalium Gallicum (Narrow-leaved Cudweed) in the Mill Hanger.

Euphorbia amygdaloïdes (Wood Spurge). E. Lathyris (Caper Spurge).

Mercurialis perennis (Perennial Mercury).

In wet pastures and wastes we find :-

Scabiosa succisa (Devils-bit Scabious).

Lysimachia Nummularia (Creeping Loose-strife, Money-wort), found also in Hodson Lane.

Rumex acetosa (Common Sorrel).

Chrysosplenium oppositifolium (Opposite-leaved Goldensaxifrage).

Lychnis Flos-Cuculi (Ragged Robin, Meadow Lychnis). Spirca Ulmaria (Meadow-sweet).

Potentilla anserina (Silver-weed, Goose-Grass, Wild Tansy).

$P$. reptans (Common Creeping Cinquefoil). 
Silaus pratensis (Meadow Pepper-Saxifrage).

Ranunculus Flammula (Less Spear-wort).

$R$. acris (Upright Meadow Crowfoot).

$R$. Ficaria (Pilewort, Lesser Celandine).

Stachys palustris (Marsh Woundwart).

Leontodon Taraxacum (Common Dandelion).

Tussilago Farfara (Colt's-foot).

Achillea Ptarmica (Sneeze-wort, Goose-tongue).

In dry pastures the following are generally distributed :-

Anthoxanthum odoratum (Sweet-scented Spring-grass). Briza media (Common Quaking-grass).

Scabiosa columbaria (Small Scabious).

Asperula Cynanchica (Squinancy Wort, Small Woodruff).

Plantago major (Greater Plantain).

$P$. media (Hoary Plantain).

$P$. lanceolata (Ribwort Plantain).

Primula veris (Cowslip, Paigle).

Campanula glomerata (Clustered Bell-flower), on the

bank of the Engine pond especially).

Erythraa Centaurium (Common Centaury), we have found a white variety of this on East Harting Down, where the species is plentiful.

Pimpinella Saxifraga (Common Burnet-saxifrage). Linum catharticum (Purging Flax).

Rumex acetosella (Sheep's Sorrel).

Lychnis vespertina (White Campion, Corn Lychnis).

Tormentilla officinalis (Common Tormentil, Septfoil).

Glechoma hederacea (Ground Ivy, Gill, Ale-hoof).

Prunella vulgaris (Self-heal).

Bartsia Odontites (Red Bartsia).

Rhinanthus Crista-galli (Yellow-rattle).

Euphrasia officinalis (Eye-bright).

Melampyrum pratense (Common Yellow Cow-wheat).

Geranium molle (Common Dove's-foot Crane's-bill). 
Anthyllis vulneraria (Kidney-vetch, Ladies-fingers). Ornithopus perpusillus (Common Bird's-foot). Lotus corniculatus (Common Bird's-foot Trefoil). Tragopogon pratensis (Yellow Goat's-beard). Apargia hispida (Rough Hawkbit). Senecio sylvaticus (Mountain Groundsel). Chrysanthemum Leucanthemum (Great White Ox-eye, Moon-flower). Achillea millefolium (Common Yarrow or Milfoil). Centaurea Scabiosa (Greater Knapweed).

Boggy places, ditches, water-courses and limpid streams, supply us with :-

Eriophorum angustifolium (Common Cotton-grass). $E$. vaginatum (Hare's-tail Cotton-grass). Arundo Phragmitis (Common Reed), Redsea. Galium palustre (White Water Bed-straw). G. uliginosum (Rough Marsh Bed-straw), Downparks. Symphytum officinale (Common Comfrey). Mcnyanthes trifoliata (Marsh Trefoil, Bog-bean). Anagallis tenella (Bog Pimpernel). Hydrocotyle vulgaris (Marsh Penny, White-rot). Helosciadium nodiflorum (Procumbent Marsh-wort). Drosera rotundifolia (Round-leaved Sun-dew). $D$. longifolia (Long-leaved Sun-dew). Peplis Portula (Water Purslane). Epilobium hirsutum (Great Hairy Willow-herb). E. palustre (Round-stalked Marsh Willow-herb). Polygonum Persicaria (Spotted Persicaria), plentiful at the Sheep-wash near East Harting.

$P$. Hydropiper (Biting Persicaria).

Ranunculus hederaceus (Ivy-leaved Crowfoot).

Stachys palustris (Marsh Woundwort).

Scutellaria galericulata (Common Skull-cap).

S. Minor (Less Skull-cap).

Pedicularis palustris (Marsh Lousewort).

$P$. sylvatica (Common Lousewort). 
Scrophularia aquatica (Water Figwort).

Scrophularia Scorodonia (Balm-leaved Figwort).

Nasturtium officinale (Common Water-cress).

Hypericum quadrangulum (Square St. John's-wort).

H. elodes (Marsh St. John's-wort).

Bidens cernua (Nodding Bur-marigold).

Eupatorium cannabinum (Hemp Agrimony), found also by the side of the Hollow.

Senecio aquaticus (Marsh Ragwort).

Pulicaria dysenterica (Common Flea-bane).

In Ponds and Pools we may collect :-

Lycopus Europous (Water Horehound, Gipsywort).

Lemna trisulca (Ivy-leaved Duckweed).

L. minor (Lesser Duckweed).

Iris Pseudacorus (Yellow Iris, Water-flag, Flower-deluce).

Potamogeton rufescens (Long-leaved Floating Pondweed).

$P$. crispum (Curled Pond-weed).

$P$. perfoliatum (Perfoliate Pond-weed).

Myosotis palustris (Great Water Scorpion-grass, Forgetme-not).

Alisma Plantago (Great Water Plantain).

Polygonum amphibium (Amphibius Persicaria).

Mentha hirsuta (Hairy Mint).

Typha latifolia (Great Cat's-tail, Reed-mace).

Sparganium ramosum (Branched Bur-reed).

S. simplex (Unbranched Bur-reed).

Downs, Heaths and similar Wastes may be successfully explored for :-

Menchia erecta (Upright Mœnchia, Least Stitchwort). Campanula rotundifolia (Round-leaved or Common Bell-flower).

Phyteuma orbiculare (Round-headed Rampion). Atropa Belladonna (Deadly Night-shade). 
Cuscuta epithymum (Lesser Dodder), West Heath.

Gentiana Amarella (Autumnal Gentian), bristling all over the Fore Down, the Main Down and West Harting Down.

Chlora perfoliata (Perfoliate Yellow-wort).

Reseda lutea (Rocket Yellow-weed, Base Rocket).

$R$. luteola (Wild Woad, Dyer's Weed, Yellow-weed).

Teucrium Scorodonia (Wood Sage, Wood Germander),

very common on West Harting Down, and not many

generations back largely used as a substitute for hops

in beer.

Thymus Serpyllum (Wild Thyme).

Origanum vulgare (Common Marjoram).

Digitalis purpurea (Foxglove).

Draba verna (Common Whitlow-grass).

Arabis hirsuta (Hairy Wall-cress), under the Beech in the Park also.

Polygala vulgaris (Common Milkwort).

Hypericum pulchrum (Small Upright St. John's-wort). Carduus nutans (Musk Thistle).

Cnicus acaulis (Dwarf Thistle).

Carlina vulgaris (Common Carline-thistle).

Conyza squarrosa (Plowman's Spikenard).

Poterium Sanguisorba (Salad-Burnet).

Gardens and Shrubberies afford us :-

Solanum nigrum (Common Night-shade).

Stellaria media (Common Chickweed, or Stitchwort). Lamium purpureum (Red Dead-nettle, Archangel). Lathroea squamaria (Greater Toothwort), in a hedgerow near Eckenfields also. Cardamine hirsuta (Hairy Cardamine).

Old walls and out-buildings, not uncommonly present :-

Parietaria officinalis (Common Pelitory of the wall). 
Epilobium montanum (Broad, Smooth-leaved Willowherb):

Sempervivum tectorum (Common House-leek).

Linaria Cymbalaria (Ivy-leaved Toad-flax).

Corydalis lutea (Yellow Corydalis).

Prenanthes muralis (Ivy-leaved Wall-lettuce).

Crepis tectorum (Smooth Hawk's-beard).

Sandy wastes produce :-

Lycopsis arvensis (Small Bugloss).

Fasione montana (Comnon Sheep's-bit).

Trifolium arvense (Hare's-foot Trefoil).

Gnaphalium uliginosum (Marsh Cudweed), in the Severals also.

G. minimum (Least Cudweed).

G. Germanicum (Common Cudweed).

Senecio Facobaa (Common Ragwort).

Solidago Virgaurea (Common Golden-rod).

Generally distributed in all soils :-

Senecio vulgaris (Common Groundsel).

Urtica urens (Small Nettle).

$U$. dioïca (Great Nettle).

Bellis perennis (Common Daisy). From a pretty poem by Miss Rogers, we extract the following lines referring to this species:-

“The Daisy was first to bid adieu

To the light of the glorious Sun ;

He had watched his journey the whole day through,

His golden eye had been fondly true

To his course till the day was done."

The characteristic of this flower, so accurately and poetically described in the last three lines, often produces a curious effect. On a bright sunny day in spring, while yet the grass was short, we once passed by a meadow that, at first sight, and at the distance of a hundred yards or so, appeared to be 
irregularly covered with chalk or lime. As we drew nearer to it, we found that this appearance was due to dense patches of daisies all "fondly true" to the course of the sun, and thus presenting their innumerable stars of white petals uniformly in one direction. On looking towards the field from the opposite side, after we had passed it, we were unable to detect a single speck of white over its whole surface.

Monotropa Hypopitys (Yellow Bird's-nest) is abundant on St. Richard's Hill, and is found occasionally in the park, where we have met with specimens growing among the roots of the trees on which it is parasitic.

Chenopodium Bonus Henricus (Mercury Goose-foot, Good Henry) ; C. rubrum (Red Goose-foot); and C. olidum (Stinking Goose-foot), are common in waste ground, on rubbish and dunghills.

In our list of Orchids we claim :-

Orchis pyramidalis (Pyramidal Orchis), in pastures on the chalk and on the Downs.

Orchis Morio (Green-winged Meadow Orchis), in Park field we have found this plentifully.

Orchis mascula (Early purple Orchis), abundantly distributed in pastures and covers.

Orchis maculata (Spotted palmate Orchis), on Downs and in waste places.

Gymnadenia conopsea (Fragrant Gymnadenia or Orchis), in pastures on the chalk.

Habcnaria viridis (Green Habenaria, Frog Orchis), we have found this sparingly on West Harting Down, and in two other localities which were pointed out to us by G. B. Wollaston, Esq.

Habenaria chlorantha (Butterfly Habenaria or Orchis), in nearly all the covers.

Herminium Monorchis (Green Musk-Orchis), in the park and two other localities on the chalk. 
Ophrys Apifera (Bee Ophrys), in the park, on the Downs, and in dry pastures on the chalk.

Ophrys Muscifera (Fly Ophrys), in the Forty acres lane, the Warren and other localities on the chalk. Neottia spiralis (Common Lady's Tresses), in the park and on the Downs.

Listera ovata (Common Twayblade), generally distributed.

Listera Nidus-Avis (Bird's-Nest), in the Warren and the Hanger on St. Richard's Hill.

Epipactis latifolia (Broad-leaved Helleborine), along the slopes of the Leith.

Epipactis grandiflora (Large White Helleborine), in the Warren.

Hyoscyamus niger (Common Henbane) and Convallaria majalis (Lily of the Valley), are said to be found here in a wild state, but we have never been so fortunate as to meet with either. We have, however, seen Helleborus viridis (Green Hellebore) flourishing in a locality just without the boundary of the parish. This rare plant was there growing in profusion, and our attention was directed to it by G. B. Wollaston, Esq.

From the flowering plants we pass on to the Ferns and Fungi with which we close our subject :-

Eupteris Aquilina (Common Brakes), in waste places, and in the park where we have seen it growing to the height of seven or eight feet and upwards.

Ctenopteris vulgaris (Common Polypody), on shady rocky banks by roadsides, and on old stumps in woods and thickets.

Cystopteris fragilis (Brittle Fern), in the park. Polysticum aculeatum (Prickly Fern).

$P$. angulare (Willdenow's Fern).

Lophodium multiflorum (Roth's Fern), on West Harting Down. 
Lophodium spinosum (Withering's Fern) West and East Harting Downs.

Dryopteris Filix-mas (Male Fern).

D. Borreri (Borrer's Male Fern).

Athyrium Felix-femina (Lady Fern), in the park and the Killing wood.

Asplenium Adiantum-nigrum (Black Spleenwort). A. Trichomanes (Maidenhair Spleenwort).

Amesium Ruta-muraria (Rue-leaved Spleenwort).

Phyllitis Scolopendrium (Hart's-tongue Spleenwort).

Notolepeum Ceterach (Scaly Spleenwort).

Osmunda Regalis (Flowering Fern).

Ophioglossum vulgatum (Adder's Tongue), in the Leith and Padswood Copse.

\section{FUNGI.}

Amanita muscaria (Fly Amanita), found at West

Heath and on the banks of the adjacent railway. This is one of our most beautiful and at the same time one of our most poisonous fungi, remarkable in the Russian annals for having caused the death of an Emperor. One of the specimens we picked measured eight inches and a half across the pileus, the upper surface of which was of a rich crimson studded with cream-coloured warts.

Agaricus proceruss (Parasol Mushroom). In the park and on the Downs.

Agaricus ostreatus (Oysler Agaric).

$A$. arvensis (Horse Mushroom).

A. campestris (Common Mushroom).

Coprinus comatus (Shaggy Coprinus).

C. atramentarius (Inky Coprinus).

C. micaceus (Glistening Coprinus).

Cantharellus cibarius (Edible Chantarelle), in Hodson

Copse.

Marasmius orcades (Fairy-ring Champignon).

Boletus edulis (Edible Boletus).

Polyporus sulfurens (Sulphury Polyporus). 
P. betulinus (Birch Polyporus).

$P$. fraxineus (Ash Polyporus).

$P$. ferriginosus (Rusty Polyporus).

Stereum.

Corticium.

Clavaria coralloides (White Coral Clavaria).

C. oristata (Crested Clavaria).

C. fastigiata (Fastigiate Clavaria).

C. vermiculata (White-tufted Clavaria).

Tremella mesenterica (Orange Tremella).

T. albida (Whitish Tremella).

Phallus impudicus.

We now venture on a little digression. At that indefinite period so frequently and conveniently referred to in many veracious histories, as "once upon a time," a middle aged gentlemen, a bachelor of somewhat humorous proclivities, occupied a neat little cottage not a hundred miles from Harting. His establishment, including himself (!) a couple of servant-maids, a boy and a man of all work, was mildly governed by a placid little housekeeper, on whom her sponsors, some fifty or sixty years before she came under our notice, had conferred the classical name of Penelope, euphemized by her master into "Pen." This lady was often heard to declare, that she could never understand why her master should be so exceptional as he was, in his notions of order and cleanliness within his limited domain. His "study," which was crowded with books, papers, fossils, shells and sundry other natural productions, in most admired disorder, was strictly tabooed to Pen and her handmaidens, while every other part of the cottage was expected by him to be scrupulously neat and clean. It must be confessed, however, that this expectation frequently fell short of realization, one stair closet, in particular, crammed with shavings, chips of wood, bits of paper, old slippers, fragments of crockery and almost every 
conceivable household article not in frequent use, had long been a subject of the master's occasional remonstrances, which fell upon Pen, as she ingenuously admitted, "like water on a duck's back," and the accumulation of unconsidered trifles still went on, until at length a decidedly unpleasant smell became perceptible in the lower part of the house. For several days, Pen and her household were at a sad loss to account for this, except on the theory that it proceeded from a dead rat in one of the rooms. Then followed a general displacement of furniture and taking up of carpets, doors and windows were set open for the purpose of ventilation (it was in the summer season), and every nook and corner of the ground floor (except the stair-closet) was carefully examined, but in vain, the nuisance still remained undiscovered and unabated. Pen's next resource would have been to storm the study, but the master allowed her to convince herself that there was nothing there to "offend the nostril," and quietly left her to prosecute her researches elsewhere. In the course of these, Pen was eventually led by the nose to the closet under the stairs, and, "Lor' a massy," she exclaimed, as a bright thought suddenly struck her, "I shouldn't wonder now if it's in this dratted closet, how stupid not to think of that before!" And so it was, for no sooner had she opened it and looked in, than, hastily withdrawing her head again and applying the corner of her apron to her nose, she declared that the stench inside was "fit to knock a body down." Without the loss of another moment, the contents of the closet were cleared out, and mop and broom was the order of the day. "Thank goodness," was Pen's remark the next morning, "its all right now, the nasty smell's gone at last; but there wasn't no dead rat after all, and whatever it could be, I can't imagine." No, and she never knew, but we were more fortunate, we learnt from the master that, finding all his complaints as to 
the heap of "matter in the wrong place". disregarded or evaded, he had cunningly concealed, in a convenient recess in the closet, a specimen of the Phallus impudicus, and allowed it to remain there until the augean stable had been thoroughly cleansed, after which consummation, he took the opportunity, unseen by any of the household, of removing it and throwing it away. The prescription, however, he carefully treasured up for future use, "pro re nata, as the doctors have it," he would add, with a merry twinkle, but we have no reason to believe that he ever had occasion to test its efficacy again. Should any of our numerous readers feel curious to exercise their olfactory sense within range of a mature specimen of the Phallus impudicus, we can gratify them with the information that they may do so at their convenience, any, time between the months of June and October, in seasons favourable to the growth of this species of fungus, and that the greater number of those who may avail themselves of the opportunity of making the experiment, will readily admit the propriety with which the common plain English name of Stinkhorn has been applied to the genus, we will not permit ourselves to harbour a doubt. This (the only species of the genus we have ever met with) is not a beautiful object, either in form or colour, and, without entering into structural details, we may roughly describe it as consisting of a yellowish-white tubular stipe, or stem, five or six inches high, of a light porous texture, and surmounted by a conical pileus, or cap, of a darker shade. We have very often found it in the Killing Wood, West Wood, Garden Wood, Park Copse, the Belt near Spithead, and other localities in the parish.

The remaining Fungi which we shall notice are :-

Geaster fornicatus (Vaulting Geaster), found at Ryefields.

Bovista nigreseens (Blackish Bovista). 
B. plumbea (Lead-coloured Bovista).

Lycoperdon gigantcum (Giant Puff-Ball). In the autumn of 1873 , we found a specimen of this species measuring $38 \frac{1}{2}$ inches in horizontal circumference, by $3 \mathrm{I}$ in vertical circumference, and weighing $6 \mathrm{lbs}$.

L. calatum (Collapsing Puff-Ball).

L. pyriforme (Pear-shaped Puff-Ball).

Cyathus striatus (Striate Cyathus).

Morchella esculenta (Common Morel).

$M$. semilibera (Half-free Morel).

Peziza onohea (Orange-ear Peziza).

$P$. aurantia (Orange Ground Peziza).

$P$. carulea (Blue Peziza).

$P$. elegans (White and red Peziza).

$P$. aruginosa (Green Peziza). This species has the singular property of conferring considerable conventional value on fragments of decaying wood. It attacks small broken branches of oak and beech, which, when thoroughly permeated by the mycelium or spawn of the fungus, assume a beautiful malachite-green, and, in this state, are manufactured into a variety of very pretty ornaments. When properly prepared, the wood admits of being easily turned in a lathe, or sawn out into very thin slips with which the covers of blotting-cases and ladies' workboxes are veneered.

Tuber astivum (Common Truffle).

T. rufum (Red Truffle).

Ustulina vulgaris (Common Ustulina).

Spheria Fraxinea (Ash Spheria). 


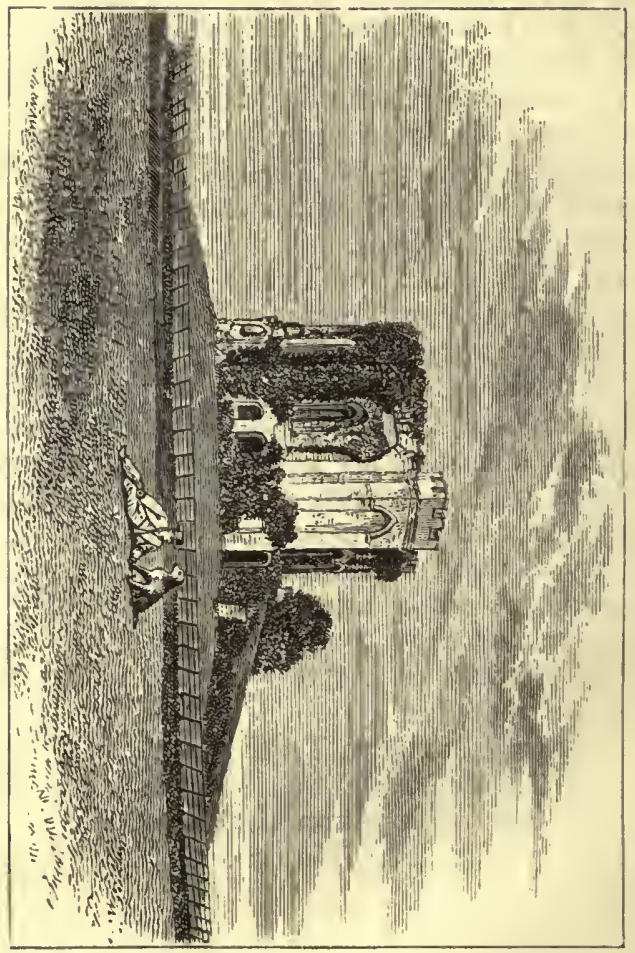


The Uppark Tower, originally the "Drdalian Tower," of which a representation is given on the opposite page, was built in commemoration of the purchase by Sir Matthew Fetherstonhaugh of a large tract of land in the Valley of the Ohio, fancifully styled "Dædalia." This purchase, however, turned out to be a barren acquisition to Sir Matthew, who lost the whole of it during the American War of Independence; so that the Tower eventually became a memento of an unfortunate speculation. For many years afterwards it was the favourite resort of pic-nic parties who visited the Park ; and among the survivors of those who may have occasionally contributed to the "sound of revelry" coming from its interior when tenanted by a lively company, there are many who no doubt recollect that it was a pretty little structure crowned with a coronet of elegantly ornamented pinnacles, that the basement was carefully fitted with every requisite for culinary purposes, and the upper apartment, with its neatly decorated ceiling, was principally lighted by three large windows, partially filled with stained glass. In 1842 it was reduced to its present ruinous state by a deliberate act of incendiarism, not unreasonably attributed to a gang of notorious poachers from an adjoining parish, whose frequent raids in the Harting covers had more than once brought them under the unfavourable notice of the magistrates. A few fragments have since then been dislodged from the battlements by the heavy gales that have swept over them; but the whole structure was so substantially built, that many years may yet elapse before it becomes a heap of crumbling ruins. 


\section{$X-21816$ \\ 492}

The Map, with sections of the local strata, at the beginning of the Geological Chapter* of this book, is taken from Mantell's Geology of Sussex. The late Sir Roderick Murchison had prepared a somewhat similar diagram, but in consequence of his lamented death in $187 \mathrm{I}$ the design was not available. In the pages, however, which he has bequeathed to us, we have the shield of a name illustrious in peace as in war, and a sacred souvenir of a friend as generous as he was noble.

\section{H. D. G.}

* Professor Boyd Dawkins, of Owens College, Manchester, has kindly revised the proof of these sheets. 
unfuenmare lady 130. 

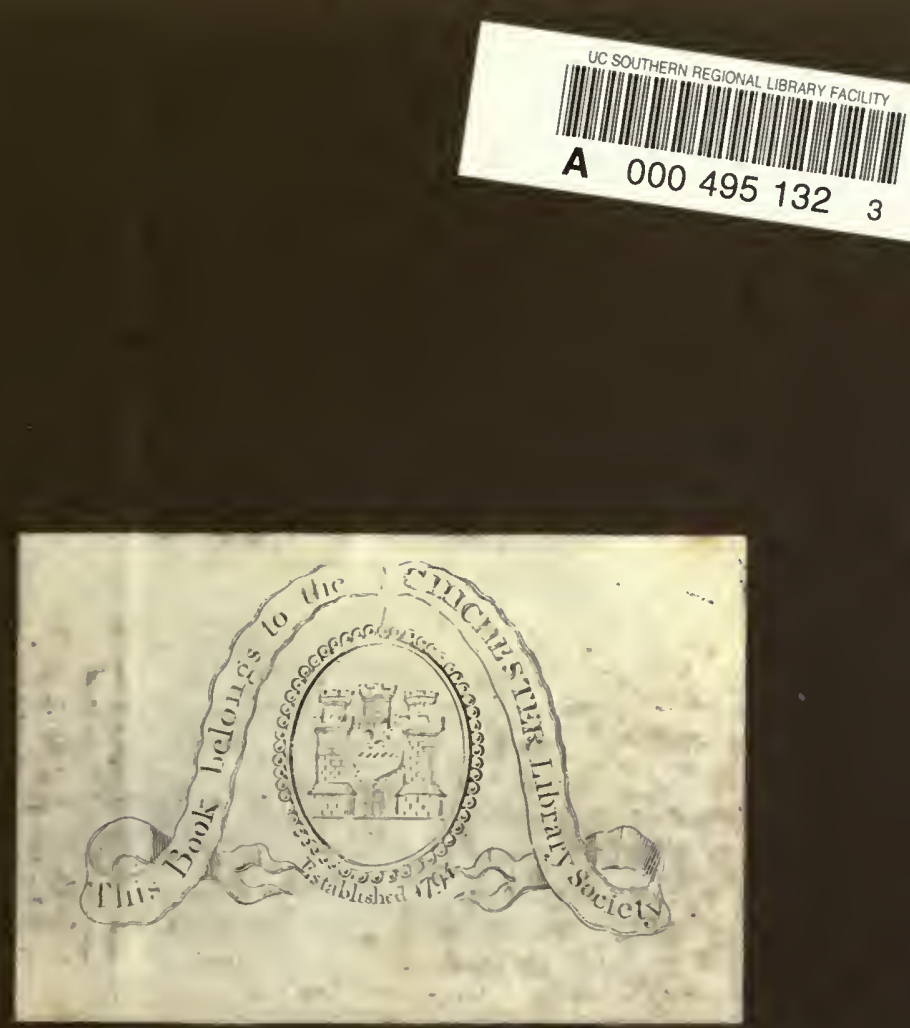


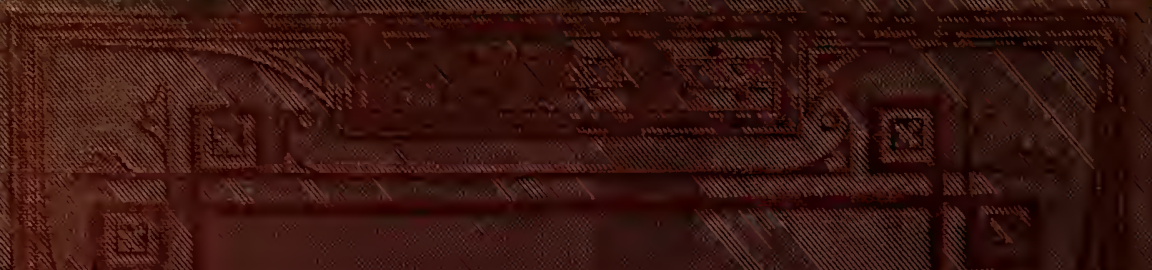

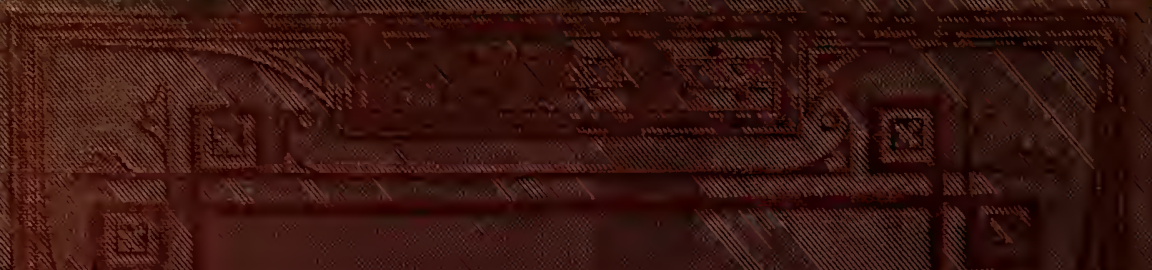

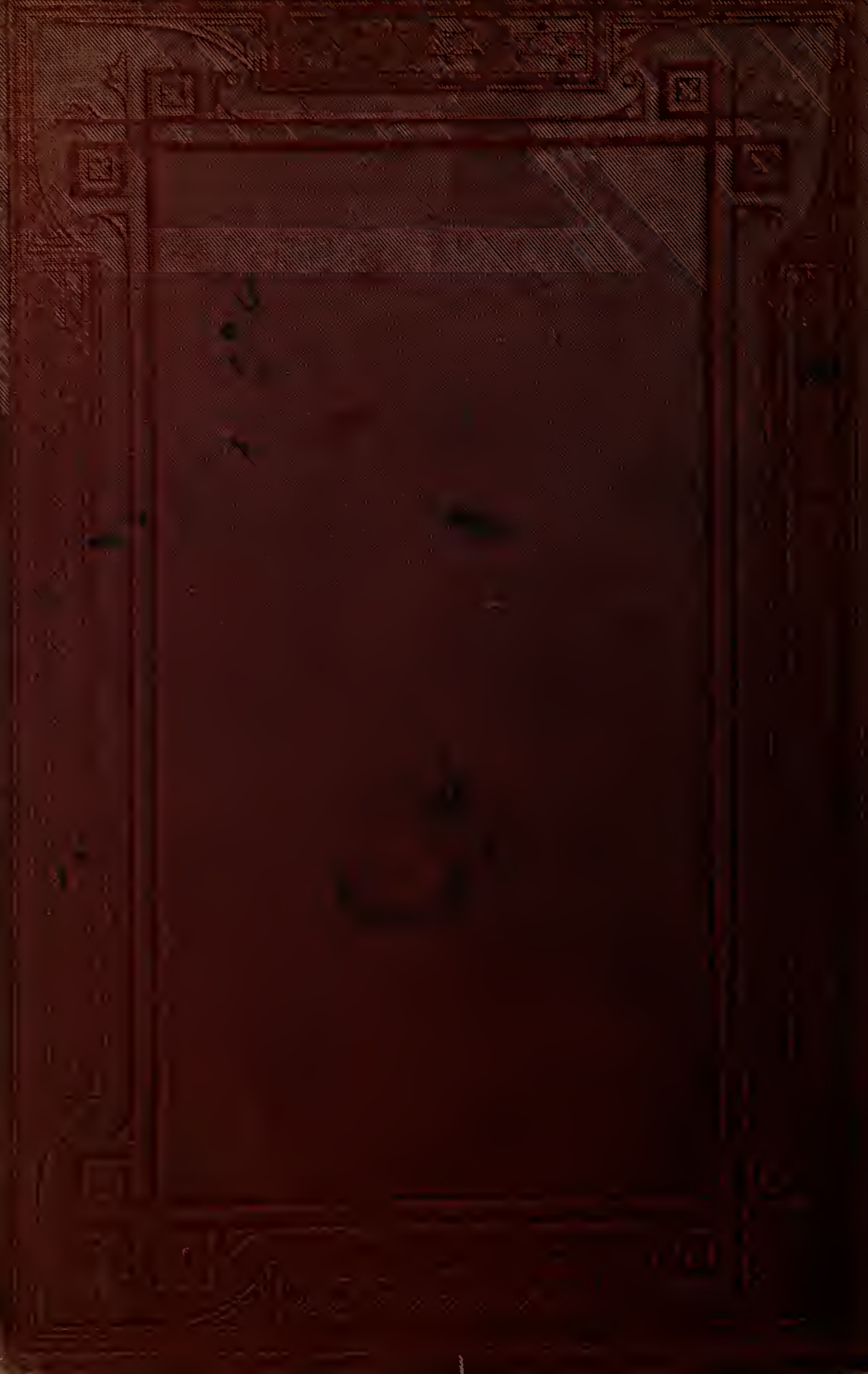

Non 